Sonia Maria Milani Gouveia

\title{
O homem, \\ o edifício e a cidade por Peter Scheier
}

Dissertação apresentada à Faculdade de Arquitetura e Urbanismo da Universidade de São Paulo como requisito para a obtenção do título de mestre.

Orientadora: Profa. Dra ${ }^{a}$ Mônica Junqueira de Camargo

Área de Concentração: História e Fundamentos da Arquitetura e do Urbanismo

São Paulo, 2008. 
AUTORIZO A REPRODUÇÃO E DIVULGAÇÃO TOTAL OU PARCIAL DESTE TRABALHO, POR QUALQUER MEIO CONVENCIONAL OU ELETRÔNICO, PARA FINS DE ESTUDO E PESQUISA, DESDE QUE CITADA A FONTE.

E-MAIL: soniammg@bol.com.br

Gouveia, Sonia Maria Milani

G719h O homem, o edifício e a cidade por Peter Scheier / Sonia Maria Milani Gouveia. - - São Paulo, 2008. 412 p. : il.

Dissertação (Mestrado - Área de Concentração: História e Fundamentos da Arquitetura e do Urbanismo) FAUUSP.

Orientadora: Mônica Junqueira de Camargo.

1. Fotografia (Arquitetura) - São Paulo 2. Fotografia documentária 3. Fotógrafos - Século XX - São Paulo 4. Scheier, Peter I. Título

CDU 77.033:72 


\section{Dedicatória}

A meu pai José (in memoriam), por ter colocado suas Rolleiflex no meu caminho. 


\section{Agradecimentos}

Agradeço a todos que acompanharam meus momentos de pesquisa.

À Mônica Junqueira e Boris Kossoy, pela orientação e apoio.

Aos professores do curso de pós-graduação, pelo conhecimento transmitido.

Às pessoas entrevistadas, pelos depoimentos valorosos.

Às instituições consultadas, pela disponibilidade do acervo.

Aos amigos, pelo estímulo constante.

Finalmente, a Marieta, Ana e Daniel, pelo apoio incondicional. Sem eles, nada teria sentido.

Pesquisa realizada com o apoio da FAPESP - Fundação de Amparo à Pesquisa do Estado de São Paulo. 


\section{(...)}

- Resta uma que você jamais menciona.

Marco Pólo abaixou a cabeça.

- Veneza - disse o Khan.

Marco sorriu.

- E de que outra cidade imagina que eu estava falando?

O imperador não se afetou.

- No entanto, você nunca citou o seu nome.

E Pólo:

- Todas as vezes que descrevo uma cidade, digo algo a respeito de Veneza. (...) Para distinguir as qualidades das outras cidades, devo partir de uma primeira que permanece implícita. No meu caso, trata-se de Veneza.

Ítalo Calvino, As cidades invisíveis. 


\section{Resumo}

Este trabalho analisa a fotografia urbana e de arquitetura com base no álbum São Paulo fastest growing city in the world, de autoria de Peter Scheier, editado em 1954 no contexto das comemorações do quarto centenário da cidade de São Paulo. Scheier insere-se em uma das linhas mais frutíferas da moderna fotografia brasileira, junto com outros refugiados da Segunda Guerra Mundial, como Hans Günter Flieg, Hildegard Rosenthal, Alice Brill, Curt Schulze e Fredi Kleemann.

O álbum traz conteúdo informacional extenso, não só sobre a cidade na década de 1950, mas também a respeito de Peter Scheier, uma vez que foi elaborado a partir de material de seu arquivo - fotografias publicadas nas revistas O Cruzeiro e Habitat e no livro Modern Architecture in Brazil, produzidas para o MASP, do qual era fotógrafo oficial, e fotografias sem fins de publicação. O objetivo é, através da análise de Peter Scheier, compreender a dinâmica da atividade dos fotógrafos que atuavam em São Paulo em meados do século XX.

Palavras-chave: fotografia - arquitetura - Peter Scheier - O Cruzeiro - MASP álbum fotográfico 


\section{Abstract}

This work analyzes the urban and architectural photography based on the album São Paulo fastest growing city in the world, by Peter Scheier, edited in 1954 in the context of celebration of the fourth century of the city of São Paulo. Scheier is part of one of the most fertile line of the Brazilian modern photography, together with other Second World War refugees, for instance: Hans Günter Flieg, Hildegard Rosenthal, Alice Brill, Curt Schulze and Fredi Kleemann.

The album has extent informational content, not only about the city in the 1950's, but also about Peter Scheier, by being elaborated with material from his archive - photographs published in O Cruzeiro and Habitat magazines and in the book Modern Architecture in Brazil; made for MASP, for which he was the official photographer, and photos without publication purpose. The aim is to understand the dynamics of the activity of the photographers who worked in São Paulo in the middle of the XX century, by the analysis of Peter Scheier.

Key words: photography - architecture - Peter Scheier - O Cruzeiro - MASP photograph album 


\section{Lista de Imagens}

Imagem 1. Bricklayer's Mate, 1928. Autoria: August Sander. Fonte: http://www. moma.org/collection/. 51

Imagem 2. Blast Furnaces, Herrenwick, 1927. Autoria: Albert Renger Pazscht. Fonte: ELWALL (2004), p. 120. 52

Imagem 3. Bauhaus Balconies, Dessau, 1926. Autoria: Lázsló Moholy-Nagy. Fonte: ELWALL (2004), p. 133. 53

Imagem 4. Gathering for the demonstration in the courtyard of the VChUTEMAS (Higher Institute of Technics and Art), 1928. Autoria: Alexander Rodchenko. Fonte: http://www.masters-of-photography.com 54

Imagem 5. On the telephone, 1928. Autoria: Alexander Rodchenko. Fonte: http://www.masters-of-photography.com 54

Imagem 6. Residência dos Scheier em Glogau. Fonte: Arquivo pessoal. 57

Imagem 7. Peter Scheier, 1928. Fonte: Arquivo pessoal. 58

Imagem 8. Páginas iniciais do passaporte de Peter Scheier, emitido em 1933. Fonte: Acervo do AHJB. 60

Imagem 9. Página 17 do passaporte de Peter Scheier, com carimbo de visto emitido pelo Consulado do Brasil na França, com data de 18 de setembro de 1937. Fonte: Acervo do AHJB. 60

Imagem 10. Página 19 do passaporte de Peter Scheier, com carimbo de visto de desembarque do Serviço de Imigração do Porto do Rio de Janeiro, com data de 25 de outubro de 1937. Fonte: Acervo do AHJB. 60

Imagem 11. Autorização emitida pela Superintendência de Segurança Política e Social, em 27 de julho de 1947. Fonte: Acervo do AHJB. 62

Imagem 12. Fábrica em Hohenau. Autoria: Peter Scheier. Fonte: Arquivo pessoal. 63

Imagem 13. Fac símile de página do Supplemento em Rotogravura do $O$ Estado de S.Paulo, n.143, com fotos de Scheier. Fonte: Acervo da FDUSP. 70

Imagem 14. Foto de Peter Scheier publicada no Supplemento em Rotogravura do O Estado de S.Paulo, n.143. Fonte: Acervo da FDUSP. . 70

Imagem 15. Fac símile de página da seção "Photographia" do Supplemento em Rotogravura do O Estado de S.Paulo, n.143, com fotos de Scheier. Fonte: Acervo da FDUSP. 
Imagem 16. Foto de Peter Scheier publicada no Supplemento em Rotogravura do O Estado de S.Paulo, n.143. Fonte: Acervo da FDUSP...

Imagem 17. Foto de Peter Scheier publicada no Supplemento em Rotogravura do O Estado de S.Paulo, n.143. Fonte: Acervo da FDUSP. .

Imagem 18. Foto de Peter Scheier publicada no Supplemento em Rotogravura do O Estado de S.Paulo. n.144. Fonte: Acervo da FDUSP. 73

Imagem 19. Fac símile de página da seção "Photographia" do Supplemento em Rotogravura do O Estado de S.Paulo, n.145, com fotos de Scheier. Fonte: Acervo da FDUSP. 73

Imagem 20. Capa da revista Íris (jan. 1951). Fonte: Acervo da FAUUSP... 74 Imagem 21. Capa da revista American Photography (jan. 1950). Fonte: Acervo da FAUUSP.

Imagem 22. Anúncio da loja da Fotóptica publicado na revista Íris, n. 43. Fonte: Acervo da FAUUSP. 75

Imagem 23. Anúncio da Kosmos Foto publicado na revista Íris, n. 46. Fonte: Acervo da FAUUSP. 76

Imagem 24. Anúncio das câmeras Zeiss-Ikon publicado na revista Íris, n. 35. Fonte: Acervo da FAUUSP. 77

Imagem 25. Anúncio dos equipamentos Leitz publicado na revista Íris, n. 44. Fonte: Acervo da FAUUSP.

Imagem 26. Anúncio dos produtos Ilford publicado na revista Íris, n. 45.Fonte: Acervo da FAUUSP. 77

Imagem 27. Peter Scheier em Brasília, em 1960, com sua Rolleiflex (6x6cm). Fonte: Acervo do AHJB. 79

Imagem 28. Peter Scheier, no Paraná, na década de 1950, com sua Leica (35mm). Fonte: Acervo do AHJB. 79

Imagem 29. Um modelo fabricado pela ICA AG $(9 \times 12 \mathrm{~cm})$, semelhante ao que Scheier trouxe da Alemanha. Fonte: www.todocolleccion.net. 79

Imagem 30. O gaveteiro original para acomodação de negativos de Peter Scheier, que se encontra atualmente no Arquivo Histórico Judaico Brasileiro. Fonte: Acervo do AHJB. 80

Imagem 31. Aspecto das gavetas, conforme organização original do fotógrafo. Fonte: Acervo do AHJB. 80 
Imagem 32. Exemplo de carimbo encontrado no verso de ampliações, com o número de série, filme e pose. Fonte: Acervo fotográfico da FAUUSP. 81

Imagem 33. Interior da Metalleve, 1959. Autoria: P. Scheier. Fonte: Acervo do AHJB. 86

Imagem 34. Marlene Dietrich, 1958. Autoria: P. Scheier. Fonte: Acervo do AHJB. 87

Imagem 35. Ella Fitzgerald em apresentação na TV Record, 1960. Autoria: P. Scheier. Fonte: Acervo do AHJB.

Imagem 37. Robert Kennedy em visita ao Brasil, 1965. Autoria: P. Scheier. Fonte: Acervo do AHJB. 88

Imagem 36. Getúlio Vargas em Campos do Jordão, janeiro 1951. Autoria: P. Scheier. Fonte: Acervo do AHJB. 88

Imagem 38. Israel, porto de Haifa, abril 1959. Autoria: P. Scheier. Fonte: Acervo do AHJB. 89

Imagem 39. Cartaz da exposição "30 Anos de Visão e Multivisão" (1970), exposição de Peter Scheier no MASP, contemplando os trinta anos de sua carreira. Fonte: Acervo do MASP 89

Imagem 40. Anões observam a máquina de Scheier. Fonte: "Um dia no bosque dos anões", em O Cruzeiro, p. 63, 08/12/1945. Acervo do MASP. 100

Imagem 41. Scheier, de pé, observa a anã. Fonte: "Um dia no bosque dos anões", em O Cruzeiro, p. 66, 08/12/1945. Acervo do MASP. 101

Imagem 42. Fac símile da página 13 da reportagem "O enterro de um grande morto", em O Cruzeiro de 02/06/1945. Fonte: Acervo do MASP. 104

Imagem 43. "Desconfiada e risonha ao mesmo tempo" (legenda original). Fonte: "Bussocaba e Vila Mascote", em O Cruzeiro, p. 53, 31/03/1945. Acervo do MASP. 105

Imagem 44. "Cem anos quase, e as rugas numerosíssimas contam a longa história de sua vida humilde" (legenda original). Fonte: "Bussocaba e Vila Mascote", em O Cruzeiro, p. 55, 31/03/1945. Acervo do MASP. .................. 106

Imagem 45. Fac símile da página 52 da reportagem "Lar São Francisco", em O Cruzeiro de 24/05/1947. Fonte: Acervo do MASP. 106

Imagem 46. Fac símile das páginas 8 e 9 da reportagem "O Braz", em $O$ Cruzeiro de 26/04/1947. Fonte: Acervo do MASP. 107 Imagem 47. Fac símile das páginas 10 e 11 da reportagem "O Braz", em $O$ 
Imagem 48. Fac símile das páginas 14 e 15 da reportagem "O Braz", em $O$ Cruzeiro de 26/04/1947. Fonte: Acervo do MASP. 109

Imagem 49. Fac símile das páginas 12 e 13 da reportagem "O Braz", em $O$ Cruzeiro de 26/04/1947. Fonte: Acervo do MASP. 110

Imagem 50. Cortiço na Rua Oscar Freire, 1938. Autoria: B. J. Duarte. Fonte: JUNIOR; LIMA; VALADARES (2007), p.74. 113

Imagem 51. Cortiço na Rua Carneiro Leão, década de 1930. Autoria: B. J. Duarte. Fonte: JUNIOR; LIMA; VALADARES (2007), p.77.

Imagem 52. Fac símile das páginas 58 e 59 da reportagem "A "Aliança" fez a força", em O Cruzeiro de 14/01/1950. Fonte: Acervo do MASP. 114

Imagem 53. Fac símile da página 57 da reportagem "Trinta mil doentes", em O Cruzeiro de 02/08/1947. Fonte: Acervo do MASP. 115

Imagem 54. Fac símile das páginas 58 e 59 da reportagem "Trinta mil doentes", em O Cruzeiro de 02/08/1947. Fonte: Acervo do MASP. 116

Imagem 55. Fac símile das páginas 60 e 61 da reportagem "Trinta mil doentes", em O Cruzeiro de 02/08/1947. Fonte: Acervo do MASP. 117

Imagem 56. Cirurgia no Hospital das Clínicas, 1949.Autoria: B. J. Duarte. Fonte: JUNIOR; LIMA; VALADARES (2007), p.181. 118

Imagem 57. Hospital das Clínicas, 1949. Autoria: B. J. Duarte. Fonte: JUNIOR; LIMA; VALADARES (2007), p.179. 118

Imagem 58. "Ninguém mais que as crianças aprecia um espetáculo circense" (legenda original). Fac símile da página 11 da reportagem "Circo-teatro do povo", em O Cruzeiro de 23/06/1945. Fonte: Acervo do MASP. 119

Imagem 59. Fac símile das páginas 62 e 63 da reportagem "O destino dos jardins", em O Cruzeiro de 27/04/1946. Fonte: Acervo do MASP. 120

Imagem 60. Fac símile das páginas 64 e 65 da reportagem "O destino dos jardins", em O Cruzeiro de 27/04/1946. Fonte: Acervo do MASP. 121

Imagem 61. Fac símile das páginas 66 e 67 da reportagem "O destino dos jardins", em O Cruzeiro de 27/04/1946. Fonte: Acervo do MASP. 122

Imagem 62. Fac símile das páginas 52 e 53 da reportagem "Santo Amaro, refúgio do paulistano", em O Cruzeiro de 24/01/1948. Fonte: Acervo do MASP. 123 
Imagem 63. Fac símile das páginas 54 e 55 da reportagem "Santo Amaro, refúgio do paulistano", em O Cruzeiro de 24/01/1948. Fonte: Acervo do MASP. 124

Imagem 64. Bardi numa das aulas de história da arte para os monitores do museu, em 1947. Fonte: TENTORI (2000), p.189. 126

Imagem 65. Fac símile das páginas 54 e 55 da reportagem "Arte para milhões", em O Cruzeiro de 01/11/1947. Fonte: Acervo do MASP. 127

Imagem 66. Fac símile das páginas 56 e 57 da reportagem "Arte para milhões", em $O$ Cruzeiro de 01/11/1947. Fonte: Acervo do MASP. 128

Imagem 67. Fac símile das páginas 94 e 95 da reportagem "Museu de Arte de São Paulo "cidadela da civilização"”, em O Cruzeiro de 05/08/1950. Fonte: Acervo do MASP. 129

Imagem 69. Desfile da Vogue no MASP, 1951. Vê-se um móbile de Alexander Calder. Autoria: P. Scheier. Fonte: Acervo do AHJB. 130

Imagem 68. Fac símile das páginas 114 e 115 da reportagem "Quatro Séculos de moda", em O Cruzeiro de 21/04/1951. Fonte: Acervo do MASP. 130

Imagem 70. Desfile da Vogue no MASP, 1951. Autoria: P. Scheier. Fonte: Acervo do AHJB. 130

Imagem 71. "The new look of Dior", Place de la Concorde, Paris, agosto 1947. Autoria: Richard Avedon. Fonte: http://www.richardavedon.com/. 131

Imagem 72. Inauguração de novas instalações do MASP, 1950. Autoria: P. Scheier. Fonte: Acervo do MASP. 132

Imagem 73. Inauguração de novas instalações do MASP, 1950. Em primeiro plano, Assis Chateaubriand. Autoria: P. Scheier. Fonte: Acervo do MASP. .. 132

Imagem 74. Aula do curso de desenho de Roberto Sambonet, 1948. Autoria: P. Scheier. Fonte: Habitat, n.11, p.2. Acervo da FAUUSP. 133

Imagem 75. Curso no MASP, década de 1950. Autoria: P. Scheier. Fonte: Acervo do MASP. 133

Imagem 76. Curso de escultura de August Zamoyski, no MASP, 1950. Autoria: P. Scheier. Fonte: Acervo do MASP. 134

Imagem 77. Curso de escultura de August Zamoyski, no MASP, 1950. Autoria: P. Scheier. Fonte: Acervo do MASP. 134

Imagem 78. Curso de fotografia Guillermo Marcone no MASP, 1953. Autoria: P. Scheier. Fonte: Acervo do MASP. 135 
Imagem 79. Curso de fotografia Guillermo Marcone no MASP, 1953. Autoria: P. Scheier. Fonte: Acervo do MASP. 135

Imagem 80. Villa Lobos no MASP, julho de 1949. Autoria: P. Scheier. Fonte: Acervo do AHJB. 136

Imagem 81. Curso de ballet infantil no MASP, 1950. Autoria: P. Scheier. Fonte: Acervo do AHJB. 137

Imagem 82. Curso de ballet infantil no MASP, 1950. Autoria: P. Scheier. Fonte: Habitat, n.11, p.2. Acervo da FAUUSP. 137

Imagem 83. Curso de dança contemporânea no MASP, 1950. Autoria: P. Scheier. Fonte: Acervo do AHJB. 138

Imagem 84. Curso de dança contemporânea no MASP, 1950. Autoria: P. Scheier. Fonte: Habitat, n.09, p.54. Acervo da FAUUSP. 138

Imagem 85. Capa da revista Habitat n.22, de maio de 1955, com foto de Peter Scheier. Fonte: Acervo da FAUUSP. 139

Imagem 86. Vitrine da loja Mappin, 1953. Autoria: P. Scheier. Fonte: Habitat, n.10, p.77. Acervo da FAUUSP. 142

Imagem 87. Vitrine da loja Mappin, 1953. Autoria: P. Scheier. Fonte: Habitat, n.10, p.77. Acervo da FAUUSP. 143

Imagem 88. Fechadura da Vila Penteado. Autoria: P. Scheier. Fonte: Habitat, n.10, p.10. Acervo da FAUUSP. 145

Imagem 89. Vitrine da loja de automóveis da Studebaker, na Avenida Ipiranga. Autoria: P. Scheier. Fonte: Habitat, n.03, p.77. Acervo da FAUUSP. 145

Imagem 90. Detalhe do painel fotográfico produzido por Scheier e Rado para a Klabin. Fonte: Habitat, n.09, p.62. Acervo da FAUUSP. 146

Imagem 91. Fac símile das páginas 78 e 79 da reportagem "O museu num álbum", em Habitat, n.13. Fonte: Acervo da FAUUSP. 147

Imagem 92. Os artistas Abraam Palatnik (sentado), Waldemar Cordeiro, Kazmer Féjer (atrás) e Tomás Maldonado ao redor da "Unidade Tripartida" de Max Bill, 1951. Autoria: P. Scheier. Fonte: Acervo do AHJB. 148

Imagem 93. Vista do pavilhão da 1a Bienal Internacional de Arte, 1951. Autoria: P. Scheier. Fonte: Acervo do AHJB 148

Imagem 94. Vista do pavilhão da 1a Bienal Internacional de Arte, 1951. Autoria: P. Scheier. Fonte: Acervo do AHJB 149 
Imagem 95. Interior do pavilhão da 1a Bienal Internacional de Arte, 1951. Autoria: P. Scheier. Fonte: Acervo do AHJB.

Imagem 96. Interior do pavilhão da 1a Bienal Internacional de Arte, 1951. Autoria: P. Scheier. Fonte: Acervo do AHJB. 150

Imagem 97. Residência Arnstein, de Bernardo Rudofsky. Autoria: P. Scheier. Fonte: "Three Patio Houses", em New Pencil Points, n.6, p.49. Acervo da FAUUSP. 153

Imagem 98. Residência Arnstein. Autoria: P. Scheier. Fonte: "Three Patio Houses", em New Pencil Points, n.6, p.51. Acervo da FAUUSP. 154

Imagem 99. Residência Arnstein. Autoria: P. Scheier. Fonte: New Pencil Points, n.6, p.51. Acervo da FAUUSP.. 154

Imagem 100. Residência Frontini, de Bernardo Rudofsky. Autoria: P. Scheier. Fonte: New Pencil Points, n.6, p.58. Acervo da FAUUSP. 155

Imagem 101. Residência Frontini. Autoria: P. Scheier. Fonte: New Pencil Points, n.6, p.59. Acervo da FAUUSP. 156

Imagem 102. Residência Frontini. Autoria: P. Scheier. Fonte: New Pencil Points, n.6, p.59. Acervo da FAUUSP. 157

Imagem 103. Residência Frontini. Autoria: P. Scheier. Fonte: New Pencil Points, n.6, p.59. Acervo da FAUUSP. 157

Imagem 104. Residência Frontini. Autoria: P. Scheier. Fonte: New Pencil Points, n.6, p.58. Acervo da FAUUSP. 158

Imagem 105. Case Study House \#20 (Bass House), Califórnia, 1958. Autoria: J. Shulman. Fonte: ELWALL (2004), p.182. 158

Imagem 106. Residência Antônio da Silva Prado Neto, de Gregori Warchavchik. Autoria: P. Scheier. Fonte: Acervo fotográfico FAUUSP. 160

Imagem 107. Residência Antônio da Silva Prado Neto. Autoria: P. Scheier. Fonte: Acervo fotográfico FAUUSP. 160

Imagem 108. Face Leste da residência Oscar Americano. Autoria: P. Scheier. Fonte: SEGAWA; DOURADO (1997), p.124. 161

Imagem 109. Fachada Oeste da residência Oscar Americano. Autoria: P. Scheier. Fonte: SEGAWA; DOURADO (1997), p.125. 161

Imagem 110. Jardim interno da residência Oscar Americano. Autoria: P. Scheier. Fonte: SEGAWA; DOURADO (1997), p.128. 162 
Imagem 111. Área de convívio do pavimento inferior, com o mosaico de Lívio Abramo. residência Oscar Americano. Autoria: P. Scheier. Fonte: SEGAWA; DOURADO (1997), p.127. 163

Imagem 112. Vista do pavilhão de lazer da residência Oscar Americano. Autoria: P. Scheier. Fonte: SEGAWA; DOURADO (1997), p.129. 164

Imagem 113. Vista da piscina e do pavilhão de lazer (ao fundo) da residência Oscar Americano. Autoria: P. Scheier. Fonte: SEGAWA; DOURADO (1997), p.130. 164

Imagem 114. Pavilhão de lazer da residência Oscar Americano. Autoria: P. Scheier. Fonte: SEGAWA; DOURADO (1997), p.131. 165

Imagem 115. Sala de estar da residência Oscar Americano. Autoria: P. Scheier. Fonte: SEGAWA; DOURADO (1997), p.128. 165

Imagem 116. Casa Francisco Matarazzo Sobrinho, de Oswaldo Bratke. Autoria: P. Scheier. Fonte: SEGAWA; DOURADO (1997), p.163. 166

Imagem 117. Casa Francisco Matarazzo Sobrinho. Autoria: P. Scheier. Fonte: SEGAWA; DOURADO (1997), p.160-161 167

Imagem 118. Alpendre da casa Francisco Matarazzo Sobrinho. Autoria: P. Scheier. Fonte: SEGAWA; DOURADO (1997), p.154. 167

Imagem 119. Alpendre da casa Francisco Matarazzo Sobrinho. No térreo, vêse Oswaldo Bratke analisando um desenho. Autoria: P. Scheier. Fonte: SEGAWA; DOURADO (1997), p.154-155 168

Imagem 120. Vista da casa Francisco Matarazzo Sobrinho. Autoria: P. Scheier. Fonte: Acrópole, n.278, p.052. Acervo da FAUUSP. 168

Imagem 121. Vista externa da casa Valéria P. Cirrell, de Lina Bo Bardi. Autoria: P. Scheier. Fonte: Arquivo ILPB. 169

Imagem 122. Vista externa da casa Valéria P. Cirrell, de Lina Bo Bardi. Autoria: P. Scheier. Fonte: GALLO (2003), p. 64 169

Imagem 123. Interior da casa Valéria P. Cirrell, de Lina Bo Bardi. Autoria: P. Scheier. Fonte: GALLO (2003), p. 67 170

Imagem 124. Interior da residência Lina Bo Bardi. Autoria: P. Scheier. Fonte: BARDI; FERRAZ (1999), p.13. 171

Imagem 125. Vista do bairro do Morumbi a partir do interior da residência Lina Bo Bardi. Autoria: P. Scheier. Fonte: FERRAZ (1993), p.81. 171 Imagem 127. Vista externa da residência Lina Bo Bardi. Autoria: P. Scheier. 
Fonte: Arquivo ILPB. 172

Imagem 126. Interior da residência Lina Bo Bardi, com bairro do Morumbi ao fundo. Autoria: P. Scheier. Fonte: MINDLIN (1956), p.43. 172

Imagem 128. Vista externa da residência Lina Bo Bardi. Autoria: P. Scheier. Fonte: BARDI; FERRAZ (1999), p.10. 173

Imagem 129. Vista geral da residência Lina Bo Bardi a partir do bairro. Autoria: P. Scheier. Fonte: Habitat, n.10, p.31. Acervo da FAUUSP. 173

Imagem 130. Fachada da Rua Venezuela da residência Milton Guper, de Rino Levi. Autoria: P. Scheier. Fonte: MINDLIN (1956), p.64. 174

Imagem 131. Vista do jardim interno da residência Milton Guper. Autoria: P. Scheier. Fonte: $A D$, n.3, s/p. 175

Imagem 132. Vista da sala de estar, com o jardim ao fundo. Residência Milton Guper. Autoria: P. Scheier. Fonte: MINDLIN (1956), p.65. 176

Imagem 133. Vista da sala de estar, com o jardim à esquerda. Residência Milton Guper. Autoria: P. Scheier. Fonte: MINDLIN (1956), p.64. 176

Imagem 134. Vista da cobertura do edifício Prudência, de Rino Levi. Autoria: P. Scheier. Fonte: MINDLIN (1956), p.96. 177

Imagem 135. Vista a partir da Avenida Higienópolis do edifício Prudência. Autoria: P. Scheier. Fonte: MINDLIN (1956), p.96. 177

Imagem 136. Rampa de acesso do edifício Prudência. Autoria: P. Scheier. Fonte: MINDLIN (1956), p.97. 178

Imagem 137. Vista do interior do Palma Studio de Arte e Arquitetura. Autoria: P. Scheier. Fonte: FERRAZ (1993), p.56. 179

Imagem 138. Estante em vidro e estrutura metálica, no interior do Palma Studio. Autoria: P. Scheier. Fonte: FERRAZ (1993), p.56. 180

Imagem 139. Modelo de cadeira criado pelo Palma Studio. Autoria: P. Scheier. Fonte: FERRAZ (1993), p.58. 180

Imagem 140. Cadeira "Z" dobrável, em pau-marfim e couro, criada pelo Palma Studio. Autoria: P. Scheier. Fonte: Arquivo ILPB. 181

Imagem 141. Cadeira "Z" dobrável, em pau-marfim e couro, criada pelo Palma Studio. Autoria: P. Scheier. Fonte: FERRAZ (1993), p.58. 181

Imagem 143. Interior da Mapa Importadora, na Rua 07 de Abril, projeto do Palma Studio. Autoria: P. Scheier. Fonte: FERRAZ (1993), p.61 182 
Imagem 142. Vista noturna da loja Olivetti Securit, na Rua 24 de Maio, projeto do Palma Studio. Autoria: P. Scheier. Fonte: Arquivo ILPB. 182

Imagem 144. Manequins de madeira, projeto do Palma Studio. Autoria: P. Scheier. Fonte: Arquivo ILPB. 182

Imagem 145. Show room da fábrica de plásticos Plavinil, projeto do Palma Studio. Autoria: P. Scheier. Fonte: Arquivo ILPB. 183

Imagem 146. Vista do acervo permanente do MASP. À direita, o próprio Scheier. Autoria: P. Scheier. Fonte: MINDLIN (1956), p.182. 184

Imagem 147. Vista geral do acervo permanente do MASP, com a "vitrine das formas” no primeiro plano. Autoria: P. Scheier. Fonte: MINDLIN (1956), p.183. 184

Imagem 148. "Vitrine das formas" do MASP. Autoria: P. Scheier. Fonte: MINDLIN (1956), p.183. 185

Imagem 149. Vista a partir da Praça Rodrigo Lefevre da sede do MASP na Avenida Paulista em construção. Autoria: P. Scheier. Fonte: Acervo do AHJB. 185

Imagem 150. Vista a partir da Avenida Nove de Julho da sede do MASP na Avenida Paulista em construção. Autoria: P. Scheier. Fonte: Acervo do AHJB. 186

Imagem 151. Vista da sede do MASP na Avenida Paulista em construção. Autoria: P. Scheier. Fonte: Acervo do AHJB. 186

Imagem 152. Obras da sede do MASP na Avenida Paulista. Autoria: P. Scheier. Fonte: Acervo do AHJB. 187

Imagem 153. Vista geral do Instituto Sedes Sapientiae, de Rino Levi. Autoria: P. Scheier. Fonte: BURLE-MARX; FILHO (1974), p.50. 188

Imagem 154. Corredor interno do Instituto Sedes Sapientiae, com seu fechamento em elementos vazados. Autoria: P. Scheier. Fonte: ANELLI; GUERRA; KON (2001), p.56. 189

Imagem 155. Escada do Instituto Sedes Sapientiae. Autoria: P. Scheier. Fonte: ANELLI; GUERRA; KON (2001), p.115. 189

Imagem 158. Marquise do Instituto Sedes Sapientiae. Autoria: P. Scheier. Fonte: ANELLI; GUERRA; KON (2001), p.90. 190

Imagem 159. Moças conversam sob a marquise do Instituto Sedes Sapientiae. Autoria: P. Scheier. Fonte: ANELLI; GUERRA; KON (2001), p.115. 190 
Imagem 156. Vista noturna do Instituto Sedes Sapientiae, com destaque para os elementos vazados. Autoria: P. Scheier. Fonte: ANELLI; GUERRA; KON (2001), p.114. 190

Imagem 157. Vista da marquise que interliga os blocos do Instituto Sedes Sapientiae. Autoria: P. Scheier. Fonte: BURLE-MARX; FILHO (1974), p.52. . 190

Imagem 160. Jardim do Instituto Sedes Sapientiae. Autoria: P. Scheier. Fonte: ANELLI; GUERRA; KON (2001), p.53. 191

Imagem 162. Vista a partir da Avenida do Estado da Cia. Jardim de Cafés Finos. Autoria: P. Scheier. Fonte: ANELLI; GUERRA; KON (2001), p.123. ... 192

Imagem 161. Vista a partir da Avenida do Estado da Companhia Jardim de Cafés Finos, de Rino Levi. Autoria: P. Scheier. Fonte: ANELLI; GUERRA; KON (2001), p.122. 192

Imagem 163. Vista a partir da Av. do Estado da Cia. Jardim de Cafés Finos. Em primeiro plano, o refeitório. Autoria: P. Scheier. Fonte: ANELLI; GUERRA; KON (2001), p.123. 192

Imagem 164. Entrada da torre de processamento. Cia. Jardim de Cafés Finos. Autoria: P. Scheier. Fonte: ANELLI; GUERRA; KON (2001), p.123. 193

Imagem 166. Detalhe entre o brise e o caixilho. Ordem dos Advogados do Brasil - OAB, de Rino Levi. Autoria: P. Scheier. Fonte: Acervo Fotográfico da FAUUSP. 193

Imagem 165. Detalhe entre o brise e o caixilho. Cia. Jardim de Cafés Finos. Autoria: P. Scheier. Fonte: ANELLI; GUERRA; KON (2001), p.52. 193

Imagem 167. Detalhe do brise. Ordem dos Advogados do Brasil-OAB. Autoria: P. Scheier. Fonte: Acervo Fotográfico da FAUUSP. 193

Imagem 168. Vista da esquina da Rua Boa Vista com Rua João Brícola. Banco Paulista do Comércio, de Rino Levi. Autoria: P. Scheier. Fonte: ANELLI; GUERRA; KON (2001), p.159. 194

Imagem 169. Banco Paulista do Comércio. Autoria: P. Scheier. Fonte: BURLEMARX; FILHO (1974), p.74. 194

Imagem 170. Vista geral do Instituto Central do Câncer, de Rino Levi. Autoria: P. Scheier. Fonte: MINDLIN (1956), p.155. 195

Imagem 171. Entrada do Instituto Central do Câncer. Autoria: P. Scheier. Fonte: MINDLIN (1956), p.154. 196

Imagem 172. Área de descanso do Instituto Central do Câncer. Autoria: P. 
Scheier. Fonte: MINDLIN (1956), p.154. 196

Imagem 173. Área de descanso do Instituto Central do Câncer. Autoria: P. Scheier. Fonte: MINDLIN (1956), p.157. 197

Imagem 174. Rampas de interligação dos blocos do Instituto Central do Câncer. Autoria: P. Scheier. Fonte: HITCHCOCK (1955), p.119. 197

Imagem 175. Rampas de interligação dos blocos do Instituto Central do Câncer. Autoria: P. Scheier. Fonte: MINDLIN (1956), p.155. 198

Imagem 176. Vista geral do Cine Ipiranga e Hotel Excelsior, de Rino Levi. Autoria: P. Scheier. Fonte: ANELLI; GUERRA; KON (2001), p.118. 198

Imagem 177. Foyer principal do Cine Ipiranga. Autoria: P. Scheier. Fonte: Acrópole, n.61, p.492. Acervo da FAUUSP. 199

Imagem 178. Sala de projeção do Cine Ipiranga. Autoria: P. Scheier. Fonte: ANELLI; GUERRA; KON (2001), p.120. 200

Imagem 179. Balcões da sala de projeção do Cine Ipiranga. Autoria: P. Scheier. Fonte: ANELLI; GUERRA; KON (2001), p.120. 200

Imagem 180. Detalhe da fachada do Hotel Excelsior. Autoria: P. Scheier. Fonte: ANELLI; GUERRA; KON (2001), p.45. 201

Imagem 181. Restaurante da cobertura do Hotel Excelsior. Autoria: P. Scheier. Fonte: ANELLI; GUERRA; KON (2001), p.121 201

Imagem 182. Edifícios Altino Arantes e Martinelli vistos a partir do restaurante da cobertura do Hotel Excelsior. Autoria: P. Scheier. Fonte: ANELLI; GUERRA; KON (2001), p.121. 202

Imagem 183. Vista noturna a partir da Avenida Ipiranga do Cine Ipiranga e Hotel Excelsior. Autoria: P. Scheier. Fonte: ANELLI; GUERRA; KON (2001), p.119. 202

Imagem 184. Obras da Garagem América, de Rino Levi. Autoria: P. Scheier. Fonte: Acervo fotográfico da FAUUSP. 203

Imagem 185. Obras da Garagem América. Autoria: P. Scheier. Fonte: Acervo fotográfico da FAUUSP. 203

Imagem 186. Garagem América vista a partir da Avenida Anhangabaú. Autoria: P. Scheier. Fonte: ANELLI; GUERRA; KON (2001), p. 195. 204

Imagem 187. Garagem América. Autoria: P. Scheier. Fonte: Acervo fotográfico da FAUUSP. 204 
Imagem 188. Garagem América. Autoria: P. Scheier. Fonte: ANELLI; GUERRA;

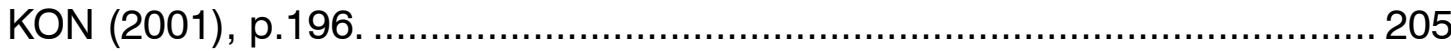

Imagem 189. Vista interna da Garagem América. Autoria: P. Scheier. Fonte: Acervo fotográfico da FAUUSP. 205

Imagem 190. Vista interna da Garagem América. Autoria: P. Scheier. Fonte: Acervo fotográfico da FAUUSP. 206

Imagem 191. Vista interna da Garagem América. Autoria: P. Scheier. Fonte: Acervo fotográfico da FAUUSP. 206

Imagem 192. Acesso pela Rua Riachuelo. Garagem América. Autoria: P. Scheier. Fonte: Acervo fotográfico da FAUUSP. 207

Imagem 193. Capa do álbum comemorativo do primeiro centenário do Estado do Paraná, publicado em 1953. Fonte: Acervo do AHJB. 212

Imagem 194. Brasília, vista noturna de um edifício. Autoria: P.Scheier. Fonte: SCHEIER (s.d.), p.11. 213

Imagem 195. Brasília. Autoria: P.Scheier. Fonte: SCHEIER (s.d.), p.28 .... 214 Imagem 196. Capa do livro sobre as cidades históricas mineiras, publicado em 1968. Fonte: Acervo do AHJB 215

Imagem 197. "Ladeira do Palácio, 1862" (legenda original). Autoria: Militão Augusto de Azevedo. Álbum Comparativo da Cidade de São Paulo: 1862-18871914, p.20. Fonte: LIMA; CARVALHO (1997), p.129. 220

Imagem 198. Rua João Alfredo (antiga Ladeira do Palácio), 1887. Autoria: Militão Augusto de Azevedo. Fonte: TOLEDO; KOSSOY; LEMOS (1981), s/p. 220

Imagem 199. "Rua General Carneiro, 1914" (legenda original). Álbum Comparativo da Cidade de São Paulo: 1862-1887-1914, p.22. Fonte: LIMA; CARVALHO (1997), p.129. 222

Imagem 200. "Ruas Direita e 15 de Novembro (vistas do Largo da Sé) - São Paulo" (legenda original). Álbum de Vistas de São Paulo. Fonte: LIMA; CARVALHO (1997), p.144. 223

Imagem 201. "Viaduto do Chá, 1916" (legenda original). Álbum Comparativo da Cidade de São Paulo: 1862-1916, p. 97. Fonte: LIMA; CARVALHO (1997), p.132. 224

Imagem 202. Palácio do Governo (legenda original). Álbum de São Paulo. Fonte: LIMA; CARVALHO (1997), p.39. 225 
Imagem 203. Teatro Municipal e edifício C.B.I. "Casas com apenas metade de existência útil são demolidas, toda vez que assim o exija a marcha triunfante dos arranha-céus" (legenda original). Autoria: Georg Paulus Waschinski./sto É São Paulo. 96 flagrantes da Capital Bandeirante. Fonte: LIMA; CARVALHO (1997), p.172. 230

Imagem 204. "Novos arranha-céus pulam para cima" (legenda original). Autoria: Georg Paulus Waschinski. Eis São Paulo, p.195. Fonte: LIMA; CARVALHO (1997), p.176. 231

Imagem 205. Bolsa do Café. Autoria: Georg Paulus Waschinski. Eis São Paulo, p.69. Fonte: LIMA; CARVALHO (1997), p.34. 233

Imagem 206. Praça da Bandeira. "(...) as companhias de transportes que, com o tráfego cada vez mais intenso, cruzam as ruas congestionadas (...)" (legenda original). Autoria: Georg Paulus Waschinski. Eis São Paulo, p. 103. Fonte: LIMA; CARVALHO (1997), p.199. 234

Imagem 207. Navio no porto. Autoria: P. Scheier. Fonte: SCHEIER (1954), p.11. 245

Imagem 208. Bolsa do Café em Santos. Autoria: P. Scheier. Fonte: SCHEIER (1954), p.12. 245

Imagem 209. Aeroporto de Congonhas. Autoria: P. Scheier. Fonte: SCHEIER (1954), p.126. 247

Imagem 210. Aeroporto de Congonhas. Autoria: Alice Brill. Fonte: FRANCESCHI (2004), p.214. 247

Imagem 211. Avião no sertão de Goiás. Autoria: P. Scheier. Fonte: SCHEIER (1954), p.127. 248

Imagem 212. "O Semeador", no Parque D. Pedro II. Autoria: P. Scheier. Fonte: SCHEIER (1954), p.128. 248

Imagem 213. Viaduto do Chá. Autoria: P. Scheier. Fonte: SCHEIER (1954), p.58. 251

Imagem 214. Avenida Ipiranga, com o Edifício Esther à direita. Autoria: P. Scheier. Fonte: SCHEIER (1954), p.38. 252

Imagem 215. Praça da República e Avenida Ipiranga ao fundo. Autoria: P. Scheier. Fonte: SCHEIER (1954), p.38. 253

Imagem 216. Loja na Avenida Ipiranga. Autoria: P. Scheier. Fonte: SCHEIER (1954), p.67. 253 
Imagem 217. Vista aérea do centro de São Paulo. Autoria: P. Scheier. Fonte: SCHEIER (1954), p.18.

Imagem 218. Vista aérea da Avenida Ipiranga, Praça da República e Avenida São Luís. Autoria: P. Scheier. Fonte: SCHEIER (1954), p.18. 255

Imagem 219. Vista aérea do centro, com destaque para os edifícios Altino Arantes, Martinelli e Banco do Brasil. Na parte superior vê-se a Catedral da Sé em construção; à esquerda, o Pátio do Colégio, com seu monumento "Glória Imortal aos Fundadores de São Paulo", de Amadeo Zani. Autoria: P. Scheier. Fonte: SCHEIER (1954), p.51. 257

Imagem 220. Avenida São João a partir do edifício Altino Arantes. Em primeiro plano, o cruzamento com a Rua Líbero Badaró, no qual se vêem os edifícios Martinelli, à esquerda, e o Banco do Brasil em obras, à direita. Autoria: P. Scheier. Fonte: SCHEIER (1954), p.14. 258

Imagem 221. Avenida São João, com o edifício Altino Arantes ao centro. À esquerda, Banco do Brasil em construção. Sobre o tapume da obra, vários anúncios de cigarros e dos móveis "Ambiente". Foto tirada às 11:30, conforme indica o relógio. Autoria: P. Scheier. Fonte: SCHEIER (1954), p.15. 259

Imagem 222. Equitable Trust Building, em New York. Autoria: Eric Mendelsohn. Fonte: ELWALL (2004), p.132. 259

Imagem 223. Esquina da Rua São Bento com Avenida São João. No térreo do Martinelli ficava o Banco da América. Lêem-se ainda as placas do "Centro Gaúcho", "Gazeta Mercantil - industrial - econômica e financeira - 5o andar publicação de balanços, atas, editais, etc", "Escritório Levy Limitada". Autoria: P. Scheier. Fonte: SCHEIER (1954), p.54. 260

Imagem 224. Praça das Bandeiras. Autoria: P. Scheier. Fonte: SCHEIER (1954), p.29. 262

Imagem 225. Vale do Anhangabaú. Autoria: P. Scheier. Fonte: SCHEIER (1954), p.41. 263

Imagem 226. New York, década de 1930. Autoria: Berenice Abbot. Fonte: ELWALL (2004), p.152. 263

Imagem 227. Vale do Anhangabaú e Edifício Matarazzo. Autoria: P. Scheier. Fonte: SCHEIER (1954), p.40. 264

Imagem 228. Vale do Anhangabaú. Autoria: P. Scheier. Fonte: SCHEIER (1954), p.45. 264

Imagem 229. Vila Normanda. Autoria: P. Scheier. Fonte: SCHEIER (1954), p.45. 
Imagem 230. Obra na cobertura do Edifício Vitória Régia. Autoria: Hans Günter Flieg. Fonte: FRANCESCHI (2004), p.198. 266

Imagem 231. Obra no Vale do Anhangabaú. Autoria: P. Scheier. Fonte: SCHEIER (1954), p.52. 267

Imagem 232. Obra na Praça da Sé. Autoria: P. Scheier. Fonte: SCHEIER (1954), p.22. 267

Imagem 233. Cine Ipiranga e Hotel Excelsior a partir da Praça da República. Autoria: P. Scheier. Fonte: SCHEIER (1954), p.32. 271

Imagem 234. Edifício Prudência. Autoria: P. Scheier. Fonte: SCHEIER (1954), p.42. 272

Imagem 235. Banco Paulista. Autoria: P. Scheier. Fonte: SCHEIER (1954), p.24. 273

Imagem 236. Edifício C.B.I., a partir do Viaduto do Chá. Autoria: P. Scheier. Fonte: SCHEIER (1954), p.27. 273

Imagem 237. Biblioteca Municipal. Autoria: P. Scheier. Fonte: SCHEIER (1954), p.70. 274

Imagem 238. Biblioteca Municipal. Autoria: Leon Liberman. Fonte: Acrópole, n.68, p.208. 274

Imagem 239. Igreja de Santo Antônio, na Praça do Patriarca. Autoria: P. Scheier. Fonte: SCHEIER (1954), p.31. 275

Imagem 240. Flatiron Building, em New York. Autoria: Alfred Stieglitz. Fonte: ELWALL (2004), p.113. 275

Imagem 241. Edifício Sobre as Ondas, Guarujá. Autoria: P. Scheier. Fonte: SCHEIER (1954), p.100. 276

Imagem 242. Edifício Residencial Washington. Autoria: P. Scheier. Fonte: SCHEIER (1954), p.35 276

Imagem 243. Residência Lina Bo Bardi. Autoria: P. Scheier. Fonte: SCHEIER (1954), p.82. 277

Imagem 244. Jardim interno da residência Lina Bo Bardi. Autoria: P. Scheier. Fonte: SCHEIER (1954), p.82. 278

Imagem 245. Oscar Niemeyer em frente à imagem do Edifício Copan. Autoria: P. Scheier. Fonte: SCHEIER (1954), p.89. 279 Imagem 246. Processo de compra e venda de imóvel construído pelo Banco 
Nacional Imobiliário. Autoria: P. Scheier. Fonte: SCHEIER (1954), p.88 ..... 280

Imagem 247. Mulher analisa os documentos do imóvel. Autoria: P. Scheier. Fonte: SCHEIER (1954), p.88. 281

Imagem 248. Homem marca as unidades já vendidas. Autoria: P. Scheier. Fonte: SCHEIER (1954), p.89. 281

Imagem 249. Vista aérea de indústria. Autoria: P. Scheier. Fonte: SCHEIER (1954), p.123. 282

Imagem 250. Indústriasiderúrgica em Mogidas Cruzes. Publicada originalmente em O Cruzeiro de 01/01/1950, à página 73. Autoria: P. Scheier. Fonte: SCHEIER (1954), p.123. 283

Imagem 251. Interior de uma fábrica. Autoria: P. Scheier. Fonte: SCHEIER (1954), p.124. 283

Imagem 252. Fábrica da Ford, em Detroit, década de 1920. Autoria: Charles Sheeler. Fonte: ELWALL (2004), p.146. 284

Imagem 253. Interior da fábrica Aliança. Autoria: P. Scheier. Fonte: SCHEIER (1954), p.125. 284

Imagem 254. Fábrica no Brás. Autoria: P. Scheier. Fonte: SCHEIER (1954), p.118. 285

Imagem 255. Operário da fábrica Aliança. Autoria: P. Scheier. Fonte: SCHEIER (1954), p.125. 285

Imagem 256. Fac símile das páginas 70 e 71 da reportagem "Mogi das Cruzes, cidadela do aço", em O Cruzeiro de 07/01/1950. Autoria: P. Scheier. Fonte: Acervo do MASP. 286

Imagem 257. Operário na fábrica Aliança. Publicada na reportagem "A "Aliança" faz a força" em O Cruzeiro de 14/01/1950, p.59. Autoria: P. Scheier. Fonte: Acervo do MASP. 287

Imagem 259. Capa do livro Arbeit!, de Paul Wolff. Fonte: http://home.snafu.de/ boehme/Liste14/221\%20wolffarbeit.JPG. 287

Imagem 258. Foto publicada no calendário Pirelli, em 1948. Autoria: Hans Günter Flieg. Fonte: http://www.fotoplus.com/flieg/index.html. 287

Imagem 260. Montagem da exposição "New World of Space". Autoria: P. Scheier. Fonte: SCHEIER (1954), p.77. 289

Imagem 261. Curso de tecelagem do IAC. Autoria: P. Scheier. Fonte: SCHEIER (1954), p.77. 290 
Imagem 262. Visitante no MASP. Autoria: P. Scheier. Fonte: SCHEIER (1954), p.75.

Imagem 263. Pinacoteca do MASP. Autoria: Hans Günter Flieg. Fonte: FRANCESCHI, p.199. 291

Imagem 264. Sala de leitura da Biblioteca Municipal. Autoria: P. Scheier. Fonte: SCHEIER (1954), p.73. 292

Imagem 265. Museu do Ipiranga. Autoria: P. Scheier. Fonte: SCHEIER (1954), p.79. 292

Imagem 266. Vista dos jardins do Museu do Ipiranga. Autoria: P. Scheier. Fonte: SCHEIER (1954), p.78. 293

Imagem 267. Lanchonete "Salada Paulista". Autoria: P. Scheier. Fonte: SCHEIER (1954), p.119. 294

Imagem 268. Cafezinho na "Salada Paulista". Autoria: P. Scheier. Fonte: SCHEIER (1954), p.59. 295

Imagem 269. Cafezinho. Autoria: Alice Brill. Fonte: FRANCESCHI (2004), p.208. 295

Imagem 270. Sala de projeção do Cine Ipiranga. Autoria: P. Scheier. Fonte: SCHEIER (1954), p.64. 296

Imagem 271. Fachada do Cine Marabá. Autoria: P. Scheier. Fonte: SCHEIER (1954), p.65. 297

Imagem 272. Casal no restaurante. Os caixotes de garrafas de vinho italianos ocupam o primeiro plano: "Fornitori Pontifici" e "Il Rufino". Os queijos tipo parmesão e as lingüiças pendurados no teto e nas paredes completam a ambientação do local. Autoria: P. Scheier. Fonte: SCHEIER (1954), p.116.. 298

Imagem 273. Praça Charles Miller e Estádio do Pacaembu. Autoria: P. Scheier. Fonte: SCHEIER (1954), p.46. 298

Imagem 274. Interior do Estádio do Pacaembu. Autoria: P. Scheier. Fonte: SCHEIER (1954), p.97 299

Imagem 275. Homens lendo jornal de esportes. Autoria: P. Scheier. Fonte: SCHEIER (1954), p.113. 299

Imagem 276. Via Anchieta. Autoria: P. Scheier. Fonte: SCHEIER (1954), p.98. 301

Imagem 277. Clube da Orla, no Guarujá. Autoria: P. Scheier. Fonte: SCHEIER (1954), p.99. 
Imagem 278. Casal dançando boogie-woogie. Autoria: P. Scheier. Fonte:

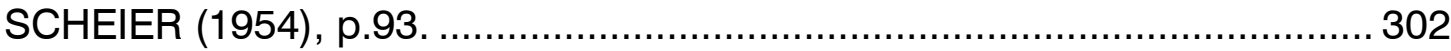

Imagem 279. Banda toca em baile. Autoria: P. Scheier. Fonte: SCHEIER (1954), p.92. 302

Imagem 280. Baile infantil de carnaval. Autoria: P. Scheier. Fonte: SCHEIER (1954), p.91 303

Imagem 282. Luiz Gonzaga toca para crianças em baile de carnaval. Autoria: P. Scheier. Fonte: SCHEIER (1954), p.92. 303

Imagem 281. Criança descansa em baile infantil de carnaval. Autoria: P. Scheier. Fonte: SCHEIER (1954), p.91. 303

Imagem 283. Palhaço Piolim. Autoria: P. Scheier. Fonte: SCHEIER (1954), p.90. 304

Imagem 284. Bebês choram. Autoria: P. Scheier. Fonte: SCHEIER (1954), p.111. 304

Imagem 285. Bebês dormem. Autoria: P. Scheier. Fonte: SCHEIER (1954), p.108. 305

Imagem 286. Escola infantil. Autoria: P. Scheier. Fonte: SCHEIER (1954), p.108. 305

Imagem 287. Planta e elevação de escola típica da arquitetura do Convênio Escolar. Fonte: Habitat, n.04, p.17. 306

Imagem 288. Mulher manipula tubos de ensaio. Autoria: P. Scheier. Fonte: SCHEIER (1954), p.81 307

Imagem 289. Vista aérea do Hospital das Clínicas. À frente vemos a Escola de Enfermagem. À direita, o Instituto de Psiquiatria e, à sua frente, a Clínica Ortopédica e Traumatológica. À esquerda, no segundo plano, vemos o Instituto Central. Ao fundo vemos a Avenida Rebouças, com árvores espaçadas no canteiro central, a Alameda Lorena e a Alameda Tietê. Autoria: P. Scheier. Fonte: SCHEIER (1954), p.120. 308

Imagem 290. Monge dominicano. Autoria: P. Scheier. Fonte: SCHEIER (1954), p.102. 309

Imagem 292. Portão do Mosteiro da Luz. Autoria: P. Scheier. Fonte: SCHEIER (1954), p.103 309

Imagem 291. Interior da Igreja Nossa Senhora do Carmo. Autoria: P. Scheier. Fonte: SCHEIER (1954), p.107. 309 
Imagem 293. Vendedor ambulante. Autoria: P. Scheier. Fonte: SCHEIER (1954), p.57. 310

Imagem 294. Banca de revistas. Autoria: P. Scheier. Fonte: SCHEIER (1954), p.58.

Imagem 295. Banca de revistas. Autoria: Alice Brill. Fonte: O mundo de Alice Brill (2005), p.25. 311 Imagem 296. Farmácia. Autoria: P. Scheier. Fonte: SCHEIER (1954), p.61. 312

Imagem 297. Comércio de auto peças na Avenida São João. Autoria: P. Scheier. Fonte: SCHEIER (1954), p.62. 313 Imagem 298. Interior do Banco da América. Autoria: P. Scheier. Fonte: SCHEIER (1954), p.66. 314 Imagem 299. Passageiros no bonde. Autoria: P. Scheier. Fonte: SCHEIER (1954), p.57. 315 Imagem 300. Entregador de lavanderia. Autoria: P. Scheier. Fonte: SCHEIER (1954), p.11 316 


\section{Sumário}

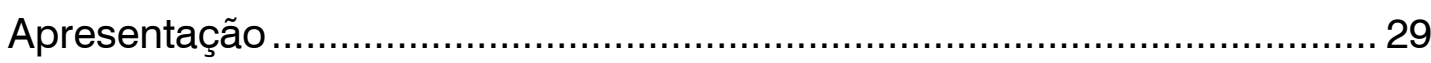

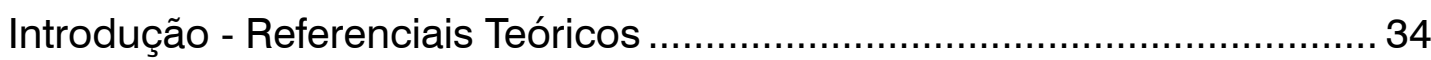

Parte I - A documentação fotográfica de Peter Scheier ................................ 42

Capítulo 1 - De comerciante a fotógrafo ..................................................... 43

1.1 A Primeira Guerra Mundial e a efervescência cultural na Alemanha ........................44

1.1.1 A fotografia na Alemanha nas primeiras décadas do século XX ................48

1.2 A Segunda Guerra Mundial e o refúgio no Brasil ............................................56

1.30 início da profissão de fotógrafo na São Paulo dos anos 1940 ..........................64

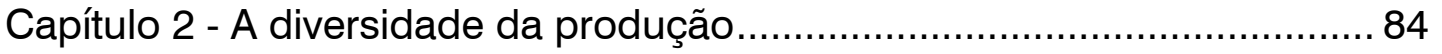

2.1 Fotojornalismo na revista O Cruzeiro (1945 a 1951) ........................................90

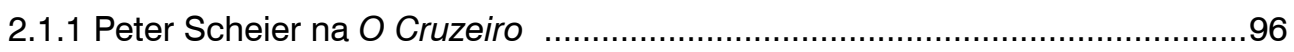

2.1.2 São Paulo nas páginas da O Cruzeiro, segundo Peter Scheier ..................102

2.2 O Museu de Arte de São Paulo (1947-1953) e a revista Habitat (1951-1953)...........126

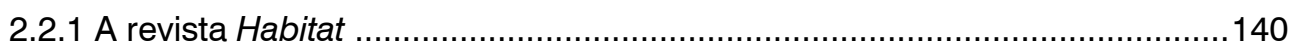

2.2.2 1a Bienal Internacional de São Paulo (1951) .....................................148

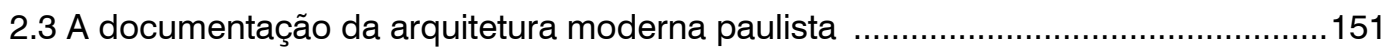

2.3.1 Cinco arquitetos nas lentes de Peter Scheier ........................................155

Parte II - A cidade que mais cresce no mundo ……….............................. 209

Capítulo 3 - A construção da imagem ideal da cidade: os álbuns fotográficos 210

3.1 O IV Centenário em obras e álbuns 226

Capítulo 4 - São Paulo como síntese da produção de Peter Scheier até os anos 1950. 238

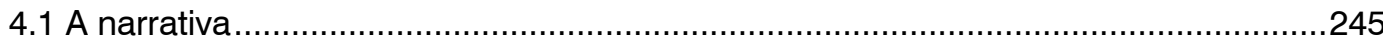

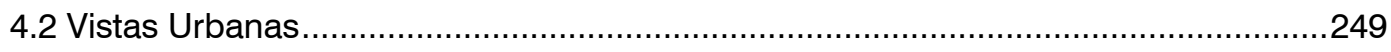

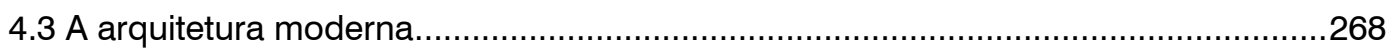

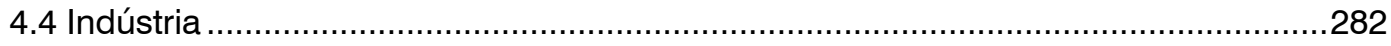


Conclusão

Referências Bibliográficas 322

Obras Consultadas 331

Apêndices

337

Apêndice A - Cronologia de Peter Scheier 338

Apêndice B - Reportagens de Peter Scheier em O Cruzeiro - 1945 a 1951. 349

Apêndice C - As fotos de São Paulo fastest growing city in the world 363

Apêndice D - O caminho de Peter Scheier no álbum São Paulo fastest growing city in the world 404

Anexo A - Textos introdutórios do álbum São Paulo fastest growing city in the world 405 


\section{Apresentação}

O tema do projeto de pesquisa inicial era "Fotografia de Arquitetura no Brasil: profissionais em São Paulo e Rio de Janeiro no século XX". A proposta visava ao traçado do panorama da produção dos profissionais estabelecidos nestas duas cidades onde a documentação específica foi mais intensa, principalmente nas décadas de 1930 a 1960, quando surgiram importantes revistas especializadas em arquitetura, como Acrópole e Habitat, em São Paulo, e Módulo, no Rio de Janeiro. O levantamento de nomes, locais de atuação e principais publicações livros e periódicos - embasaria a discussão a respeito da fotografia de arquitetura e a compreensão de seus mecanismos, suas diretrizes, seus métodos e sua contribuição para a formação e difusão da imagem e identidade da arquitetura brasileira.

Após a fase preliminar, o progresso da coleta de dados se estagnou. 
A inexistência ou divergência de créditos nas publicações não permitia a sistematização e formatação do banco de dados. Somado a isso, poucos fotógrafos mantiveram acervo organizado e em condições adequadas de conservação.

Notou-se que a concentração da pesquisa em um único fotógrafo seria mais enriquecedor, ao permitir maior aprofundamento, tanto de questões teóricas quanto práticas. Seria possível perceber as influências de sua vivência pessoal, de sua prática profissional em eventuais outras produções e, a partir disso, inseri-lo dentro do quadro geral. A fotografia de arquitetura não deve ser examinada isoladamente: a referência a outras práticas solidifica a análise.

Após o estudo de publicações referenciais de arquitetura e o acervo de fotografias da FAU, certos nomes eram constantes. O passo seguinte foi a coleta de material específico sobre cada profissional, começando por livros autorais. Dois trabalhos chamaram a atenção pela qualidade das fotos e importância dentro da bibliografia especializada: São Paulo fastest growing city in the world e Brasília vive!, de Peter Scheier. Foram encontradas referências do álbum São Paulo em vários livros, como Fotografia e cidade: da razão urbana à lógica de consumo: álbuns de São Paulo, 1887-1954, de Solange Ferraz de Lima, Vânia Carneiro de Carvalho, e no catálogo da exposição "SP 450: entre lembranças e utopias", realizada em 2004 pelo Museu de Arte Brasileira da FAAP. A partir das pesquisas em acervos, das entrevistas e do material iconográfico coletado, Scheier foi selecionado. A disponibilidade de um acervo ainda não analisado, no Arquivo Histórico Judaico Brasileiro, constituiu um campo de pesquisa amplo.

O objeto de pesquisa é a fotografia urbana e de arquitetura. Nesta dissertação, ela é analisada com base em um álbum comemorativo do quarto centenário da cidade de São Paulo, de autoria de Peter Scheier. O recorte justifica-se pelo maior aprofundamento possibilitado e pela dinamização da 
pesquisa, que ganha maior consistência e maior volume de informações, que compõem uma base sólida para a continuidade do estudo neste campo.

Editado em 1954, São Paulo fastest growing city in the world traz conteúdo informacional extenso, não só sobre a cidade na década de 1950, mas também a respeito de Peter Scheier, uma vez que foi elaborado a partir de material de seu arquivo - fotografias publicadas, por exemplo, nas revistas $O$ Cruzeiro e Habitat, no livro Modern Architecture in Brazil e produzidas para o MASP, do qual era fotógrafo oficial. Através da prática profissional de Peter Scheier é possível compreender a dinâmica da atividade dos fotógrafos de arquitetura e o mercado em que atuavam. Cada profissional tinha suas particularidades, mas a composição de um quadro bem detalhado de Scheier forma uma base para discussão e análise dos demais fotógrafos.

A dissertação está organizada em duas partes.

Na primeira parte - A documentação fotográfica de Peter Scheier -, composta por dois capítulos, são tratados os fatos biográficos, desde sua vida na Alemanha, o quadro cultural da época, a deflagração da Segunda Guerra e seu estabelecimento no Brasil. O primeiro capítulo contextualiza a situação política, econômica, social e cultural da Alemanha no início do século XX. São analisados os condicionantes da imigração de Peter Scheier e o início da sua profissão em São Paulo. São levantadas também a produção cultural e fotográfica na Alemanha, base referencial para a obra de Scheier. Relata-se o início de sua profissão como fotógrafo e um quadro das condições dos profissionais na época - equipamentos, materiais de laboratório, bibliografia disponível, estabelecimentos comerciais, clientes e mercado de trabalho - composto por informações colhidas através de depoimentos, do levantamento de bibliografia especializada e da análise de material original de Scheier. 
No segundo capítulo é abordado o amadurecimento de seu trabalho, pontuando sua documentação de eventos sociais, publicitária e industrial. Enfatiza-se seu trabalho como fotojornalista da revista $O$ Cruzeiro e como fotógrafo oficial do Museu de Arte de São Paulo - MASP - e colaborador da revista Habitat. Sua documentação da arquitetura moderna paulista também é analisada neste capítulo, descrevendo seu registro das obras de Rino Levi, Lina Bo Bardi, Gregory Warchavchik, Oswaldo Bratke e Bernardo Rudofsky.

A segunda parte - A cidade que mais cresce no mundo - baseia-se no álbum São Paulo, considerado aqui como uma síntese dos primeiros quinze anos da produção fotográfica de Peter Scheier por reunir imagens de seu acervo produzidas para O Cruzeiro, para o MASP, de arquitetura e fotos produzidas sem fins de publicação. Essa característica destaca-o dos seus demais livros sobre Paraná, Brasília e Minas Gerais, cujo material foi produzido especificamente para sua publicação. Assim, o álbum pode ser interpretado como o primeiro momento de reunião e revisão de sua obra. O segundo foi cerca de vinte anos mais tarde, em 1970, às vésperas de fechar seu estúdio, quando o MASP recebeu sua única exposição em vida: "30 Anos de Visão e Multivisão".

No terceiro capítulo são feitas considerações sobre a documentação dos álbuns fotográficos, suas origens, seus condicionantes e seus objetivos. Refletese mais profundamente sobre o IV Centenário da cidade de São Paulo, momento em que a cidade presenciou transformações em todos os campos, adquirindo contornos de metrópole. O ritmo de vida urbana foi alterado, sendo que a antiga cidade - moldada na dinâmica da economia cafeeira - cedia o lugar para a nova, baseada na indústria. E não somente a indústria crescia, mas também a rede de transporte, a diversificação do comércio e o sistema bancário. Em suma, a cidade passava por transformações na dinâmica da produção e nas formas de sociabilidade. 
No último capítulo é analisado o álbum. Dentro do discurso corrente no IV Centenário, são levantadas as questões sobre a organização do álbum, os temas escolhidos, as regiões documentadas. Por se tratar de uma coletânea de imagens anteriormente produzidas por Peter Scheier, são feitas comparações, quando coerentes, sobre o contexto original da publicação e sua nova inserção no álbum.

A análise deste livro fornece não só um quadro característico da cidade dos anos 1950, mas também complementa as informações pessoais de Peter Scheier, desvendando muitas vezes seu método de trabalho, seus relacionamentos, suas referências. Acredita-se que essa análise conclui todos os temas abordados durante a pesquisa, reunindo a pesquisa histórica, biográfica e documental. 


\section{Introdução - Referenciais Teóricos}

A análise das imagens neste trabalho se baseia nos fundamentos teóricos discutidos durante o curso de pós-graduação e levantadas na bibliografia especializada, sendo uma das principais referências os textos de Boris Kossoy, cujos principais pontos são aqui transcritos. De Fotografia \& História ${ }^{1}$ foram tomados pontos referentes à metodologia de análise da fotografia enquanto documento. De Realidades e Ficções na Trama Fotográfica ${ }^{2}$, onde é abordada a questão da fotografia como representação, foram fundamentais os conceitos ligados ao processo de construção de interpretação da imagem fotográfica. Finalmente, a leitura de Os Tempos da Fotografia: o Efêmero e o Perpétuo ${ }^{3}$ complementou pontos dos dois primeiros textos referentes à questão dos 1 KOSSOY, Boris. Fotografia \& História. São Paulo, Ateliê Editorial, 2001.

2 . Realidades e Ficções na Trama Fotográfica. São Paulo, Ateliê Editorial, 2002.

3 - Os Tempos da Fotografia: o Efêmero e o Perpétuo. Cotia, SP: Ateliê Editorial, 2007. 
tempos da fotografia e ao processo de elaboração mental de conceitos e interpretações.

A questão fundante da fotografia é a soma de um recorte espacial e de uma interrupção temporal (ou seja, a paralisação do tempo), cujo resultado é um fragmento. Disto derivam imediatamente dois pontos: o primeiro refere-se à palavra recorte, que supõe um agente seletor e, conseqüentemente, uma subjetividade. O segundo refere-se ao fragmento, ou seja, a parte de um todo, mas que freqüentemente é usado como o geral - $\mathrm{e}$ isto nos remete à questão da fidedignidade. De maneira geral esta operação somatória aponta para dois elementos definidores da fotografia, denominadas nos textos referidos como coordenadas de situação - tempo e espaço, que determinam o contexto histórico específico em seus desdobramentos sociais, econômicos, políticos, culturais. Todo o processo de construção da imagem fotográfica é originado por três elementos constitutivos: ASSUNTO, TÉCNICA e FOTÓGRAFO.

Toda imagem fotográfica é construída através de mecanismos mentais: o processo de construção da representação - a produção da obra fotográfica pelo fotógrafo e sua pós-produção - e o processo de construção da interpretação - a recepção da obra fotográfica por parte dos diferentes receptores, em diferentes momentos da história. A imagem fotográfica não pode ser compreendida independentemente dos processos de construção que a geraram.

A construção da imagem engloba a produção (elaborada pelo fotógrafo) e a pós-produção ou edição. É um processo de criação, uma elaboração mental que embute na imagem diversos códigos. É materializado cultural, estética, ideológica e tecnicamente, de acordo com a visão particular e a intenção do fotógrafo e dos demais agentes.

É fundamental compreender que o processo de criação é uma somatória 
de construções, de montagens. A fotografia incorpora componentes de ordem material (recursos técnicos, ópticos, químicos ou eletrônicos, necessários para a sua materialização) e de ordem imaterial (mentais e culturais), articulados na mente e nas ações do fotógrafo ao longo do processo de criação. Sua conexão física com seu referente se dá, portanto, através de um filtro cultural, estético e técnico. Ou seja, o fotógrafo constrói a representação, segundo seu desejo individual de expressão (motivação interior e pessoal) ou determinada aplicação (motivação exterior ou profissional).

A manipulação ocorre em todas as etapas do processo de construção. $O$ fotógrafo produz a imagem em função de sua forma particular de compreensão do real, seu repertório pessoal, seus filtros individuais e sua ideologia. A primeira opção feita pelo fotógrafo é a seleção do assunto em função de determinada finalidade; em seguida organiza visualmente os detalhes e explora os recursos oferecidos pela tecnologia. A construção, pois, é uma soma de seleções diferentes: assunto, equipamento, filme, composição (organização visual), do momento, materiais de laboratório, interferências diretas. Essa sucessão de interferências que ocorre entre o assunto e a imagem materializada altera a informação primeira: o assunto representado na imagem é um novo real, interpretado e idealizado, no qual transparece a atitude do fotógrafo diante da realidade, seu estado de espírito e sua ideologia, sua sensibilidade e sua criatividade. Qualquer imagem pode ser dramatizada ou estetizada de acordo com a ênfase pretendida pelo fotógrafo conforme a aplicação a que se destina. Assim, qualquer que seja o assunto registrado, a foto sempre documenta a visão de mundo do fotógrafo, constituindo-se, deste modo, em duplo testemunho: testemunho daquilo que mostra do passado e daquilo que nos informa acerca do fotógrafo. É o que Kossoy denomina de binômio testemunho-criação ou documento-representação, que é a ambigüidade inerente à fotografia. 
A foto é a organização do aparente, elaborada pelo fotógrafo num dado instante da realidade, produzindo uma imagem que fornece testemunho visual e material dos fatos aos espectadores ausentes naquela determinada cena. Devido ao registro indicial da aparência, é tomada como documento do real e seu conteúdo é usado como prova e evidência. Há uma falsa idéia de objetividade, neutralidade e isenção, que garante a fidedignidade do registro e a aceitação e assimilação de seus conteúdos como expressão da verdade pelas massas. Desta forma, a foto pode se prestar aos mais diferentes e interesseiros usos dirigidos de usuários como a polícia, a jurisprudência e o jornalismo, que vêem na fotografia um poderoso instrumento para veiculação das idéias e conseqüente formação e manipulação da opinião pública. Entretanto, a realidade da foto não corresponde necessariamente à verdade histórica, mas apenas ao registro expressivo da aparência, no qual ocorrem omissões intencionais, acréscimos e manipulações, em diferentes níveis. Em suma, não é verdade absoluta, é apenas verdade iconográfica.

Até aqui falamos da produção da imagem, elaborada pelo fotógrafo. O clique fotográfico, o ato no qual o objeto tem sua imagem cristalizada na bidimensionalidade do material sensível, marca dentro do processo de construção da representação o fim do tempo da criação, isto é, o tempo da concepção até o momento do registro (a produção), e o início do tempo da representação, que é a história do documento (pós-produção e interpretação).

Para as fotos veiculadas nos meios de comunicação, o processo de construção da representação não se finaliza com a materialização da imagem através do processo de criação do fotógrafo. Continua na chamada pós-produção ou editoração da imagem, na qual sofre adaptações visando sua inserção na página. Estas adaptações podem ser alterações físicas em sua forma, como cortes no seu formato original para que se encaixe em determinado espaço, ou 
cortes intencionais para que mostre apenas parte do assunto, segundo algum interesse determinado do editor.

As imagens são vulneráveis às alterações de seus significados em função do título, dos textos, das legendas, da forma como são paginadas e da diagramação com outras fotos (em busca de possíveis contrapontos). Também podem ter seus significados alterados devido à sua reutilização em situação diferente daquela para a qual foram produzidas originalmente, facilmente exeqüível através da inserção uma nova legenda ou título.

A imagem aplicada em algum veículo de informação sempre sofre o acréscimo de um texto, o que influencia a sua percepção. Aplicada em determinado artigo, de forma comprobatória ou opinativa, ela passa por uma reelaboração em conjunto com o texto, com o propósito de conduzir e controlar o ato de recepção numa determinada direção. Ou seja, interpretações préconstruídas pelo próprio veículo que influenciarão a interpretação. Ou ainda, a criação de um novo documento a partir do original visando gerar uma diferente compreensão dos fatos. Uma nova realidade.

Todas as considerações até aqui trataram do processo de construção da representação - a produção da obra fotográfica pelo fotógrafo e sua pósprodução. Todas as ações - conscientes ou inconscientes - deste primeiro processo culminarão no processo de construção da interpretação, que se constitui na recepção da obra fotográfica por parte dos diferentes receptores, em diferentes momentos da história.

O processo de construção da interpretação está fundado na evidência fotográfica, elaborado no imaginário dos receptores, de acordo com seus repertórios pessoais culturais, seus conhecimentos, concepções ideológicas e estéticas, convicções morais, éticas, religiosas, interesses econômicos, 
profissionais, mitos. Resulta, portanto, em leituras plurais, dependendo de quem as aprecia.

Toda vez que uma fotografia é assimilada pela mente, estabelece-se em nossa memória um arquivo visual de referência, composto por imagens mentais originadas da nossa experiência do real e configuradas em função de nosso repertório pessoal. Esse arquivo, mesclado à nossa personalidade, sensibilidade, moral, etc. forma os chamados filtros culturais. Frente a uma fotografia, cada um tem uma reação diferente, em função de seus filtros e, além disso, de sua imaginação e emoção.

$\mathrm{Na}$ mente do receptor a imagem fotográfica ultrapassa $\mathrm{o}$ fato que representa. Dependendo dos estímulos provocados pela imagem o receptor entra num processo de recriação de situações conhecidas ou jamais vivenciadas. Ou ainda esta imagem sofre adaptações e interpretações convenientes, seja por quem desconhece o referente, seja por quem é engajado a determinada ideologia e busca adequar significados a seus valores, comprometimentos ou posturas. Como coloca Kossoy, não há "interpretações-padrão" 4: a recepção é moldável de acordo com nossas imagens mentais, conhecimentos e intenções. Este é o processo de criação/construção de realidades e de ficções, quando as imagens técnicas e visuais (produtos da indústria cultural) interagem com nossas imagens mentais.

A fotografia é a transposição de realidades: da realidade visual do assunto selecionado no contexto da vida - que Kossoy denomina de primeira realidade - para a realidade da representação - a segunda realidade. A primeira realidade é o próprio passado, a história particular do assunto independente da representação. A segunda realidade é a realidade do assunto representado bidimensionalmente. É a realidade fotográfica do documento, da representação $4 \quad$ KOSSOY (2002). Op. cit, p. 46. 
construída e, portanto, codificada.

A imagem também é parte da primeira realidade, por um único momento: o instante de curtíssima duração em que se dá o ato do registro, quando o referente reflete a luz. Neste exato instante em que o objeto foi interrompido, o ato gerador torna-se passado e a imagem obtida já integra a segunda realidade, na qual o objeto, embora ausente, pode ser (re)apresentado, eternamente. O tempo da representação perpetua a memória, sempre disponível, de um passado, inacessível.

Do ponto de vista do receptor existe um confronto constante entre o documento presente (originado no passado) e o próprio passado, inatingível fisicamente - em outras palavras, um confronto entre a realidade visível (segunda realidade - a representação) e a que se imagina, invisível (primeira realidade - o fato passado). O fato passado é fixo, imutável e irreversível; a realidade registrada também o é, porém está sujeita a múltiplas interpretações que integram um processo sucessivo e interminável de construção e criação de novas realidades.

Para desconstruir estas realidades é preciso ultrapassar a barreira iconográfica do registro em busca de seus significados implícitos. Decifrar significa resgatar a realidade interior, o sentido da vida e das idéias - primeira realidade - escondido sob a aparência de suas realidades exteriores, aparentes - segunda realidade. Deve-se estudar a trama histórica particular que envolveu a produção da imagem, sempre tendo em mente que ela foi produto de uma série de seleções definidas cultural, estética, técnica e ideologicamente, de acordo com as intenções de uso. Nenhuma análise pode se desvincular do processo de produção, uma vez que não há imagem sem contexto.

Toda foto é sempre um meio de expressão e documento. Como toda fonte 
histórica, não pode ser aceita imediatamente como espelho fiel dos fatos, pois carrega em si significados não explícitos e omissões pensadas. Seu potencial informativo só é explorado se for contextualizada na trama histórica em seus múltiplos desdobramentos (sociais, políticos, econômicos, religiosos, artísticos, enfim, culturais) que circunscreveu no tempo e no espaço o ato da tomada do registro.

A metodologia adotada nesta dissertação segue também os princípios abordados nos textos supracitados de Boris Kossoy. Entretanto, por não se tratar da análise de originais e sim de reproduções publicadas em um álbum, considerações a respeito do artefato fotográfico foram desconsideradas. A ênfase da análise estará no processo de construção da representação, somando as informações referentes ao fotógrafo e à pós-produção.

A análise do álbum se iniciou com a determinação dos elementos icônicos do registro visual, ou seja, do conteúdo da representação, do conjunto de informações visuais que compõem o conteúdo do documento. Em seguida, a análise iconológica resgatou a história própria do assunto, decifrando a chamada primeira realidade (realidade interior), com o auxílio de fontes de informações históricas que contextualizam espacial, temporal, econômica e socialmente o objeto de estudo. Da somatória dos dados históricos, do processo gerador deste documento e das informações icônicas levantadas resulta a desmontagem da realidade expressa em São Paulo fastest growing city in the world. 
Parte I - A documentação fotográfica de Peter Scheier

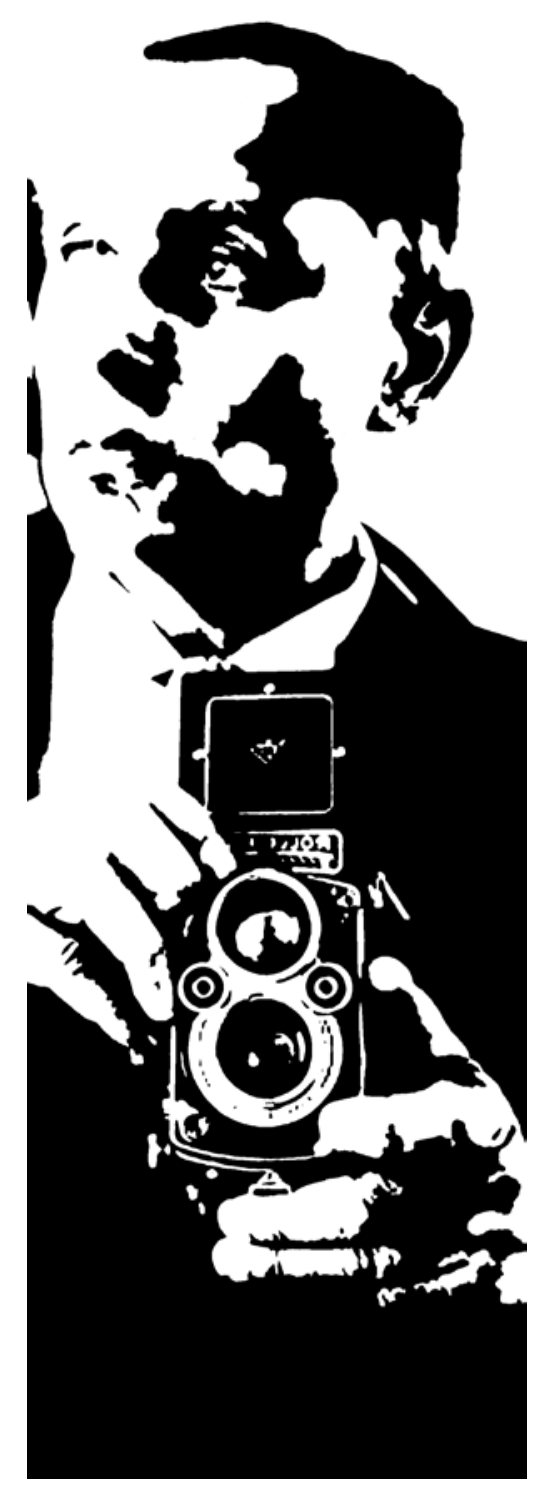


Capítulo 1 - De comerciante a fotógrafo

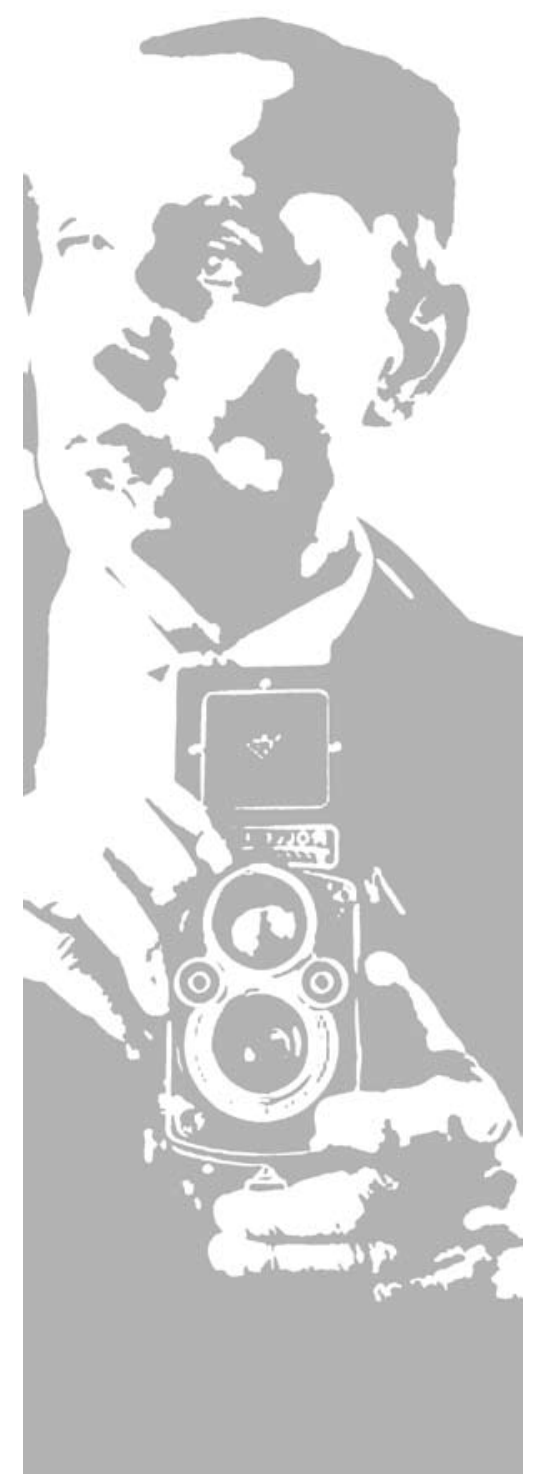




\subsection{A Primeira Guerra Mundial e a efervescência cultural} na Alemanha

Peter Scheier nasceu em 1908 na pequena cidade de Glogau, sudeste da Alemanha, à margem do Rio Oder, na região da Silésia. Glogau contava com cerca de 33.000 habitantes $^{1}$. Naquele início do século XX, a Alemanha vivia sob a unificação ainda recente. O II Reich Alemão, iniciado em 1871 - após a vitória alemã na Guerra Franco-Prussiana -, existiria até o fim da Primeira Guerra. No processo de formação da nação alemã foram incorporados territórios que se estendiam desde a Rússia até a França.

Peter era filho de Julius Scheier e Hedwig Strakosch. Sua mãe vinha de família abastada e tinha uma formação culta. Seu pai era comerciante, dono de

1 http://en.wikipedia.org/wiki/G\%C5\%82og\%C3\%B3w. Acesso em: 30 jan. 2008, às 16:00. 
um negócio equivalente a uma loja de departamentos, na qual Peter trabalhou até seu fechamento, em 1928. Embora de origem judaica, Julius serviu como oficial do exército alemão na Primeira Guerra (1914-1918).

Aos seis anos, Scheier vivenciou o clima de instabilidade deste conflito. Em 1918, a Alemanha assinou a rendição que encerrou a guerra. O II Reich cedeu lugar à República de Weimar, que adotou o modelo parlamentarista democrático como sistema de governo. A Alemanha recebeu punições pesadas definidas no Tratado de Versalhes, de 1919: foi responsabilizada pela guerra, sendo, assim, obrigada a se desmilitarizar; sofreu ocupação militar; perdeu possessões ultramar e territórios para nações como França e Polônia e assumiu as dívidas de guerra. As condições impostas pelo Tratado de Versalhes limitavam qualquer possibilidade de ressurgimento econômico do país por causa das reparações de guerra e das restrições à indústria e ao exército alemão.

Um clima de desilusão e instabilidade dominou a Alemanha pós-Primeira Guerra, campo fértil para a germinação das idéias nazistas. A reconstrução se efetivou somente após 1924 e seria logo atingida pela crise econômica de 1929. A estabilidade conseguida arduamente desmoronou: a repatriação de capitais estrangeiros investidos no país provocou falências e desemprego.

Contudo, a incerteza não se restringia à Alemanha. A Rússia, que se retirara em 1917 da Guerra em função da eclosão da Revolução, enfrentava lutas internas. Em 1921, Lênin e os bolcheviques consolidaram-se no poder e instituíram o comunismo. Em 1924, Stalin assumiu o poder. Neste mesmo ano, a Itália assistiu à ascensão do Partido Fascista de Mussolini.

Apesar da instabilidade vivida desde os meados da década de 1910, a Europa propiciou o desenvolvimento de escolas e movimentos artísticos em grande intensidade. As idéias e conceitos de correntes como Expressionismo 
alemão, Construtivismo russo, Futurismo italiano, École de Paris, Dadaísmo, Surrealismo e Neoplasticismo holandês amadureciam e se difundiam.

Na Alemanha, a corrente expressionista - nascida em 1905 com o movimento Die Brücke ("a ponte"), que resultaria no movimento Der blaue Reiter ("o cavaleiro azul"), de 1911 - teria desdobramentos significativos no entreguerras, no trabalho de artistas como Vassili Kandinsky e Paul Klee. De natureza realista, os expressionistas buscavam enfrentar a situação histórica presente. Nos anos precedentes à guerra, posicionaram-se contra a sociedade, que não buscava uma conciliação e a superação das diferenças culturais na Europa. Argan aponta que a agudização da divergência entre a cultura latina e a cultura germânica era usada para justificar por motivos ideais a disputa pela hegemonia econômica e política na Europa, que logo conduziria à guerra² .

O movimento expressionista Nova Objetividade (Neue Sachlichkeit) surgiu no pós-guerra, com tendência figurativa, forte acento realista e conseqüente recusa de inclinações abstratas. Era marcado pela denúncia, pela sátira social, pela crítica à sociedade burguesa e à guerra. Buscavam apresentar uma imagem crua da sociedade alemã depois da guerra de 1914. O termo foi criado em 1923 por Gustav Hartlaub, quando, em carta aos jornais, manifestou a intenção de realizar uma exposição com o título Nova Objetividade - concretizada dois anos depois no Kunsthalle de Munique. Otto Dix, George Grosz, Max Beckman e George Scholz foram os principais artistas do grupo.

A arquitetura expressionista alemã desenvolveu-se no pós-guerra, em meio à necessidade de reconstruir uma sociedade em ruínas e envolvida num conflito entre forças democráticas e forças reacionárias. Os arquitetos tomaram consciência de seu papel e inseriram-se no processo revolucionário, assim como

2 ARGAN, Giulio Carlo. Tradução de Denise Bottmann e Federico Carotti. Arte Moderna. São Paulo: Companhia das Letras, 1992. p.228. 
o fizera a vanguarda russa, que vinculou o processo de renovação da arte ao processo revolucionário da sociedade. Em 1918 formou-se o Novembergruppe ("Grupo de Novembro"), composto por nomes como Bruno Taut e E. Mendelsohn e definido como um núcleo de pesquisa e experimentação da construção civil, visando responder às exigências de vida e de trabalho do povo. Este grupo relacionava o problema da funcionalidade à visibilidade e à comunicação e não só à técnica construtiva e a exigências práticas. Para Argan, esta experimentação formal mais audaz, esta inventividade e criatividade funcionavam como antídoto à depressão geral ${ }^{3}$.

A consciência da catástrofe e a ânsia por um renascimento ideal advinda dos expressionistas foi a autocrítica da sociedade e da cultura alemã promovida pelos intelectuais: "exaltara-se excessivamente o mito da nação, do Estado ético, da missão de domínio e guia atribuída pelo destino à raça germânica"4 . Naquele momento de reconstrução, era preciso opor-se ao irracionalismo político e usar a lógica para resolver as questões. O Racionalismo alemão, assim, nasceu a partir do Expressionismo do Novembergruppe.

ABauhaus foi fundada por Walter Gropius em 1919, mesmo ano da assinatura do Tratado de Versalhes. Gropius propunha uma escola "democrática" ${ }^{5}$, sendo que, para ele, a escola era a semente da sociedade democrática ${ }^{6}$. A escola estava fundada na colaboração e na pesquisa conjunta entre mestres e alunos. Gropius não acreditava na universalidade da arte e convocou os artistas mais avançados, como Vassilii Kandinsky, Paul Klee, Josef Albers e László MoholyNagy, para colaborarem no ensino, que era a tarefa social do artista.

A finalidade da Bauhaus era recompor o antigo vínculo entre arte e

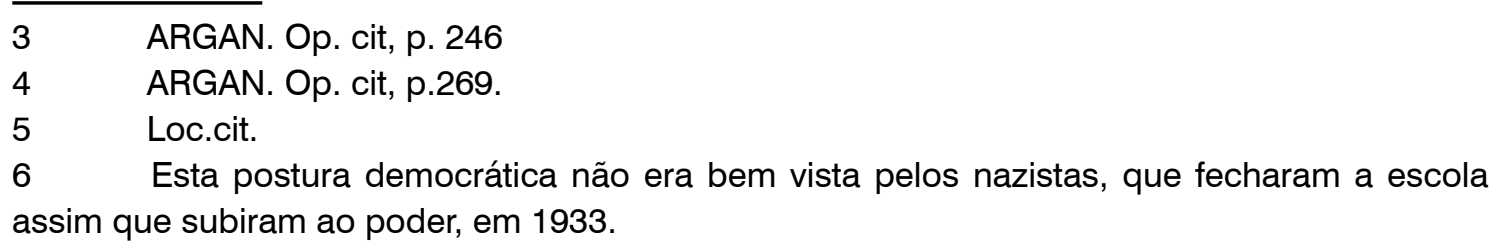


artesanato, agora definido como sendo entre arte e a indústria produtiva. Era objeto de análise e projeto na Bauhaus tudo o que podia ser incluído no vasto âmbito da comunicação visual: traçado da cidade, edifício, veículos, móveis, objetos, publicidade, embalagens, artes gráficas, etc. Apesar de racionalista, a escola valorizava as atividades para estimular a imaginação, e mantinha-se sempre em contato com todas as tendências avançadas da arte européia.

\subsubsection{A fotografia na Alemanha nas primeiras décadas do século $\mathbf{X X}$}

No período entre-guerras o mundo assistiu à proliferação da indústria, que implicou em mudanças no modo de trabalhar e nos tipos e variedades de mercadorias. As imagens desejadas pelas pessoas também eram outras: na década de 1920, o nível da industrialização da fotografia elevou-se em função da expansão surpreendente da mídia de massa (jornais, revistas de interesse geral ou específico - moda, saúde, automóveis - e periódicos profissionais). Foi nesta época que o termo fotojornalismo foi popularizado.

As pessoas estavam acostumadas a ver repetidamente os cartes-de-visite e estereoscópios, geralmente organizados em álbuns pessoais ou coleções. Agora, um novo cenário se constituía: as pessoas em países industrializados viam muito mais fotos - impressas, reproduzidas em jornais e revistas - selecionadas por editores de foto ou designers de anúncios, que circulavam por pouco tempo até serem substituídas por outras imagens mais recentes. Portanto, a grande quantidade de imagens produziu uma audiência visualmente sofisticada que rapidamente via e entendia as imagens impressas como transitórias e efêmeras. Desejavam receber informações visuais de eventos não diretamente vividos por 
elas.

Berlim era muito conhecida por seus experimentos em artes visuais, influenciada em parte pela presença da ilustração foto-mecânica. Nela havia, nos anos 1920, 45 jornais matinais e 14 diurnos. ${ }^{7}$ Berliner Illustrierte Zeitung era um periódico semanal muito popular, cuja circulação iniciou-se em 1890. Passou por redesenho editorial para abrir mais espaço para a inserção de fotografias, sendo considerado o pioneiro no ensaio fotográfico, que depois seria copiado por centenas de outras publicações. Na Alemanha também apareceram diversas revistas politicamente engajadas, como a Arbeiter Illustrierte Zeitung, de Willi Münzenberg, de esquerda, com posição crítica em relação ao capitalismo, e o Die Illustrierte Beobachter, nazista.

Em 1928, na França, foi lançada a revista Vu ("visto"), cujo objetivo era comunicar idéias liberais para classe trabalhadora. Esta revista serviria de modelo para futuras publicações, como a brasileira O Cruzeiro - também lançada em 1928 e redesenhada na década de 1940 para adaptar-se ao formato das revistas ilustradas modernas - e a Life Magazine - lançada nos Estados Unidos em 1936.

Nesta época também ocorreu o rápido desenvolvimento do tablóide, caracterizado por ser um jornal compacto, com ênfase nas imagens e com pouco texto. A rotogravura - processo no qual todo o original, incluindo o texto, passa por um processo de reticulagem e cuja impressão é rotativa - foi largamente empregada na impressão de jornais voltados para a classe média. Seções temáticas em rotogravura eram inseridas nos jornais de domingo, geralmente abordando moda e alta sociedade.

Os avanços tecnológicos traziam mais possibilidades para a fotografia.

7 MARIEN, Mary Warner. "A New Vision (1918-1945)". In: Photography: a cultural history. London: Laurende King Publishing, 2002. p. 239. 
O lançamento da Leica para o grande público, em 1924, oferecia novas potencialidades para o equipamento, mais leve e versátil. Muitos fotógrafos continuavam com câmeras de grande formato, mas havia uma tendência para a aparência espontânea das fotos das câmeras de pequeno formato (35mm). Paulo Wolff popularizou o 35mm através de seus livros - como As minhas experiências com a Leica (1934) - nos quais ensinava a usar uma Leica e apresentava novas perspectivas e ângulos de visão. Os filmes com sensibilidade maior também permitiam novas experiências.

Os artistas percebiam rapidamente a significância social da mídia de massa, cujo crescimento também se dava em outros meios. Na década de 1920, o cinema alcançava um público maior, preenchendo a necessidade emergencial de uma cultura popular, para uma audiência massiva e popular. No cinema alemão, o expressionismo ganhava feições nos filmes de Fritz Lang, Robert Wiene e do produtor Erich Pommer. O clássico O Gabinete do Dr. Caligari (Das Kabinett des Dr. Caligari, 1919) demonstrava um clima sombrio de terror e morte que refletia o estado de espírito da Alemanha após a derrota na Primeira Guerra. Metropolis ${ }^{8}$, de 1926, é uma ficção científica que metaforicamente retrata a crescente luta de classes e demonstra uma preocupação com a mecanização da vida industrial nos grandes centros urbanos. Como pano de fundo, a valorização da cultura, expressa no filme através da tecnologia e, principalmente, da arquitetura. M - O vampiro de Dusseldorf (M - Eine Stadt sucht einen Morder, 1931) foi o primeiro filme falado do diretor Fritz Lang - um suspense no qual um assassino de crianças é caçado por marginais. O filme foi proibido na Alemanha, pelos nazistas, em 1934. Nos filmes expressionistas alemães é possível notar efeitos de luz e sombra e ângulos de câmera distorcidos típicos da Nova Visão.

8 À época, Metropolis impressionou tanto Adolf Hitler que, quando ele chegou ao poder, solicitou ao Ministro da Propaganda, Joseph Goebbels, que convidasse Lang para produzir filmes para o partido nazista. Lang se recusou e fugiu para Paris, onde chegou a produzir filmes antinazistas. Em 1934 emigrou para os Estados Unidos. 


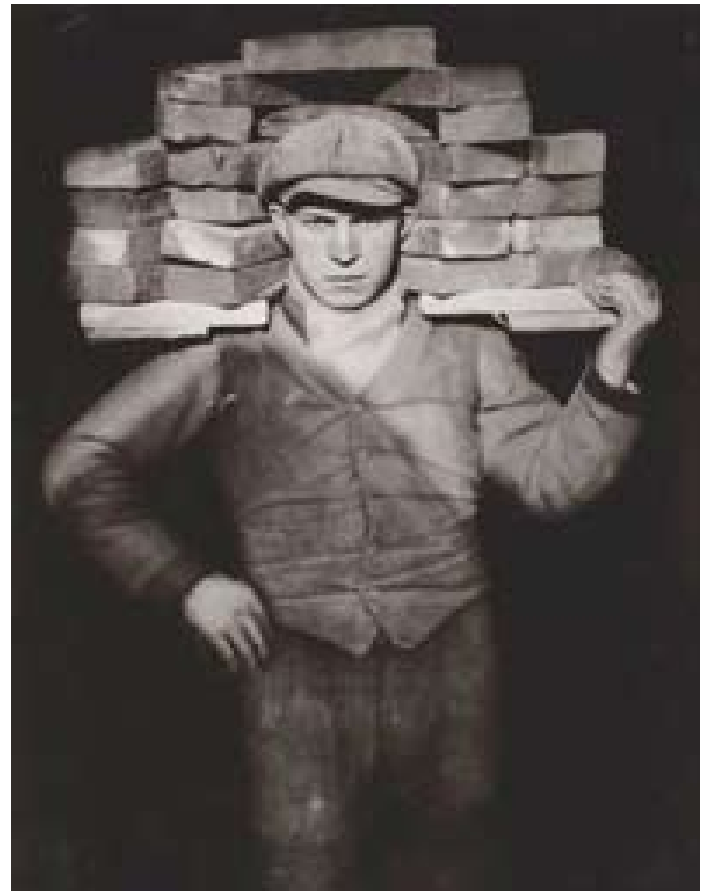

Imagem 1. Bricklayer's Mate, 1928. Autoria: August Sander. Fonte: http://www.moma. org/collection/

Nova Visão, Foto Modernista ou Nova Fotografia eram termos usados para denotar uma nova postura dos fotógrafos, baseada em novos enquadramentos, limpeza formal, ênfase em assuntos industriais, close-ups, ângulos estranhos e padrões visuais repetitivos, contra-luzes rasantes, iluminação contrastada e sombras duras. Posicionavam-se contra o Picturialismo. Do movimento de arte alemã contemporânea adotaram o nome - Nova Objetividade.

$\mathrm{Na}$ Alemanha dos anos 1920, as referências na fotografia eram August Sander, Albert Renger-Patzch e Lászlo Moholy-Nagy. August Sander iniciou em 1910 um projeto de catálogo fotográfico sistemático do povo alemão, composto por imagens arquetípicas supostamente neutras (Imagem 1). Neste "levantamento", cada pessoa era um emblema de uma classe ou profissão. Sander não só escolheu indivíduos de acordo com seu caráter representativo, mas também mostrou que a câmera não podia deixar de revelar os rostos como máscaras sociais. 


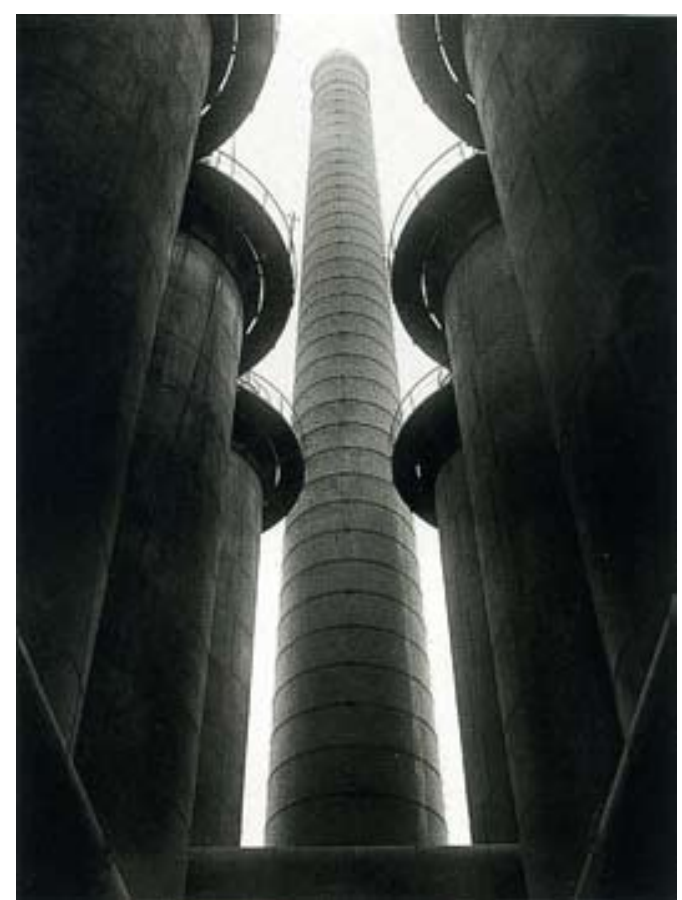

Imagem 2. Blast Furnaces, Herrenwick, 1927. Autoria: Albert Renger Pazscht. Fonte: ELWALL (2004), p. 120.

Suas fotos não pretendiam o julgamento, a descrição ou a crítica; buscavam elucidar a ordem social com um grande número de tipos, desde os ricos aos mais miseráveis. Todos eram fotografados da mesma maneira inexpressiva e impassível, resultando ora em fotos espontâneas, fluentes e naturalistas, ora em imagens ingênuas e constrangidas. Um inventário sem condescendência, sem sentimentalismo, sem comoção. Em 1934 os nazistas apreenderam seu material, sob a acusação de anti-social devido à sua imparcialidade - em suma, suas fotos não retratavam a superioridade ariana.

Albert Renger-Patzch opunha-se à fotografia artística - criticando também a foto de Nagy e sua exposição FIFO -, alegando que a adoção de ângulos estranhos era uma moda. Renger buscava a reprodução exata da forma e tornouse um expoente de temas industriais e técnicos (Imagem 2). Em livros como Die Welt ist schön (“O mundo é belo", 1928), mostrou imagens de assuntos e produtos 


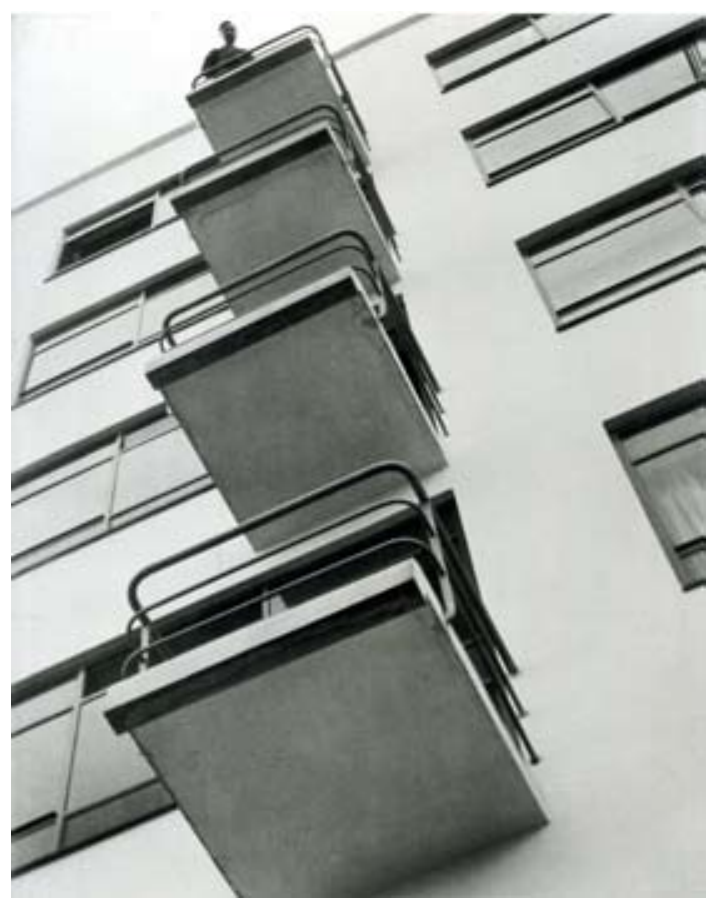

Imagem 3. Bauhaus Balconies, Dessau, 1926. Autoria: Lázsló Moholy-Nagy. Fonte: ELWALL (2004), p. 133.

industriais, com um olhar objetivo e realista. Sua postura influenciou muito a fotografia de arquitetura, na medida em que se concentrava na articulação clara das superfícies e no retrato de detalhes isolados de seus contextos, buscando a identificação do edifício através de um fragmento significativo.

Em oposição a esta fotografia objetiva, realista e submetida à técnica, László Moholy-Nagy buscava a experimentação e novos conceitos. Para ele, uma nova visão seria criada quando a foto fosse praticada por suas qualidades inerentes e não como uma imitação da pintura. A mais importante questão para foto era determinar sua linguagem exata, independente do passado e dos outros meios de expressão. A característica principal da foto é a luz, por isso artistas deveriam experimentar novos padrões de luz e sombras. Acreditava que a foto experimental deveria fazer parte da educação formal, a fim de que esta se adaptasse ao mundo cada vez mais retratado visualmente nos jornais e revistas 


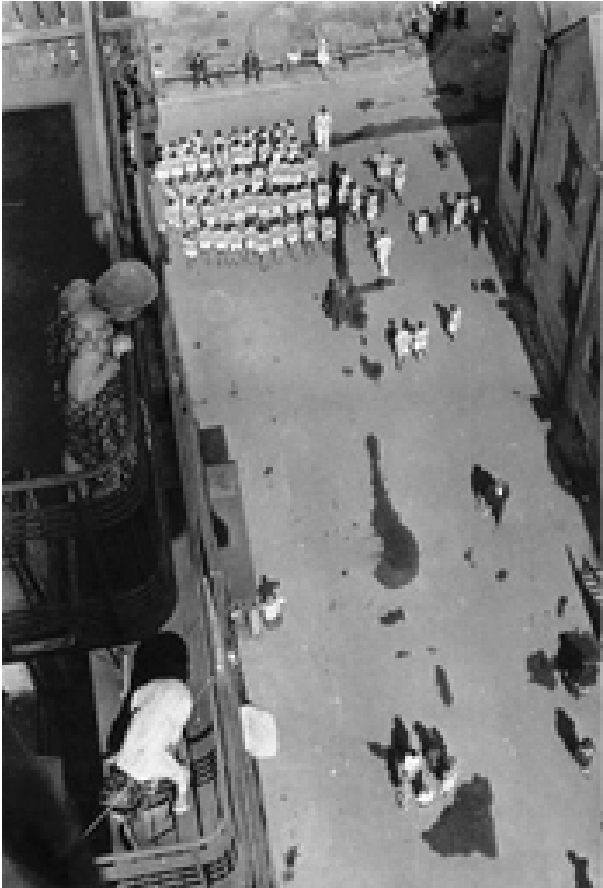

Imagem 4. Gathering for the demonstration in the courtyard of the VChUTEMAS (Higher Institute of Technics and Art), 1928. Autoria: Alexander Rodchenko. Fonte: http:// www.masters-of-photography.com

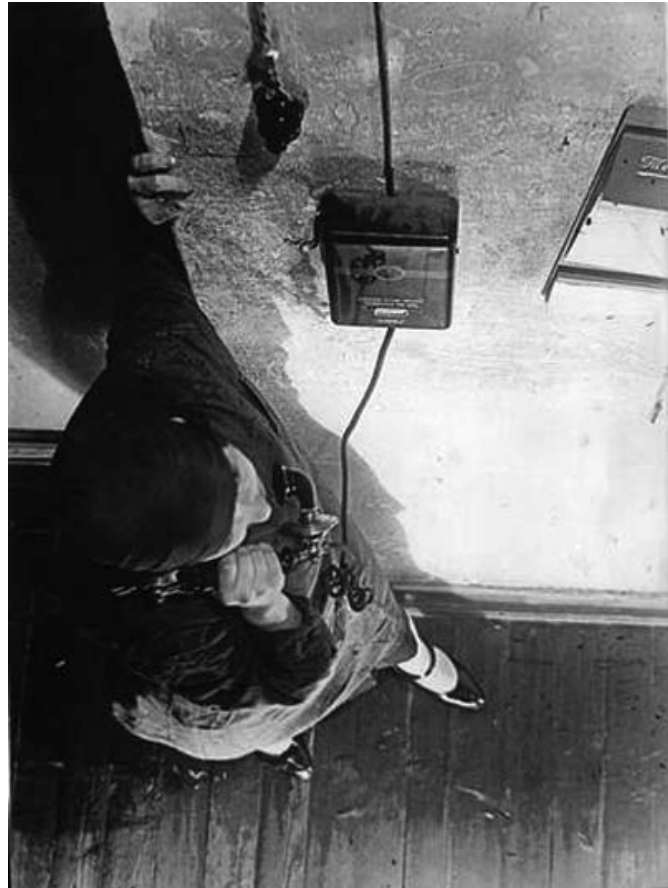

Imagem 5. On the telephone, 1928. Autoria: Alexander Rodchenko. Fonte: http://www.masters-of-photography.com

de cultura de massa.

Em 1923 Nagy foi convidado para participar da Bauhaus. Contudo, a escola não incluía aulas de foto em seu currículo ${ }^{9}$, pois ela era entendida como um instrumento de ampliação da percepção e da sensibilidade visual. Em 1925, Nagy publicou, pela Bauhaus, seu livro Malerei, Photographie, Film ("Pintura, Fotografia, Filme"), no qual delineava claramente pintura e fotografia. A fotografia não era apenas um instrumento, mas um novo material artístico. Seus livros se tornaram referência para a nova foto. Neles eram explicitados os pontos da nova visão, com mudanças radicais do ângulo de visão da câmera (pontos de vista ascendentes e descendentes), mudança de escala, novas experiências espaciais, rejeição às noções tradicionais da representação perspéctica, uso de

$9 \quad$ Fotografia como disciplina seria incluída apenas em 1929 no currículo da Bauhaus. 
microscópios, fotogramas e fotomontagens (Imagem 3).

Em 1929, Lászlo Moholy-Nagy organizou uma exibição internacional em Stuttgart chamada "Film und Foto" - FIFO ("Filme e Foto"). Era composta por mais de 97 elementos, somando-se fotografias, fotomontagens e fotogramas. Sua intenção era mostrar como a foto tinha mudado, desde a aparência vaga e os temas rurais do Pictorialismo. Os fotógrafos participantes da FIFO habitavam o ambiente urbano-industrial e buscavam enfatizar a forma e a textura deste ambiente. A FIFO e a exposição "Das Lichtbild” (“A foto”) em Munique (1930) foram muito criticadas, sendo definidas como uma moda visual esvaziada de seu ativismo social inicial.

Formalmente, muitas das experiências de Moholy-Nagy aproximavam-se daquelas do russo Alexander Rodchenko, que também propunha redescobrir a experiência, fazendo o familiar parecer estranho. Ele intencionava encorajar as pessoas a ver coisas de pontos de vista revigorados. Seu estilo de ângulos oblíquos estendeu à fotografia as composições diagonais dinâmicas de suas primeiras pinturas, o que ajudou a formar uma estética vibrante e experimental de perspectivas móveis, que surgia na Europa na segunda metade da década de 1920 (Imagem 4/5).

Este cenário fértil foi desestruturado com os desdobramentos que culminaram na eclosão da Segunda Guerra Mundial. Muitas experiências foram interrompidas, como a Bauhauss, fechada em 1933. O panorama aqui sintetizado tem a função de esclarecer a cultura em que Peter Scheier foi educado e se restringe às três primeiras décadas do século $X X$, período que vai de seu nascimento à sua partida para o Brasil. 


\subsection{A Segunda Guerra Mundial e o refúgio no Brasil}

Em 1933, Peter Scheier deixou sua cidade natal. Naquele ano, Adolf Hitler ascendeu ao poder e passou a ser denominado como Reichfürer ${ }^{10}$. Dissolveu o parlamento (Reichstag), encerrando, assim, a República de Weimar e iniciando o III Reich. A derrota na Primeira Guerra e seus desdobramentos políticos, econômicos e nacionalistas abriram terreno fértil para o desenvolvimento e expansão do ideário nazista.

Apopulação alemã foi seduzida pela ideologia nazista: o clima de organização sistemática, euforia e sacralização sustentado pelo nacional-socialismo levouos a assimilar as ordens de ódio e destruição, acatando, sem protestos, as radicais medidas anti-semitas. O Estado se auto-atribuiu a missão de sanear a sociedade, eliminando o que era considerado impuro e feio, isto é, "tudo que pudesse ser identificado como desvio do modelo de homem apontado como perfeito"11. Era instaurado o anti-semitismo apoiado nas ciências biológicas e nas teorias racistas do século XIX.

No mesmo ano de 1933 foram suspensos os direitos humanos na Alemanha através de decreto. A suástica passou a estar presente em todas as repartições públicas. Os opositores políticos e funcionários judeus foram demitidos. A campanha anti-semita em jornais de Josef Goebbels - ex-chefe da propaganda nazista e então ministro nacional de propaganda - ganhava o apoio da população, que aderia ao boicote econômico aos estabelecimentos judeus, encorajada por cartazes proclamando: "Jewish Business! Anyone shopping here will be photographed"12. A fotografia era usada como instrumento, arma para

$10 \quad$ Fürer significa aquele que conduz, o guia.

11 CARNEIRO, Maria Luiza Tucci. Brasil, um refúgio nos trópicos. São Paulo: Estação Liberdade, 1996. p.42.

12 "Loja judia! Quem comprar aqui será fotografado". MARIEN, Mary Warner. Photography: 


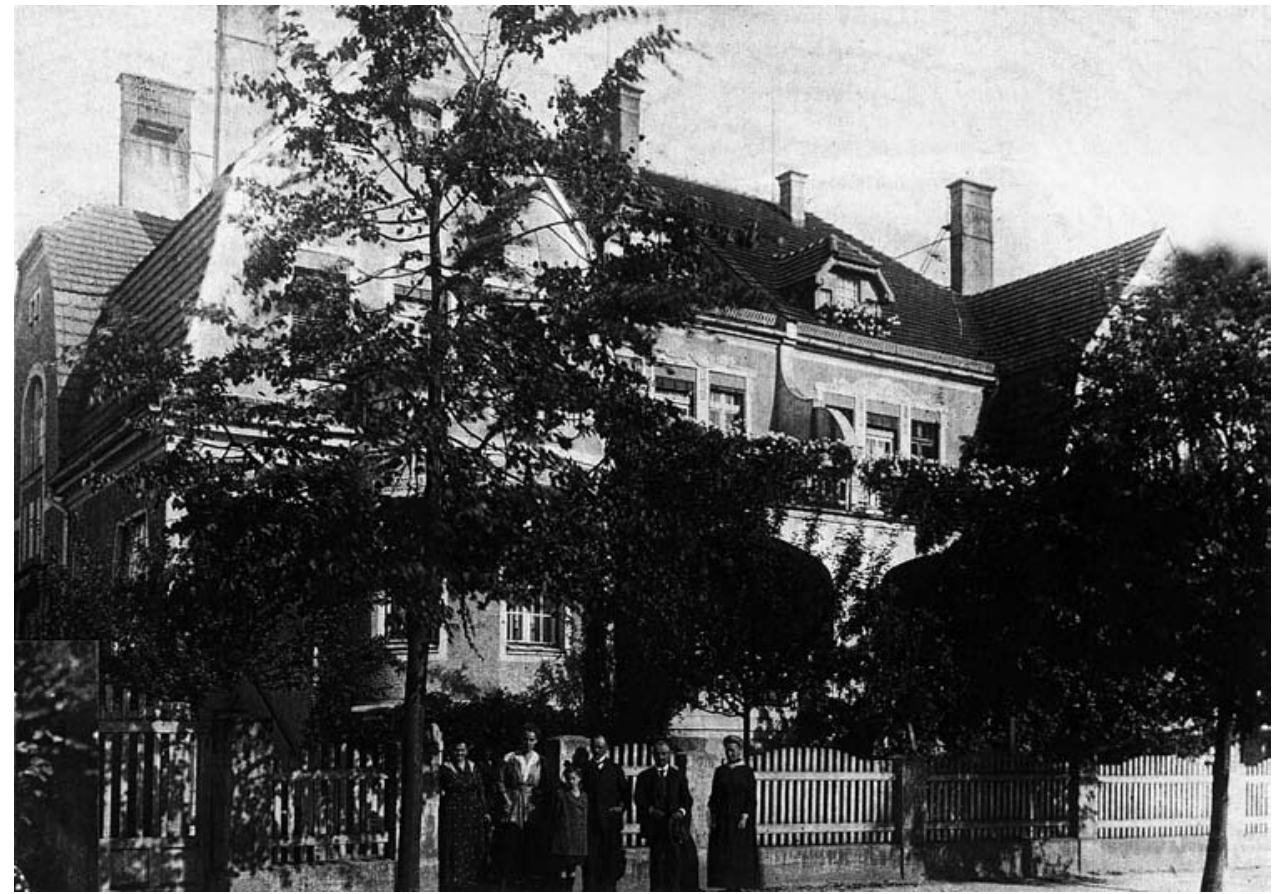

Imagem 6. Residência dos Scheier em Glogau. Fonte: Arquivo pessoal.

amedrontar e acusar ${ }^{13}$

1933 é marcado pela primeira grande onda emigratória de judeus alemães, que se dirigiram a outros países europeus, como Bélgica e França. Peter Scheier era um deles. A posição geográfica de Glogau era-Ihe pouco favorável: estava próxima ao chamado "corredor polonês" - faixa de terra tomada da Alemanha através do Tratado de Versalhes, que dava à Polônia acesso ao Mar Báltico,

a cultural history. London: Laurende King Publishing, 2002. p.300. Tradução da autora.

13 Os nazistas congelaram toda experimentação fotográfica e mandaram muitos fotógrafos para fora do país. Por outro lado, reconheciam o poder da fotografia como meio de difusão e tinham especial apego às imagens nacionalistas. Em 1933, organizaram o primeiro evento de propaganda bem sucedido, a exposição Die Kamera, em Berlim. Com exposições como esta, Joseph Goebbels tentou criar uma cronologia gloriosa da ascensão dos nazistas ao poder. Exaltava a fotografia, afirmando que a experiência do individual se tornou a experiência do público, graças somente à câmera. Depois de 1933, os nazistas ordenaram que todos os fotógrafos alemães se registrassem junto ao governo. Isso permitiu que Hitler tivesse o total controle sobre a produção fotográfica bem como acabasse com os movimentos contestatórios. Sua ascensão era mostrada pela mídia impressa através de fotos heróicas, em geral produzidas por Heinrich Hoffmann, seu fotógrafo favorito. A mídia agora era o veículo que permitia a construção de uma imagem de líder forte e popular. A conseqüência foi que, até as vésperas da Segunda Guerra, não havia mídia independente na Alemanha: todos os fotógrafos estavam inscritos na Divisão de Propaganda do Exército. 


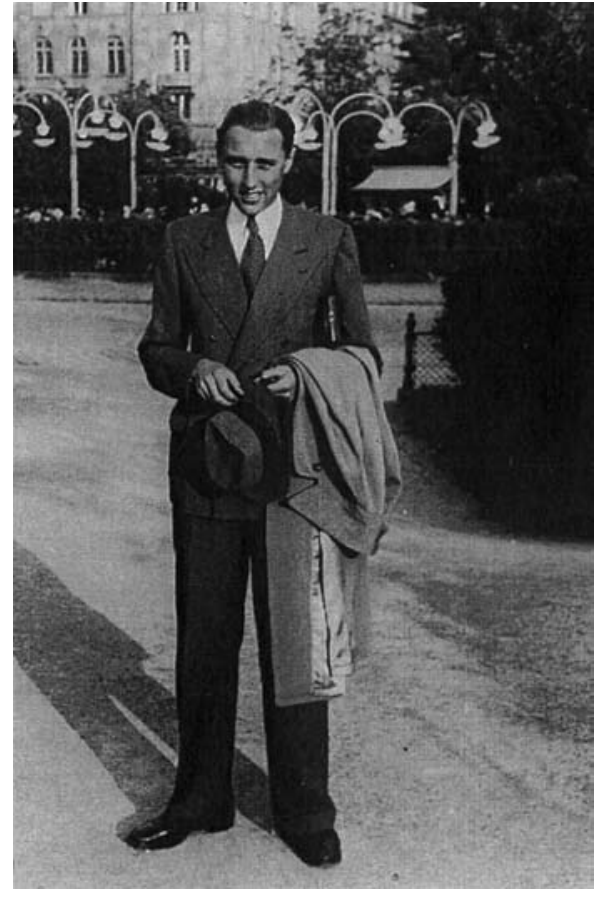

Imagem 7. Peter Scheier, 1928.

Fonte: Arquivo pessoal.

seccionando a Alemanha em duas partes. O estopim da Segunda Guerra, em 1939, foi a invasão das tropas alemãs na Polônia, para retomar o "corredor". Ao final da guerra, Glogau estava totalmente em ruínas. Em 1945, em função da nova configuração das fronteiras, a Polônia estendeu-se até o Rio Oder e Glogau passou a pertencer a este país ${ }^{14}$. Os alemães sobreviventes foram expulsos da cidade. As ruínas da antiga cidade foram demolidas, bem como a prefeitura e a igreja evangélica Kirche Zum Schifflein Christi, embora pouco danificadas. As ruínas da Igreja de St. Nicholas permaneceram como memória. A igreja de Corpus-Christi e o castelo foram restaurados. A cidade só retomaria seu crescimento vinte anos depois, com a construção de uma fundição de cobre em 1967, que se tornaria a principal atividade industrial da cidade.

14 Este foi mais um revés para a família Scheier: uma vez que Glogau não pertencia mais à Alemanha, o governo alemão não Ihe restituiu os bens tomados ao fim da guerra. 
Em outubro de 1933, Scheier estabeleceu-se na cidade alemã de Hohenau, na região da Bavária, próxima às divisas com Tchecoslováquia e Áustria. Nesta cidade trabalhou na fábrica de açúcar dos Strakosch, dirigida por seu tio materno. Começou a planejar sua emigração, auxiliado por Oskar Strakosch. Seu tio escreveu uma carta de recomendação, que the garantiria seu primeiro emprego no Brasil, em um frigorífico.

Em 1935, foram proclamadas as Leis de Nuremberg - Lei para os Cidadãos do Reich e Lei para a Defesa do Sangue e da Honra - que institucionalizaram as idéias de pureza racial. Proibia casamentos entre judeus e alemães. Os judeus, em suma, tornaram-se fora da lei na Alemanha. A situação culminaria com a Noite dos Cristais, em 1938. Adotando como pretexto o assassinato de um alto funcionário da embaixada alemã em Paris, por um jovem judeu polonês, foram destruídas sinagogas e locais de rezas. Centenas de judeus foram socialmente enclausurados em guetos ou foram levados para os campos de concentração, submetidos a trabalhos forçados com o objetivo de exploração econômica, humilhação e extermínio. Após 1938, também os fascistas passaram a perseguir os judeus. A Noite é um marco de ruptura no processo de assimilação dos judeus na Alemanha.

Em 1937, Peter Scheier foi para Viena, na Áustria, antes da anexação deste país pela Alemanha, em 1938. Em Viena conheceu Gertrude Willheim, uma jovem tcheca de 20 anos, com quem se casaria dois anos mais tarde, no Brasil. Uma vez que não abdicara de sua nacionalidade tcheca, Gertrude passou por um processo emigratório mais seguro, retirando-se da Áustria em 1939, mesmo após a invasão alemã. Em 18 de setembro de 1937, Scheier saiu de Viena rumo à França, onde embarcou no navio para o Brasil - provavelmente no porto de Marselha. Em 25 de outubro, desembarcou no porto do Rio de Janeiro, dirigindo-se em seguida para São Paulo (Imagem 8/9/10). 


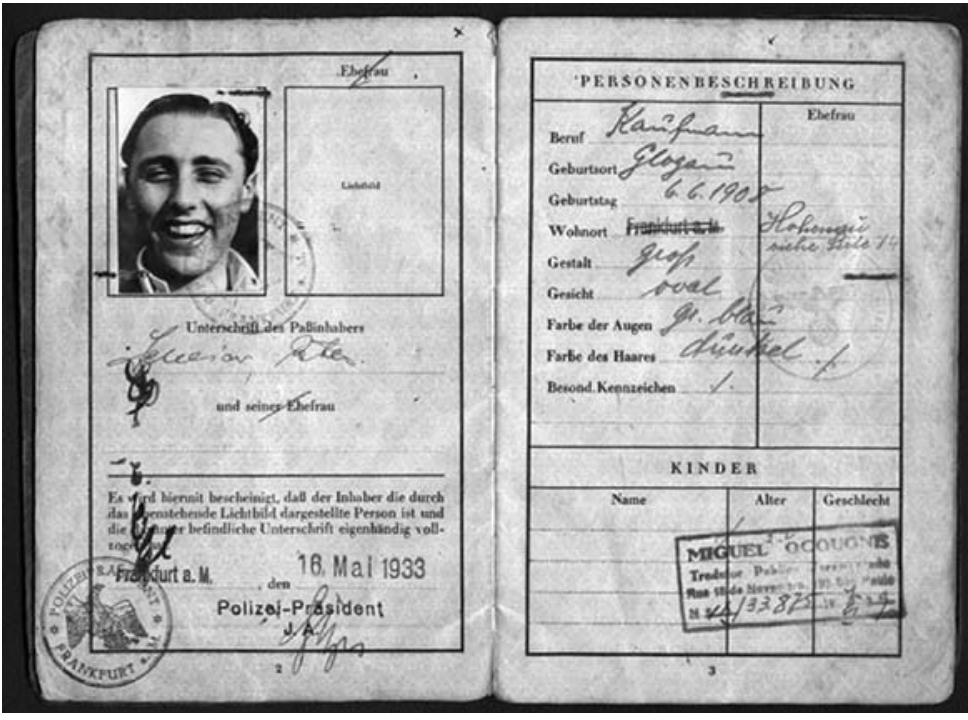

Imagem 8. Páginas iniciais do passaporte de Peter Scheier, emitido em 1933. Fonte: Acervo do AHJB.

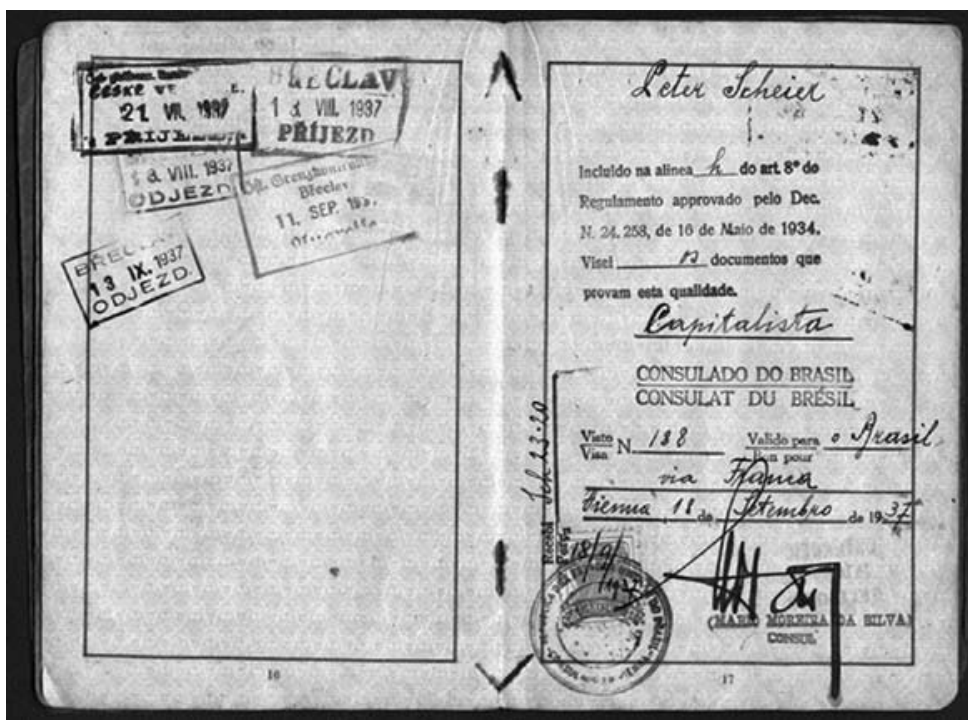

Imagem 9. Página 17 do passaporte de Peter Scheier, com carimbo de visto emitido pelo Consulado do Brasil na França, com data de 18 de setembro de 1937 . Fonte: Acervo do AHJB.

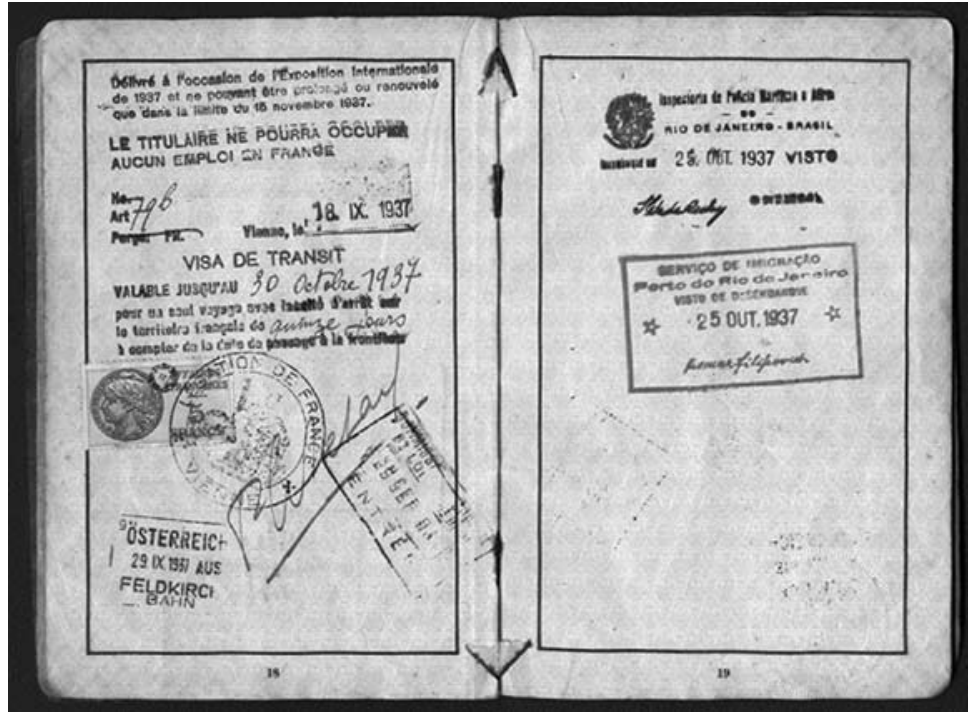

Imagem 10. Página 19 do passaporte de Peter Scheier, com carimbo de visto de desembarque do Serviço de Imigração do Porto do Rio de Janeiro, com data de 25 de outubro de 1937. Fonte: Acervo do AHJB. 
Os pais de Scheier viveram em Glogau até 1938. Partiram para o Brasil nos últimos momentos possíveis de emigração, trazendo consigo tapetes e prata que seriam vendidos aqui para famílias abastadas. Em janeiro de 1939, uma comissão alemã foi formada para controlar a saída em massa, que se tornava, a partir de então, praticamente impossível. Em setembro daquele mesmo ano, os alemães invadiram a Polônia, dando início à Guerra. Ao derrubarem as fronteiras com Polônia, formou-se um cordão de isolamento nazista, que impedia a entrada e a saída de qualquer pessoa. Em 1941 os judeus foram impedidos de deixar a Alemanha e os que residiam no exterior tiveram sua cidadania cassada.

Enorme era a dificuldade para se obter informações sobre emigração, em meio ao caos social. Na Alemanha sabia-se pouco sobre o Brasil, e muitos judeus vieram para cá por mero acaso, falta de opção melhor ou porque já conheciam alguém residente aqui. Segundo Carneiro, a partir de 1936 começou a circular na Alemanha um sedutor material de propaganda sobre o Brasil, com o objetivo de orientar aqueles que pretendiam emigrar. Este material visava também à venda de terras em áreas programadas de colonização, como Rolândia, no Paraná, promovida pela Companhia de Terras Norte do Paraná15. O Caderno Brasileiro para a Imigração de Judeus, organizado em 1936 pelo Comitê de Auxílio aos Judeus na Alemanha, informava judeus sobre as condições e possibilidades de investimentos econômicos no Brasil, reorganização familiar, custo de vida, classes sociais, especulação imobiliária, nível de cultura, etc. O Brasil como país-destino da imigração de judeus na Alemanha divulgava uma falsa imagem do Brasil como uma nação sem problemas.

Até 1938 o ponto de irradiação de emigrantes era a própria Alemanha. Após este ano, os principais pontos de irradiação eram Áustria, Polônia, França, União Soviética e Itália. Trieste, Marselha, Gênova e Livorno eram os principais

15 CARNEIRO. Op.cit. p.80. 


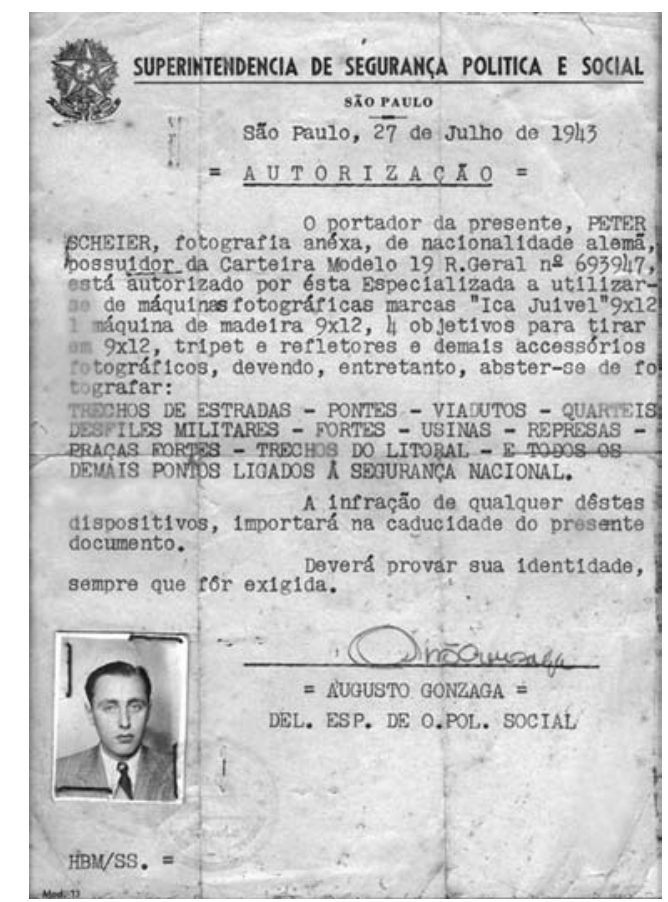

Imagem 11. Autorização emitida pela Superintendência de Segurança Política e Social, em 27 de julho de 1947. Fonte: Acervo do AHJB.

portos para embarque para o Brasil. Os judeus procuravam refúgio por todos os continentes. Na América, os países que mais receberam imigrantes foram os Estados Unidos, a Argentina e o Brasil, seguidos por Bolívia, Canadá, Cuba, Uruguai, Venezuela e República Dominicana.

Scheier, seus pais e Gertrude chegaram ao Brasil num período em que vigoravam circulares secretas proibindo a entrada de semitas em território nacional. Getúlio Vargas demonstrava simpatia e admiração pela Alemanha e mantinha estreitos laços diplomáticos. Havia um clima de tensão e repressão sustentado pelo governo Vargas, preocupado em legitimar-se no poder. Como lembra Carneiro, Vargas manipulou - com a ajuda da Igreja Católica e de intelectuais racistas - um conjunto de símbolos que contribuíram para a instituição de perigos, como o perigo semita e o perigo comunista. 


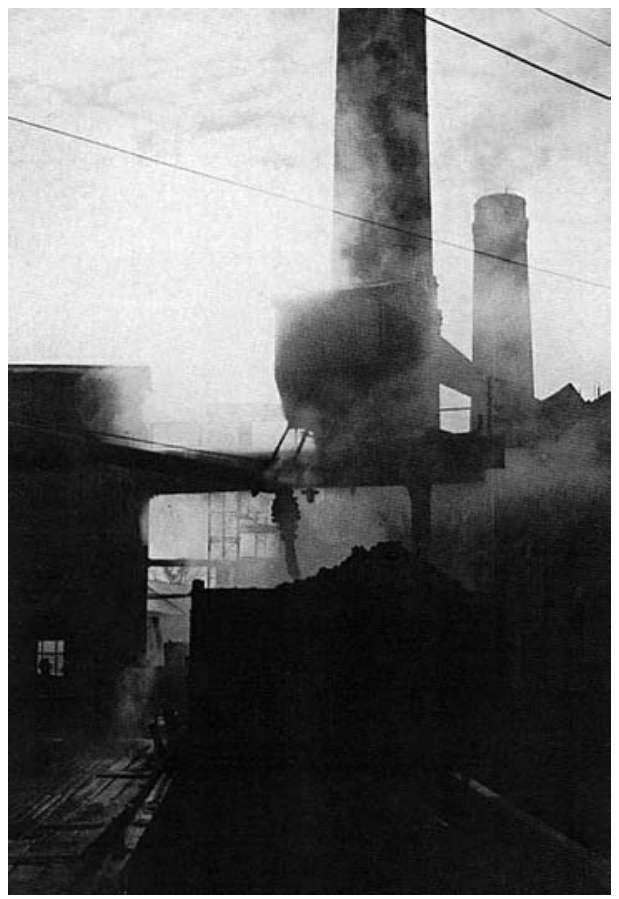

Imagem 12. Fábrica em Hohenau. Autoria: Peter Scheier. Fonte: Arquivo pessoal.

A partir de 1942, contudo, o Brasil envolveu-se na guerra, lutando ao lado dos aliados. A partir deste momento, todos os alemães e italianos eram considerados perigosos à segurança nacional. Os refugiados eram os principais alvos de desconfiança da polícia. Portar máquina fotográfica, falar alemão em público ou ir ao litoral brasileiro eram provas de espionagem e traição à nação brasileira. Para poder exercer sua profissão, Scheier precisou de uma autorização, emitida pela Superintendência de Segurança Política e Social em 1943, para poder utilizar seus equipamentos. Ficava proibido, entretanto, de fotografar estradas, pontes, viadutos, quartéis, desfiles militares, fortes, represas e quaisquer outros pontos ligados à segurança nacional (Imagem 11).

Assim que se instalou em São Paulo, Peter Scheier começou a trabalhar em um frigorífico, graças à carta de recomendação escrita por seu tio. Scheier morava em um apartamento no Largo do Arouche. Para complementar seu 
salário, vendia cúpulas de abajour. O incômodo em carregá-las pelas ruas levou-o a fotografá-las a fim de montar um pequeno catálogo para as vendas. Em seguida, montou um catálogo para a Lorenzetti. A fotografia, que até então se colocava como um passatempo, tornou-se sua profissão. Seu conhecimento amador foi comprovado em fotografias encontradas com a família, nas quais são retratadas passagens de sua vida na Europa, como as viagens e a fábrica em Hohenau, onde trabalhou. Nas fotos da fábrica, é possível notar um contra-luz intenso e um cuidado em posicionar o sol atrás da chaminé (Imagem 12).

Em julho de 1939, Scheier casou-se com Gertrude, recém-chegada ao Brasil. No ano seguinte, abriram o Foto Studio Peter Scheier, em uma casa na Rua Teodoro Baima, 87, próximo à Rua da Consolação e Praça da República. Seus pais Júlio e Hedwig chegaram ao Brasil também em 1939, permanecendo no país por cerca de sete anos - mudaram-se para New York, cidade na qual residia a irmã mais velha de Scheier, Susie.

\subsection{0 início da profissão de fotógrafo na São Paulo dos anos 1940}

Scheier insere-se num grupo amplo de intelectuais - arquitetos, engenheiros, urbanistas, designers, pintores, escultores e fotógrafos - que deixaram a Alemanha nazista e se estabeleceram no Brasil, trazendo consigo suas vivências pessoais e sua formação cultural européia e atuando como "agentes modernizadores nos seus diversos campos de influência"16. Com suas tendências arrojadas e polêmicas, contribuíram para uma nova situação cultural

16 FALBEL, Anat. "Immigrant Architects in Brazil: a Historiographical Issue". Docomomo. São Paulo, março 2006, n. 34, p. 60. Tradução da autora. 
no Brasil. "Acompanhando o espírito modernista dos anos 40, souberam extrair da paisagem e do cotidiano a essência do caráter nacional, atraídos - estrangeiros que eram - pelo exótico, pelo popularesco e pelos "tipos brasileiros"." ${ }^{17}$ Carneiro lembra ainda que os fotógrafos imigrantes ficaram perplexos diante do processo de urbanização de São Paulo nos anos 1950 e de seu cotidiano de grande metrópole. O crescimento vertiginoso da economia brasileira na década de 1950 ofereceu-lhes campo de trabalho.

Interessante notar que, no campo da fotografia, houve duas correntes migratórias distintas vindas da Europa nos anos 1930 e 1940. Da França vieram Jean Manzon, Henri Ballot, Marcel Gautherot e Pierre Verger, impulsionados por motivos diversos. Para os fotojornalistas Jean Manzon e Henri Ballot ${ }^{18}{ }_{-}$ que chegaram ao Brasil em 1940 - a imigração deu-se em função da Segunda Guerra. No mesmo ano, Marcel Gautherot desembarcou em Belém, interessado pelo país após a leitura do romance Jubiabá, de Jorge Amado. Pierre Verger chegou em 1946, depois de catorze anos consecutivos de viagens ao redor do mundo, sobrevivendo exclusivamente da fotografia.

Da Alemanha imigraram, além de Peter Curt Scheier, Alice Brill, Hildegard Rosenthal, Hans Günter Flieg, Curt Schulze, Heinrich Joseph, Fredi Kleemann. Refugiados do nazismo, esses profissionais encontraram aqui trabalho nas áreas de arquitetura, publicidade, jornalismo e indústria, impondo inovações e posturas estéticas avançadas. Hans Günter Flieg ${ }^{19}$ lembra como os imigrantes, até o fim da Segunda Guerra, sentiam o atraso do Brasil em relação aos avanços europeus, agravado pela falta de comunicação e dificuldade de transportes:

$17 \quad$ CARNEIRO. Op.cit. p.165.

18 Filho de pai francês, Henri Ballot nasceu em Pelotas, Rio Grande do Sul, e aos dois anos foi para França.

19 Em entrevista à autora, em 05 set. 2005. 
Então, eu chego e vejo álbuns de fotografia (...): páginas cinza couro, no meio disso folhas calandradas ou com estrelinhas ou com meiasluas, papel de seda, e capas, no melhor dos casos, com desenho em madeira de lei, várias madeiras, em outros casos com couro. Enfim, coisas que a gente sentia um pouco ultrapassadas. Eu tinha aprendido, em 39, junho-julho, a montar fotos sangradas com michelin. Michelin era cola de borracha, em cartolina cor de creme. Era uma outra aparência. E quando chego aqui, quando mostro isso, não é usual.

O cenário da fotografia encontrado por estes imigrantes era bem distinto do vivido na Europa. A fotografia moderna no Brasil não encontrava muito espaço e tinha presença nula ou inexpressiva nas manifestações artísticas. Nos fotoclubes ainda prevalecia a postura acadêmica ligada ao Picturialismo do final do século XIX, cujo projeto ideológico era o de elevar a fotografia à categoria de arte, a partir de uma intervenção radical sobre o próprio artefato fotográfico. Em 1939 foi fundado o Foto Clube Bandeirante - FCB. Embora sem conexão ideológica com as vanguardas européias, alguns membros do FCB - como José Yalenti, Thomas Farkas, German Lorca e Geraldo de Barros - propunham mudar na direção de uma estética moderna, inspirados pelo cenário moderno e desenvolvimento cultural de São Paulo. Temas cotidianos começaram a ser tratados a partir de uma visualidade moderna, marcada por contra-luzes, ângulos inusitados, alto-contrastes, sombras e silhuetas, exploração de nuvens, elementos geométricos e detalhes.

Esta visualidade moderna experimentada por membros do FCB, contudo, ficava limitada aos seus associados e não se expandia para além do clube. Kossoy aponta que, fechados em seus regulamentos, os fotoclubes cada vez mais restringiam a repercussão de suas obras ${ }^{20}$. Essa realidade era oposta àquela vivenciada pelos fotógrafos imigrantes, que conviviam na Europa com

20 KOSSOY, Boris. "Luzes e sombras da metrópole: um século de fotografias em São Paulo (1850-1950)". In: PORTA, Paula (org.). História da Cidade de São Paulo: a cidade no Império. São Paulo: Paz e Terra, 2004, v.2. p.448. 
as experiências vanguardistas, presentes nas revistas e jornais ilustrados, em cartazes e em exposições de arte, relatadas no início deste capítulo.

Peter Scheier estava inserido em um grupo que convivia nos ambientes culturais, como os museus e redações de revistas e jornais, como Alice Brill, Hildegard Rosenthal e Hans Günter Flieg. Alice Brill, filha de um pintor e uma jornalista, chegou ao Brasil com 14 anos. Freqüentou o Grupo Santa Helena, convivendo com artistas como Paulo Rossi Osir, Aldo Bonadei e Mario Zanini. Além da fotografia, praticada principalmente na década de 1950, dedicou-se às artes plásticas, foi gravadora, ensaísta e educadora. Colaborou com a revista Habitat, produzindo fotografias de arquitetura, reproduções de obras de arte e retratos. Sua obra apresenta grande diversidade temática que, segundo Kossoy, deriva de sua "necessidade de captar o mundo novo" ${ }^{21}$. A modernidade paulistana foi registrada por ela através de vistas urbanas panorâmicas bem como através do indivíduo anônimo. Brill também documentou as cidades coloniais mineiras e a vida indígena. $\mathrm{O}$ retrato foi parte significativa de sua obra, dedicando-se com freqüência às classes mais abastadas, os artistas em seus afazeres e especialmente as crianças.

Hildegard Rosenthal, apesar de não ter origem judaica, emigrou e chegou ao Brasil em 1937, para acompanhar seu futuro marido Walter Rosenthal, judeu. Ainda em Frankfurt, Hildegard fez um curso com o fotógrafo Paul Wolffe freqüentou o Instituto Gaedel, aprendendo operações químicas fotográficas básicas. No Brasil, por sua condição de mulher e imigrante recém-chegada, enfrentou dificuldades para encontrar emprego. Primeiro trabalhou como orientadora de laboratório na Kosmos Foto, empresa de comércio e serviços fotográficos, na Rua São Bento. Em seguida, tornou-se diretora, junto com Kurt Schendel e Geraldo Vicente Martins, de uma agência de notícias, a Press Information. Seu objetivo

21 KOSSOY, Boris. "Construção de uma visualidade moderna". In: O mundo de Alice Brill. Catálogo de exposição. São Paulo: Instituto Moreira Salles, set 2005. p. 10. 
era fornecer matérias sobre determinados temas da realidade brasileira, para veiculação em publicações no Brasil e exterior. Uma carta de recomendação para Lasar Segall abriu-Ihe caminhos, introduzindo-a no ambiente artístico da cidade e colocando-a em contato com a elite dos intelectuais, artistas e críticos da época, como Mário de Andrade, Guilherme de Almeida e Alfredo Volpi. Seu trabalho fotográfico foi do final dos anos 1930 ao final da década seguinte. Seus temas eram as vistas urbanas que mostravam a dinâmica da cidade, seus edifícios, o transporte e a face do povo, os personagens da cultura e das artes. Segundo Kossoy, o "forte de sua produção é o movimento das ruas, com ênfase especial no elemento humano" ${ }^{22}$, como pedestres de diferentes classes socioeconômicas. O autor salienta seu "cuidado na representação da presença feminina, sempre valorizada e independente; uma mulher que, assim como ela própria, deveria trabalhar, mas também guardar um certo mistério" ${ }^{23}$.

Hans Günter Flieg chegou ao Brasil em 1939. Em Berlim teve aulas com Grete Karplus, fotógrafa do Museu Judaico, que oferecia cursos de fotografia para jovens judeus que pretendiam emigrar e precisavam de alguma instrução profissional. Já em São Paulo, no início da década de 1940, Flieg foi assistente de estúdio de Peter Scheier. Esta experiência foi curta, em função de uma doença que o manteve isolado do convívio social por meses, durante os quais pode estudar e ler muito sobre o Brasil. Em seguida, conseguiu emprego no estúdio de retratos Foto Paramount, na Rua Líbero Badaró, de propriedade de Irene Lenthe, húngara. Depois, trabalhou na Companhia Litográfica Ypiranga e Indústria Gráfica Niccolini, nas quais aprendeu muito sobre artes gráficas. Em 1945 abriu seu estúdio, que funcionou até 1988. Teve clientes nas áreas de arquitetura, indústria e publicidade. Reproduzia obras de arte de Bruno Giorgi, Felícia Leirner, Tarsila do Amaral, Nelson Leirner e Lina Bo Bardi. Em 1951 registrou a demolição do 22 KOSSOY, Boris. Os Tempos da Fotografia: o Efêmero e o Perpétuo. Cotia, SP: Ateliê Editorial, 2007, p.97.

23 Loc. cit. 
belvedere e da pérgola do Trianon, bem como a construção do pavilhão-sede da I Bienal de Artes, da qual foi o fotógrafo oficial. Suas vistas de São Paulo, geralmente tomadas dos altos dos edifícios, enquadravam principalmente o vale do Anhangabaú, nas proximidades dos viadutos do Chá e Santa Ifigênia.

Naquele momento, significativo dentro da história da fotografia brasileira, o papel destes imigrantes foi, portanto, inserir suas experiências vivenciais na cultura visual da época, ampliando a extensão das correntes vanguardistas para muito além dos círculos restritos dos fotoclubes, atingindo uma grande parcela da população através da fotografia comercial, publicitária, industrial, fotojornalística, etc. ${ }^{24}$

Outro fator importante era a existência de revistas e jornais ilustrados. Desde o início do século $X X$ as publicações ilustradas reservavam espaço generoso à fotografia, embora ela estivesse destinada à mera função ilustrativa. Na publicidade, o desenho prevalecia. Revistas como Kosmos (1904), Fon-Fon (1907), A Cigarra (1914) e O Cruzeiro (1928) eram fartamente ilustradas.

Alguns fotógrafos já se destacavam no fotojornalismo. Aurélio Beccherini foi o primeiro fotógrafo de jornal da imprensa paulistana, trabalhando desde 1910 no O Estado de S.Paulo, além do Correio Paulistano, Jornal do Comércio, A Cigarra, Vida Doméstica e Cri-Cri. Theodor Preising e Benedito Junqueira Duarte (sob o codinome Vamp) destacavam-se na Revista S.Paulo, que circulou em 1936, totalizando dez números. Dirigida por Cassiano Ricardo, Menotti Del Picchia e Leven Vampré, era definida como o "órgão documental das realizações paulistas" ${ }^{25}$. Neste periódico a fotografia aparecia como ferramenta de propaganda política das realizações do governo de Armando de Salles Oliveira - mesma finalidade dos álbuns ou livros patrocinados pelo Estado. Contudo, seu projeto

24 Boris Kossoy, em aula da disciplina do curso de pós-graduação CJE5907 "Fotografia, Comunicação e Memória".

25 KOSSOY, 2004. Op. cit. p. 428 


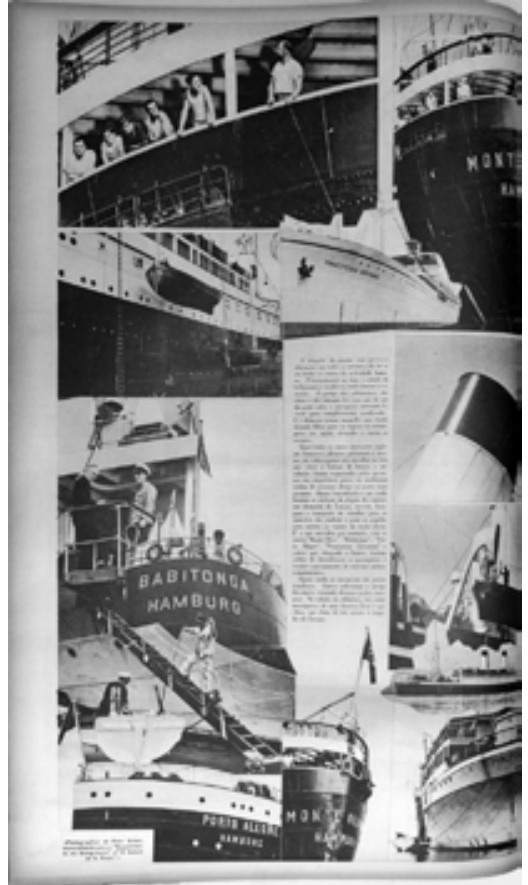

Imagem 13. Fac símile de página do Supplemento em Rotogravura do $O$ Estado de S.Paulo, n.143, com fotos de Scheier. Fonte: Acervo da FDUSP.

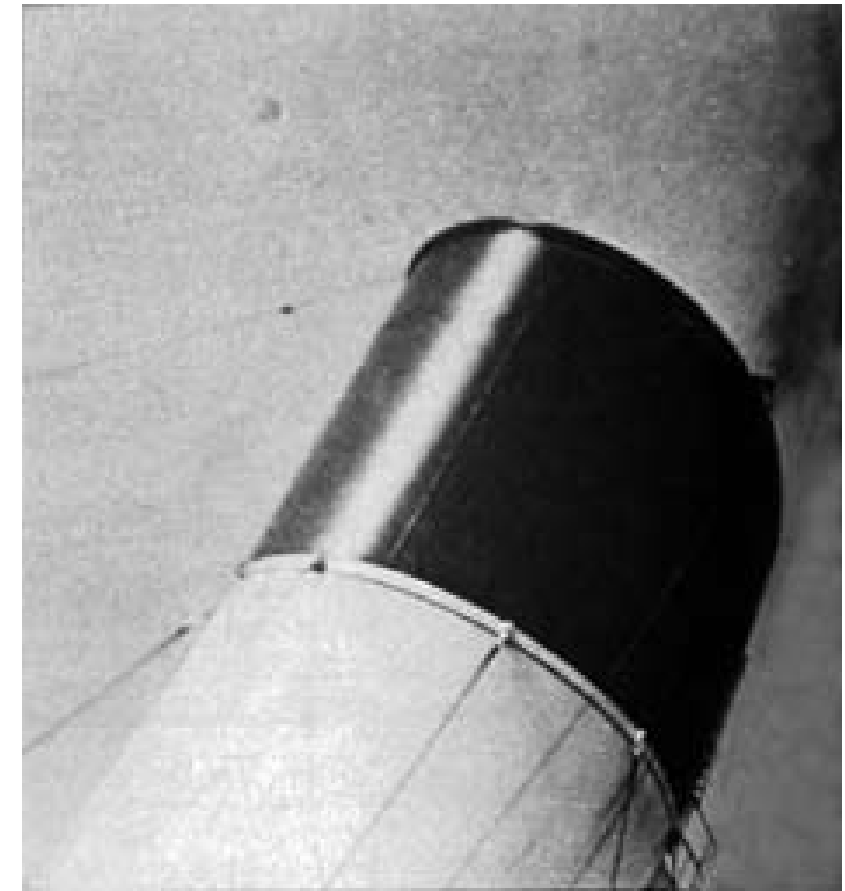

Imagem 14. Foto de Peter Scheier publicada no Supplemento em Rotogravura do O Estado de S.Paulo, n.143. Fonte: Acervo da FDUSP.

gráfico era moderno e ousado, privilegiando as imagens, apesar de sua linha editorial conservadora.

As casas tipográficas multiplicavam-se. A fotografia impressa era cada vez mais empregada, em função da substituição das técnicas artesanais de reprodução de imagens por técnicas modernas, como a rotogravura. Desde o início da década de 1930 o jornal O Estado de S.Paulo publicava o Supplemento em Rotogravura, de periodicidade quinzenal. No mesmo formato do jornal, o suplemento apresentava muitas fotografias e ilustrações por página e exibia composições ousadas com sobreposições, ângulos inclinados e fotos recortadas. Continha seções de poesia, literatura, turismo, contos, infantil, variedades, cinema, artes, música, rádio, automóveis, moda e quadrinhos. Em sua seção de fotografia - ou Photographia, na grafia original - era comum ver nomes como 


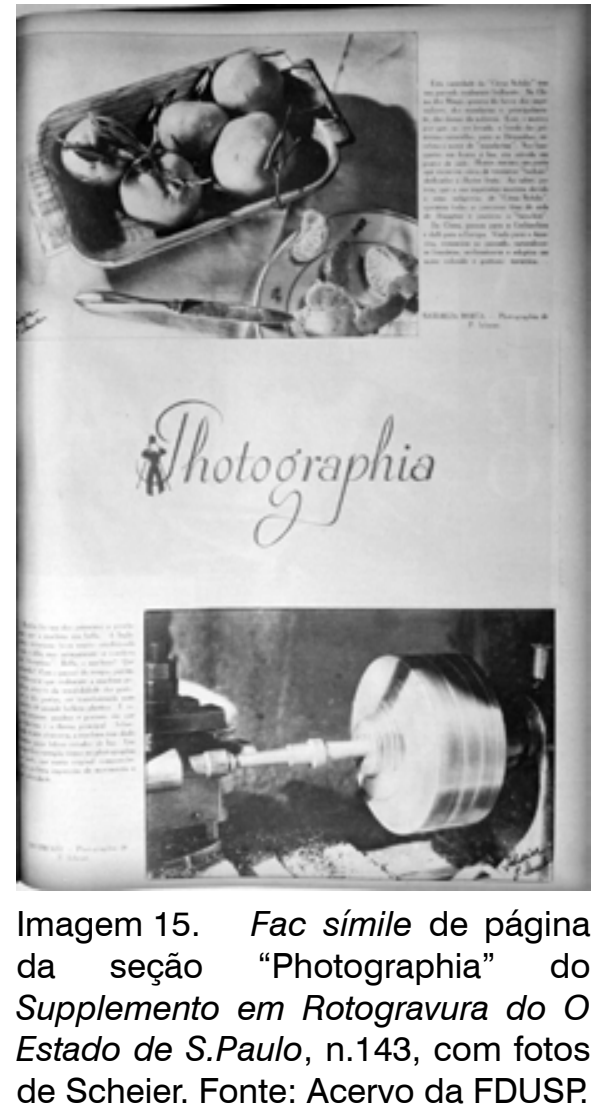

Benedito J. Duarte e José Medina.

Em setembro de 1939 Peter Scheier teve suas primeiras fotos publicadas no Supplemento. As imagens mostravam navios europeus ancorados no porto de Santos, identificados nos cascos com os locais de origem, como Hamburg, ou com seus nomes estrangeiros, como "Principessa Giovanna". As imagens (Imagem 13/14), recortadas para compor uma fotomontagem - recurso muito utilizado por este jornal -, mostram detalhes dos navios e alguns tripulantes. A imagem de uma chaminé exibe um arrojado enquadramento diagonal, típico das experimentações vanguardistas de László Moholy-Nagy, Alexander Rodchenko e Renger-Patzsch, que exploravam novos ângulos e posicionavam-se contra os pontos de vista usuais. Esta imagem - publicada logo após sua chegada ao Brasil - mostra como os anos de vivência na cultura européia marcaram sua vida e seu modo de olhar. 


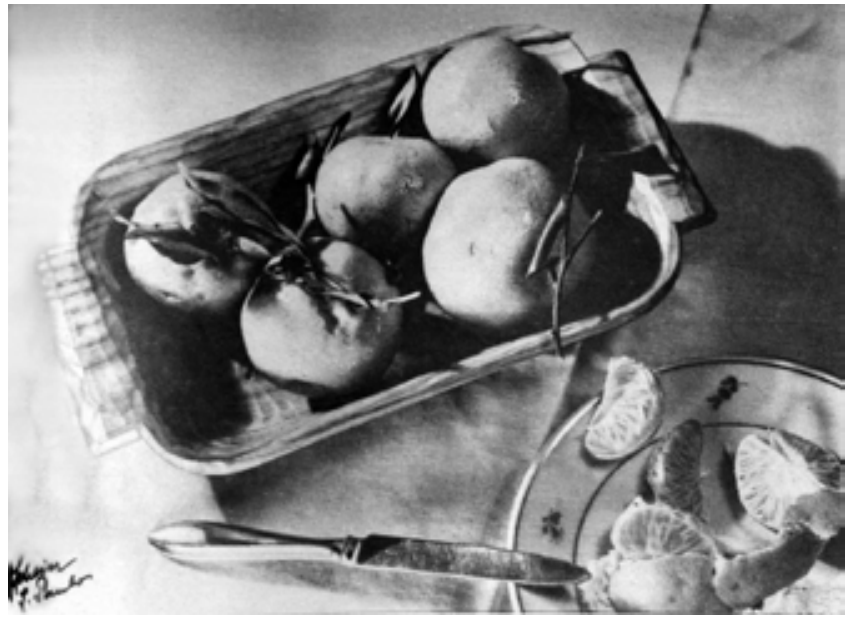

Imagem 16. Foto de Peter Scheier publicada no Supplemento em Rotogravura do O Estado de S.Paulo, n.143. Fonte: Acervo da FDUSP.

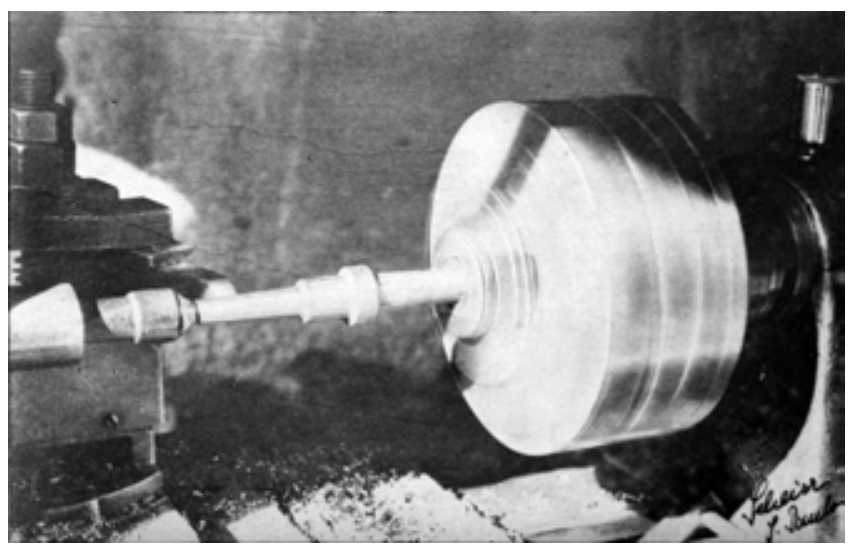

Imagem 17. Foto de Peter Scheier publicada no Supplemento em Rotogravura do O Estado de S.Paulo, n.143. Fonte: Acervo da FDUSP.

Neste mesmo número aparecem duas fotos de Scheier na seção Photographia, com sua assinatura - Scheier, S.Paulo - nos cantos inferiores (Imagem 15). De inspiração picturialista e com o título “Natureza Morta”, uma delas mostra uma composição com mexericas sobre um prato e dentro de uma cesta de madeira (Imagem 16). Na outra, com o título de "Movimento", é mostrada uma máquina rotativa em ação (Imagem 17). No número seguinte Scheier publicou "No alto do arranha-céu", um flagrante urbano de dois operários instalando um letreiro (Imagem 18). O olhar estrangeiro começava a apreender o cotidiano 


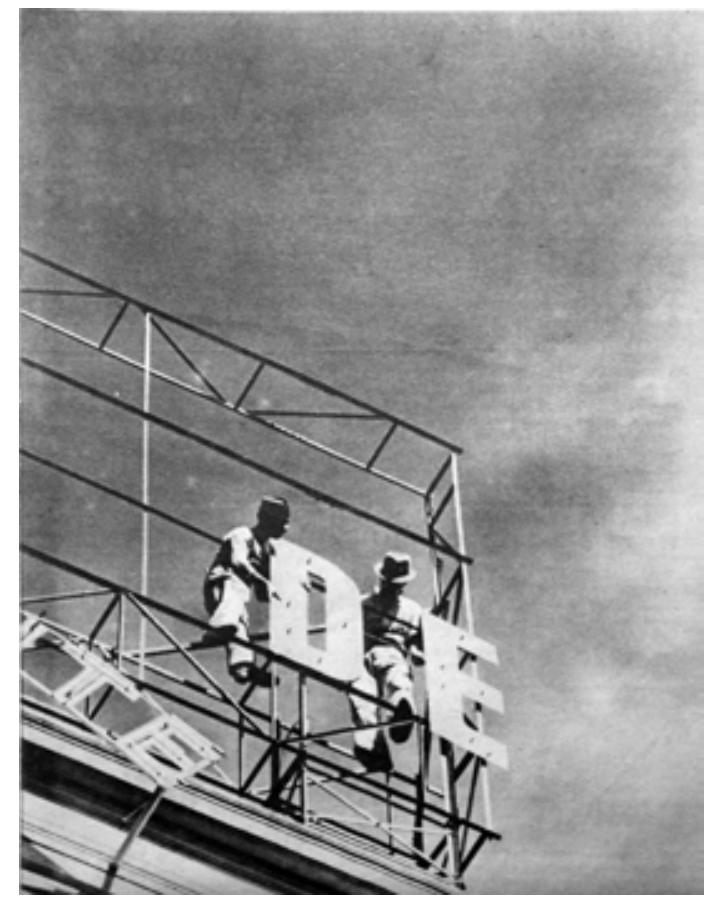

Imagem 18. Foto de Peter Scheier publicada no Supplemento em Rotogravura do O Estado de S.Paulo. n.144. Fonte: Acervo da FDUSP.

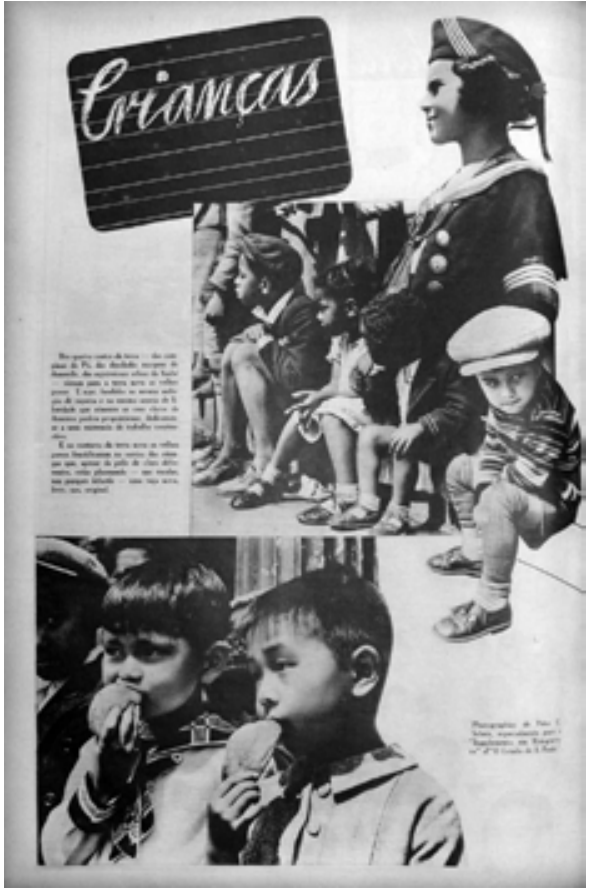

Imagem 19. Fac símile de página da seção "Photographia" do Supplemento em Rotogravura do $\mathrm{O}$ Estado de S.Paulo, n.145, com fotos de Scheier. Fonte: Acervo da FDUSP.

de sua nova cidade. Na segunda quinzena de outubro, na seção "Crianças" e com a legenda "Photographias de Peter C. Scheir (sic), especialmente para o “Supplemento em Rotogravura d' "O Estado de S.Paulo", suas fotos compuseram uma fotomontagem com crianças de várias origens étnicas (Imagem 19). No final deste ano Scheier venceu o concurso "Centenário da Photographia", promovido pelo jornal, em comemoração àquele evento, com o tema paisagem brasileira.

A ausência de escolas especializadas levava os fotógrafos a buscarem o aprendizado e a atualização em bibliografia específica, composta por revistas e manuais - geralmente importados, franceses e alemães. Minhas experiências com a Leica, de Paul Wolff, era amplamente conhecido e utilizado. Periódicos especializados, editados por fabricantes ou fornecedores para divulgação e instrução, existiam desde 1909, com a Revista Photográphica (1909-1929). 


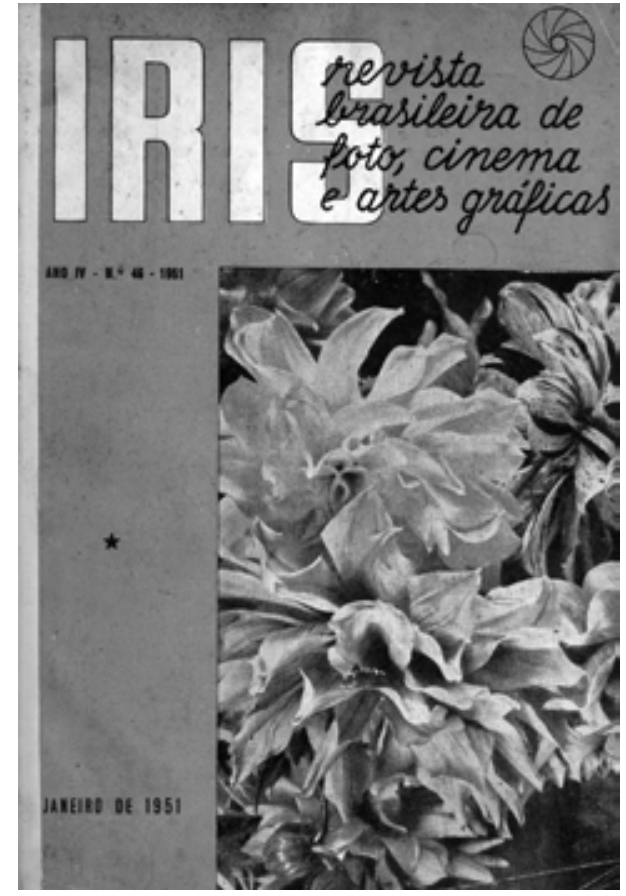

Imagem 20. Capa da revista Íris (jan. 1951). Fonte: Acervo da FAUUSP.

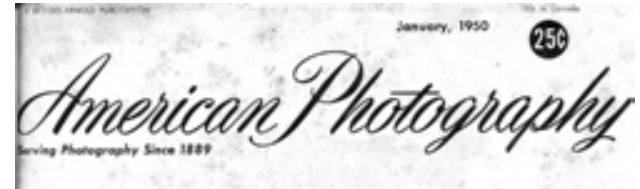

Feaiture Lengiti: Ilow to Pholograph Peis, by Molph Meral

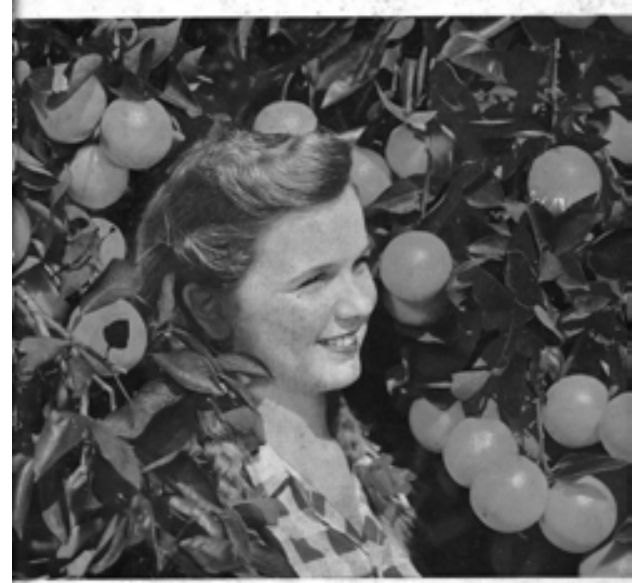

Children's Ski School - Photomurals - Focus on the Hoou

Imagem 21. Capa da revista American Photography (jan. 1950). Fonte: Acervo da FAUUSP.

Outras surgiram, porém a mais duradoura foi a Revista Íris - Revista Brasileira de Foto, Cinema e Artes Gráficas, fundada em 1946 pelo imigrante alemão Hans Koranyi (Imagem 20). Foi a primeira publicação de porte com circulação comercial, não vinculada a fotoclubes. Contava com uma comissão patrocinadora composta por Eduardo Salvatore, Gregory Warchavchik, Norberto Mafra, Thomaz Farkas e Bernardo Pedroso. Seguia a linha editorial de revistas estrangeiras, como American Photo (Imagem 21). Lançou a "Enciclopédia Fotográfica" em dez volumes, abordando temas como a focalização, a exposição, os filtros, a revelação, correção e ampliação do negativo, o instantâneo, a luz artificial e as fotos artísticas, assim como um curso de fotografia por correspondência, um dicionário fotográfico e vários livros técnicos. Apresentava seções temáticas fotografia de paisagens, retratos, movimento, esportes -, artigos sobre laboratório e química, sobre novos modelos de equipamentos, etc. 


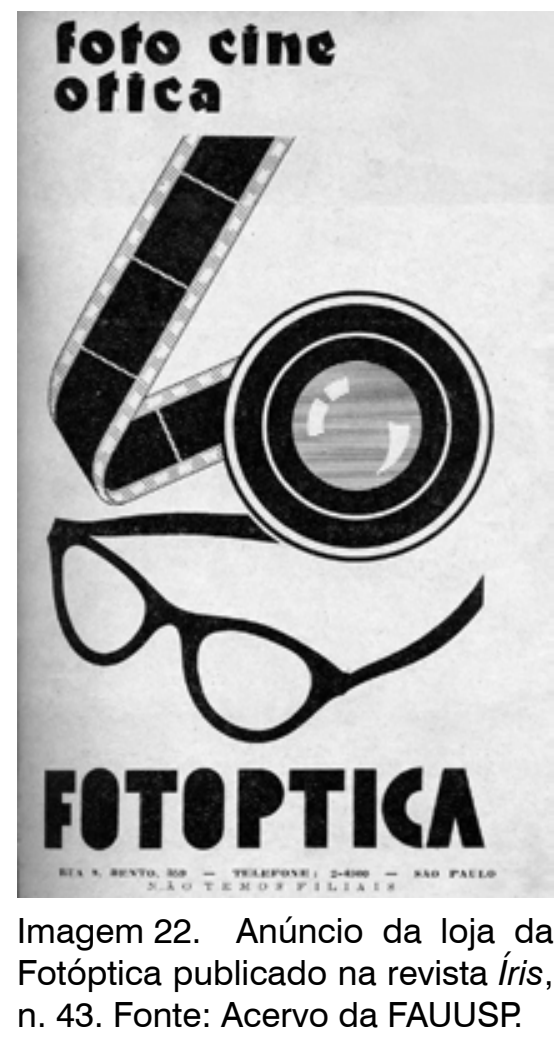

Em suas páginas havia amplo espaço para a propaganda de estabelecimentos comerciais e de fabricantes. Íris surgiu no pós-guerra, quando as opções de aquisição de materiais e equipamentos tendia a melhorar. Entretanto, durante o período em que o Brasil se envolveu no conflito (19421945), a importação difícil causava problemas. Vários navios que transportavam material e equipamentos foram afundados. A recessão européia resultava em embalagens de filmes e papéis sem acabamento: caixas de papelão bruto grampeado, sem revestimento, com uma etiqueta impressa e colada na parte superior. O fotógrafo Hans Günter Flieg relata a necessidade de recorrer a vendedores que comercializavam mercadorias provenientes de contrabando. Para os imigrantes, acostumados a adquirir sem dificuldades produtos da llford, Kodak e outros, este era mais um desafio: 


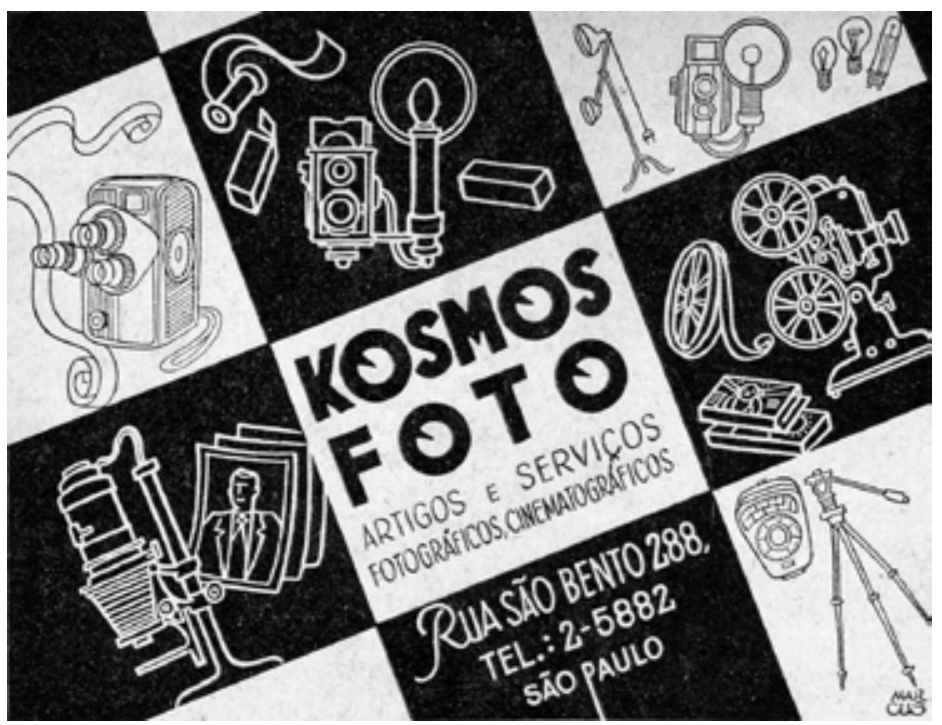

Imagem 23. Anúncio da Kosmos Foto publicado na revista Íris, n. 46. Fonte: Acervo da FAUUSP.

Se você vivia no país onde se fabricava, você tinha todas as opções possíveis. Tinha todas as superfícies, as duas grossuras: papel fino ou papel W-weight. Era bom, né? E todas as superfícies em todos os tamanhos. [No Brasil] a preferência era pelo papel que chegou a ser importado. ${ }^{26}$

Ladislao Farkas - tio do fotógrafo Thomaz Farkas e irmão de Desidério Farkas, dono da Fotóptica - era proprietário da Brasport, importadora de equipamento fotográfico. Aos poucos, a empresa buscou suprir as necessidades dos fotógrafos, produzindo alguns acessórios como secadeiras de filmes, marginadores para ampliador e refletores e flashes para iluminação de estúdio. A firma Sanibras - Sociedade Anônima Importadora Brasileira - de propriedade de Norberto Schaffner, era uma importadora de produtos da inglesa llford.

Peter Scheier morou na região central de São Paulo, primeiramente no Largo do Arouche e em seguida na Rua Dr. Teodoro Baima. Essa área concentrava grande número de estabelecimentos especializados em fotografia. A Fotóptica, 

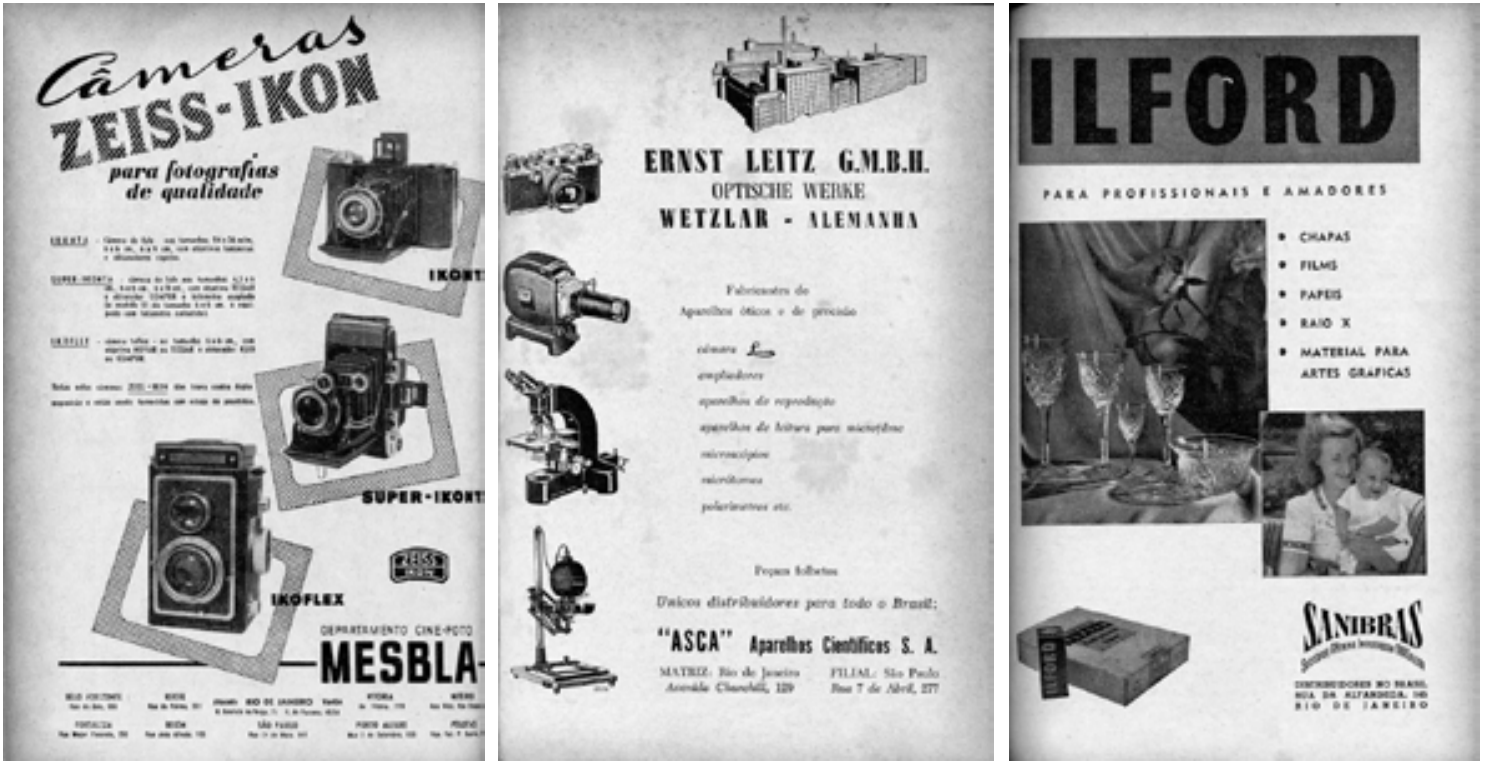

Imagem 24. Anúncio das câmeras Zeiss-lkon publicado na revista Íris, n. 35. Fonte: Acervo da FAUUSP.

Imagem 25. Anúncio dos equipamentos Leitz publicado na revista Íris, n. 44. Fonte: Acervo da FAUUSP.

Imagem 26. Anúncio dos produtos llford publicado na revista Íris, n. 45. Fonte: Acervo da FAUUSP.

fundada em 1921, tinha uma loja na Rua São Bento, 359 e em 1941 abriu uma filial na Rua Barão de Itapetininga e depois na Rua Sete de Abril (Imagem 22). A Fotóptica destacava-se por oferecer um grande laboratório para amadores. $\mathrm{Na}$ São Bento havia ainda a Panamericana - revendedora de produtos Kodak - e a Kosmos Foto (Imagem 23), de propriedade de um imigrante húngaro chamado Laslo. Na Rua Sete de Abril ficava a Asca, distribuidor de produtos Leica. Na Xavier de Toledo, além da redação e administração da revista Íris, encontrava-se a Duperial - representante da americana Dupont, fabricante de filmes, papéis e químicos. A distribuidora Cipan ficava na Rua Dom José de Barros, e a loja Mesbla, na Rua Vinte e Quatro de Maio (Imagem 24). Além dessas lojas, havia oficinas que adaptavam e consertavam equipamentos. Uma delas era a de Alberto Trentini, localizada no edifício do Grande Hotel, também na Rua São Bento. Uma das adaptações comuns era a transformação de máquinas de fole 
9x12cm em ampliadores neste formato, que não eram fabricados. Havia também um fabricante de tripés de madeira muito conhecido, chamado Bernardi.

No Brasil, o químico Conrado Wessel produziu durante cerca de trinta anos papel fotográfico. Contudo, Wessel não sobreviveu à concorrência dos grandes fabricantes da indústria fotográfica: fez sociedade com a Kodak, primeiramente vendendo sua produção e, depois, em 1949, criando a Fábrica de Papel Fotográfico Kodak-Wessel em Santo Amaro, São Paulo. Foi diretor da fábrica até 1954, quando transferiu os direitos de inventor definitivamente. Sem fabricação nacional, os papéis mais consumidos, além da norte-americana Kodak, eram importados da Agfa (alemã - papel Agfa Brovira), Ilford, Leonar (alemã) e Gevaert (belga). Após o fim da Segunda Guerra, as patentes da Agfa passaram para os americanos, que criaram a marca Ansco, também muito utilizada.

Os filmes - inclusive os importados e produzidos pelos já citados fabricantes - eram encontrados mais comumente nos formatos $6 \times 6 \mathrm{~cm}, 4 \times 5$ ", $12 \times 18 \mathrm{~cm}$ ou $35 \mathrm{~mm}$. Até o início da década de 1950, os filmes utilizados eram com base de nitrato de celulose. Eles eram extremamente inflamáveis e decompunham-se em um gás também inflamável, aumentando o risco de combustão espontânea ${ }^{27}$. Estes filmes foram substituídos por aqueles com base de acetato, muito menos inflamável. Os filmes com base de acetato passaram a trazer a inscrição "Safety Film" e pequenos cortes em forma de "V" ou circulares nas bordas. Na década de 1960 estes seriam substituídos por filmes à base de poliéster.

No arquivo de Peter Scheier foram encontrados negativos $6 \times 6 \mathrm{~cm}$ (rolos de doze poses) e $4 \times 5$ " (chapas) da Kodak, base de nitrato e acetato. No formato $35 \mathrm{~mm}$ foram encontrados negativos Ilford FP3 (Fine Grain). Grande parte de sua obra foi realizada com a máquina Rolleiflex em formato 6x6 (Imagem 27).

$27 \quad$ Um exemplo de acidente com filmes à base de nitrato foi apresentado no filme Cinema Paradiso, do diretor Giuseppe Tornatore (1989). 

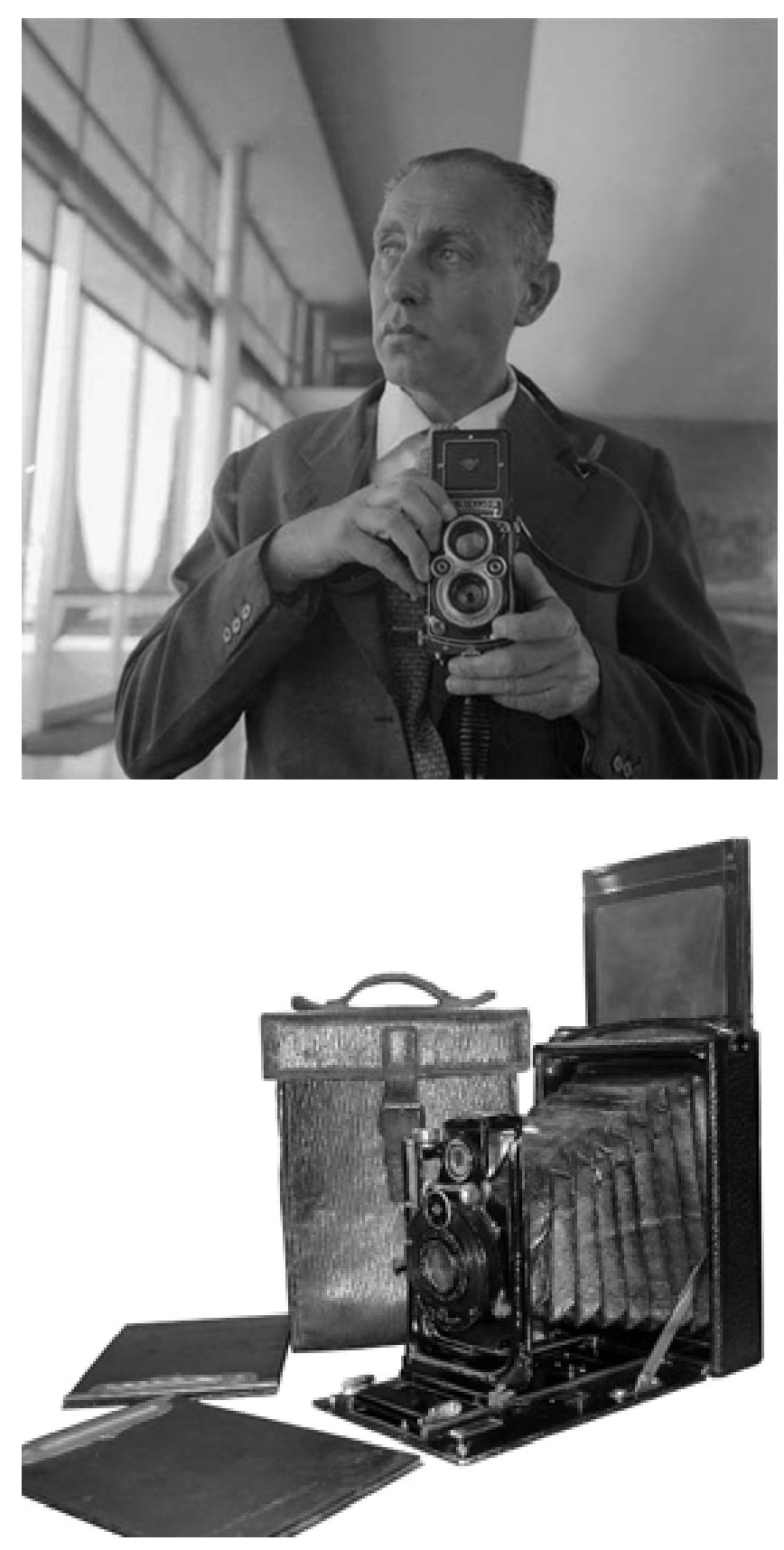

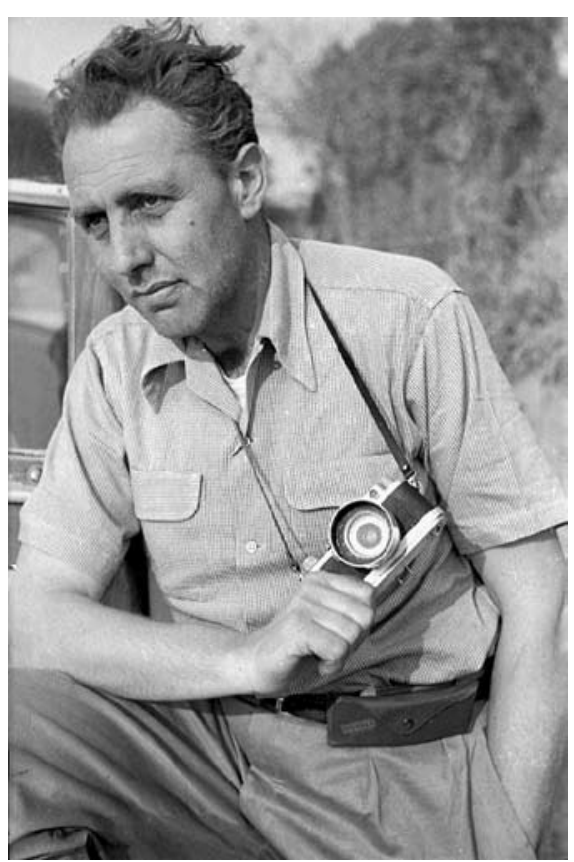

Imagem 27. Peter Scheier em Brasília, em 1960, com sua Rolleiflex (6x6cm). Fonte: Acervo do AHJB.

Imagem 28. Peter Scheier, no Paraná, na década de 1950, com sua Leica (35mm). Fonte: Acervo do AHJB.

Imagem 29. Um modelo fabricado pela ICA AG $(9 \times 12 \mathrm{~cm})$, semelhante ao que Scheier trouxe da Alemanha. Fonte: www.todocolleccion.net.

Os trabalhos de arquitetura eram feitos em 4x5", provavelmente com máquinas trazidas da Alemanha, cuja descrição consta de sua autorização emitida pela Superintendência de Segurança Política e Social: uma máquina de madeira e uma ICA ${ }^{28}$ Juivel 9x12 (Imagem 29). O formato 35mm (Imagem 28) era usado,

28 ICA AG (International Camera Aktiengesellschaft) surgiu em 1909 a partir da união de quatro companhias fotográficas da cidade de Dresden, Alemanha (AG, Camera work Dr., Wish AG, Zeiss Palmos Camerabau). Em 1926 se tornou Zeiss Ikon, grande empresa alemã, principal 


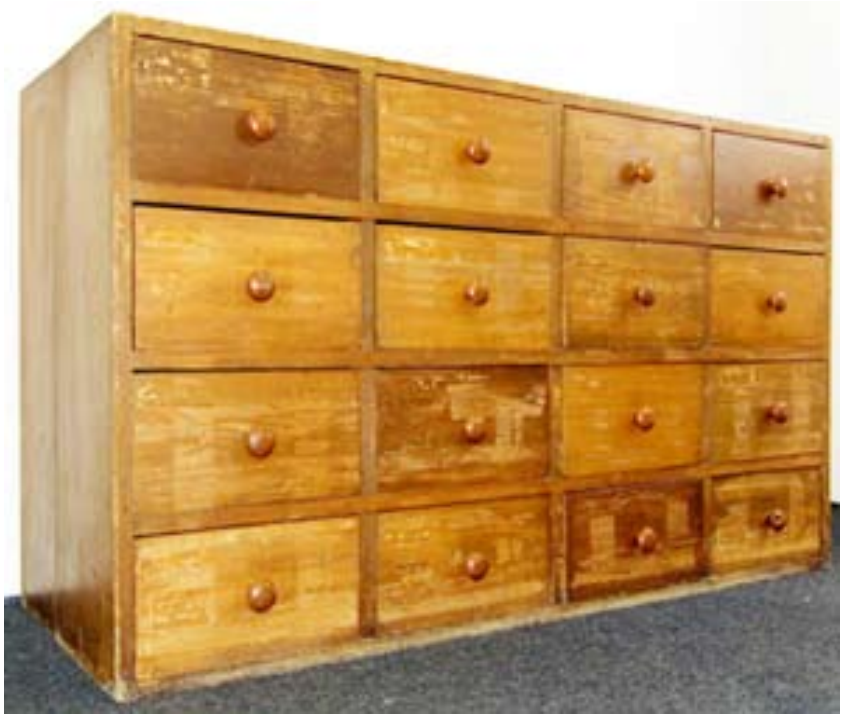

Imagem 30. O gaveteiro original para acomodação de negativos de Peter Scheier, que se encontra atualmente no Arquivo Histórico Judaico Brasileiro. Fonte: Acervo do AHJB.

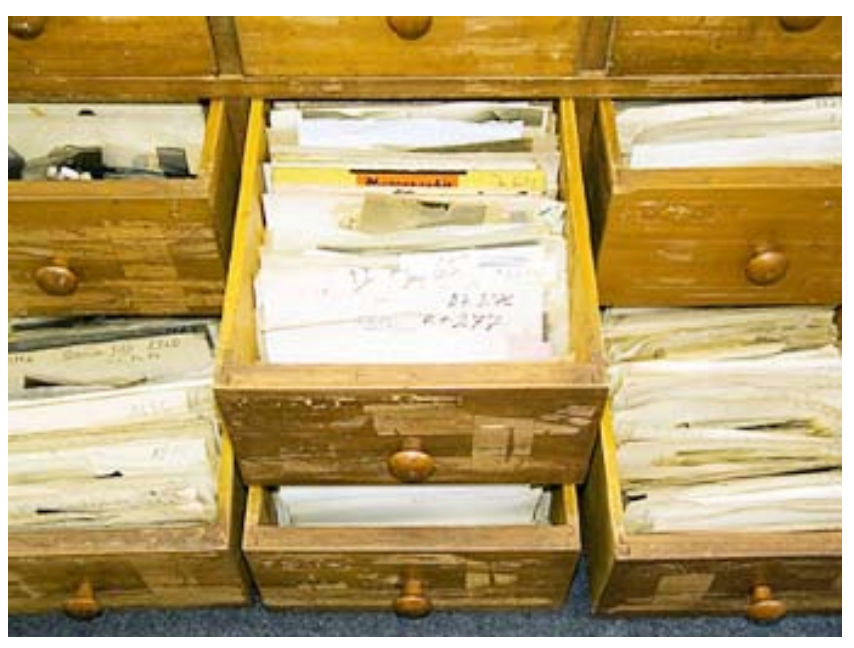

Imagem 31. Aspecto das gavetas, conforme organização original do fotógrafo. Fonte: Acervo do AHJB.

a princípio, como um caderno de notas, no qual Scheier experimentava alguns ângulos antes de fazer a foto definitiva no $6 \times 6$. Como os rolos de filmes $35 \mathrm{~mm}$ continham mais poses (36 no total), o fotógrafo adotava uma postura mais solta e menos cuidadosa.

Seus negativos eram guardados em envelopes de papel manteiga ou de papel comum, acondicionados em um gaveteiro de madeira (Imagem 30/31). Eram separados por pedaços de embalagens de papel, cartolinas ou pedaços de ampliações descartadas. Os negativos eram organizados por temas e em concorrente da conterrânea Ernst Leitz, fabricante da Leica. 


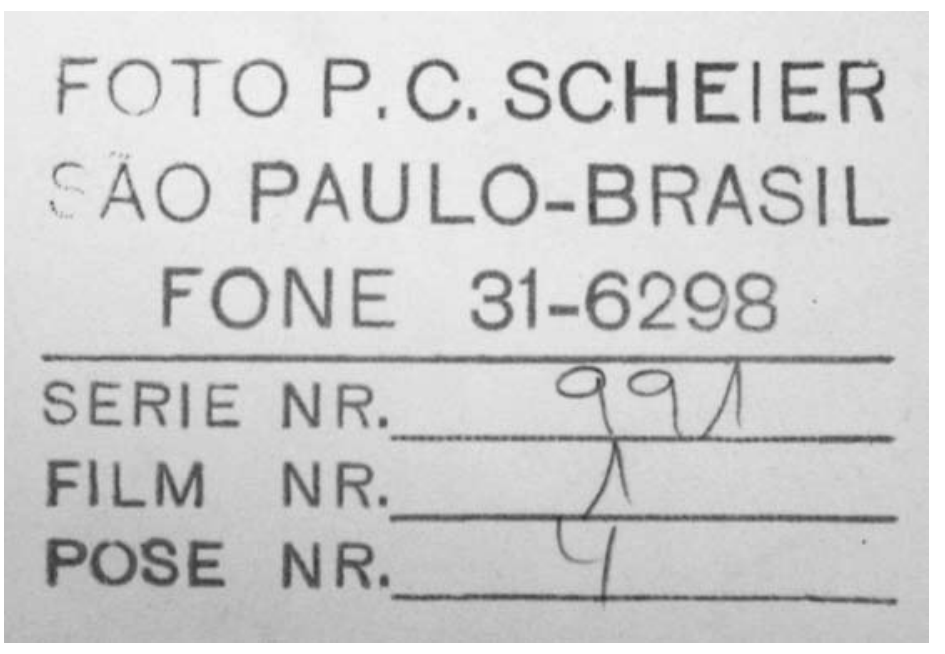

Imagem 32. Exemplo de carimbo encontrado no verso de ampliações, com o número de série, filme e pose. Fonte: Acervo fotográfico da FAUUSP.

séries, identificadas pelas siglas RJ para "Reportagens Jornalísticas" e SP para "Serviços Particulares" seguidas de números - esta identificação era escrita à caneta na margem do negativo. Por exemplo, a sigla SP700 identifica uma série de fotos aéreas da fábrica da Rhodia, produzidas em 1954; RJ116 identifica fotos do curso de bailado infantil do MASP na década de 1950; a série 515 refere-se às fotos do Hospital Central do Câncer, de Rino Levi e Roberto Cerqueira César, produzidas em 1954. Aos clientes eram entregues cópias-contato sobre as quais eram anotados os números das poses, para facilitar o pedido das ampliações. Estas, geralmente em papel brilhante, tamanho $18 \times 24 \mathrm{~cm}$, recebiam um carimbo no verso, contendo o nome de Peter Scheier, seu endereço e telefone e eventualmente o número da série, do filme e da pose (Imagem 32).

Scheier sempre trabalhou com uma grande equipe de ajudantes, além da constante companhia de sua esposa, Gertrude, que o auxiliava na administração e no atendimento aos clientes. Naquela época, os fotógrafos realizavam também os serviços de laboratório, revelando e ampliando suas fotos. Após seu primeiro estúdio na Rua Bento Freitas, os laboratórios e estúdios de Scheier eram sempre 
integrados às suas residências - que freqüentemente eram objeto de reformas para melhor adequação ao negócio. Após morar no apartamento no Largo do Arouche, Scheier mudou-se com a família para a Rua Teodoro Baima, 87 (Tel. 4-7310). Em seguida foram para a Rua Monte Alegre e para a Alameda Casa Branca, 363 (tel: 7-6298, depois 31-6298), onde permaneceram por quase trinta anos. Em 1972, às vésperas de partir para a Alemanha, o estúdio mudou-se pela última vez, para a Alameda Santos, 1398 - cj. 7 - térreo.

Scheier interessava-se por novidades da área dafotografia, e freqüentemente experimentava novas possibilidades. Benedito J. Duarte ${ }^{29}$ afirmou que Scheier introduziu no Brasil o uso de flash sincronizado. Na década de 1940, trouxe dos Estados Unidos um equipamento para revelação e ampliação de fotografias em cores. Contudo, sua preferência pelo filme preto e branco e seu desinteresse em montar um laboratório comercial o fizeram vendê-lo para o fotógrafo Curt Schulze, que iniciaria, assim, a rede de laboratórios Curt. No final dos anos 1960 Scheier iniciou a pesquisa e a produção de fotografias para projeção em grandes telas, que incluíam fundo musical e locução. Esta pesquisa resultou em trabalhos para o Ministério das Relações Exteriores apresentados na Exposição Internacional de Alimentação (1968, Paris, França) e na Expo'70 (1970, Osaka, Japão). Desta experiência surgiu também a exposição "Trinta Anos de Visão e Multivisão", no MASP, em 1970.

O Foto Studio Peter Scheier, fundado em 1940, iniciou suas atividades com a documentação de eventos sociais. Em poucos anos o fotógrafo já apresentava trabalhos em diversas áreas. Ao final da década de 1940, Scheier já documentara várias obras de Rino Levi, como o Cine Ipiranga e Hotel Excelsior, o Edifício Prudência, o Banco Paulista do Comércio, o Edifício Porchat, e a Companhia Kossoy, Moracy de Oliveira, Hans Günter Flieg e Máximo Barro. Data: 14.05.1981. Acervo: Museu da Imagem e do Som. Transcrição feita por: Carolina da Costa e Silva. 
Jardim de Cafés Finos. Já publicara uma foto da Residência Arnstein de Bernardo Rudofsky no livro Brazil Builds. Suas atividades de fotojornalista dos Diários Associados intensificaram-se com a nova linha editorial da revista O Cruzeiro e com a documentação das atividades do Museu de Arte.

Peter Scheier foi um homem que soube aproveitar a conjuntuta, transformando a adversidade da guerra numa oportunidade e o passatempo numa profissão. Neste trabalho, veremos parte de sua ampla e diversificada obra, produzida ao longo de trinta anos. Notaremos como sua vivência européia esteve constantemente presente no seu modo de registrar o Brasil. 
Capítulo 2 - A diversidade da produção

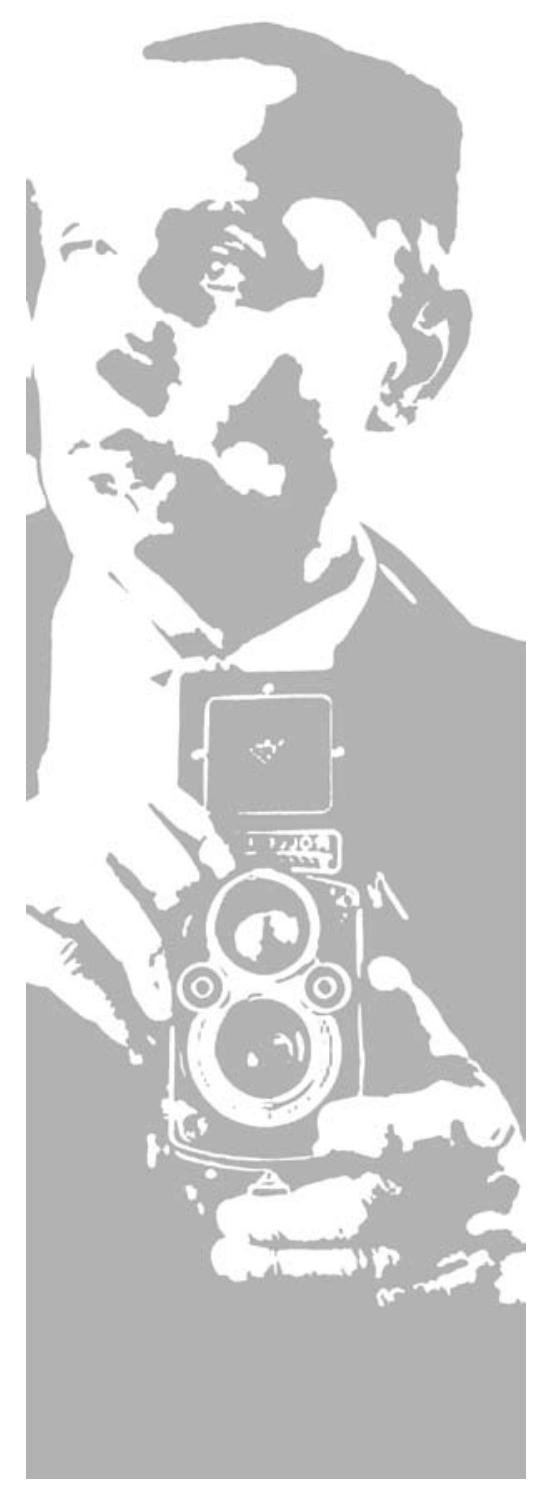


Extensa é a gama de temas fotografados por Peter Scheier. Embora este trabalho concentre-se na primeira metade de sua carreira, é de suma importância registrar a sua dinâmica e seu interesse em diversas áreas, pois salienta sua postura e suas escolhas. Visando como objeto final o álbum São Paulo fastest growing city in the world, neste capítulo será abordada especificamente sua produção na revista $O$ Cruzeiro, no Museu de Arte de São Paulo e na área de arquitetura.

O Foto Studio Peter Scheier dedicou-se constantemente ao registro de eventos sociais, como festas no Jóquei Clube, na Hípica e no Clube Paulistano, desfile do grupo Matarazzo no Teatro Municipal (1957), os concursos "Glamour Girl", casamentos, bailes e inaugurações. A confecção de álbuns foi uma atividade constante em seu estúdio, coordenada por sua esposa Gertrude: álbuns de casamento, de crianças e álbuns de formatura - como o realizado para o Sedes Sapientiae. 


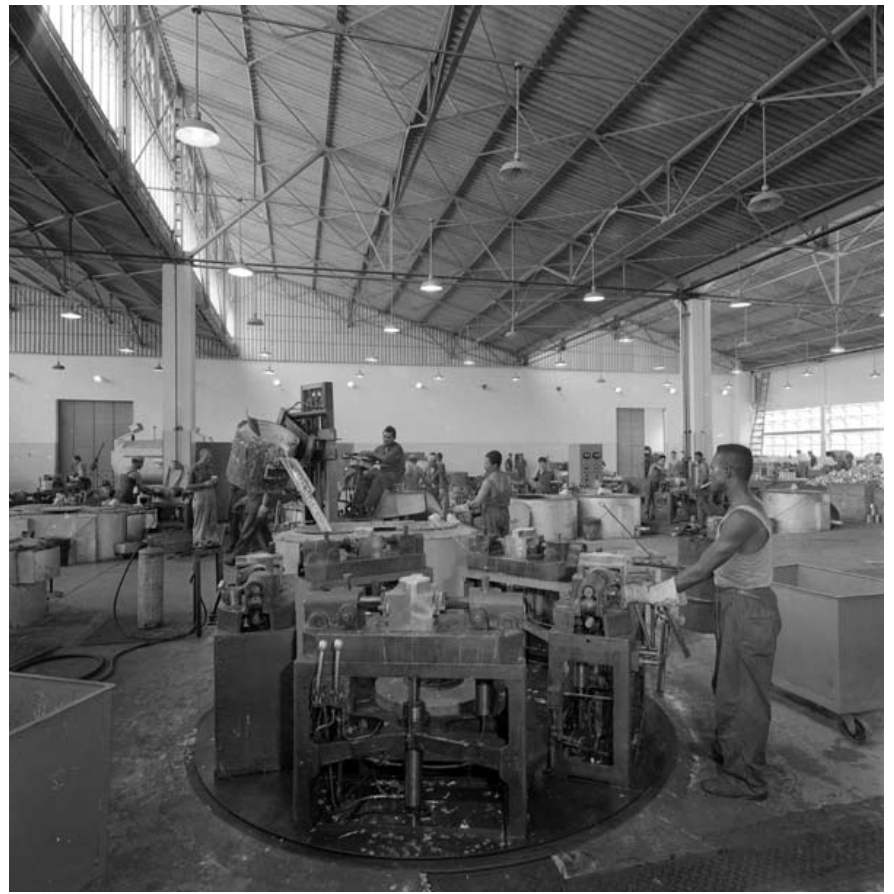

Imagem 33. Interior da Metalleve, 1959. Autoria: P. Scheier. Fonte: Acervo do AHJB.

A partir de 1952 - após seus anos na O Cruzeiro - Peter Scheier produziu fotografia industrial. Ultragaz (1952-1954), Klabin (1953, 1963), Rhodia (19541968), Volkswagen (1954-1957), Labortherapica (1958), Bimetal (1958), Metalleve (1959), Usafarma (1961-1968), Coldex (1964-1966), Metalúrgica Barbará (1965) e Aço Villares (1968) foram algumas das empresas que contrataram seus serviços para a documentação de novas unidades, da linha de produção e da expansão, sendo freqüentes as vistas aéreas. Nas fotografias internas, Scheier buscava sempre inserir o operário no cenário (Imagem 33), imprimindo um significado baseado na força motriz, no homem como elemento transformador e empreendedor, que traz progresso para a economia do país.

De 1958 a 1962 Peter Scheier foi fotógrafo oficial dos eventos da TV Record, inaugurada cinco anos antes. Utilizando-se mais constantemente do formato $35 \mathrm{~mm}$, criou registros memoráveis de artistas internacionais nos palcos da emissora como Johnny Ray, Roy Hamilton, Nat King Cole, Cab Calloway, Yma 


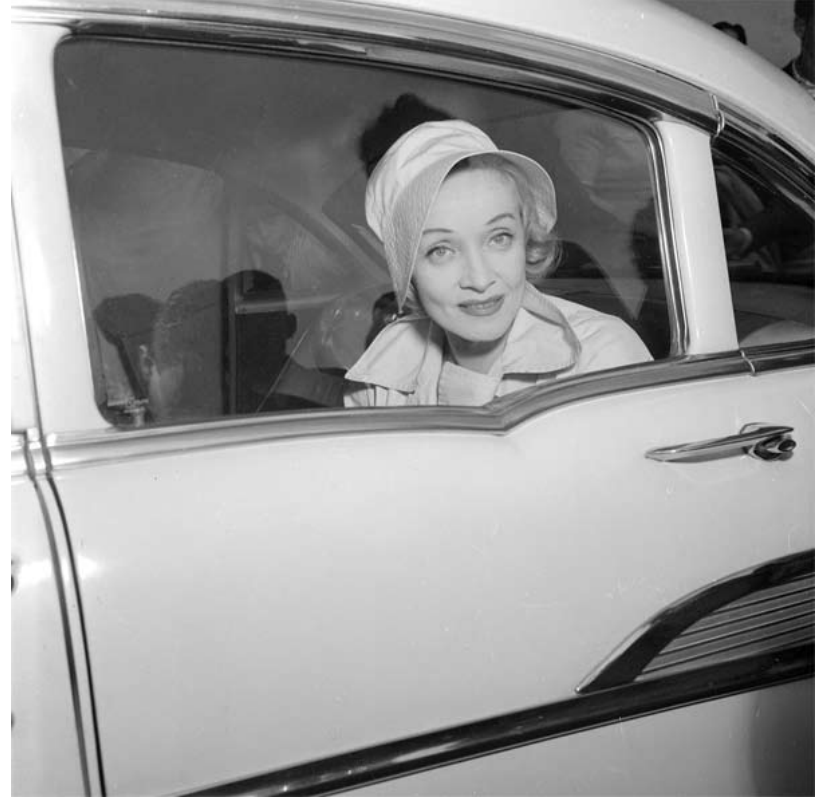

Imagem 34. Marlene Dietrich, 1958. Autoria: P. Scheier. Fonte: Acervo do AHJB.

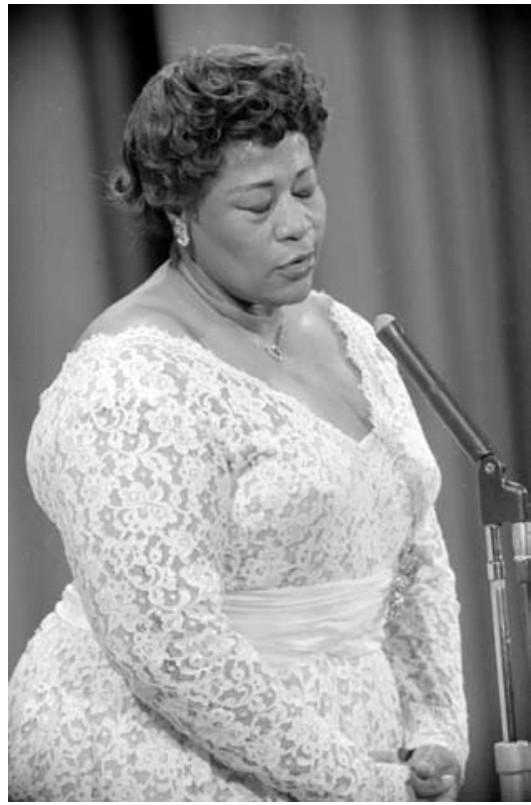

Imagem 35. Ella Fitzgerald em apresentação na TV Record, 1960. Autoria: P. Scheier. Fonte: Acervo do AHJB.

Sumac, Marlene Dietrich (Imagem 34), Sarah Vaughan, Domenico Modugno, Brenda Lee, Ivone de Carlo, Ella Fitzgerald (Imagem 35), Sammy Davis Junior e Catherina Valente. Com uma proximidade e intimidade notáveis, fotografava a chegada do artista ao aeroporto, seu caminho pela cidade, os outdoors que anunciavam a atração, a preparação do artista no camarim, os bastidores, os equipamentos para transmissão, os anúncios dos patrocinadores e o público.

Notável também era sua proximidade com figuras políticas de grande vulto. Juscelino Kubitschek e Getúlio Vargas foram personalidades retratadas em momentos de descontração e em locais mais reservados. Um pequeno álbum produzido em Campos do Jordão mostra Getúlio muito à vontade entre seus vários convidados e ante à câmera fotográfica (Imagem 36). Em 1965 Scheier cobriu a visita de Robert Kennedy ao Brasil (Imagem 37).

Outro ponto relevante são as inúmeras viagens que Peter Scheier realizava 


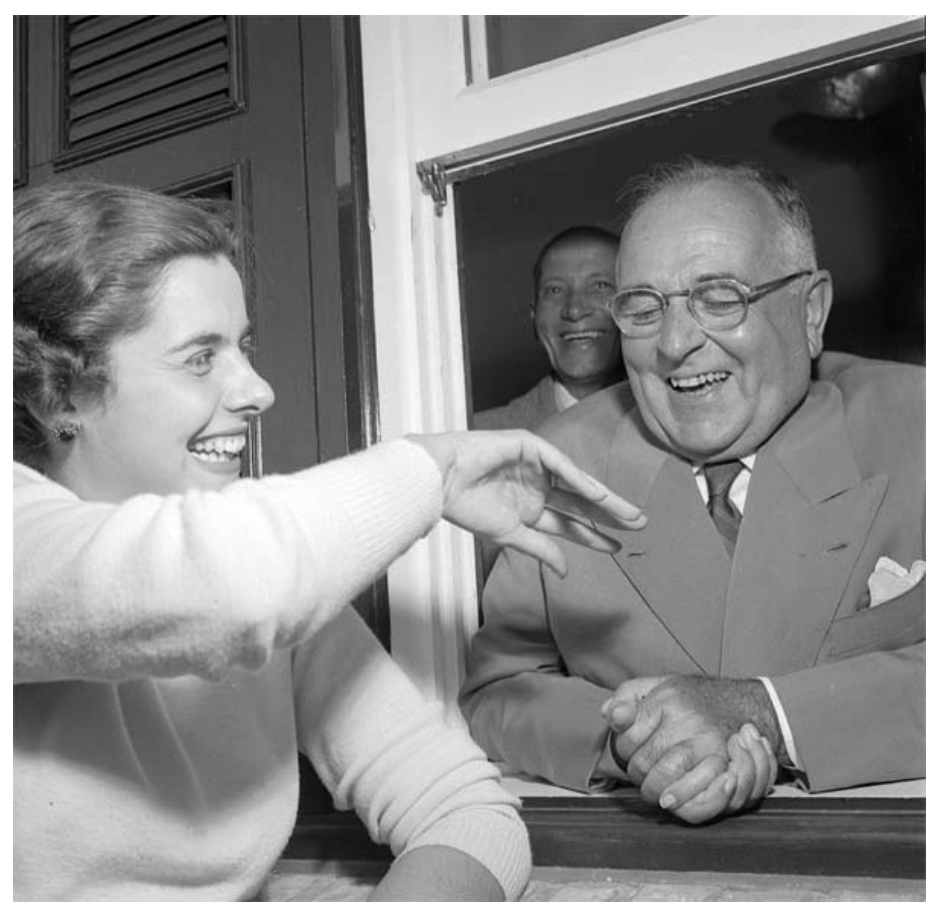

Imagem 36. Getúlio Vargas em Campos do Jordão, janeiro 1951. Autoria: P. Scheier. Fonte: Acervo do AHJB.

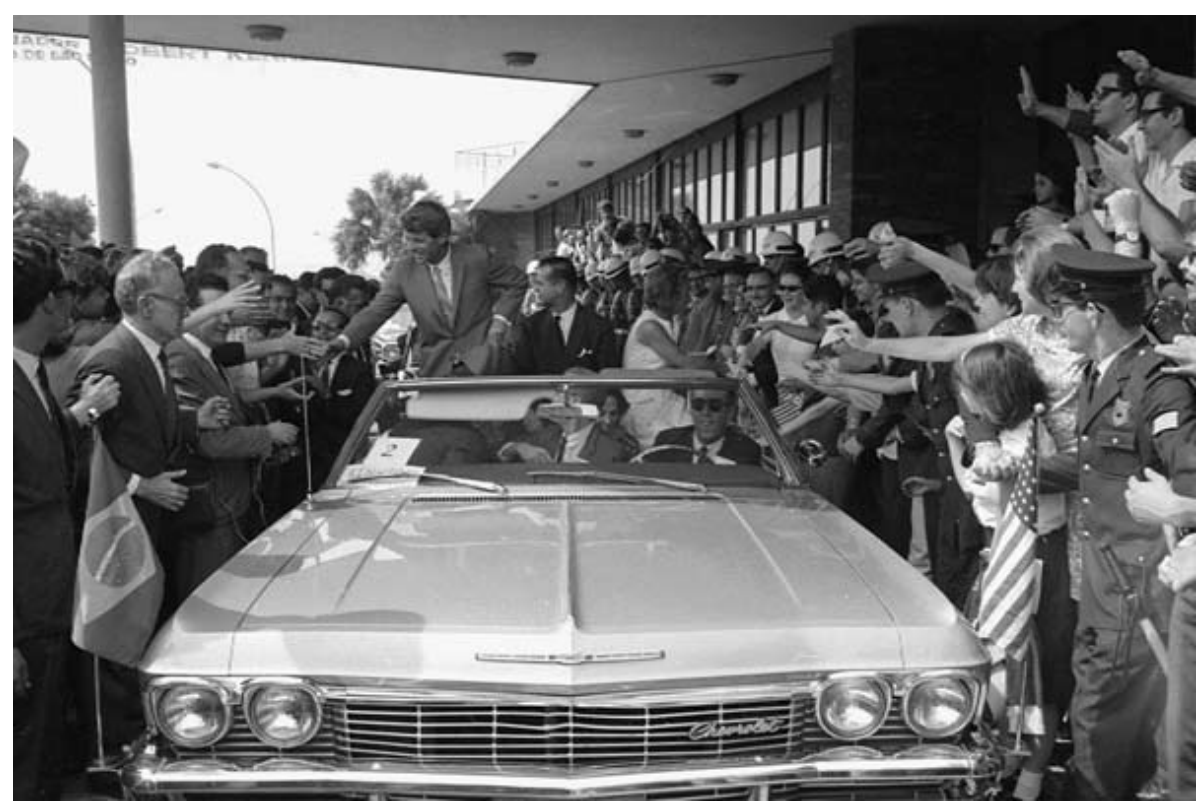

Imagem 37. Robert Kennedy em visita ao Brasil, 1965. Autoria: P. Scheier. Fonte: Acervo do AHJB. 


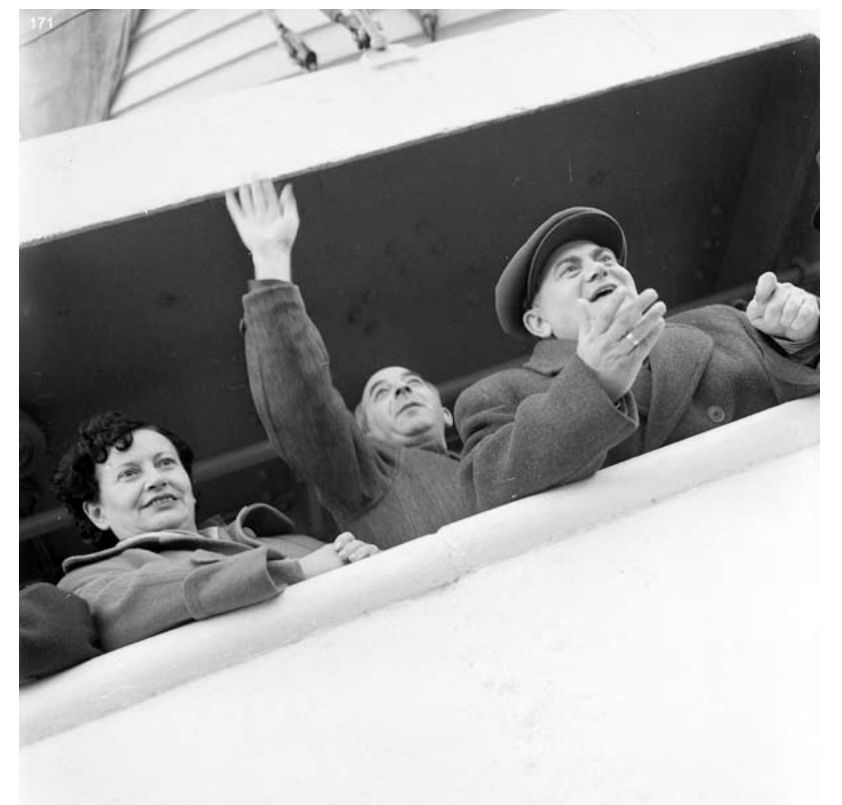

Imagem 38. Israel, porto de Haifa, abril 1959. Autoria: P. Scheier. Fonte: Acervo do AHJB.

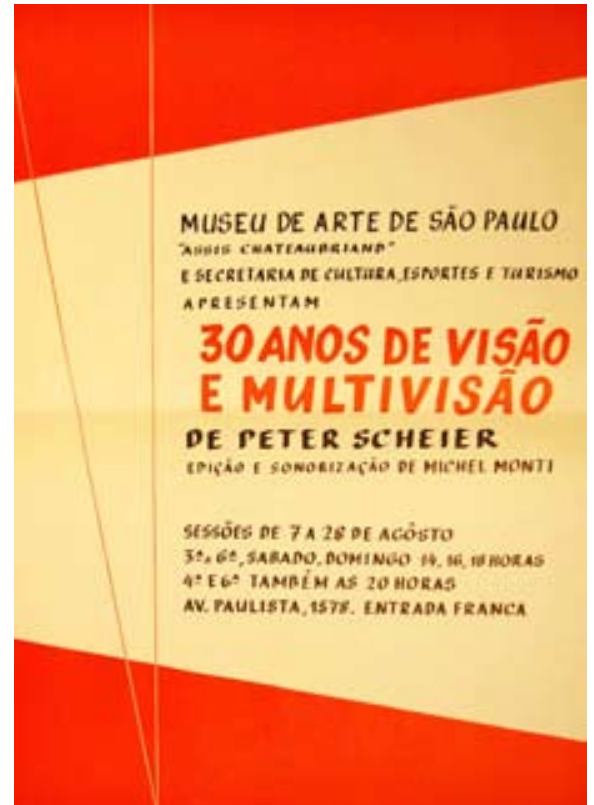

Imagem 39. Cartaz da exposição "30 Anos de Visão e Multivisão" (1970), exposição de Peter Scheier no MASP, contemplando os trinta anos de sua carreira. Fonte: Acervo do MASP

pelo país e exterior, freqüentemente acompanhado da família. Segundo depoimento de sua filha ${ }^{1}$, Scheier adorava viajar. Acomodavam-se todos em seu veículo modelo Kombi e paravam em qualquer lugar no qual fosse possível acampar. Desta forma conheceram o Brasil de norte a sul, com registros memoráveis da Bahia, de Minas Gerais, Paraná, Santa Catarina, Recife e Goiás.

Comoventes são as fotos produzidas numa viagem a Israel, em 1959, por ocasião do décimo aniversário da criação daquele Estado, nas quais são vislumbrados os costumes locais, a arquitetura, as cidades e seus habitantes. Estas fotos foram publicadas posteriormente em uma série no Diário de S. Paulo e organizadas numa exposição. Seu olhar demonstra uma atenção, sensibilidade e emoção de quem, após ter sido julgado por suas origens e ser obrigado a fugir

1 Bettina Lenci, filha do fotógrafo, em depoimento à autora, em 04 abr 2006. 
de seu país, visitava pela primeira vez a terra de seus ancestrais. São fotos nas quais está expressa sua curiosidade na descoberta de um país e de um povo. Nas imagens no porto de Haifa, são notadas suas características formais marcantes - obliqüidade, ângulos ascendentes e a presença humana, destacadas desde suas primeiras fotos e amadurecidas na revista O Cruzeiro (Imagem 38).

Em 1965 iniciou suas pesquisas em multivisão (Imagem 39). Produziu fotografias paraprojeçãoemgrandesarranjoseletrônicos, acrescidas decomentário musical e locução, garantindo assim maior dinamização das apresentações, que se diferenciavam das projeções simples em telas convencionais de então. Scheier desenvolveu trabalhos especialmente para o Ministério das Relações Exteriores, apresentados na Exposição Internacional de Alimentação (Paris, França, 1968) e na Exposição Internacional de Osaka (Expo'70, Osaka, Japão). A primeira parte da projeção apresentava aspectos históricos do país, as riquezas naturais e o potencial brasileiro. A segunda mostrava os variados aspectos humanos e sociais do Brasil, com comentário musical de autores nacionais clássicos e populares.

A seguir trataremos do trabalho de Peter Scheier como fotojornalista na revista O Cruzeiro. Na seqüência, veremos seu trabalho no MASP e revista Habitat e na documentação de arquitetura.

\subsection{Fotojornalismo na revista O Cruzeiro (1945 a 1951)}

De março de 1945 a outubro de 1951 Peter Scheier foi colaborador da revista O Cruzeiro, revista semanal ilustrada, do grupo dos Diários Associados, de Assis Chateaubriand. A revista, de grande formato $(34 \times 50 \mathrm{~cm})$, continha seções e reportagens variadas e sua característica marcante era a fotorreportagem. 
Como visto no capítulo anterior, a fotografia estava presente na imprensa brasileira desde o início do século XX com periódicos como a Revista da Semana (lançada em 1900), a llustração Brasileira (em 1901) e a Kosmos (1904). Inicialmente a fotografia servia apenas como ilustração do texto, tornando-o mais agradável. Costa e Silva lembram que "nossos primeiros repórteres fotográficos eram provenientes das classes populares, pessoas sem formação e com instrumental técnico inadequado à sua atividade". ${ }^{2}$

A imagem tinha amplo espaço dentro da O Cruzeiro desde seu lançamento, em 1928. Contudo, sua reformulação na década de 1940 transformou quantidade em qualidade: a fotografia, a partir de então, desempenhou outro papel, sobressaindo-se ao texto. O pivô desta reformulação foi o fotógrafo francês Jean Manzon, que se integrou à publicação em 1943. Ex-fotógrafo da revista francesa Paris Match, chegou ao Brasil em 1942. A partir de 1943, junto com o jornalista David Nasser, criou uma nova linguagem visual, promovendo uma mudança radical nos padrões da revista. Nasser-Manzon foi uma das duplas mais importantes na produção das grandes reportagens.

O fotojornalismo se especializou no mundo inteiro no período entre guerras, devido a fatores técnicos - a aplicação de câmeras de pequeno formato e a efetiva industrialização e especialização da imprensa -, econômicos e sociais - solidificação dos meios de comunicação de massa. Além do desenvolvimento tecnológico, Costa aponta como fatores determinantes para a instauração do fotojornalismo moderno no Brasil o fortalecimento do monopólio de comunicações de Assis Chateaubriand e a vinculação ao capital da publicidade (o montante recebido dos anunciantes era maior que o referente às vendas em banca), a existência de um público potencial de massa, a possibilidade de ampla distribuição, a implantação de uma linguagem adequada aos novos meios de produção e a

2 COSTA, Helouise \& SILVA, Renato Rodrigues da. A fotografia moderna no Brasil. São Paulo: Cosac Naify, 2004, p. 103. 
experiência modernista dos imigrantes que compunham o quadro de fotógrafos da revista ${ }^{3}$. Como já visto, a experiência modernista na fotografia brasileira se deu somente a partir do início da década de 1940, no âmbito fechado do movimento fotoclubista, sem uma repercussão significativa na produção fotográfica local como um todo. A disseminação do novo modelo de fotojornalismo, pois, viabilizouse através da atuação de profissionais imigrantes.

Após cerca de dez anos da chegada de Jean Manzon, o departamento fotográfico de O Cruzeiro - que contava inicialmente apenas com Edgar Medina, além do próprio Manzon - contabilizava mais de vinte profissionais (incluindo os dois já citados): Salomão Scliar, Carlos Lutero Ávila, José Medeiros, Eugênio Silva, Luciano Carneiro, Flávio Damm, Douglas Alexandre, João Martins, Indalécio Wanderley, Badaró Braga, Antônio Ronek, José Pinto, Antônio Rudge, Jorge Audi, Rubens Américo, Nello Berto e Marcel Gautherot, Ed Keffel, Peter Scheier, Henri Ballot e Pierre Verger, sendo os últimos imigrantes. ${ }^{4}$ Dois depoimentos, o primeiro de José Medeiros e o segundo de Flávio Damm, ilustram bem esta época:

O Cruzeiro passou a ser a etapa final do jornalismo no Brasil, o sonho dourado das pessoas. Um fotógrafo da revista era tão famoso quanto é hoje um galã da Globo. Aonde íamos tinha gente esperando para nos badalar. Cheguei até a dar autógrafos na rua. ${ }^{5}$

3 COSTA, Helouise. Um olho que pensa. São Paulo: FAUUSP, 1998. Tese de Doutorado, p. 275.

$4 \quad$ COSTA, Helouise. Aprenda a ver as coisas: fotojornalismo e modernidade na revista O Cruzeiro. São Paulo: Escola de Comunicações e Artes de São Paulo, 1992. Dissertação de mestrado. p.14

5 MEDEIROS, José. Apud: COSTA; SILVA. loc. cit. 
Graças ao Manzon o fotógrafo brasileiro conquistou um novo lugar. Antes ele era tido como um marginal que ia para a festa de casamento e roubava os presentes. Fotógrafo não usava nem paletó, nem gravata. Era um pobre desdentado, o equipamento de péssima qualidade e o salário miserável. O Manzon chegou ao Brasil e moralizou a profissão. ${ }^{6}$

Ao ingressar na revista, Jean Manzon deparou-se com um quadro completamente diverso daquele vivenciado na imprensa européia. O desenho da O Cruzeiro era insatisfatório. Em depoimento, o fotógrafo desabafou:

Isso não é uma revista, é um catálogo, uma galeria de retratos de família, fixos, posados, idênticos. Ademais, sem dúvida para parecer rica, há um máximo de pequenos clichês, agrupados sobre uma só página como uma coleção de pequenos selos. A tinta, o papel, a impressão são de tão má qualidade que poderíamos dizer que se trata de manchas. ${ }^{7}$

$\mathrm{Na}$ nova linguagem visual implantada por Manzon, as reportagens eram essencialmente visuais, compostas por grandes fotografias ocupando praticamente a totalidade do espaço das páginas. As imagens de Manzon, pautadas pela encenação, pelo simbolismo e pelas características formais construtivas, eram vibrantes e carregadas de dramaticidade, o que dava um tom opinativo, às vezes até sensacionalista. Esta linha editorial agradou o público e as vendagens eram sempre satisfatórias. Uma pesquisa do IBOPE de novembro de 1946 apontou O Cruzeiro como a revista mais lida no país, vendendo quatro vezes mais que a segunda colocada, a Revista da Semana ${ }^{8}$. Com o tempo, talvez a ambição dos diretores e editores por furos jornalísticos tenha conduzido

$6 \quad$ DAMM, Flávio. Apud: COSTA; SILVA. loc. cit.

7 REBATEL, Henry. Le regard du jaguar. Rennes; France: Éditions Ouest-France, 1991. Apud: COSTA (1998). Op. cit, p. 149.

$8 \quad$ COSTA (1998). Op. cit, p. 153 
os fotógrafos a adotar um sentimentalismo exagerado. O real passou a ser tão manipulado que atingiu o ponto de ser forjado, em cenas arrumadas, simuladas, onde objetos eram inseridos a fim de criar um determinado fato.

O modelo da O Cruzeiro era a americana Life. As fotorreportagens eram montadas segundo as diretrizes daquela revista: a essência era a história, com fotos principais (que estruturavam a narrativa), fotos de transição (que guiavam de uma idéia à outra), fotos de ação (que transmitiam o drama) e fotos que concluíam ${ }^{9}$. A fotorreportagem, em suma, era constituída de manchete, apresentação, texto, foto e legenda. Em geral começavam em página dupla, sendo que a da esquerda trazia uma foto sangrada e a da direita, fotos, manchete, apresentação e texto. A primeira imagem funcionava como uma imagem-manchete, uma imagem forte que desempenhava o papel de síntese da matéria ${ }^{10}$.

A nova configuração propiciou status ao fotógrafo. A pauta era sugerida por ele, juntamente com o jornalista. Esta autoria conjunta do repórter e do repórter-fotográfico era destacada logo abaixo da manchete, concedendo à foto a mesma autoridade do texto. Muitas vezes o próprio fotógrafo escrevia o texto e as legendas. Contudo, seu trabalho era objeto de profunda interferência da edição - cortes ${ }^{11}$, ampliações, reduções, inversões, retoques e montagens - para melhor adequação ao esquema de paginação.

Os temas recorrentes nas páginas do periódico seguiam a tendência da imprensa internacional, com as adaptações cabíveis à realidade brasileira. De um modo geral, concentravam-se no culto à personalidade (reportagens sobre artistas ou glamourização das pessoas comuns); esporte e lazer (futebol, praias e carnaval); artes, literatura e ciência; natureza e aventuras (desvendando as

$9 \quad$ COSTA (1998). Op. cit, p. 158.

10 COSTA (1992). Op. cit, p. 82.

11 Considerando que o formato $6 \times 6 \mathrm{~cm}$ ainda era muito empregado e que a maioria das fotografias eram publicadas em formato retangular, nota-se que praticamente todas as imagens sofriam cortes. 
riquezas naturais e as peculiaridades regionais do Brasil); a cidade (como ideal de modernidade). A revista dedicava ainda considerável porcentagem de suas páginas ao grotesco e o exótico, explorando os cultos religiosos não-católicos, as festas populares - para demonstrar a diversidade cultural - e os crimes, as deformações físicas, a loucura, as doenças (cegueira, lepra, tuberculose), num sensacionalismo explícito combinado com uma "preocupação de normatização de certas condutas sociais, para que a sociedade possa se precaver da existência de indivíduos "anormais"” 12. Costa aponta que a visão propagada pela O Cruzeiro é uma visão dual do mundo (o bem e o mal, o belo e o feio, o preto e o branco, o normal e o anormal, o são e o doente, o civilizado e o selvagem) ${ }^{13}$.

A nova forma de organização das reportagens implantada por Jean Manzon e plenamente aceita pelos editores mostrava o desejo de um jornalismo moderno, equiparável ao produzido no exterior, muito adequado aos ideais dos governos de Vargas e Juscelino. Demonstrava um comprometimento com uma proposta de modernização do país ${ }^{14}$. As grandes cidades viviam um processo de urbanização acelerado, com o aumento da população - interpretado também como a formação de um público de massa. São Paulo, por exemplo, estava às vésperas de completar 400 anos. Além disso, a fotorreportagem respondia à demanda por informações visuais de uma sociedade em processo de modernização ${ }^{15}$.

Na década de 1950 O Cruzeiro foi superada pela Manchete, o "veículo da ideologia do desenvolvimentismo no Brasil"16, mostrando o empreendedorismo da era $\mathrm{JK}^{17}$. Muitos fotógrafos da O Cruzeiro foram para Manchete, inclusive

\footnotetext{
12 COSTA (1998). Op. cit, p. 224.

13 COSTA (1992). Op. cit, p. 71.

14 COSTA (1992). Op. cit, p. 13.

15 COSTA (1998). Op. cit, p. 176.

16 COSTA; SILVA. Op. cit. p.105.

17 Adolpho Bloch, dono da Bloch Editores - que produzia a revista Manchete - era amigo próximo de Juscelino Kubitschek. http://pt.wikipedia.org/wiki/Adolfo_Bloch. Acesso em: 10 mar 2008, às 17:00
} 
Jean Manzon. Com o aparecimento da televisão, as revistas ilustradas perderam espaço.

\subsubsection{Peter Scheier na O Cruzeiro}

Nos seis anos que colaborou com a revista, Peter Scheier publicou suas fotografias em 116 reportagens, com uma periodicidade inconstante - em uma mesma edição Scheier chegou a contribuir em mais de uma reportagem, ao passo que em algumas épocas seu nome não aparecia por até cinco meses. Em geral, no último e no primeiro bimestre do ano apareciam poucas reportagens, fato relacionado às férias e viagens ao exterior, que com freqüência resultavam em material para novas reportagens. Em 1950 encontra-se o maior número de reportagens publicadas, 38 no total. No outro extremo, 1948 apresenta apenas 07 reportagens - de maio a novembro daquele ano nenhuma foto de Scheier foi publicada.

Ao longo destes seis anos, Peter Scheier não compôs com nenhum jornalista uma dupla fixa aos moldes de Jean Manzon e David Nasser. Fez reportagens com Alceu Pena, Alceu Pereira, David Nasser, Fernando Lôbo, Franklin de Oliveira, Geraldo Banas, Jorge Ferreira, José Amádio, Margarida Izar, Rocha Pitta, Samuel Wainer e outros. Arlindo Silva foi sua dupla mais usual, em 59 reportagens de 1947 a 1951. Nelson Motta (14 reportagens de 1945 a 1946) e Freitas Nobre (6 reportagens de 1945 a 1946) também foram colaboradores freqüentes.

Em todas as reportagens, Peter Scheier manteve seus traços característicos: a proximidade das pessoas, o uso de flash, os ângulos ascendentes e as 
diagonais marcantes. Seu fotojornalismo define-se menos por flagrantes e denúncias e mais por seu caráter documental. Retratos posados e closes, estruturação formal, uso de legendas internas e até mesmo sua inserção nas fotografias demonstram uma dinâmica que possibilitava a prévia elaboração e programação da pauta. Assim, Scheier estava completamente inserido na linguagem fotográfica característica da fotorreportagem moderna, apontados por Costa: ângulos de baixo para cima e vice-versa, tomadas oblíquas, ênfase em detalhes expressivos e uso intencional da cenografia ${ }^{18}$.

Peter Scheier não se dedicava a um assunto específico. As 116 reportagens foram organizadas em onze categorias (por ordem de ocorrência): personalidades e eventos $(27)^{19}$, variedades (22), instituições (15), esportes (10), sociedade (8), lazer (7), saúde (7), economia (7), política (5), religião (5) e cidades (3). É importante salientar que estas categorias não são rigorosas, pois os assuntos se mesclam e a inclusão de uma mesma reportagem em mais de uma categoria é cabível, de acordo com a leitura que se faz. As categorias, portanto, servem como guia da análise.

A predominância está nas reportagens de "personalidades e eventos", nas quais eram explorados aspectos da vida de pessoas conhecidas pela sociedade, como o lazer - corridas de cavalo, bailes de debutantes, casamentos, enterros e concursos de beleza. Nesta categoria estão incluídos textos biográficos, opinativos e entrevistas, como a de Heitor Villa-Lobos ${ }^{20}$. Em "eventos" foram incluídos desfiles de moda, encontro aéreo, convenções e congressos. "Variedades" aborda assuntos como animais - leões marinhos, abelhas, cobras, sapos, pássaros, bois -, cabeleireiros, fábrica de gaitas, garimpo de diamantes, concurso de gêmeos, extração de ouro, selos, gasogênio, anões e profecias.

$18 \quad$ COSTA (1998). Op. cit, p.157.

19 Os números entre parênteses indicam a quantidade de reportagens incluídas na categoria.

20 AMÁDIO, José. Viva Villa! O Cruzeiro, São Paulo, p.86-89, 17 set 1949. 
"Instituições" incluem o manicômio do Juqueri, o Hospital das Clínicas, abrigo de desamparados, casa para crianças paralíticas, Cruz Vermelha, escolas, casa de banho, além do Museu de Arte - MASP - cujas reportagens serão tratadas a seguir, no item específico sobre a documentação de arte. "Esportes" inclui competições, modalidades e a cobertura da Copa do Mundo de 1950. Em "sociedade" foram reunidas reportagens sobre imigração, alfabetização, colonização e guetos. "Lazer" trata das formas de entretenimento: circo, dança e carnaval. Reportagens sobre doenças - tuberculose, esquistossomose - e procedimentos médicos compõem o grupo "saúde"; agricultura, indústria e bolsas de valores compõem o grupo "economia"; eleições e eventos partidários, o grupo "política"; festas religiosas e Exército da Salvação, "religião"; particularidades de bairros da cidade de São Paulo compõem o grupo "cidades".

Aproximadamente 90 reportagens ( $80 \%$ do total) foram feitas no estado de São Paulo. Destas, 82 se situavam na cidade de São Paulo. Scheier também realizou reportagens na Amazônia (AM), Chavantina (GO), Curitiba (PR), Florianópolis (SC), Paracatu (MG) e Recife (CE). Viajou também para Punta Del Leste (Uruguai) para as fotos de "A ilha dos lobos"21. Aos Estados Unidos viajou ao menos três vezes. Em março de 1947, a reportagem "Fiacres de Central Park"22 era publicada após quatro meses desde a última - "A batalha da terra"23. Este intervalo pode significar que Scheier tenha viajado em novembro de 1946. Pela introdução do texto, contudo, deduz-se que a viagem tenha ocorrido em 1945:

21 SILVA, Arlindo. A ilha dos lobos. O Cruzeiro, São Paulo, p.46-49, 04 fev 1950.

22 LÔBO, Fernando. Fiacres de Central Park. O Cruzeiro, São Paulo, p.38-42, 22 mar 1947.

23 RODRIGUES, Meira. A batalha da terra. O Cruzeiro, São Paulo, p.60-64, 09 nov 1946. 
Há dois anos, precisamente, "O CRUZEIRO" enviava aos Estados Unidos como correspondente especial, o conhecido jornalista Fernando Lobo. Alguns meses depois o fotógrafo Peter Scheier tomava o mesmo rumo. E agora novamente e em terra firme, ei-los contando o que viram e apreciaram no país onde tudo "é o maior do mundo", numa série de reportagens que iniciamos hoje com "Fiacres em Central Park". ${ }^{24}$

A publicação de inúmeras reportagens entre 1945 e março de 1947 questiona tal colocação. A inexistência do passaporte mais atual de Scheier, no qual constariam os vistos de entrada naquele país, inviabiliza a confirmação das datas. A imprecisão destes dados, entretanto, não compromete a constatação de viagens aos Estados Unidos, que geraram reportagens em O Cruzeiro: para New York - onde registrou curiosidades como os fiacres ${ }^{25}$, a parada do Dia de Ação de Graças $^{26}$ e o pianista Bernardo Segall ${ }^{27}$-, para Washington onde acompanhou o resultado das eleições presidenciais ${ }^{28}$ e a posse de Harry Salomon Truman (1948) ${ }^{29}$ - e a Boca Haton (1951) - sobre desfile de $\operatorname{moda}^{30}$ e o preço do café brasileiro na bolsa ${ }^{31}$.

Em alguns textos é possível encontrar referências à vida pessoal ou a histórias de Peter Scheier. A primeira menção foi em 1945, quando seu equipamento - provavelmente a câmera ICA Juivel 9x12 trazida da Alemanha despertou o interesse dos anões (Imagem 40). Algumas páginas adiante, Scheier observava uma anã costurando, sentada em um sofá de vime (Imagem 41). Scheier, mesmo reclinado, parecia um gigante comparado à pequena mulher.

$24 \quad$ LÔBO. Op. cit. p. 39

25 Tipo de carruagem de aluguel, puxado por um cavalo e conduzido por cocheiro.

26 Kikoler. Natal na Broadway. O Cruzeiro, São Paulo, p. 76-79, 25 dez 1948.

27 SCHEIER, Peter. A música e a dança. O Cruzeiro, São Paulo, p. 40-43, 23 abr 1949.

28 OLIVEIRA, Franklin de. A bandeira de Roosevelt. O Cruzeiro, São Paulo, p. 18-24, 27 nov 1948.

29 SCHEIER, Peter. Meia-volta volver. O Cruzeiro, São Paulo, p.84-90, 12 fev 1949.

30 PENA, Alceu. Desfile em Boca Raton. O Cruzeiro, São Paulo, p. 76-79, 13 jan 1951.

31 Geraldo. O café é rei em Boca Raton. O Cruzeiro, São Paulo, p. 86-87, 27 jan 1951. 


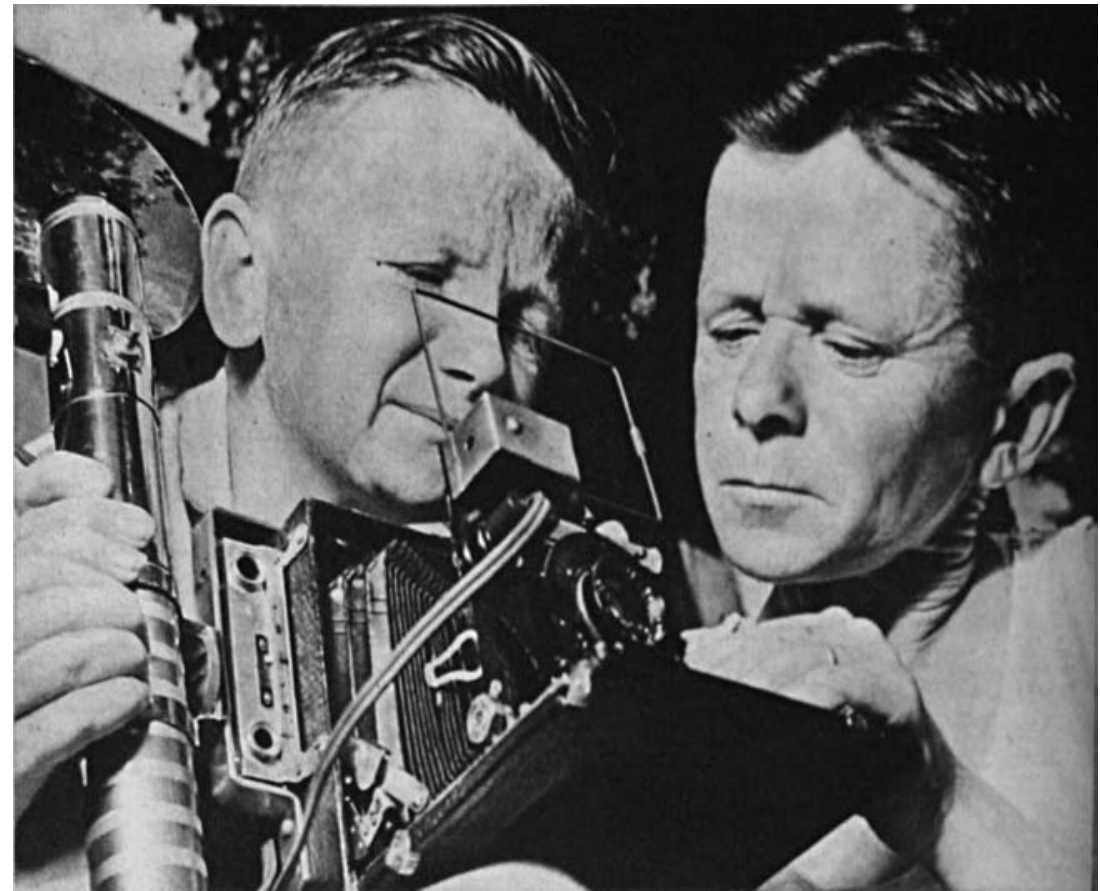

Imagem 40. Anões observam a máquina de Scheier. Fonte: "Um dia no bosque dos anões", em O Cruzeiro, p. 63, 08/12/1945. Acervo do MASP.

Curiosidade grande nos pequenos homens. Uma das máquinas de Peter Scheier, o grande fotógrafo que empresta suas atividades, em São Paulo, a "O Cruzeiro", corre perigo de se desmantelar nas mãos dos anões de Santo André. Pela proporção da máquina, que é de tamanho normal, pode-se aquilatar o porte desses artistas. ${ }^{32}$

Seu gosto pela música brasileira foi mencionado na reportagem sobre a inauguração do novo transmissor da Rádio Tupi. "Outro dia, viajávamos pelo interior de Santa Catarina, e a certa altura, meu companheiro Peter Scheier, que aprecia muito as músicas populares brasileiras, pediu ao chofer do carro que ligasse o rádio." ${ }^{33} \mathrm{Na}$ transmissão da audição do frei José Mojica no MASP,

32 PITTA, Rocha. Um dia no bosque dos anões. O Cruzeiro, São Paulo, p. 63, 08 dez 1945.

33 SILVA, Arlindo. PRG-2 conquista o espaço. O Cruzeiro, São Paulo, p. 94, 07 jan 1950. 


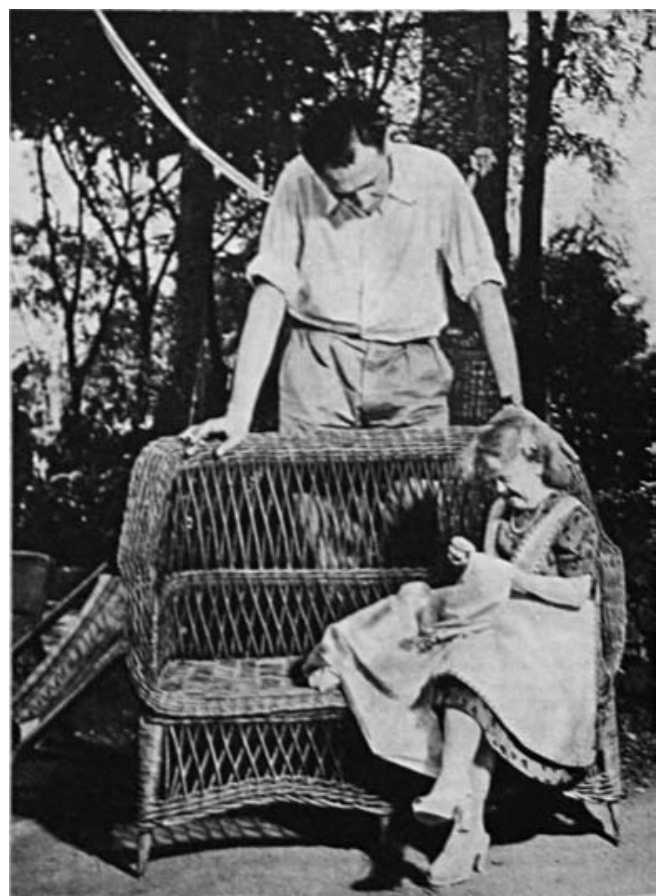

Imagem 41. Scheier, de pé, observa a anã. Fonte: "Um dia no bosque dos anões", em O Cruzeiro, p. 66, 08/12/1945. Acervo do MASP.

ele também foi citado: "O fotógrafo Peter Scheier, que viveu muito tempo nos Estados Unidos, confessou que nunca antes havia visto uma reprodução de imagens tão nítidas e tão perfeitas." ${ }^{34}$ Fatos cômicos também foram relatados, como o ocorrido na noite em que Scheier e o repórter Arlindo Silva foram à "boite" subterrânea da Rádio América, para produzir o material sobre a dança do boogie-woogie.

Ao atingirmos a porta, tivemos vontade de voltar. Aquilo não era dança nem nada. (...) Meu companheiro fotógrafo falou:

- É "swing" ou malabarismo?

$(\ldots)$

- Não tem jeito de entrar - disse eu.

34 SILVA, Arlindo. A televisão funcionando! O Cruzeiro, São Paulo, p. 24, 12 ago 1950. 
- O único jeito é sair no barulho também - atalhou Scheier.

Mal acabava de pronunciar a frase e o meu companheiro viu-se agarrado por uma pequena e arrastado para o meio do reboliço. ${ }^{35}$

\subsubsection{São Paulo nas páginas da $O$ Cruzeiro, segundo Peter Scheier}

Peter Scheier via São Paulo através de seus costumes, suas festas, suas personalidades, seus eventos, suas instituições, traçando um quadro rico da sociedade da época. Seu genuíno interesse pelo elemento humano está fortemente presente em seu trabalho na $O$ Cruzeiro. E esse quadro construído ao longo dos seis anos na revista é muito semelhante ao constituído no livro São Paulo the greatest growing city in the world. Uma cidade dinâmica, mostrada como "modelo de metrópole" e "ideal de modernidade" ${ }^{36}$, que crescia rapidamente, que acolhia imigrantes, que tentava absorver as diferenças e que procurava sanar seus problemas dentro das suas possibilidades. São Paulo abrigava todos os níveis sociais, cada qual com suas particularidades. Scheier demonstrava a mesma desenvoltura e curiosidade ante as classes mais ricas e as mais baixas - o que atendia também ao público leitor do periódico, que englobava todas as faixas sociais.

Ele retratou os eventos da alta sociedade, que se reunia em clubes e em museus para desfiles, bailes, vernissages. Aos domingos, nas tardes hípicas, competições de tênis e de natação ou numa partida de futebol no Estádio do Pacaembu ${ }^{37}$ era possível encontrar membros das famílias mais abastadas -

35 SILVA, Arlindo. Boogie-Woogie Brasileiro. O Cruzeiro, São Paulo, p. 39, 16 set 1950.

36 COSTA (1992). Op. cit, p. 71.

37 ANTÔNIA, Maria. A sociedade paulista vai ao futebol... O Cruzeiro, São Paulo, p. 60 63, 16 jun 1945. 
Crespi, Mesquita Sampaio, Azevedo Marques ou Moreira Salles. Ou ainda no Clube Paulistano ou no Clube de Caça e Pesca de São Paulo, nos quais o governador Adhemar de Barros aparecia com freqüência para dedicar-se ao tiro ao pombo $^{38}$.

A revista prestava-se também à promoção das empreitadas de Assis Chateaubriand. O Museu de Arte de São Paulo foi assunto em quatro ocasiões, detalhadas a seguir. Além do MASP, Chateaubriand estava envolvido em outras atividades. A cerimônia de inauguração do novo transmissor da Rádio Tupi de São Paulo, em novembro de $1949^{39}$, foi documentada por Scheier. Meses depois, a audição de Frei José Mojica no auditório do $\mathrm{MASP}^{40}$ era transmitido pela primeira vez para reprodução em aparelhos de televisão ${ }^{41}$. A TV Tupi - primeira rede de televisão da América do Sul - era inaugurada.

As figuras da alta sociedade apareciam em eventos políticos, como a Jornada Democrática da União Democrática Nacional ${ }^{42}$, no Estádio do Pacaembu - que não era palco apenas para jogos de futebol. O comício contava com a presença de Artur Bernardes - ex-presidente da República -, Júlio Prestes e do Brigadeiro Eduardo Gomes, candidato à presidência ${ }^{43}$. No enterro de Armando Salles de Oliveira ${ }^{44}$ - ex-presidente de São Paulo - Scheier produziu imagens que enfatizavam a comoção da população que acompanhava o cortejo. Uma

38 SILVA, Arlindo. Tiro aos pombos. O Cruzeiro, São Paulo, p. 38-41, 31 mai 1947.

39 SILVA, Arlindo. PRG-2 conquista o espaço. O Cruzeiro, São Paulo, p.94-97, 07 jan 1950.

$40 \quad O$ assunto foi abordado em três reportagens: SILVA, Arlindo. José Mojica, soldado da igreja. O Cruzeiro, São Paulo, p. 50-53, 29 jul 1950; SILVA, Arlindo. A televisão funcionando! O Cruzeiro, São Paulo, p. 24-25, 12 ago 1950; SILVA, Arlindo. A televisão para milhões. O Cruzeiro, São Paulo, p. 37-39, 28 out 1950.

41 A recepção ficou restrita a dois aparelhos, no saguão do edifício dos Diários Associados na rua Sete de Abril, uma vez que não havia aparelhos nas casas.

42 MOTTA, Nelson. A jornada do Pacaembu. O Cruzeiro, São Paulo, p. 54-61, 30 jun 1945.

43 Eduardo Gomes foi derrotado pelo general Eurico Gaspar Dutra, ministro da Guerra de Vargas.

44 MOTTA, Nelson. O enterro de um grande morto. O Cruzeiro, São Paulo, p. 8-17, 02 jun 1945. 


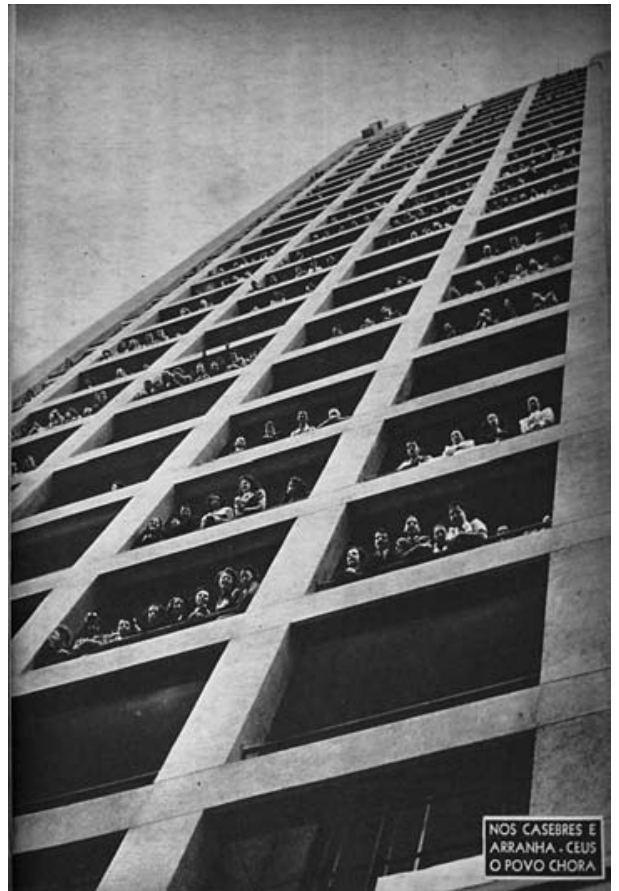

Imagem 42. Fac símile da página 13 da reportagem "O enterro de um grande morto", em $O$ Cruzeiro de 02/06/1945. Fonte: Acervo do MASP.

foto chama a atenção por seu acentuado ângulo ascendente - para registrar as pessoas que se reclinavam nas janelas de um edifício, Scheier inclinou sua câmera para cima, de forma que todas as linhas convergem para o canto superior direito, numa enfática perspectiva (Imagem 42).

Peter Scheier fotografou igualmente a São Paulo dos menos favorecidos. Estas reportagens, de um modo geral, visavam mostrar o diferente, o anormal, imbuídas de sensacionalismo e tom dramático. Dentro da sociedade moderna paulistana, a exceção era composta pelos cegos auxiliados pelo Instituto Padre Chico ${ }^{45}$; os tuberculosos que viajavam para Campos do Jordão em busca de cura $^{46}$; os imigrantes sem dinheiro, vivendo num gueto no Bom Retiro ${ }^{47}$; os 45 NOBRE, Freitas. Os cegos do "Padre Chico". O Cruzeiro, São Paulo, p. 56-61, 21 abr 1945.

46 MOTTA, Nelson. A montanha contra a morte. O Cruzeiro, São Paulo, p. 8-15, 06 out 1945.

47 PITTA, Rocha. Judeus sem dinheiro. O Cruzeiro, São Paulo, p. 62-64, 12 jan 1946. 


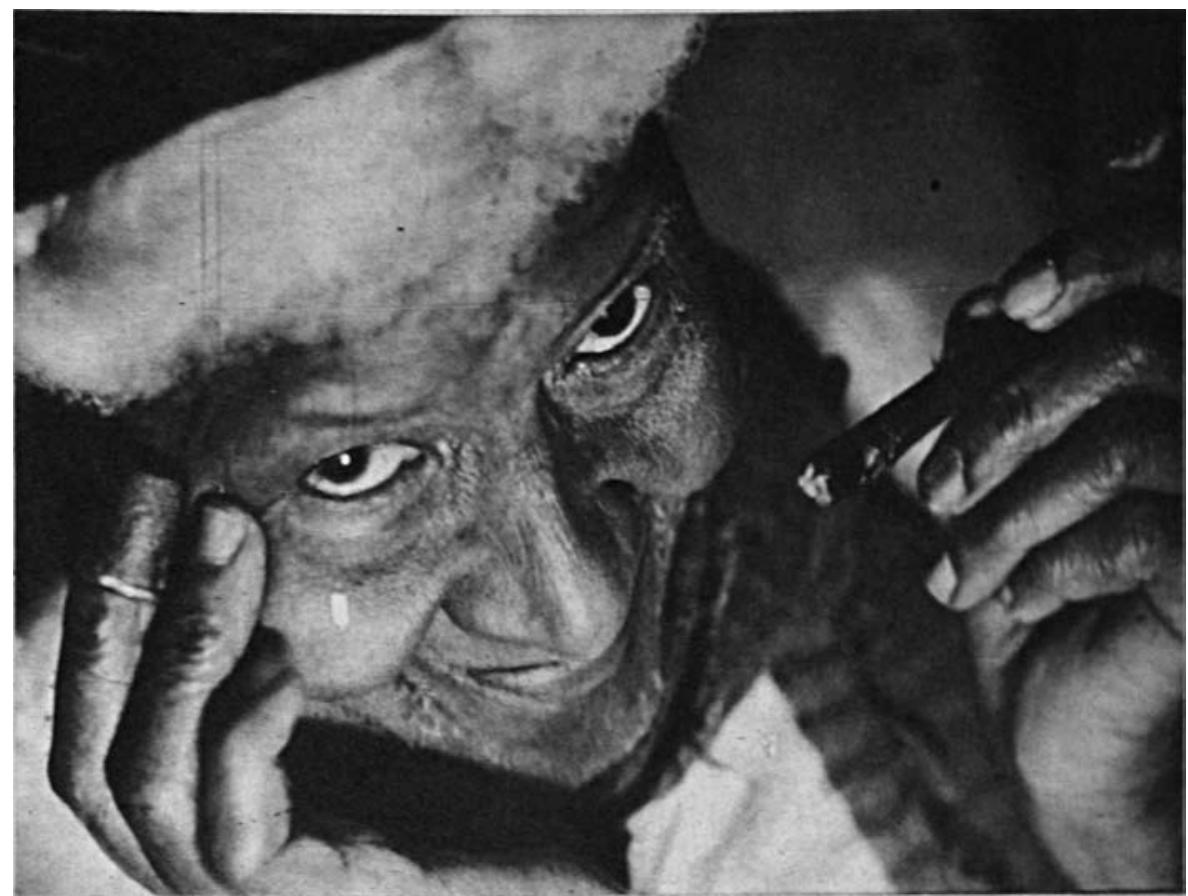

Imagem 43. "Desconfiada e risonha ao mesmo tempo" (legenda original). Fonte: "Bussocaba e Vila Mascote", em O Cruzeiro, p. 53, 31/03/1945. Acervo do MASP.

freqüentadores da casa de banho na Rua Capitão Salomão, no centro ${ }^{48 ;}$ os artistas aposentados que viviam na Casa dos Atos ${ }^{49}$; as crianças paralíticas; os doentes mentais internados no manicômio do Juqueri50; os adultos alvos da campanha de alfabetização ${ }^{51}$.

Formalmente, as fotografias de Peter Scheier conservavam suas características. Contudo, o sensacionalismo desse tipo de reportagem exigia imagens mais dramáticas, o que resultava em retratos em close, com intenso uso de flash para enfatizar a textura da pele, os traços de expressão do rosto reforçar, dentro das diretrizes do periódico, o sofrimento e dor que faziam parte do dia-a-dia dessas pessoas.

48 MOTTA, Nelson. A última fila. O Cruzeiro, São Paulo, p. 60-63, 12 out 1946.

49 NOBRE, Freitas. Casa das recordações. O Cruzeiro, São Paulo, p. 36-40, 05 abr 1947.

50 SILVA, Arlindo. O outro lado do mundo. O Cruzeiro, São Paulo, p. 08-13, 28 jun 1947.

51 SILVA, Arlindo. A nova abolição. O Cruzeiro, São Paulo, p. 58-61, 06 set 1947. 


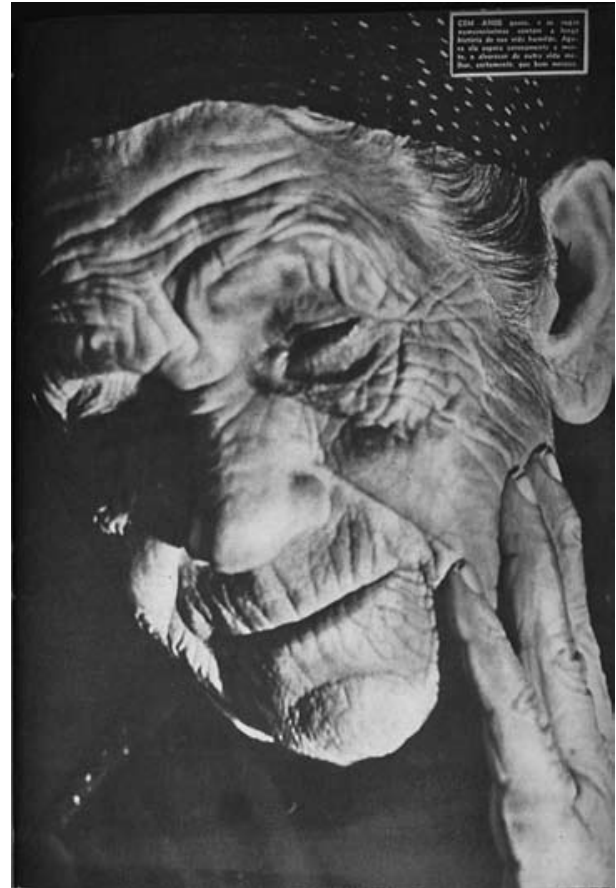

Imagem 44. "Cem anos quase, e as rugas numerosíssimas contam a longa história de sua vida humilde" (legenda original). Fonte: "Bussocaba e Vila Mascote", em O Cruzeiro, p. 55, 31/03/1945. Acervo do MASP.

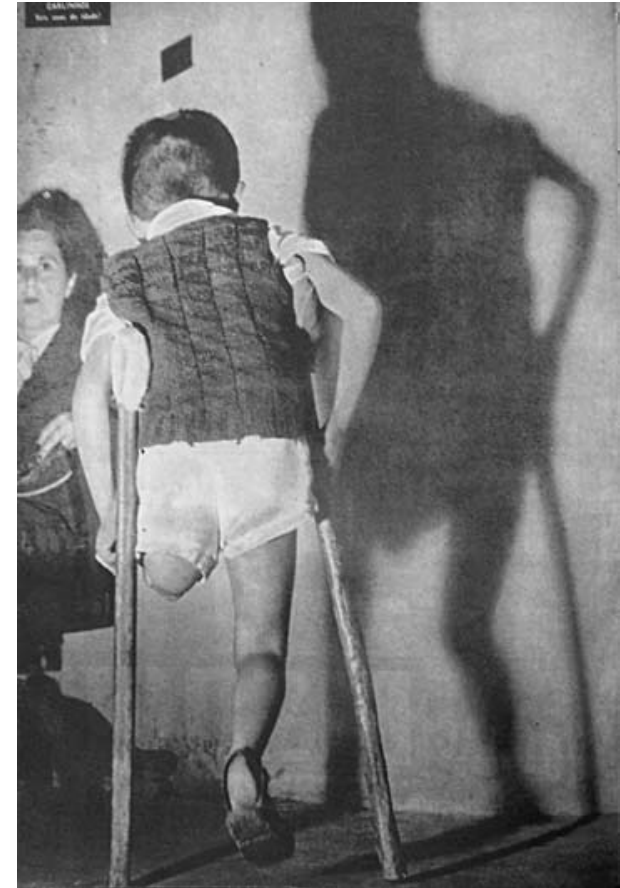

Imagem 45. Fac símile da página 52 da reportagem "Lar São Francisco", em O Cruzeiro de 24/05/1947. Fonte: Acervo do MASP.

Para ilustrar o público assistido pelos abrigos Vila Bussocaba - masculino, em Santo Amaro - e Vila Mascote - feminino, em Osasco52-, composto por mendigos, desamparados, idosos, alcoólatras e doentes, Scheier realizou alguns retratos, como o da senhora afro-descendente vista de cima para baixo (Imagem 43). A pouca profundidade de campo centraliza o foco nos seus olhos, voltados para cima. Em outra foto, mais dramática, Scheier usou flash direto, de forma a criar sombras que enfatizaram as rugas no rosto da senhora (Imagem 44). Numa reportagem sobre o Lar São Francisco, instituição de assistência a crianças com problemas de locomoção, o mesmo recurso foi empregado: a imagem de página inteira, que abre o artigo, sangrada, mostra um garoto com a perna esquerda amputada, andando com o auxílio de muletas (Imagem 45). A luz direta projetou 52 NOBRE, Freitas. Bussocaba e Vila Mascote. O Cruzeiro, São Paulo, p. 52-57, 31 mar 1945. 


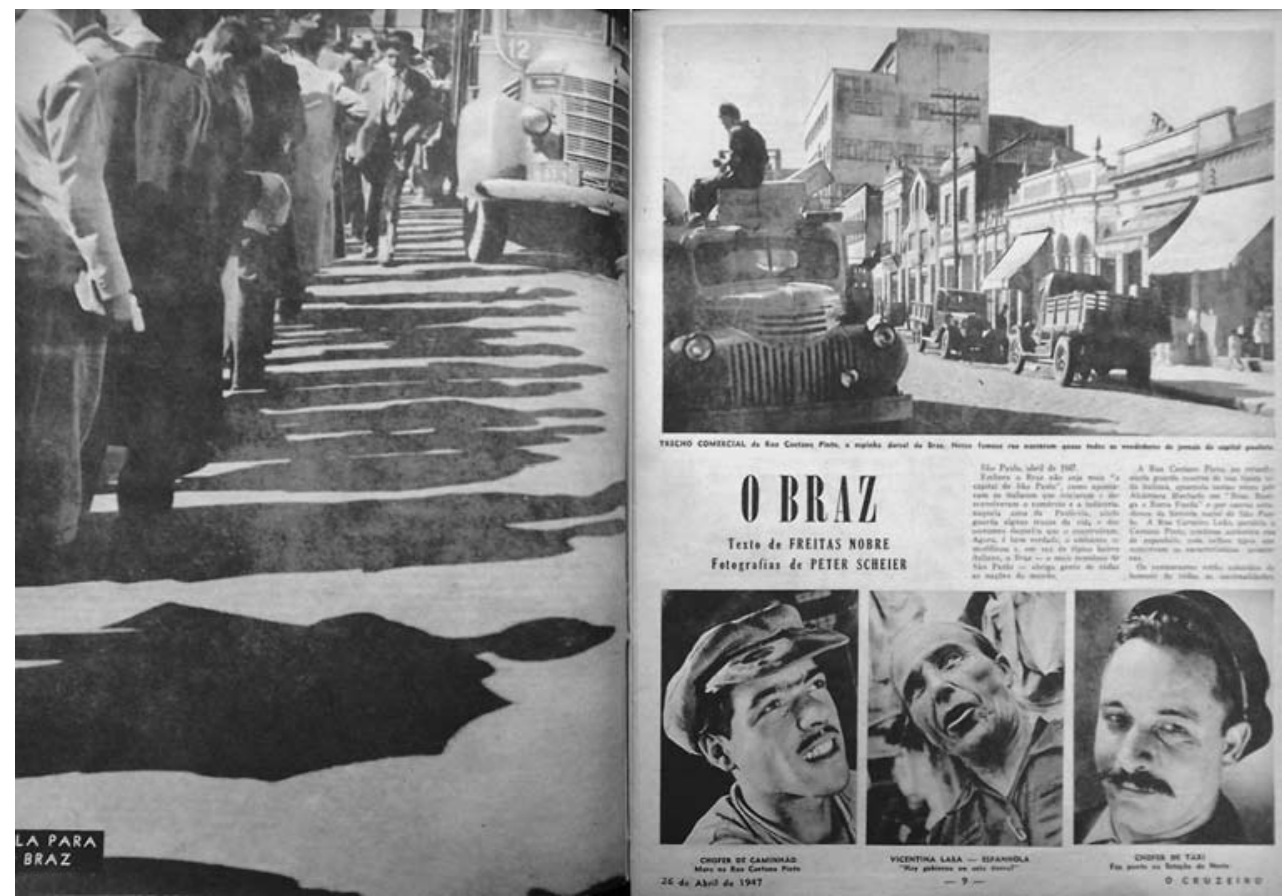

Imagem 46. Fac símile das páginas 8 e 9 da reportagem "O Braz", em O Cruzeiro de 26/04/1947. Fonte: Acervo do MASP.

uma sombra na parede, na qual simbolicamente uma das muletas parece estar no lugar da perna ausente.

Uma das reportagens mais significativas dentro desta linha foi a realizada em 1947, no Brás ${ }^{53}$. Naquela década, o bairro figurava entre os mais populosos da cidade de São Paulo, ao mesmo tempo em que se consolidava como um centro de fiação e tecelagem de algodão. As principais questões apontadas pela reportagem são o comércio, a alteração do caráter exclusivamente italiano do bairro, onde agora conviviam imigrantes de diversos países (judeus, alemães, turcos, espanhóis); a mudança dos antigos costumes, como a arrecadação de donativos que beneficiavam a família mais necessitada da Rua Caetano Pinto; a presença das fábricas; os cortiços - locais onde "centenas de famílias residiam como se fôssem uma só" 54; o jogo de futebol do Palmeiras, ex-Palestra Itália.

$53 \quad$ NOBRE, Freitas. O Braz. O Cruzeiro, São Paulo, p. 8-16, 26 abr 1947.

54 NOBRE. Op. cit. p.10. 


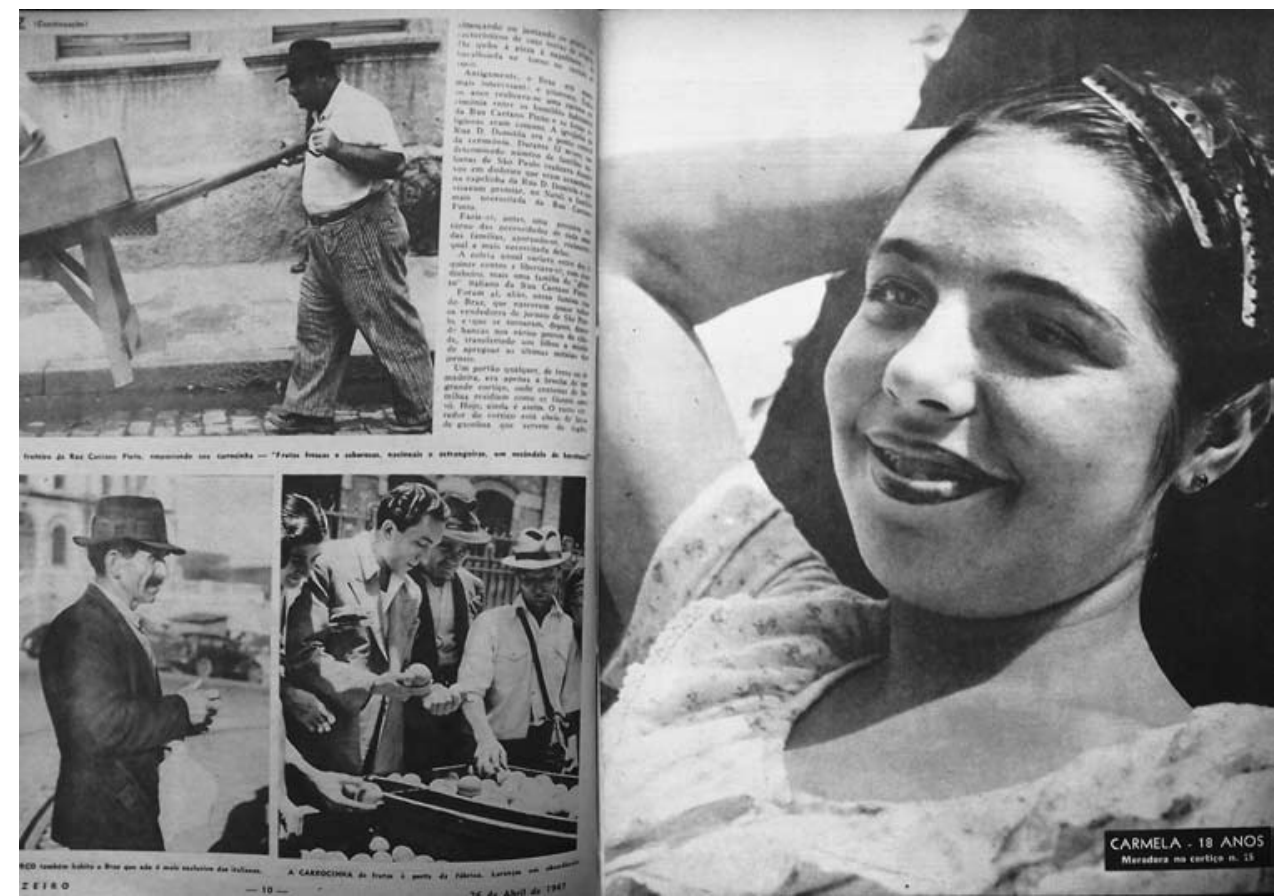

Imagem 47. Fac símile das páginas 10 e 11 da reportagem "O Braz", em 0 Cruzeiro de 26/04/1947. Fonte: Acervo do MASP.

A primeira fotografia mostra uma fila de homens aguardando para embarcar em um ônibus, cuja legenda "Fila para o Braz" leva a induzir que era uma fila de trabalhadores voltando para seus lares, naquele bairro (Imagem 46). Pela projeção das sombras deduz-se que a foto tenha sido feita no fim da tarde. A segunda imagem mostra o trecho comercial da Rua Caetano Pinto, denominada pela legenda como a "espinha dorsal do Braz" e pelo texto como o gueto italiano, que ainda guardava as características do bairro (Imagem 46). As construções apresentadas têm um ou dois pavimentos e eram típicas dos anos 1920 e 1930, com seus telhados de telha cerâmica, excluindo-se um edifício ao fundo, mais moderno, de seis andares. Emalgumas casas, o andar térreo era ocupado por lojas, cujos toldos de tecido serviam de suporte para os nomes dos estabelecimentos. Na rua, calçada com paralelepípedo, havia pequenos caminhões, que serviam às lojas, e nenhum automóvel. O pouco movimento e as sombras baixas indicam que provavelmente o horário do registro foi cedo. 


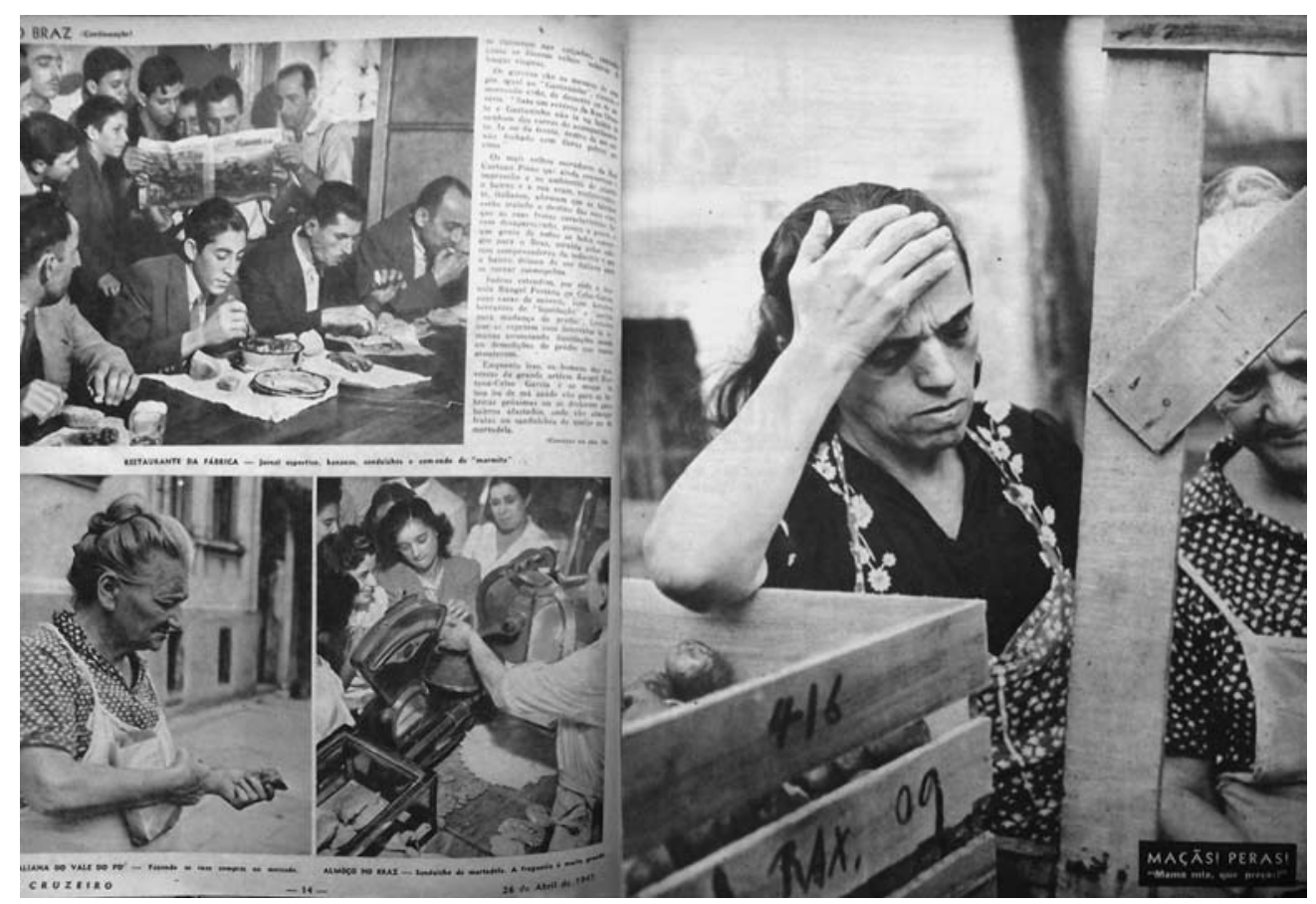

Imagem 48. Fac símile das páginas 14 e 15 da reportagem "O Braz", em O Cruzeiro de 26/04/1947. Fonte: Acervo do MASP.

Os diversos tipos humanos que habitavam aquele bairro foram apresentados em retratos estereotipados, nos quais são "classificados" segundo suas atividades e nacionalidades: o chofer de caminhão e o de táxi, o fruteiro, o operário alemão especialista; a espanhola, o velho turco e os velhos italianos, saudosos da Itália e do antigo Brás. A literatura parece ter fornecido imagens mentais dos moradores. Brás, Bexiga e Barra Funda ${ }^{55}$ não aparece citado apenas no texto: a legenda relacionada à foto da moça faz alusão direta à personagem Carmela, de origem italiana, bonita e atraente, moradora do Brás, que fascinava os homens e que se aproveitava de seus atributos físicos para relacionar-se furtiva e rapidamente com rapazes ricos, que passavam de carro nas redondezas e a convidavam para dar uma volta pela Avenida Rangel Pestana ou pelo Largo da Concórdia ou para ir ao Cine Universo ou o Babilônia (Imagem 47). A foto do velho italiano representa a saudade da terra natal e dos tempos em que o bairro era 


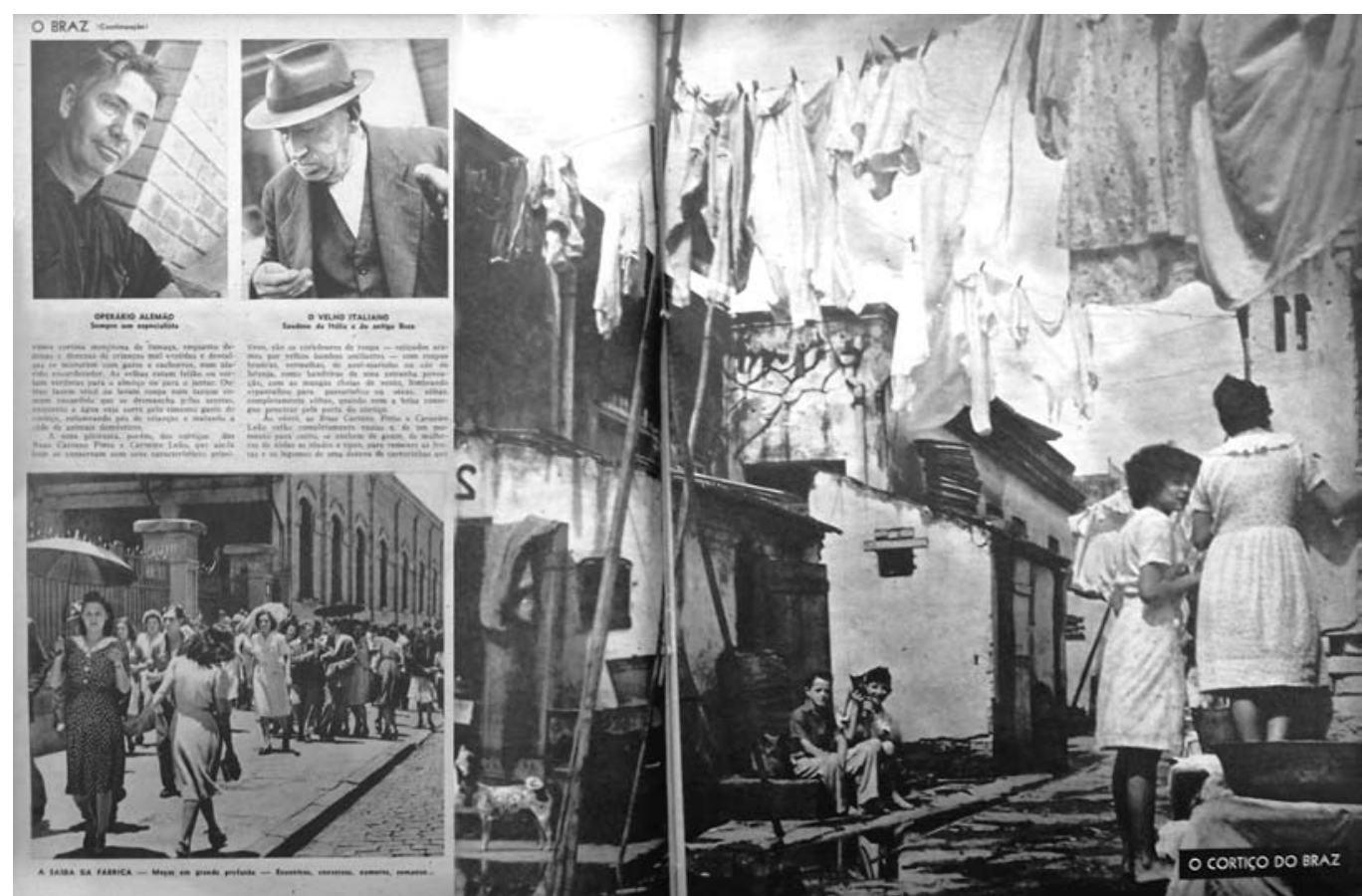

Imagem 49. Fac símile das páginas 12 e 13 da reportagem "O Braz", em O Cruzeiro de 26/04/1947. Fonte: Acervo do MASP.

tipicamente italiano.

Os mais velhos moradores da Rua Caetano Pinto que ainda conservam a impressão e os ambientes de quando o bairro e a rua eram, exclusivamente, italianos, afirmam que as fábricas estão traindo o destino das suas ruas, que as suas festas características foram desaparecendo, pouco a pouco, e que gente de todos os lados convergiu para o Braz, atraída pelos salários compensadores da indústria e que o bairro deixou de ser italiano para se tornar cosmopolita. ${ }^{56}$

O baixo padrão de vida da população do Brás está expresso em imagens das refeições e das compras (Imagem 48). A carroça de frutas aparece como elemento típico do bairro, registrada em dois momentos: quando o fruteiro um homem forte, vestido com roupas simples e calçando sapatos velhos - a 
empurrava através das ruas e quando alguns homens se aglomeravam ao seu redor em frente a uma fábrica, escolhendo as frutas, cujos preços eram muito baixos.

Às vêzes, as Ruas Caetano Pinto e Carneiro Leão estão completamente vazias e, de um momento para outro, se enchem de gente, de mulheres de tôdas as idades e tipos, para remexer as frutas e os legumes de uma dezena de carrocinhas que se encontram nas calçadas, cansadas como se fôssem velhos veleiros de longas viagens. ${ }^{57}$

Na fotografia do mercado (Imagem 48), a senhora coloca uma das mãos sobre a testa, em sinal de preocupação - assentida pela legenda: "Mama mia, que preços!". Numa lanchonete, as pessoas almoçavam um sanduíche de mortadela, ao passo que, no restaurante da fábrica, vêem-se três meninos, o que revela que a presença de crianças nestes locais era comum. A refeição dos operários era simples, composta por pão, frutas (uvas e bananas) e comida caseira em uma marmita de ferro amassada e enferrujada, acompanhada de um copo d'água. Ao fundo, os homens liam a Gazeta Esportiva, cuja capa exibia uma foto de uma partida de futebol, uma de suas principais diversões.

A fábrica era outro ponto característico do Brás (Imagem 49). No texto, é apontada como o fator preponderante para a descaracterização do bairro italiano. A foto mostra o momento da saída dos trabalhadores no horário de almoço: as sombras correspondem ao sol a pino e o relógio instalado na pilastra do gradil indica 12:30. Chama a atenção a grande quantidade de mulheres. Na legenda, este momento foi colocado como a hora para "encontros, conversas, namoros, romance...".

A maior fotografia da reportagem registra um cortiço (Imagem 49). Este $57 \quad$ NOBRE. Op. cit. p.12. 
tipo de habitação coletiva era muito comum no entorno das fábricas. Suas condições eram insalubres: as casas registradas eram de baixo padrão, muito próximas umas às outras, sem recuos. As portas de madeira eram frágeis e os telhados, simples, sem forro. As paredes estavam trincadas e com revestimento deteriorado. Não havia condições de ventilação e insolação adequadas, num lugar onde "nem a brisa consegue penetrar" ${ }^{58}$. Nota-se elementos característicos dos cortiços: a circulação central, com calçamento precário, sobre o qual se formavam poças d'água, pontos de concentração de sujeira e bactérias; o tanque comum, junto ao qual estavam as duas mulheres; a presença dos animais domésticos, que agravava a situação, uma vez que suas fezes se misturavam com a água parada e a terra e acabavam por contaminar as crianças, que normalmente andavam descalças. Os varais cheios de roupas cruzavam a circulação, numa forte referência às roupas penduradas entre as janelas nas ruas de pequenas cidades italianas, uma cena típica daquele país.

\footnotetext{
Um portão qualquer, de ferro ou de madeira, era apenas a brecha de um grande cortiço, onde centenas de famílias residiam como se fôssem uma só. Hoje, ainda é assim. O vasto corredor do cortiço está cheio de latas de gasolina que servem de fogão, numa cortina monótona de fumaça, enquanto dezenas e dezenas de crianças mal vestidas e descalças se misturam com gatos e cachorros, num alarido ensurdecedor. As velhas contam feijão ou cortam verduras para o almôço ou para o jantar. Outras fazem tricô ou lavam roupa num tanque comum encardido que se desmancha pelas arestas, enquanto a água suja escorre pelo cimento gasto do cortiço, enlameando pés de crianças e matando a sêde de animais domésticos. ${ }^{59}$
}

No Brás, os cortiços das ruas Carneiro Leão e Caetano Pinto eram os mais conhecidos. Na década anterior, o fotógrafo Benedito Junqueira Duarte fizera uma série de fotografias pelos cortiços de São Paulo, como os da Rua Oscar

$58 \quad$ NOBRE. Op. cit. p.12.

59 NOBRE. Op. cit. p.10. 


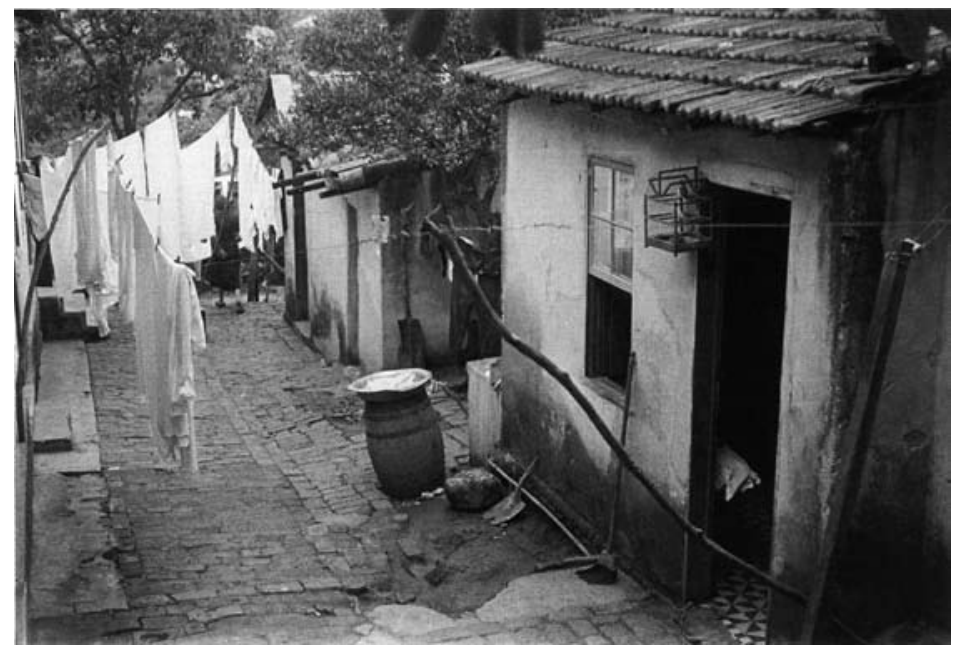

Imagem 50. Cortiço na Rua Oscar Freire, 1938. Autoria: B. J. Duarte. Fonte: JUNIOR; LIMA; VALADARES (2007), p.74.

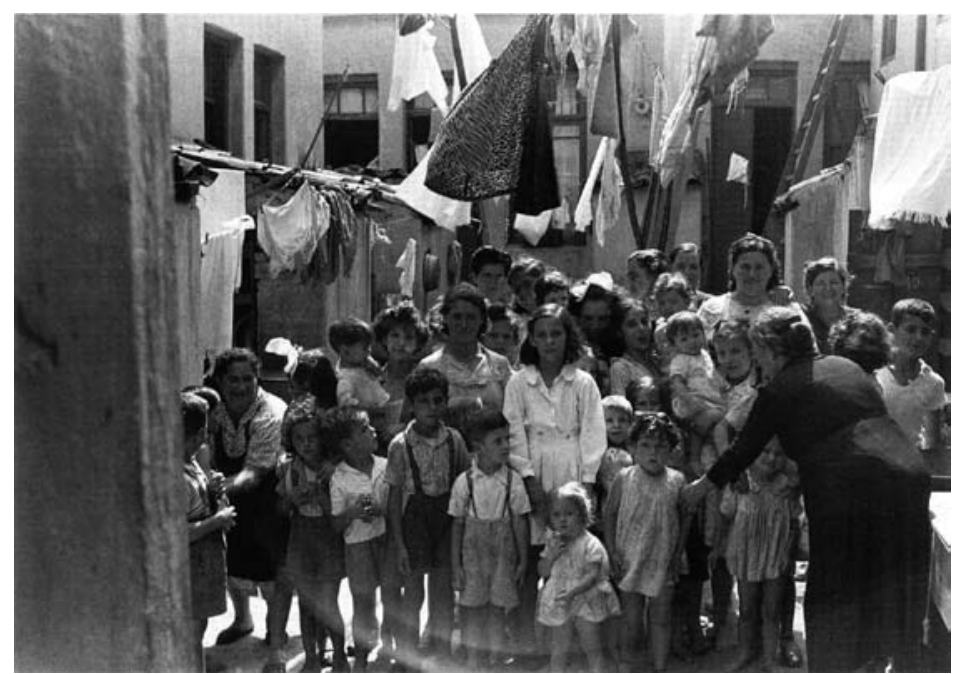

Imagem 51. Cortiço na Rua Carneiro Leão, década de 1930. Autoria: B. J. Duarte. Fonte: JUNIOR; LIMA; VALADARES (2007), p.77.

Freire (Imagem 50), Rua das Flores, Rua Cardeal Arcoverde, Rua da Assembléia, Avenida Nove de Julho e, também, o da Rua Carneiro Leão. Em imagens mais panorâmicas, B.J. Duarte buscava o registro da implantação das casas, sua relação com a rua e seus espaços de circulação. Na Carneiro Leão, retratou cerca de quarenta mulheres e crianças agrupadas numa área entre as casas, cujo espaço era cortado pelos varais apinhados de roupas (Imagem 51). Peter 


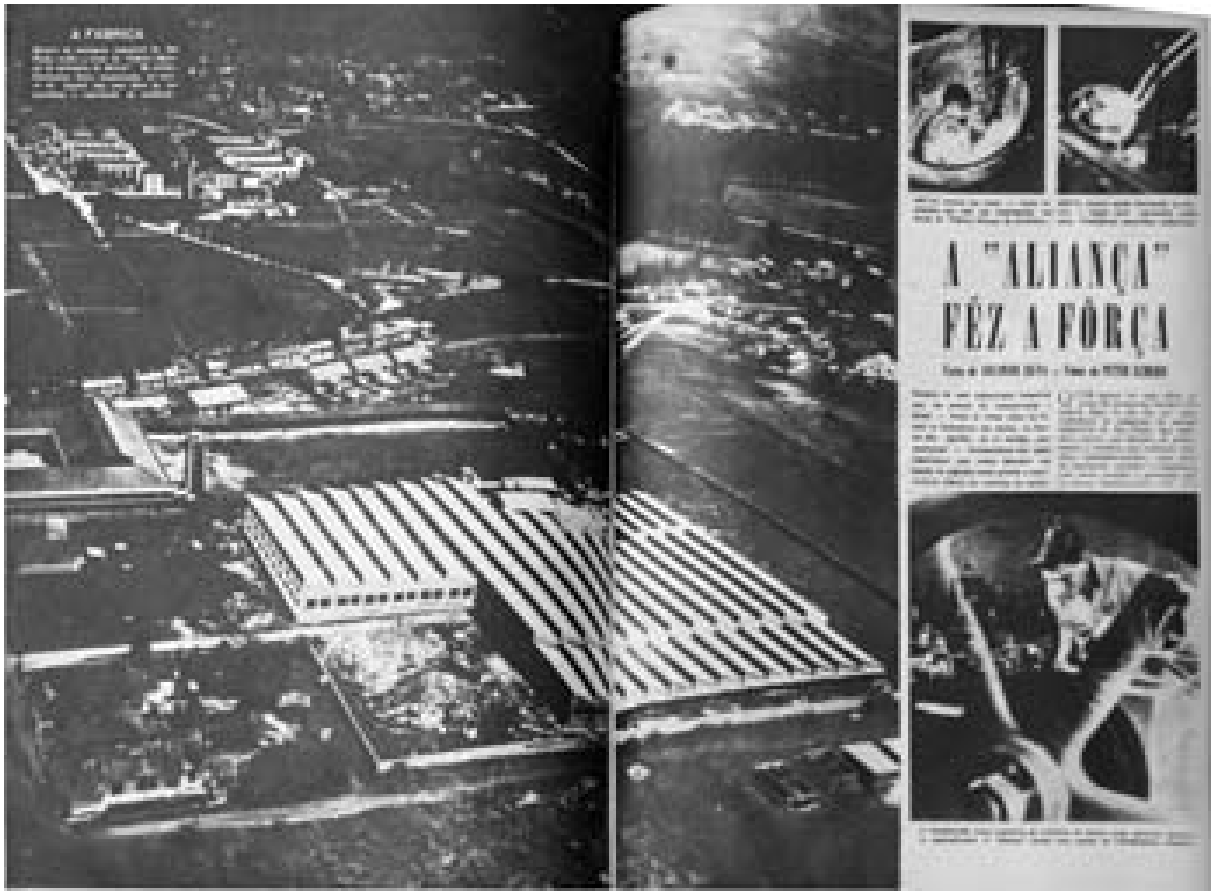

Imagem 52. Fac símile das páginas 58 e 59 da reportagem "A "Aliança" fez a força”, em O Cruzeiro de 14/01/1950. Fonte: Acervo do MASP.

Scheier ocupou-se menos das questões espaciais e urbanas e concentrou-se nas pessoas e nas suas atividades. Scheier, pois, interpretou o bairro do Brás através de seus habitantes.

Além dos eventos e das minorias sociais, o comportamento da sociedade paulistana era registrado através do trabalho de instituições - de assistência, filantrópicas, culturais e educacionais. A Escola Santa Rita ${ }^{60}$, por exemplo, preparava moças bem-nascidas para serem eficientes donas-de-casa, ministrando aulas de culinária, etiqueta e afazeres domésticos, demonstrando o ainda predominante comportamento machista da sociedade, que destinava suas mulheres aos serviços do lar. Entretanto, o confronto dessas imagens com aquelas feitas no Brás esclarece que, ao menos nas classes mais baixas, as mulheres começavam a assumir um lugar no mercado de trabalho - como nas fábricas.

60 MOTTA, Nelson. Barricada na cozinha. O Cruzeiro, São Paulo, p. 54-63, 23 jun 1945. 


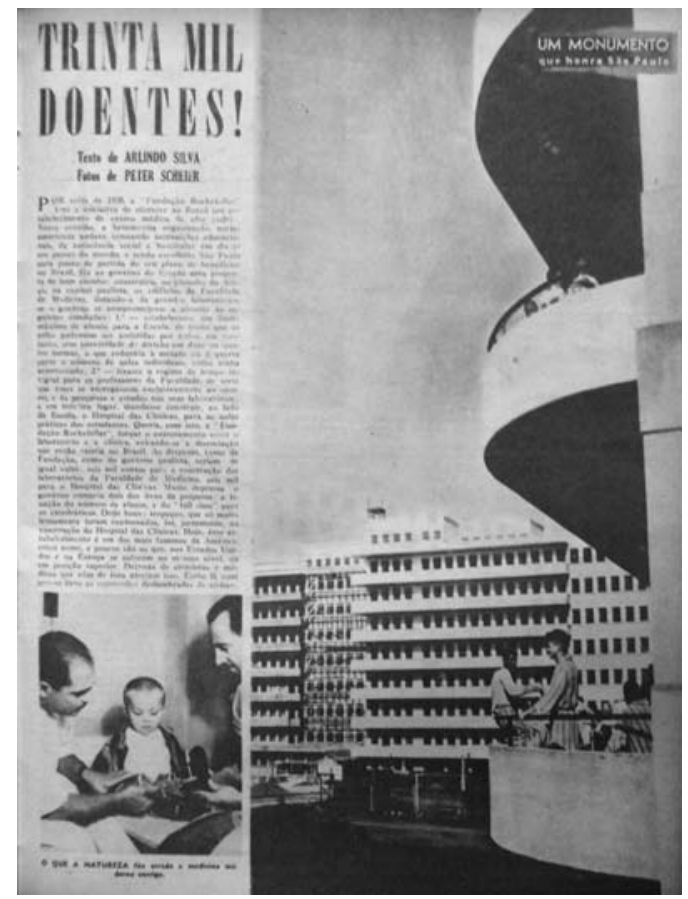

Imagem 53. Fac símile da página 57 da reportagem "Trinta mil doentes", em 0 Cruzeiro de 02/08/1947. Fonte: Acervo do MASP.

A prosperidade de São Paulo era colocada em reportagens sobre agricultura e indústria - principalmente a siderúrgica. As fábricas eram descritas como engenhos maravilhosos, capazes de realizar façanhas inimagináveis. Estas reportagens começavam com uma grande foto aérea das instalações das fábricas, enfatizando sua extensão e complexidade (Imagem 52). Nas tomadas internas, Scheier buscava arranjos interessantes do maquinário, com freqüência explorando sua geometria e sua repetição. Contudo, sua ênfase incidia sobre as ações, posturas e esforço dos operários. Scheier gostava de registrá-los em ângulos fechados e muitas vezes os enquadrava em frestas ou elementos das máquinas.

Para ilustrar o progresso da cidade, O Cruzeiro publicou uma reportagem sobre a inauguração do Hospital das Clínicas, em abril de 1944. O texto exaltava 


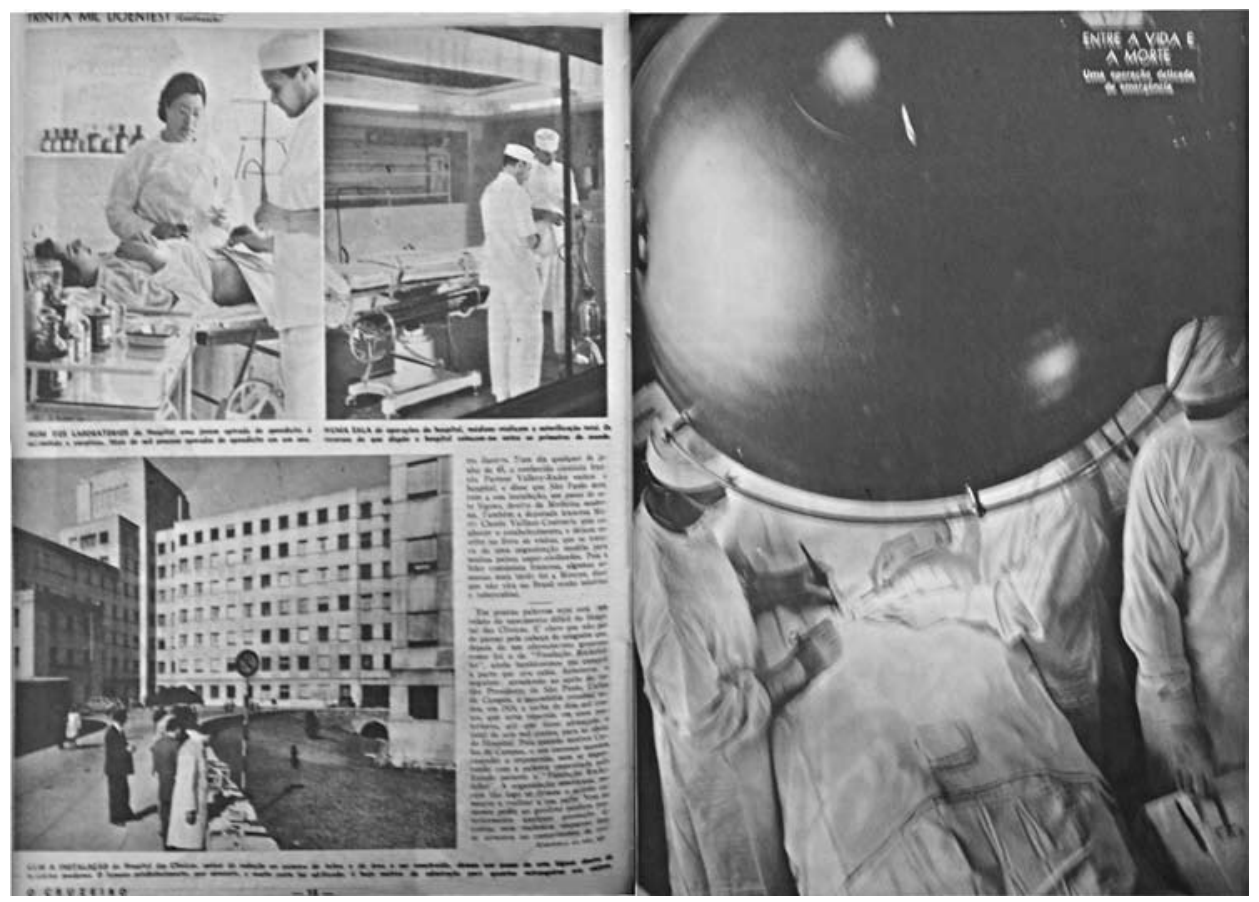

Imagem 54. Fac símile das páginas 58 e 59 da reportagem "Trinta mil doentes", em O Cruzeiro de 02/08/1947. Fonte: Acervo do MASP.

o hospital como uma referência na América e no mesmo nível dos hospitais dos Estados Unidos e Europa, comprovado pelos "cientistas e médicos que vêm de fora" ${ }^{61}$. "Estão lá num grosso livro as expressões deslumbradas de visitantes ilustres", "uma organização modelo para muitos países super-desenvolvidos" e "um monumento que honra São Paulo" ${ }^{2}$ são algumas das frases encontradas ao longo do texto. O título "Trinta mil doentes" foca na quantidade de doentes e não em outras características, como números de médicos, de metragem quadrada ou de leitos, nem mesmo utiliza outros termos, como pacientes - talvez a doença tivesse mais apelo junto ao público leitor.

As imagens podem ser separadas em dois grupos, o que documenta o edifício e outro, os procedimentos médicos. As três imagens do primeiro grupo mostram vistas gerais ou parciais do conjunto, nas quais o contraponto reta

61 SILVA, Arlindo. Trinta mil doentes. O Cruzeiro, São Paulo, p. 57, 02 ago 1947.

62 SILVA. Op. cit. p. 57-58. 


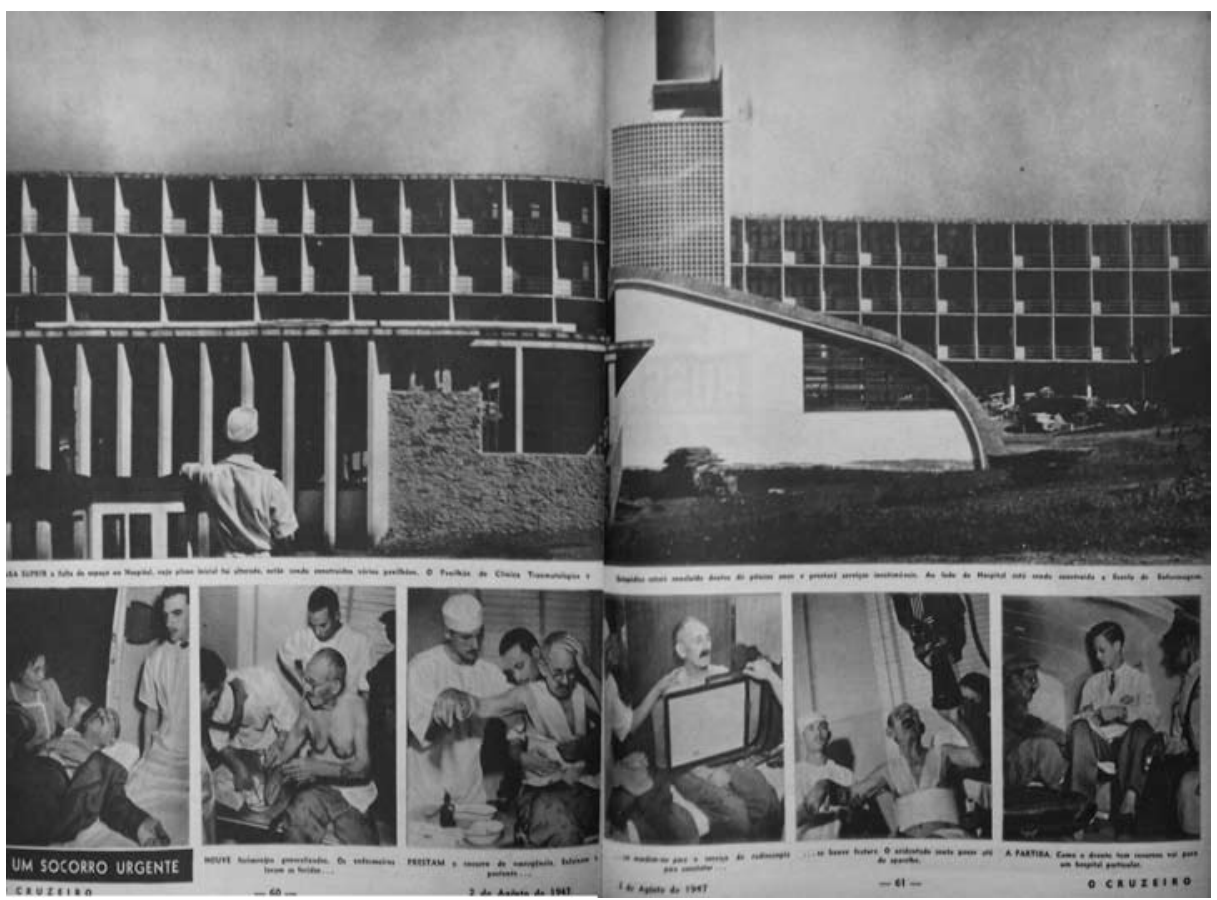

Imagem 55. Fac símile das páginas 60 e 61 da reportagem "Trinta mil doentes", em O Cruzeiro de 02/08/1947. Fonte: Acervo do MASP.

- curva é comum. Na primeira (Imagem 53), as varandas curvas - nas quais se vêem alguns pacientes - foram focadas à direita, em primeiro plano, com a vista geral do conjunto, ainda em construção, ao fundo. Em outra, o edifício, através da seqüência de suas janelas, volumes e linhas, marca um fundo geométrico, que se contrapõe às figuras humanas distribuídas ao longo do passeio curvo - o que fornece uma noção de escala (Imagem 54). Este arranjo - geometria rigorosamente reta e ritmada ao fundo e curva acentuada à frente lembra algumas imagens feitas do Edifício Prudência, de Rino Levi, que serão vistas ainda neste capítulo. Na terceira imagem, o rigor geométrico dos brises verticais e horizontais foi quebrado pelas linhas curvas do pavilhão da Clínica Traumatológica e Ortopédica (Imagem 55). A incidência solar sobre os brises salientou suas formas, tal como na colocação de Mário Pedrosa, segundo a qual os "painéis móveis dos brise-soleil animam as fachadas e criam, às vezes, graças aos jogos de sombras e de luzes, e à utilização da cor, uma impressão 


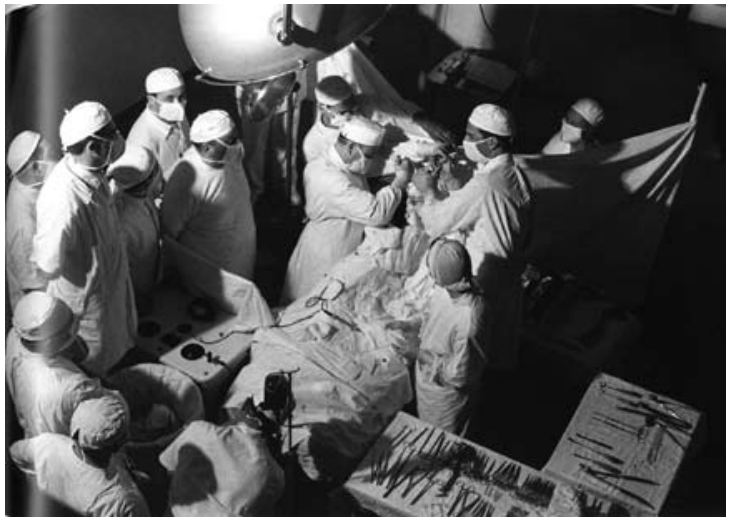

Imagem 56. Cirurgia no Hospital das Clínicas, 1949.Autoria: B. J. Duarte. Fonte: JUNIOR; LIMA; VALADARES (2007), p.181.

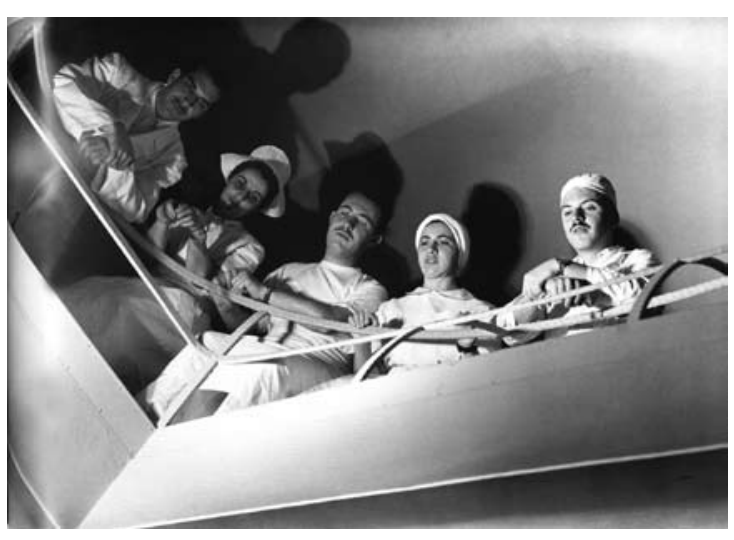

Imagem 57. Hospital das Clínicas, 1949. Autoria: B. J. Duarte. Fonte: JUNIOR; LIMA; VALADARES (2007), p.179.

picturial" 63.

No segundo grupo, mais numeroso, Scheier posicionou-se em uma passarela alta que percorria o perímetro da sala, para documentar uma cirurgia (Imagem 54). Contudo, quase metade da área da foto é dominada pela luminária, que adquiriu grandes proporções devido à sua proximidade à câmera. Assim, a imagem foi organizada em duas áreas: uma inferior branca e uma superior preta. Além de proporcionar uma composição interessante, este recurso resguardou a cabeceira da maca e o procedimento médico. Uma foto desta mesma série foi publicada no livro São Paulo the fastest growing city in the world.

Na mesma época, Benedito Junqueira Duarte também realizou uma série de imagens de uma cirurgia na mesma sala. Suas fotos são mais incisivas ao registrar de perto os procedimentos. Quando na passarela, B.J.Duarte abaixou a câmera e esquivou-se da luminária, focando diretamente a maca e os médicos (Imagem 56). Foi-lhe possível entrar na sala e fazer fotos próximas à operação. Deste nível mais baixo, B.J. fotografou a tal passarela, na qual enfermeiras e 63 PEDROSA, Mário. A Arquitetura Moderna no Brasil. In:XAVIER, Alberto (org.). Depoimento de uma geração - arquitetura moderna brasileira. São Paulo: Cosac \& Naify, 2003, p. 103. Texto originalmente publicado em L'Architecture d'aujourd'hui, n. 50-51, Boulogne (Seine), pp. XXIXXIII, nov - dez 1953. 


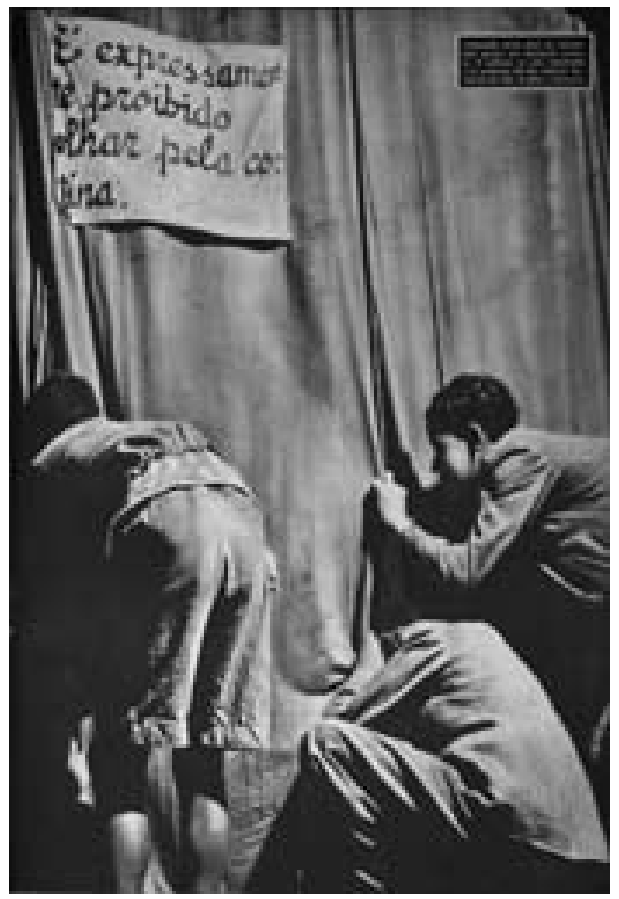

Imagem 58. "Ninguém mais que as crianças aprecia um espetáculo circense" (legenda original). Fac símile da página 11 da reportagem "Circoteatro do povo", em O Cruzeiro de 23/06/1945. Fonte: Acervo do MASP.

prováveis estudantes também assistiam a cirurgia (Imagem 57).

Um recurso narrativo freqüente na $O$ Cruzeiro foi empregado nesta reportagem: uma história, contada quadro-a-quadro. "Um socorro urgente" é o título dramático da seqüência de fotos do atendimento de um paciente, desde o momento em que chegou ao hospital e foi retirado da ambulância em uma maca, acompanhado de uma mulher - provavelmente da família (Imagem 55). As quatro fotos seguintes mostram os procedimentos médicos para limpeza dos ferimentos e exames e registram o aparente temor do paciente frente ao aparelho de raio-x. Na última foto, com a legenda "A partida", o paciente já recuperado e vestido, conversa com o médico. 


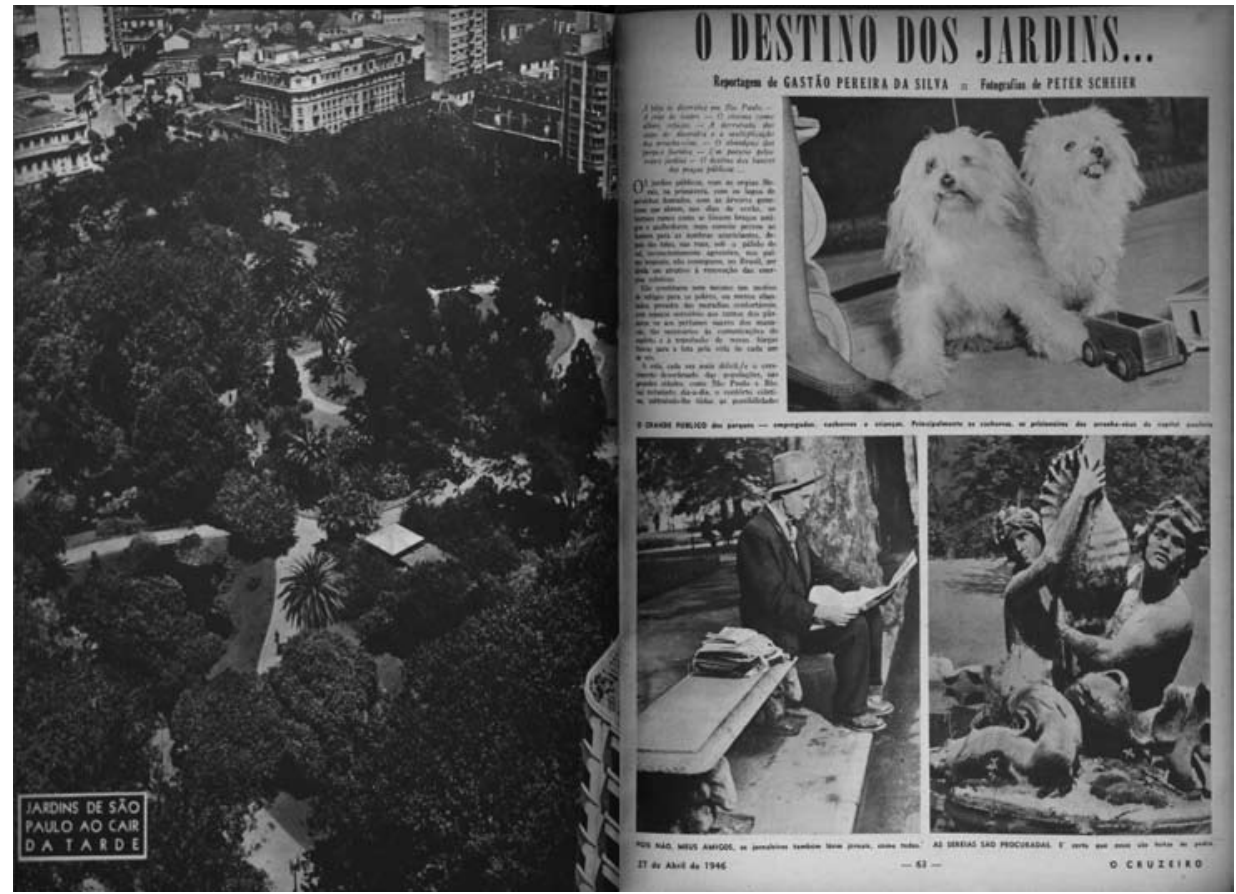

Imagem 59. Fac símile das páginas 62 e 63 da reportagem "O destino dos jardins”, em O Cruzeiro de 27/04/1946. Fonte: Acervo do MASP.

Entretenimento - campeonatos esportivos, estilos de dança e bailes de carnaval - era outro tema através do qual a cidade era retratada pelas lentes de Scheier. Numa imagem do circo Piolin ${ }^{64}$, ele usou um recurso que, embora soubesse utilizá-lo com sutileza e bom humor, raramente explorava: o emprego de legenda interna (Imagem 58). Nela, três garotos assistem ao espetáculo pelas frestas da lona do circo, ignorando o cartaz que afirmava ser expressamente proibido olhar pela cortina.

A degradação dos espaços de lazer em São Paulo foi assunto da "O destino dos jardins" ${ }^{65}$, de 1946. O texto aponta o crescimento desordenado da cidade como a razão para o fim dos espaços dos jardins públicos, destruídos constantemente para a construção de edifícios de apartamentos, "modernos

$64 \quad$ NOBRE, Freitas. Circo-teatro do povo. O Cruzeiro, São Paulo, p. 8-13, 23 jun 1945.

65 SILVA, Gastão Pereira da. O destino dos jardins. O Cruzeiro, São Paulo, p. 62-67, 27 abr 1946. 


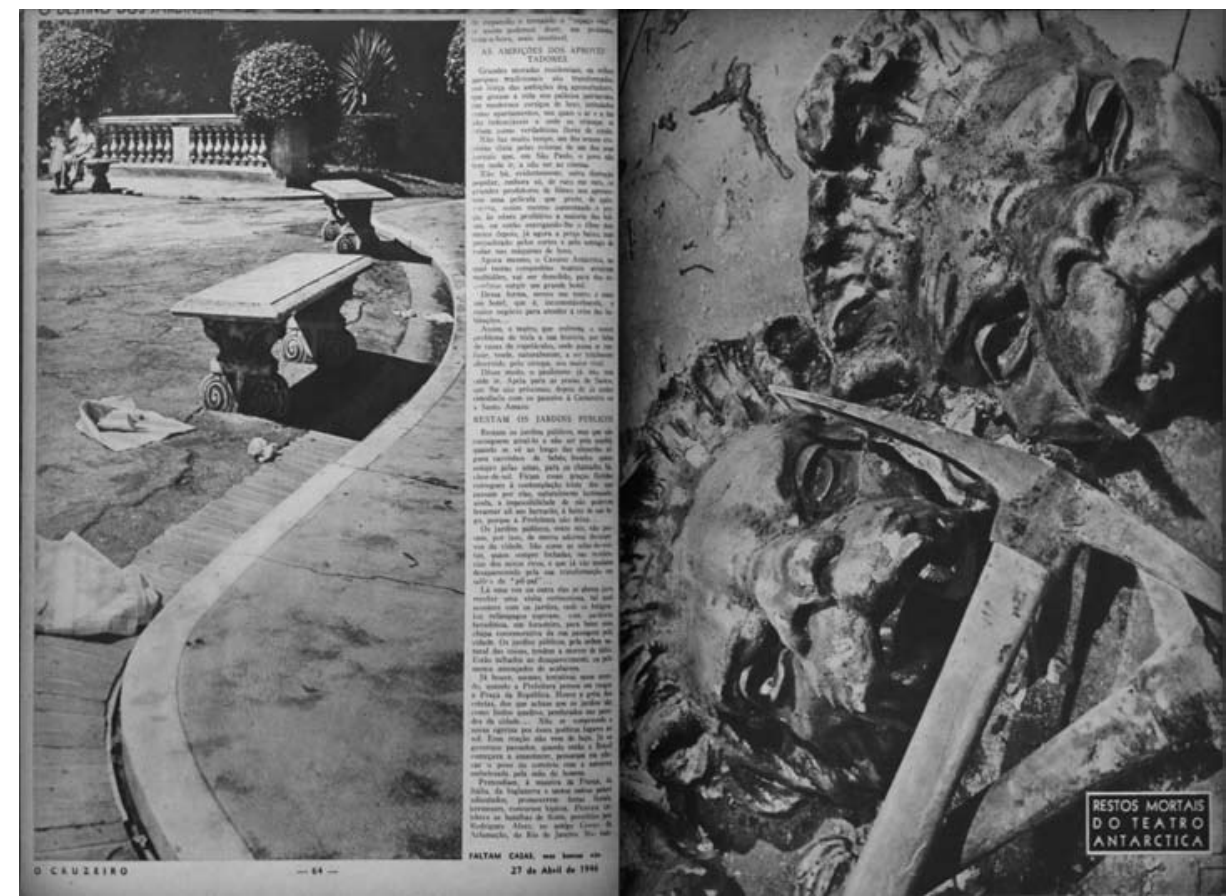

Imagem 60. Fac símile das páginas 64 e 65 da reportagem "O destino dos jardins", em O Cruzeiro de 27/04/1946. Fonte: Acervo do MASP.

cortiços de luxo" "66. A falta de diversões, a ascensão do cinema, a conseqüente crise do teatro e o abandono dos parques eram apontados com tristeza, restando ao paulistano apenas três opções: as praias de Santos, os passeios à Serra da Cantareira e a Santo Amaro.

O discurso montado pelas imagens e legendas parte de uma vista aérea da Praça da República e continua através de detalhes: as estátuas, os passeios, os bancos e seus freqüentadores. Foram criados estereótipos dos usuários como na reportagem sobre o Brás. A imagem com dois cachorros sintetiza os maiores freqüentadores dos parques, segundo o texto: as babás, as crianças e os cachorros, estes "os prisioneiros dos arranha-céus" 67 (Imagem 59). Trata-se de uma foto posada, na qual à esquerda aparece parcialmente uma perna de mulher e, junto aos cachorros, alguns brinquedos habilmente colocados. Os 


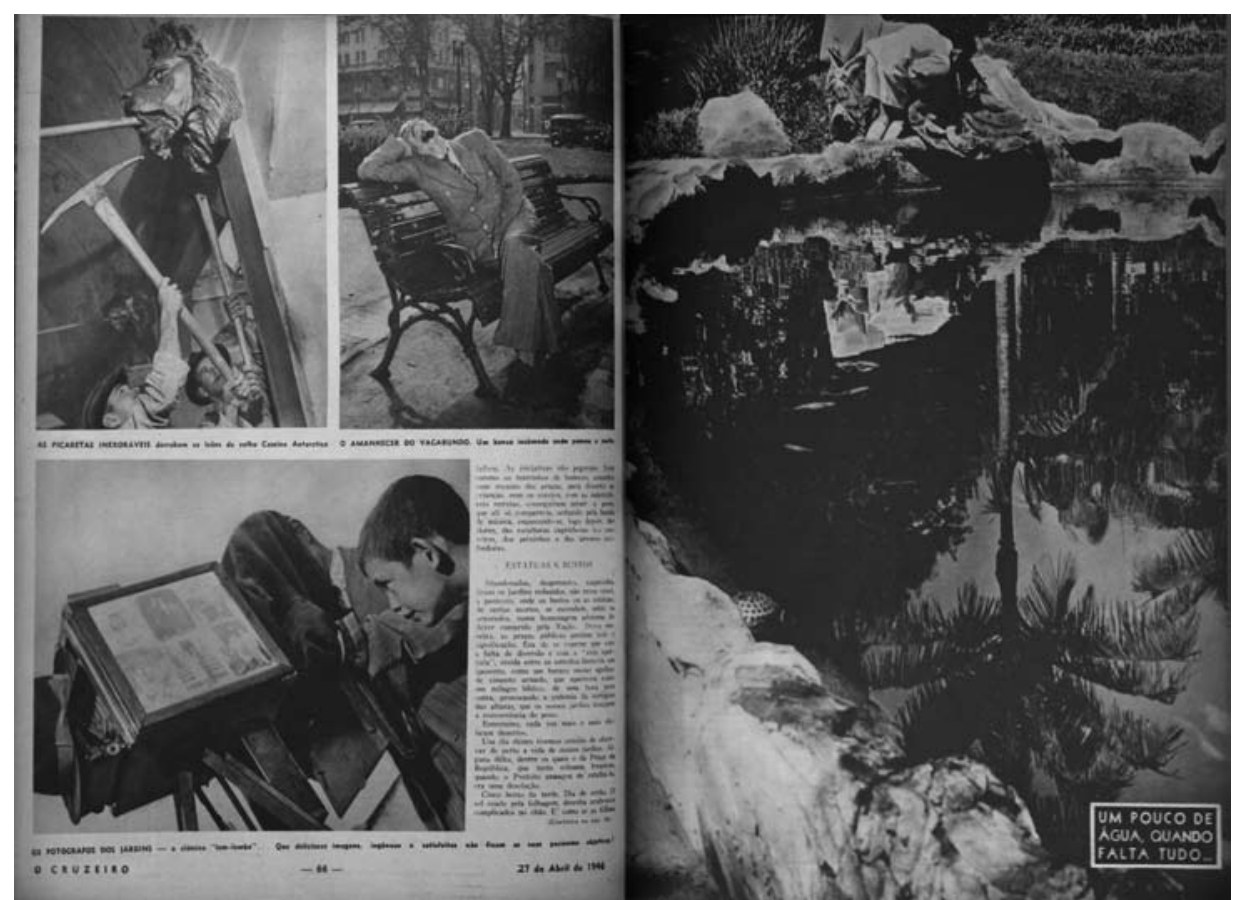

Imagem 61. Fac símile das páginas 66 e 67 da reportagem "O destino dos jardins", em O Cruzeiro de 27/04/1946. Fonte: Acervo do MASP.

estereótipos continuam com a figura do jornaleiro, sentado no banco, lendo o jornal (Imagem 59); com a foto do homem que aparentemente dormia no banco, rotulado imediatamente de vagabundo pela legenda - sua postura, no entanto, corresponde mais a uma pose que a uma posição de quem ali dormiu durante a noite toda, como a legenda tende a sugerir (Imagem 61). E ainda no fotógrafo "lambe-lambe", com sua máquina de grande formato que causava admiração nas crianças (Imagem 61). Nesta imagem, também posada, Scheier compôs novamente diagonalmente, colocando a máquina em primeiro plano, ocultando o rosto do fotógrafo sob o tecido preto e inserindo apenas a cabeça do menino do lado direito.

A demolição do Cassino Antarctica ${ }^{68}$, no centro, para a construção de

68 O Theatro Cassino Antarctica ficava na Rua Anhangabaú (futura Avenida 23 de Maio). Inaugurado em 1913, após a construção do Viaduto Santa Ifigênia, era composto por uma grande sala de espetáculo para canto, dança e variedades e um bar em um terraço coberto. Foi demolido para construção da Av. Prestes Maia. Fonte: PONTES, José Alfredo Vidigal. São Paulo de Piratininga: de pouso de tropas a metrópole. São Paulo: O Estado de S.Paulo / Editora Terceiro Nome, 2003, p. 169. 


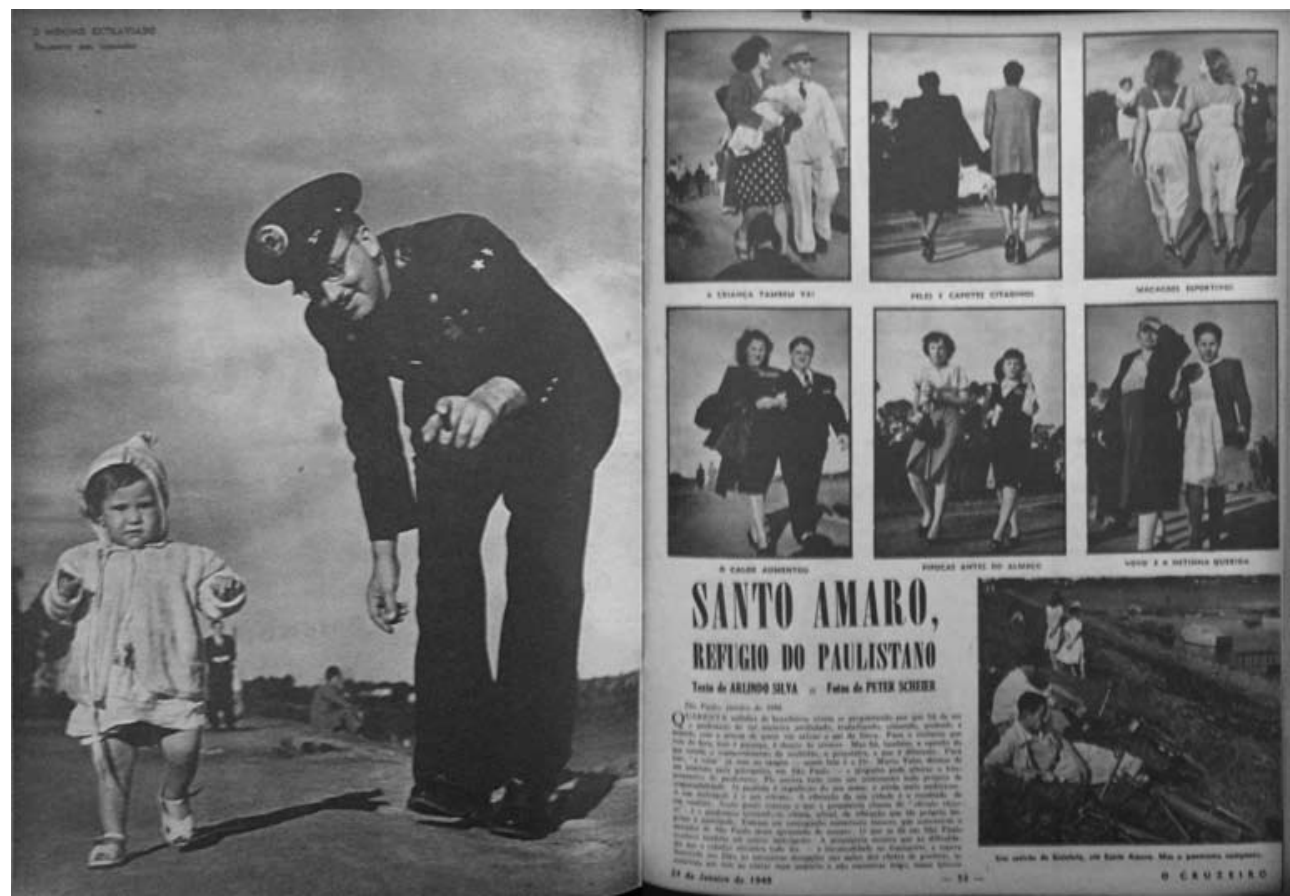

Imagem 62. Fac símile das páginas 52 e 53 da reportagem "Santo Amaro, refúgio do paulistano", em O Cruzeiro de 24/01/1948. Fonte: Acervo do MASP.

um hotel, foi registrada em imagens de detalhes construtivos. Com a legenda dramática "Restos mortais do Teatro Antarctica", duas imagens simbolizam o abandono e o fim dos teatros (Imagem 60). Numa composição diagonal, duas picaretas foram cuidadosamente colocadas sobre os adornos em forma de cabeça de leão - animal feroz que, apesar de sua bravura, não resistiria à destruição. Em seguida, foi encenado o primeiro golpe contra o leão prestes a ser "abatido" (Imagem 61).

Da mesma maneira como foi aberta, a reportagem encerra-se com uma imagem de página inteira da Praça da República, sangrada, dominada pelo reflexo da vegetação circundante sobre a água de um espelho d'água (Imagem 61). Na parte superior, sobre as pedras, um garoto reclinado. A legenda "um pouco de água, quando falta tudo..." é dúbia e distorce a leitura da imagem: pode 


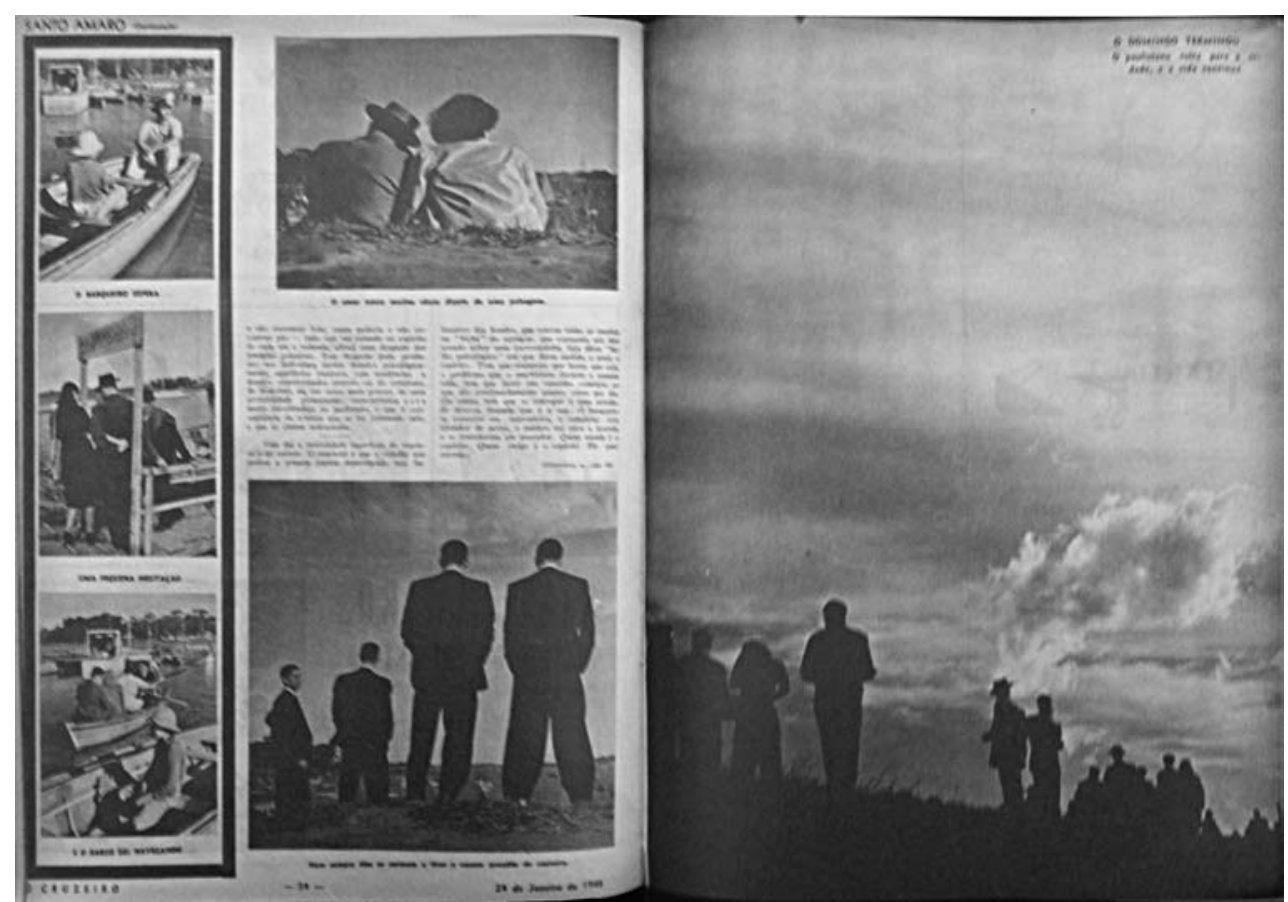

Imagem 63. Fac símile das páginas 54 e 55 da reportagem "Santo Amaro, refúgio do paulistano", em O Cruzeiro de 24/01/1948. Fonte: Acervo do MASP.

ser entendido que faltava tudo ao garoto - que, assim, seria um menino de rua ou ao próprio espaço, degradado e abandonado.

Dois anos após esta reportagem, Scheier foi a Santo Amaro documentar uma das três opções de lazer do paulistano ${ }^{69}$, segundo a reportagem anterior. Aqui, suas preocupações estavam voltadas para as pessoas e suas atividades e menos para o registro do lugar. Mas Scheier - apreciador de retratos e da proximidade com as pessoas - parecia estranhamente constrangido em fotografar as pessoas, mostradas de costas com freqüência.

Uma imagem de página inteira inicia esta reportagem, com um policial reclinado na direção de uma criança, chamando sua atenção para a câmera (Imagem 62). Scheier colocou-se num plano baixo, para registrar a criança frontalmente, caminhando em sua direção. Na seqüência, uma série de seis 69 SILVA, Arlindo. Santo Amaro, refúgio do paulistano. O Cruzeiro, São Paulo, p. 53-56, 24 jan 1948. 
fotos mostra os estereótipos dos freqüentadores do parque, registrados em duplas: o casal com o bebê, a avó com a neta, as jovens (Imagem 62). As roupas chamavam a atenção, sendo que casacos de pele desfilavam ao lado de macacões esportivos. E nisso residia o interesse do fotógrafo: no tipo humano, suas ações, seus costumes e suas extravagâncias. O recurso da história quadroa-quadro foi utilizada para narrar um passeio de barco (Imagem 63). Na primeira imagem, o barqueiro aguardava a próxima saída; na segunda, o casal mostravase hesitante em embarcar; finalmente, o barco partia para o passeio.

Scheier criou arranjos interessantes, como na foto em que os rapazes, deitados na grama, vislumbram a paisagem, com suas bicicletas ao lado (Imagem 62). Uma composição bastante eficiente e bem resolvida, com os rapazes em primeiro plano, no canto esquerdo, com o olhar direcionado para a direita. Mais uma vez, uma diagonal descendente - o declive do terreno - marca a imagem. A última foto da reportagem é caracterizada pelo contra-luz que reduziu as pessoas às suas silhuetas (Imagem 63). A identidade não revelada poderia significar a igualdade de todos nos espaços públicos, onde em tese todos são bem-vindos, sem distinção.

Em suma, a análise do trabalho de Peter Scheier na revista $O$ Cruzeiro delineia pontos-chave no modo como ele documentava a cidade de São Paulo. Ele retratava São Paulo da mesma forma como retratou o parque através de seus usuários e o bairro do Brás através de seus habitantes. Scheier via a cidade através de seus cidadãos, através de suas atividades e de seu fluir - nisto residia seu interesse primário. 


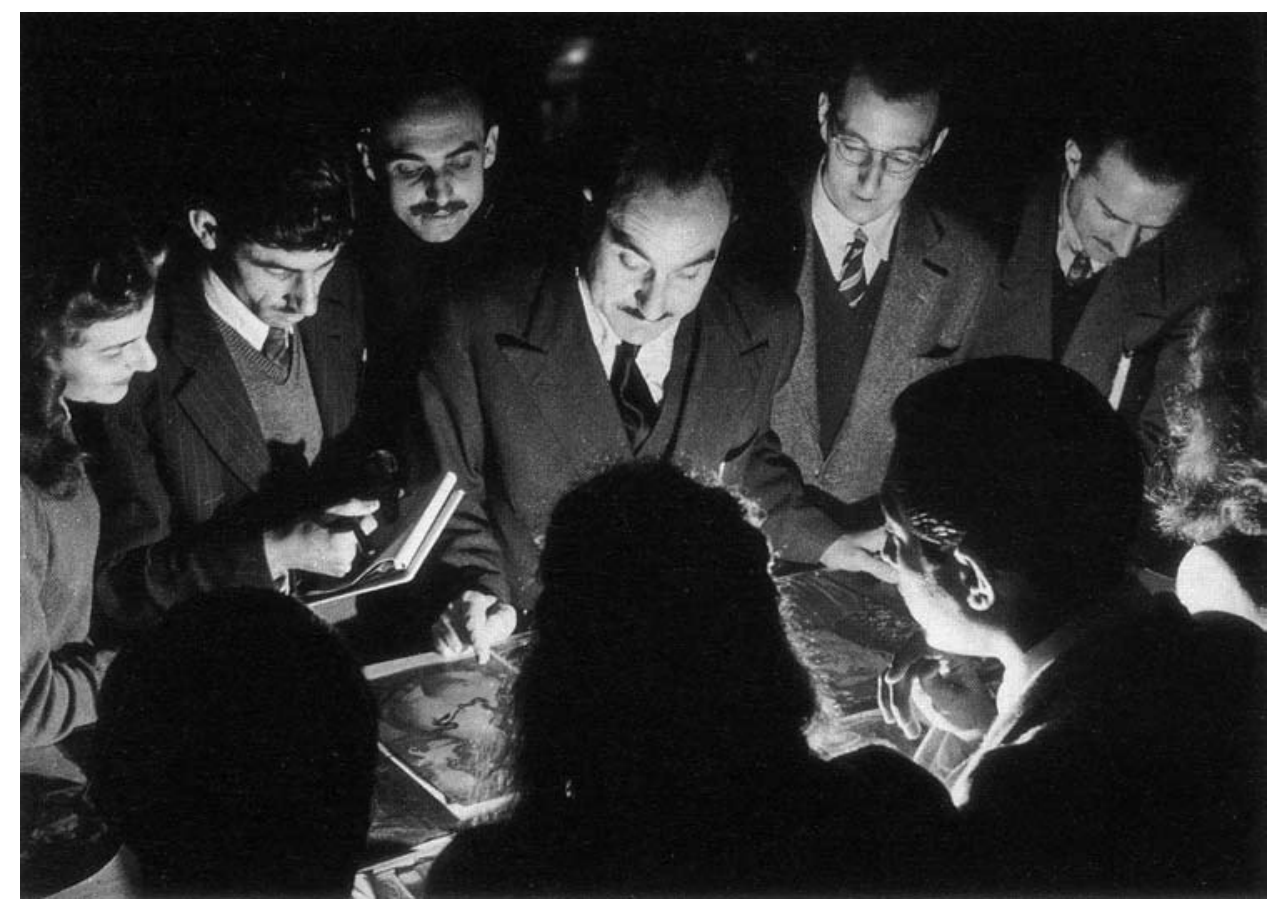

Imagem 64. Bardi numa das aulas de história da arte para os monitores do museu, em 1947. Fonte: TENTORI (2000), p.189.

\subsection{O Museu de Arte de São Paulo (1947-1953) e a revista Habitat (1951-1953)}

Peter Scheier fotografou as atividades e eventos do Museu de Arte de São Paulo - MASP - por cerca de cinco anos, desde sua inauguração em 08 de outubro de 1947 até 1953. As circunstâncias de seu primeiro contato com Pietro M. Bardi e sua chegada à instituição são desconhecidas, mas a coexistência no edifício Guilherme Guinle do museu e da redação dos Diários Associados conglomerado ao qual a revista $O$ Cruzeiro pertencia e ao qual Scheier prestava serviços - pode elucidar o fato. É provável que Pietro conhecera Scheier pouco antes da inauguração do museu, quando este fotografava para a reportagem "Monitores para o Museu de Arte", publicada naquela revista em 20 de setembro de 1947. Nesta reportagem, sobre o curso de história da arte ministrado por 


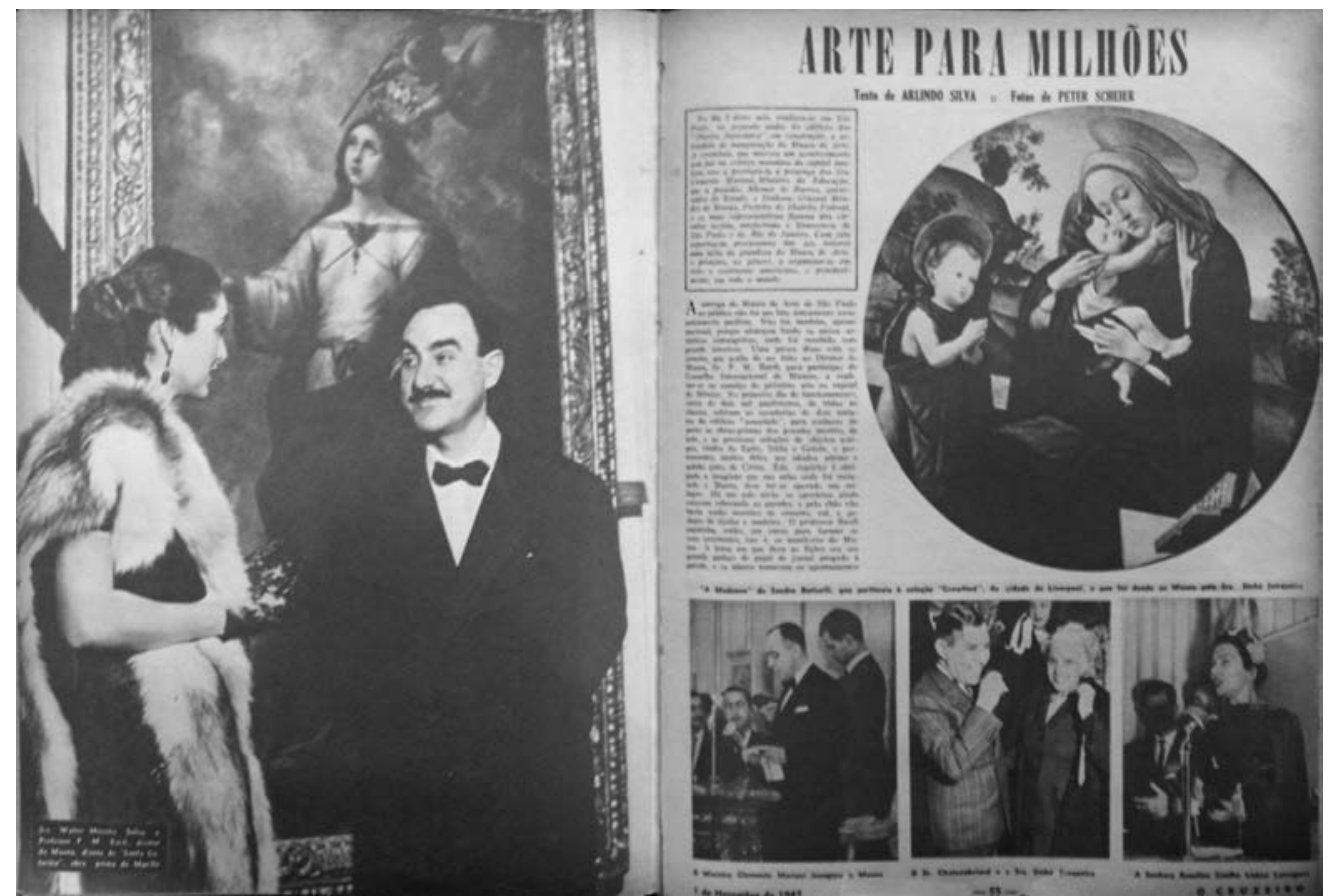

Imagem 65. Fac símile das páginas 54 e 55 da reportagem "Arte para milhões", em O Cruzeiro de 01/11/1947. Fonte: Acervo do MASP.

Bardi para a formação de monitores para o museu, foi publicada uma das fotos mais reproduzidas e conhecidas de Scheier, na qual Pietro, debruçado sobre uma mesa de luz, explica uma obra aos alunos que o rodeiam (Imagem 64).

A história do MASP começou em 1946, quando o jornalista e empresário Assis Chateaubriand convidou Pietro Bardi, recém-chegado da Europa, para montarem juntos um museu. $\mathrm{O}$ prédio que abrigaria a sede dos Diários Associados, principal jornal de Chateaubriand, estava em construção na Rua Sete de Abril, centro de São Paulo. Surgiu a idéia de ocupar um de seus andares com o museu. Assim, em 1947, o Museu de Arte de São Paulo foi inaugurado. Desde o primeiro momento, Lina Bo Bardi foi responsável pelo projeto arquitetônico do museu.

A proposta era realizar exposições periódicas, promover os aspectos didáticos da arte com cursos e conferências e também abrir escolas sobre 


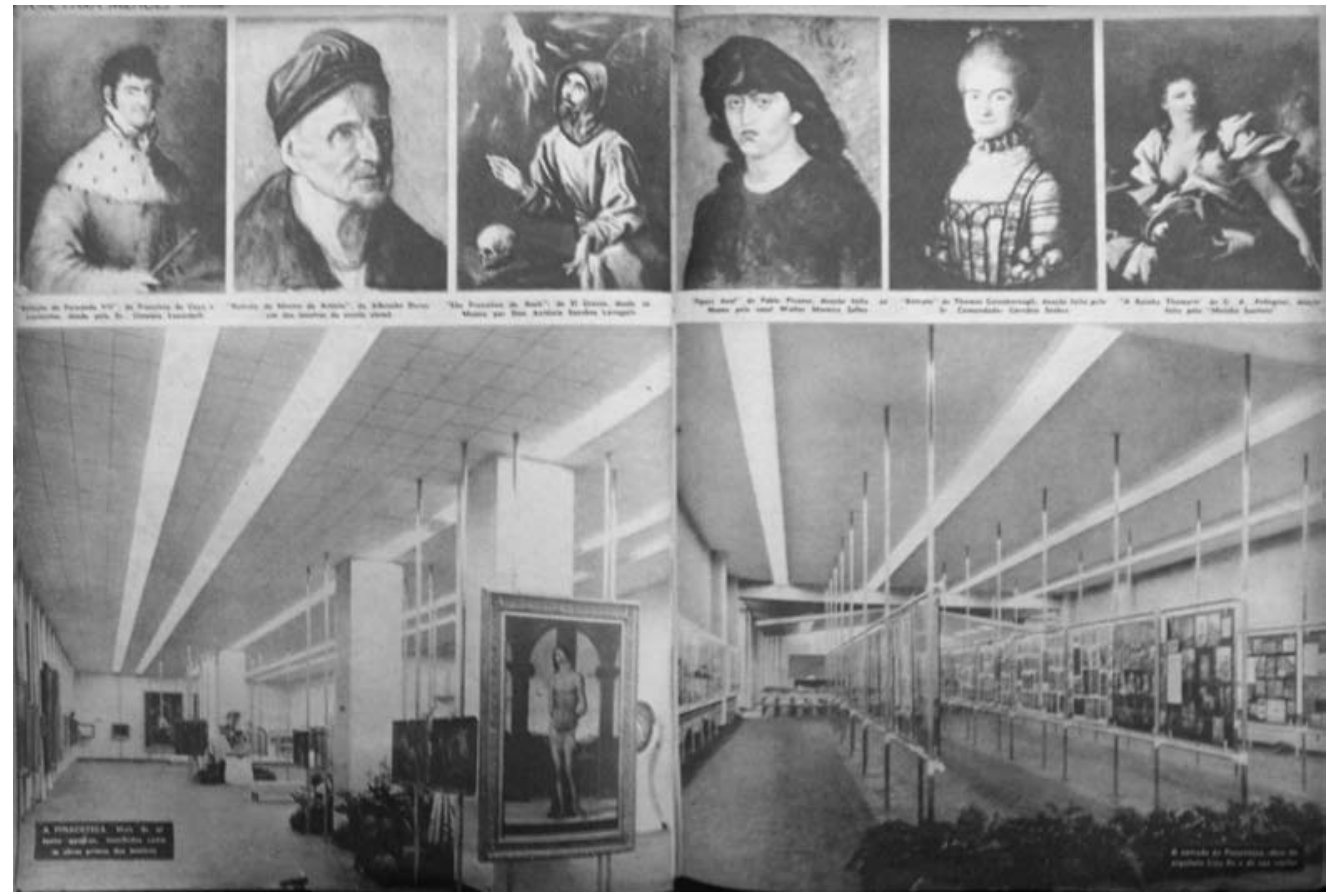

Imagem 66. Fac símile das páginas 56 e 57 da reportagem "Arte para milhões", em O Cruzeiro de 01/11/1947. Fonte: Acervo do MASP.

assuntos pouco difundidos. Desta forma, o museu desassociava-se da idéia de conservação e especialização e adquiria um sentido social novo, o de instruir o público através da classificação elementar e didática. Bardi queria criar um museu dinâmico e encontrou no Brasil o cenário perfeito para seu objetivo.

Eu venho da Europa. Lá, os museus são instalados em edifícios históricos e quando são construídos novos, a tarefa é confiada a ruminadores de velhos estilos arquitetônicos, com a intenção sádica de fazer nascer morto um edifício que deve conservar coisas mortas. Assim, na minha opinião, os americanos serão verdadeiramente os primeiros a compreender a função educativa dos novos museus. $O$ Museu de Arte de São Paulo também será um deles. ${ }^{70}$

Com base em sua experiência européia, Pietro pôs em prática no MASP

70 "MASP - Um museu no país das idéias audazes". Disponível em:

http://www.institutobardi.com.br/bardi/masp/masp2.html. Acesso em: 07 nov. 2007 às 11:30. 


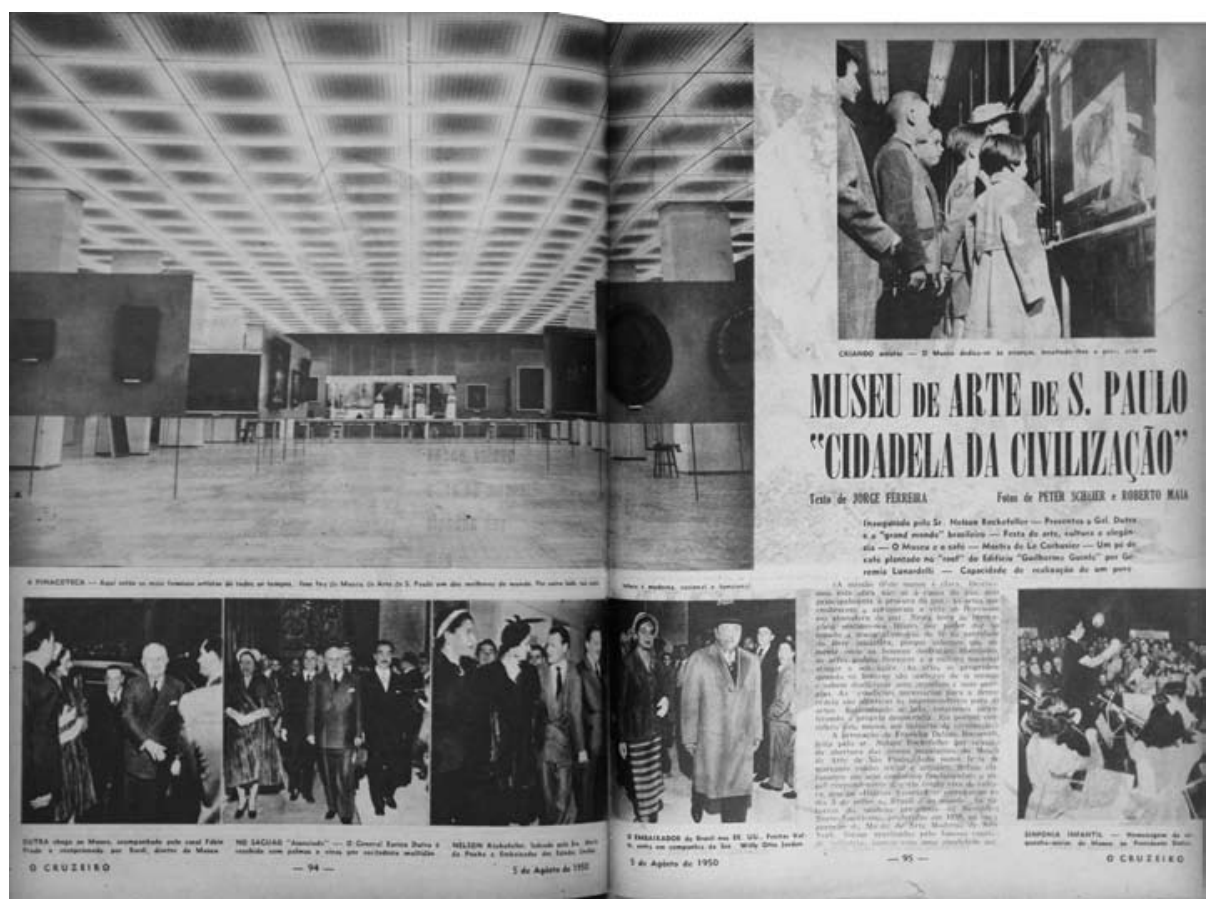

Imagem 67. Fac símile das páginas 94 e 95 da reportagem "Museu de Arte de São Paulo "cidadela da civilização"”, em O Cruzeiro de 05/08/1950. Fonte: Acervo do MASP.

um programa inovador no meio museológico brasileiro. Tornou-se um dinâmico centro de formação, com cursos e ciclos de conferências em diversas áreas. Com o objetivo de torná-lo mais popular e atrair novos públicos, em especial os jovens, Pietro, muitas vezes em conjunto com Lina, criava diversas exposições didáticas sobre história da arte. Em 1950, Lina criou, dentro do MASP, o IAC Instituto de Arte Contemporânea - que promovia cursos de gravura, pintura, desenho industrial, escultura, fotografia, cinema, teatro, dança e moda.

Os inúmeros eventos e cursos que ocorriam no museu eram registrados por vários fotógrafos. Sascha Harnish, German Lorca, Roberto Maia, Nelson Jurno, Jean Manzon, Edgar Peine, Richard Sasso e Ernesto Mandowski são nomes que constam do acervo fotográfico da instituição. Peter Scheier aparece com grande freqüência, em fotos em geral identificadas com seu carimbo no verso, no qual também é possível encontrar diversas anotações de terceiros, 


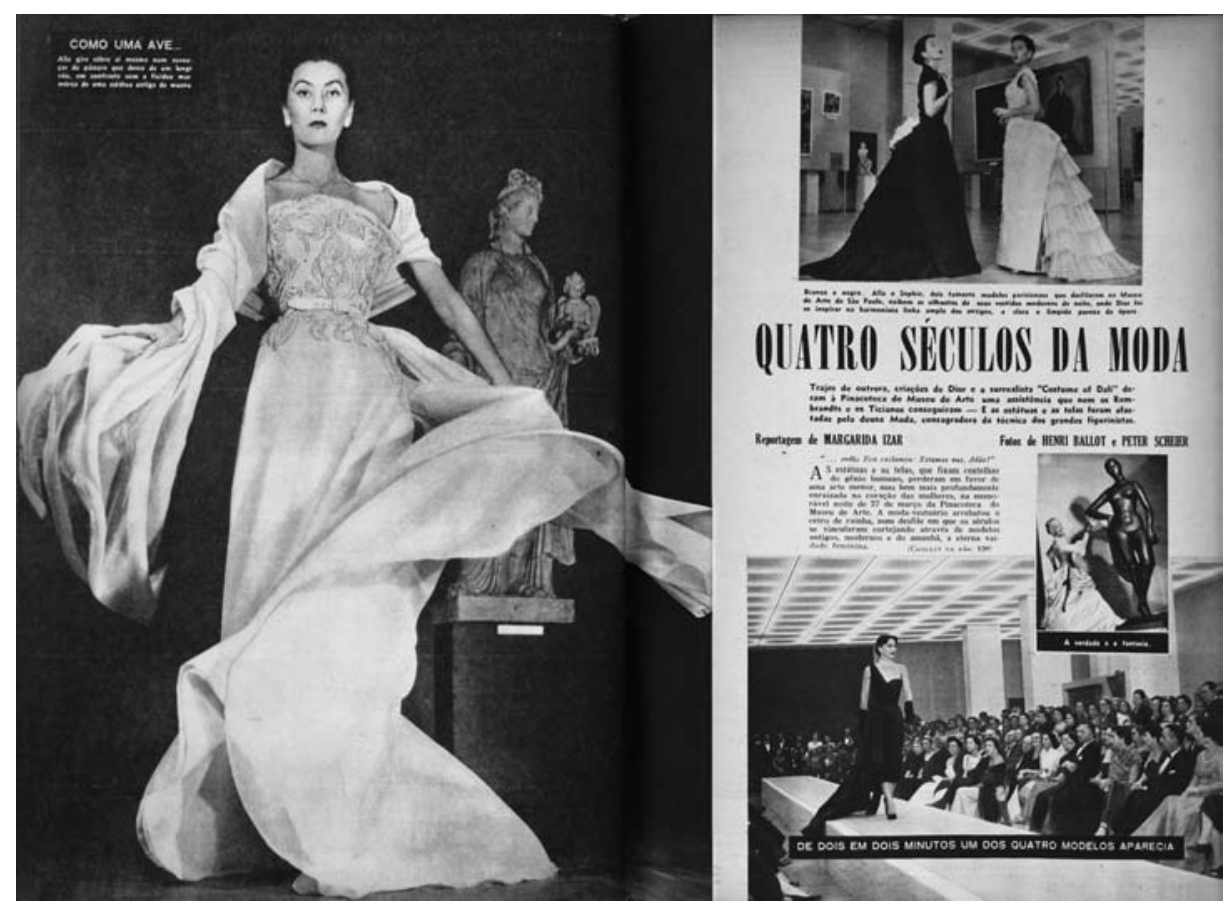

Imagem 68. Fac símile das páginas 114 e 115 da reportagem "Quatro Séculos de moda", em O Cruzeiro de 21/04/1951. Fonte: Acervo do MASP.

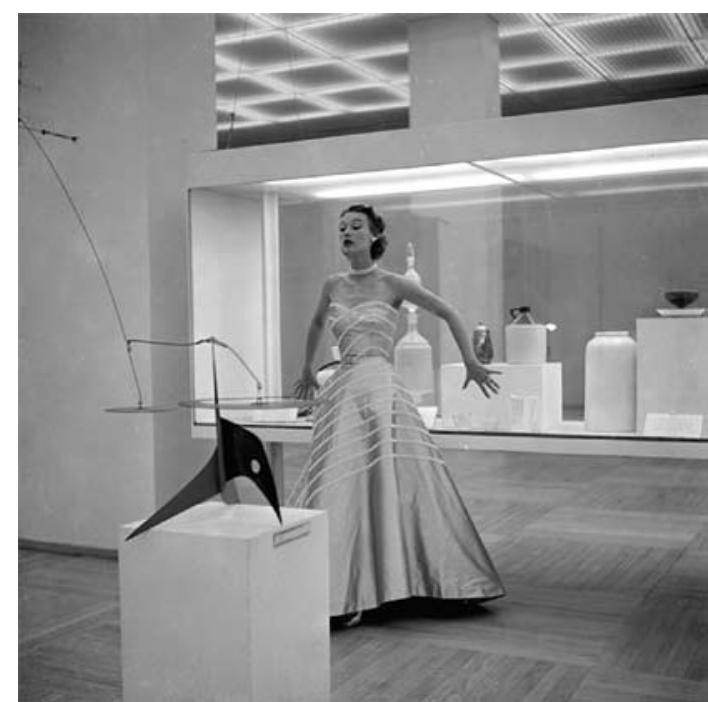

Imagem 69. Desfile da Vogue no MASP, 1951. Vê-se um móbile de Alexander Calder. Autoria: P. Scheier. Fonte: Acervo do AHJB.

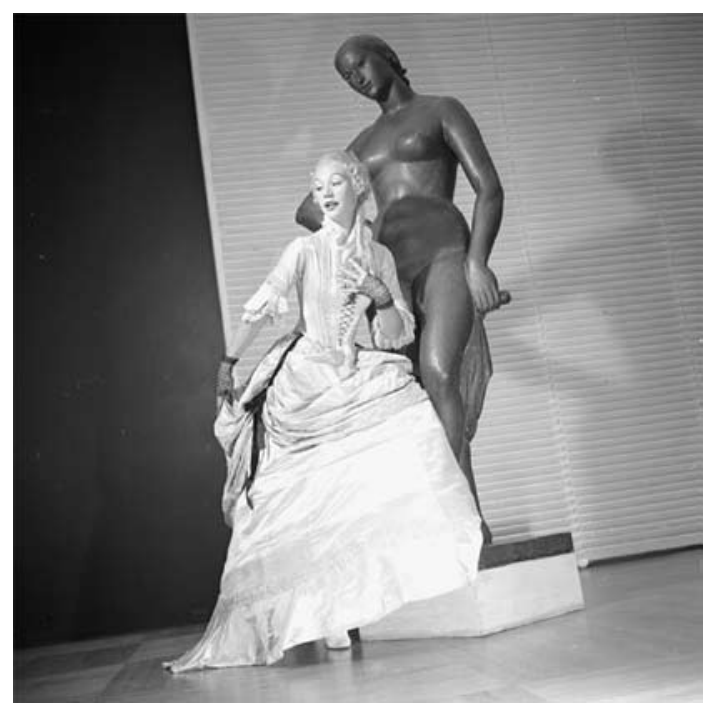

Imagem 70. Desfile da Vogue no MASP, 1951. Autoria: P. Scheier. Fonte: Acervo do AHJB. 


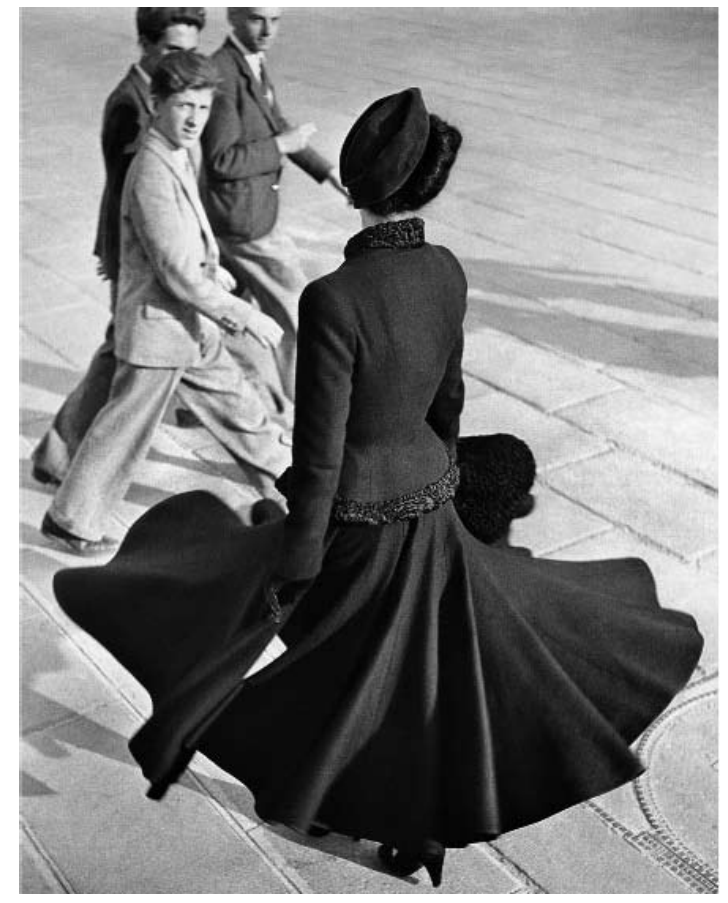

Imagem 71. "The new look of Dior", Place de la Concorde, Paris, agosto 1947. Autoria: Richard Avedon. Fonte: http://www. richardavedon.com/.

muitas vezes bilíngües, e marcações de cortes, indícios de que estas imagens foram difundidas e reproduzidas em publicações, no Brasil e no exterior.

Scheier esteve presente em numerosos eventos sociais. Seu trânsito entre os Diários Associados e o MASP resultou em registros de acontecimentos memoráveis. Além de Assis e Pietro, personalidades como Nelson Rockefeller, o presidente Eurico Gaspar Dutra, Horácio Lafer, Fábio Prado e outros aparecem em fotos de jantares, vernissages, apresentações musicais e desfiles. Esses acontecimentos sociais tinham espaço amplo na revista O Cruzeiro.

Em 01 de novembro de 1947, a revista dedicou seis páginas à inauguração do museu. Constavam imagens dos convidados, dos espaços museográficos e reproduções de quadros (Imagem 65/66). Três anos depois, a revista reservou dez páginas para a festa de inauguração das novas instalações do museu 


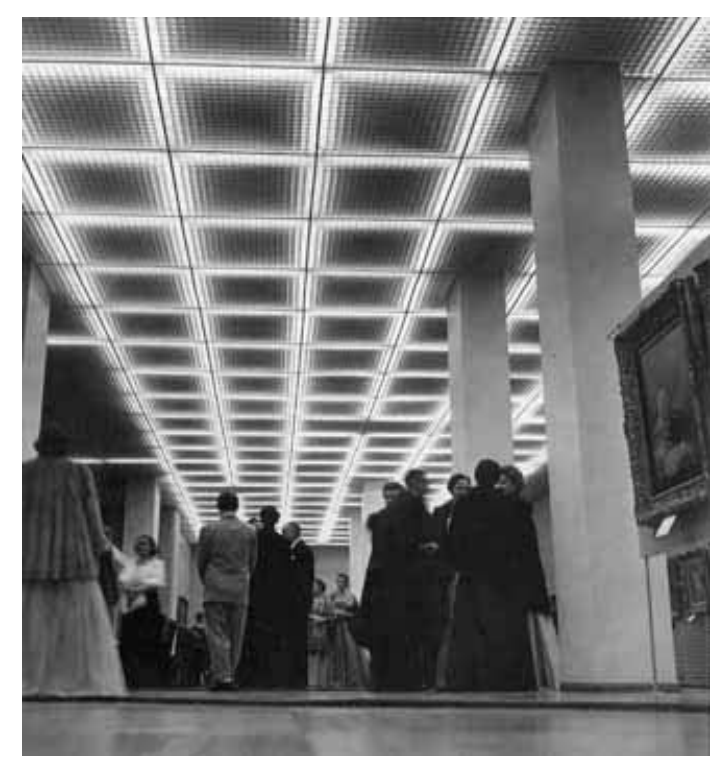

Imagem 72. Inauguração de novas instalações do MASP, 1950. Autoria: P. Scheier. Fonte: Acervo do MASP.

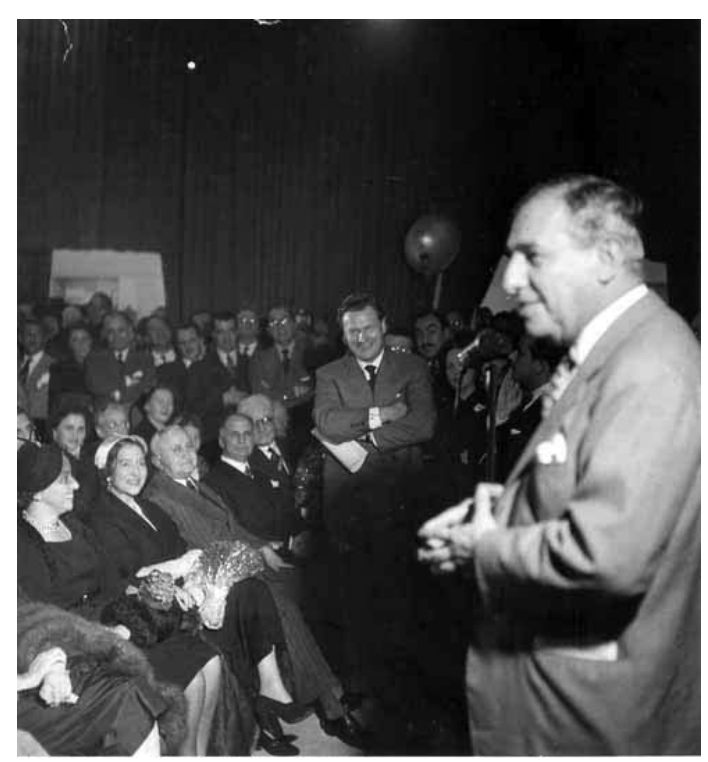

Imagem 73. Inauguração de novas instalações do MASP, 1950. Em primeiro plano, Assis Chateaubriand. Autoria: P. Scheier. Fonte: Acervo do MASP.

(Imagem 67). Nesta segunda vez, Peter Scheier dividiu os créditos com Roberto Maia. Em abril de 1951, o desfile de modas de Dior na passarela montada na pinacoteca preencheu seis páginas (Imagem 68). Nesta ocasião, Scheier fez fotos interessantes que combinavam de forma equilibrada o glamour da alta costura e as obras de arte. O museu não só aparecia como pano de fundo, mas também era elemento ativo e compositivo da cena. As modelos interagiam com estátuas e quadros, reproduzindo suas posições ou brincando com alguma das suas particularidades - como a modelo que, frente a um móbile de Alexander Calder, faz uma pose que ora simula os elementos móveis do objeto, ora lembra uma reação de espanto ou desconfiança em relação ao objeto (Imagem 69). Ou a modelo vestida em traje do século XVIII que, junto à escultura de bronze "Depois do Banho", de Victor Brecheret, direciona seu olhar tal qual a figura, compondo uma diagonal descendente bem marcada (Imagem 70). As fotografias podem ter sido inspiradas na série "The new look of Dior", 


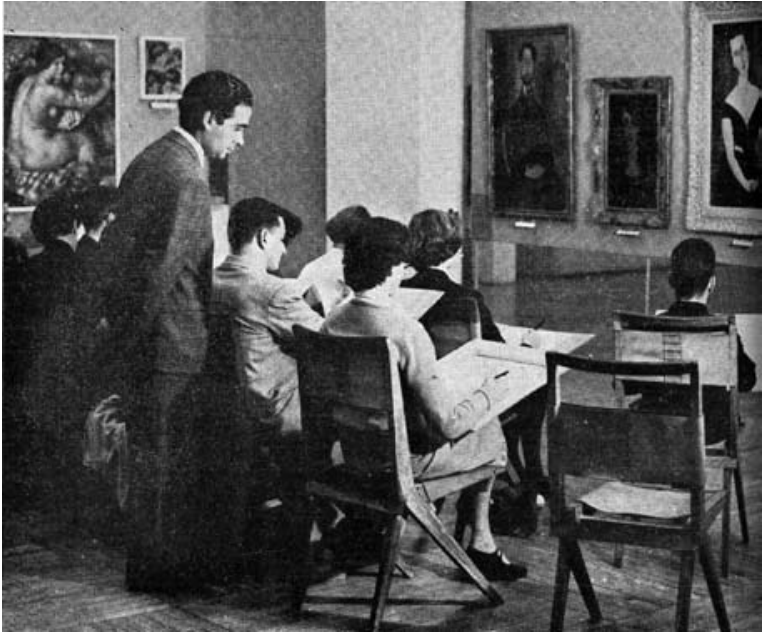

Imagem 74. Aula do curso de desenho de Roberto Sambonet, 1948. Autoria: P. Scheier. Fonte: Habitat, n.11, p.2. Acervo da FAUUSP.

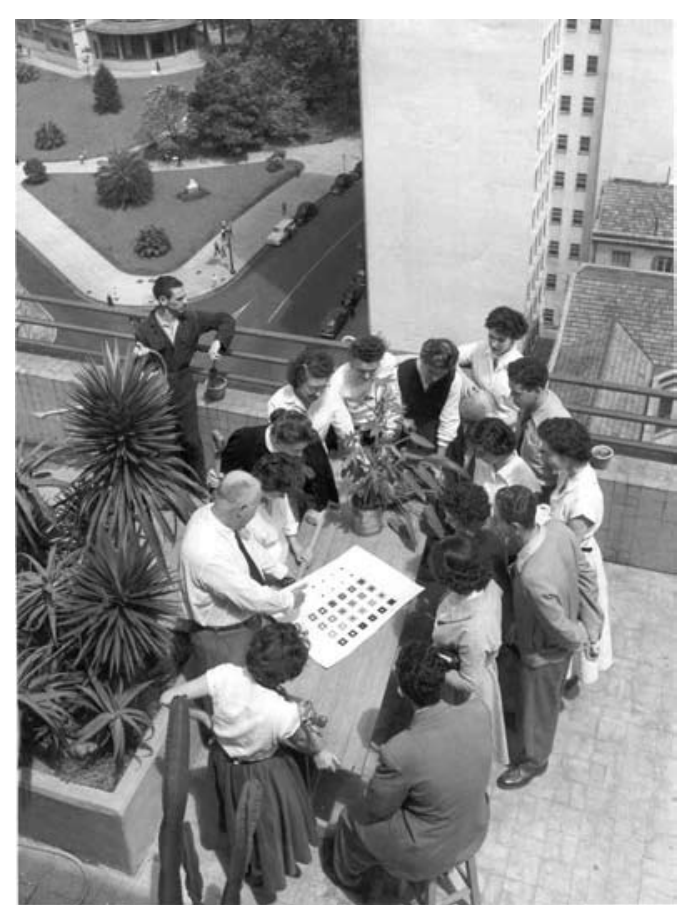

Imagem 75. Curso no MASP, década de 1950. Autoria: P. Scheier. Fonte: Acervo do MASP.

produzidas por Richard Avedon em 1947 (Imagem 71). Avedon revolucionou a foto de moda ao eliminar seu caráter estático e rígido em estúdio e propor mais dinamismo, com as modelos em movimento em ambientes como a rua, o café ou a loja.

Os registros dos eventos sociais eram menos amplos em suas possibilidades de exploração de linguagem, uma vez que o fotógrafo deveria cumprir uma pauta pré-estabelecida. A dinâmica deste tipo de fotografia exigia rapidez e restringia as tomadas a ângulos convencionais. Contudo, Scheier criou algumas imagens dignas de ressalva. Na noite do concerto da Orquestra Sinfônica Brasileira, sob a regência do maestro Eleazar de Carvalho, em 1953, a pinacoteca do MASP foi retratada a partir de um ponto de vista muito baixo (Imagem 72). Ele posicionou a máquina no chão, inclinou-a para cima de forma que dois terços da imagem ficassem preenchidos pelo desenho geométrico do 


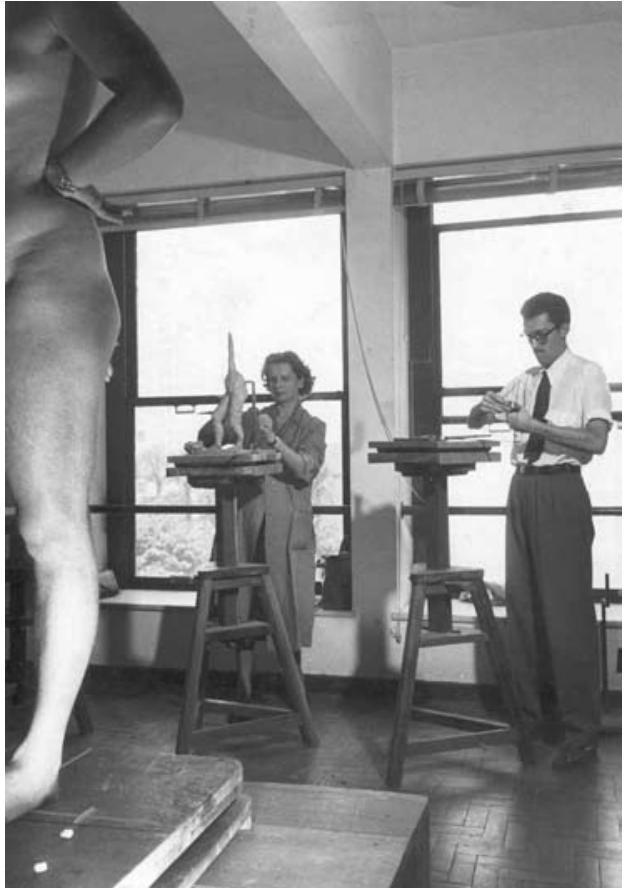

Imagem 76. Curso de escultura de August Zamoyski, no MASP, 1950. Autoria: P. Scheier. Fonte: Acervo do MASP.

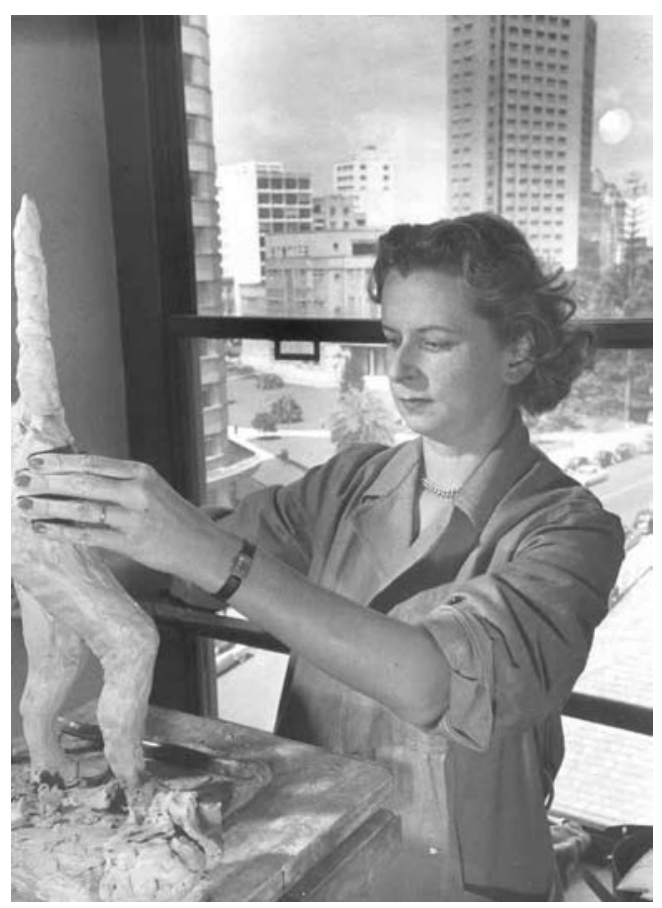

Imagem 77. Curso de escultura de August Zamoyski, no MASP, 1950. Autoria: P. Scheier. Fonte: Acervo do MASP.

forro metálico modulado, enfatizando a perspectiva e aumentando a sensação de profundidade do ambiente. No terço inferior estavam os convidados, reunidos em rodas de conversa ou andando entre as obras de arte.

Durante um discurso de Assis Chateaubriand no auditório do MASP, por ocasião da inauguração das novas instalações do museu, em 1950, Scheier criou uma imagem interessante na qual o foco foi colocado centralmente no segundo plano, na figura de Nelson Rockefeller, em pé em meio à platéia (Imagem 73). Logo atrás dele estava Pietro. À sua direita, sentados, Eurico Gaspar Dutra, Antenor Novais Filho (ministro da Agricultura), Samuel Ribeiro (presidente do Museu de Arte), Renata da Silva Prado e Yolanda Penteado. Em primeiro plano e no canto direito, Assis apareceu desfocado, porém perfeitamente identificável.

Embora as imagens de eventos sociais sejam inúmeras e de grande 


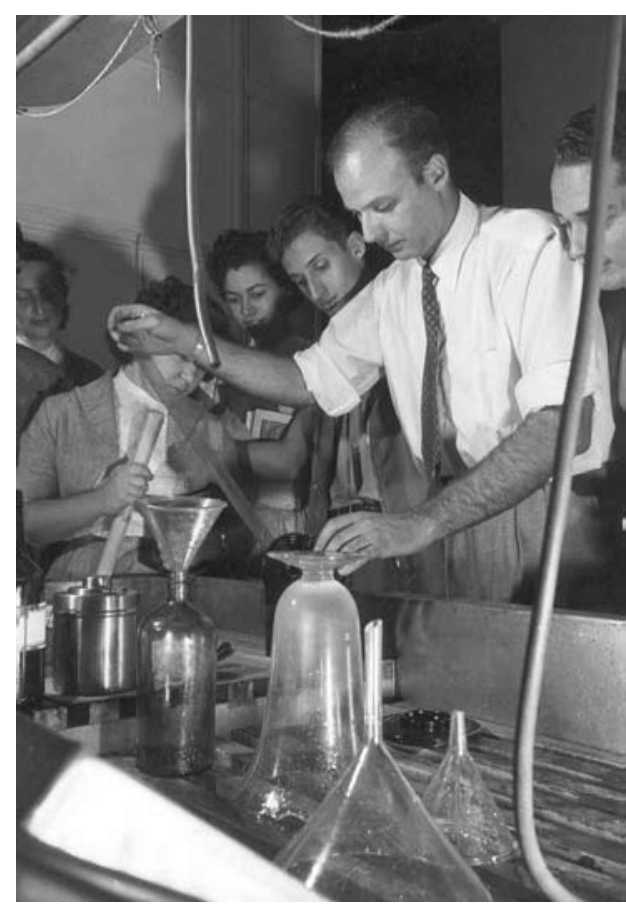

Imagem 78. Curso de fotografia Guillermo Marcone no MASP, 1953. Autoria: P. Scheier. Fonte: Acervo do MASP.

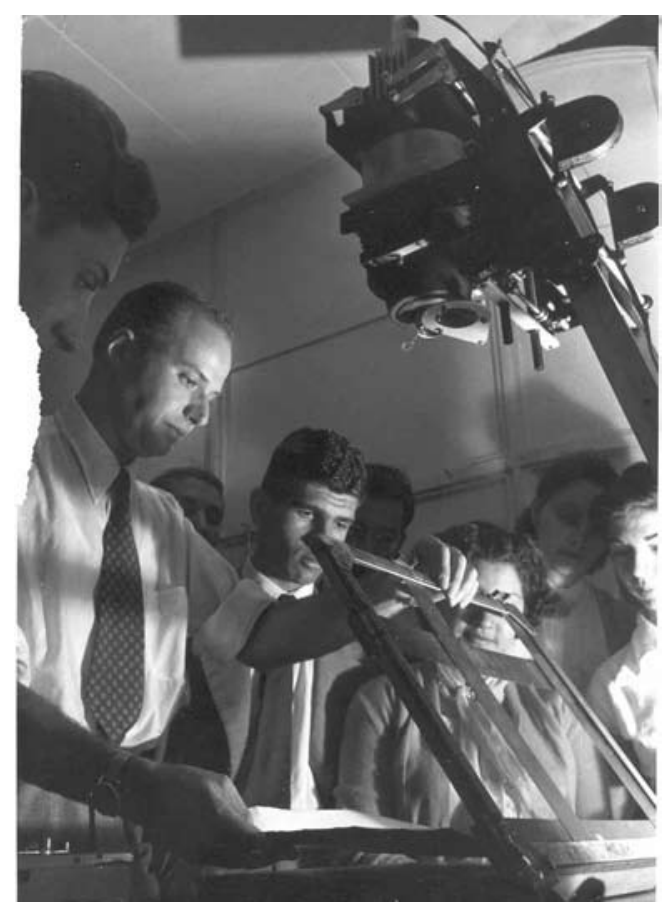

Imagem 79. Curso de fotografia Guillermo Marcone no MASP, 1953. Autoria: P. Scheier. Fonte: Acervo do MASP.

valor documental, os registros das atividades do IAC e dos espaços do museu compõem o conjunto mais interessante do trabalho do fotógrafo dentro do MASP. Neles são perceptíveis a liberdade e o cuidado não tão desfrutados no registro fotojornalístico dos eventos. Assim, são imagens mais expressivas que se diferenciam dos retratos posados dos eventos e que trazem em si as características marcantes de seu trabalho, como o uso das diagonais, de obliqüidade e de flash direto - resultando em uma luz incidente forte e em sombras bem delimitadas.

Uma postura de resguardo pode ser sentida em algumas situações, como aulas de desenho e pintura, nas quais o fotógrafo parecia não se sentir completamente à vontade em interromper e, portanto, procurava não ser notado. São séries nas quais ele se colocava no fundo da sala, de onde fazia algumas tomadas gerais nas quais as pessoas eram retratadas de costas. Um 


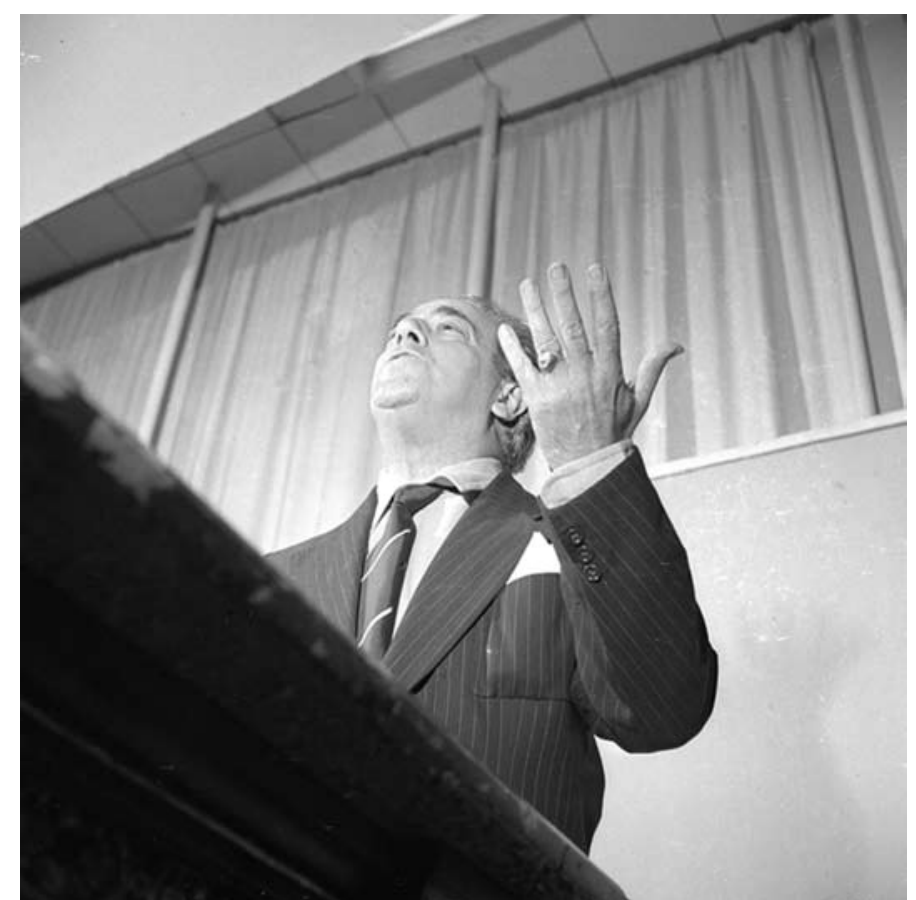

Imagem 80. Villa Lobos no MASP, julho de 1949. Autoria: P. Scheier. Fonte: Acervo do AHJB.

exemplo é uma foto feita em 1948, durante uma aula de desenho de observação do curso ministrado pelo artista Roberto Sambonet: Scheier se colocou a uma certa distância do grupo - cerca de dez alunos, sentados nas cadeiras desenhadas por Lina Bo Bardi, com pranchetas sobre o colo (Imagem 74). Os alunos foram retratados de costas, enquanto observavam e reproduziam os quadros de Amedeo Modigliani (da esquerda para a direita: "Retrato de Leopoldo Zborowski”, “Renée” e "Madame G. Van Muyden”). Em outra ocasião, Scheier registrou, a partir de uma das janelas, o grupo de estudantes reunido no terraço (Imagem 75). Ninguém aparentemente notou sua presença, uma vez que todos prestavam atenção nas palavras do professor - nem mesmo o jardineiro que, displicentemente, regava as plantas no jardim. 


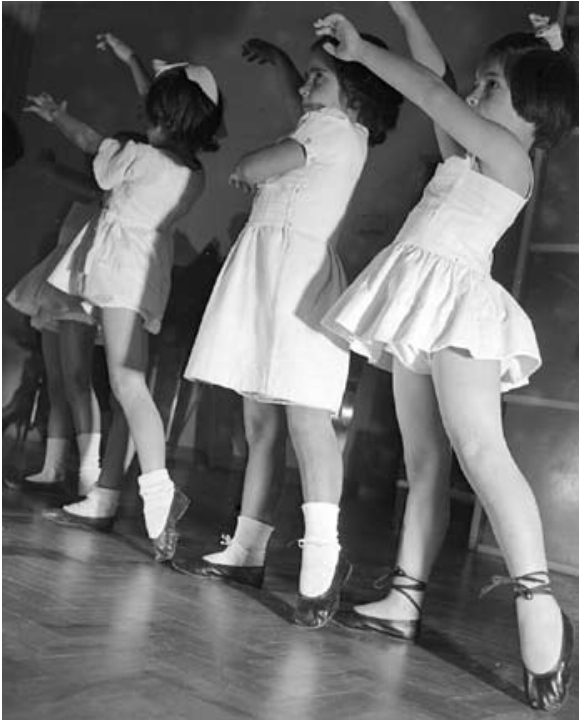

Imagem 81. Curso de ballet infantil no MASP, 1950. Autoria: P. Scheier. Fonte: Acervo do AHJB.

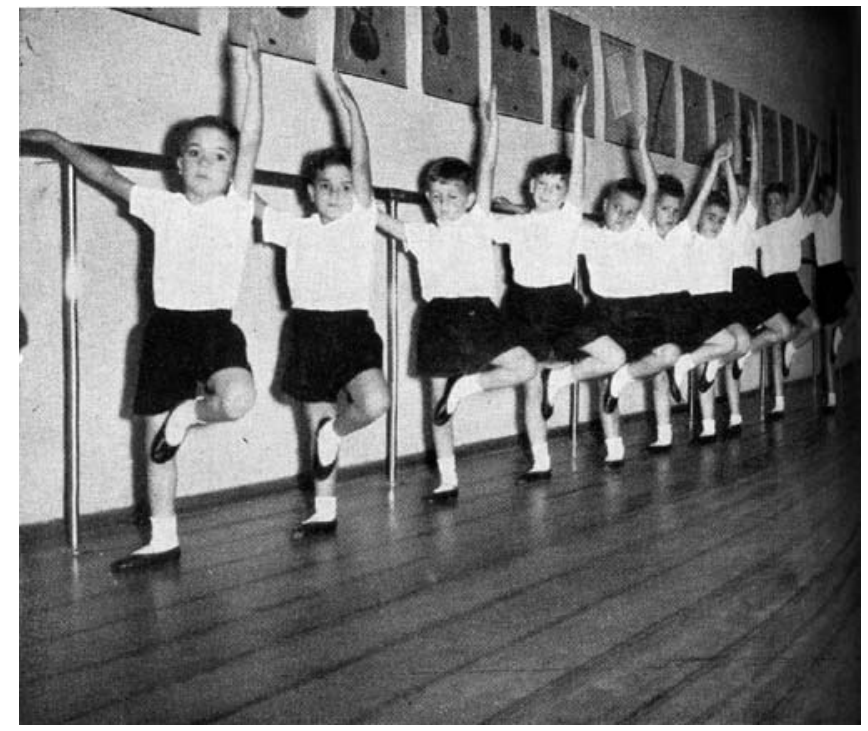

Imagem 82. Curso de ballet infantil no MASP, 1950. Autoria: P. Scheier. Fonte: Habitat, n.11, p.2. Acervo da FAUUSP.

Porém, na maior parte dos registros do IAC é provável que Scheier tivesse liberdade para conversar com os alunos e professores, pedir-lhes autorização para fotografar e solicitar-Ihes uma pose, resultando em fotos mais soltas e mais características, que guardam algo que o fotógrafo prezava muito: sua proximidade das pessoas. Carboncini ${ }^{71}$ lembra a simpatia de Scheier pelas pessoas que aparecem em suas fotos.

No curso de escultura do professor polonês August Zamoyski (1950), Scheier posicionou na lateral esquerda do fotograma a modelo, enquadrando apenas a perna, quadril e braço esquerdos, ocultando a cabeça, as genitais, os seios e a porção direita do corpo (Imagem 76). Atrás dois alunos executavam seus trabalhos. Em outra foto desta mesma série, o fotógrafo se aproximou da aluna para registrar em detalhes sua atividade e a escultura já parcialmente executada (Imagem 77). Durante uma aula prática de laboratório ${ }^{72}$ do curso de

71 Anna Carboncini, coordenadora da coleção Masp-Pirelli de fotografia, em depoimento à autora, em 24 ago 2006.

72 O laboratório do MASP foi projetado e instalado por Thomaz Farkas em 1950, por ocasião da reforma das instalações do museu. 


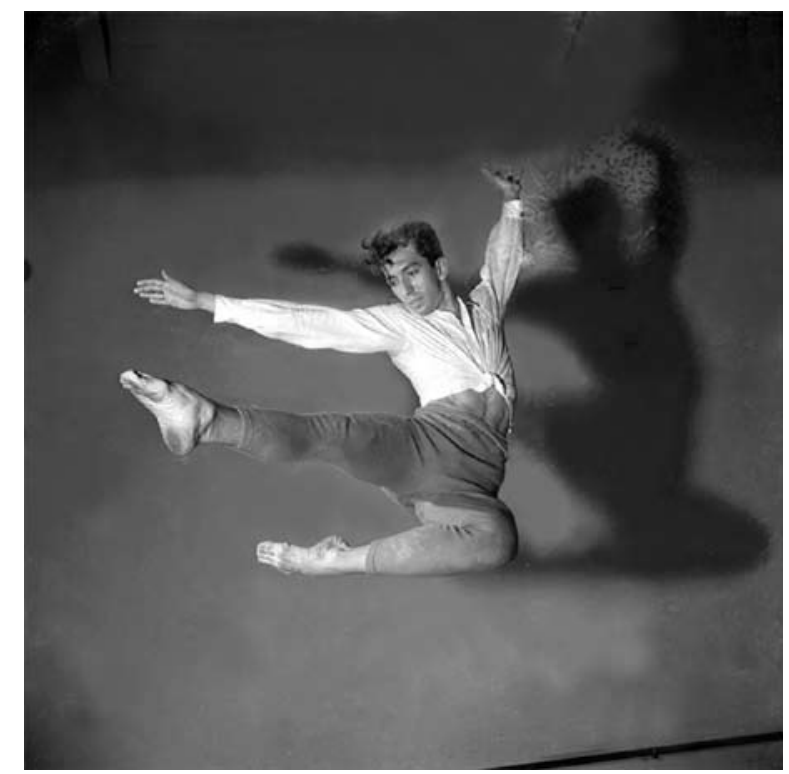

Imagem 83. Curso de dança contemporânea no MASP, 1950. Autoria: P. Scheier. Fonte: Acervo do AHJB.

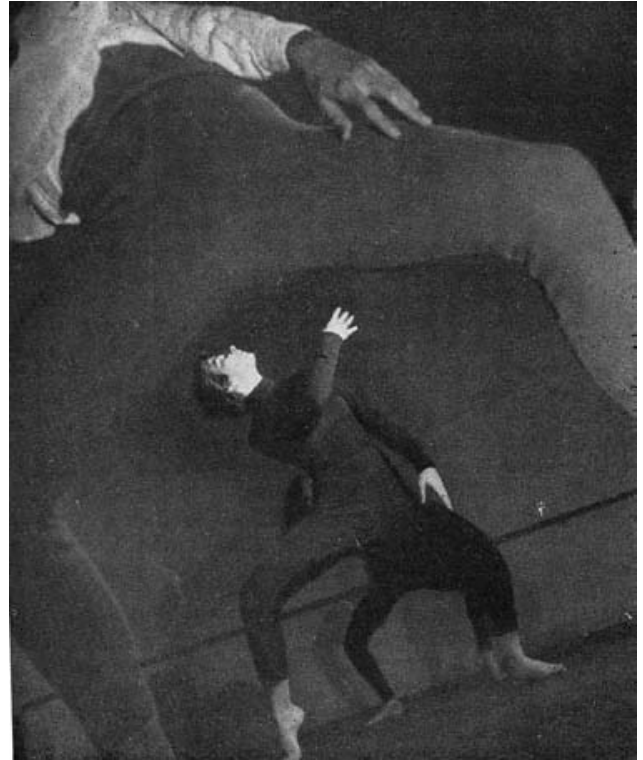

Imagem 84. Curso de dança contemporânea no MASP, 1950. Autoria: P. Scheier. Fonte: Habitat, n.09, p.54. Acervo da FAUUSP.

fotografia do engenheiro Guillermo Marcone (1953), Scheier esteve muito perto dos alunos. Em três imagens encontradas no acervo do museu, ele documentou o ato de enrolar o filme na espiral metálica e colocá-la no tanque de revelação (Imagem 78) e a colocação do papel fotográfico no marginador e ampliador (Imagem 79). $O$ uso de flash indica que se tratava de fotos combinadas ou apenas uma demonstração dos procedimentos, pois, para a correta revelação e ampliação, o laboratório deveria estar escuro.

Peter Scheier buscava composições inusitadas, com ângulos não-usuais. Por ocasião de uma palestra de Heitor Villa-Lobos no museu, Scheier sentouse no chão, encostado na lateral da mesa de madeira, e inclinou a máquina para cima (Imagem 80). Assim, o compositor foi retratado de modo criativo, de baixo para cima, espontaneamente enquanto proferia suas palavras. $\mathrm{O}$ tampo da mesa formou um campo escuro à esquerda, cuja borda compôs um desenho com as linhas do forro e do caixilho. No centro destes elementos gráficos, estava 


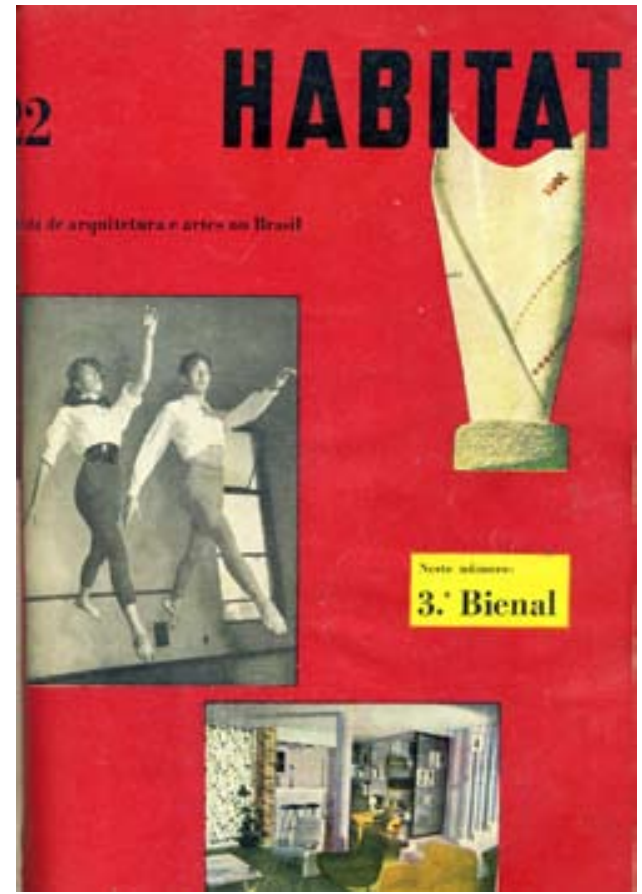

Imagem 85. Capa da revista Habitat n.22, de maio de 1955, com foto de Peter Scheier. Fonte: Acervo da FAUUSP.

a figura de Villa-Lobos.

Essa característica da obliqüidade e do ângulo ascendente foi bastante explorada nas imagens da escola de dança. Na aula de ballet infantil, Scheier posicionou as meninas em uma linha diagonal marcada pelos seus pés e acentuada pela posição dos braços, que apontavam para o canto superior esquerdo (Imagem 81). Arranjo semelhante encontra-se numa foto na qual a barra de apoio desenha uma linha diagonal que atravessa toda a imagem, acentuada pelas tábuas do piso em assoalho de madeira, pelas imagens coladas sobre a parede e pelos garotos, em movimento sincronizado (Imagem 82).

A dança contemporânea, por suas características de maior liberdade e despojamento nos movimentos, requereu outras posturas do fotógrafo. A 
seqüência na qual os movimentos foram congelados no ar chama a atenção pela precisão, pelos ângulos vanguardistas e pela sensação de proximidade que transmitem - como na imagem na qual o corpo isolado do bailarino, executando um movimento completamente solto no ar, alinha-se com sua sombra, desenhada em contornos precisos e dramatizada em função do flash direto (Imagem 83). Scheier registrou a performance do bailarino com as alunas, combinando seus saltos com passos sincronizados, sempre buscando ângulos diferenciados, como a dançarina enquadrada entre as pernas do bailarino, em primeiro plano (Imagem 84).

\subsubsection{A revista Habitat}

Esse registro das atividades do museu resultou naturalmente na colaboração de Peter Scheier na revista Habitat. Seu nome fora listado essencialmente na primeira fase ${ }^{73}$ do periódico - das quinze edições dirigidas pelo casal Bardi, Scheier apenas não apareceu no número 07 (1952). Depois do afastamento de Pietro e Lina da direção da revista, em 1954, houve uma mudança editorial que omitia os créditos fotógrafos, inviabilizando o levantamento total da participação do fotógrafo. Seu nome ainda apareceu nas edições 20 (jan-fev 1955) e 22 (maijun 1955), sendo que na capa desta última fora utilizada uma foto sua do curso de dança do museu (Imagem 85).

A revista Habitat foi um periódico sobre cultura contemporânea, dedicada à arquitetura, pintura, escultura, desenho industrial, artes gráficas e artes visuais. No prefácio da primeira edição encontramos definições claras sobre a postura e os valores que conduziriam a publicação. Segundo ele, embora ostentando uma

73 A primeira fase da revista Habitat compreende as quinze primeiras edições, período desde sua fundação, em outubro de 1950, até a saída de Lina e Pietro da redação, em abril de 1954. Habitat foi publicada de outubro de 1950 a dezembro de 1965, totalizando 84 números, cuja periodicidade variou entre trimestral, bimestral e mensal. 
produção artística rica, o Brasil não apresentava documentação e informação adequadas, e sua História das Artes permanecia inédita. Ao mesmo tempo, o desejo de conhecimento aumentava, com a consolidação da arquitetura moderna, a abertura de museus, a valorização de pintores nacionais, da música, teatro e cinema. Neste quadro, a pretensão da Habitat era traçar um roteiro e um quadro das atividades culturais. O nome do periódico, que significa "ambiente, dignidade, conveniência, moralidade de vida, e portanto espiritualidade e cultura", foi escolhido por estar "intimamente ligada à arquitetura, a qual damos um valor e uma interpretação não apenas artística, mas uma função artisticamente social" ${ }^{74}$.

$\mathrm{Na}$ sua primeira fase, os valores da revista refletiam os valores e a personalidade de Lina, sua diretora da edição 1 a 9 e mais tarde, juntamente com Pietro, nas de número 14 e 15. A revista julgava importante o essencialmente brasileiro, o vernacular, as artes populares, assim como o fazia Lina. Estrangeira, a arquiteta compreendeu a cultura brasileira através de um olhar antropológico, particularmente atento para a convergência entre vanguarda estética e tradição popular. Teve o olhar sempre sensível à abundante arte popular brasileira, que considerava "matéria-prima de uma contribuição fecunda à modernidade" ${ }^{75}$. A revista compartilhava a crença na missão da arte como agente transformador do mundo e o desenvolvimento como orientação ideológica.

O Museu de Arte, junto com a arquitetura brasileira, era o grande tema da revista. Fundada três anos após o museu, Habitat no princípio ocupou-se da promoção da instituição, apresentando, em casos extremos (como no número 1) o caráter de uma publicação oficial. Através da divulgação de aquisições e de eventos (exposições, cursos, consertos, desfiles), o periódico supria $74 \quad$ Prefácio. Habitat, São Paulo, n.1, p.1, out-dez 1950.

75 http://www.itaucultural.org.br/aplicexternas/enciclopedia_ic/index. $\mathrm{cfm}$ ?fuseaction $=$ artistas_biografia\&cd_verbete $=1481 \& \mathrm{~cd}$ _item $=1 \& \mathrm{~cd}$ _idioma $=28555$. Acesso em: 07 nov. 2007 às 11:40. 


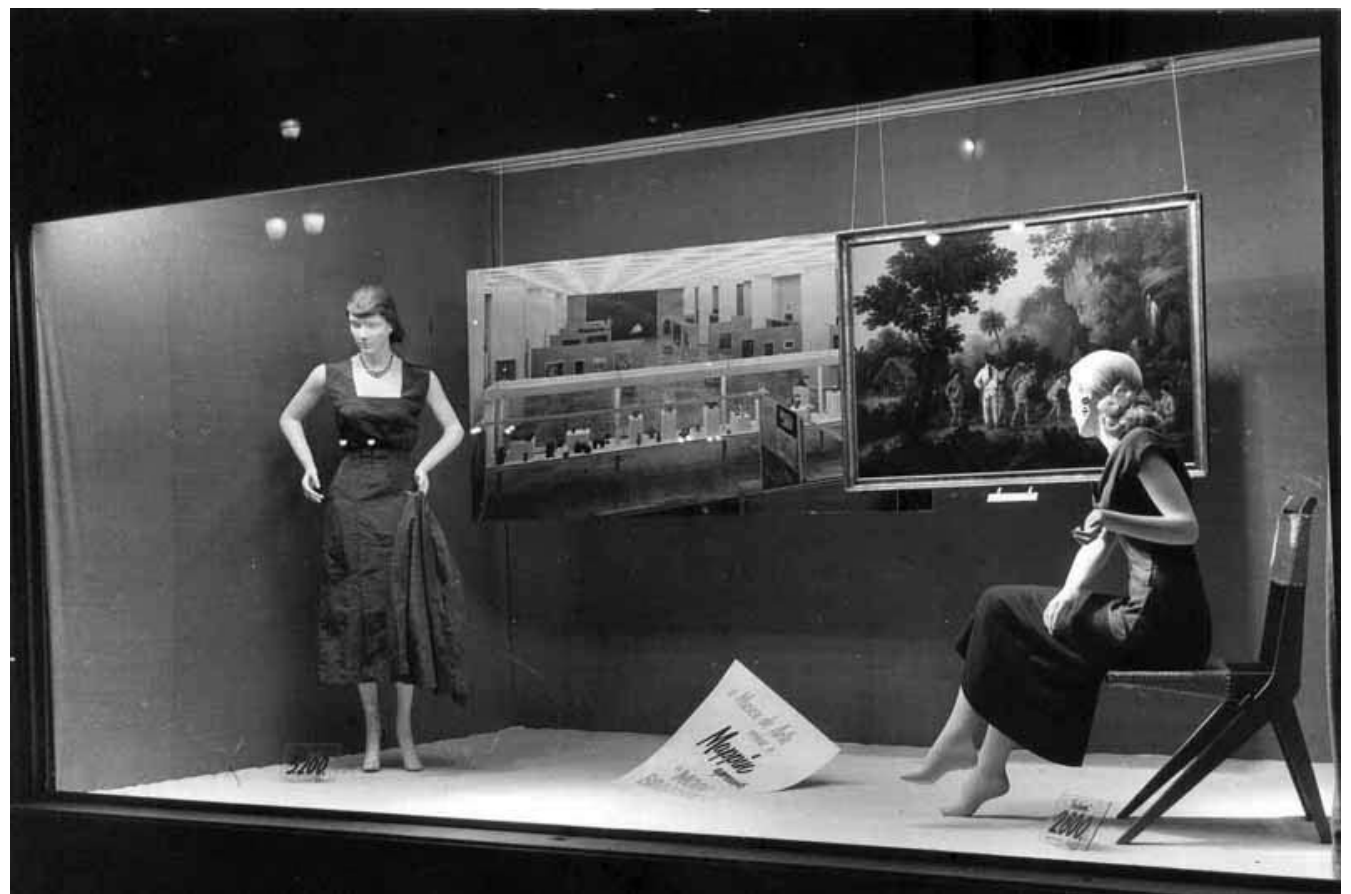

Imagem 86. Vitrine da loja Mappin, 1953. Autoria: P. Scheier. Fonte: Habitat, n.10, p.77. Acervo da FAUUSP.

a necessidade de expressar por escrito as decisões e ações do museu, bem como legitimar o conceito e projeto de museu moderno proposto, no qual este era entendido como uma instância educativa de massas e um mecanismo de democratização do acesso a bens culturais. "É neste novo sentido social que se constitui o museu de Arte de São Paulo, que se dirige à massa não informada nem intelectual, nem preparada." 76

Em Habitat eram publicadas fotografias de vários fotógrafos. Apesar da freqüência constante de certos profissionais, não havia uma equipe fixa que trabalhava para a revista. Com exceção da primeira edição, os créditos nunca foram específicos: os nomes dos fotógrafos eram listados no sumário, junto aos dados técnicos da revista, sem relação com suas fotos. Além de Peter Scheier, apareciam os nomes de Fernando Albuquerque, Sacha Harnish, Alice Brill, Hugo

76 BARDI, Lina Bo. Função social dos museus. Habitat, São Paulo, n.1, p.17, out-dez 1950. 


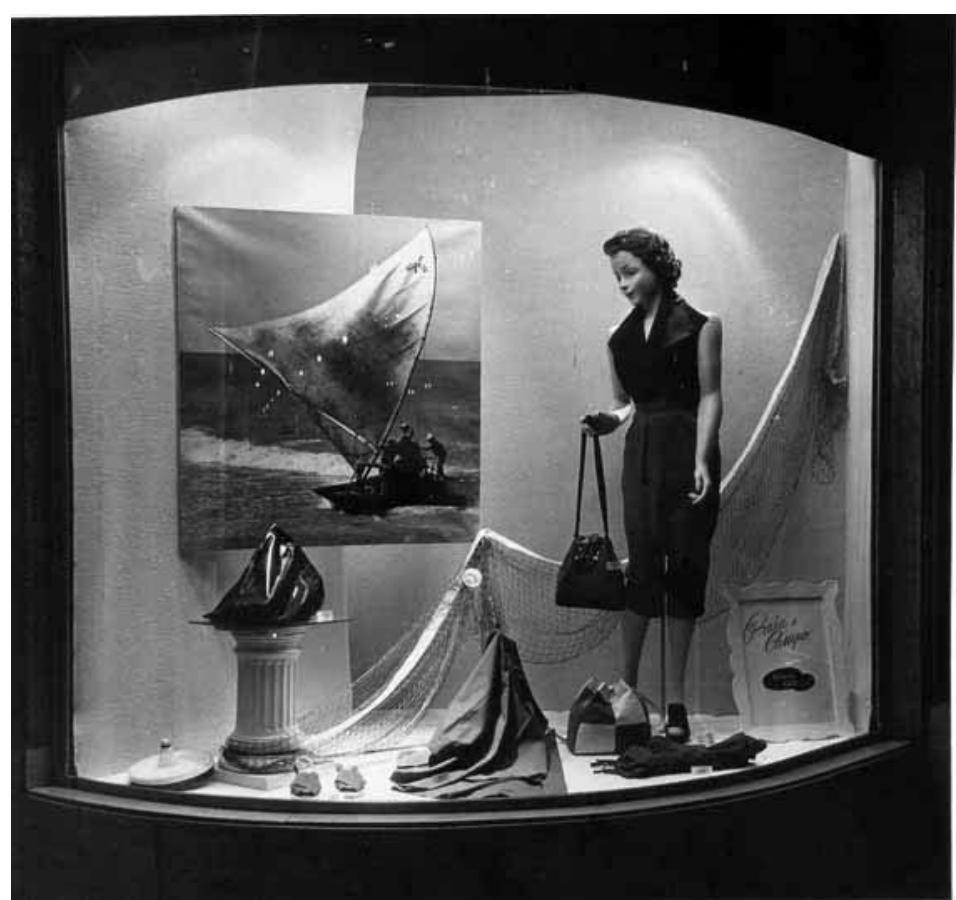

Imagem 87. Vitrine da loja Mappin, 1953. Autoria: P. Scheier. Fonte: Habitat, n.10, p.77. Acervo da FAUUSP.

Zanella, José Moscardi, Roberto Maia, Hans Günter Flieg, Boer, Leon Liberman, Ernesto Mandowsky, Vasari, Zygmunt Haar (Haar Studios), Landau, Aertsens Michel, Foto Jerry, Pierre Verger, Chico Vizzoni, Marcel Gautherot, Freddy Kleemann, Foto Curt, Carlos, Alexandre Smilg, José Medeiros, Henri Ballot, German Lorca e Aurélio Becherini. Na primeira fase, era freqüente a referência aos Diários Associados nos créditos, o que ilustra a relação estreita entre aquela empresa, o museu e a revista.

Peter Scheier contribuía em geral com as fotografias dos eventos e dos cursos do museu. Várias fotografias encontradas no arquivo fotográfico do MASP foram publicadas na revista. Hossaka lembra que Scheier também fazia reproduções das obras de arte e fotografia de arquitetura. 
Era o Scheier que predominantemente fotografava, documentava as obras de arte, para publicação, livros de arte, solicitação de publicações estrangeiras, era tudo em preto e branco. Naquela época só fazíamos trabalho em preto e branco. $\mathrm{E}$ os eventos que tinham no museu, os cursos, os eventos importantes, conferências, gente importante que vinha fazer conferência, e, sobretudo, o pessoal da música, ele fotografou muito isso aí. (...) E na minha área, que era exatamente da documentação do acervo, reprodução de imagem, era com a gente que o Scheier tratava. Quer dizer, o Bardi solicitava e eu pedia para o Scheier. (...) Fotografava todas as coisas de arquitetura que o Bardi pedia, porque naquele tempo a revista Habitat também divulgava muita arquitetura. ${ }^{77}$

Além das atividades dos cursos e dos eventos, Scheier publicou três fotografias de vitrines compostas por Roberto Sambonet, numa parceria entre o museu e a loja de departamentos Mappin para o lançamento da Moda Brasileira. As fotos-sem a identificação do autor - acompanhavam a reportagem "Problemas de vitrina" ${ }^{78}$. Eram três vitrines temáticas. Na maior imagem, lê-se num cartaz: "O Museu de Arte criou e Mappin apresenta a moda brasileira" (Imagem 86). Tratase da vitrine ambientada no MASP, composta por dois manequins femininos, estando um deles sentado numa cadeira articulada desenhada por Lina Bo Bardi para o museu. Ao fundo foram colocadas duas imagens: a da esquerda é uma ampliação de uma vista geral da pinacoteca do museu feita pelo próprio Scheier, na qual se vê, em primeiro plano, a "vitrine das formas". À direita estava a tela "Índios Atravessando um Riacho", do francês Jean-Baptiste Debret ${ }^{79}$, pertencente ao acervo do museu. Na vitrine da praia e campo, entre todos os elementos foi colocada uma fotografia da série de jangadas de Fernando Albuquerque, que fora exposta no museu no ano anterior ${ }^{80}$ (Imagem 87).

$77 \quad$ Luiz Hossaka, curador-chefe do MASP, em entrevista à autora em 10 ago 2006.

78 A.C. Problemas de vitrina. Habitat, São Paulo, n. 10, p.77-78, jan-mar 1953.

79 Em janeiro de 2008, o pesquisador Pedro Corrêa do Lago contestou a autoria do quadro, que seria do italiano Augustin Brunias. Contudo, essa questão não tem relevo dentro dos propósitos deste trabalho.

80 Sobre o assunto, ver: MARTINS, Frans. A jangada segundo Albuquerque. Habitat, São Paulo, n. 8, p.50-57, jul-set 1952. 


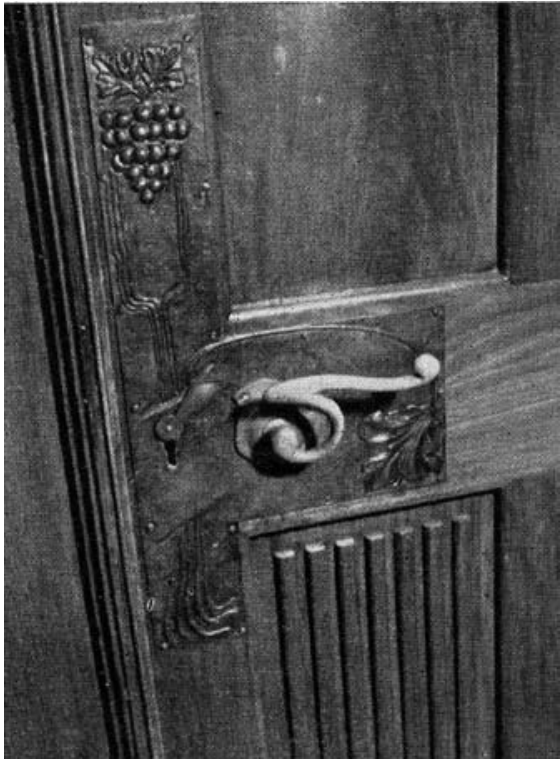

Imagem 88. Fechadura da Vila Penteado. Autoria: P. Scheier. Fonte: Habitat, n.10, p.10. Acervo da FAUUSP.

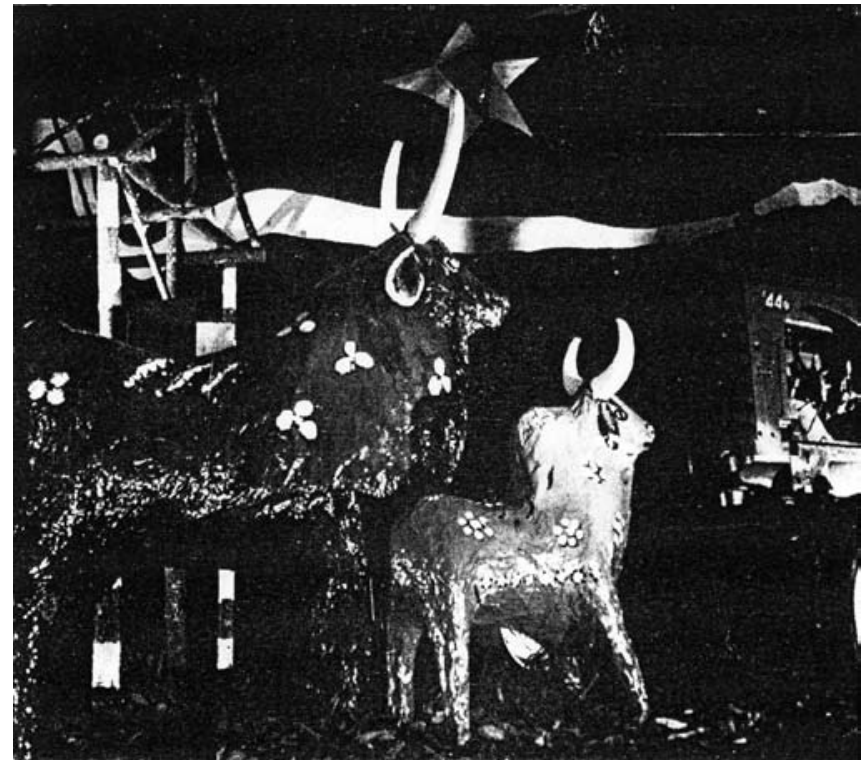

Imagem 89. Vitrine da loja de automóveis da Studebaker, na Avenida Ipiranga. Autoria: P. Scheier. Fonte: Habitat, n.03, p.77. Acervo da FAUUSP.

As fotografias que Peter Scheier fez da Vila Penteado ${ }^{81}$ ilustraram a reportagem "São Paulo e o "art nouveau”", de Flávio Motta82. São vinte fotos, marcadas pelos ângulos bem fechados, de detalhes da residência: porta em madeira, lampadário, arco de ferro batido no jardim, lareiras, pinturas nas paredes, baixos-relevos, entalhes, corrimãos, forros, lustres, escadas e fechaduras (Imagem 88). Esta documentação estava perfeitamente de acordo com a arquitetura fotografada: o art nouveau caracterizava-se de fato pelas formas sinuosas, curvilíneas, orgânicas e assimétricas inspiradas em folhagens, flores e animais, presentes nos detalhes arquitetônicos.

Peter Scheier teve três menções específicas na revista. Na seção "Fotografia" da edição 3, consta uma foto da vitrine de Natal da loja de automóveis da empresa americana Studebaker, na Avenida Ipiranga (Imagem 89). Na mesma

$81 \quad$ Projetado pelo arquiteto Carlos Ekman em 1902, o edifício hoje abriga o curso de pósgraduação da FAUUSP, na Rua Maranhão, 88.

82 MOTTA, Flávio. São Paulo e o "art nouveau". Habitat, São Paulo, n. 10, p.3-18, jan-mar 1953. 


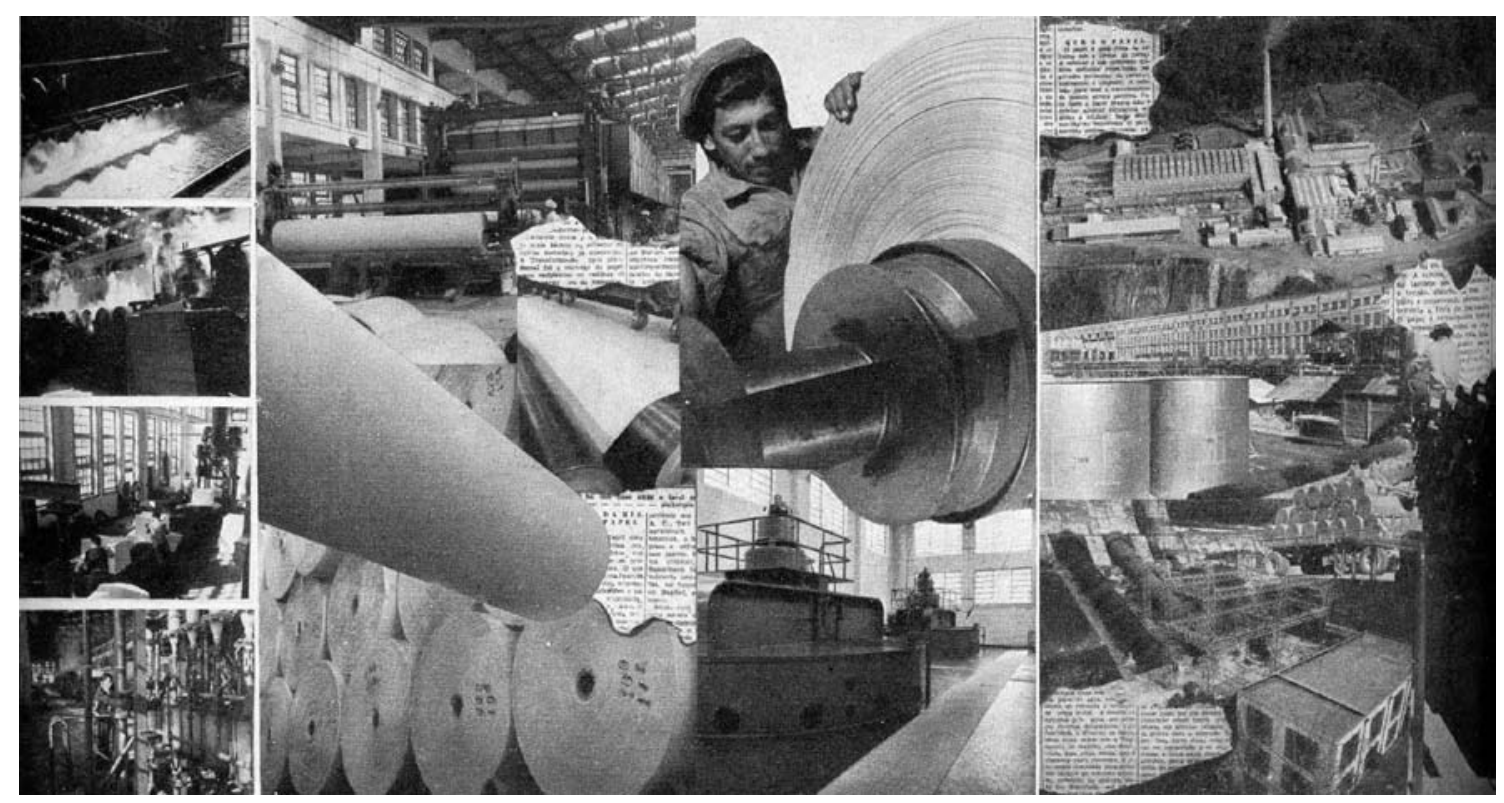

Imagem 90. Detalhe do painel fotográfico produzido por Scheier e Rado para a Klabin. Fonte: Habitat, n.09, p.62. Acervo da FAUUSP.

página havia outra foto, de Roberto Maia, e um pequeno texto que discorria sobre o ato de fotografar.

Fotografar significa ver, reter a lembrança de algo que descobrimos. Em toda parte é possível encontrar algo que valha a pena ser conservado. Mas isto depende da sensibilidade de quem tem um objetivo à disposição, depende do grau de educação visual e da capacidade inventiva. $^{83}$

Na edição 9, também na seção "Fotografia", foi publicado um painel fotográfico para as Indústrias Klabin (Imagem 90), com fotos de Peter Scheier (aéreas, externas e internas) e diagramação de George ${ }^{84}$ Rado - designer gráfico que expusera no $1^{\circ}$ Salão de Propaganda do MASP, em 1951, e que diagramaria mais tarde o livro São Paulo fastest growing city in the world, de Scheier, lançado

83 Habitat, São Paulo, n. 3, p.77, abr-jun 1951.

84 Foi encontrada também a grafia Jorge. 


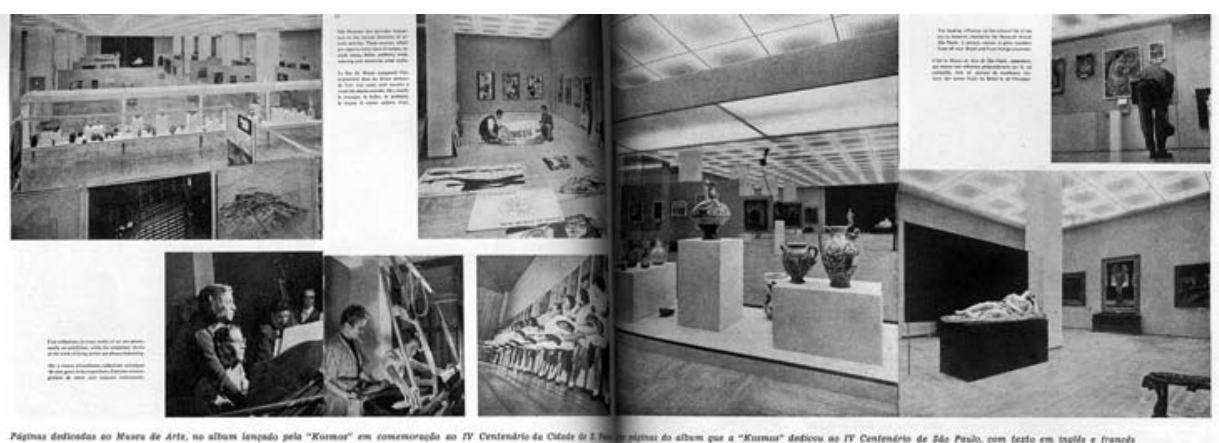

0 museu num album

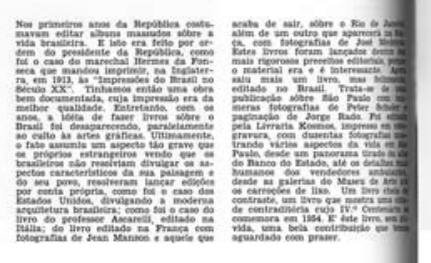

Imagem 91. Fac símile das páginas 78 e 79 da reportagem "O museu num álbum", em Habitat, n.13. Fonte: Acervo da FAUUSP.

pela Livraria Kosmos Editora em comemoração ao quarto centenário da cidade.

Este livro seria objeto do artigo "O museu num álbum", publicado na edição

13 (Imagem 91). Foram escolhidas para ilustrar o artigo as páginas 74 a 77 do álbum, que contêm fotografias dos espaços e atividades do MASP.

Trata-se de uma publicação sobre São Paulo com inúmeras fotografias de Peter Scheier e paginação de Jorge Rado. Foi editado pela Livraria Kosmos, impresso em rotogravura, com duzentas fotografias mostrando vários aspectos da vida em São Paulo, desde um panorama tirado do alto do Banco do Estado, até os detalhes mais humanos dos vendedores ambulantes, desde as galerias do Museu de Arte até os carroções de lixo. Um livro cheio de contraste, um livro que mostra uma cidade contraditória cujo VI.o Centenário se comemora em 1954. É este livro, sem dúvida, uma bela contribuição que temos aguardado com prazer. ${ }^{85}$

85 FONZARO, Guido. O museu num álbum. Habitat, São Paulo, n. 13, p.78-79, out-dez 1953. 


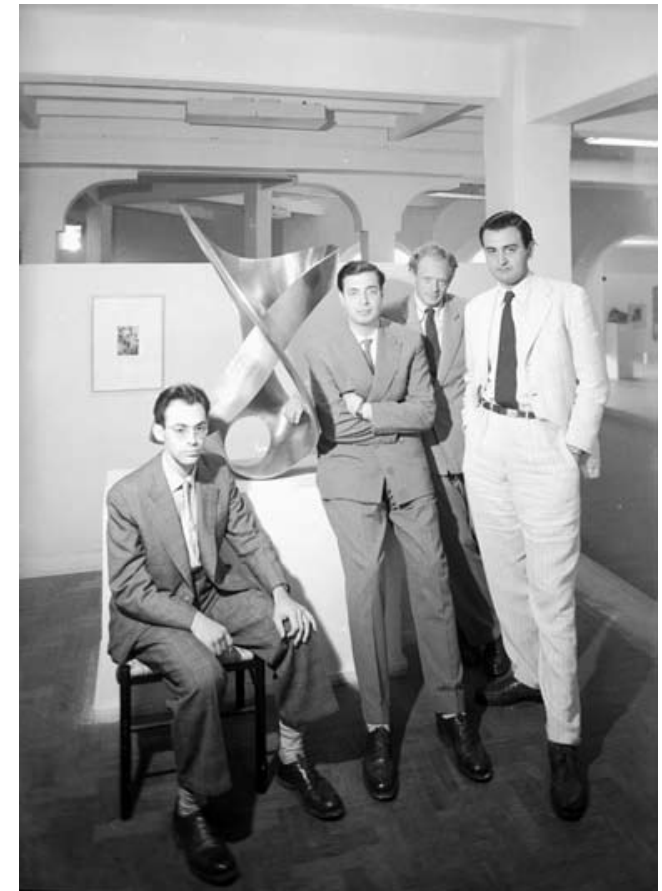

Imagem 92. Os artistas Abraam Palatnik (sentado), Waldemar Cordeiro, Kazmer Féjer (atrás) e Tomás Maldonado ao redor da "Unidade Tripartida" de Max Bill, 1951. Autoria: P. Scheier. Fonte: Acervo do AHJB.

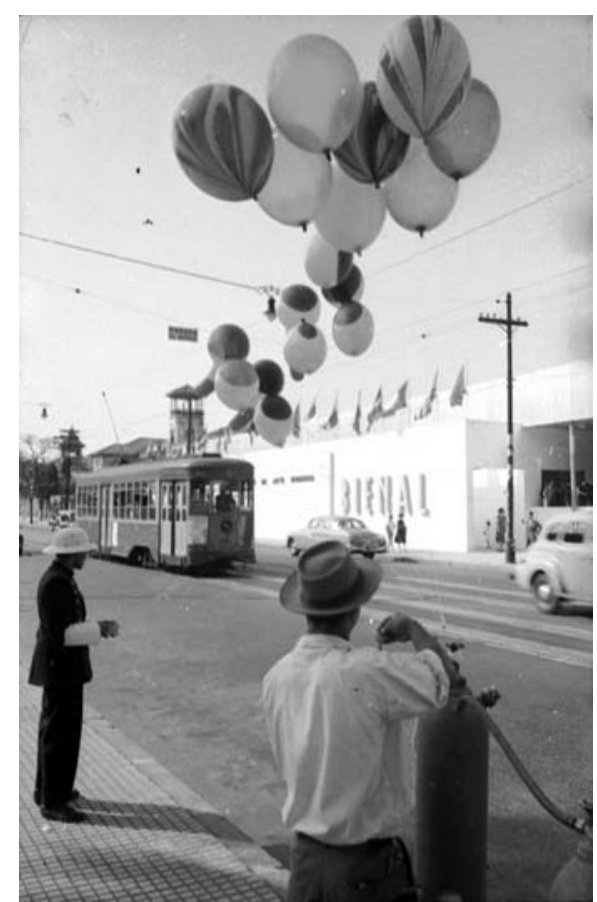

Imagem 93. Vista do pavilhão da 1a Bienal Internacional de Arte, 1951. Autoria: P. Scheier. Fonte: Acervo do AHJB.

\subsubsection{1̣ Bienal Internacional de São Paulo (1951)}

Além de seu amplo trabalho junto ao MASP, foram encontradas no acervo de Peter Scheier fotografias realizadas em 1951 durante a 1 a Bienal Internacional de São Paulo. A Bienal foi criada pelo empresário Francisco Matarazzo Sobrinho - conhecido por Ciccilo Matarazzo, fundador do MAM (1946) -, sendo a primeira exposição de arte moderna de grande porte realizada fora dos centros culturais europeus e norte-americanos. Foi construído um pavilhão na esplanada do Trianon, local hoje ocupado pelo MASP. O espaço, projetado pelos arquitetos Luís Saia e Eduardo Kneese de Mello, abrigou 1.800 obras de 23 países, além da representação nacional. O pavilhão, bem como sua localização, foi criticado 


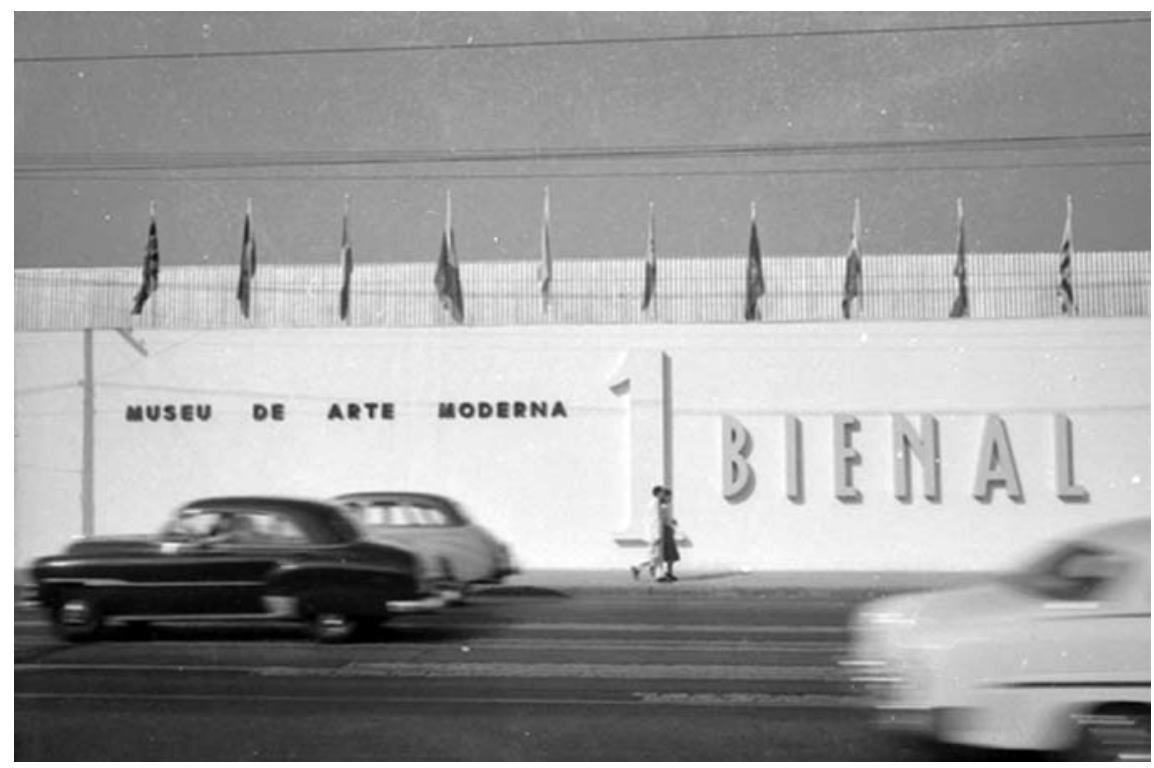

Imagem 94. Vista do pavilhão da 1a Bienal Internacional de Arte, 1951. Autoria: P. Scheier. Fonte: Acervo do AHJB.

pela revista Habitat em sua quinta edição, de outubro de 1951. Seu editorial censurou a organização que, ao invés de propor um novo modelo de gestão, copiou o da Bienal de Veneza; questionou os gastos, com os quais poderiam ser adquiridas mais obras de arte para os acervos museográficos da cidade; levantou a falta de critério na seleção das obras e nas mostras nacionais ${ }^{86}$.

Foram encontradas poucas imagens deste evento no acervo do fotógrafo. Entre elas está um retrato posado dos artistas Abraam Palatnik (sentado), Waldemar Cordeiro, Kazmer Féjer (atrás) e Tomás Maldonado ao redor da escultura em aço "Unidade Tripartida" de Max Bill - vencedora do prêmio para escultura de autor estrangeiro (Imagem 92). As fotos externas demonstram um olhar diferenciado, interessado não no registro isolado do pavilhão, mas na sua

$86 \quad$ A postura inicial (não-declarada) da Habitat como veículo de propaganda do Museu de Arte de São Paulo desmantelou-se com a saída de Lina e Pietro, abrindo um espaço de divulgação importante também para outras instituições, como a Galeria Ambiente e o Museu de Arte Moderna - MAM. Alvo de críticas pesadas na primeira fase da revista, o MAM passou a ter um amplo espaço para divulgação de seus eventos, principalmente as Bienais de Arte Moderna. Não por coincidência, na edição 16 (mai-jun 1954), logo após a saída de Lina e Pietro, o regulamento aprovado pelo MAM para a III Bienal de Arte Moderna de São Paulo foi publicado na íntegra, em página dupla, com grande visibilidade. 


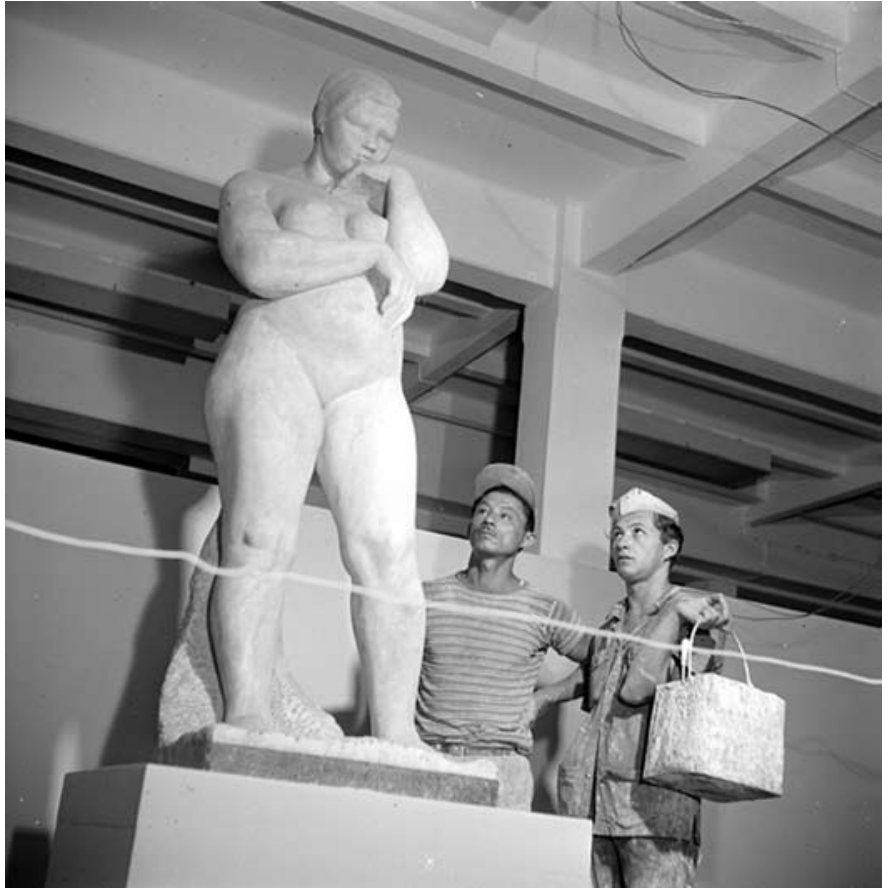

Imagem 95. Interior do pavilhão da 1a Bienal Internacional de Arte, 1951. Autoria: P. Scheier. Fonte: Acervo do AHJB.

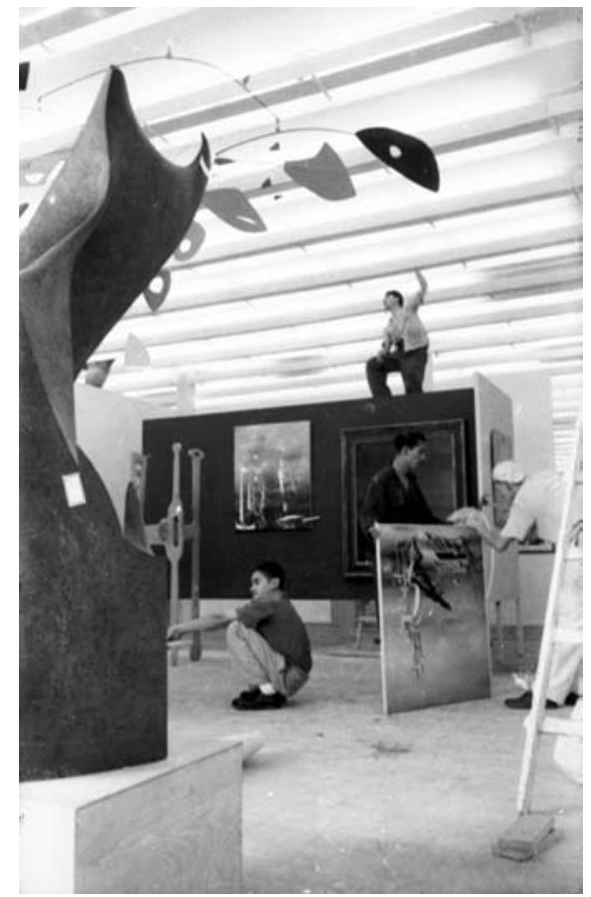

Imagem 96. Interior do pavilhão da 1a Bienal Internacional de Arte, 1951. Autoria: P. Scheier. Fonte: Acervo do AHJB.

contextualização dentro do ambiente vivo e dinâmico ao qual se relacionava . Em uma das imagens, colocou-se paralelo à fachada, sobre a qual se lia "Museu de Arte Moderna - 1 Bienal”. À frente da fachada - mostrada parcialmente carros passavam em velocidade e pedestres caminhavam pela calçada, nos constantes fluxos da cidade (Imagem 94). Em outra vista externa, seu gosto pela presença humana sobressai, num recurso que utilizou em muitas ocasiões: focar em primeiro plano uma pessoa em atividade - neste caso, o vendedor de balões a gás -, acrescentar outros elementos no plano intermediário - o guarda de trânsito, o bonde, os veículos - e, ao fundo, o edifício (Imagem 93).

As fotos internas mostram um pavilhão ainda em arrumação, com obras sendo desembaladas e posicionadas em seus lugares. Em uma foto posada, dois operários, com suas roupas de trabalho e segurando uma lata de tinta, observavam uma escultura, numa postura pouco à vontade (Imagem 95). Uma 
sombra bem marcada indica o uso de flash. Em outra, os operários faziam os últimos ajustes e os acabamentos (Imagem 96). Um móbile de Alexander Calder pendia do teto. Enquanto um homem verificava o forro e outros dois preparavam um quadro, um rapaz colocou-se agachado no meio do salão - numa posição que lembra o personagem Jeca Tatu, de Monteiro Lobato. Esta postura provavelmente solicitada por Scheier - aparentemente não tem justificativa, talvez uma referência ao primitivismo brasileiro nesta empreitada artística internacional ${ }^{87}$. Dificilmente Scheier comporia uma foto imbuída de um espírito depreciativo, que não parece estar de acordo com seu respeito e admiração ao povo brasileiro.

\subsection{A documentação da arquitetura moderna paulista}

A produção da fotografia especializada de arquitetura nas décadas de 1940 e 1950 no Brasil concentrava-se nos dois grandes centros irradiadores da arquitetura moderna, Rio de Janeiro e São Paulo. Esta concentração justifica-se não apenas pela demanda, mas também pelo número de fotoclubes e escolas, pelo acesso mais fácil a materiais, equipamentos e bibliografia. A demanda crescia em função das revistas especializadas e da bibliografia, inclusive estrangeira, que buscava material para discorrer sobre a arquitetura moderna brasileira. Brazil Builds: Architecture new and old 1652-1942 (1943), Latin

$87 \quad$ Outra hipótese seria o contato de Peter Scheier com as pesquisas de mobiliário e arte vernacular de Lina bo Bardi, no ambiente do MASP. Por exemplo, para o concurso de Cantú, na Itália, Lina apresentou um banco inspirado no ato de sentar de cócoras, peculiar ao índio e ao caboclo, com o objetivo de caracterizar os móveis como produtos de uma tradição local. Ver: ORTEGA, Cristina Garcia. O Moderno e o Vernáculo no Móvel de Lina Bo Bardi. In: Congresso Internacional de Pesquisa em Design, 4., 11-13 out 2007, Rio de Janeiro, RJ. Disponível em: http://www.anpedesign.org.br/artigos/pdf/O\%20Moderno\%20e\%200\%20Vern\%E1culo\%20 no\%20M\%F3vel\%20de\%20Lina\%20Bo\%20Bardi.pdf. Acesso em: 11 out 2008, às 08:00. 
American Architecture since 1945 (1955) e Modern Architecture in Brazil (1956) foram exemplos de livros nos quais a arquitetura brasileira se destacou.

No Rio de Janeiro, a documentação da arquitetura ficou a cargo de Aertsens Michel, Rafael Landau, Carlos Botelho, José e Humberto Franceschi (Foto Franceschi), Jean Manzon, Foto Carlos e Marcel Gautherot. Quase todos colaboravam freqüentemente com a revista Módulo - Arquitetura e Artes Visuais no Brasil (1955-1989), dirigida por Oscar Niemeyer. Marcel Gautherot destacouse neste grupo por seu amplo registro das obras da arquitetura moderna desde os primórdios - Affonso Eduardo Reidy, Lúcio Costa, Alcides da Rocha Miranda, Paulo Antunes Ribeiro, Milton e Marcelo Roberto. A sólida amizade com Roberto Burle Marx e Oscar Niemeyer rendeu-lhe a quase exclusividade da documentação de seus projetos.

Peter Scheier inseria-se num grupo de profissionais que registrava a arquitetura moderna paulista: Boer, Alexandre Smilg, Ernesto Mandowski, Francisco Albuquerque, Sascha Harnish, Hugo Zanella, José Moscardi, Hans GünterFlieg e Leon Liberman, entre outros. Todos eram colaboradores constantes das revistas Acrópole (1938-1971), AD - arquitetura e decoração (1953-1957) e Habitat - Revista das Artes no Brasil (1950-1965). A revista Acrópole consolidou os nomes de Leon Liberman, Hugo Zanella ${ }^{88}$ e José Moscardi, que lhe forneciam as imagens com quase total exclusividade. Liberman atuou na cidade a partir da década de 1920 e acompanhou a Acrópole durante sua primeira fase, sob a direção de Roberto Corrêa de Brito. Hugo Zanella apareceu a partir da década de 1940, e seu nome estaria freqüentemente associado ao de Moscardi, seu sócio e cunhado, que se tornaria "o fotógrafo da Acrópole" ${ }^{89}$ - nas palavras de Max Gruenwald, o proprietário da revista em sua segunda fase (1953-1971) - e

88 Foram encontradas grafias diferentes: Hugo e Ugo Zanella.

89 SERAPIÃO, Fernando. Uma saga fotográfico-arquitetônica. Revista ProjetoDesign, São Paulo, n. 323, p. 102, jan. 2007. 


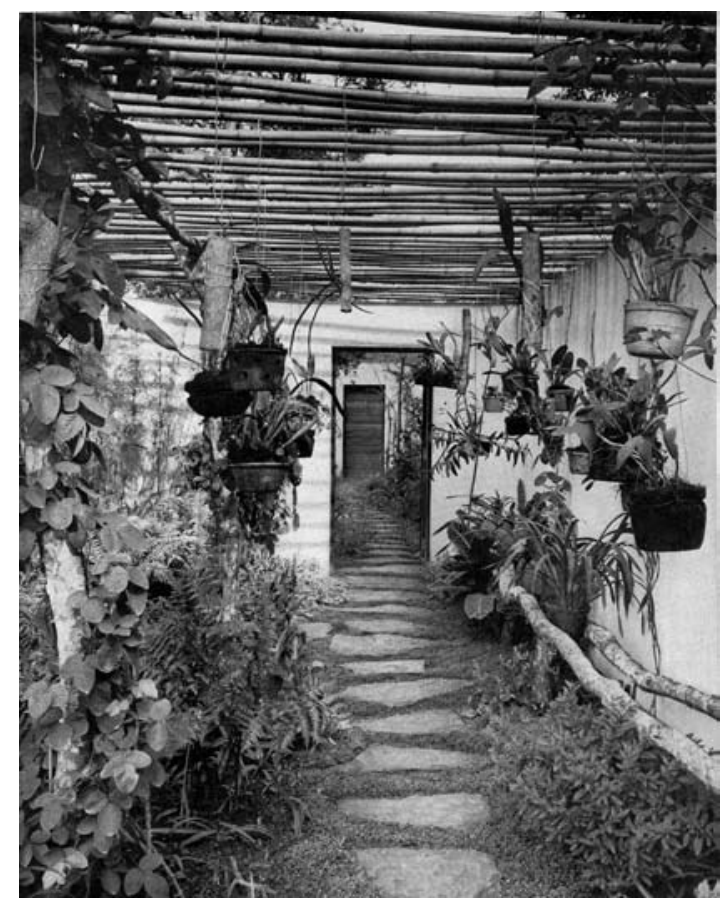

Imagem 97. Residência Arnstein, de Bernardo Rudofsky. Autoria: P. Scheier. Fonte: "Three Patio Houses", em New Pencil Points, n.6, p.49. Acervo da FAUUSP.

a grande referência em documentação de arquitetura em São Paulo.

Peter Scheier circulava pela região da Praça da República, área de efervescência urbana e cultural da São Paulo dos anos 1950, de grande concentração de escritórios de arquitetura. No $13^{\circ}$ andar do edifício dos Diários Associados, na Rua Sete de Abril, 230, ficava o escritório de Lina, cinco andares acima da redação da revista Habitat e dez acima do MASP. Rino Levi trabalhou no Edifício Esther (Av. Ipiranga, 480) e depois se mudou para a Sede do IAB - Instituto de Arquitetos do Brasil - à Rua Bento Freitas, 306, onde também trabalhavam João Vilanova Artigas, Ícaro de Castro Melo e Henrique Mindlin. Na Rua Barão de Itapetininga encontravam-se Roberto Aflalo, Eduardo Corona, Gregori Warchavchik, Plínio Croce e Miguel Forte; na Rua Avanhandava, Oswaldo Arthur Bratke. A sede da revista Acrópole ficava na Rua Líbero Badaró. 


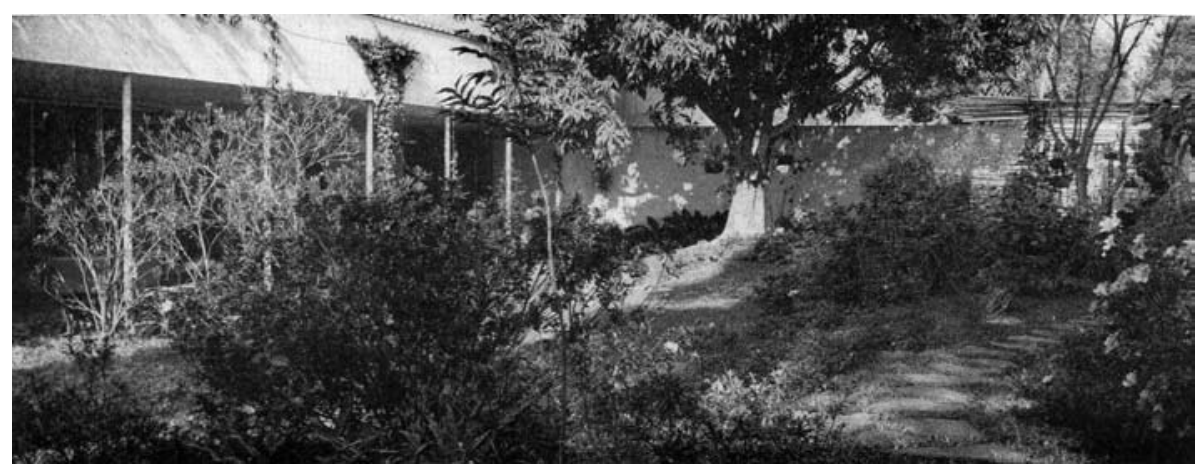

Imagem 98. Residência Arnstein. Autoria: P. Scheier. Fonte: "Three Patio Houses", em New Pencil Points, n.6, p.51. Acervo da FAUUSP.

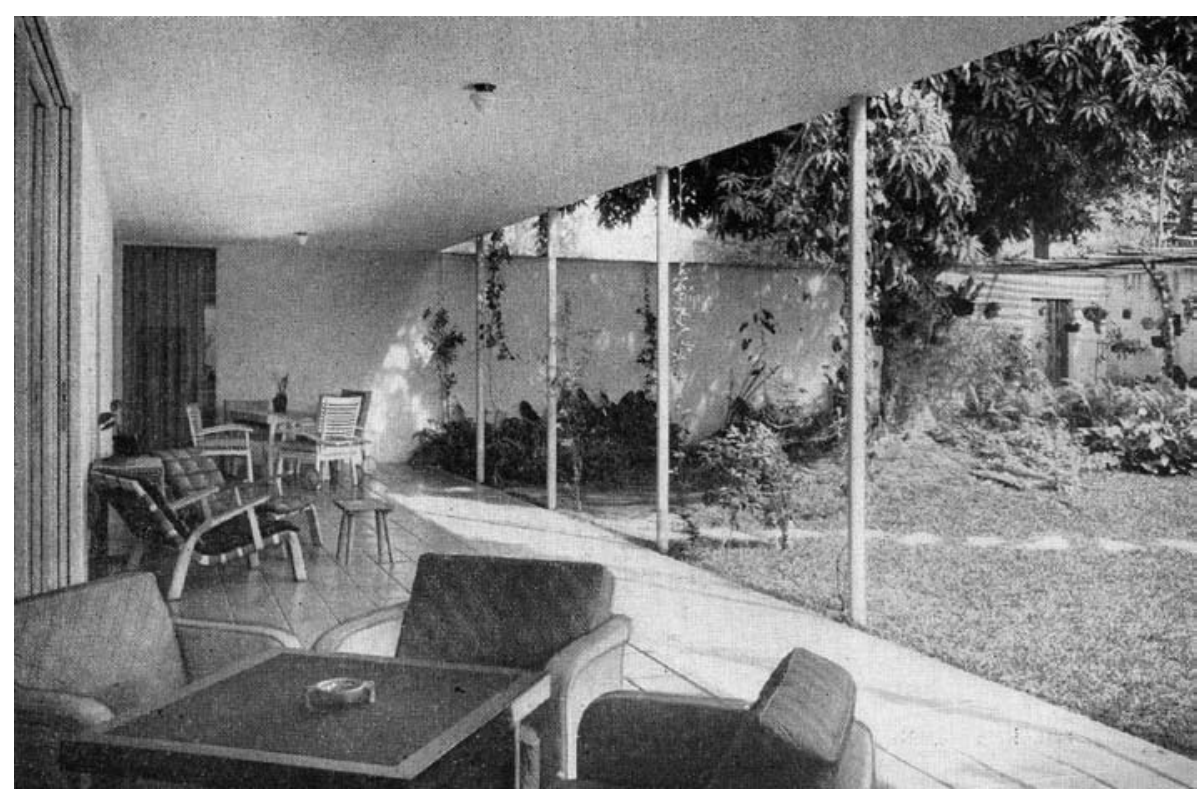

Imagem 99. Residência Arnstein. Autoria: P. Scheier. Fonte: New Pencil Points, n.6, p.51. Acervo da FAUUSP.

Peter Scheier documentou obras de Bernardo Rudofsky, Gregori Warchavchik, Oswaldo Bratke, Lina Bo Bardi e Rino Levi, sendo deste último o maior volume de obras registradas. Mais que isso, Scheier documentou a arquitetura inserida no contexto urbano. Assim, ele foi testemunha ocular de obras de arquitetos como Lucjan Korngold (Edifício CBI Esplanada e Edifício Thomas Edison), Álvaro Vital Brasil (Edifício Esther), Jacques Pilon (Biblioteca Municipal e sede de O Estado de S.Paulo) e Oscar Niemeyer (Edifício Copan) que se destacavam no tecido urbano paulistano. 


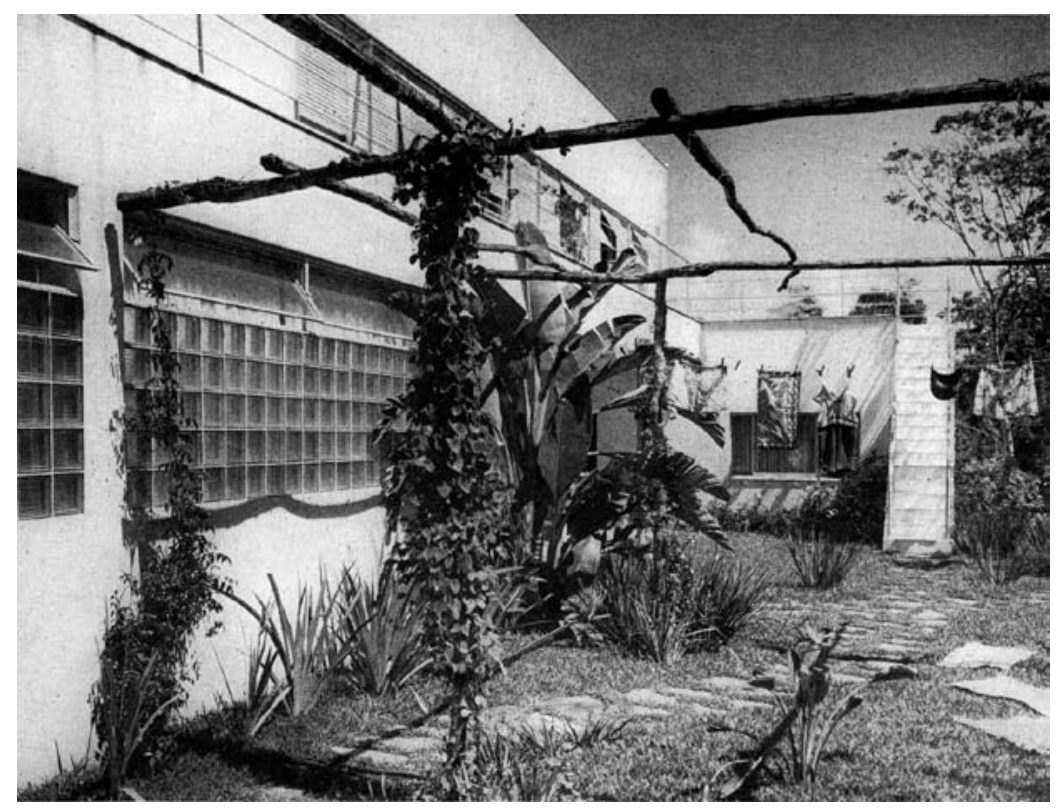

Imagem 100. Residência Frontini, de Bernardo Rudofsky. Autoria: P. Scheier. Fonte: New Pencil Points, n.6, p.58. Acervo da FAUUSP.

No conjunto da obra de um fotógrafo cuja variedade de temas foi grande, é provável haver penetração de algumas práticas fotográficas próprias de certos temas em outros. O trabalho de seis anos no fotojornalismo certamente influenciou a fotografia de arquitetura de Peter Scheier. Podemos ainda considerar sua origem estrangeira e suas referências culturais como fatores que distinguem suas fotografias dos demais. Em algumas situações é possível notar composições oblíquas e ângulos não-usuais, cujo resultado visual transforma o edifício não em elemento arquitetônico e espacial, mas em elemento geométrico e gráfico.

\subsubsection{Cinco arquitetos nas lentes de Peter Scheier}

Bernardo Rudofsky, imigrante austríaco, morou em São Paulo de 1938 a 1942, quando se mudou para New York. Seu trabalho como editor associado e 


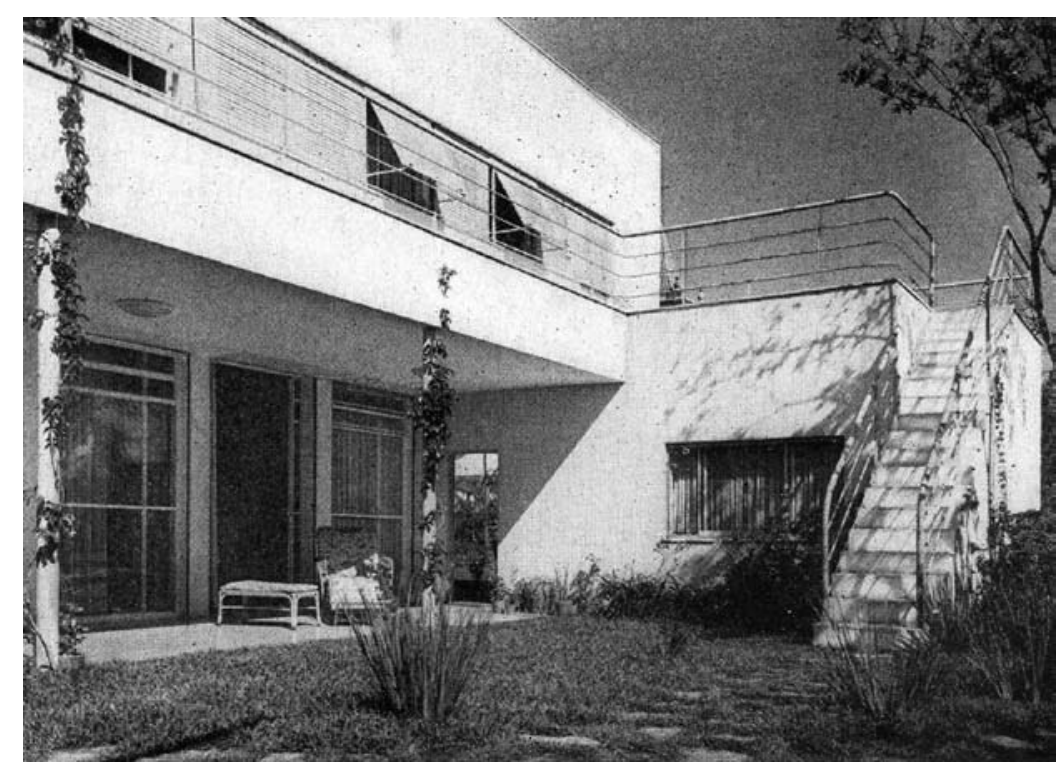

Imagem 101. Residência Frontini. Autoria: P. Scheier. Fonte: New Pencil Points, n.6, p.59. Acervo da FAUUSP.

diretor de arte na revista americana New Pencil Points resultou na reportagem "Three Patio Houses" ${ }^{90}$, em junho de 1943, neste mesmo periódico. Duas das três residências abordadas - a João Arnstein (1941) e a Virgílio Frontini (194041), ambas em São Paulo - foram documentadas por Peter Scheier.

Da casa Arnstein, a imagem frontal do viveiro (Imagem 97), com a porta de acesso dos quartos ao fundo alinhada ao eixo vertical, apresenta pontos típicos da fotografia clássica de arquitetura, encontrados na obra de fotógrafos como o americano Ezra Stoller: ponto de vista como uma elevação e uso de perspectiva com um ponto de fuga para aumentar dramaticamente o senso de profundidade. A irregularidade do pergolado de bambu é marcante, criando sombras sobre a parede dos fundos.

$\mathrm{Na}$ foto externa Scheier enfatizou o jardim tropical abundante, que provia sombreamento em contraposição ao sol intenso (Imagem 98). O mesmo

90 RUDOFSKY, Bernardo. Three Patio Houses. New Pencil Points, East Stroudsburg, $\mathrm{n}^{\circ} 6$, p. 48-65, jun 1943. 


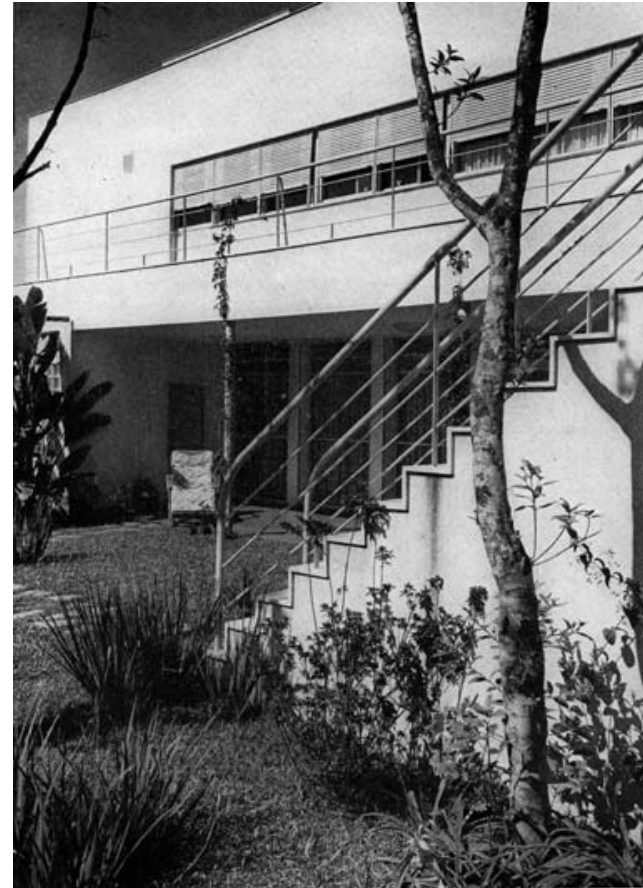

Imagem 102. Residência

Frontini. Autoria: P. Scheier. Fonte: New Pencil Points, n.6, p.59. Acervo da FAUUSP.

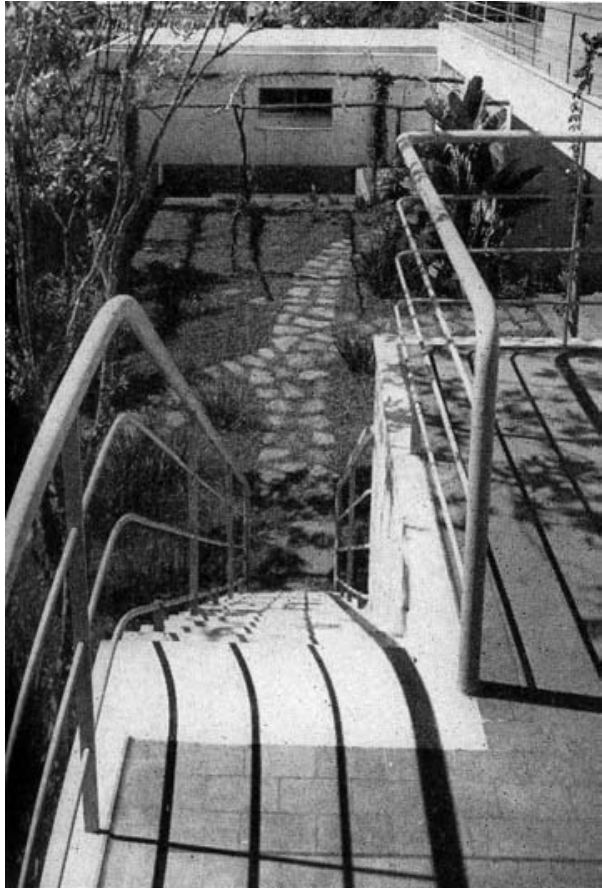

Imagem 103. Residência Frontini. Autoria: P. Scheier. Fonte: New Pencil Points, n.6, p.59. Acervo da FAUUSP.

pergolado aparece ao lado direito, sendo que no segundo plano vêem-se as grandes portas de vidro de correr, que integravam a parte interna ao pátio. Essa integração fica mais clara na imagem interna, na qual a luz solar penetra no terraço, transmitindo uma sensação de conforto e de bem-estar (Imagem 99). Scheier sabia explorar a transparência da arquitetura moderna muito bem em suas fotografias - a residência Lina Bo Bardi, Milton Guper e as posteriores fotos dos edifícios de Brasília revelam essa qualidade.

Na residência Frontini, Scheier explorou mais as relações espaciais do pátio com elementos como o pergolado, a escada, a passarela, a piscina e os volumes da construção. As imagens retratam o pátio a partir de vários pontos: numa imagem (Imagem 100), percebe-se claramente a implantação do pátio, com o pergolado de madeira em primeiro plano e a escada de acesso aos dormitórios ao fundo; em outra (Imagem 101), Scheier colocou-se um pouco à direita da 


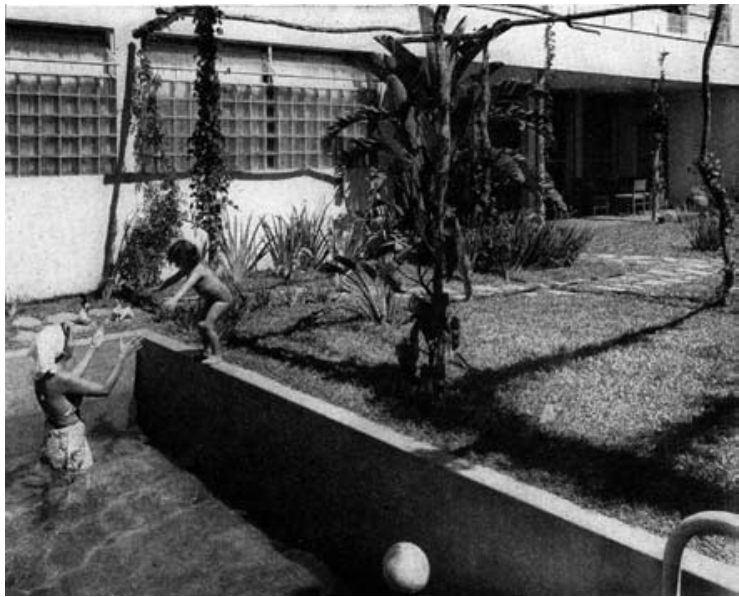

Imagem 104. Residência Frontini. Autoria: P. Scheier. Fonte: New Pencil Points, n.6, p.58. Acervo da FAUUSP.

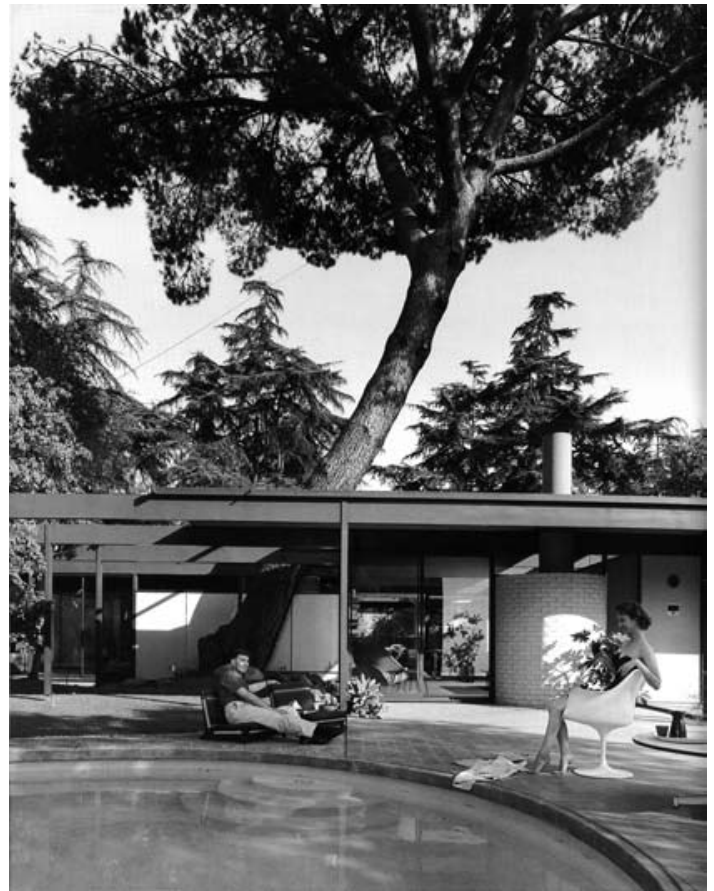

Imagem 105. Case Study House \#20 (Bass House), Califórnia, 1958. Autoria: J. Shulman. Fonte: ELWALL (2004), p.182.

anterior, ocultando o pergolado e mostrando a porta de vidro de correr que dá acesso ao jardim; numa terceira (Imagem 102), vê-se a escada em primeiro plano e o volume principal atrás, com os caixilhos dos dormitórios e a porta de correr. Por fim, ele registrou o pátio do nível superior, a partir do patamar da escada, com os degraus em primeiro plano, que conduzem o olhar até o caminho de pedras do jardim, com o pergolado e a piscina ao fundo (Imagem 103).

Uma fotografia desta série chama a atenção por seu caráter raro (Imagem 104). Curiosamente, na documentação de arquitetura de Peter Scheier raramente há presença humana. A ênfase nas pessoas, que lhe é característica no fotojornalismo e na fotografia urbana, cede lugar ao registro preciso das formas dos edifícios. Contudo, na casa Frontini, Scheier retratou uma mulher brincando na piscina com uma criança, numa postura que lembra as fotografias do americano Julius Shulman, que transformava a arquitetura em estilo de vida, o 
"American Way of Life" - as pessoas e objetos, portanto, exerciam papel primordial na composição (Imagem 105). Esta fotografia de Scheier, realizada no início da década de 1940, antecipou de certa forma aquele ideário californiano retratado por Shulman, vigente principalmente no período pós-guerra, caracterizado por um "tempo de famílias perfeitas, posando para as fotografias em suas casas ensolaradas e transparentes, com crianças loiras e cães de raça labrador (jamais um dobermann)." ${ }^{91}$ Do contato de Bernardo Rudofsky com as revistas americanas pode ter surgido esta referência para a foto de Scheier, uma vez que Julius Shulman começara seu trabalho em meados da década de 1930, junto ao arquiteto Richard Neutra.

Na residência de Antônio da Silva Prado Neto (São Paulo, 1931), projeto de Gregori Warchavchik, Scheier produziu imagens externas que enfatizam a relação da casa com as áreas adjacentes do terreno, repletas de árvores, gramado e providas de piscina. Numa das imagens (Imagem 106), posicionado a uma distância suficiente para enquadrar a casa, a piscina e parte da vegetação e gramado, o fotógrafo colocou-se sob uma árvore, de forma que seus galhos superiores pendessem sobre o visor da máquina, preenchendo, assim, o vazio superior da imagem. Na tomada do terraço (Imagem 107), Scheier compôs uma perspectiva acentuada pelos planos compostos pela parede à esquerda, a laje e o piso. No segundo plano, o caixilho de vidro de canto suaviza a geometria, assim como a vegetação à direita.

Este projeto, como as casas de Oswaldo Bratke retratadas, voltavase para a área externa. Desta maneira, Peter Scheier demonstrou um cuidado em documentá-los de pontos de vista mais distantes, que provessem ângulos amplamente abertos para captar a natureza circundante e expor sua

91 TOUCEDA, Adriana Marta Irigoyen de. Da Califórnia a São Paulo: referências norteamericanas na casa moderna paulista 1945-1960. São Paulo: FAUUSP, 2005. Tese de Doutorado, p.254. 


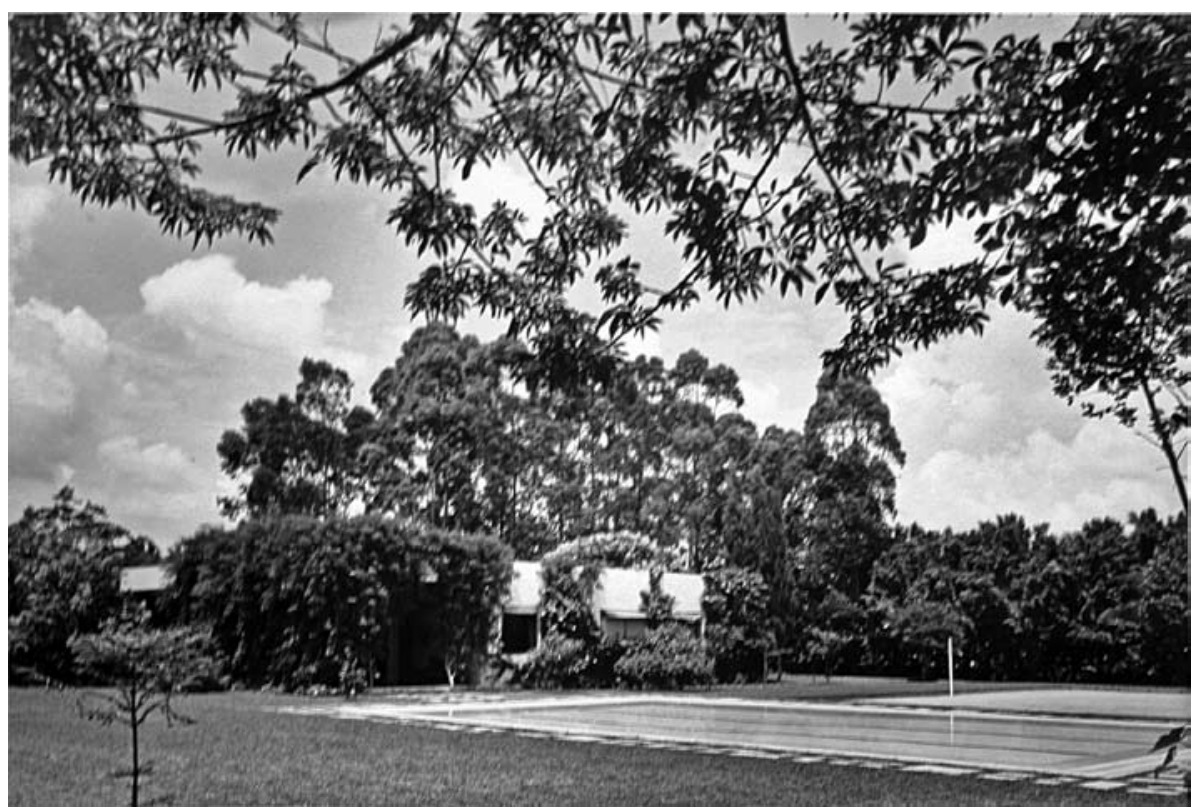

Imagem 106. Residência Antônio da Silva Prado Neto, de Gregori Warchavchik. Autoria: P. Scheier. Fonte: Acervo fotográfico FAUUSP.

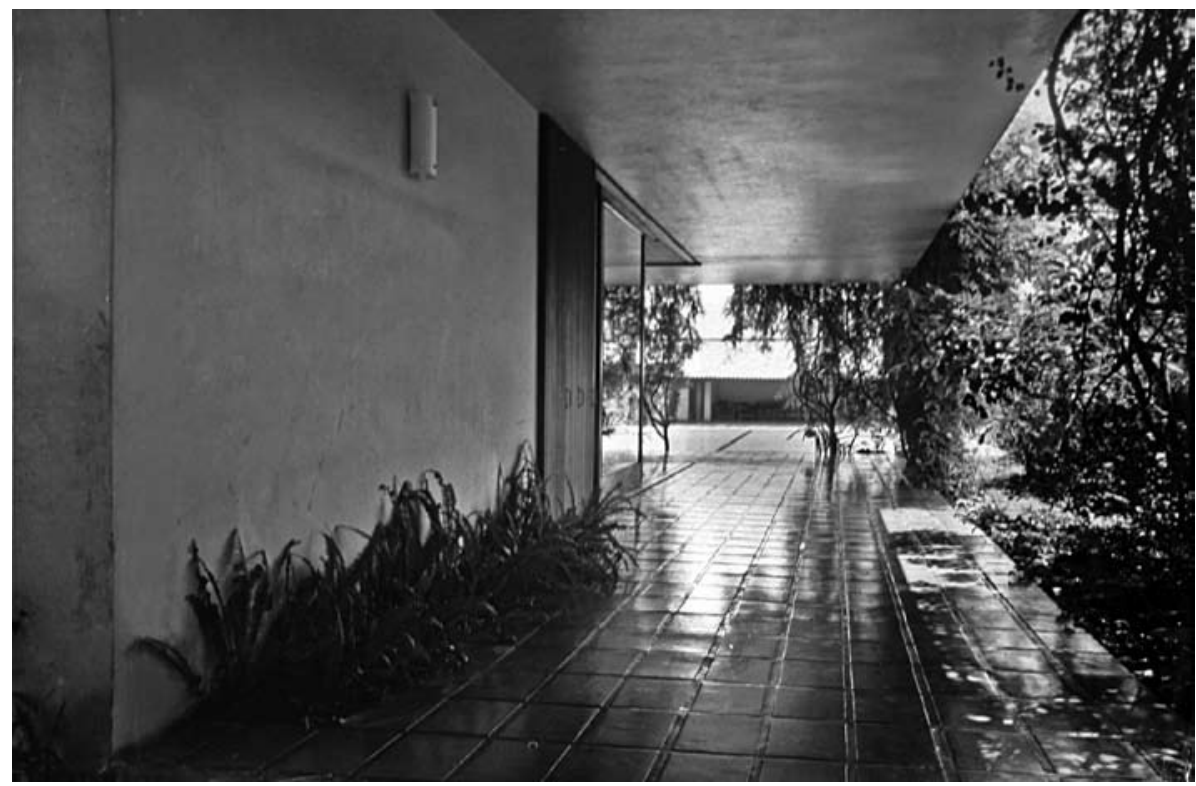

Imagem 107. Residência Antônio da Silva Prado Neto. Autoria: P. Scheier. Fonte: Acervo fotográfico FAUUSP.

implantação.

Assim, a casa Oscar Americano (Oswaldo Bratke, São Paulo, 1952) foi documentada tanto a partir de pontos distantes quanto de pontos mais próximos, que retrataram todas as fachadas e enfatizaram o declive - que resulta em um 


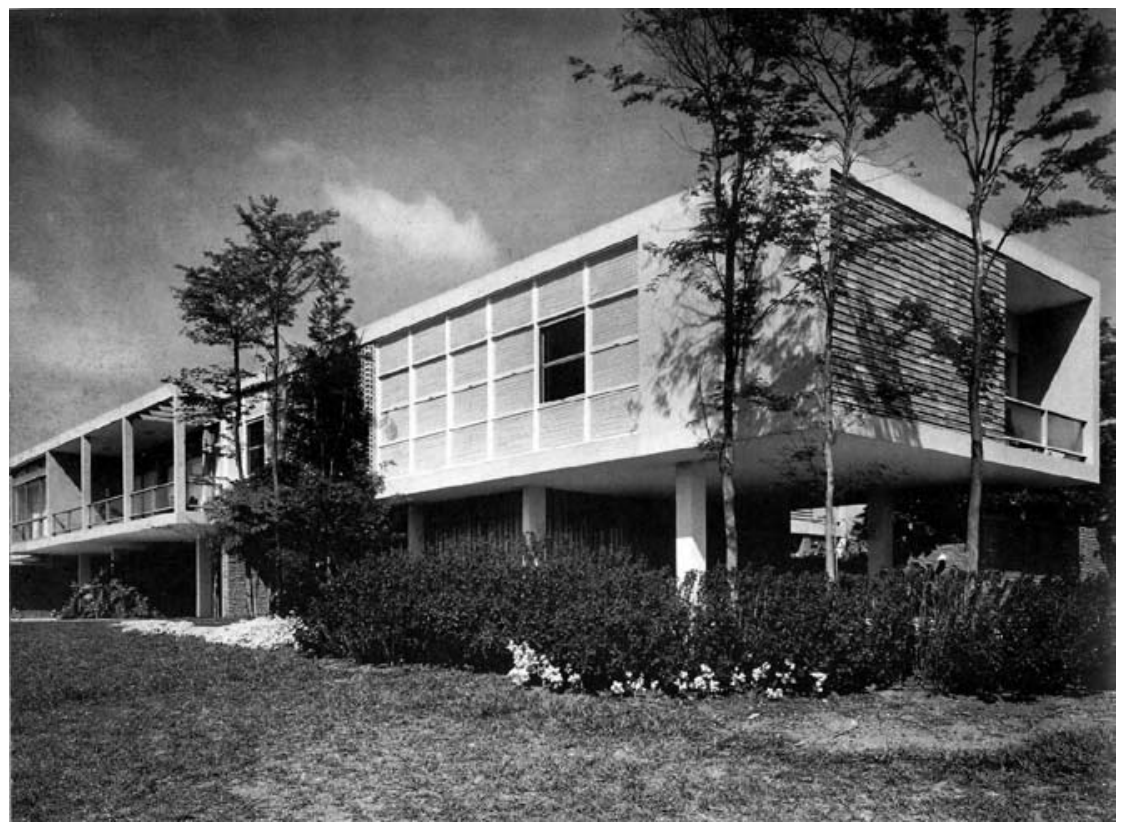

Imagem 108. Face Leste da residência Oscar Americano. Autoria: P. Scheier. Fonte: SEGAWA; DOURADO (1997), p.124.

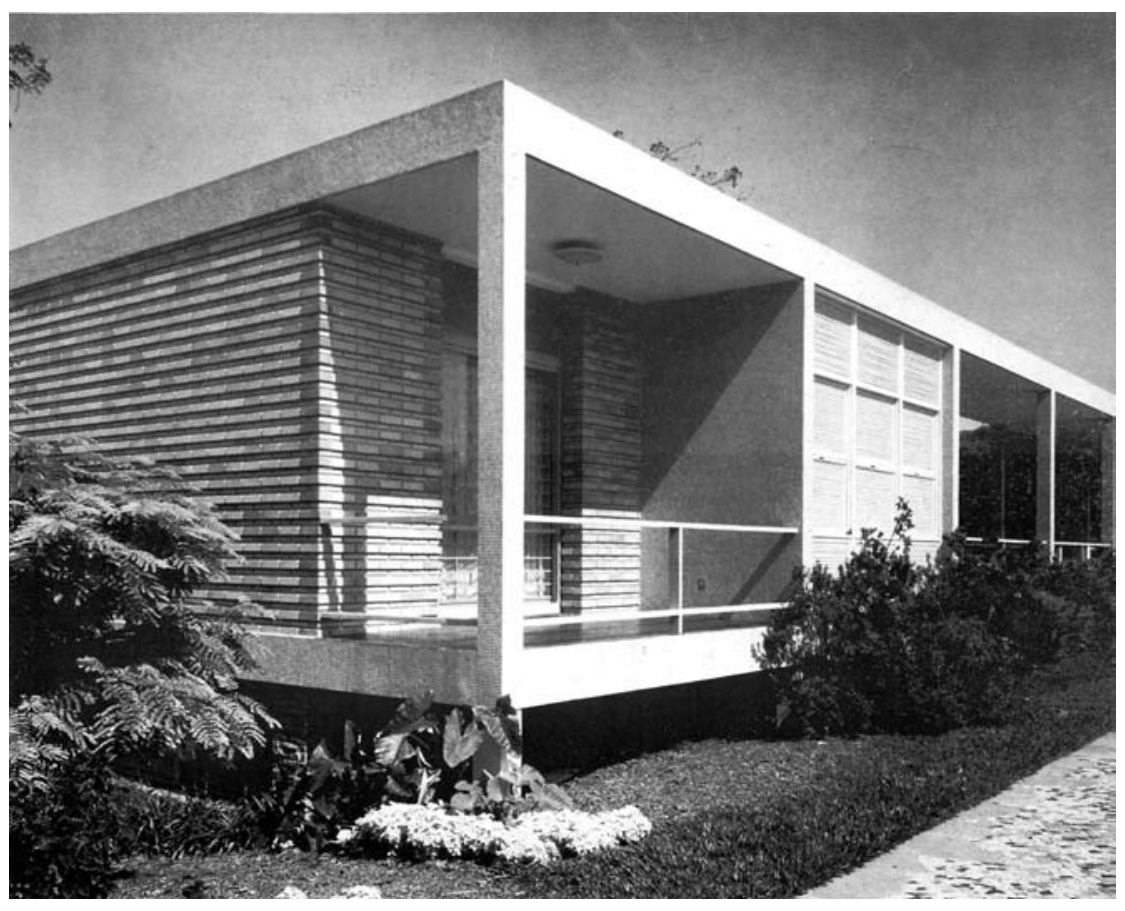

Imagem 109. Fachada Oeste da residência Oscar Americano. Autoria: P. Scheier. Fonte: SEGAWA; DOURADO (1997), p.125. 


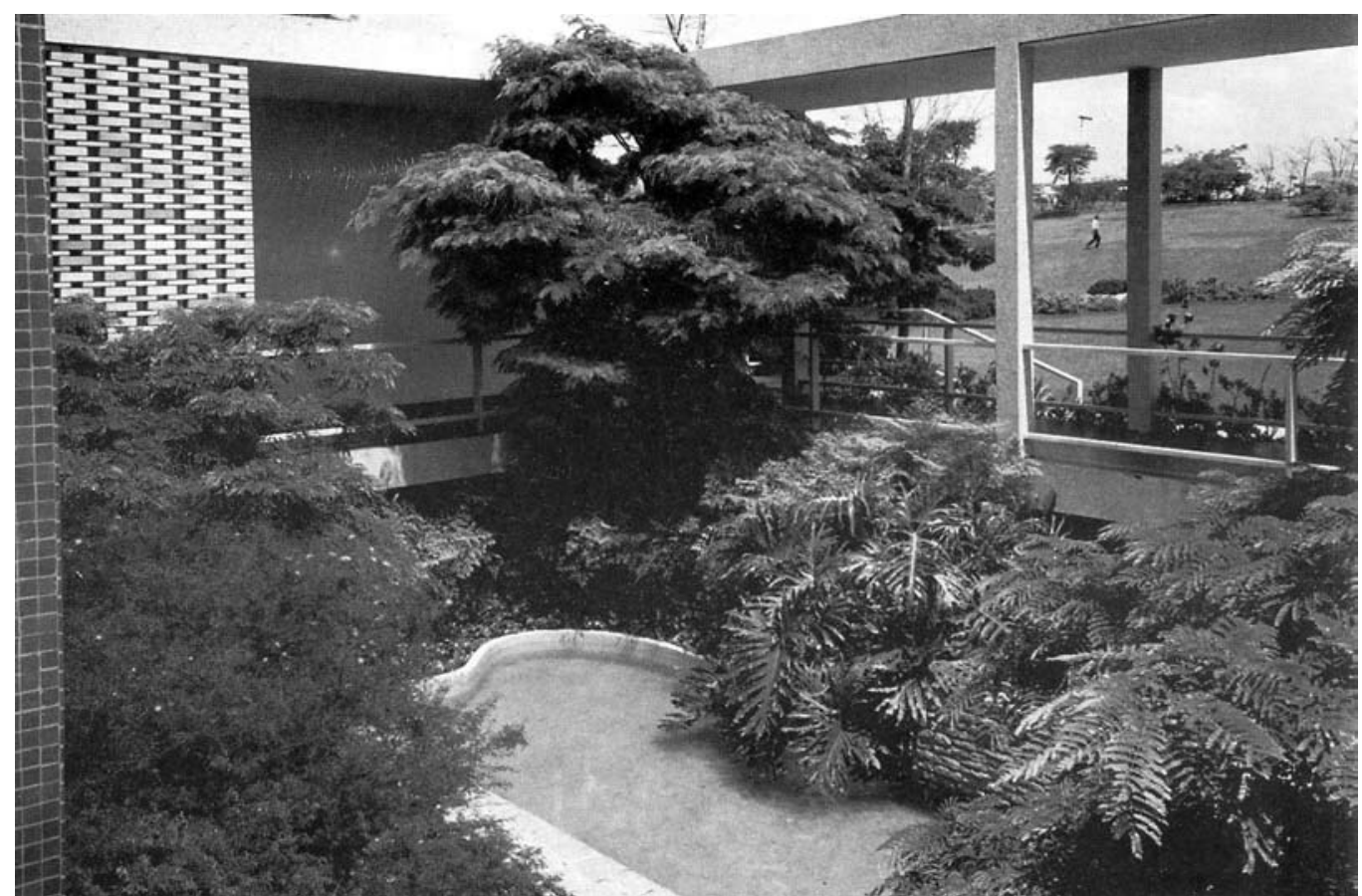

Imagem 110. Jardim interno da residência Oscar Americano. Autoria: P. Scheier. Fonte: SEGAWA; DOURADO (1997), p.128.

pavimento a mais na fachada leste - e a implantação no amplo terreno.

Para o registro das fachadas (Imagem 108/109), Scheier esquivou-se dos ângulos frontais, paralelos a elas, e posicionou-se sempre obliquamente, mostrando simultaneamente duas fachadas. Essas imagens mostram o rigor geométrico da estrutura regular que forma retângulos na fachada, ora preenchidos por alvenaria pintada, ora por tijolos aparentes, ora venezianas de madeira, ora por panos de vidro, ora por vazios definidos pelo recuo da alvenaria e pela colocação de guarda-corpo. A incidência solar enfatizou os cheios e vazios, a multiplicidade de materiais e texturas e as diversas situações de fechamento.

Ojardim interno, dominado pela exuberante vegetação tropical e pelo espelho d'água de forma livre, se contrapõe à rigidez geométrica do volume da casa. Posicionado na galeria, Scheier registrou-o de cima para baixo, enquadrando, à esquerda, uma parte da estrutura revestida em pastilhas de porcelana (em 


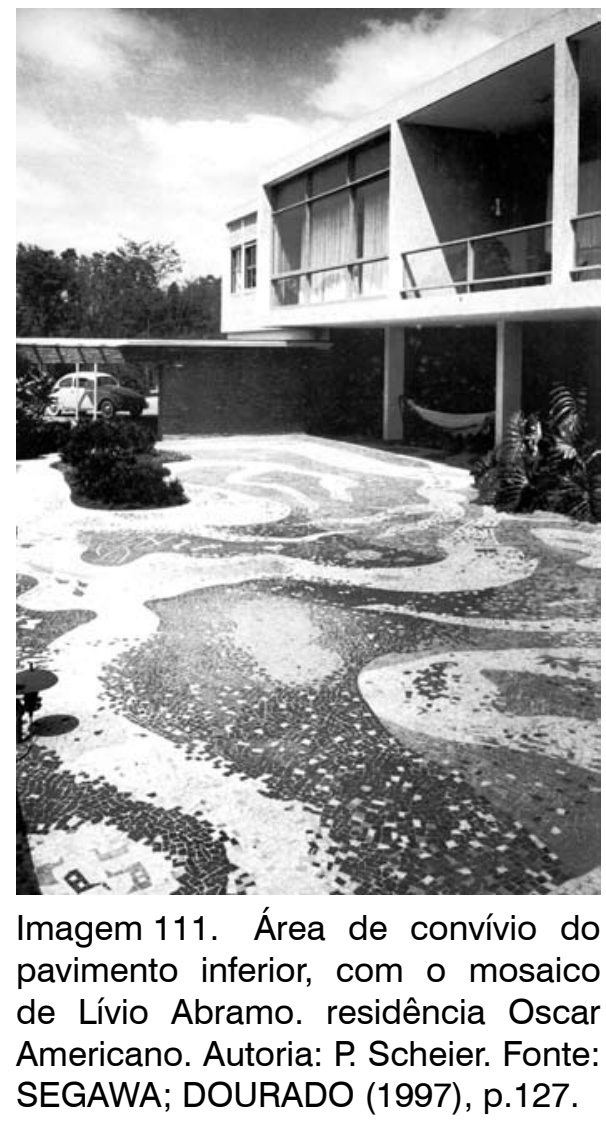

primeiro plano) e a parede de tijolos trançados que protege a entrada principal (em segundo plano) (Imagem 110). Ao fundo, entre dois pilares da galeria, Scheier enquadrou um homem que caminhava pelo amplo gramado - a única pessoa presente nesta série. Na foto da área de convívio (Imagem 111), cujo piso foi revestido com o trabalho em mosaico português "Foz do Rio Amazonas", de Lívio Abramo, notam-se alguns traços da presença humana, como o veículo Fusca ao fundo e a rede instalada entre os pilares.

O pavilhão da piscina foi documentado em ângulos que reproduzem a aproximação de uma pessoa - o trajeto que o próprio Scheier percorreu até alcançá-lo. A seqüência começa no caminho sinuoso e inclinado - características destacadas pela tomada a partir de um nível mais baixo - que explicita a implantação do pavilhão (Imagem 112). Na segunda imagem (Imagem 113), 


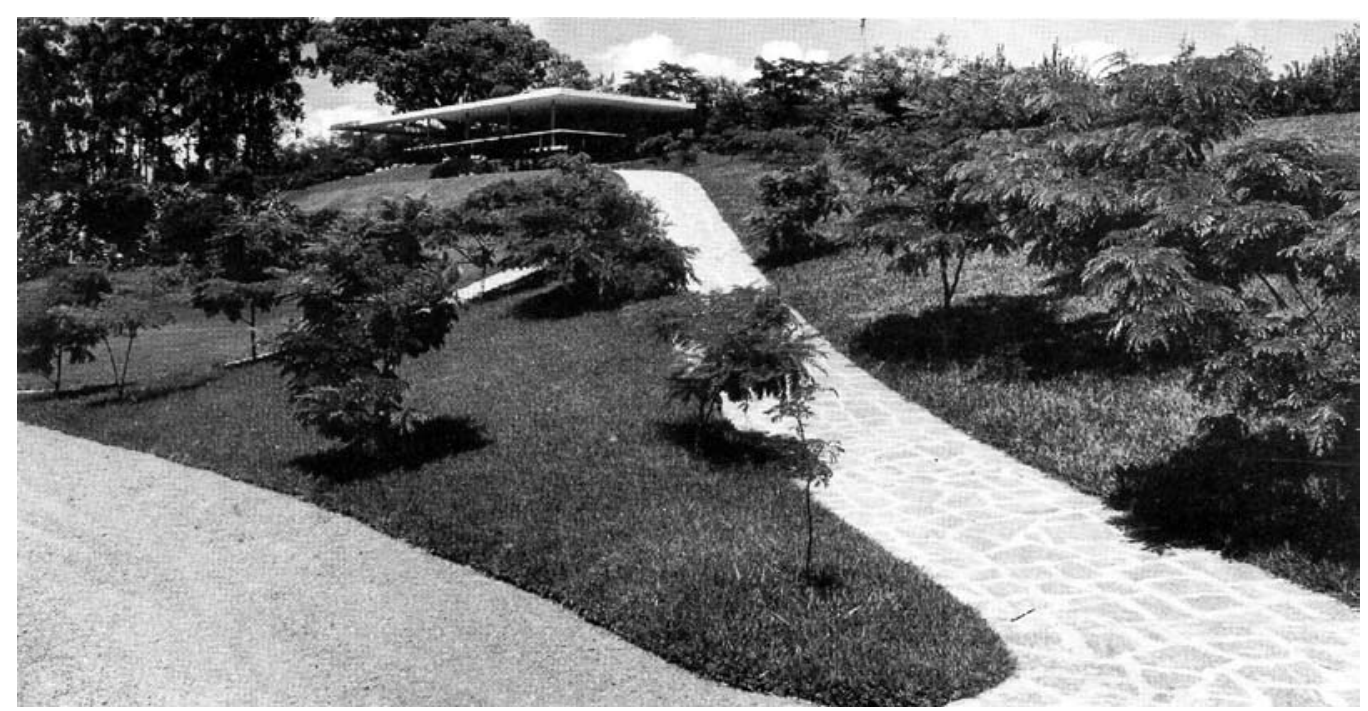

Imagem 112. Vista do pavilhão de lazer da residência Oscar Americano. Autoria: P. Scheier. Fonte: SEGAWA; DOURADO (1997), p.129.

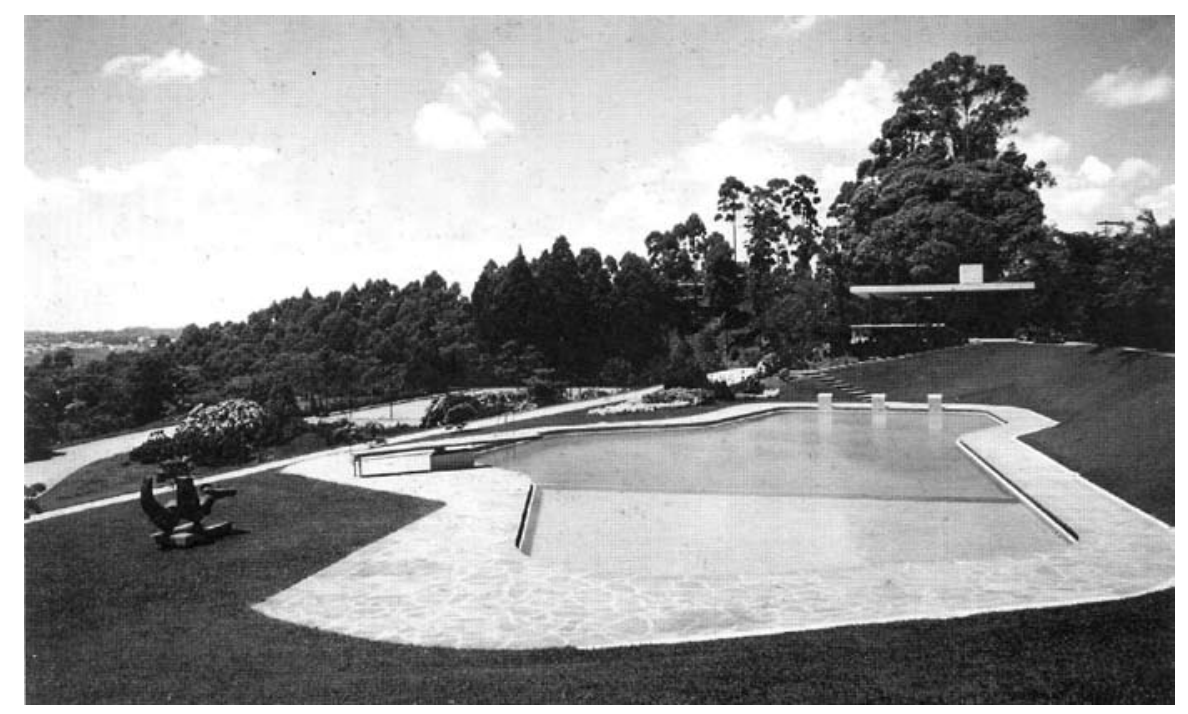

Imagem 113. Vista da piscina e do pavilhão de lazer (ao fundo) da residência Oscar Americano. Autoria: P. Scheier. Fonte: SEGAWA; DOURADO (1997), p.130.

no platô da piscina, além da relação entre o pavilhão, a piscina e o terreno - que aqui apresenta densa vegetação ao fundo - Scheier estabeleceu a relação da casa, implantada no então deserto e pouco ocupado bairro do Morumbi, com a cidade, vista no horizonte distante. E numa terceira imagem (Imagem 114), Scheier mostrou o pavilhão com mais detalhes: a grande árvore que "corta" a 


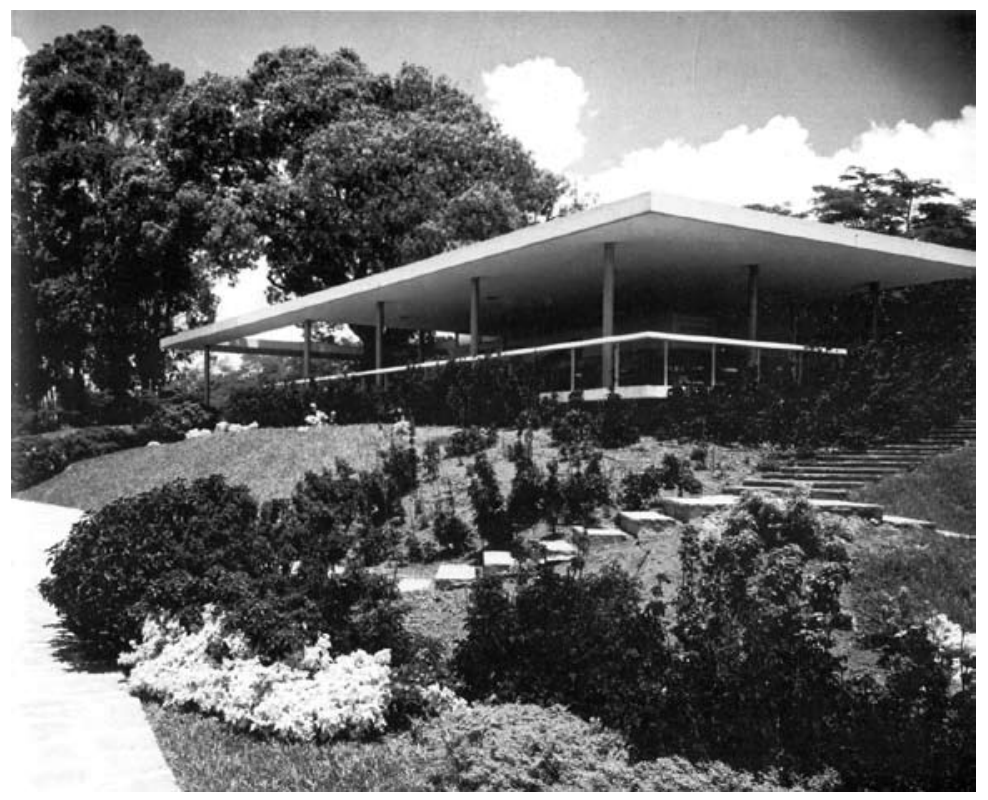

Imagem 114. Pavilhão de lazer da residência Oscar Americano. Autoria: P. Scheier. Fonte: SEGAWA; DOURADO (1997), p.131.

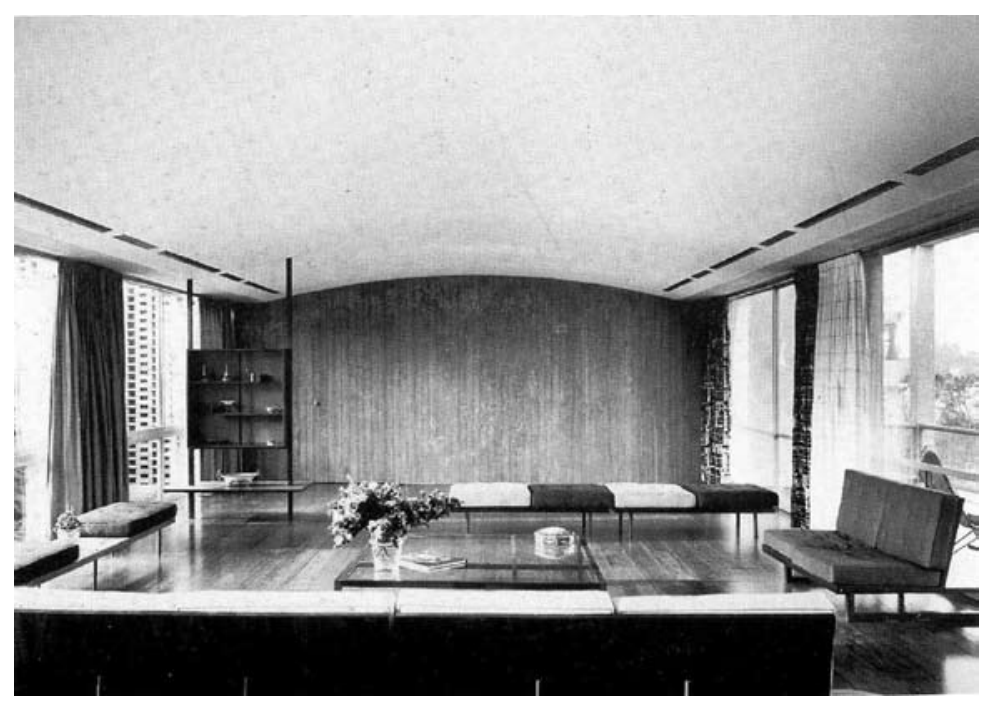

Imagem 115. Sala de estar da residência Oscar Americano. Autoria: P. Scheier. Fonte: SEGAWA; DOURADO (1997), p.128.

delgada laje sustentada por pilotis. O mesmo ângulo de viés utilizado nas vistas gerais da casa foi mantido. 


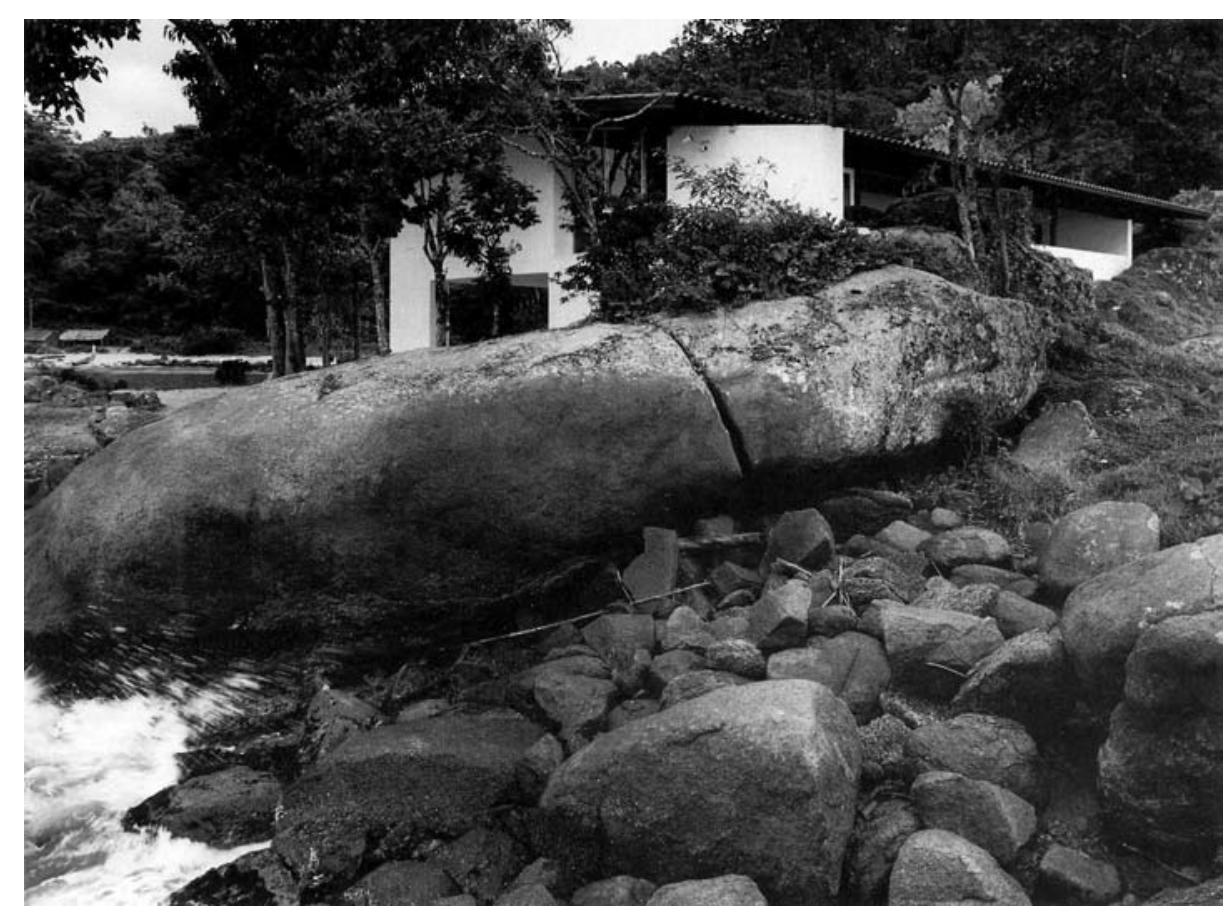

Imagem 116. Casa Francisco Matarazzo Sobrinho, de Oswaldo Bratke. Autoria: P. Scheier. Fonte: SEGAWA; DOURADO (1997), p.163.

A fotografia interna (Imagem 115), numa composição quase simétrica, mostra a sala de estar central, com seus móveis da loja Branco \& Preto ${ }^{92}$ e seu teto abobadado, invadida pela luz natural que penetrava através dos caixilhos de vidro, com suas cortinas abertas. O terreno é vislumbrado através desses caixilhos, presentes em ambos os lados.

A natureza exuberante de Ubatuba fez Peter Scheier documentar a casa de Francisco Matarazzo Sobrinho (Oswaldo Bratke, 1959/60) como coadjuvante do entorno, totalmente inserida e harmoniosa com a praia, a vegetação nativa e as pedras circundantes. Postura que fica clara na imagem em que Scheier se posicionou em meio às pedras à beira-mar e enquadrou uma delas, de grandes dimensões, centralmente no primeiro plano: a casa aparece totalmente incrustada em meio às rochas e à vegetação, quase camuflada (Imagem 116).

$92 \quad$ Escritório de arquitetura e design composto por Carlos Millan, Chen Y Hwa, Jacob M. Ruchti, Miguel Forte, Plínio Croce e Roberto Aflalo. SANTOS, Maria Cecilia Loschiavo dos. Móvel moderno no Brasil. São Paulo: Studio Nobel / FAPESP, 1995, p. 111. 


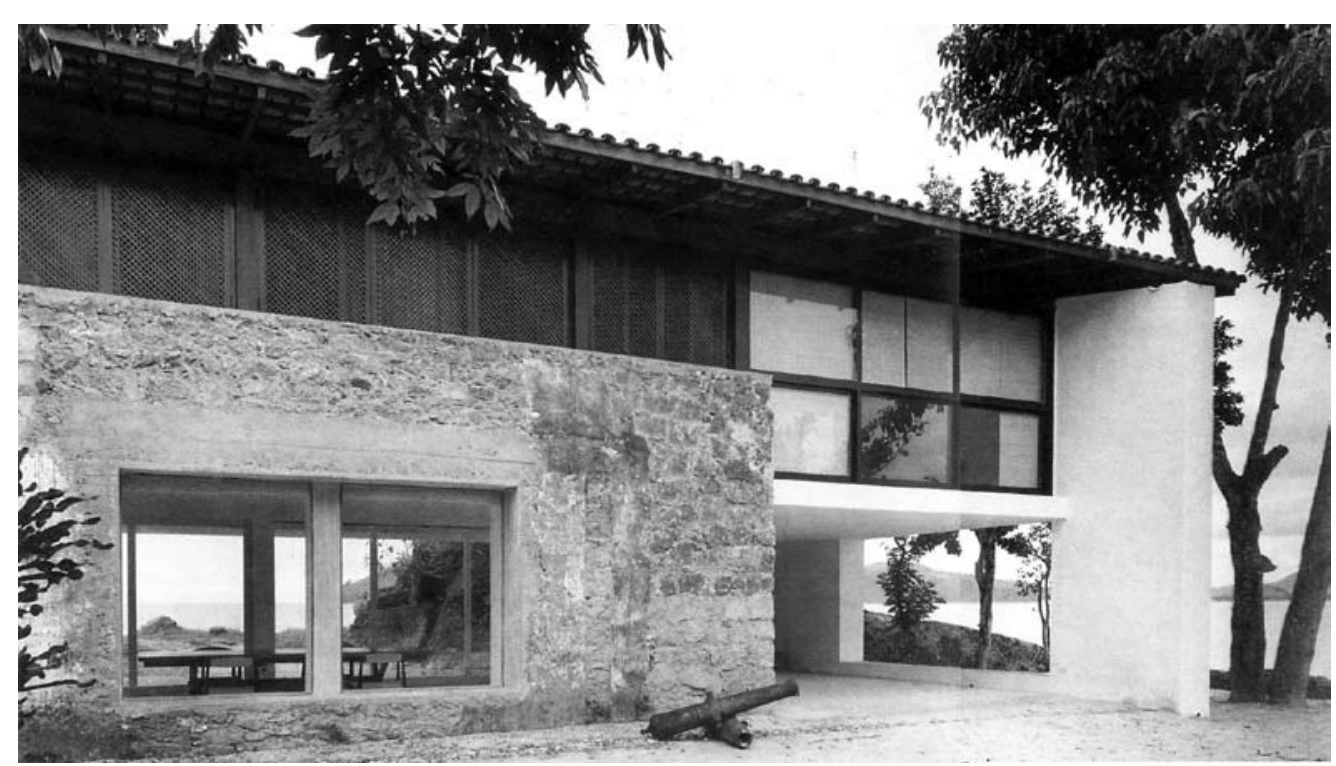

Imagem 117. Casa Francisco Matarazzo Sobrinho. Autoria: P. Scheier. Fonte: SEGAWA; DOURADO (1997), p.160-161

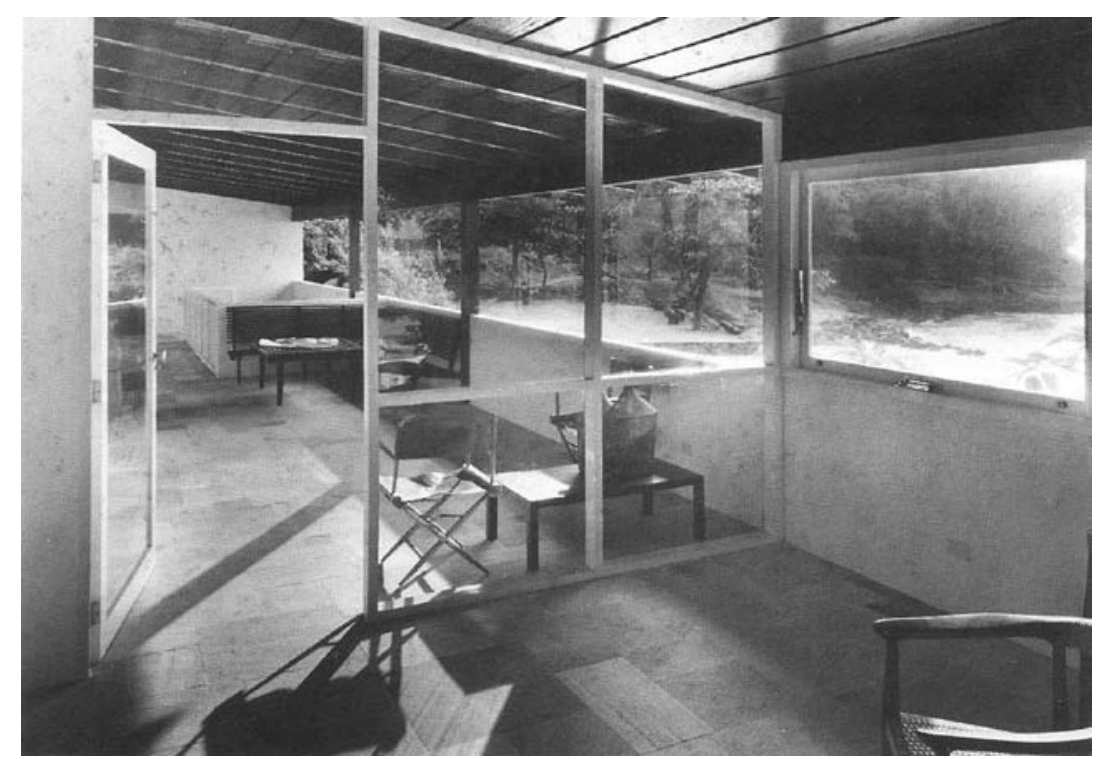

Imagem 118. Alpendre da casa Francisco Matarazzo Sobrinho. Autoria: P. Scheier. Fonte: SEGAWA; DOURADO (1997), p.154.

A praia é vista através de janelas e do alpendre ou refletida nas grandes portas de vidro. Na imagem da fachada lateral (Imagem 117), a praia ao fundo foi enquadrada nos caixilhos de vidro e no vazio aberto na alvenaria. Aqui se vê uma composição de planos muito bem resolvida, numa seqüência de muxarabis, caixilhos de vidro, alvenaria revestida e muro de pedra existente (incorporado à 


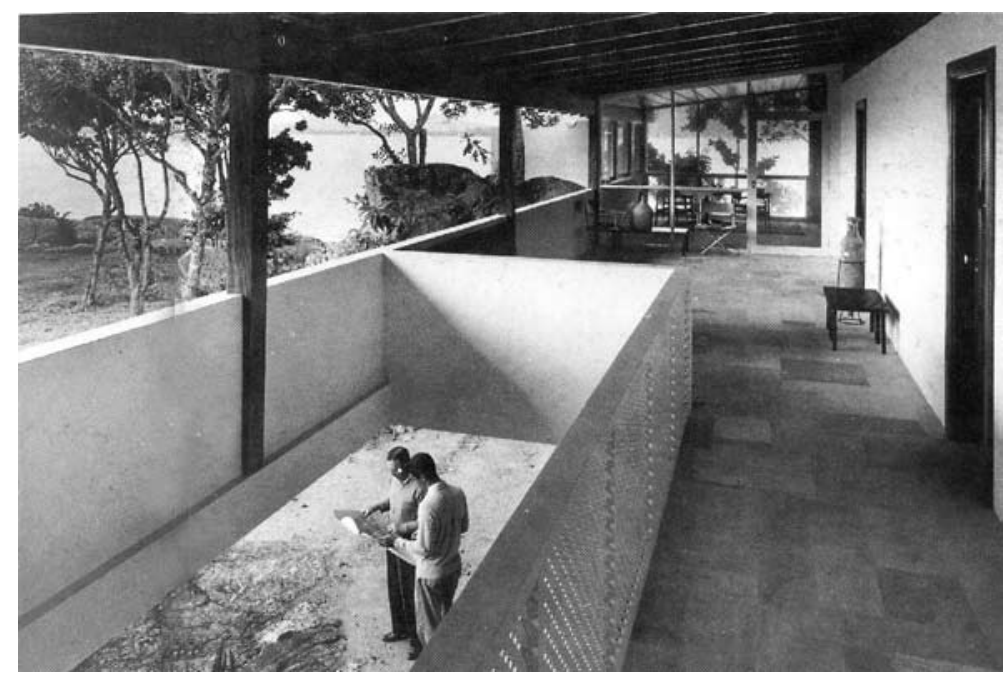

Imagem 119. Alpendre da casa Francisco Matarazzo Sobrinho. No térreo, vê-se Oswaldo Bratke analisando um desenho. Autoria: P. Scheier. Fonte: SEGAWA; DOURADO (1997), p.154155.

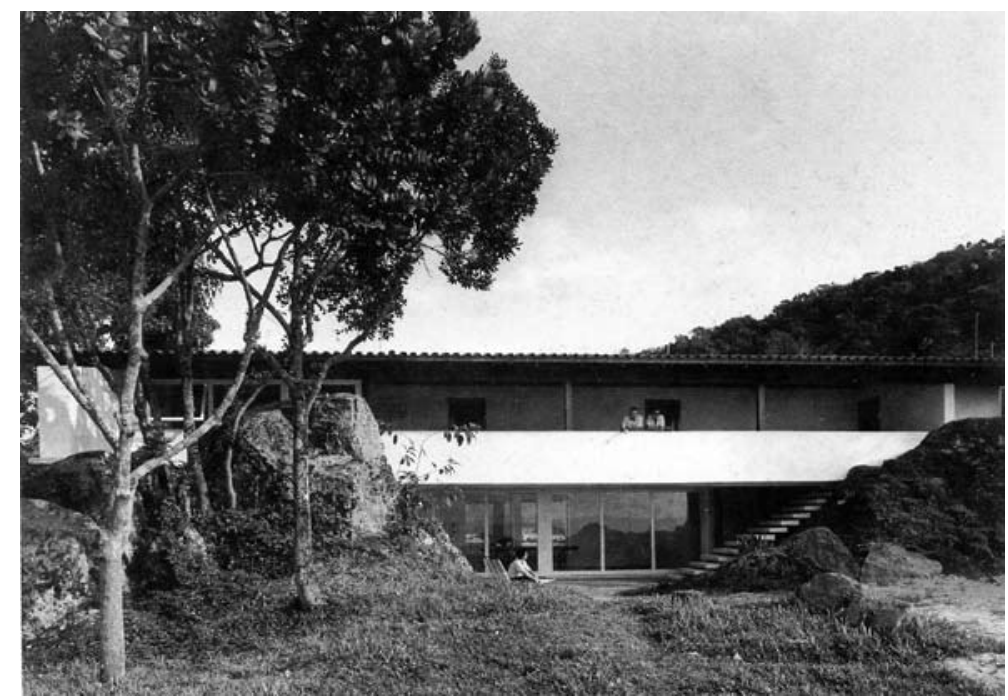

Imagem 120. Vista da casa Francisco Matarazzo Sobrinho. Autoria: P. Scheier. Fonte: Acrópole, n.278, p.052. Acervo da FAUUSP.

construção) encabeçada pelo plano horizontal do telhado.

Nas fotos feitas no alpendre, no andar superior - sempre com a praia como pano de fundo - Scheier ressaltou a transparência e a abertura da casa. Em uma delas, feita de dentro da sala de estar, a luz rasante que entra pelo 


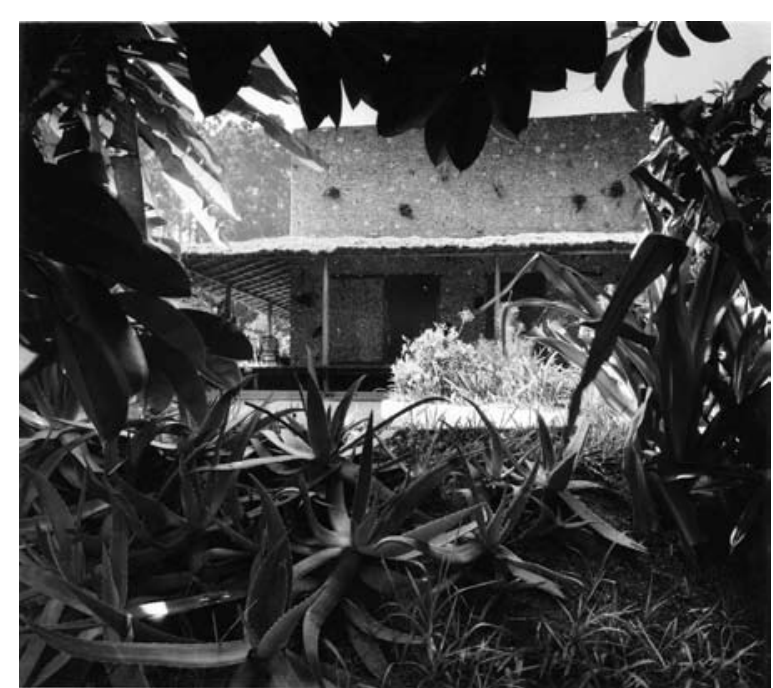

Imagem 121. Vista externa da casa Valéria P. Cirrell, de Lina Bo Bardi. Autoria: P. Scheier. Fonte: Arquivo ILPB.

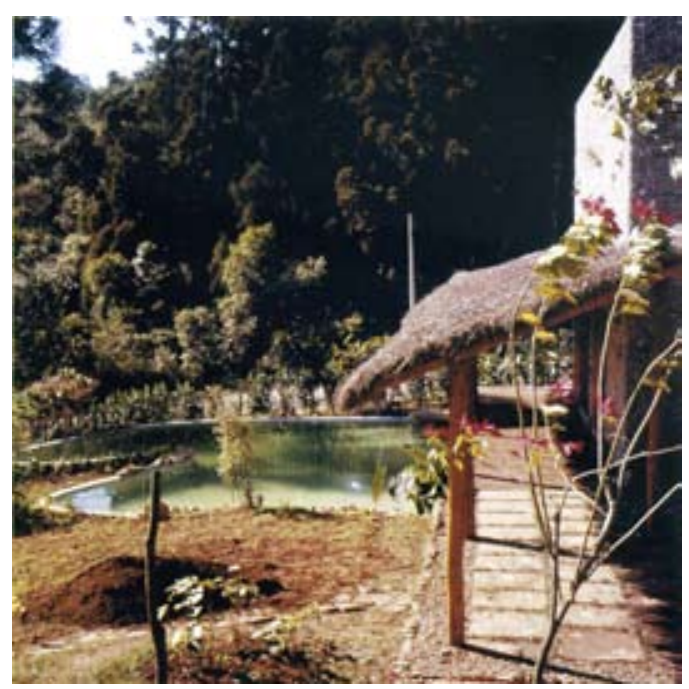

Imagem 122. Vista externa da casa Valéria P. Cirrell, de Lina Bo Bardi. Autoria: P. Scheier. Fonte: GALLO (2003), p. 64.

terraço projeta sombras longas dos móveis sobre o piso (Imagem 118). Em outra, enquadrou dois homens que analisavam um desenho - sendo um deles o próprio arquiteto - no vão da escada, entre o guarda-corpo de madeira e o de alvenaria (Imagem 119). Essas pessoas aparecem novamente em uma fotografia externa, debruçadas sobre o guarda-corpo do alpendre, acompanhadas de uma terceira, sentada na espreguiçadeira no térreo (Imagem 120).

Esta simbiose entre a construção e a natureza circundante foi explorada por Scheier nas fotos da casa Valéria P. Cirrell (Lina Bo Bardi, São Paulo, 1958). A casa foi retratada totalmente inserida na vegetação, traduzindo assim as idéias que permearam o projeto de Lina Bo Bardi (Imagem 121). Em uma rara foto colorida (Imagem 122), Scheier enquadrou a varanda com sua cobertura de sapê, a parede revestida de pedras roladas de rio, o espelho d'água de forma irregular, a vegetação e o jardim recém-implantado, numa composição que deixa clara a integração casa-entorno.

Na foto interna, porém, o exterior não é referenciado, uma vez que se trata 


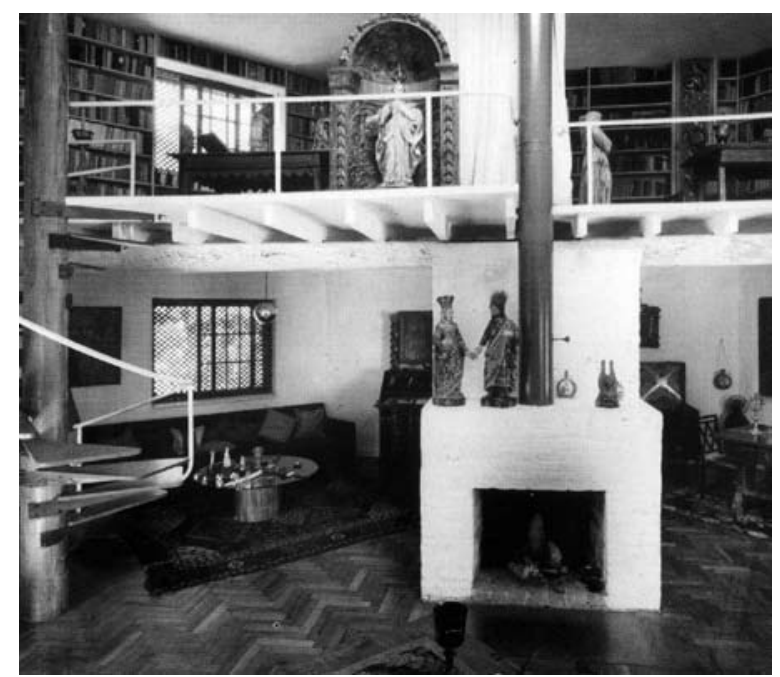

Imagem 123. Interior da casa Valéria P. Cirrell, de Lina Bo Bardi. Autoria: P. Scheier. Fonte: GALLO (2003), p. 67.

de uma casa fechada, voltada para si (Imagem 123). Seu interior era denso, repleto de obras de arte e objetos: estátuas, adornos, tapetes e móveis. Em primeiro plano, vê-se a lareira suspensa, ladeada pela estrutura do mezanino; à esquerda, vê-se parcialmente a escada em caracol. O desenho do piso em tacos de madeira reverbera na disposição dos livros na estante no piso superior.

Na residência Lina Bo Bardi (São Paulo, 1951), a integração com o entorno e a comunicação com o exterior é abordada tal qual na Oscar Americano. A implantação da casa na parte mais alta do terreno, com vista para o ainda desocupado bairro do Morumbi ${ }^{93}$, a grande área de jardim e a vedação em vidro estão sintetizadas em quase todas as imagens internas da residência: o bairro é revelado através dos grandes panos transparentes e permeado por móveis, objetos de arte e livros organizados nas estantes desenhadas pela arquiteta (Imagem 124/125). Posicionado junto à caixilharia, Scheier fez um dos mais

93 A residência Lina Bo Bardi foi a "primeira casa que se construiu no 'Jardim Morumby', quando o bairro ainda tinha esse nome (antiga Fazenda de Chá Muller Carioba)". Fonte: FERRAZ, Marcelo Carvalho (org.). Lina Bo Bardi. São Paulo: Empresa das Artes / Instituto Lina Bo e P.M.Bardi, 1993, p.78. 


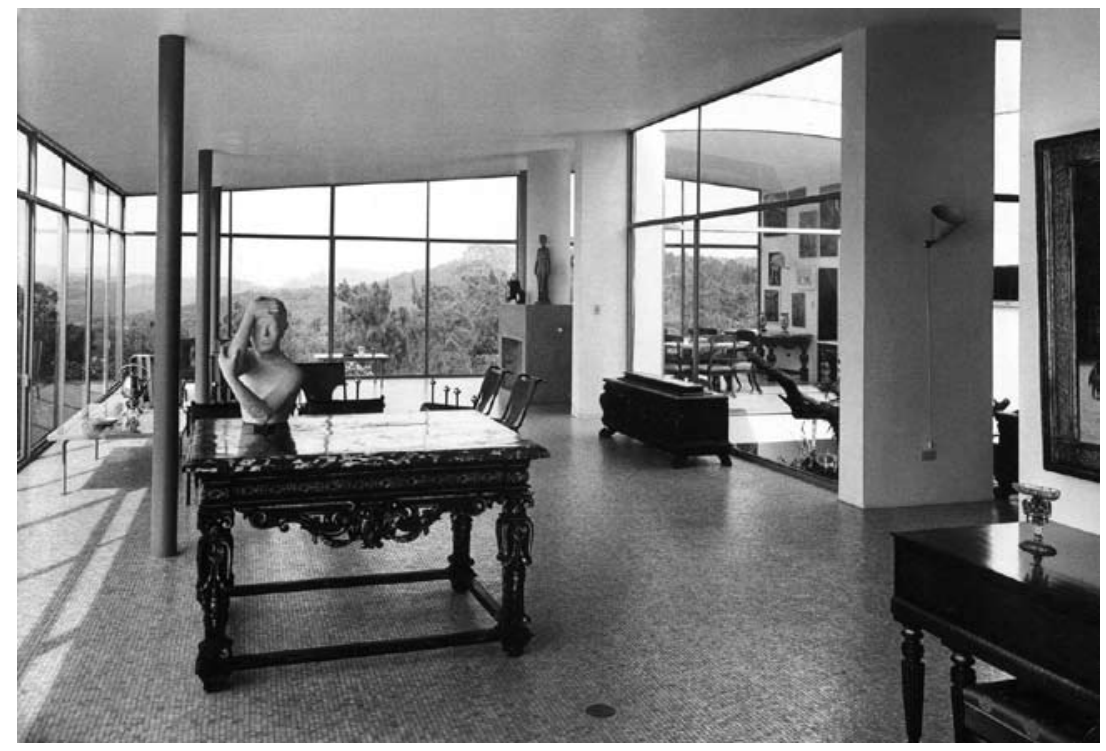

Imagem 124. Interior da residência Lina Bo Bardi. Autoria: P. Scheier. Fonte: BARDI; FERRAZ (1999), p.13.

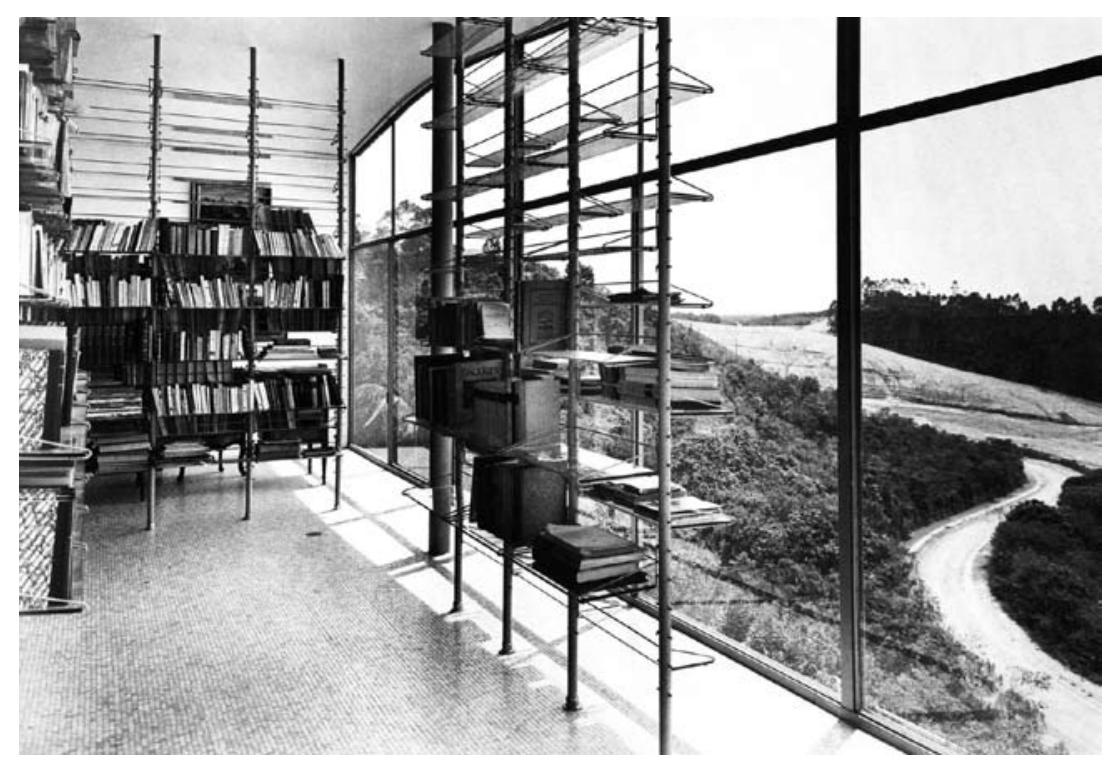

Imagem 125. Vista do bairro do Morumbi a partir do interior da residência Lina Bo Bardi. Autoria: P. Scheier. Fonte: FERRAZ (1993), p.81.

completos retratos do projeto, publicado em Modern Architecture in Brazil e na revista Habitat94 (Imagem 126).

Dentro do lote, Scheier se concentrou nos ângulos que revelavam a mesma 


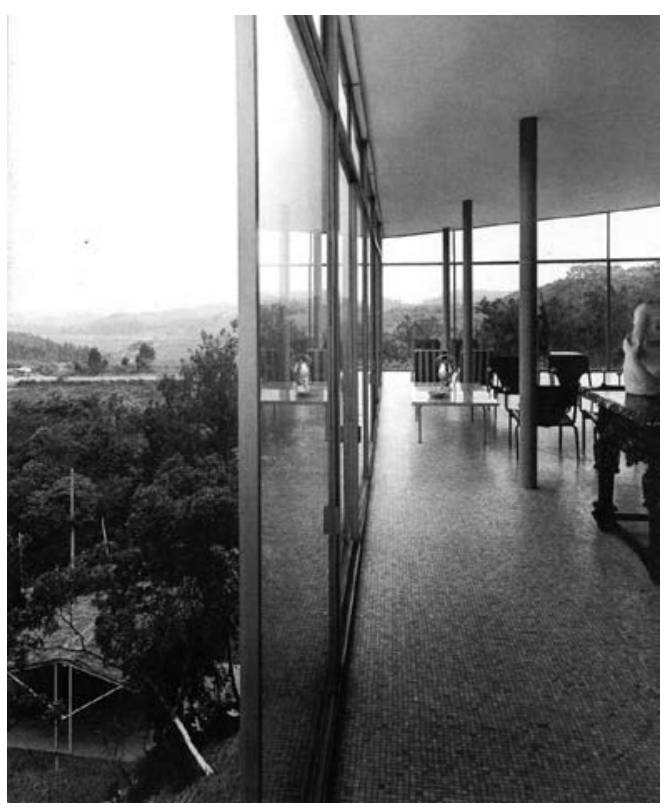

Imagem 126. Interior da residência Lina Bo Bardi, com bairro do Morumbi ao fundo. Autoria: P. Scheier. Fonte: MINDLIN (1956), p.43.

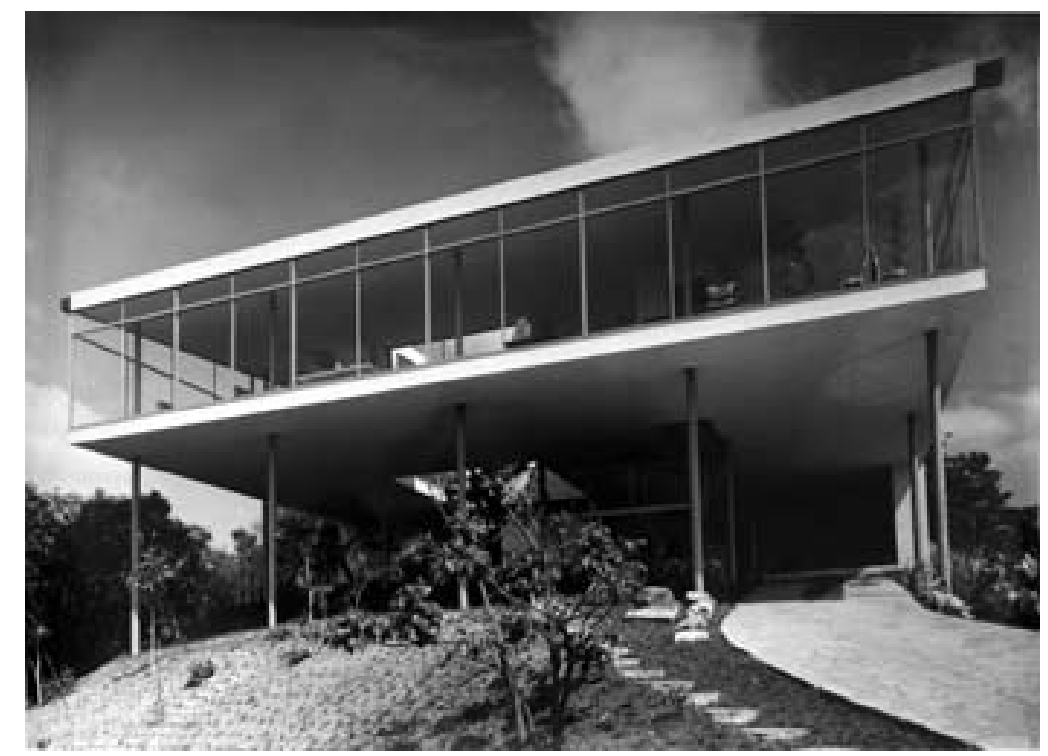

Imagem 127. Vista externa da residência Lina Bo Bardi. Autoria: P. Scheier. Fonte: Arquivo ILPB.

transparência, porém no sentido oposto. Os objetos internos foram retratados a partir de tomadas externas, que exploravam a leveza da construção sobre os delgados pilotis, cujo desenho que segue através da laje de piso até a cobertura 


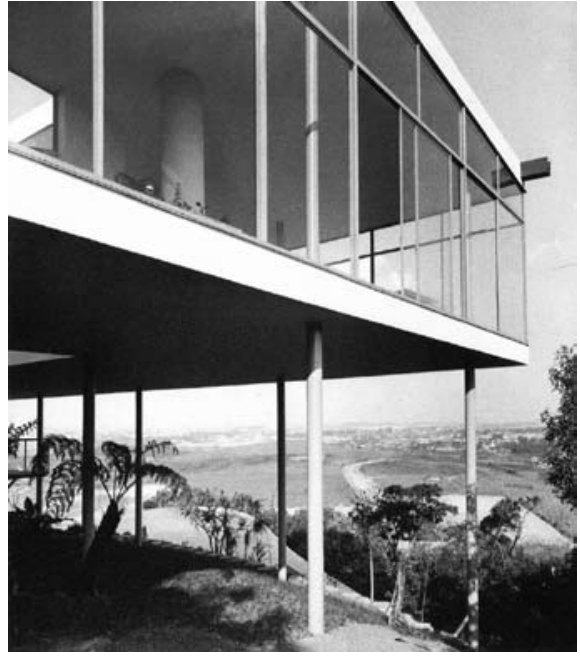

Imagem 128. Vista externa da residência Lina Bo Bardi. Autoria: P. Scheier. Fonte: BARDI; FERRAZ (1999), p.10.

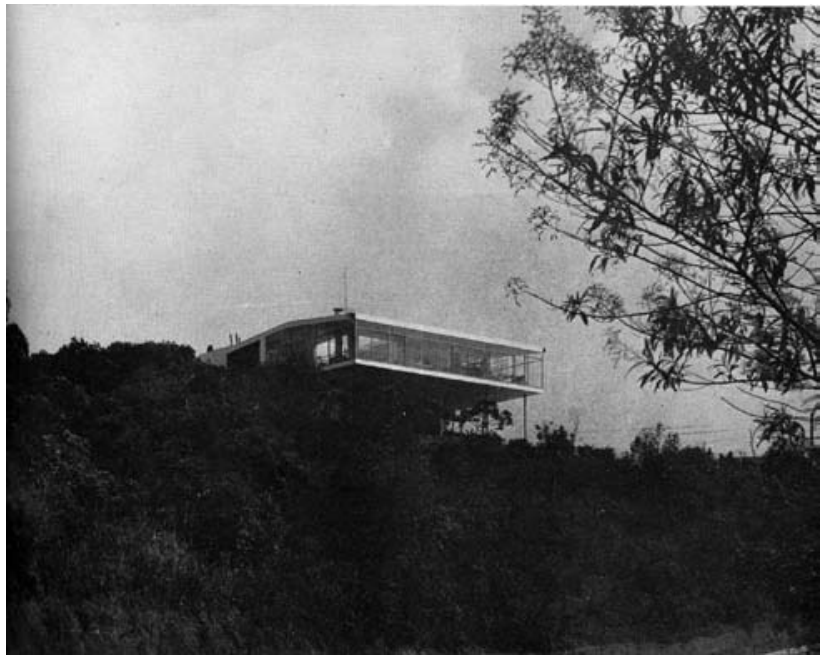

Imagem 129. Vista geral da residência Lina Bo Bardi a partir do bairro. Autoria: P. Scheier. Fonte: Habitat, n.10, p.31. Acervo da FAUUSP.

os mescla com os montantes verticais da caixilharia. O caminho sinuoso que conduz à garagem, a acentuada subida pela escada de pedras brutas, as rochas misturadas à vegetação, a escada metálica vazada e a árvore que penetra no interior da casa através da abertura na laje também são alvo de documentação (Imagem 127). E no intento de retratar a residência de todas as direções, Scheier nos proveu com duas imagens externas relevantes. Uma documenta apenas uma quina do volume da casa, mostrando, através dos pilotis, o bairro do Morumbi, tal qual nas imagens internas (Imagem 128). Outra fotografia, feita a partir da rua, mostra claramente a implantação da casa no ponto mais alto da colina, em meio à vegetação nativa, sem a presença de construções vizinhas (Imagem 129).

Estas relações espaciais mudam de caráter na residência Milton Guper (São Paulo, 1951-1953), de Rino Levi. Roberto Aflalo Filho lembra que em "um lote urbano, o muro passa a ser parte integrante da casa. A casa-pátio surge como uma solução natural. Não é a residência isolada dos limites de um terreno 


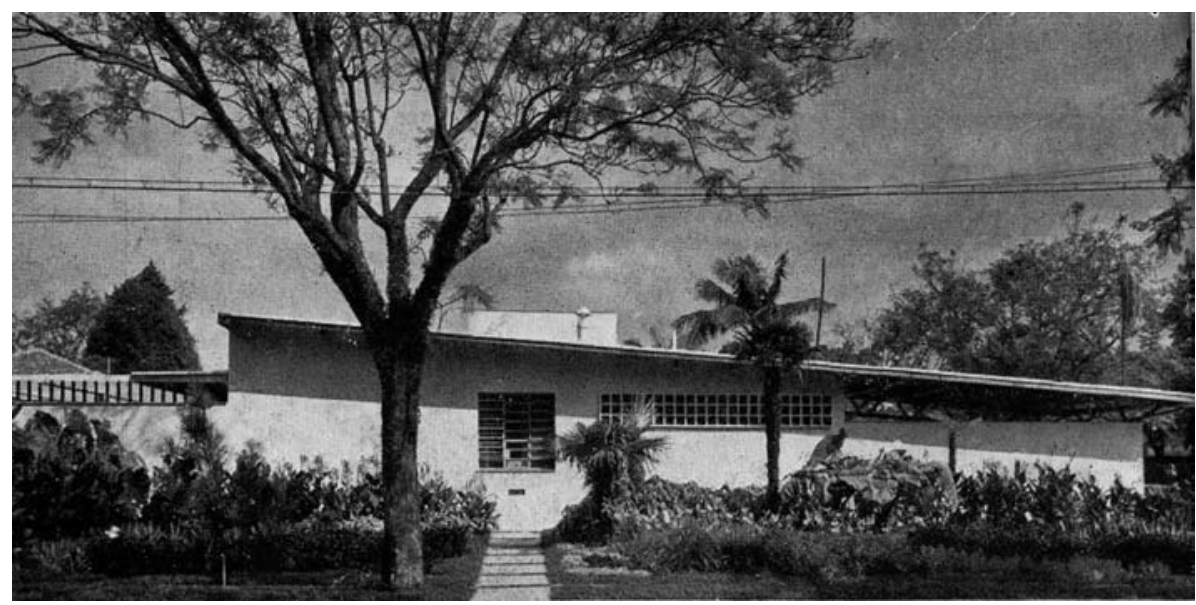

Imagem 130. Fachada da Rua Venezuela da residência Milton Guper, de Rino Levi. Autoria: P. Scheier. Fonte: MINDLIN (1956), p.64.

de grandes dimensões" ${ }^{95}$. A casa-pátio aparece como "uma maneira de abrir o interior da casa sem perder o sentido de intimidade do ambiente doméstico" ${ }^{96}$. Assim, Scheier retomou posturas adotadas nas casas de Bernardo Rudofsky e abandonou as preocupações de inserção do projeto no entorno, como nos projetos de Warchavchik, Bratke e Lina.

Peter Scheier mostrou sensibilidade para ressaltar os pontos primordiais do projeto: o jardim como extensão da sala de estar e o conforto fornecido pelo pergolado, cujo sombreamento protege a área da incidência solar direta. Todas as imagens demonstram seu cuidado com o paralelismo das linhas verticais e o equilíbrio de suas composições, em geral frontais e com um único ponto de fuga.

A fachada para a Rua Venezuela não é a principal, entretanto corresponde à seção mais elucidativa do projeto, com o pergolado à esquerda e a treliça da cobertura da garagem à direita, ligadas pelo plano inclinado do telhado de uma água (Imagem 130). Vale ressaltar que em Scheier não são tão freqüentes $95 \quad$ Apud. TOUCEDA. Op. cit, p. 240.

96 ANELLI, Renato; GUERRA, Abílio; KON, Nelson. Rino Levi - arquitetura e cidade. São Paulo: Romano Guerra Editora, 2001, p. 93. 


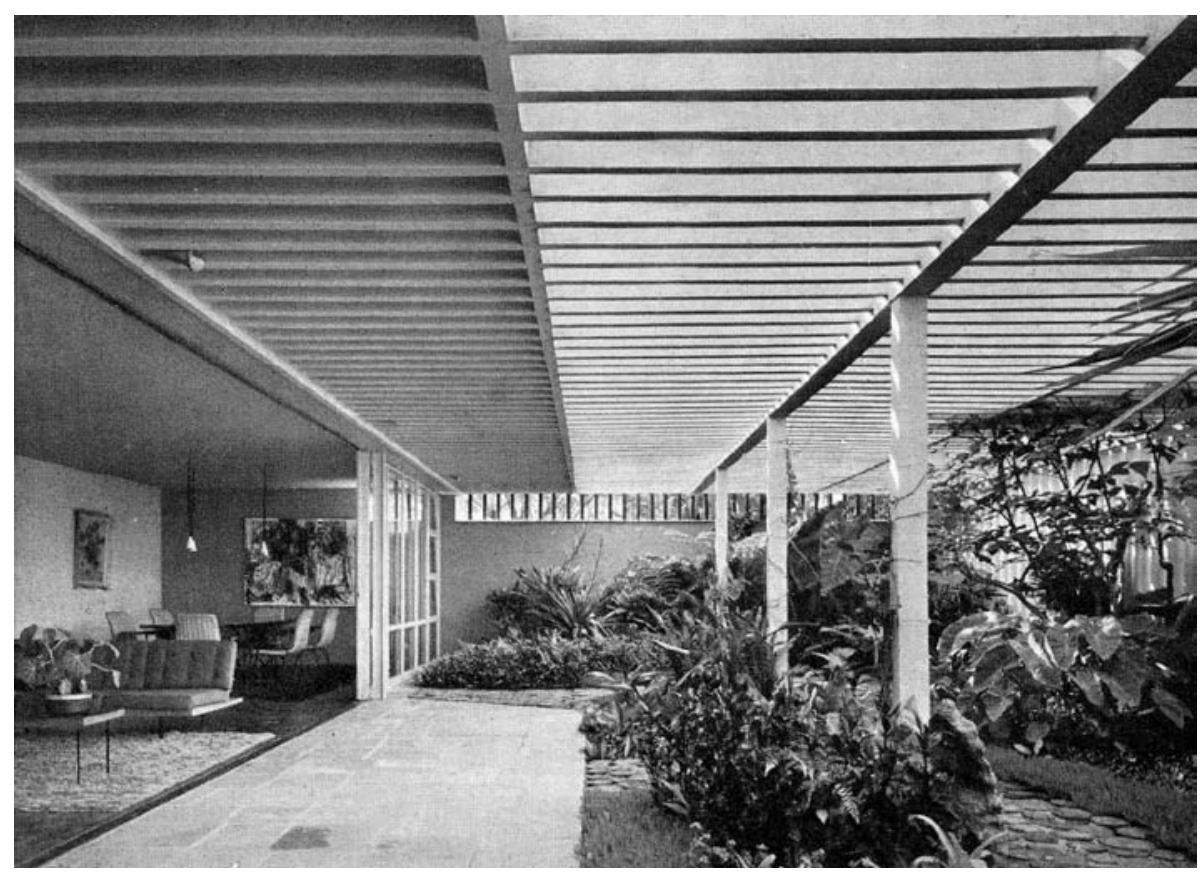

Imagem 131. Vista do jardim interno da residência Milton Guper. Autoria: P. Scheier. Fonte: $A D, \mathrm{n} .3, \mathrm{~s} / \mathrm{p}$.

registros frontais das fachadas, uma vez que os ângulos oblíquos, que tomam duas fachadas, são mais comuns.

A relação entre o jardim e a sala de estar predomina num conjunto formado por três fotografias complementares, uma frontal ao jardim e as outras perpendiculares a ele, opostamente direcionadas. O rigor geométrico exprimese nas vigas do pergolado, no fechamento vertical e nos planos dos módulos do caixilho da sala - rigor suavizado pela presença da vegetação.

Na vista do jardim, com a sala de estar à esquerda (Imagem 131), há um contraponto entre as linhas horizontais do pergolado e as verticais compostas pelos pilares à direita e o caixilho à esquerda. O predomínio da área de teto valoriza o desenho em linhas paralelas do pergolado, reforçando a horizontalidade do projeto. Uma segunda foto, frontal e paralela ao caixilho da sala, dá uma visão total do jardim (Imagem 132). Em outra imagem (Imagem 133), na qual o jardim está à esquerda, o aparador em primeiro plano e toda a disposição 


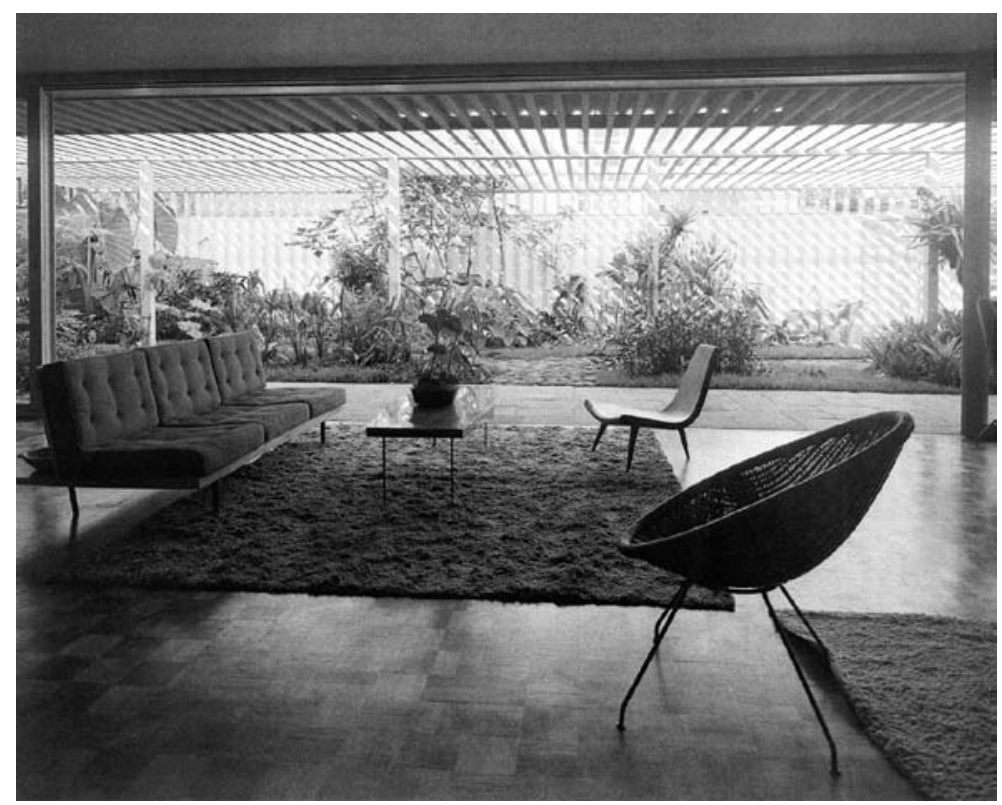

Imagem 132. Vista da sala de estar, com o jardim ao fundo. Residência Milton Guper. Autoria: P. Scheier. Fonte: MINDLIN (1956), p.65.

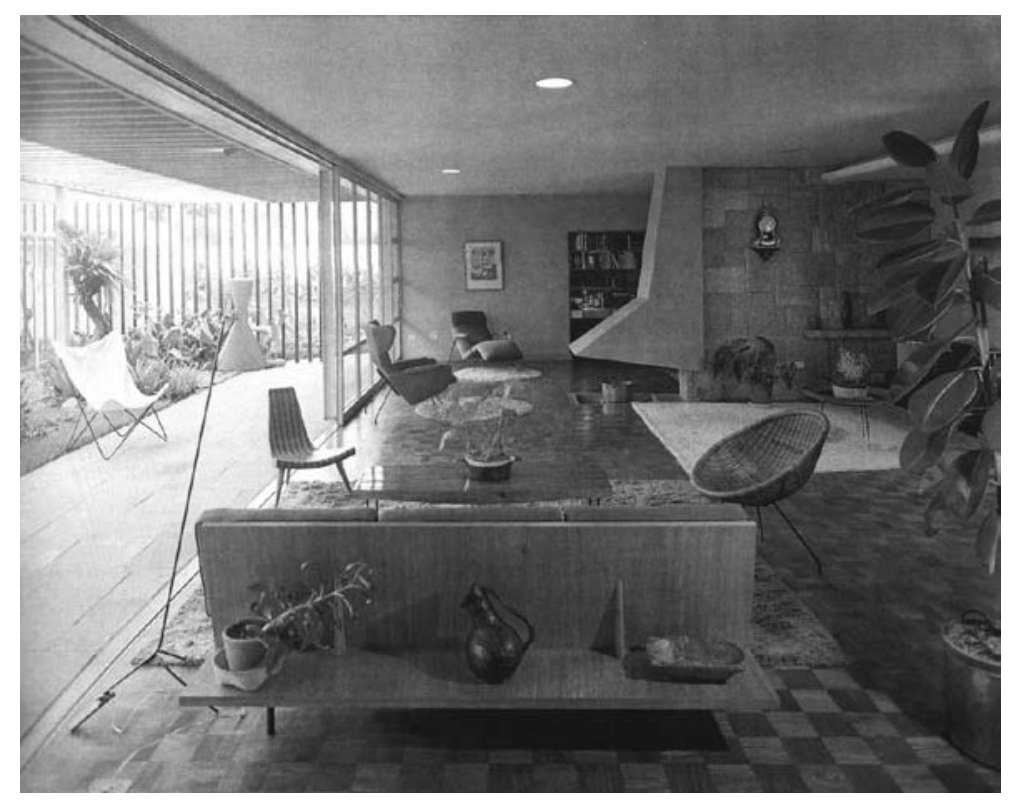

Imagem 133. Vista da sala de estar, com o jardim à esquerda. Residência Milton Guper. Autoria: P. Scheier. Fonte: MINDLIN (1956), p.64. 


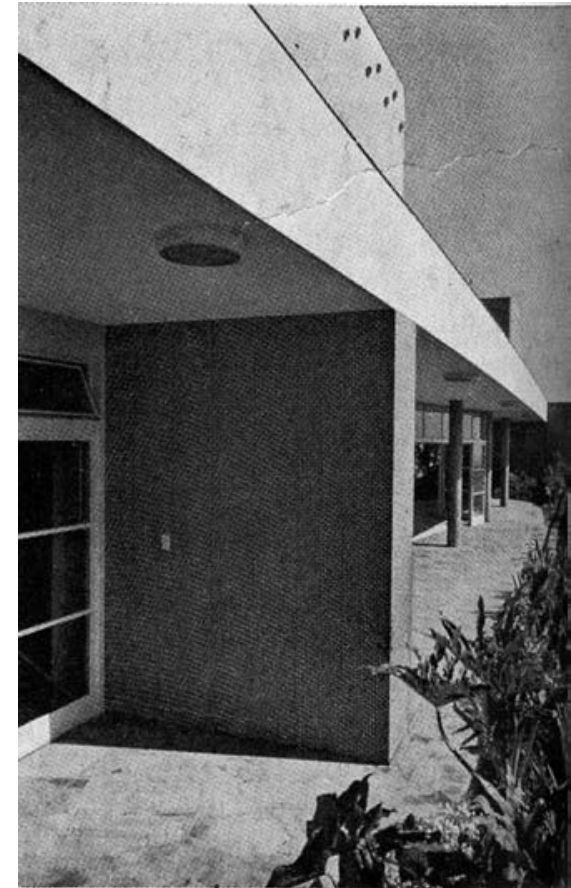

Imagem 134. Vista da cobertura do edifício Prudência, de Rino Levi. Autoria: P. Scheier. Fonte: MINDLIN (1956), p.96.

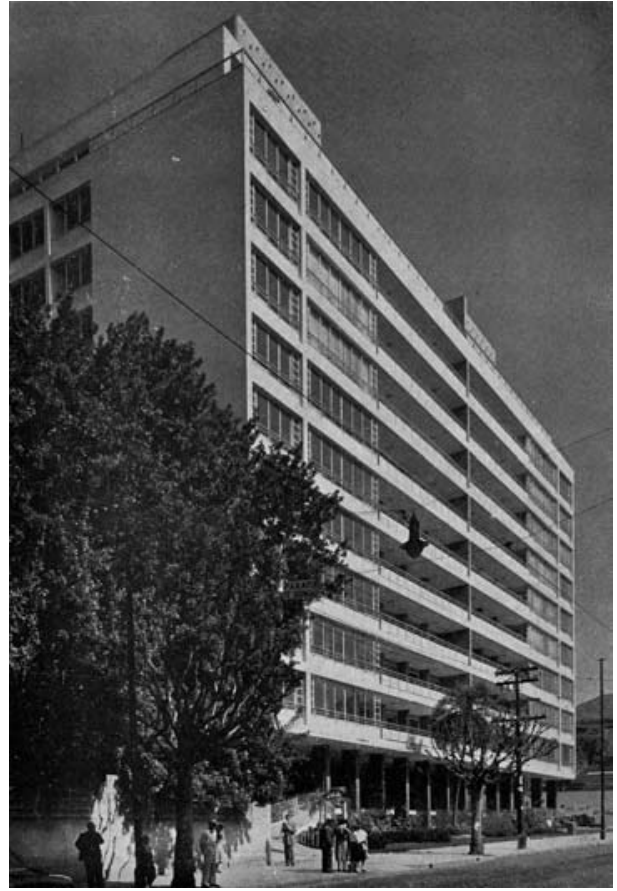

Imagem 135. Vista a partir da Avenida Higienópolis do edifício Prudência. Autoria: P. Scheier. Fonte: MINDLIN (1956), p.96.

interna dos móveis mostra a utilização do mobiliário como divisão interna de ambientes. Para equilibrar a composição, mais densa no lado direito em virtude da mobiliário, Scheier posicionou uma poltrona BKF ${ }^{97}$ no jardim e uma luminária do lado esquerdo - comparando-a com outras fotos, é possível encontrar estes elementos em outros lugares.

As imagens do Edifício Prudência (Rino Levi, São Paulo, 1950), também focam menos o entorno. Na foto da cobertura (Imagem 134), por exemplo, Scheier fechou o campo visual na marquise, e não explorou ângulos que contemplassem também o bairro de Higienópolis. Porém demonstrou o cuidado

$97 \quad$ "BKF é o nome da poltrona desenhada em 1939 por Antonio Bonet, Juan Kurchan e Jorge Ferrari Hardoy, batizada com as iniciais dos autores. Protagonista de nove em cada dez fotografias de casas californianas e imortalizada pela lente de Julius Shulman. (...) Depois de conhecer os hábitos de produção fotográficos de Ezra Stoller e Paul Rudolph, não seria de estranhar que as mesmas BKF passeassem pelas obras de diversos arquitetos de São Paulo." TOUCEDA. Op. cit, p.199. 


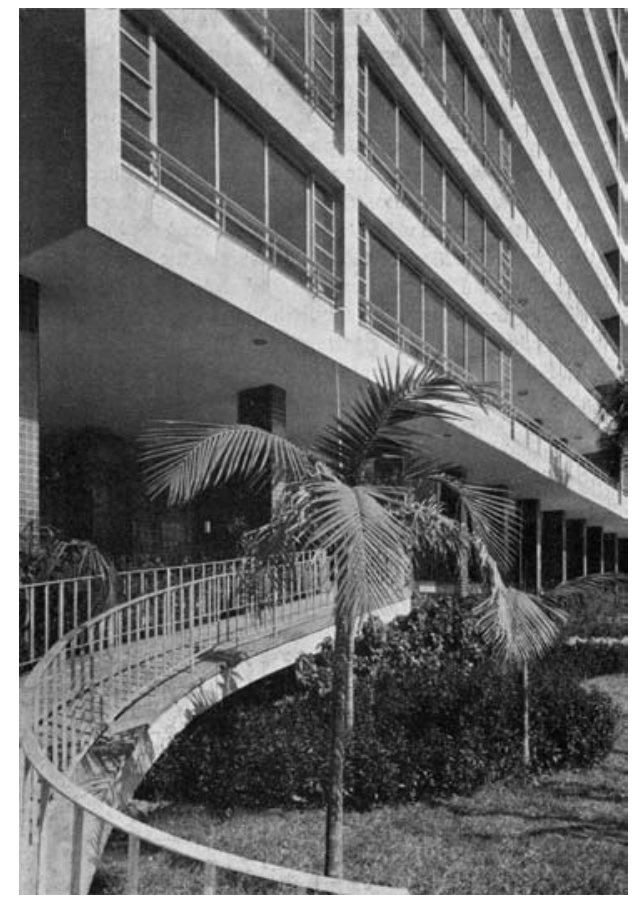

Imagem 136. Rampa de acesso do edifício Prudência. Autoria: P. Scheier. Fonte: MINDLIN (1956), p.97.

de sua documentação arquitetônica: o domínio das verticais, a amarração de elementos externos aos componentes do edifício, a busca de uma lógica no posicionamento e na composição.

O ângulo oblíquo da imagem mais geral acentua a aresta do edifício e permite visualizar duas fachadas do edifício: a principal, na Avenida Higienópolis, e a lateral, com os caixilhos das salas e dormitórios (Imagem 135). A placa "Parada de Bondes", presa ao fio e próximo à luminária, explica a aglomeração de pessoas na calçada, que aguardavam o transporte.

A rampa de acesso e o jardim frontal estão mais detalhados em uma fotografia na qual é possível analisar as soluções dadas à caixilharia e ao guardacorpo (Imagem 136). A imagem parece composta segundo um zoneamento, no qual a curva da rampa se junta aos elementos orgânicos da vegetação, no plano inferior, contrapondo-se à ortogonalidade do caixilho, no plano superior. 


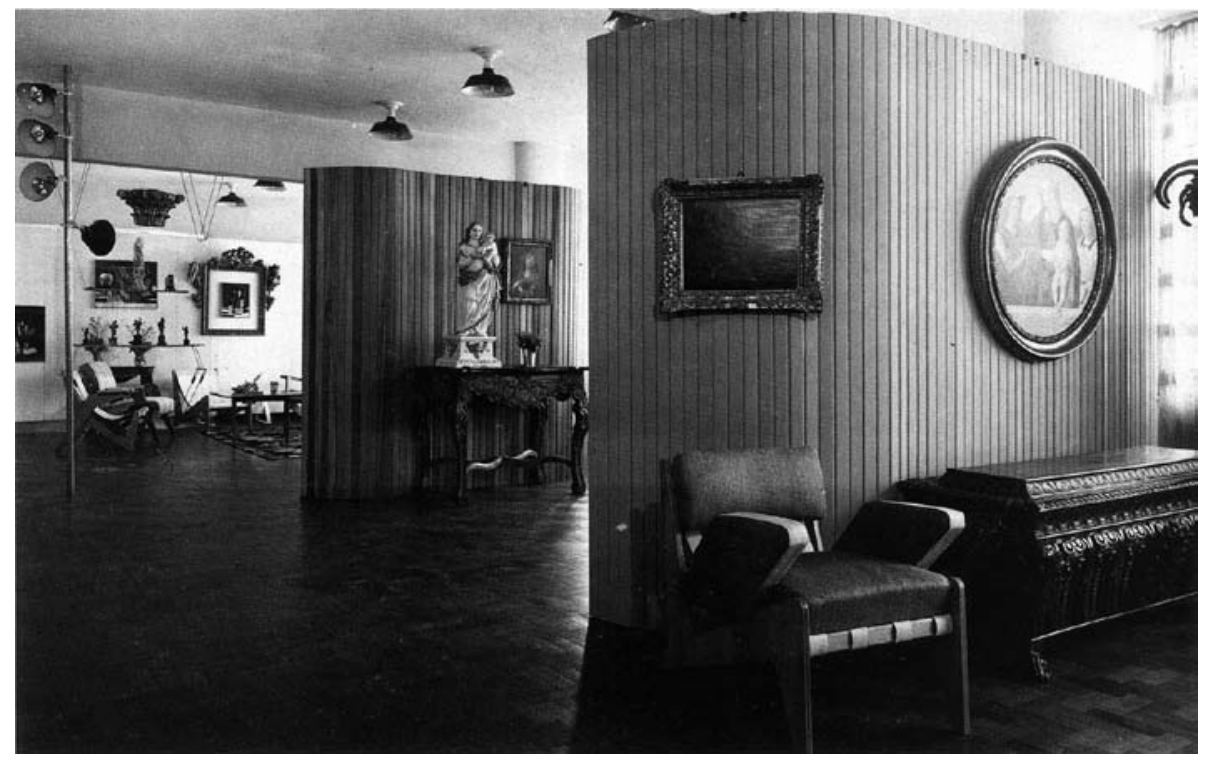

Imagem 137. Vista do interior do Palma Studio de Arte e Arquitetura. Autoria: P. Scheier. Fonte: FERRAZ (1993), p.56.

Entre edifícios residenciais Scheier fotografou também o Edifício Porchat (Rino Levi, São Paulo, 1940-42), na Avenida São João, caracterizado como um conjunto de quatro edifícios independentes que compunham uma fachada denteada. Além do programa habitacional, Peter Scheier documentou projetos institucionais, educacionais, industriais e comerciais de Lina Bo Bardi e Rino Levi.

Em 1948, Pietro Bardi, Lina e Giancarlo Palanti fundaram o Palma Studio de Arte e Arquitetura, com o objetivo de desenvolver um mobiliário moderno, produzido industrialmente e com a preocupação com o clima, os modos de vida e as técnicas vernaculares. Os materiais empregados - madeira e tecidos - eram sempre brasileiros. "O ponto de partida foi a simplicidade estrutural, aproveitandose a extraordinária beleza das veias e da tinta das madeiras brasileiras, assim como seu grau de resistência e capacidade."98

Peter Scheier documentou as instalações do escritório, localizado em uma 


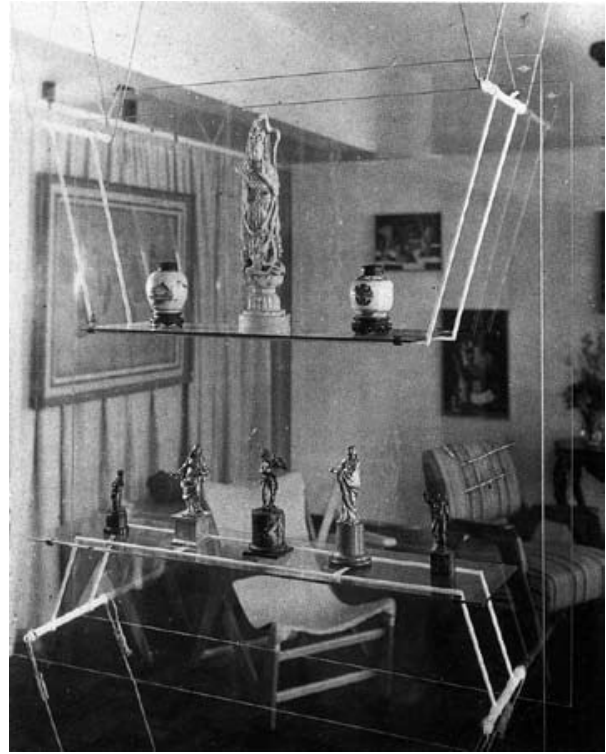

Imagem 138. Estante em vidro e estrutura metálica, no interior do Palma Studio. Autoria: P. Scheier. Fonte: FERRAZ (1993), p.56.

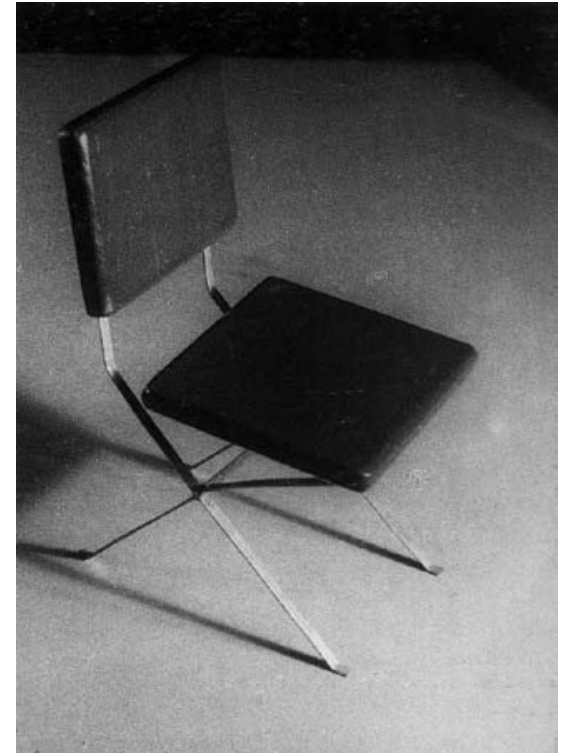

Imagem 139. Modelo de cadeira criado pelo Palma Studio. Autoria: P. Scheier. Fonte: FERRAZ (1993), p.58.

sala do Edifício Thomas Edison, de Lucjan Korngold, no centro. Em conjunto com a função de estúdio, havia ainda um antiquário e uma seção de exposições periódicas de arte antiga e contemporânea. As divisórias curvas, revestidas em lambris de madeira, marcavam o espaço (Imagem 137). Uma estante em vidro e ferro, atirantada no teto, contrapunha-se com leveza aos demais objetos, de constituição e materiais mais pesados (Imagem 138).

Até o início da década de 1950, a produção do Palma em mobiliário e projetos de interiores foi ampla99. Peter Scheier fotografava modelos (Imagem 139) e móveis (Imagem 140/141) isoladamente, em geral contra um fundo escuro, ressaltando, assim, as formas simples e modernas. A documentação também se estendia para os interiores de residências e lojas projetados por Palanti e Lina.

99 Para a fabricação do mobiliário, os sócios fundaram uma fábrica. Há divergências sobre seu nome, mas, segundo pesquisas do Instituto Lina Bo Bardi, o correto seria PAUBRA, encontrado com freqüência em documentos do seu arquivo. 


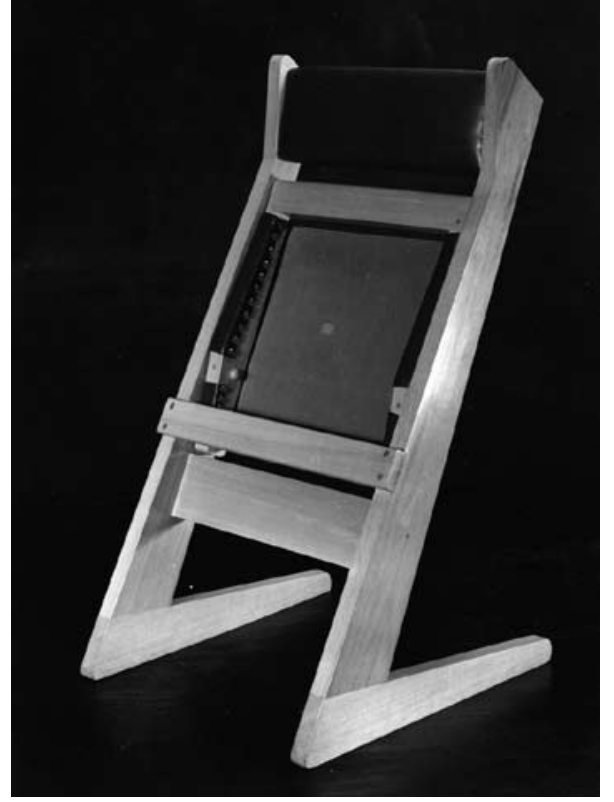

Imagem 140. Cadeira "Z" dobrável, em pau-marfim e couro, criada pelo Palma Studio. Autoria: P. Scheier. Fonte: Arquivo ILPB.

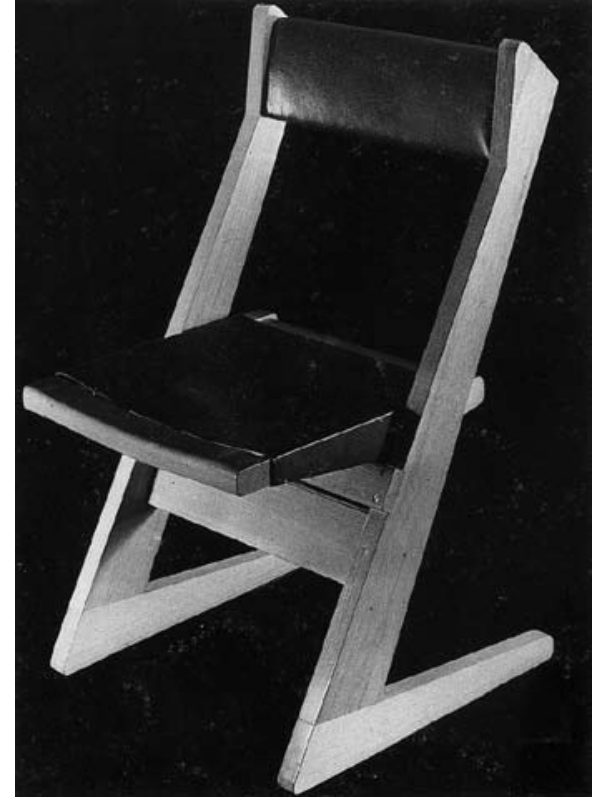

Imagem 141. Cadeira "Z" dobrável, em pau-marfim e couro, criada pelo Palma Studio. Autoria: P. Scheier. Fonte: FERRAZ (1993), p.58.

Na loja da Olivetti Securit (1948), na Rua 24 de Maio, Scheier explorou a transparência da vitrine numa foto noturna, feita a partir da rua, em que todo o interior iluminado se revela em conjunto com o letreiro da fachada (Imagem 142). Esta postura se repetiria com freqüência nas fotos feitas na década de 1960 em Brasília, nas quais também explorava a transparência dos grandes panos de vidro dos palácios e dos edifícios residenciais das super-quadras para retratar seus interiores.

A série da Mapa Importadora, na Rua Sete de Abril, 267 (1948), é composta por fotos da vitrine e vistas internas. Os amplos mostruários de tecidos, compostos por módulos de bobinas apoiados sobre as paredes, marcavam a área de atendimento, com mesas e cadeiras do Studio (Imagem 143). Os manequins em madeira desenhados por Lina e Palanti, de formas elementares, foram registrados no Studio e na vitrine da loja, envoltos em tecidos e em posições 


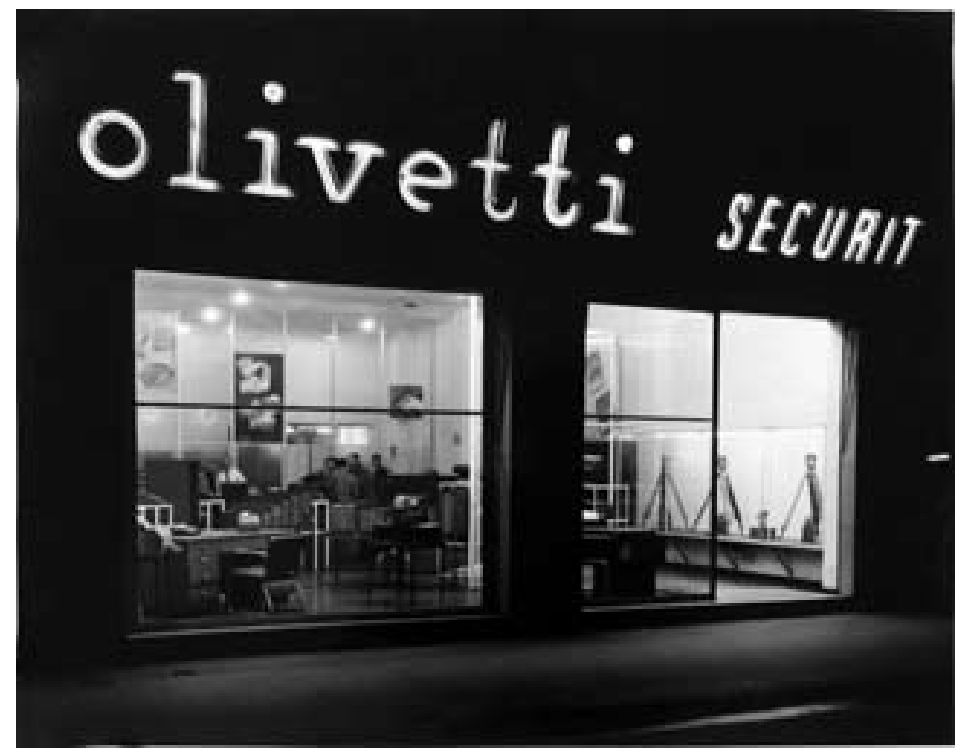

Imagem 142. Vista noturna da loja Olivetti Securit, na Rua 24 de Maio, projeto do Palma Studio. Autoria: P. Scheier. Fonte: Arquivo ILPB.

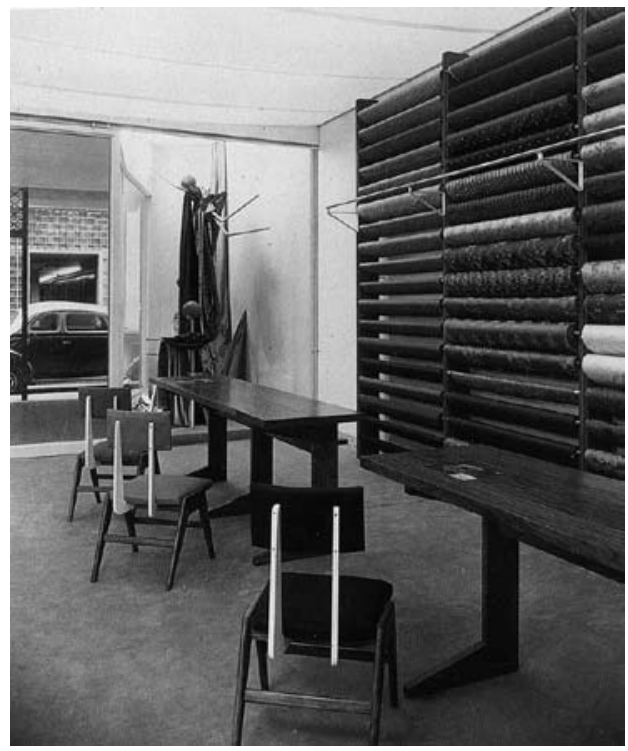

Imagem 143. Interior da Mapa Importadora, na Rua 07 de Abril, projeto do Palma Studio. Autoria: P. Scheier. Fonte: FERRAZ (1993), p.61.

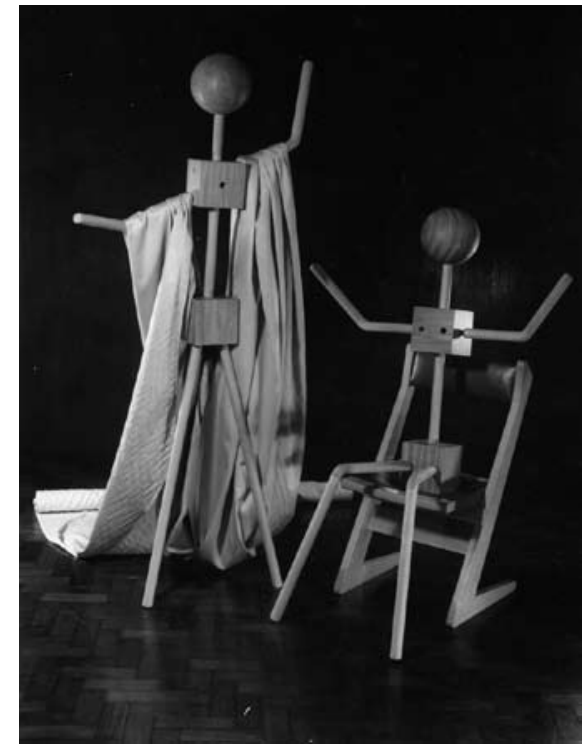

Imagem 144. Manequins de madeira, projeto do Palma Studio. Autoria: P. Scheier. Fonte: Arquivo ILPB.

diferentes, possíveis em função de seu sistema de articulação (Imagem 144).

O show room da fábrica de plásticos Plavinil (Lina Bo Bardi, 1950) foi documentado em todas as suas peculiaridades. Num espaço estreito, repleto 


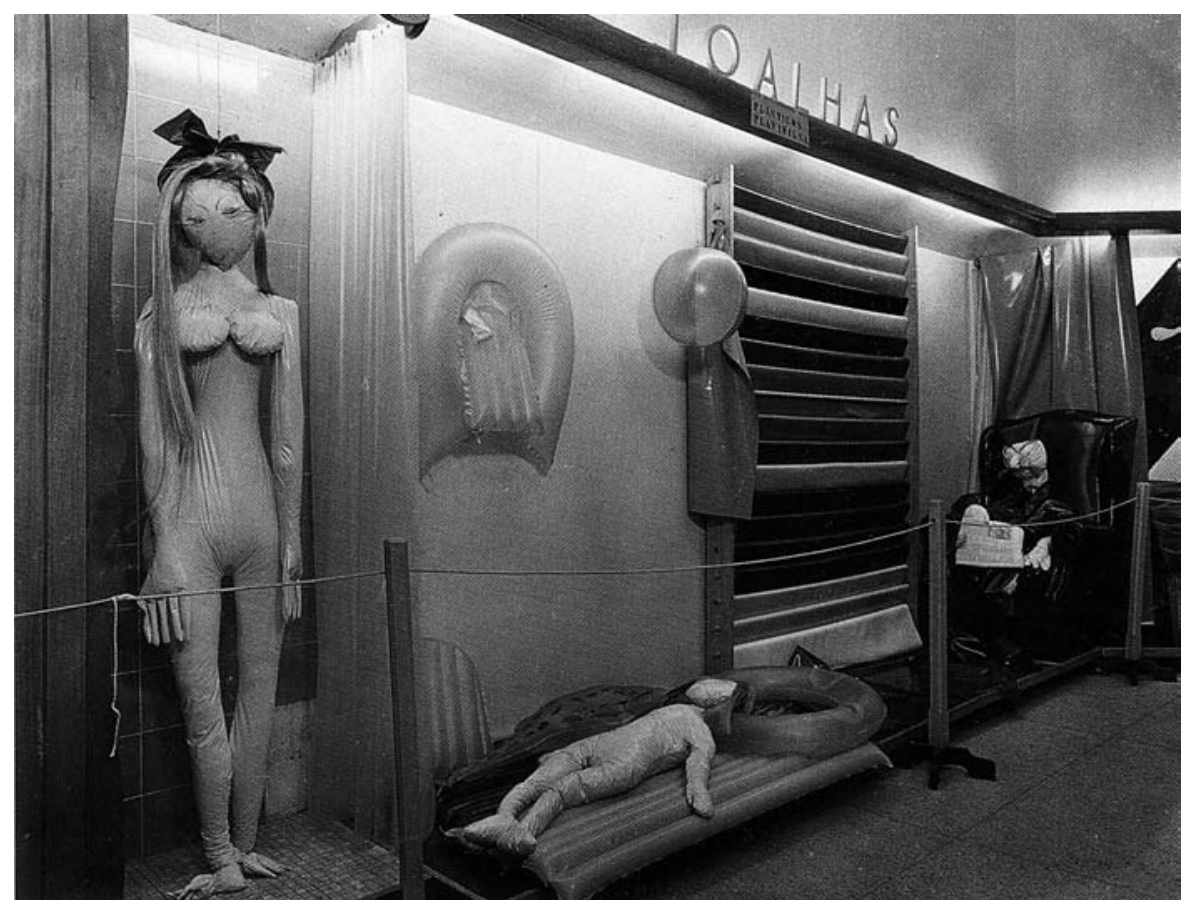

Imagem 145. Show room da fábrica de plásticos Plavinil, projeto do Palma Studio. Autoria: P. Scheier. Fonte: Arquivo ILPB.

de produtos dos mais diversos segmentos, Scheier captou o humor que Lina empregou na disposição das seções temáticas (Imagem 145). Para demonstrar a aplicação dos produtos, bonecos infláveis de plástico foram colocados em diversas situações cotidianas, tais como sentado em poltrona lendo um jornal, no chuveiro, em uma mesa ou deitado sobre um colchão de ar, como se tomasse um banho de sol.

Contemporâneas à documentação do Palma Studio são as fotografias do MASP. O Museu de Arte de São Paulo (Lina Bo Bardi, 1947) ocupava dois andares da sede dos Diários Associados, na Rua Sete de Abril. No primeiro andar ficavam os auditórios, laboratório de fotografia, secretaria e biblioteca, ao passo que no segundo ficava exposto o acervo permanente. Os cursos promovidos pelo IAC aconteciam em outros andares do edifício.

As estátuas localizadas no fundo do salão de exposição do acervo 


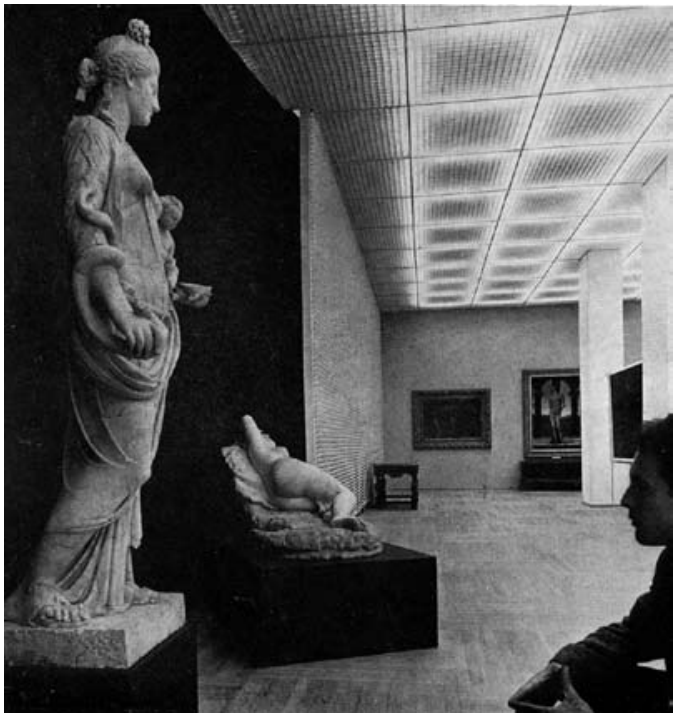

Imagem 146. Vista do acervo permanente do MASP. À direita, o próprio Scheier. Autoria: P. Scheier. Fonte: MINDLIN (1956), p.182.

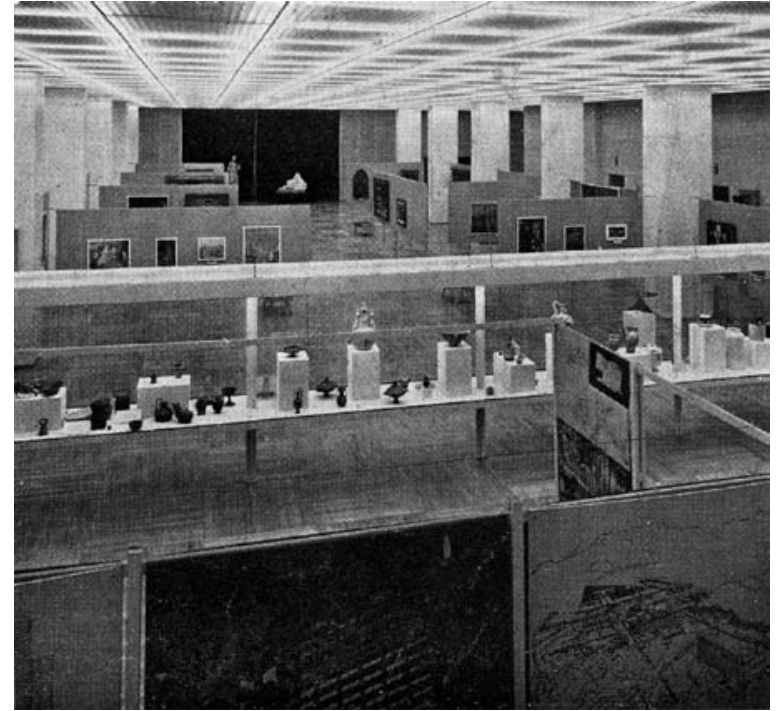

Imagem 147. Vista geral do acervo permanente do MASP, com a "vitrine das formas" no primeiro plano. Autoria: P. Scheier. Fonte: MINDLIN (1956), p.183.

permanente estão em uma fotografia frontal (Imagem 146), estruturada de forma interessante: do lado esquerdo, dominado pelo fundo preto, estão duas grandes estátuas, uma escultura grega do século IV, em primeiro plano, e uma deitada, "Bacante Adormecida", de Valério Villareale, logo a seguir. Ao fundo, móveis e quadros atraem a atenção, como a tela "São Sebastião na Coluna", de Pietro Perugino, à direita. Para equilibrar a composição, cujo vazio à direita seria incômodo, Scheier colocou-se sentado em frente à estátua, observando-a, preenchendo o primeiro plano ${ }^{100}$.

As demais fotografias apresentam ângulo oblíquo, para mostrar a extensão do espaço da coleção permanente. Enfatizam a iluminação e o forro vazado de elementos metálicos e a continuidade e flexibilidade do espaço garantida pelos suportes metálicos dos painéis de exposição, cuja interferência é quase nula. A foto mais geral (Imagem 147) foi feita com o equipamento num plano elevado,

100 Este recurso já foi visto na seção referente à revista $O$ Cruzeiro. Scheier costumava inserir-se em fotografias, valendo-se de retrovisores de carro, espelhos, tripés e disparadores para produzir seus auto-retratos. 


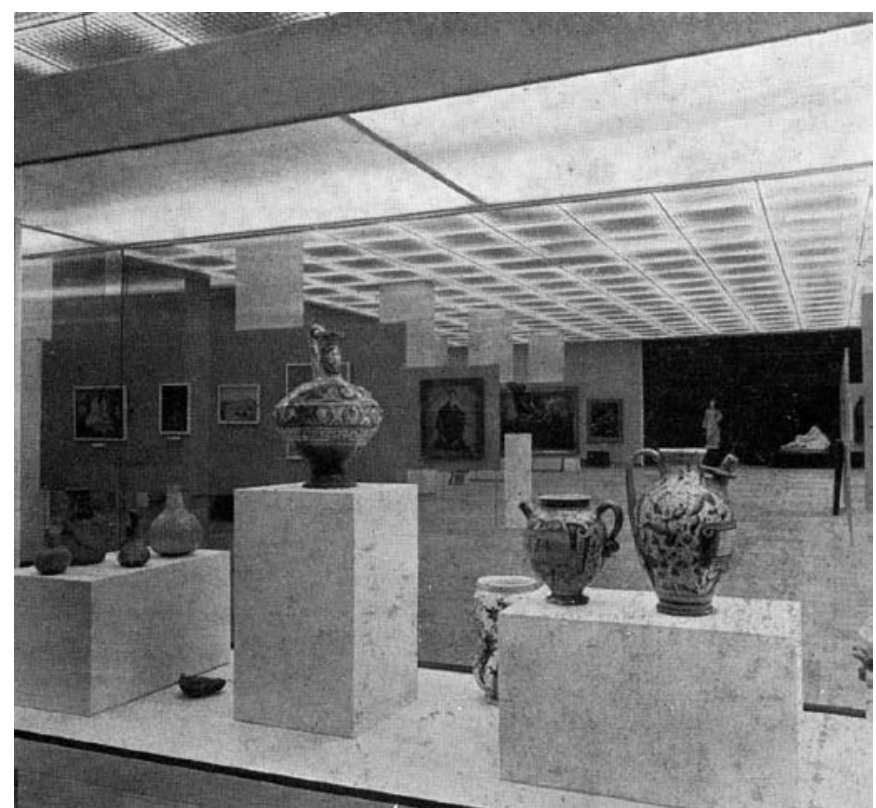

Imagem 148. "Vitrine das formas" do MASP. Autoria: P. Scheier. Fonte: MINDLIN (1956), p.183.

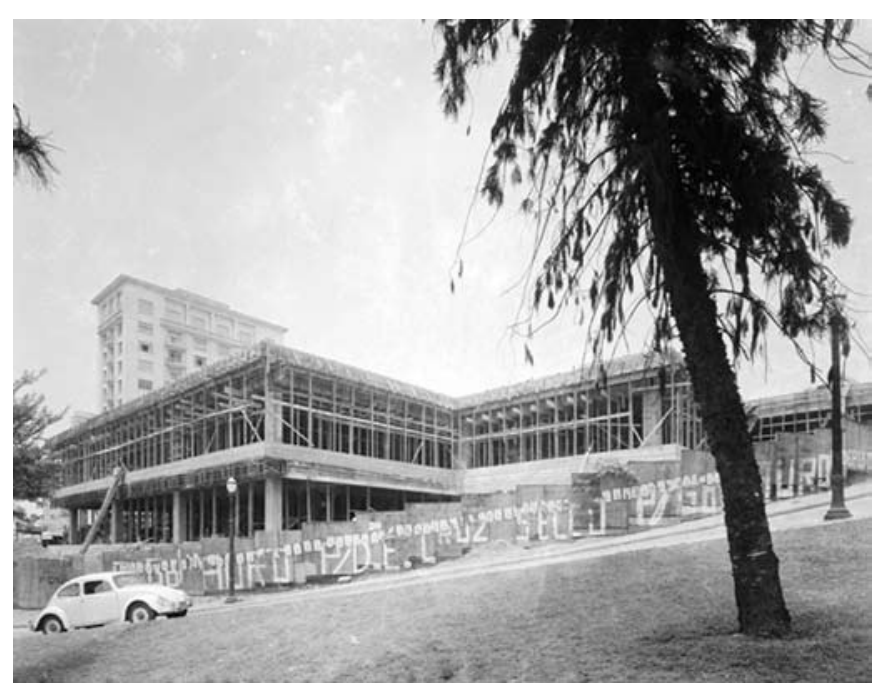

Imagem 149. Vista a partir da Praça Rodrigo Lefevre da sede do MASP na Avenida Paulista em construção. Autoria: P. Scheier. Fonte: Acervo do AHJB.

resultando em mais de 2/3 da área ocupados pelo piso. Nela é possível ver as mesmas esculturas da foto anterior ao fundo. No centro, traçando uma diagonal, está o expositor em vidro projetado por Lina, preso ao teto por tirantes. Scheier explorou a transparência da "vitrine das formas" de Lina em outra imagem 


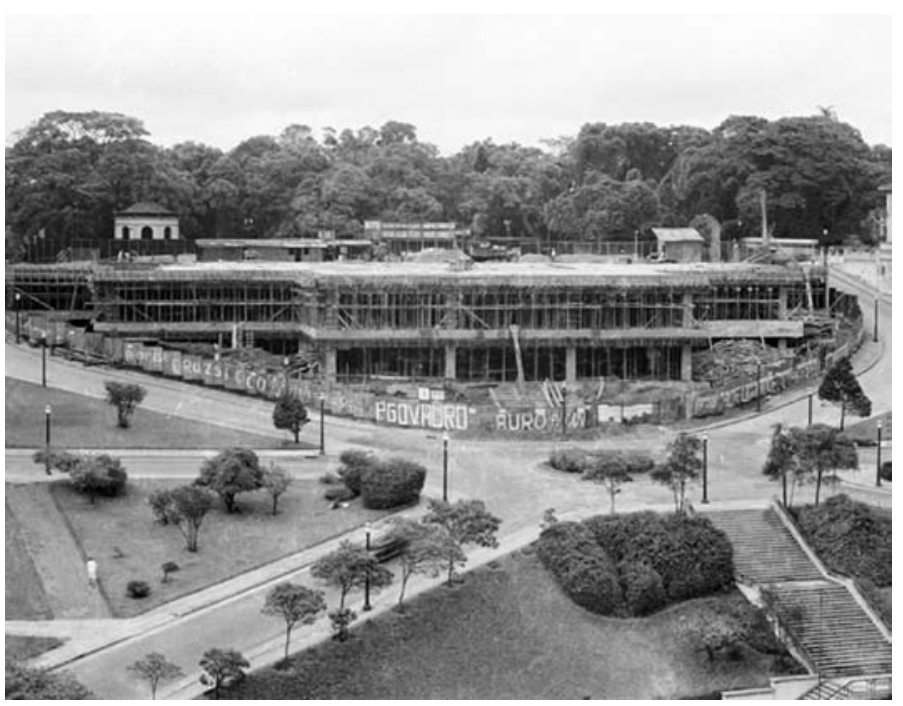

Imagem 150. Vista a partir da Avenida Nove de Julho da sede do MASP na Avenida Paulista em construção. Autoria: P. Scheier. Fonte: Acervo do AHJB.

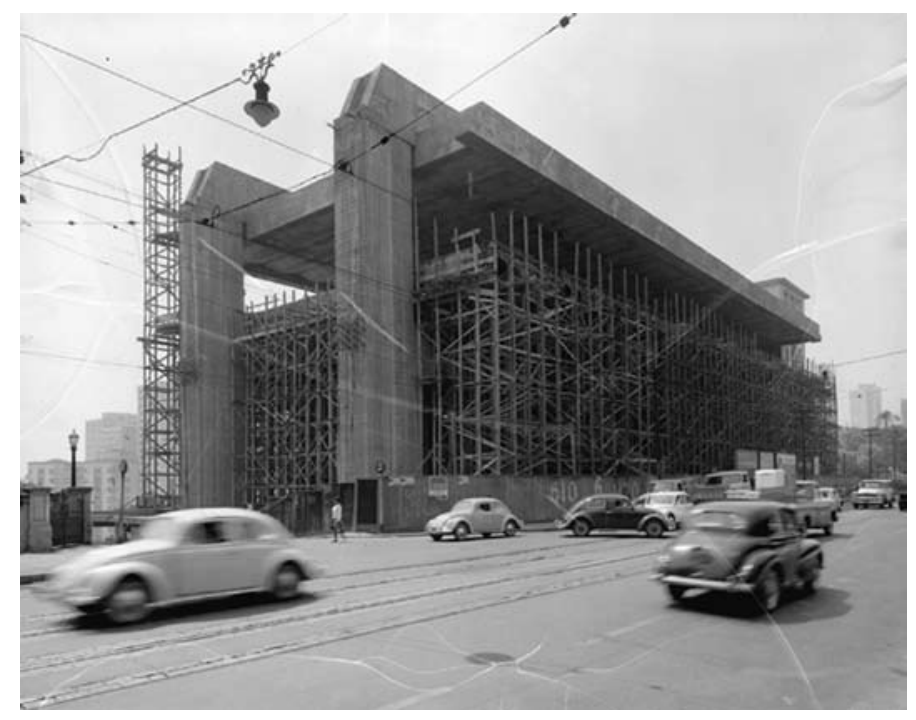

Imagem 151. Vista da sede do MASP na Avenida Paulista em construção. Autoria: P. Scheier. Fonte: Acervo do AHJB.

(Imagem 148), colocando-a em primeiro plano e visualizando toda a pinacoteca através de seus vidros. Um jogo geométrico estabelece-se com a profusão de planos verticais - os expositores de quadros e a parede ao fundo - e o plano horizontal do forro metálico modulado. 


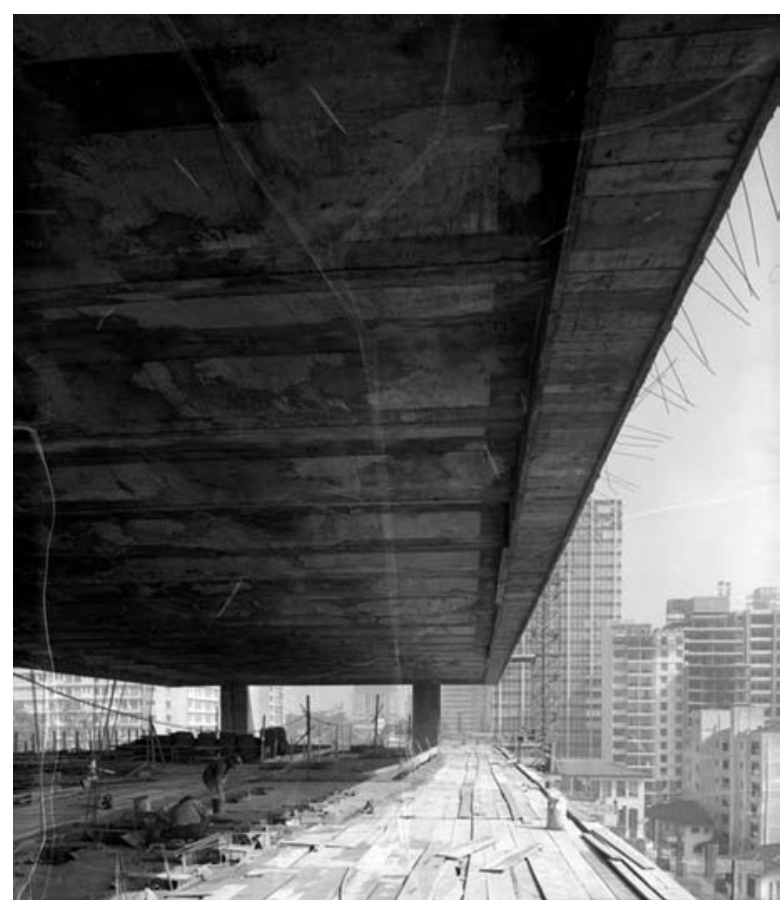

Imagem 152. Obras da sede do MASP na Avenida Paulista. Autoria: P. Scheier. Fonte: Acervo do AHJB.

Cerca de quinze anos depois, Peter Scheier documentou a sede do Museu de Arte de São Paulo (Lina Bo Bardi, 1957-1968) na Avenida Paulista em dois estágios da construção. No primeiro, apenas a estrutura dos andares inferiores e a laje do belvedere estavam construídas. Foram fotos feitas a partir da Praça Rodrigo Lefevre (Imagem 149) e de algum edifício da Avenida Nove de Julho (Imagem 150). Ao fundo, a densa mata do parque Trianon parece envolver o canteiro de obra, com destaque para o coreto, do lado esquerdo. Vêem-se os jardins e, na parte inferior, a escadaria de acesso à Nove de Julho.

No segundo estágio, os pórticos e todas as lajes já estavam construídos, porém ainda entremeados por fôrmas de madeira e andaimes. Nessa imagem (Imagem 151), nota-se uma Avenida Paulista já muito distinta daquela retratada durante a $1^{\text {a }}$ Bienal. Vêem-se os trilhos do bonde pelo chão e um volume de veículos muito maior - Fuscas, caminhões e outros num vaivém intenso. A partir 


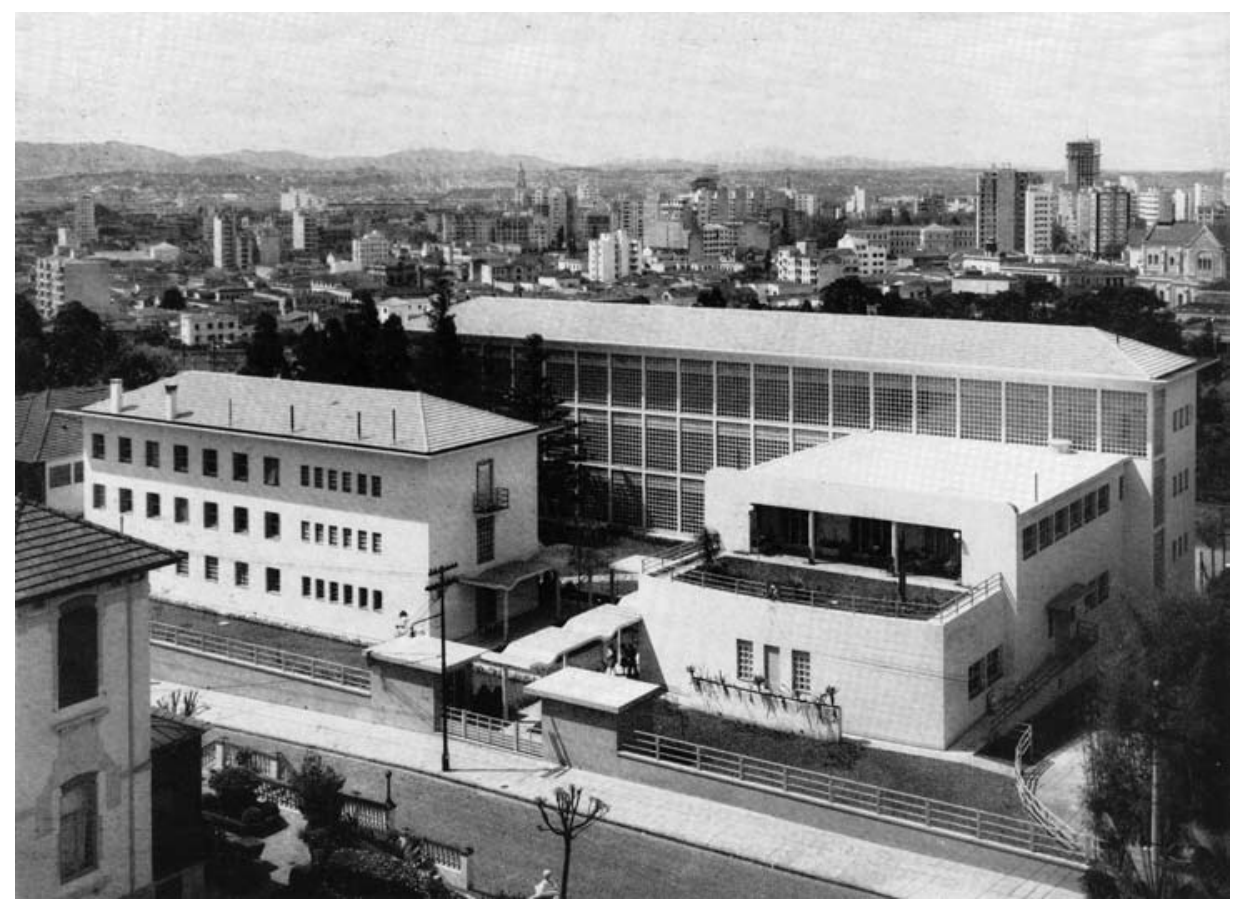

Imagem 153. Vista geral do Instituto Sedes Sapientiae, de Rino Levi. Autoria: P. Scheier. Fonte: BURLE-MARX; FILHO (1974), p.50.

do interior da obra (Imagem 152), Scheier destacou, além do trabalho dos operários, o novo skyline que se configurava em conseqüência do processo de verticalização da região a partir dos anos 1950, com os grandes arranha-céus que substituíam as chácaras e mansões. À direita ainda era possível avistar algumas casas remanescentes em meio aos edifícios.

A mesma verticalização é percebida numa vista geral (Imagem 153) do Instituto Sedes Sapientiae (Rino Levi, São Paulo, 1940-42). Na Avenida Consolação e no centro, ao fundo, antigas casas conviviam com os edifícios altos e com o adensamento da região. À direita, ao fundo, nota-se um alto edifício em construção, envolto em andaimes. Vê-se também a Igreja Nossa Senhora da Consolação.

A vista geral esclarece a implantação e as relações entre os três volumes do conjunto, interligados pela marquise ondulante de concreto armado: os 


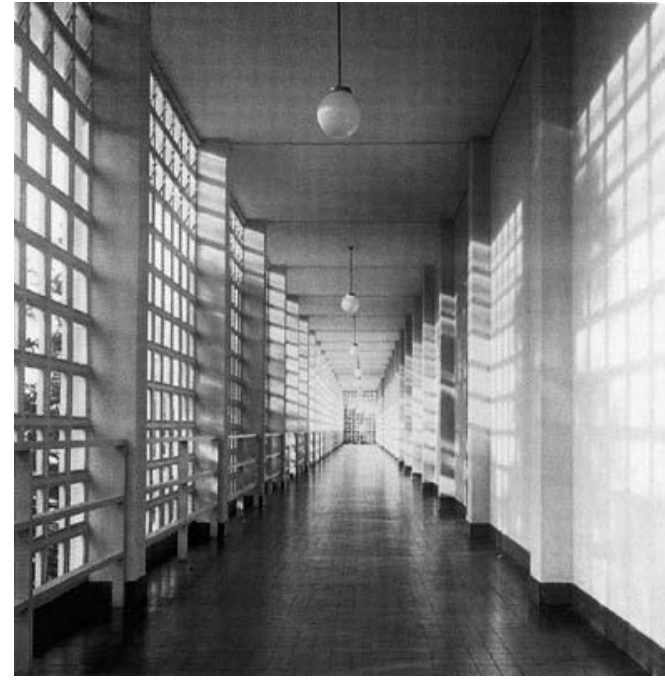

Imagem 154. Corredor interno do Instituto Sedes Sapientiae, com seu fechamento em elementos vazados. Autoria: P. Scheier. Fonte: ANELLI; GUERRA; KON (2001), p.56.

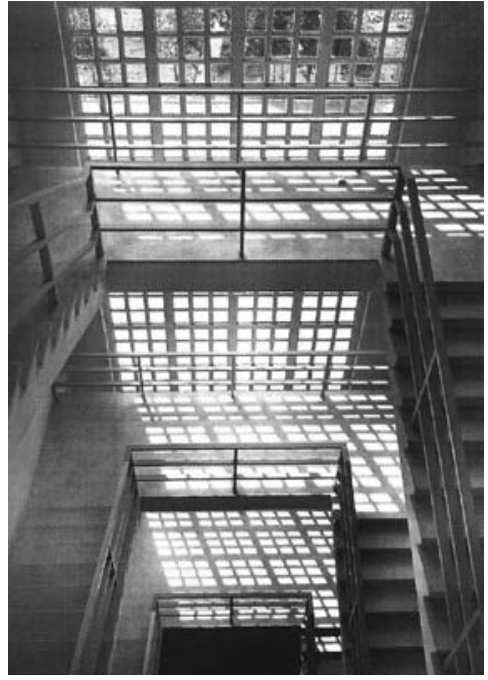

Imagem 155. Escada do Instituto Sedes Sapientiae. Autoria: P. Scheier. Fonte: ANELLI; GUERRA; KON (2001), p.115.

dormitórios (à esquerda); auditório, secretaria e biblioteca, com seu teto jardim (à direita); salas de aula, com seus elementos vazados (ao fundo). Algumas pessoas caminhavam sob a marquise ou estavam sentadas no terraço sobre o auditório. Naquela tarde (nota-se a orientação solar), a Rua Marquês de Paranaguá estava vazia.

Peter Scheier documentou o Sedes através de dois aspectos: sua relação com a luz, tanto diurna quanto noturna, e sua utilização pelas alunas e professoras. Aluz que penetra através dos elementos pré-fabricados de concreto foi destacada em fotos internas do corredor de circulação (Imagem 154) e da escada (Imagem 155), resultando em imagens com forte grafismo definido pelas sombras projetadas pelos brises. Na escada, as linhas dos degraus e do guardacorpo intensificam este efeito. Externamente, a luz incidente destacou a grelha de concreto, que, no entanto, ficou mais evidente na fotografia noturna, em virtude da contraluz gerada pela iluminação interna (Imagem 156). A luz rasante 


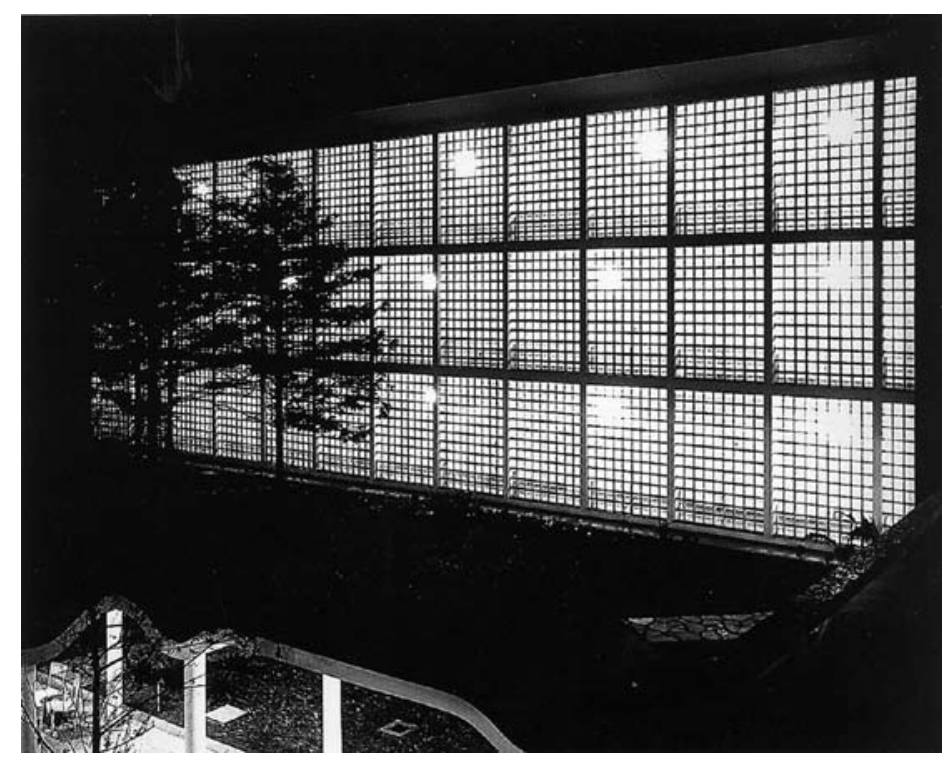

Imagem 156. Vista noturna do Instituto Sedes Sapientiae, com destaque para os elementos vazados. Autoria: P. Scheier. Fonte: ANELLI; GUERRA; KON (2001), p.114.

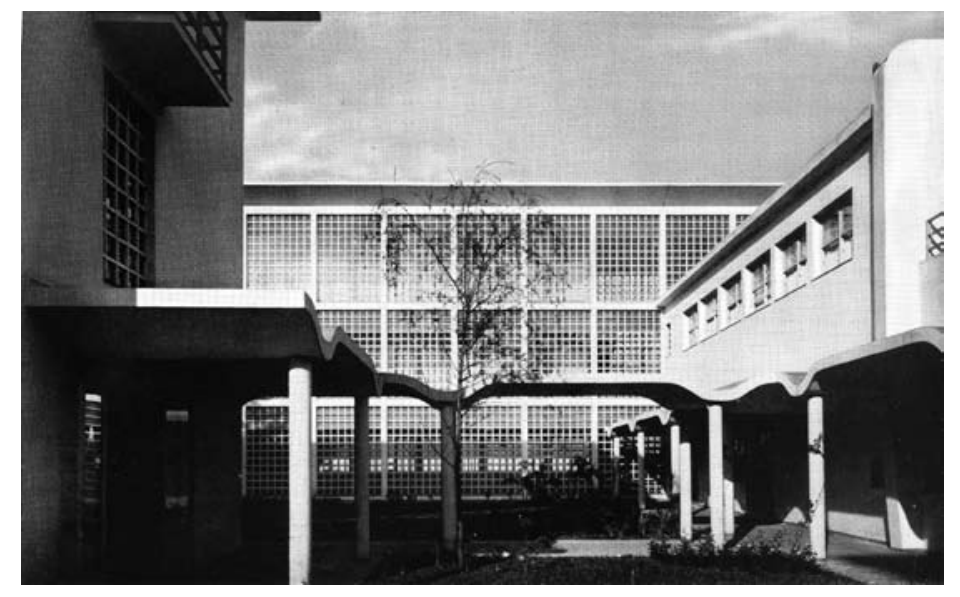

Imagem 157. Vista da marquise que interliga os blocos do Instituto Sedes Sapientiae. Autoria: P. Scheier. Fonte: BURLE-MARX; FILHO (1974), p.52.

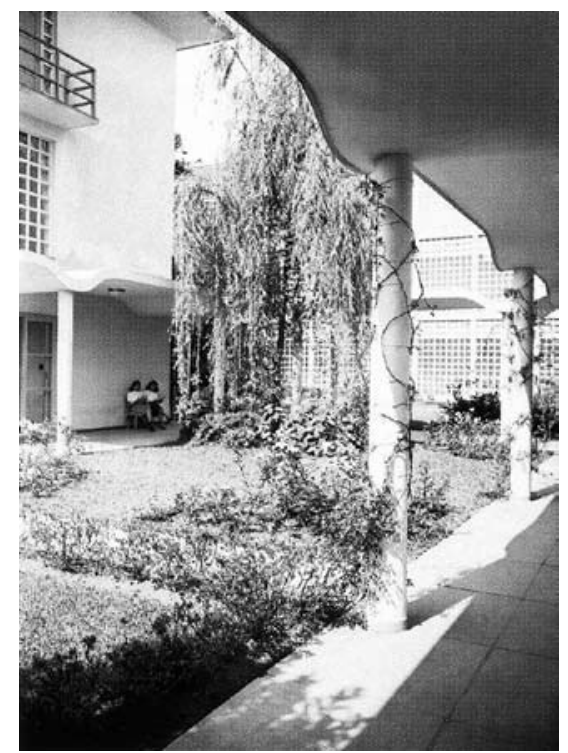

Imagem 158. Marquise

Instituto Sedes Sapientiae. Autoria: P. Scheier. Fonte: ANELLI; GUERRA; KON (2001), p.90.

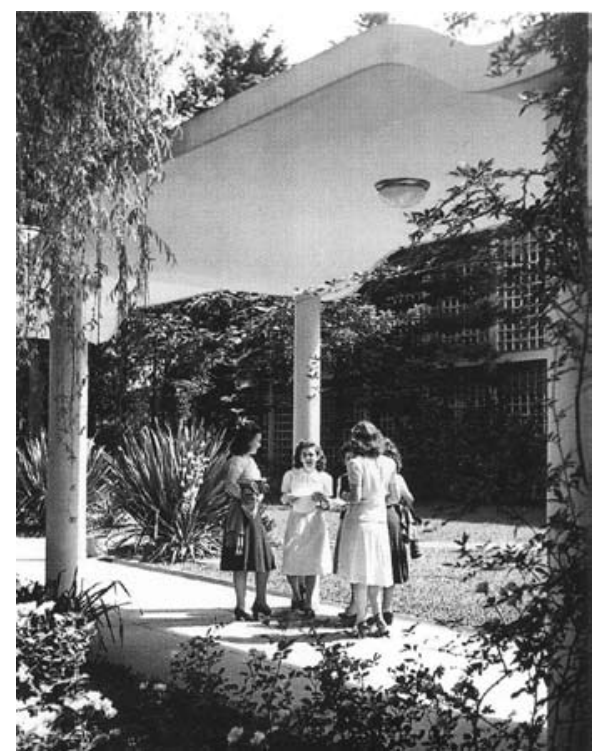

Imagem 159. Moças conversam sob a marquise do Instituto Sedes Sapientiae. Autoria: P. Scheier. Fonte: ANELLI; GUERRA; KON (2001), p.115. 


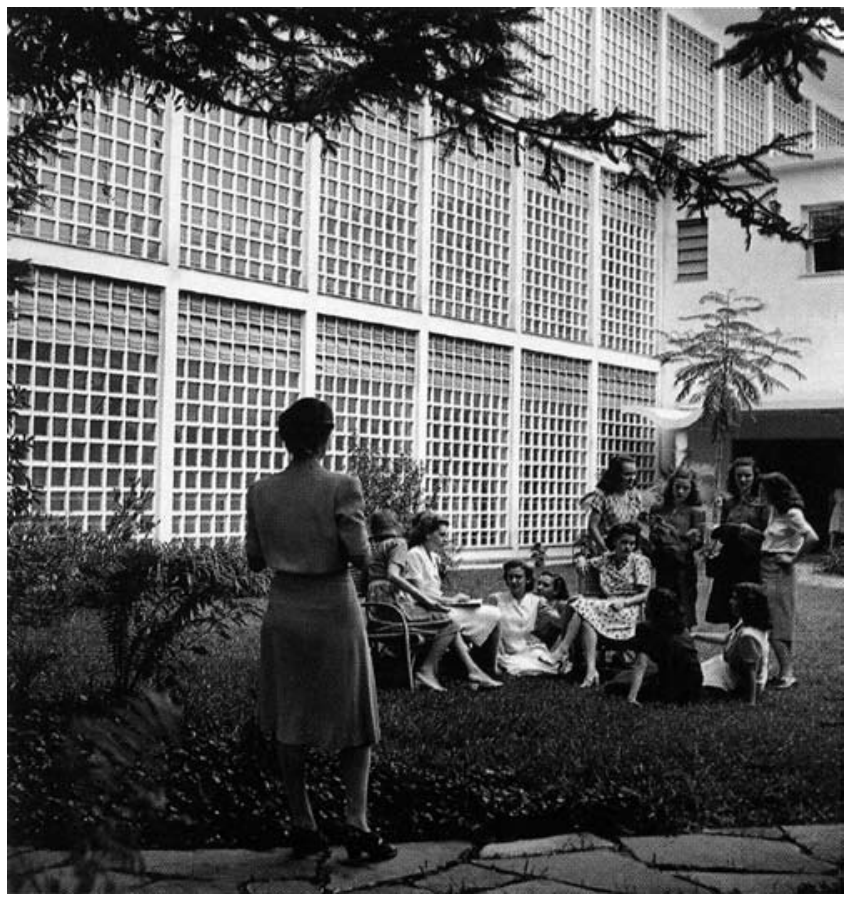

Imagem 160. Jardim do Instituto Sedes Sapientiae. Autoria: P. Scheier. Fonte: ANELLI; GUERRA; KON (2001), p.53.

vespertina, através de suas sombras e altas luzes, enfatizou também as formas ondulantes da marquise (Imagem 157/158).

O pátio é uma área ativa no projeto, que organiza os espaços e estimula o convívio entre as alunas. Scheier retratou-as conversando sob a marquise (Imagem 159), sentadas sobre o gramado em frente ao bloco de salas de aula (Imagem 160) e sentadas em bancos, com seus livros e cadernos, em meio à vegetação tropical do pátio.

A Avenida do Estado deserta aparece na vista geral (Imagem 161) da Companhia Jardim de Cafés Finos (Rino Levi, São Paulo, 1942-43). Da esquerda para a direita estão os armazéns, a torre de processamento (torrefação, moagem e embalagem) e os escritórios. Nesta vista foram ressaltadas as três soluções dadas para os brises: o sentido horizontal acentua os blocos do armazém e de escritórios, mais baixos, ao passo que a verticalidade da torre é destacada 


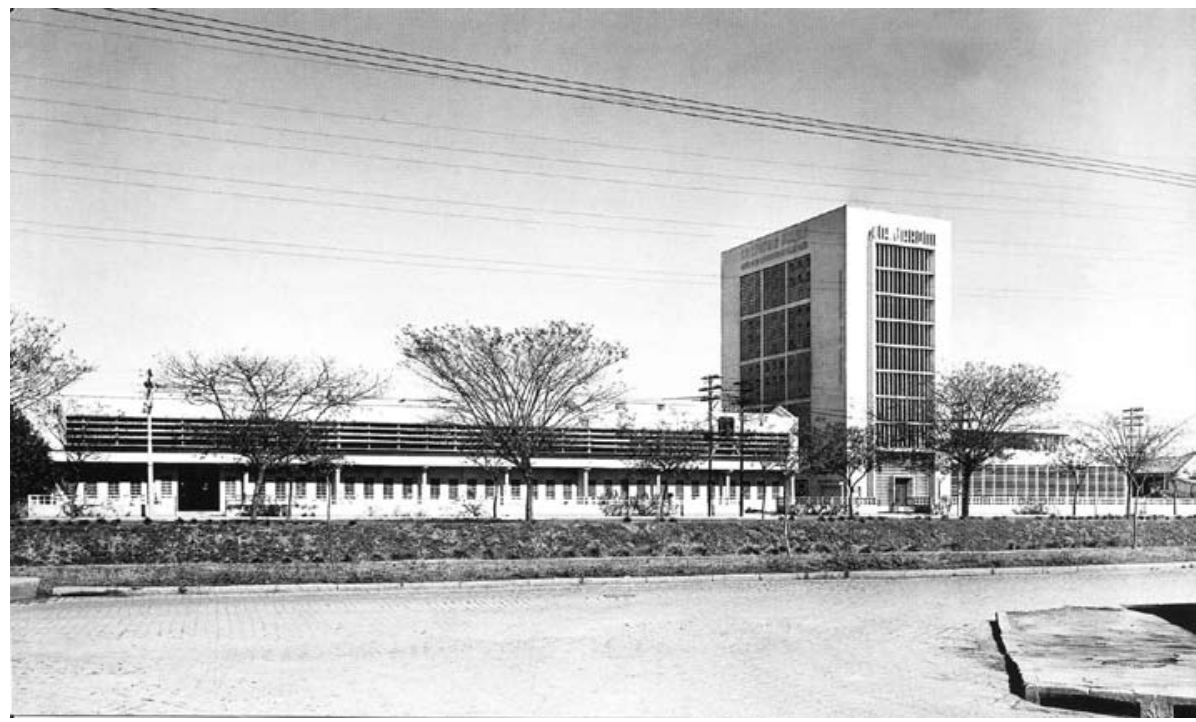

Imagem 161. Vista a partir da Avenida do Estado da Companhia Jardim de Cafés Finos, de Rino Levi. Autoria: P. Scheier. Fonte: ANELLI; GUERRA; KON (2001), p.122.

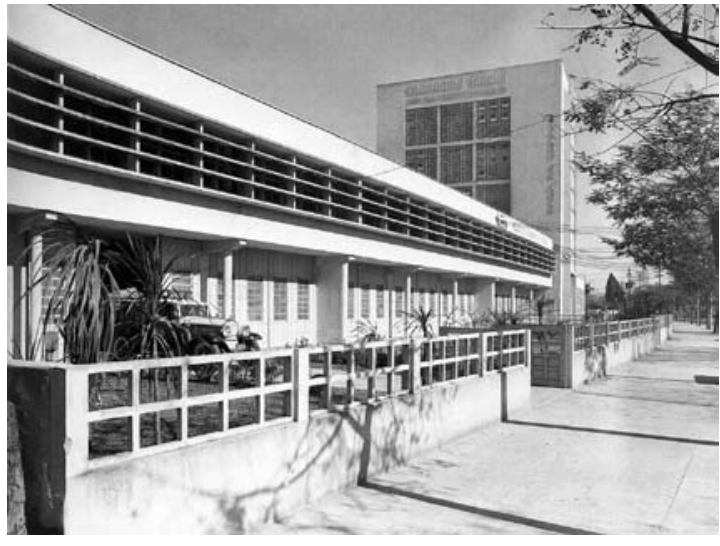

Imagem 162. Vista a partir da Avenida do Estado da Cia. Jardim de Cafés Finos. Autoria: P. Scheier. Fonte: ANELLI; GUERRA; KON (2001), p.123.

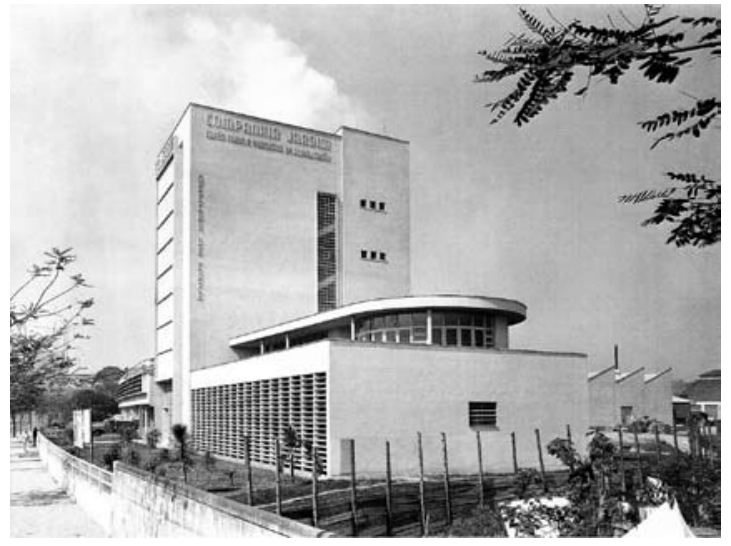

Imagem 163. Vista a partir da Av. do Estado da Cia. Jardim de Cafés Finos. Em primeiro plano, o refeitório. Autoria: P. Scheier. Fonte: ANELLI; GUERRA; KON (2001), p.123.

pelos brises no outro sentido. Feita esta imagem geral, Scheier aproximouse do edifício por suas extremidades (Imagem 162/163). Quando próximo à administração, conseguiu enfatizar o refeitório curvo - pouco visível na fotografia geral - e a relação de altura da torre com o bloco administrativo (Imagem 163). A vista da entrada da torre (Imagem 164) destaca, além dos brises verticais, o padrão quadriculado que envolve a porta. 


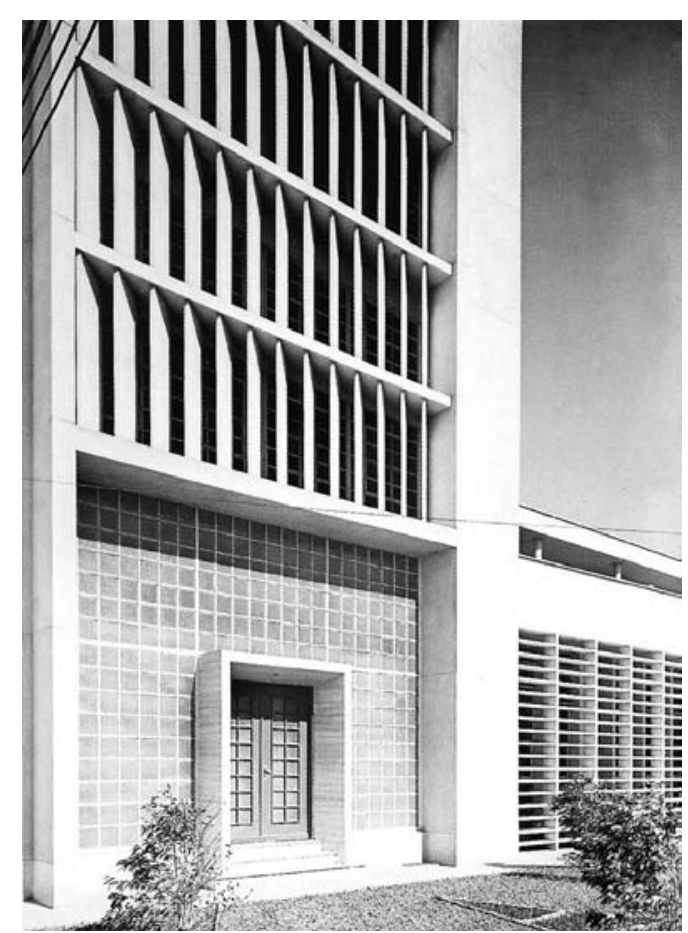

Imagem 164. Entrada da torre de processamento. Cia. Jardim de Cafés Finos. Autoria: P. Scheier. Fonte: ANELLI; GUERRA; KON (2001), p.123.

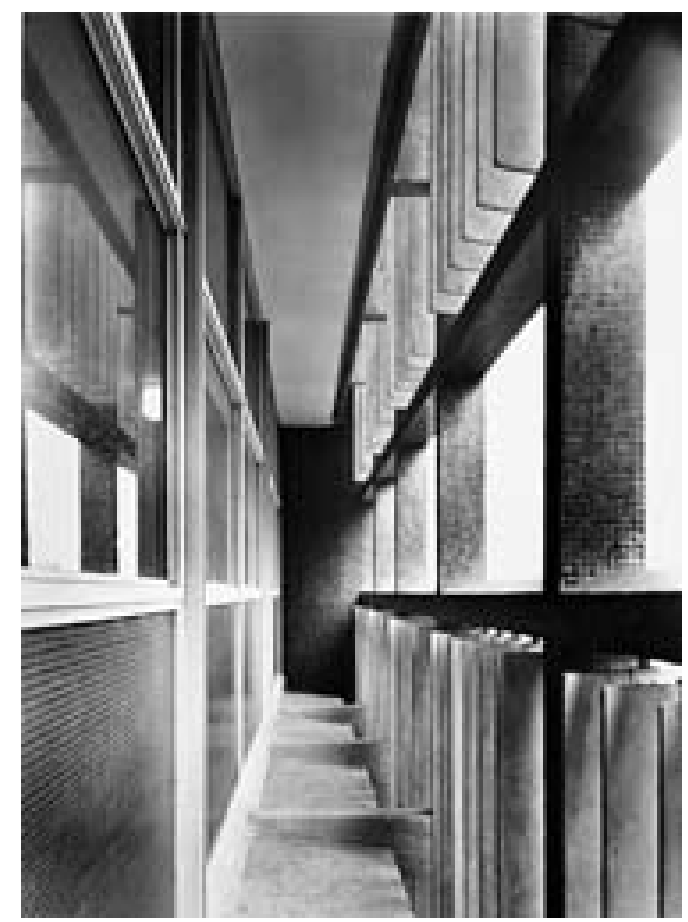

Imagem 166. Detalhe entre o brise e o caixilho. Ordem dos Advogados do Brasil - OAB, de Rino Levi. Autoria: P. Scheier. Fonte: Acervo Fotográfico da FAUUSP.

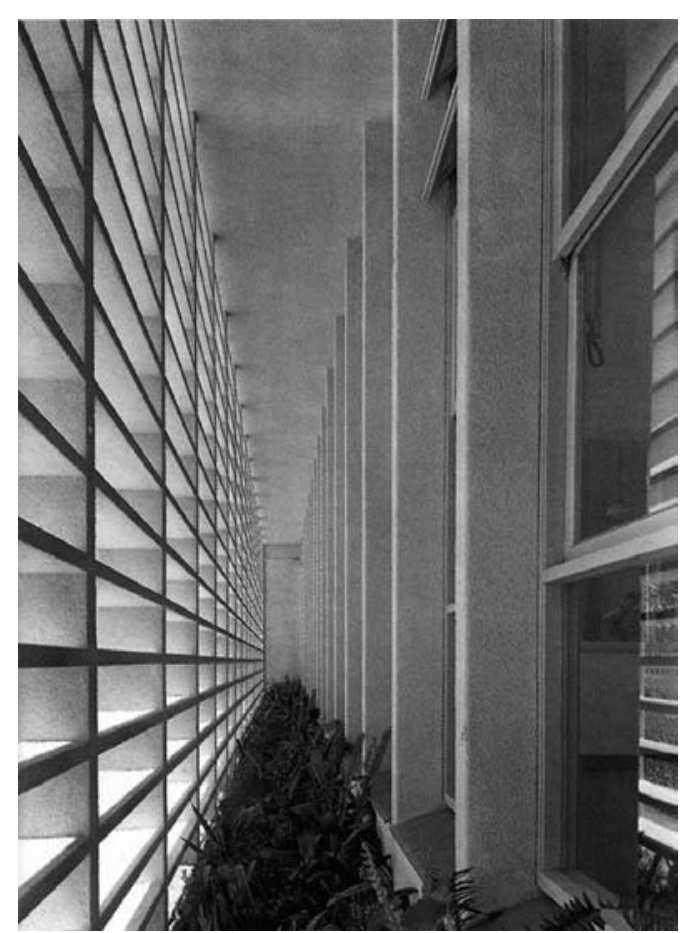
Imagem 165. Detalhe entre $\mathrm{o}$ brise $\mathrm{e}$ o caixilho. Cia. Jardim de Cafés Finos. Autoria: P. Scheier. Fonte: ANELLI; GUERRA; KON (2001), p.52.

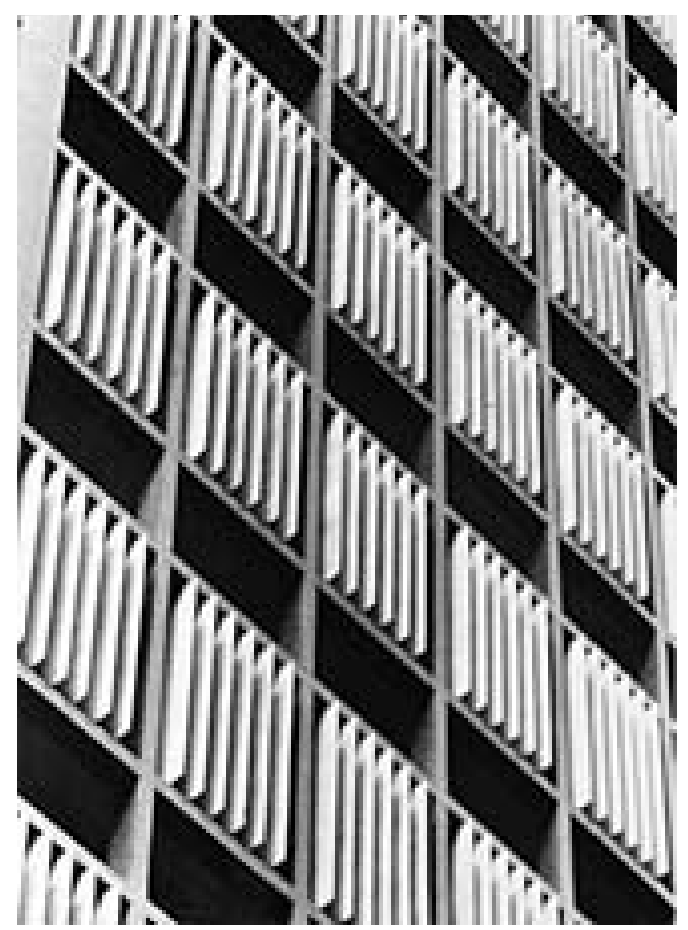

Imagem 167. Detalhe do brise. Ordem dos Advogados do Brasil - OAB. Autoria: P. Scheier. Fonte: Acervo Fotográfico da FAUUSP. 


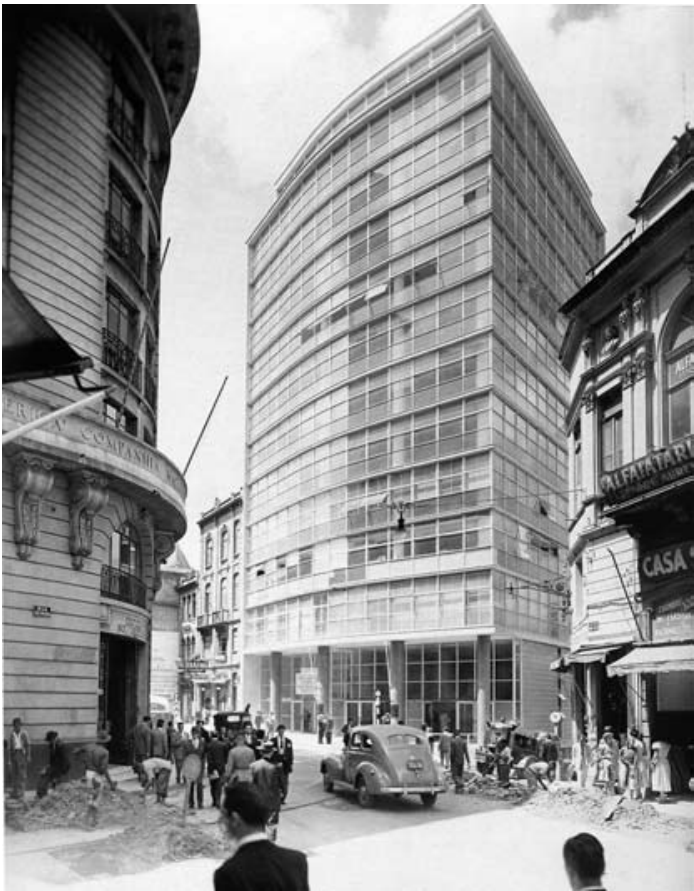

Imagem 168. Vista da esquina da Rua Boa Vista com Rua João Brícola. Banco Paulista do Comércio, de Rino Levi. Autoria: P. Scheier. Fonte: ANELLI; GUERRA; KON (2001), p.159.

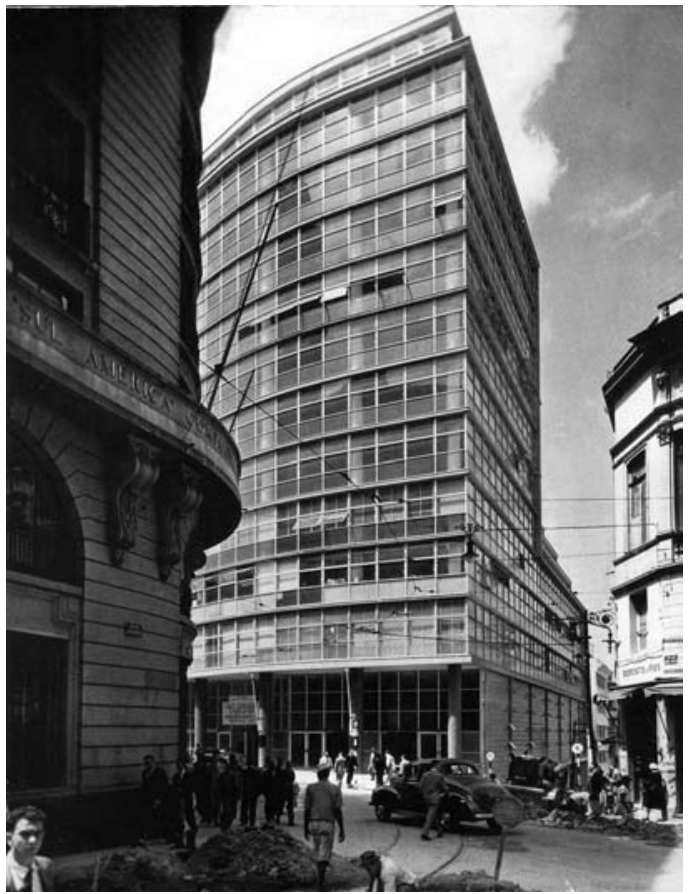

Imagem 169. Banco Paulista do Comércio. Autoria: P. Scheier. Fonte: BURLE-MARX; FILHO (1974), p.74.

Scheier deteve-se na jardineira entre os elementos vazados de concreto e os caixilhos dos escritórios administrativos (Imagem 165). A perspectiva frontal foi acentuada pelo ritmo constante dos brises e dos montantes verticais da esquadria. O mesmo ângulo seria adotado anos mais tarde no edifício da Ordem dos Advogados do Brasil - OAB (Rino Levi, São Paulo, 1953), com os caixilhos à esquerda e as placas de fibrocimento fixas na estrutura de concreto à direita (Imagem 166). Num jogo de abstração, Scheier isolou os brises do $O A B$ numa composição geométrica, de elementos essencialmente verticais, ritmados, compassados por linhas horizontais, em jogos de luz e sombra - como nas palavras de Mário Pedrosa ${ }^{101}$ (Imagem 167).

O intenso movimento do centro de São Paulo foi explicitado numa fotografia

101 Ver a primeira parte deste capítulo, sobre a revista O Cruzeiro. 


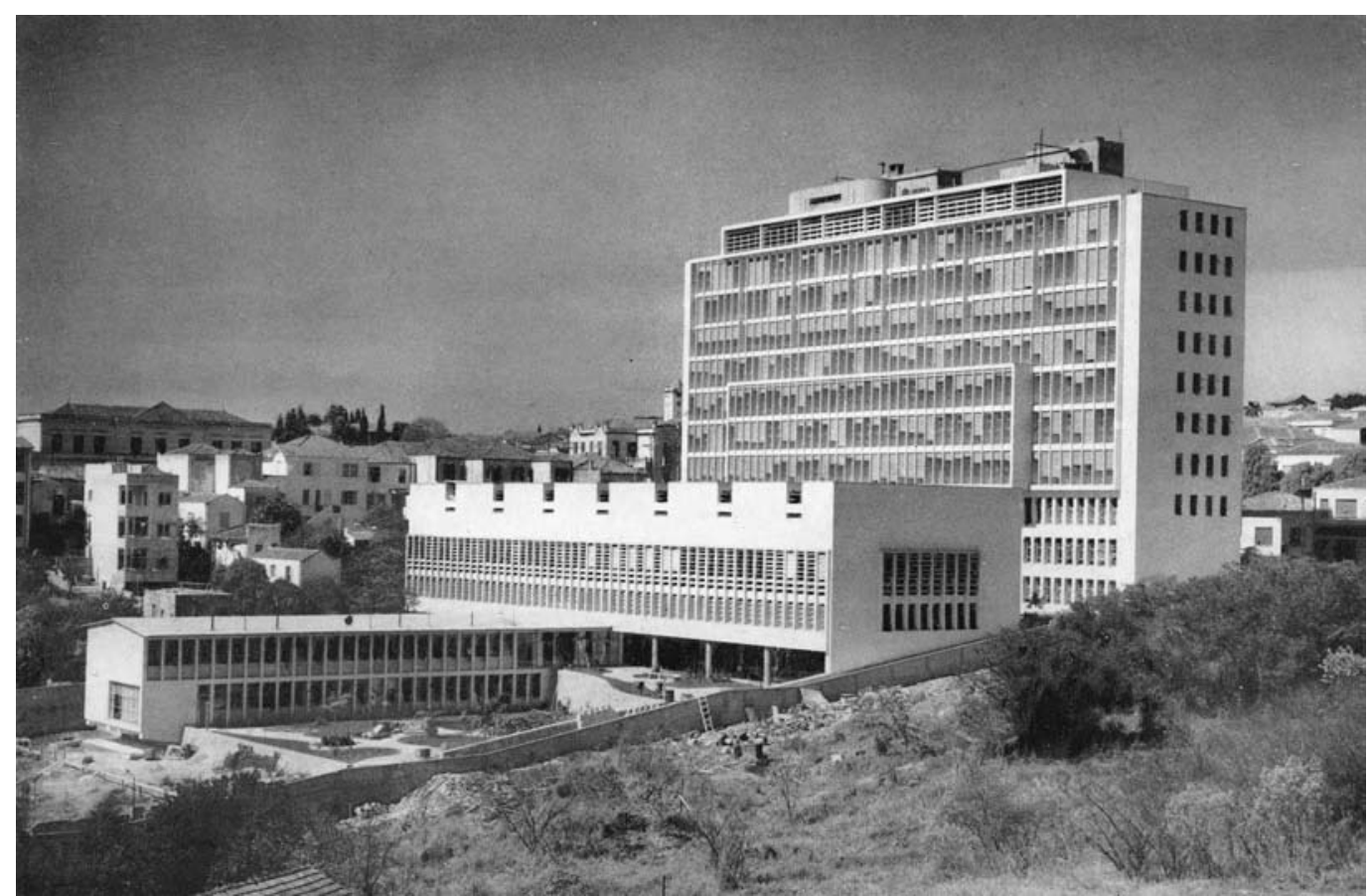

Imagem 170. Vista geral do Instituto Central do Câncer, de Rino Levi. Autoria: P. Scheier. Fonte: MINDLIN (1956), p.155.

(Imagem 168/169) do Banco Paulista do Comércio (Rino Levi, 1947-48). Embora esteja implantado numa esquina, é um prédio difícil de ser fotografado, em virtude do entorno denso e da largura estreita das ruas circundantes. $\mathrm{Na}$ imagem feita no nível do pedestre não é possível observar o escalonamento dos últimos andares - em respeito ao gabarito mais baixo da Ladeira Porto Geral. Ele fica visível na imagem em que Scheier colocou-se mais ao centro da Rua João Brícola, interrompendo, contudo, a fachada principal.

Para garantir o enquadramento de toda a fachada, Scheier precisou distanciar-se do edifício, resultando no aumento da área do entorno e criando muitas interferências: obras públicas na Rua Boa Vista e na Rua João Brícola, comércio circundante, os transeuntes em primeiro plano, o eclético Edifício Sul Americano em frente, a torre do mosteiro de São Bento ao fundo. Uma versão publicada em Latin American since $1945^{102}$ sofreu um grande corte com o objetivo 


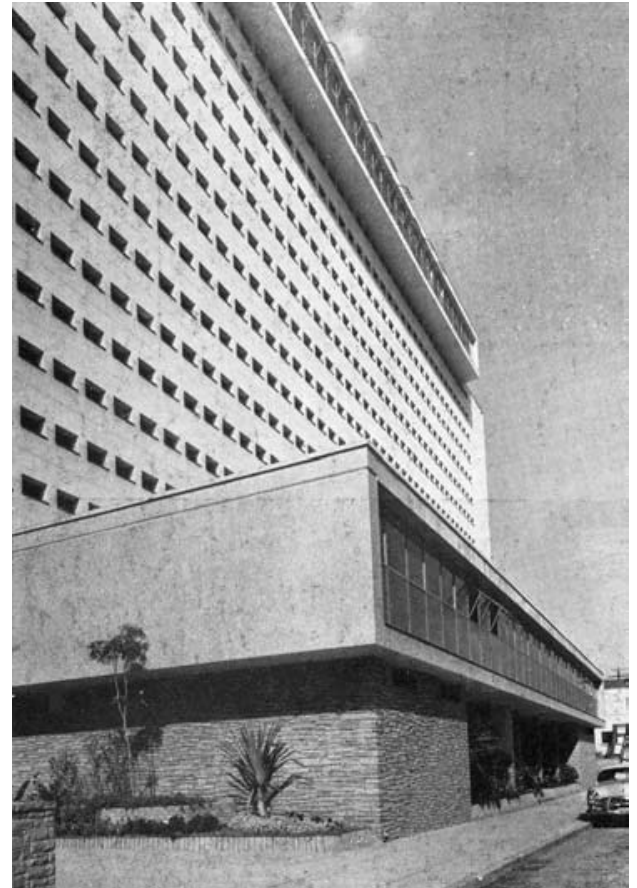

Imagem 171. Entrada do Instituto Central do Câncer. Autoria: P. Scheier. Fonte: MINDLIN (1956), p.154.

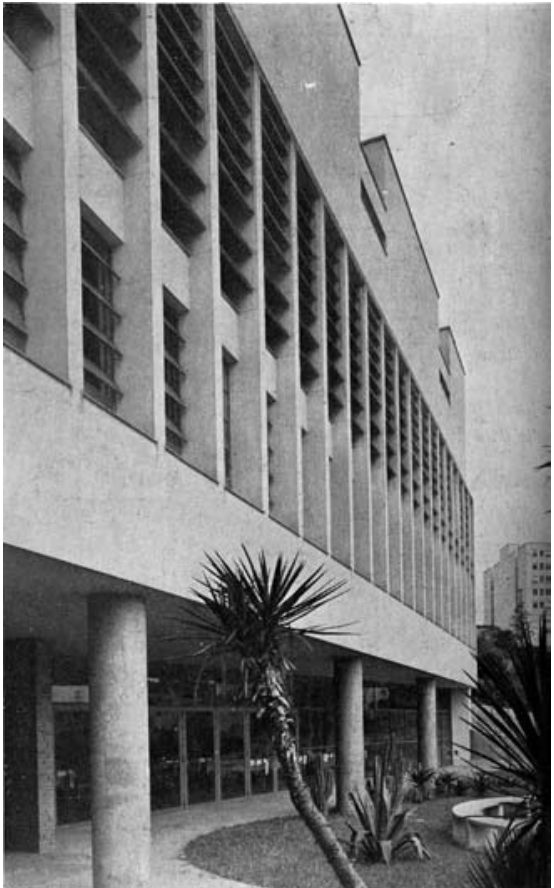

Imagem 172. Área de descanso do Instituto Central do Câncer. Autoria: P. Scheier. Fonte: MINDLIN (1956), p.154.

de eliminar essas interferências, mas trouxe danos ao eliminar quase totalmente a fachada lateral voltada para a Ladeira, na qual estão os painéis de blocos de vidro pontilhado, que garantem a privacidade dos clientes na agência bancária, no térreo. O corte, portanto, criou uma situação urbana distinta da real.

O Instituto Central do Câncer (Hospital Antônio Cândido de Camargo, São Paulo, 1949-54) foi o primeiro projeto hospitalar de Rino Levi a ser construído e teve grande repercussão na mídia especializada, nacional e internacional. As fotos foram feitas pouco antes da inauguração: a presença de materiais de construção e entulho nas áreas externas demonstra que o edifício não estava totalmente concluído. Peter Scheier fotografou também o Hospital Cruzada PróInfância (atual Hospital Pérola Byington, São Paulo, 1950) para o arquiteto. 


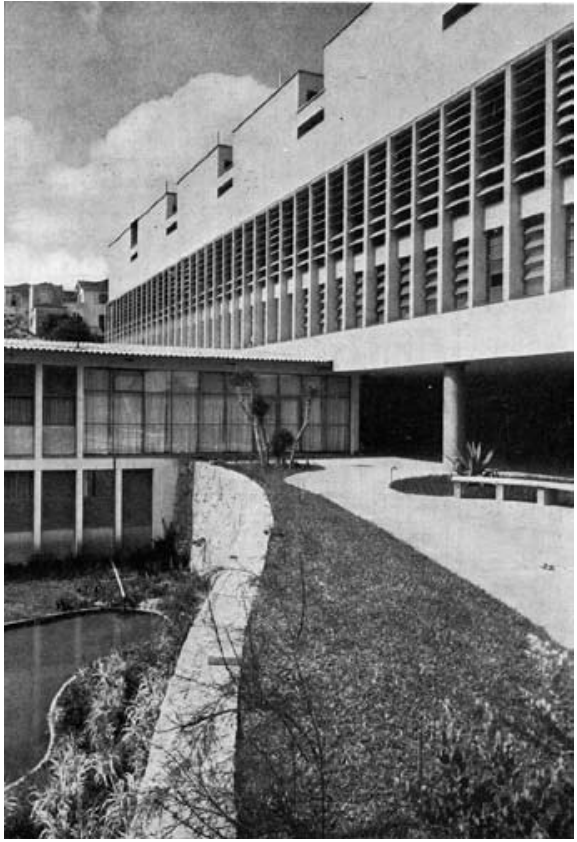

Imagem 173. Área de descanso do Instituto Central do Câncer. Autoria: P. Scheier. Fonte: MINDLIN (1956), p.157.

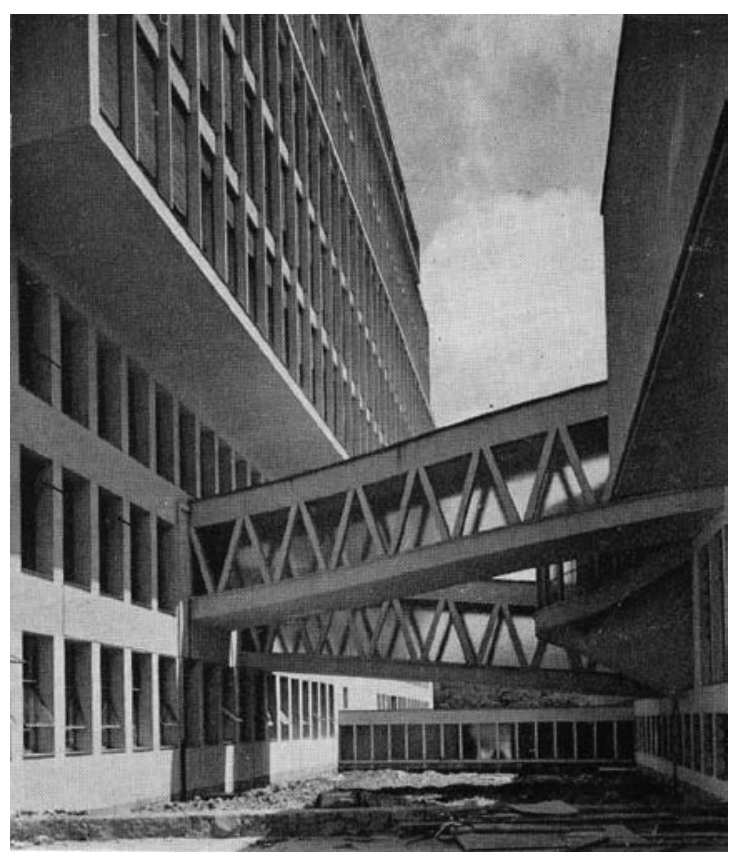

Imagem 174. Rampas de interligação dos blocos do Instituto Central do Câncer. Autoria: P. Scheier. Fonte: HITCHCOCK (1955), p.119.

As informações contidas na foto externa geral do conjunto ${ }^{103}$ são ricas (Imagem 170). Nota-se claramente a solução encontrada para o desnível do terreno, com a divisão do programa em blocos distintos, implantados em platôs de diferentes níveis. Além disso, a foto permite analisar o impacto de um empreendimento destas proporções no entorno pouco denso do bairro da Liberdade, na época essencialmente residencial.

A partir do exterior, Scheier procurou ressaltar a relação da calçada com o volume vertical de dez pavimentos do bloco de quartos, intermediada pelo bloco de dois andares da entrada (Imagem 171). A área de descanso de funcionários e de pacientes internados foi registrada em duas imagens: na primeira (Imagem 172) ressalta-se o acesso ao jardim e os brises metálicos, ao passo

103 Há uma divergência sobre a autoria desta imagem. Em Latin American Architecture since 1945, de Henry-Russell Hitchcock, ela é atribuída à J. Siqueira Silva e não a Peter Scheier, como é feito em Modern Architecture in Brazil, de Henrique Mindlin. 


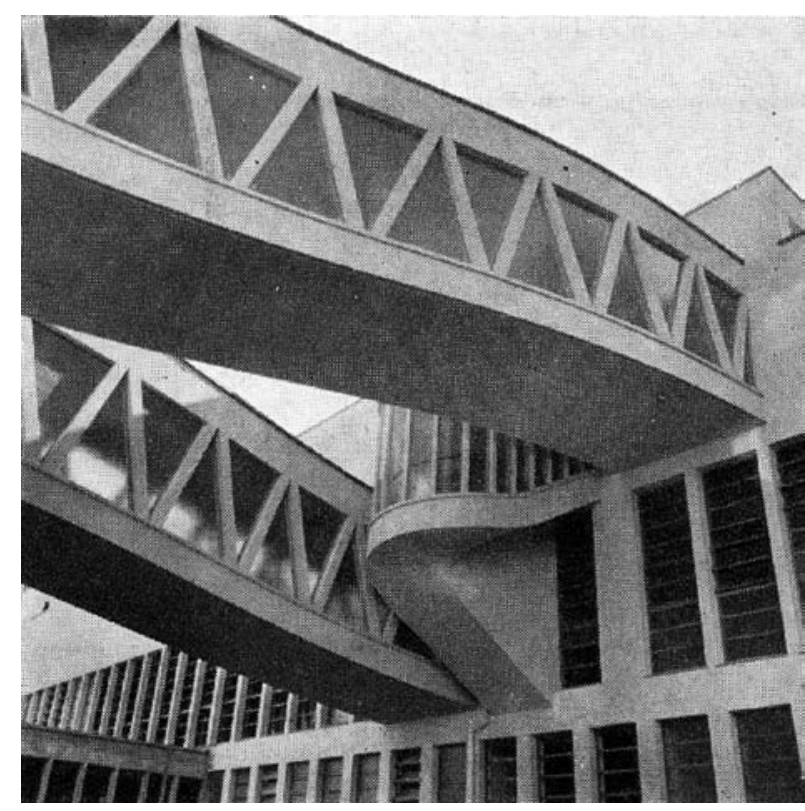

Imagem 175. Rampas de interligação dos blocos do Instituto Central do Câncer. Autoria: P. Scheier. Fonte: MINDLIN (1956), p.155.

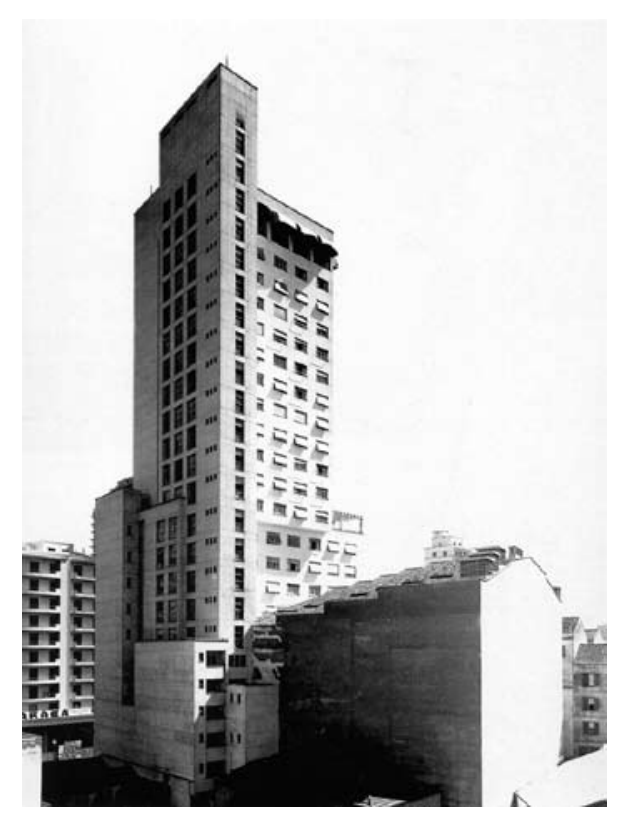

Imagem 176. Vista geral do Cine Ipiranga e Hotel Excelsior, de Rino Levi. Autoria: P. Scheier. Fonte: ANELLI; GUERRA; KON (2001), p.118.

que na segunda (Imagem 173) o jardim sobre laje e o inferior são mostrados, simultaneamente, num arranjo interessante das formas orgânicas dos canteiros e espelhos d'água.

As rampas que ligam a recepção aos níveis de atendimento ao público no bloco posterior foram retratadas a partir de dois ângulos diferentes. $A$ imagem frontal (Imagem 174), com um único ponto de fuga perspectivo traz mais informação a respeito do projeto, ao mostrar nitidamente o desnível vencido pelo sistema de circulação - rampas e escada - entre os dois blocos interligados. Esta relação fica menos explícita em outra (Imagem 175): seu ângulo oblíquo ascendente resultou em grande distorção e sua abertura focal permitiu ver apenas o encontro das rampas com a caixa de escada. A passarela fechada, que na primeira aparece claramente ao fundo, na segunda configura-se como um ruído incômodo do lado esquerdo, que não informa e não se esclarece. Do ponto 


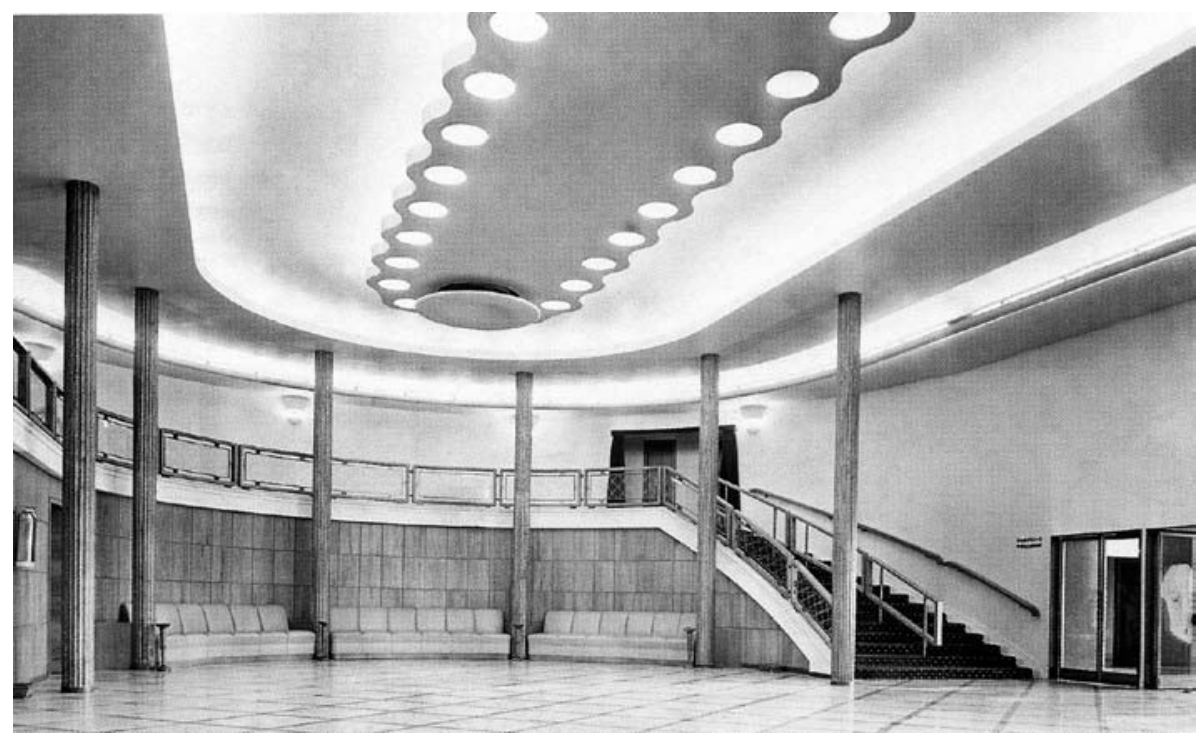

Imagem 177. Foyer principal do Cine Ipiranga. Autoria: P. Scheier. Fonte: Acrópole, n.61, p.492. Acervo da FAUUSP.

de vista compositivo e estético, a segunda é mais interessante por seu ângulo instigante e por ressaltar as curvas das rampas e da escada. No que concerne à informação arquitetônica, a outra é mais favorável, apesar de seu ângulo frontal não ressaltar as formas curvas, uma sutileza do arquiteto no desenho destas circulações.

O conjunto do Cine Ipiranga e Hotel Excelsior (Rino Levi, São Paulo, 1941) foi implantado num terreno na "recém-alargada Avenida Ipiranga" ${ }^{104}$. A partir de algum edifício na Rua Dom José de Barros ou Rua Joaquim Gustavo, Scheier produziu a vista posterior do conjunto, que esclarece a implantação deste denso conjunto no terreno (Imagem 176). Vê-se claramente o volume de circulação vertical, mais alto e esbelto; o bloco dos quartos do hotel, com os toldos nas janelas do restaurante, na cobertura; o volume do cinema, com seu telhado escalonado em telha cerâmica. Ao fundo aparece a Avenida Ipiranga e o Cine Marabá.

104 ANELLI, GUERRA, KON. Op. cit, p.118. 


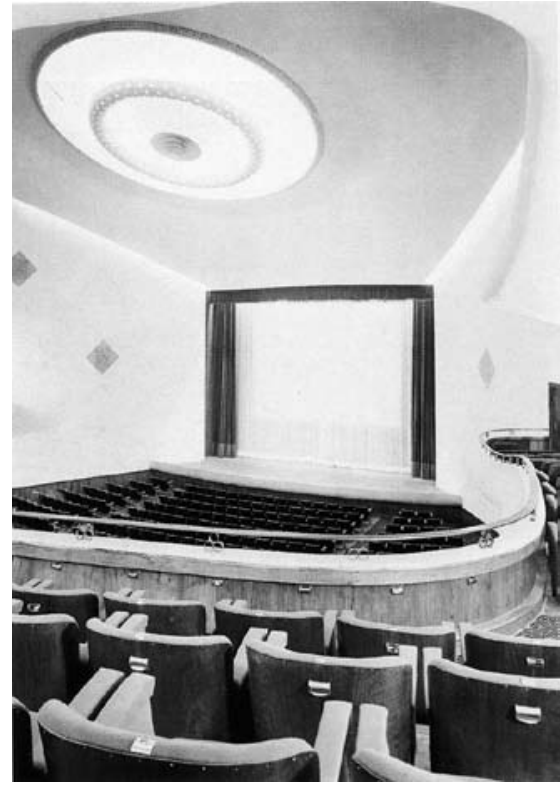

Imagem 178. Sala de projeção do Cine Ipiranga. Autoria: P. Scheier. Fonte: ANELLI; GUERRA; KON (2001), p.120.

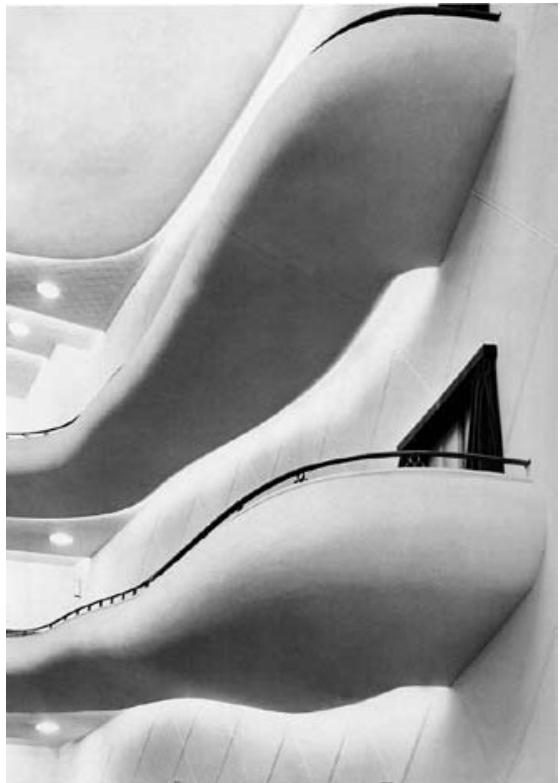

Imagem 179. Balcões da sala de projeção do Cine Ipiranga. Autoria: P. Scheier. Fonte: ANELLI; GUERRA; KON (2001), p.120.

Nas fotos internas foi documentado o amplo foyer de entrada do cinema (Imagem 177), com sua forma curva e seu teto dominado pela luminária, de grande efeito gráfico, os sofás de espera e as escadarias de acesso aos balcões - a partir dos quais fez uma excelente imagem geral da sala de projeção, com seu grande lustre no centro do forro (Imagem 178). A obliqüidade e ângulo ascendente surgem numa imagem que explora as formas sinuosas dos balcões (Imagem 179), e reaparecem num detalhe da fachada (Imagem 180), feito a partir do nível da marquise da entrada do cinema, dominado pelo grafismo da grelha geométrica composta pelos blocos de vidro, pela estrutura de concreto, pelas lajes e pelos guarda-corpos metálicos dos terraços.

No restaurante da cobertura, Peter Scheier tomou duas posturas distintas. Fez uma vista geral do ambiente (Imagem 181), com seu bar ao fundo e a profusão de mesas e cadeiras arrumadas, que demonstram o luxo do hotel. Em 


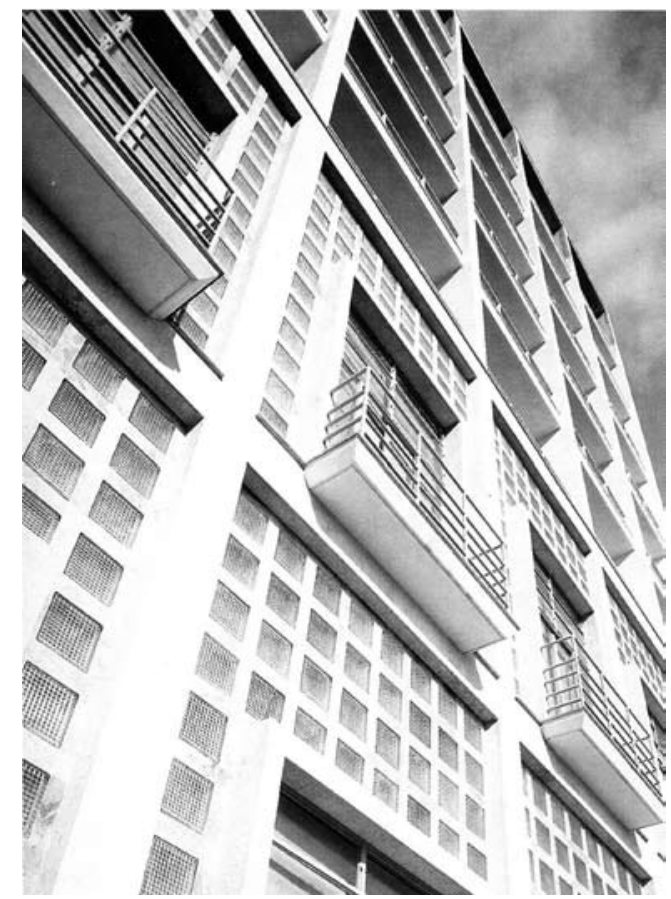

Imagem 180. Detalhe da fachada do Hotel Excelsior. Autoria: P. Scheier. Fonte: ANELLI; GUERRA; KON (2001), p.45.

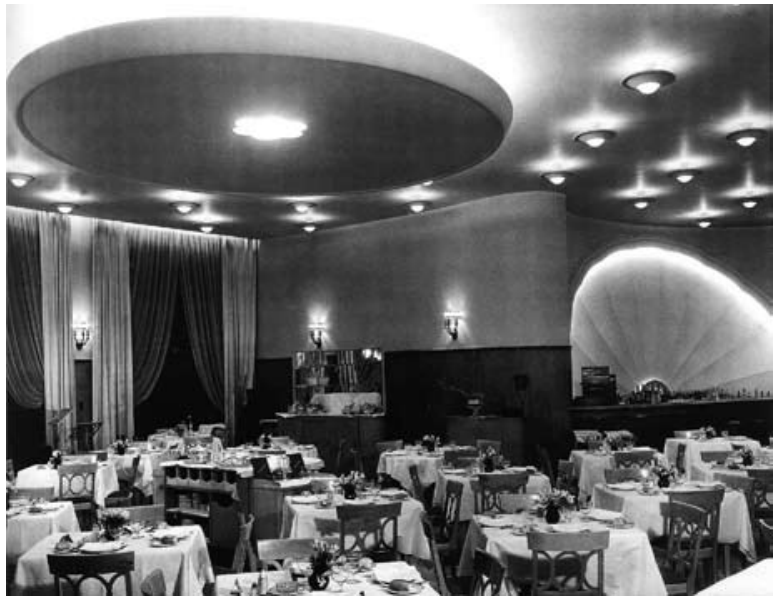

Imagem 181. Restaurante da cobertura do Hotel Excelsior. Autoria: P. Scheier. Fonte: ANELLI; GUERRA; KON (2001), p.121.

outra, o restaurante é uma moldura para o centro. O Edifício Martinelli e o Banco do Estado aparecem enquadrados em uma de suas janelas (Imagem 182).

Talvez uma das fotos mais belas da documentação de arquitetura de Peter Scheier seja a imagem noturna da entrada do cinema (Imagem 183). Penduradas aparecem as placas do arquiteto - "Projeto e fiscalisação (sic) architeto (sic) Rino Levi - CREA n 416. Av. Ipiranga, 480 Tel: 4-0595" - e da construtora - "Construção da Sociedade Commercial (sic) e Constructora (sic) Ltda. - Engenheiros, Empreiteiros, Construtores - Rua Líbero Badaró, 282 - $8^{\circ}$ andar Tel: - 3-2148".

O luminoso anunciava: "Hoje no mais luxuoso cinema do Brasil $20^{\text {th }}$ Century Fox apresenta 'Seis Destinos'105" e descrevia o elenco: Charles Boyer,

105 Seis Destinos (Título Original: Tales of Manhattan), do diretor francês Julien Duvivier, de 1942, produzido nos Estados Unidos. Fonte: http://melhoresfilmes.com.br/filmes/seis-destinos. Acesso em: 23 mai 08, às 13:00. 


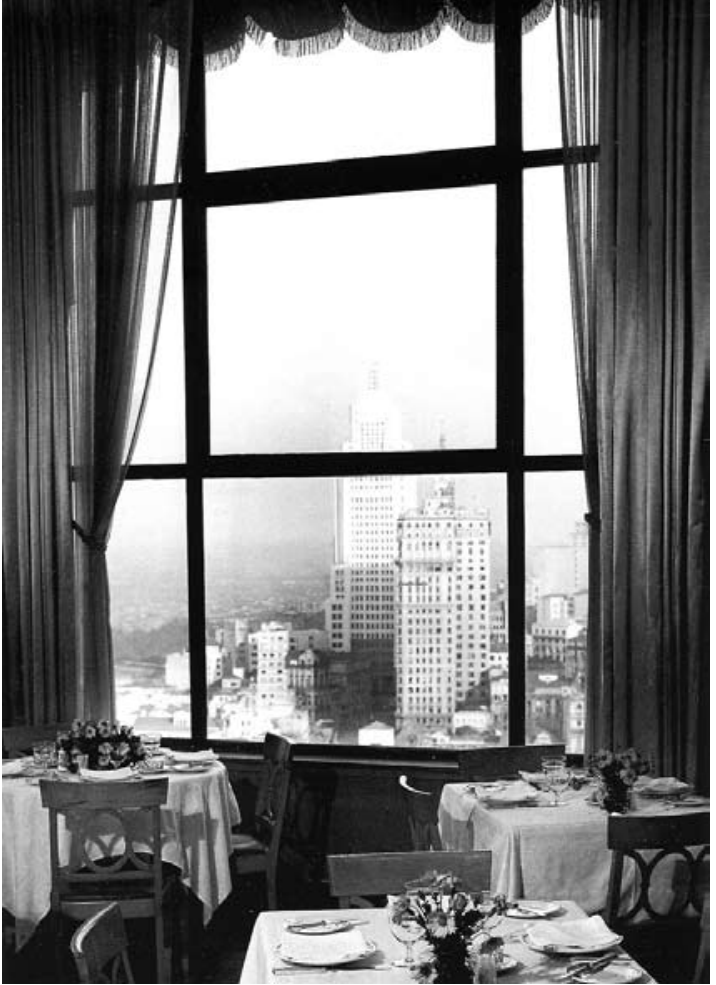

Imagem 182. Edifícios Altino Arantes e Martinelli vistos a partir do restaurante da cobertura do Hotel Excelsior. Autoria: P. Scheier. Fonte: ANELLI; GUERRA; KON (2001), p.121.

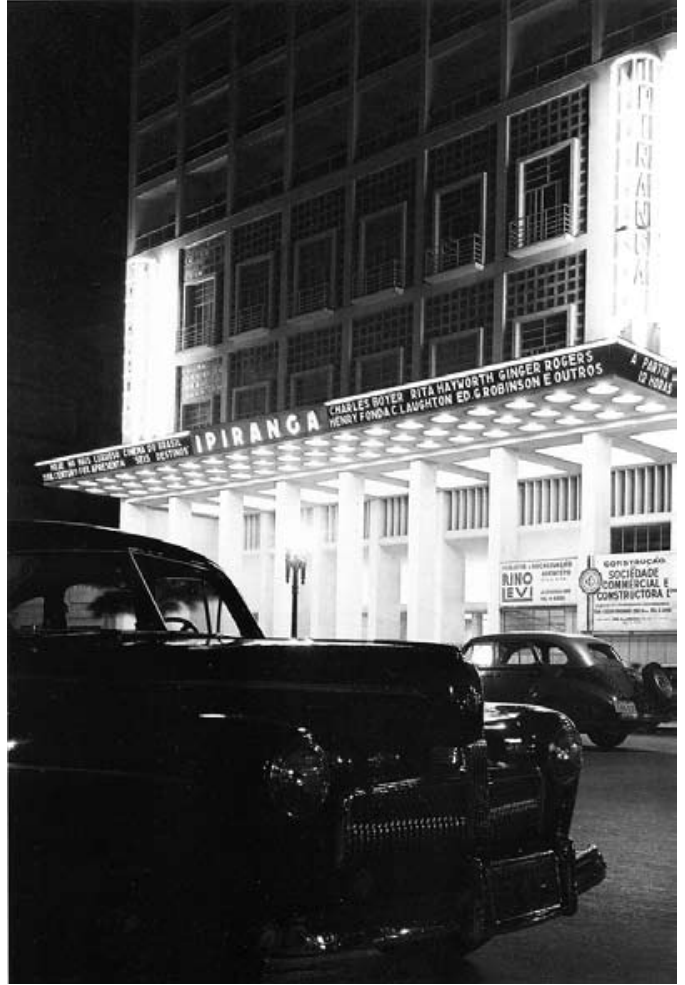

Imagem 183. Vista noturna a partir da Avenida Ipiranga do Cine Ipiranga e Hotel Excelsior. Autoria: P. Scheier. Fonte: ANELLI; GUERRA; KON (2001), p.119.

Rita Rayworth, Ginger Rogers, Henry Fonda, C. Laughton, Ed.G.Robinson e outros. A iluminação intensa da entrada se contrapunha ao Ford Mercury preto estacionado em primeiro plano. Todos os elementos desta imagem constroem um clima de modernidade e progresso - a arquitetura moderna, o novo programa que se desenvolvia na cidade, o filme dos estúdios de Hollywood, os automóveis. Elwall afirma que, a partir da década de 1930, a analogia entre a utilidade e a beleza do automóvel e da arquitetura moderna tornara-se comum ${ }^{106}$. O carro era usado para vender a arquitetura moderna e vice-versa. Le Corbusier promoveu muito essa relação, tanto em seu livro Por uma arquitetura quanto nas fotos de suas obras, que, com freqüência, incluíam um veículo. Um dos capítulos de

106 ELWALL, Robert. Building with Light: the international history of architectural photography. Londres: Merrel Publishers, 2004, p. 134. 


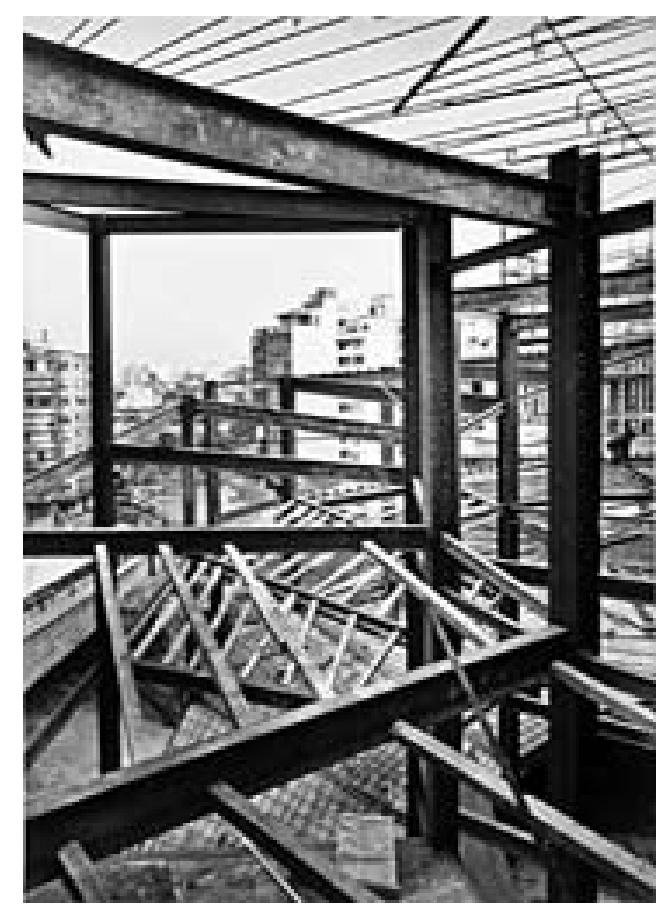

Imagem 184. Obras da Garagem América, de Rino Levi. Autoria: P. Scheier. Fonte: Acervo fotográfico da FAUUSP.

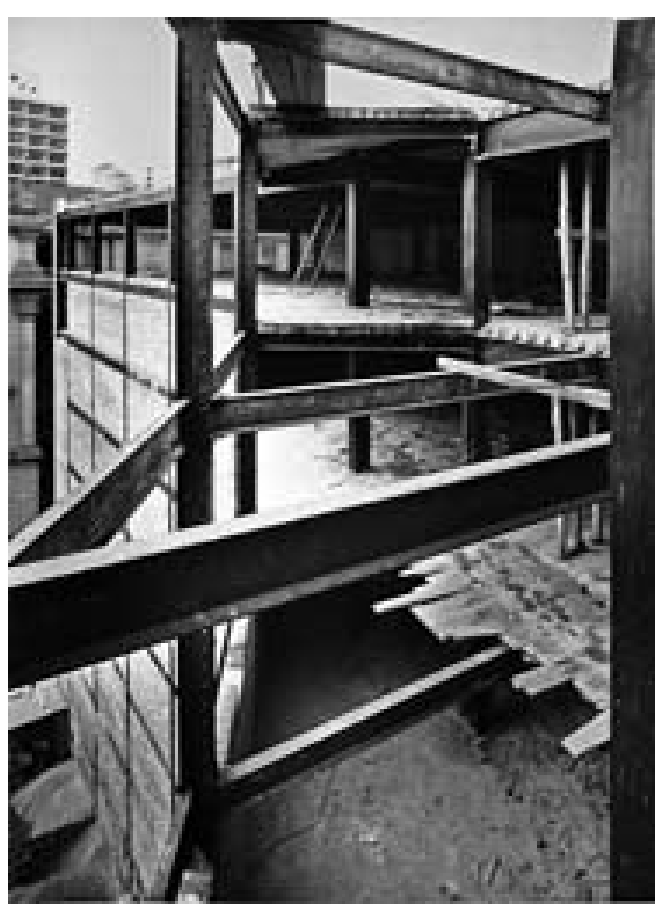

Imagem 185. Obras da Garagem América. Autoria: P. Scheier. Fonte: Acervo fotográfico da FAUUSP.

seu livro foi dedicado aos automóveis, exemplos de padronização eficiente em "busca de uma perfeição, de uma harmonia, afastado do dado bruto prático, uma manifestação não somente de perfeição e harmonia, mas de beleza." 107 Para ele:

107 CORBUSIER, Le. Por uma arquitetura. São Paulo: Editora Perspectiva, 1998, p.93. 


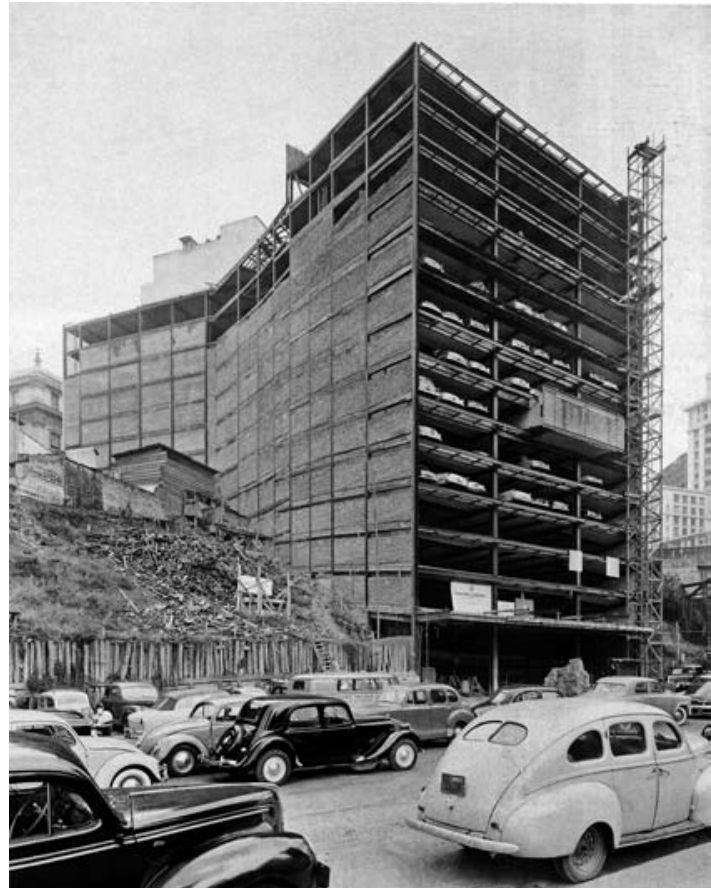

Imagem 186. Garagem América vista a partir da Avenida Anhangabaú. Autoria: P. Scheier. Fonte: ANELLI; GUERRA; KON (2001), p. 195.

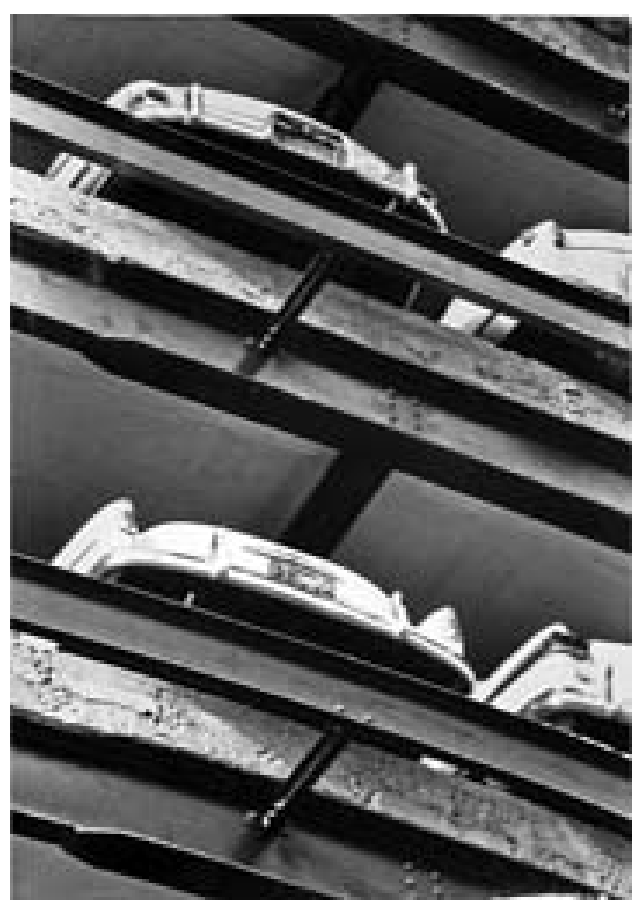

Imagem 187. Garagem América. Autoria: P. Scheier. Fonte: Acervo fotográfico da FAUUSP.

Se o problema da habitação do apartamento fosse estudado como um chassis, veríamos nossas casas se transformarem, melhorarem rapidamente. Se as casas fossem construídas industrialmente, em série, como os chassis, veríamos surgir rapidamente formas inesperadas, porém sadias, justificáveis e a estética se formularia com uma precisão surpreendente. ${ }^{108}$

Os automóveis protagonizam as imagens da Garagem América (Rino Levi, São Paulo, 1952-58), outro novo programa numa cidade já caracterizada pelo domínio dos veículos. Scheier fotografou a garagem durante sua construção e posteriormente.

As vigas metálicas, as esperas de aço e as fôrmas de madeira tornaramse linhas gráficas nas suas lentes. Fotografou a estrutura da rampa curva 


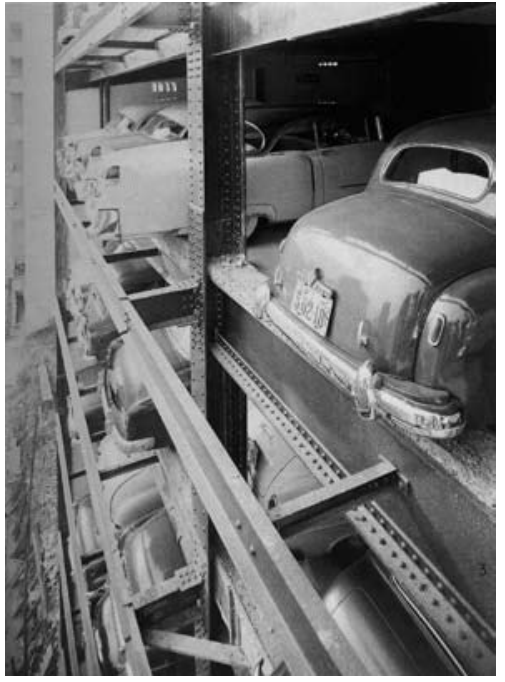

Imagem 188. $\mathrm{G}$ a $\mathrm{r}$ a g e $\mathrm{m}$ América. Autoria: P. Scheier. Fonte: ANELLI; GUERRA; KON (2001), p.196.

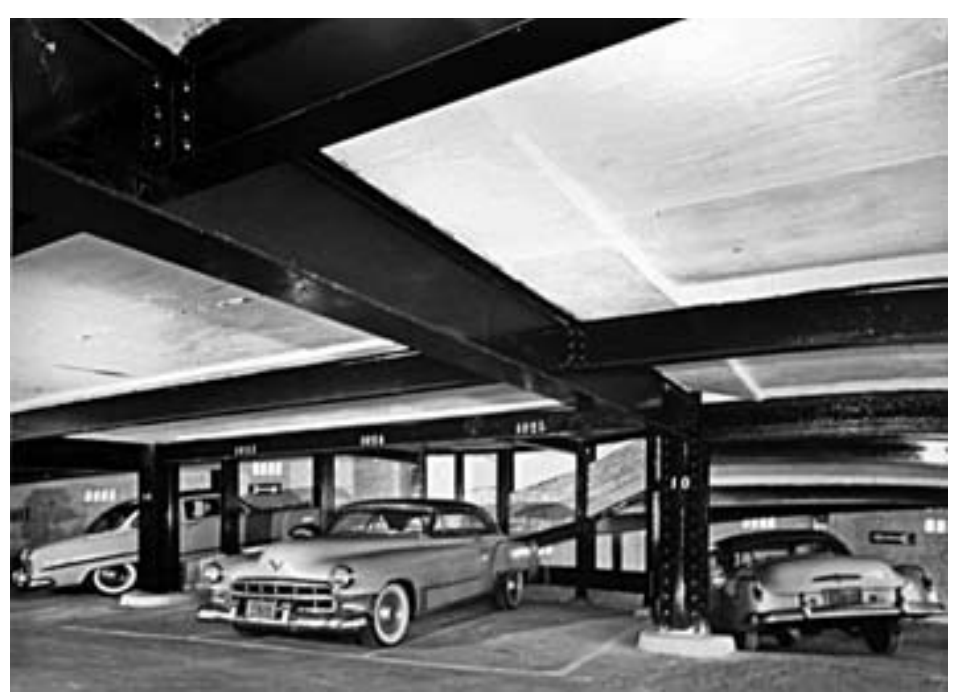

Imagem 189. Vista interna da Garagem América. Autoria: P. Scheier. Fonte: Acervo fotográfico da FAUUSP.

(Imagem 184), um operário fazendo ajustes e o encontro das vigas com os vêdos de alvenaria (Imagem 185). Ao fundo, entre os vãos ainda abertos, vê-se a Avenida Anhangabaú (atual Av. Vinte e Três de Maio) e um detalhe da fachada da Faculdade de Direito do Largo São Francisco, na íngreme Rua Riachuelo.

$\mathrm{Na}$ imagem externa (Imagem 186), vê-se uma proliferação de carros Fusca, Kombi, Ford, Chevrolet, Buick, Citroen - estacionados nos andares da garagem e na pista da Avenida Anhangabaú. Andaimes e entulho indicam que, embora já em uso, o edifício não estava concluído. A fachada da Anhangabaú permaneceu incompleta, sem os elementos de concreto, cerâmica e fibrocimento projetados. O volume das instalações sanitárias dos empregados que se sobressai à fachada também não recebeu o painel decorativo proposto. Notase o grande desnível entre a Rua Riachuelo e a avenida. À esquerda, ao fundo, vê-se a Faculdade de Direito. Scheier fez outras duas imagens desta fachada: a partir da calçada da avenida, inclinou a câmera para cima, numa composição em que as linhas horizontais da estrutura metálica e da laje se contrapõem às 


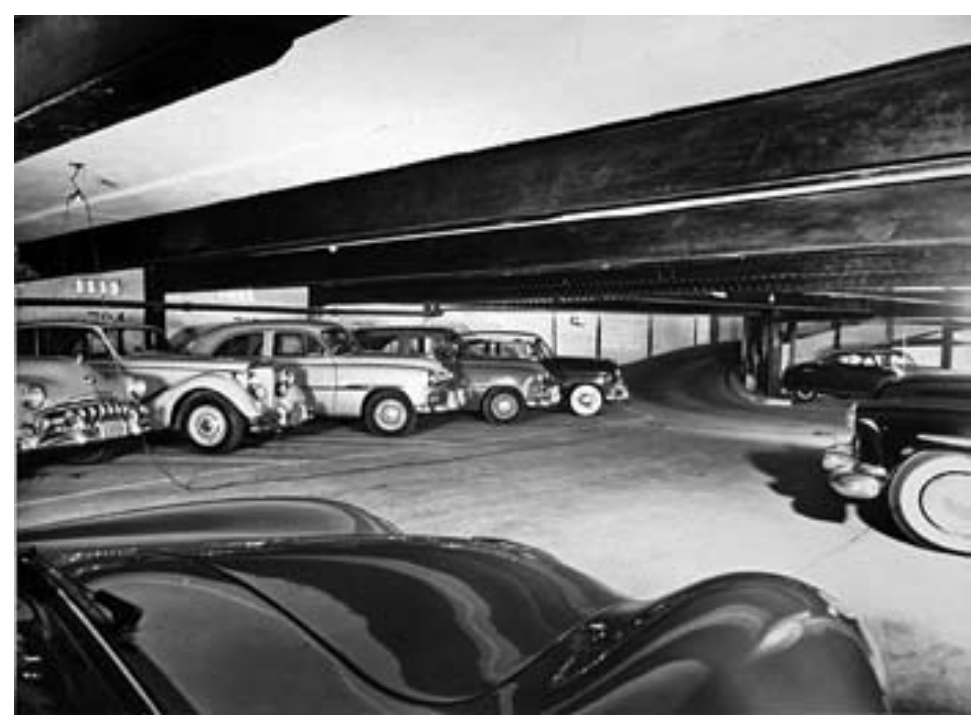

Imagem 190. Vista interna da Garagem América. Autoria: P. Scheier. Fonte: Acervo fotográfico da FAUUSP.

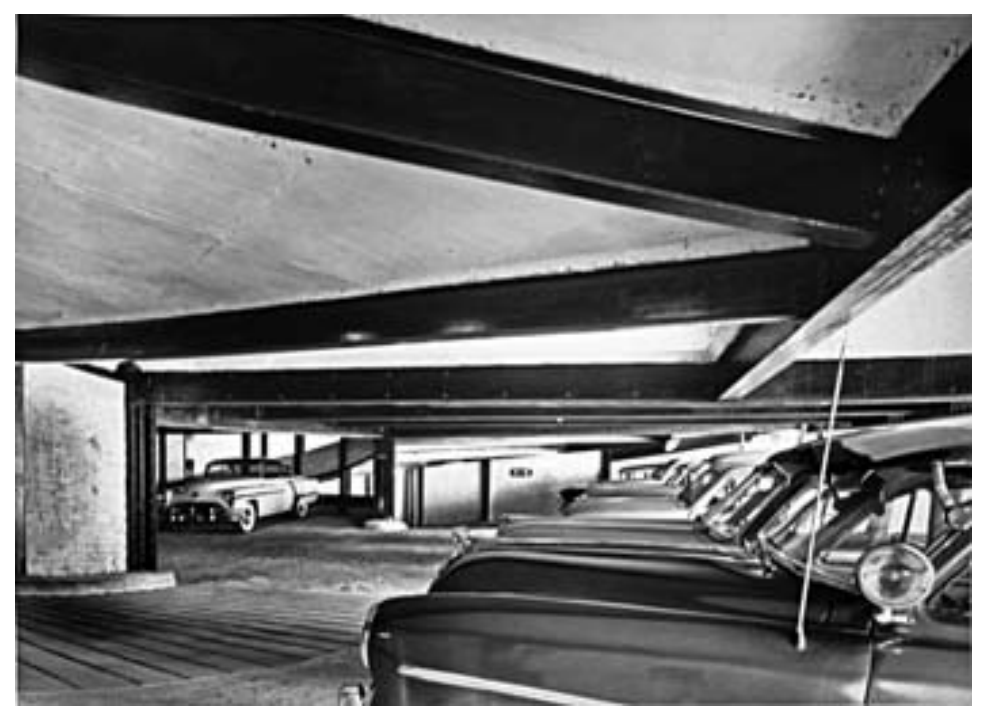

Imagem 191. Vista interna da Garagem América. Autoria: P. Scheier. Fonte: Acervo fotográfico da FAUUSP.

formas arredondadas dos automóveis estacionados de ré (Imagem 187); a partir da laje do volume dos sanitários, numa perspectiva acentuada, na qual as linhas convergem para um ponto central (Imagem 188).

Nas imagens internas (Imagem 189/190/191), Scheier documentou os 


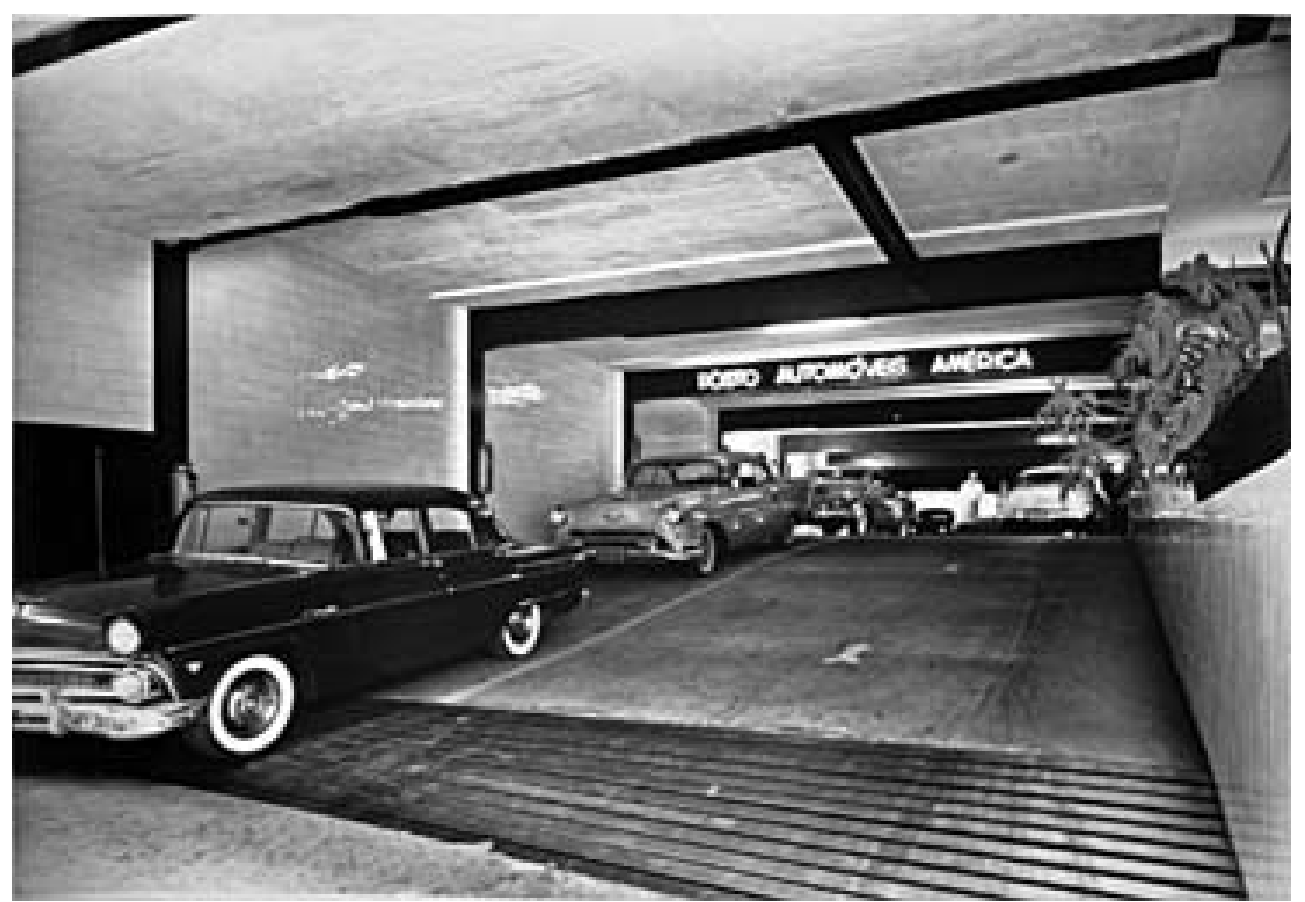

Imagem 192. Acesso pela Rua Riachuelo. Garagem América. Autoria: P. Scheier. Fonte: Acervo fotográfico da FAUUSP.

automóveis estacionados e circulando pelas rampas. Lâmpadas e fios elétricos pendurados - sinais de construção inacabada - são vistos entre os carros, cujos capôs refletem as vigas metálicas, criando um efeito interessante. Também foi fotografada a rampa de entrada na Rua Riachuelo, com o luminoso "Posto Automóveis América" (Imagem 192).

Peter Scheier demonstrou dinamismo em sua documentação de arquitetura. Em ângulos frontais ou oblíquos, teve a preocupação e o cuidado com a organização dos elementos. Os ângulos ascendentes ou descendentes, típicos de seu trabalho autoral ou fotojornalístico e permeados pela cultura visual da época, são usados com mais comedimento, para ressaltar determinados etalhes. Scheier em geral optava por ângulos mais convencionais e equilibrados, sem distorções, baseados nos elementos clássicos da fotografia de arquitetura, como o ponto de vista elevacional, a composição fortemente simétrica, o uso de perspectiva com um ponto de fuga para aumentar o senso de profundidade 
e o foco preciso em toda a área ${ }^{109}$. A perfeita compreensão das intenções do arquiteto e das relações espaciais envolvidas criou registros impecáveis, como na Residência Oscar Americano e na Residência Milton Guper.

Embora a presença humana seja uma característica marcante no seu trabalho fotojornalístico, não é tão freqüente em sua documentação de arquitetura. Os espaços quase sempre estavam vazios. Não mostrava a arquitetura sendo usada, ao contrário, mostrava-a limpa, desprovida de interferências. Esta ausência era constante em fotógrafos das décadas de 1950 e 1960, que buscavam comunicar as relações espaciais e o desenho original do arquiteto em imagens precisas e limpas, sem a presença de elementos móveis, como pessoas e veículos ${ }^{110}$.

Apesar da fotografia de arquitetura não ser a produção mais volumosa e conhecida de Peter Scheier, ela corresponde a um acervo significativo da arquitetura moderna paulista. Ao lado de outros profissionais, Scheier documentou exemplares construídos nas décadas de 1940 e 1950, período de amadurecimento desta arquitetura. Período também de estreitamento das relações entre estas duas artes, num objetivo único de divulgação e consolidação da identidade da arquitetura brasileira, no país e no exterior.

Após as questões biográficas e a análise do trabalho de Peter Scheier como fotojornalista, documentador de arte e de arquitetura, encerramos a parte I da dissertação. A seguir, trataremos dos álbuns fotográficos, a produção de Scheier neste ramo e, por fim, analisaremos seu álbum São Paulo fastest growing city in the world.

109 ELWALL. Op. cit, p.180.

110 Em meados da década de 1960 esse paradigma de "remoção de signos da vida" passou a ser contestado, principalmente nos Estados Unidos, onde profissionais buscavam revigorar o registro de arquitetura inspirados no fotojornalismo, a fim de comunicar algum senso de realidade, mostrar edifícios contextualizados e em uso por pessoas agindo em atividades cotidianas, em oposição a figuras firmes e estáticas servindo de escala. Ver: ELWALL. Op. cit, p. 162-163. 
Parte II - A cidade que mais cresce no mundo

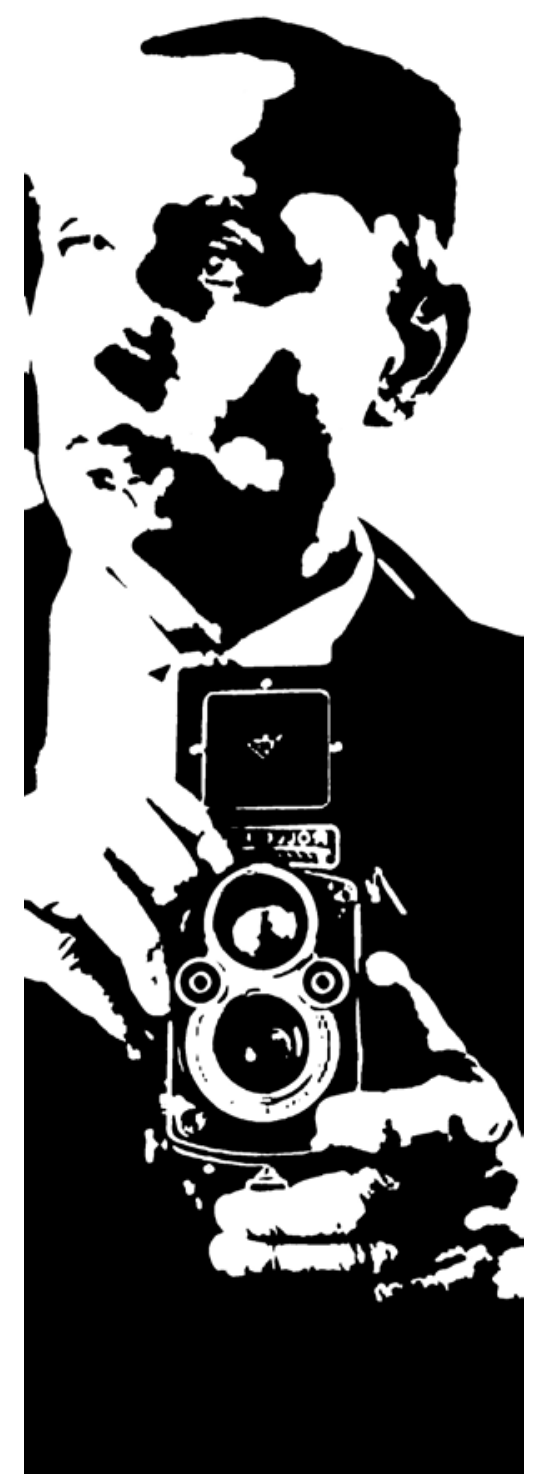


Capítulo 3 - A construção da imagem ideal da cidade: os álbuns fotográficos

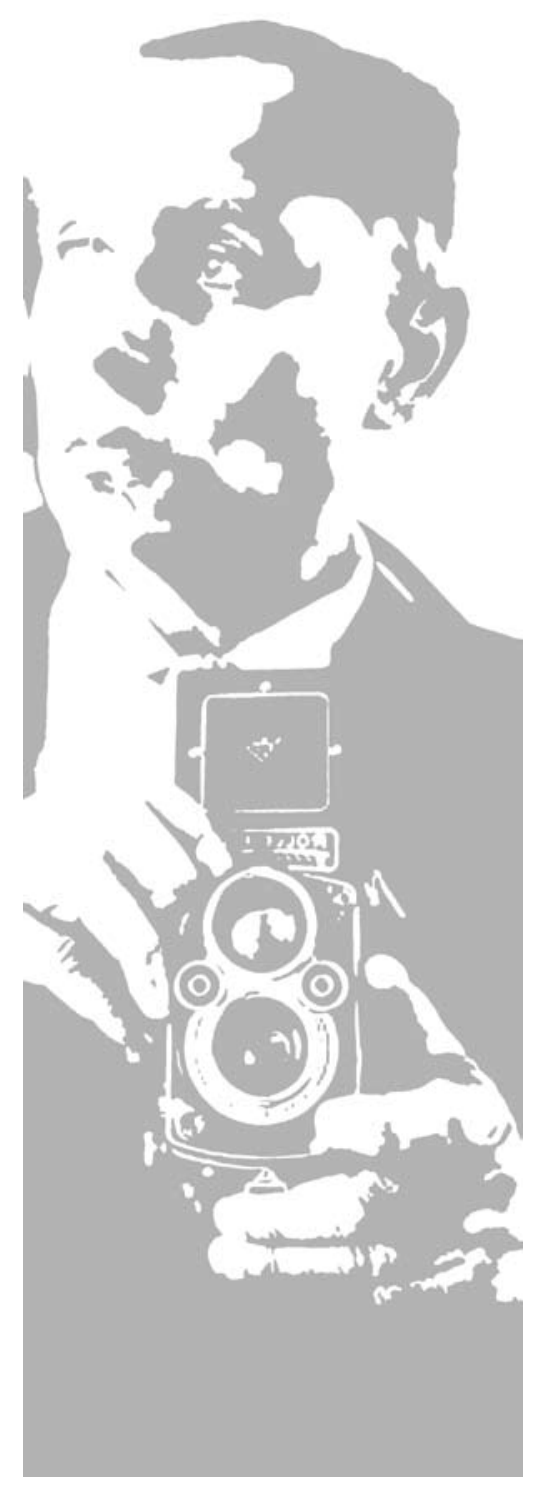


Ao longo de sua carreira, Peter Scheier produziu quatro álbuns temáticos sobre Paraná, São Paulo, Brasília e Minas Gerais. Com exceção do primeiro, todos foram publicados pela Livraria Kosmos Editora.

O primeiro - Paraná, Brasil (1953) - foi uma edição comemorativa do I Centenário do Estado do Paraná (Imagem 193). Com fotos em preto e branco, retrata vários aspectos daquele estado: sua agricultura, sua população, a forte presença imigrante e a economia. Logo em seguida, publicou São Paulo fastest growing city in the world, na comemoração do IV Centenário da cidade de São Paulo, analisado mais profundamente a seguir.

Na década de 1960, Scheier documentou Brasília, em imagens nas quais soube captar não só as linhas da arquitetura de Oscar Niemeyer, mas também sua relação com o homem e com o entorno. Seu livro Brasília vive! mostra uma cidade viva e pulsante. Diferente de sua fotografia de arquitetura analisada anteriormente, na qual o homem está ausente, Peter Scheier apresentou uma 


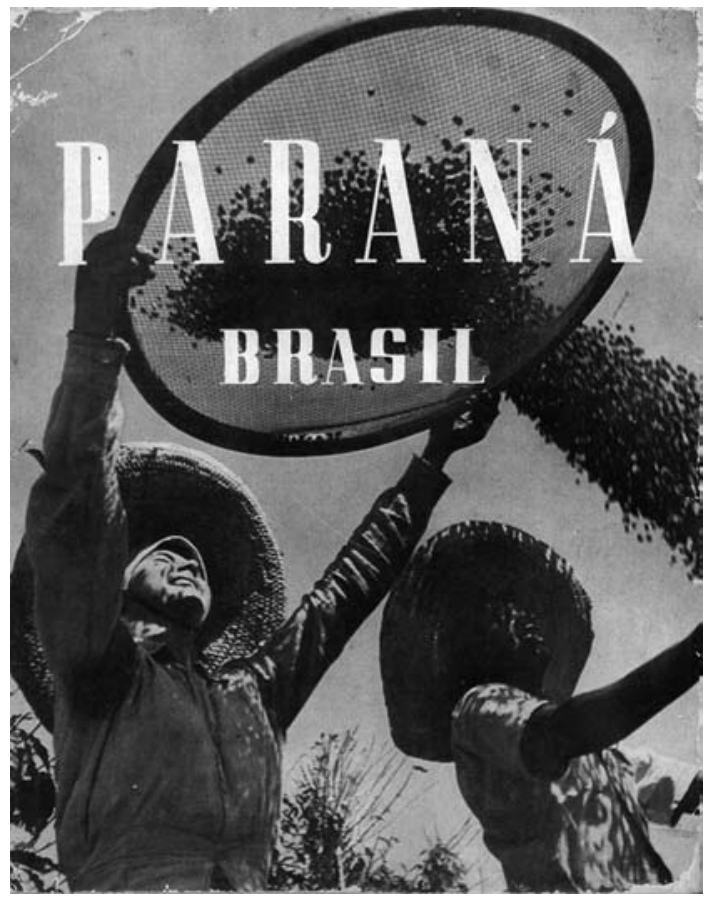

Imagem 193. Capadoálbum comemorativo do primeiro centenário do Estado do Paraná, publicado em 1953. Fonte: Acervo do AHJB.

arquitetura subjetiva e humanista, buscando sempre a presença do homem como elemento atuante sobre o edifício e a cidade circundante, valendo-se de seus espaços para exercer suas atividades. As fotos noturnas dos edifícios, sejam os residenciais, sejam os institucionais, revelam freqüentemente seus interiores, destacando as pessoas em atividade, os móveis, o contraste entre 0 interno e o externo. Em uma destas imagens vê-se uma funcionária sentada à sua mesa de trabalho, concentrada em seus afazeres, enquanto dois guardas faziam a vigília do lado de fora (Imagem 194).

A figura humana aparece freqüentemente como objeto principal, ocupando grande área das composições, com as obras construídas ao fundo. Seja o trombonista ou a tropa carregando as bandeiras em evento oficial com um Ministério ao fundo, sejam os trabalhadores em fila no térreo livre, ou o operário cabisbaixo, que parece repousar a cabeça no espaço entre duas colunas do 


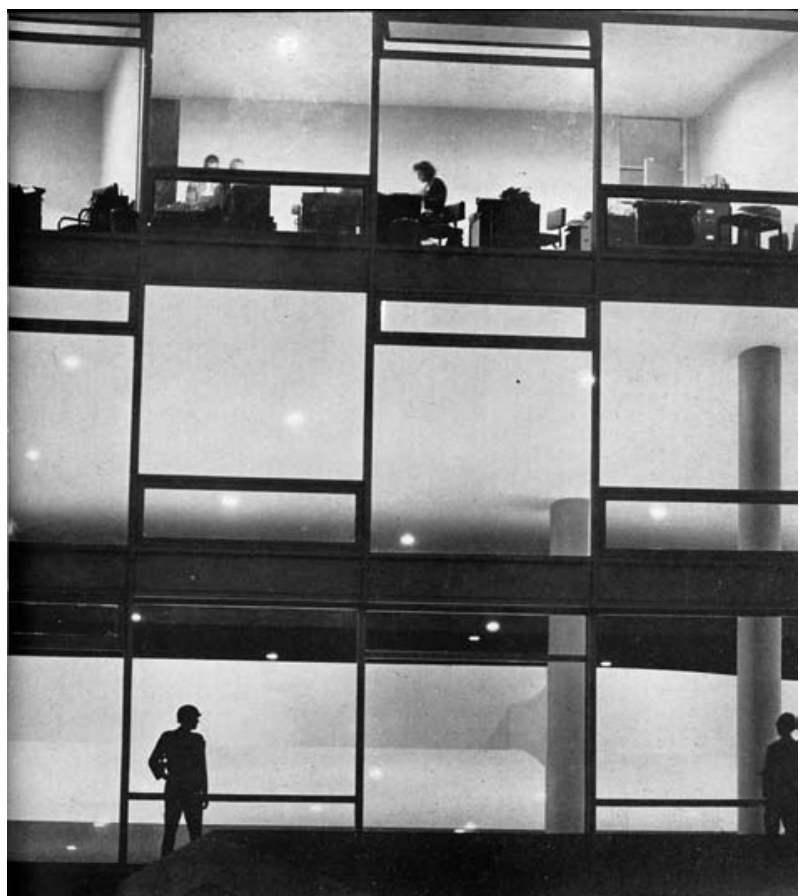

Imagem 194. Brasília, vista noturna de um edifício. Autoria: P.Scheier. Fonte: SCHEIER (s.d.), p.11.

Palácio da Alvorada (Imagem 195), o homem assume outro papel que não o de referência de escala: tem identidade, sendo reconhecível tanto pelas feições quanto pelo ofício.

Em 1968 foi lançado seu Imagens do Passado de Minas Gerais (Imagem 196), com cerca de trinta fotografias coloridas de Tiradentes, Congonhas do Campo, Mariana e Ouro Preto, que documentam detalhes das igrejas, das estátuas, os tetos pintados, os altares, as portas de entrada, vistas gerais das ruas e os rituais religiosos - cerimônia de casamento e uma procissão de Corpus Christi. Com longos textos de Mário Barata e Orlandino Seitas Fernandes sobre a vida e obra de Aleijadinho e com informações das cidades e do estado de Minas no século XVIII, este volume caracteriza-se mais como um livro, uma vez que não apresenta, como os três anteriores, as características típicas do álbum: 


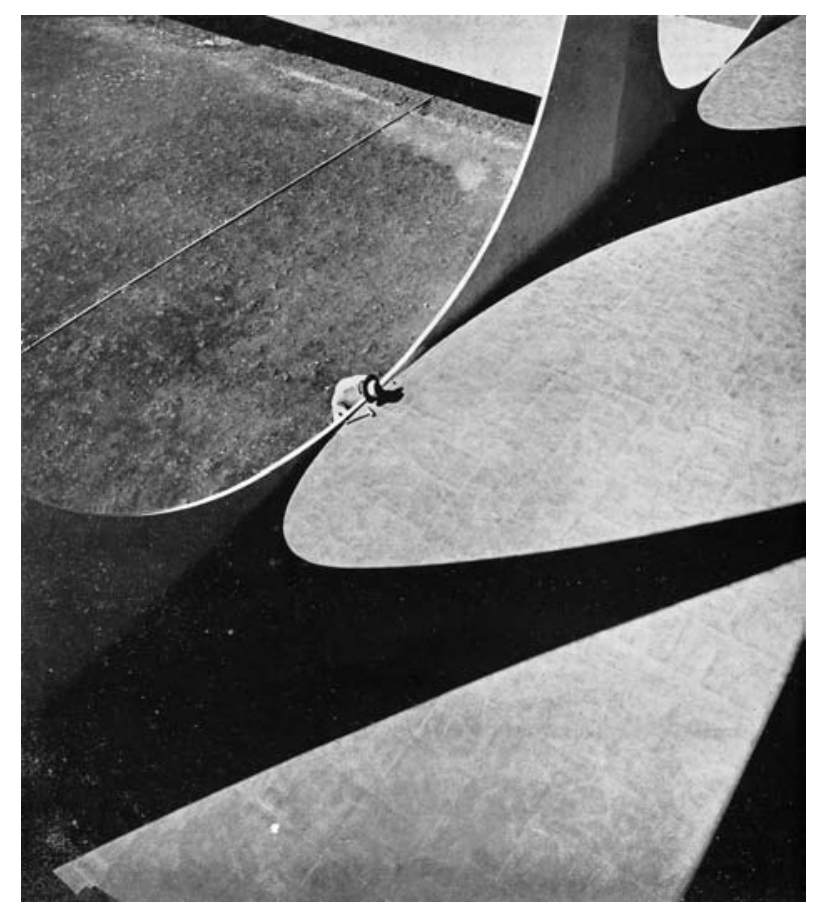

Imagem 195. Brasília. Autoria: P.Scheier. Fonte: SCHEIER (s.d.), p.28.

O álbum é um tipo de publicação iconográfica na qual são aglutinadas, segundo um arranjo específico, fotografias que pretendem representar diversos aspectos da cidade. Trata-se de um tipo de publicação no qual a imagem visual é predominante e assume um papel ativo na construção de sentidos, articulando-se, ao invés de submeter-se aos textos e legendas. ${ }^{1}$

O objetivo do álbum é apresentar uma síntese daquilo que se julga representativo. Segundo Lima e Carvalho, as fotografias urbanas expressam a transformação social e geram modelos aos quais se aglutinam valores e representações "associados ao poder público, à estética, à racionalidade, à organização do espaço, ao trabalho, ao consumo, aos lugares sociais, à riqueza, ao desenvolvimento, às formas de acesso e de participação na rede

1 LIMA, Solange Ferraz de, CARVALHO, Vânia Carneiro de. Fotografia e Cidade: da razão urbana à lógica do consumo - Álbuns de São Paulo (1887-1954). Campinas: Mercado das Letras, São Paulo: FAPESP, 1997, p.19. 


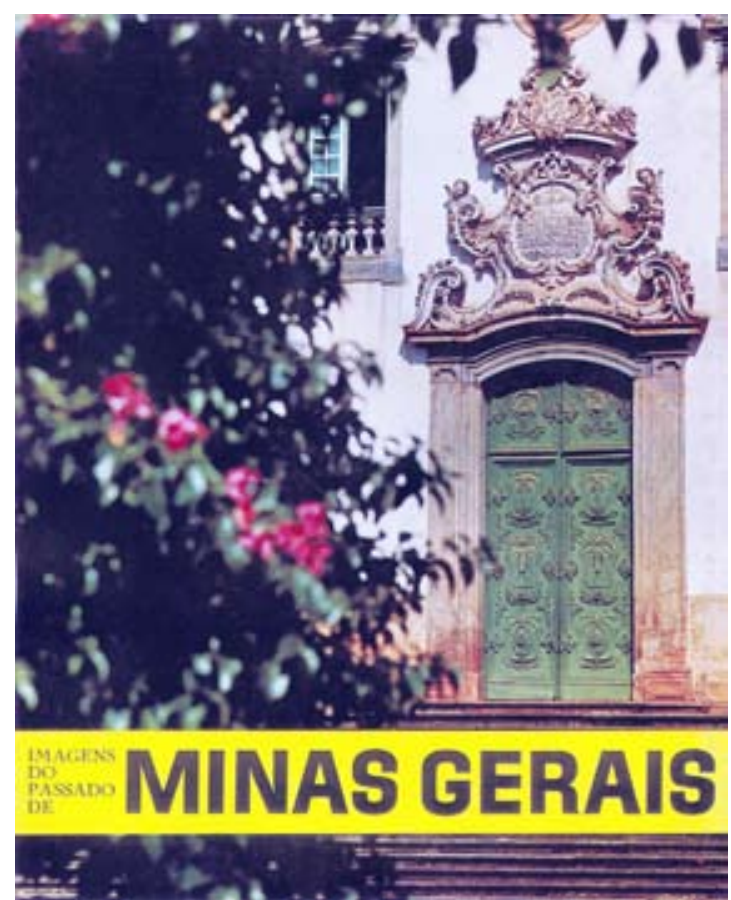

Imagem 196. Capa do livro sobre as cidades históricas mineiras, publicado em 1968. Fonte: Acervo do AHJB

de relações sociais" "2. Assim, os álbuns se prestam ao estudo da sociedade por permitir a análise de quais áreas foram selecionadas para representar a cidade no seu conjunto, qual o grau de extensão da noção de cidade e quais temas foram excluídos por contrariar o modelo pretendido. Segundo as autoras, não se trata de uma luta contra os problemas urbanos, mas contra uma imagem do passado que se quer superar. O álbum de cidade, pois, "se constrói sob a tensão do binômio totalidade/exclusão, ou seja, a dupla necessidade de apresentar todos os elementos constitutivos da cidade, oferecendo uma síntese, e ocultar aqueles que comprometem as premissas sobre as quais estão ancoradas as imagens" 3 .

Segundo Kossoy, os álbuns convergem entre o documento (testemunho) e a propaganda (ficção), apresentando, de forma geral, a finalidade promocional 2 LIMA, CARVALHO. Op. cit, p.13.

3 LIMA, CARVALHO. Op. cit, p.109. 
- política, comercial, institucional, comemorativa -, construindo uma identidade visual para a cidade e veiculando a imagem de uma cidade fotogênica ao gosto das elites. ${ }^{4}$ Contudo, a cidade também tem seu submundo - cenários sombrios (imigrantes e cortiços, doença, insalubridade, anomalia, estigmas sociais) - que a fotografia não registra diretamente, mas permite múltiplas leituras, através do desvendamento da vida implícita nas imagens. ${ }^{5}$

Kossoy enfatiza que a foto é comprometida, engajada estética e ideologicamente, e que teve papel decisivo na construção do imaginário social paulistano, interferindo, inclusive, no processo histórico. Deve haver, portanto, o cuidado na busca da verdade. Por sua generalidade e ambigüidade, a foto documental se presta a múltiplos usos e seu objetivo pode ser alterado em sua aparência de modo que a imagem resultante nada tenha em comum com o modelo. São farsas respaldadas no realismo do testemunho fotográfico e no seu alto grau de credibilidade e nos textos que os acompanham 6 .

Kossoy lembra que a fotografia foi instrumento de registro dos diversos cenários paulistanos em diferentes momentos de sua história, desde sua configuração colonial, presente até quase o final do século $\mathrm{XIX}$, até as transformações urbanas em função do crescimento da economia cafeeira, da indústria e do comércio que geraram uma nova sociabilidade das elites e da modernidade e que deram feições européias à cidade, meio século mais tarde. ${ }^{7}$ Os períodos de 1887-1919 e de 1951-1954 foram de intensa produção de álbuns fotográficos em São Paulo, ao contrário das décadas que os entremeiam, nas quais foram publicados apenas três. No primeiro período são incluídos fotógrafos

4 KOSSOY, Boris. Luzes e sombras da metrópole: um século de fotografias em São Paulo (1850-1950). In: PORTA, Paula (org.) História da Cidade de São Paulo: a cidade no Império. São Paulo: Paz e Terra, 2004, v.2, p. 405.

$5 \quad$ Loc. cit.

6 KOSSOY, Boris. Os Tempos da Fotografia: o Efêmero e o Perpétuo. Cotia, SP: Ateliê Editorial, 2007, p. 137-138.

$7 \quad$ KOSSOY (2004). Op. cit, p. 388. 
como Militão Augusto de Azevedo e Guilherme Gaensly e, no segundo, José Medina, Peter Scheier, Peter Kurt Karfeld, Georg Paulus Waschinski, Francisco Schlachter, Alice Brill Czapski e Leon Liberman.

As origens dos álbuns encontram-se nos primeiros cadernos para condicionamento de retratos fotográficos produzidos em meados do século XIX. Norteava-os a idéia de coleção e de arranjo pessoal de registros fotográficos produzidos por encomenda ou souvenires de viagem. Havia o desejo de diminuir os horizontes, de entender o mundo, de tornar os grandes monumentos visíveis. Entre 1856 e 1860 o britânico Francis Frith documentou os grandes monumentos arqueológicos do Egito. Na Paris de meados do XIX, foi constituída a Comissão dos Monumentos Históricos com o objetivo de documentar o patrimônio arquitetônico que, naquele momento, encontrava-se sob risco de desaparecimento em função das obras do prefeito Haussmann que, sob a bandeira do Segundo Império e os poderes extensos do Imperador Napoleão III, buscava "enobrecer o novo ambiente urbano" 9 . Edouard-Denis Baldus, Gustave Le Gray, Hippolyte Bayard e Henri Le Secq foram fotógrafos contratados pela Comissão para esta tarefa. Destaca-se a figura de Charles Marville, o primeiro fotógrafo a se preocupar em registrar o espaço urbano e contextualizar o edifício e a adotar a presença humana para dar senso de escala.

As primeiras notícias de atividades fotográficas na cidade de São Paulo datam de 1850, no trabalho de daguerreotipistas como Manuel José Bastos, Inácio Mariano da Cunha Toledo, Henrique Deslandes e Jesus Christo Müller ${ }^{10}$. Em 1862, a firma Carneiro \& Smith, do Rio de Janeiro, abriu uma filial em São Paulo. Comercializava vistas urbanas avulsas ou organizadas em álbum. Militão Augusto foi contratado como funcionário e, neste mesmo ano, produziu a primeira $8 \quad$ LIMA, CARVALHO. Apud: KOSSOY (2004). Op. cit, p. 405.

9 BENÉVOLO, Leonardo. História da Cidade. São Paulo: Editora Perspectiva, 1997, p.595.

$10 \quad$ KOSSOY (2004). Op. cit, p. 394. 
série de vistas, considerada a "primeira reportagem fotográfica de São Paulo" ${ }^{11}$, com a finalidade da venda de uma recordação da cidade para os estudantes da Academia de Direito. Eram imagens que mostravam ruas estreitas, esquinas desalinhadas, traçado urbano irregular e o casario colonial de taipa e pedra. Em 1875, Militão abriu seu próprio estúdio, o Photographia Americana ${ }^{12}$, na Rua da Imperatriz (atual Rua Quinze de Novembro) ${ }^{13}$, e continuou a venda de vistas avulsas. A partir desta época, destacaram-se outros profissionais como Carlos Hoenen, Francisco Theodoro Passig, Alberto Henschel, Jean Georges Renouleau, Pedro Hoenen e Valério Vieira.

Até a primeira década do século XX, a fotografia disseminou-se rapidamente na cidade, com o aumento do número de estabelecimentos e diversidade de produtos e conseqüente queda do preço de vistas urbanas, tanto avulsas como em álbuns, num "processo de massificação (...) devido à integração do gênero ao circuito editorial" ${ }^{14}$. O mercado de vistas urbanas era bem diversificado, com uma produção oficial destinada a divulgar o Brasil no exterior e uma voltada ao mercado interno, representado pelos estrangeiros - imigrantes e turistas - em São Paulo ${ }^{15}$.

Empresas estrangeiras como a São Paulo Railway e The São Paulo Tramway, Light and Power Company contratavam o acompanhamento fotográfico das obras, para seu controle técnico e avaliação à distância ${ }^{16}$. Guilherme Gaensly

11 LAGO, Pedro Corrêa do. Militão Augusto de Azevedo. Rio de Janeiro: Capivara, 2001, p.16.

12 Carneiro Joaquim Feliciano Alves teve Smith como seu primeiro sócio. A filial paulista de Carneiro \& Smith - na Rua da Cruz Preta, 22 - era dirigida por Gaspar Antonio da Silva Guimarães. Em 1865, Carneiro encerrou sua sociedade com Smith e associou-se a Gaspar, formando o ateliê Carneiro \& Gaspar. Após o falecimento de Gaspar, Militão sucedeu-o no negócio, até que, em 1875, o ateliê passou a se denominar Photographia Americana. Ver: KOSSOY, Boris. Dicionário Histórico-Fotográfico Brasileiro - Fotógrafos e ofício da fotografia no Brasil (18331910). São Paulo: Instituto Moreira Salles, 2002, p.67, 103-104.

13 KOSSOY (2004). Op. cit, p.394.

14 LIMA, CARVALHO. Op. cit, p.22.

15 LIMA, CARVALHO. LOc.cit.

16 LIMA, CARVALHO. Op. cit, p.115. 
foi o principal fotógrafo da paisagem paulistana do fim do século XIX até os anos 1920. Registrou, por mais de 20 anos, as obras destas duas firmas, responsáveis pela instalação do sistema de bondes elétricos, pelo fornecimento de energia, telefone e gás ${ }^{17}$. Também trabalhou para a Secretaria de Agricultura, Comércio e Obras Públicas (1902-1906) e para o arquiteto Ramos de Azevedo. Frederic Manoel foi contratado para registrar a construção do viaduto Santa Ifigênia. Hensler \& Kowalsky, Lindemann, Otto Rudolph Quaas e P. Doumet foram outros fotógrafos que registraram obras de infra-estrutura.

No Rio de Janeiro, Augusto Malta e Marc Ferrez registraram o processo de urbanização. Augusto Malta foi contratado pelo Prefeito Francisco Pereira Passos, em 1903, como fotógrafo oficial da prefeitura da cidade do Rio de Janeiro. Marc Ferrez foi contratado, em 1902, pela Comissão Construtora da Avenida Central, para documentar o projeto aprovado das fachadas de todos os prédios a serem construídos e, depois da construção, fotografar estes edifícios concluídos, para organizar o Álbum da Avenida Central.

A produção de vistas urbanas, com o objetivo da elite de apresentar, nacional e internacionalmente, uma imagem europeizante de São Paulo, acontecia em outras capitais latino-americanas, como na cidade do México, com o trabalho de Abel Briquet ${ }^{18}$. Além da produção de álbuns e vistas avulsas, os cartões postais tornaram-se populares. Neles, uma cidade movimentada e repleta de jardins e parques decorativos era exibida em imagens inspiradas nas culturas inglesa, francesa, alemã e suíça, para parecer uma cidade civilizada à altura das européias. Guilherme Gaensly, Casa Rosenhain, Rosenhain \& Meyer, Mazieri, Malusardi, Vanorden, Steidel, Colombo, Fotolabor (Werner Haberkorn), Gustavo Prugner e Theodor Preising ${ }^{19}$ foram alguns profissionais que se dedicaram a $17 \quad$ KOSSOY (2004). Op. cit, p.402.

18 KOSSOY (2004). Op. cit, p.400.

19 Theodor Preising se destacaria também, na década de 1930, por seu trabalho na revista Revista São Paulo, em parceria com Benedito Junqueira Duarte. 


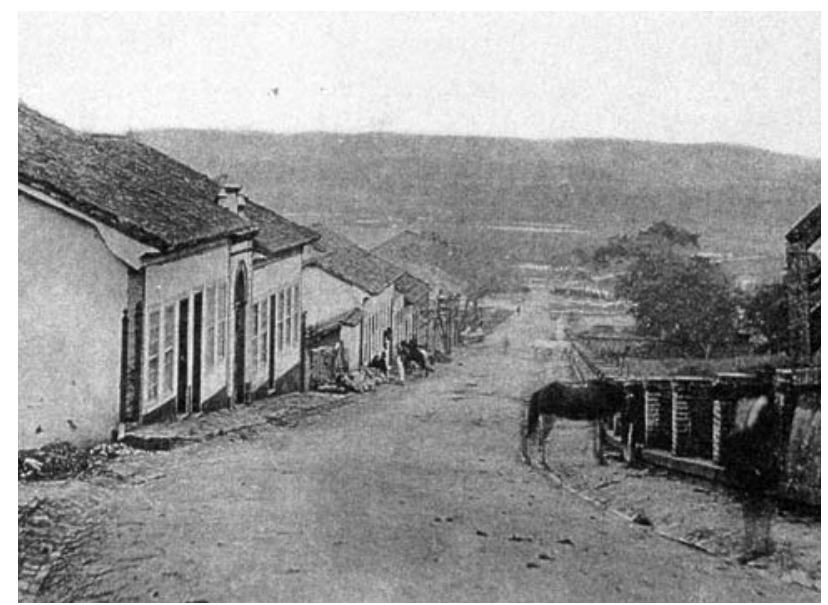

Imagem 197. "Ladeira do Palácio, 1862" (legenda original). Autoria: Militão Augusto de Azevedo. Álbum Comparativo da Cidade de São Paulo: 18621887-1914, p.20. Fonte: LIMA; CARVALHO (1997), p.129.

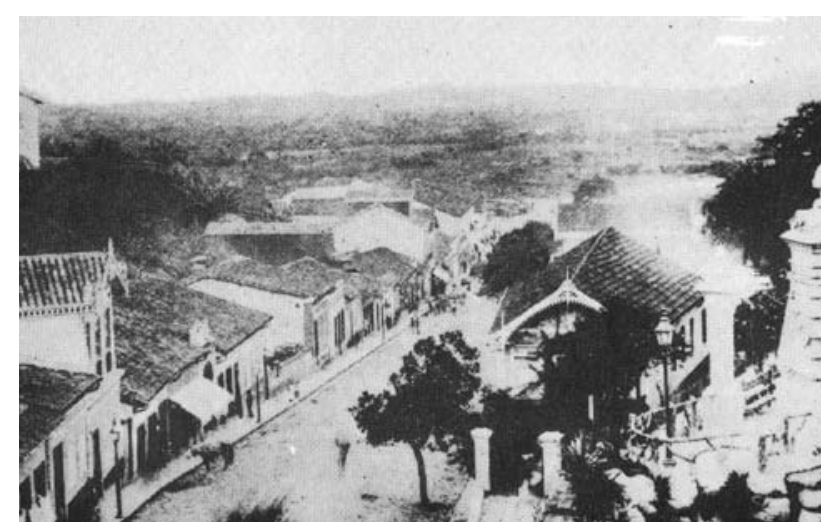

Imagem 198. Rua João Alfredo (antiga Ladeira do Palácio), 1887. Autoria: Militão Augusto de Azevedo. Fonte: TOLEDO; KOSSOY; LEMOS (1981), s/p.

esse ramo ${ }^{20}$. Kossoy lembra como era

imprescindível para a camada enriquecida da sociedade paulistana apagar os "vestígios" coloniais da Cidade e divulgar para o exterior a imagem sedutora de um Estado promissor, com o objetivo de atrair colonos europeus para suprirem a mão-de-obra necessária à contínua expansão da lavoura cafeeira e também à indústria, cujo crescimento era notório. ${ }^{21}$

$20 \quad$ KOSSOY (2004). Op. cit, p.404.

$21 \quad$ KOSSOY (2004). Op. cit, p.401. 
O primeiro álbum comparativo foi publicado por Militão Augusto de Azevedo em 1887 e tornou-se referência para outros (Imagem 197/198). O Álbum Comparativo da cidade de São Paulo (1862-1887) incluía as imagens realizadas ainda no estúdio Carneiro \& Smith, única fonte para conhecimento da cidade antes das transformações que eliminaram suas características coloniais. Até o início da década de 1870, São Paulo manteve praticamente a mesma configuração espacial. Com o desenvolvimento da lavoura cafeeira, a expansão da rede ferroviária e a imigração européia, a cidade começou a se tornar um centro de negócios ligados à cafeicultura. Isso implicou em transformações na vida social e no cenário urbano, que agora apresentava ruas mais largas e numerosas, iluminação pública a gás e bonde.

Com uma abordagem globalizante da cidade, o álbum focava na topografia, nas estruturas de circulação, na tipologia das construções e no perfil dos moradores. Toledo afirma que o fotógrafo "documentou a cidade primeiro com seu ar de "cidade de barro" (...) e depois a "cidade dos fazendeiros" do fim do Império" ${ }^{22}$. Lemos completa: as "fotos de 1887 mostram-nos, em pleno processamento, a transformação da cidade de taipa em cidade de tijolos. São os flagrantes de uma alteração que durou mais ou menos quarenta anos" ${ }^{23}$.

Os álbuns publicados entre 1887 e 1919 abordavam as qualidades espaciais da cidade. A seqüência das imagens sugeria a articulação espacial dos logradouros do centro. Não havia um projeto editorial e, com freqüência, as imagens eram também encontradas na forma de cartões-postais, para aproveitar

22 TOLEDO, Benedito Lima de. A Imperial cidade de São Paulo vista por Militão. In: TOLEDO, Benedito Lima de; KOSSOY, Boris; LEMOS, Carlos. Álbum comparativo da cidade de São Paulo/1862-1887: Militão Augusto de Azevedo. São Paulo: Prefeitura do Município de São Paulo - Secretaria Municipal de Cultura, 1981. p.21.

23 LEMOS, Carlos A.C. A arquitetura que Militão de Azevedo fotografou em São Paulo. In: TOLEDO; KOSSOY; LEMOS. Op. cit, p.27. 


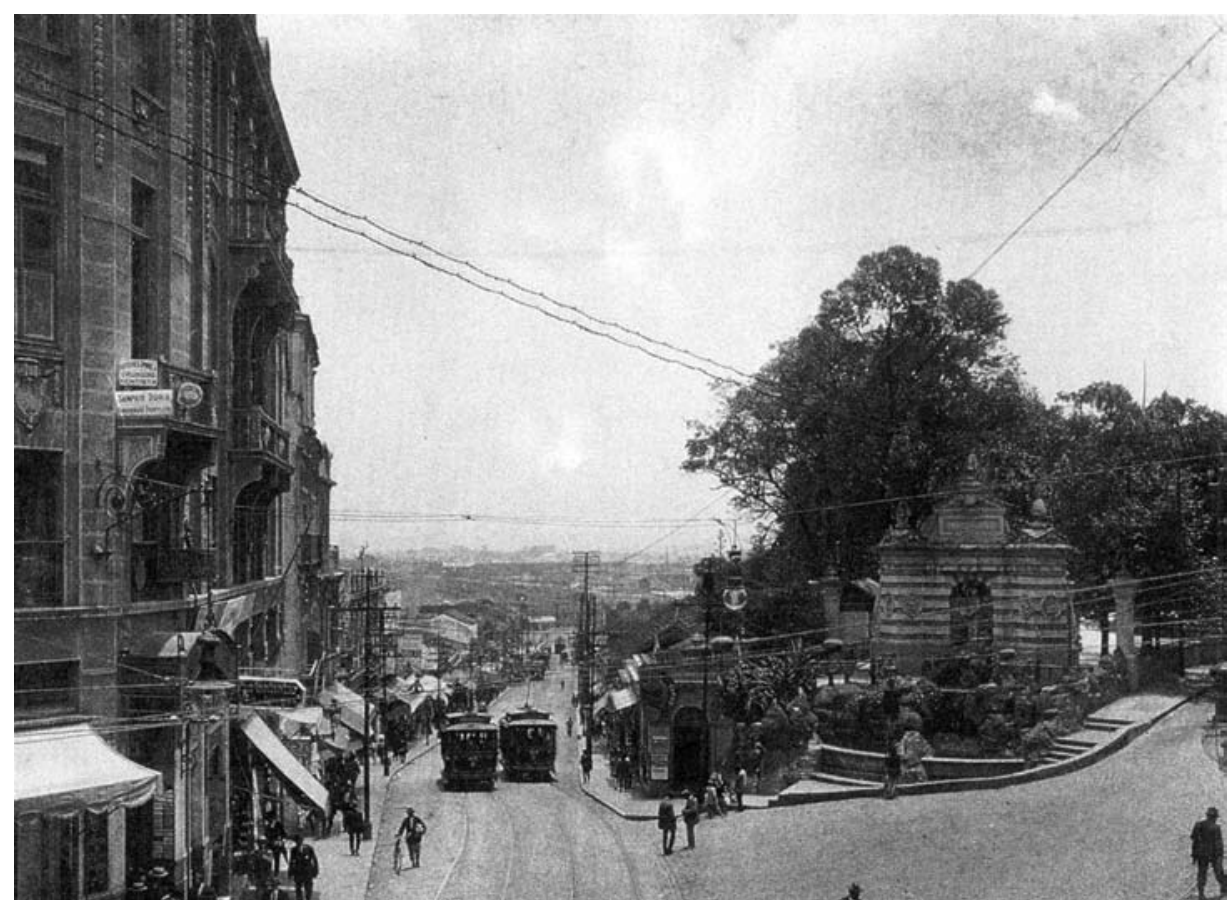

Imagem 199. "Rua General Carneiro, 1914" (legenda original). Álbum Comparativo da Cidade de São Paulo: 1862-1887-1914, p.22. Fonte: LIMA; CARVALHO (1997), p.129.

os mesmos clichês. Caracterizavam-se por uma justaposição de imagens sintéticas, estereotipadas e individualizadas, que seguiam a lógica da circulação avulsa, típica do cartão postal ${ }^{24}$. Não havia textos: as legendas eram as únicas referências, e limitavam-se à identificação do motivo fotografado.

Os álbuns comparativos seguiam uma ordenação cronológica. Seu tema principal era o centro como indicador de adensamento de pessoas e edificações (ou seja, do crescimento da cidade) e como objeto de reformulações urbanas. A partir de 1910, as obras de infra-estrutura urbana, como o alinhamento, pavimentação e alargamento de ruas e a reurbanização do Vale do Anhangabaú (com base no Plano Bouvard), passaram a constar deste tipo de álbum, principalmente daqueles produzidos pelo poder público, preocupado em apresentar as realizações da gestão municipal. O prefeito Washington Luiz Pereira da Silva organizou e 


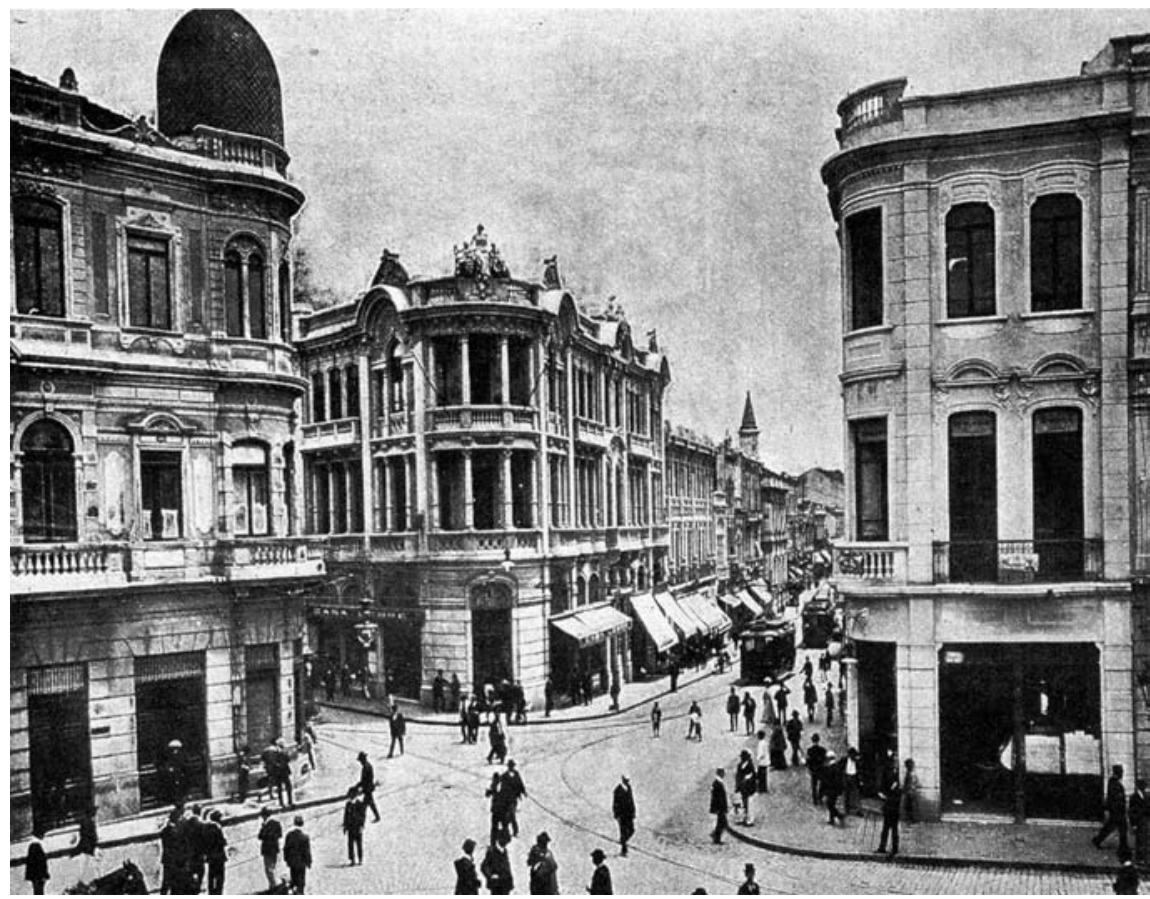

Imagem 200. "Ruas Direita e 15 de Novembro (vistas do Largo da Sé) São Paulo" (legenda original). Álbum de Vistas de São Paulo. Fonte: LIMA; CARVALHO (1997), p.144.

autorizou em 1916 três álbuns comparativos. Culto e consciente da importância da obra de Militão, contratou o fotógrafo Aurélio Beccherini para registrar os mesmos locais anteriormente fotografados, com o objetivo de lançar um novo álbum comparativo da cidade com imagens de 1862-1887-1914 (Imagem 199). Compostos por originais fotográficos e legendas manuscritas, tinham circulação no âmbito administrativo e de divulgação política ${ }^{25}$.

Os registros focavam na área central, em logradouros como a Rua Quinze de Novembro, Rua Direita (Imagem 200), Rua São Bento, Rua Líbero Badaró, Rua Quintino Bocaiúva, os largos da Sé e São Bento, Avenida São João e Viaduto do Chá (Imagem 201). As partes da cidade selecionadas evidenciavam o processo de reorganização espacial pautado pela racionalidade urbana, explícito na remodelação da área central e nos novos padrões de ocupação dos bairros 


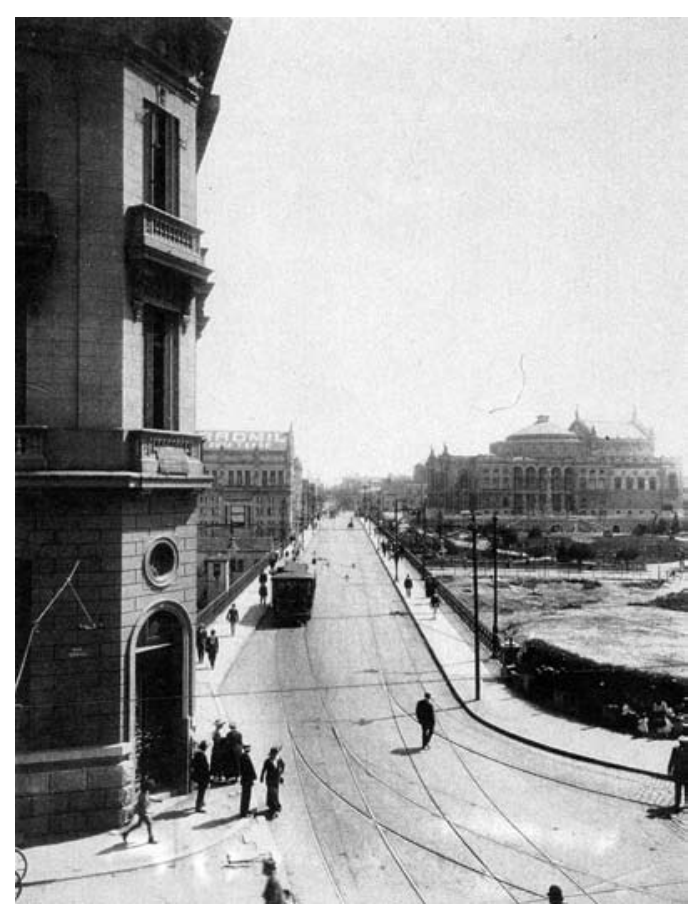

Imagem 201. "Viaduto do Chá, 1916" (legenda original). Álbum Comparativo da Cidade de São Paulo: 1862-1916, p. 97. Fonte: LIMA; CARVALHO (1997), p.132.

residenciais. As ruelas estreitas e de chão batido do fim do século XIX foram substituídas por vias de circulação alinhadas no início do XX. A necessidade de infra-estrutura para dinamizar a circulação de mercadorias era explicitada, realçando a figura do poder público.

As vistas panorâmicas de bairros adjacentes à área central, como o Bom Retiro, Campos Elíseos e principalmente Brás, na Várzea do Carmo, mostravam a área central como o foco irradiador do crescimento da cidade. Nos álbuns comparativos era possível comparar os estágios do crescimento urbano e visualizar os limites da cidade, assim como perceber o processo de homogeneização do gabarito das edificações e a concentração do setor terciário no centro, que não mais se caracterizava como uma área residencial ${ }^{26}$.

26 LIMA, CARVALHO. Op. cit, p.64. 


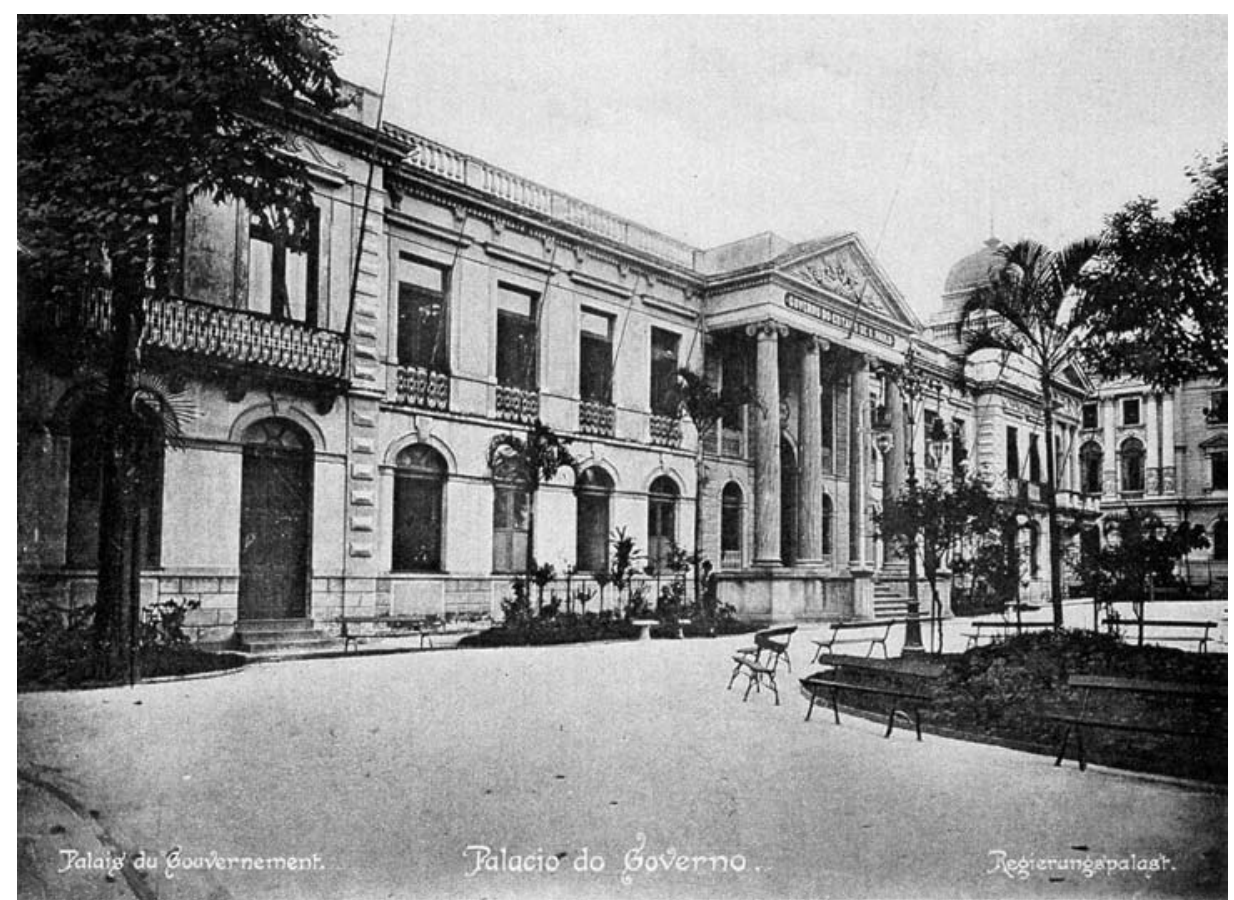

Imagem 202. Palácio do Governo (legenda original). Álbum de São Paulo. Fonte: LIMA; CARVALHO (1997), p.39.

As edificações típicas da arquitetura vernacular eram excluídas dos álbuns por negar os novos valores estéticos. O objetivo, naquele momento, era construir uma imagem moderna do Brasil republicano "a partir de modelos racionalizadores do espaço urbano" ${ }^{27}$. A arquitetura eclética e imponente dos edifícios públicos era a novidade no contexto urbano. Ramos de Azevedo, o "arquiteto oficial" desse período, seguia os modelos europeus para as obras mais significativas. Estes edifícios - Palácio do Governo (Imagem 202), Secretarias Públicas, Escola Normal ${ }^{28}$, Teatro Municipal, institutos, escolas secundárias e de ensino superior normalmente eram retratados descontextualizados do tecido urbano ${ }^{29}$.

Em suma, nos álbuns produzidos no final do século XIX e início do XX a cidade era um espaço público, externo e de uso diurno, caracterizado por ruas recém-construídas, edifícios públicos imponentes, parques, jardins e ferrovias. 0

27 LIMA, CARVALHO. Op. cit, p.16.

28 Instituto Caetano de Campos, projeto de Ramos de Azevedo.

29 LIMA, CARVALHO. Op. cit, p.84. 
agente principal era o poder das elites ${ }^{30}$. A ênfase estava na circulação urbana, em ruas com poucas pessoas e meios de transporte escassos. A cidade era, então, vista como infra-estrutura.

\title{
3.1 O IV Centenário em obras e álbuns
}

\begin{abstract}
Certamente, o sentimento que levou Militão de Azevedo a fotografar sua cidade pela segunda vez foi muito parecido com toda aquela vaidade provocada entre os paulistas da época pelo repentino progresso que o dinheiro do café trouxe. (...) Essa vaidade era, pois, mais que compreensível porque havia uma espécie de vergonha do caipirismo do passado pobre bem recente. ${ }^{31}$
\end{abstract}

Assim como os álbuns do final do século XIX e início do XX estavam comprometidos com uma imagem europeizante da cidade de São Paulo, que conotava sofisticação e desenvolvimento, os álbuns produzidos entre 1951 e 1954 referenciavam-se à imagem de progresso e modernidade que dominava os eventos comemorativos do $400^{\circ}$ aniversário da cidade.

O IV Centenário resultou na ampliação de mercado para este tipo de produção iconográfica que há tempos apresentava estagnação e que agora se tornava um investimento altamente rentável, graças a um amplo contexto social de produção e consumo de imagens da cidade. Seu mercado abrangia o público privado através da venda a varejo, a esfera pública e institucional através da Comissão Comemorativa do IV Centenário e o exterior através de representantes da autarquia ou dos escritórios e embaixadas brasileiras ${ }^{32}$.

\footnotetext{
$30 \quad$ LIMA, CARVALHO. Op.cit, p.182.

31 LEMOS. Op. cit. p.23.

32 LIMA, CARVALHO. Op. cit, p.25.
} 
Entre 1951 e 1954 - ano das comemorações - foram produzidos sete álbuns, sendo dois comparativos, São Paulo antigo, São Paulo moderno: álbum comparativo, editado pela Melhoramentos em 1953, e São Paulo, o que foi e o que é, com imagens do fotojornalista José Medina. Os dois volumes de Isto é São Paulo. Flagrantes da capital bandeirante, São Paulo: álbum de fotografias em cores, de Peter Kurt Karfeld, Eis São Paulo: uma obra realizada e editada no ano de 1954, com grande parte das fotos feitas por Georg Paulus Waschinski e São Paulo fastest growing city in the world, de Peter Scheier, completam esta lista ${ }^{33}$. Em comum, o tom ufanista em relação ao crescimento e a transformação estrutural da cidade.

Camargo aponta para a euforia que contaminou boa parte do mundo ocidental na década de 1950, conhecida como "anos dourados", que vislumbrava novas perspectivas econômicas, sociais e culturais. Na capital paulista, esta euforia era refletida no "dinamismo de sua vida cotidiana e nas transformações de seu ambiente urbano", que adquiria ares de metrópole ${ }^{34}$. O grande tema das comemorações, pois, era a modernidade, delineada na "nova etapa, de grandiosidade territorial e demográfica, de pujança econômica e de efervescência cultural" ${ }^{35}$ nunca antes vista. Naquele momento, a referência era o futuro rico e grandioso, não o passado de tempos difíceis de sobrevivência e provincialismo ${ }^{36}$ e muito menos a derrota sofrida, vinte anos antes, na Revolução Constitucionalista de 1932.

A São Paulo dos anos 1950 passava por transformações em todos os campos. A cidade substituía definitivamente seu caráter oligárquico e rural ligado à cultura do café - para o urbano e industrial. Lourenço afirma que rever as $33 \quad$ Ver: LIMA; CARVALHO. Op. cit, p.24.

34 CAMARGO, Mônica Junqueira de. IV Centenário da cidade de São Paulo: um espetáculo do progresso. Desígnio: revista de história da arquitetura e do urbanismo, São Paulo, v. 4, p. 51, 2005.

35 CAMARGO. Op. cit, p. 53.

$36 \quad$ CAMARGO. Op. cit, p. 52. 
antigas posturas era necessário frente à falência das oligarquias, baseadas em "coalizões, entendimentos e privilégios discriminatórios" ${ }^{37}$. Empreendedorismo era a chave para alcançar econômica, política, industrial, artística e culturalmente os países centrais. Assim, visando o futuro, a cidade varreu seus traços do passado, na "relação sempre difícil entre as partes antigas ou velhas e as partes novas da cidade" que se exaspera "em incompatibilidade e rejeição" ${ }^{38}$.

Dentro deste contexto, o objetivo implícito nas fotos urbanas dos álbuns era apresentar a cidade como expressão da modernidade. "A intenção não é apenas sugerir a modernidade da cidade paulistana, mas dar uma configuração precisa a seus agentes." 39 Contudo, lembra Lima e Carvalho, não se podia abusar das fotos vanguardistas sob o risco de comprometer a própria identidade da documentação. "Afinal, trata-se de um álbum da cidade de São Paulo e não de um álbum de fotografias que usa a cidade como objeto de pesquisa de linguagem." 40 Formalmente os álbuns recorriam a recursos da linguagem fotográfica moderna, próprios da produção norte-americana e européia do início do século $X X$, como já apontado no primeiro capítulo. Subtração do ambiente urbano, ênfase na plasticidade do edifício em detrimento da percepção do conjunto estrutural, tomadas fragmentadas, valorização da altura por meio de tomada ascensional, justaposição, tendência ao abstracionismo, inversão de escala, rotação do eixo e supressão da linha do horizonte eram utilizados para prover de dinamismo os álbuns ${ }^{41}$.

Além da consciência das possibilidades oferecidas pela composição visual para a reorganização do espaço urbano representado e para a produção de

37 LOURENÇO, Maria Cecília França. Operários da Modernidade. São Paulo: Hucitec / EDUSP, 1995, p.29.

38 ARGAN, Giulio Carlo. História da Arte como História da Cidade. Tradução de Píer Luigi Cabra. São Paulo: Martins Fontes, 1998, p. 248.

$39 \quad$ LIMA, CARVALHO. Op. cit, p. 187.

40 LIMA, CARVALHO. Op. cit, p. 109.

41 LIMA, CARVALHO. Op. cit, p.101. 
sentido, o projeto editorial contava com as inovações técnicas, exemplificadas pela reprodução simultânea de texto e imagem, proporcionando maior integração entre ambos e a adaptação da imagem através de cortes seletivos, de acordo com o conteúdo do texto. Construía-se, assim, o sentido pela justaposição de imagens e de imagem e texto. ${ }^{42}$

Neste conjunto, as legendas - que se tornaram elemento de narrativa, em substituição ao texto corrido - vinham carregadas de observações, descrições e adjetivações genéricas sobre a cidade, retomando por vez o conteúdo da introdução e alinhando, desta forma, o conjunto de imagens. "Na década de 1950, as legendas desvinculam-se da imagem e transformam-se em pequenos textos ou fragmentos de frases que só adquirem sentido na leitura seqüencial do álbum." " ${ }^{33}$ Ainda segundo Lima e Carvalho, as relações de significação dependem exclusivamente da existência do conjunto: o tema geral era apresentado em uma imagem mais abrangente - panorâmica ou vista externa da cidade - e as imagens subseqüentes seccionavam o tema proposto pela imagem de abertura, sem a necessidade de sua identificação ${ }^{44}$. Sua ênfase "recai sobre descrições genéricas, comentários sobre o crescimento, a mudança de fisionomia da cidade, seus locais pitorescos, a relação do trabalho com o progresso urbano, locais de passeio e lazer, os tipos humanos etc." ${ }^{45}$.

Os álbuns focavam nos bairros de Santa Cecília e Campos Elíseos - Praça da República, Largo do Arouche, Avenida São Luís, Vale do Anhangabaú, Avenida Ipiranga e outros logradouros. Esta área substituiu iconograficamente a cidade por ser o segmento que melhor demonstrava as conotações positivas das transformações. Era o pólo de integração da organização social e a referência material de todas as atividades urbanas:

\begin{tabular}{ll}
\hline 42 & LIMA, CARVALHO. Loc. cit. \\
43 & LIMA, CARVALHO. Op. cit, p.23. \\
44 & LIMA, CARVALHO. Op. cit, p.106. \\
45 & LIMA, CARVALHO. Op. cit, p.24.
\end{tabular}




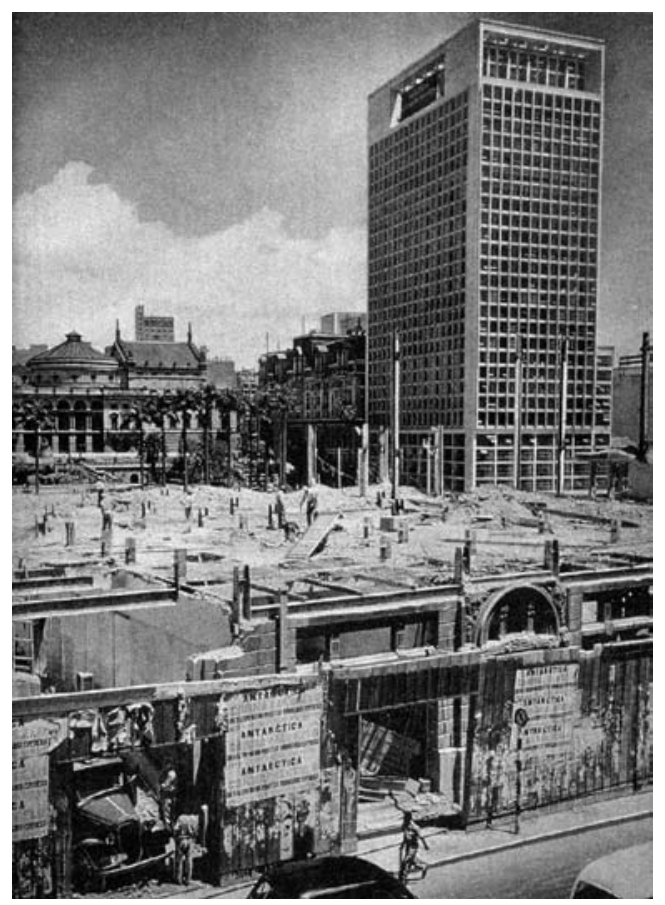

Imagem 203. Teatro Municipal e edifício C.B.I. "Casas com apenas metade de existência útil são demolidas, toda vez que assim o exija a marcha triunfante dos arranha-céus" (legenda original). Autoria: Georg Paulus Waschinski.lsto É São Paulo. 96 flagrantes da Capital Bandeirante. Fonte: LIMA; CARVALHO (1997), p.172.

Em resumo, o centro urbano concentra fisicamente e explica em termos ideológicos o poder econômico da sociedade de consumo. Nele estão concentrados os bancos, as filiais de multinacionais (...), as sedes administrativas de empresas nacionais, o comércio, os serviços, a arquitetura projetada por renomados artistas, e, por fim, a publicidade direta. ${ }^{46}$

Em função do crescimento urbano, o centro era objeto de constante alteração física - construções, demolições e implantação de infra-estrutura (canalização, pavimentação, alargamento de via) (Imagem 203). Seu caráter

46 LIMA, CARVALHO. Op. cit, p.150. 


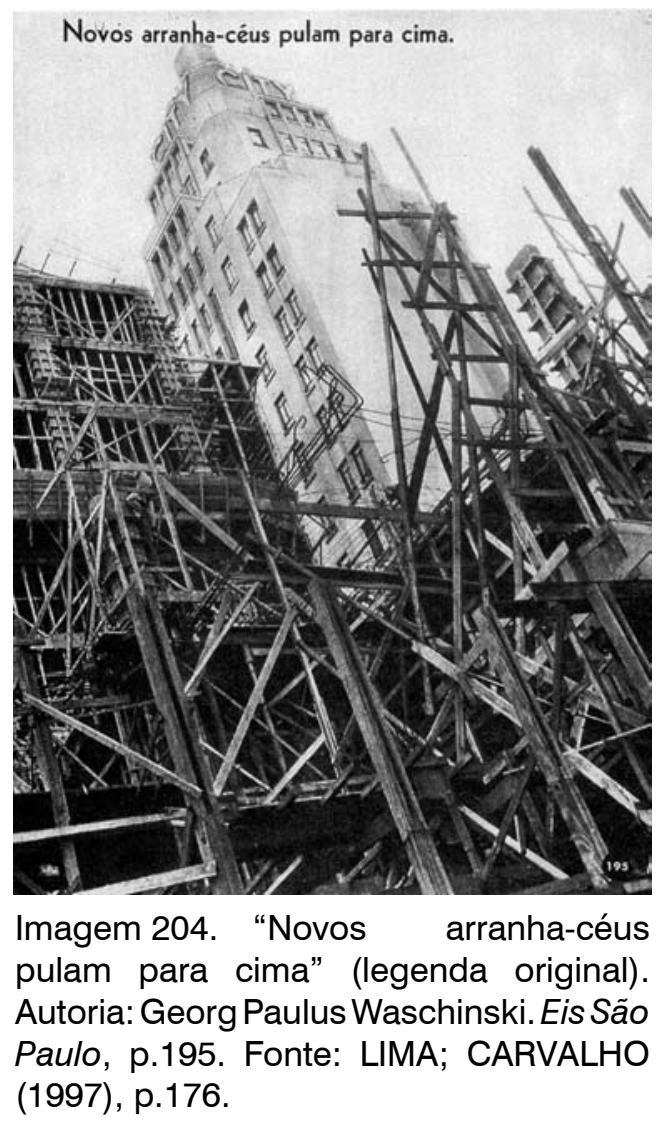

transitório era interpretado positivamente, como "expressão visual de uma sociedade com mobilidade" ${ }^{47}$. Às alterações na estrutura do tecido urbano e à expansão do perímetro da cidade juntava-se a destruição de antigas edificações, transformadas em pontos pitorescos: "a capacidade de demolir e reconstruir torna-se um motivo de orgulho, uma demonstração de força e de capacidade de trabalho" 48 .

Em substituição aos prédios antigos eram construídos edifícios de alto gabarito (Imagem 204). A verticalização aparecia como a solução técnica para o adensamento e para a concentração das atividades econômicas. A soma de verticalização, adensamento populacional e crescimento do número de automóveis era a fórmula para uma nova cidade. Tudo se moldava segundo $47 \quad$ LIMA, CARVALHO. Op. cit, p.155.

48 LIMA, CARVALHO. Op. cit, p.90. 
"um compromisso com uma nova forma de construir, de comprar, de morar, de circular, de divertir-se, de usufruir e produzir objetos artísticos, de comunicar-se e sobretudo de conviver de forma cosmopolita" ${ }^{49}$. Contudo, a falta de planejamento trouxe conseqüências irreversíveis não mensuradas naquele momento, como a poluição, o adensamento do tráfego urbano e a ineficiência do transporte coletivo. "O crescimento era o dado mais impressionante da vida urbana, mesmo que reconhecidamente desordenado e com conseqüências imprevisíveis; acreditavase que esse era o caminho do progresso e os transtornos que dele surgissem, um ônus legítimo." 50

Assim como a verticalização, a multidão era considerada própria da sociedade urbana industrial e um símbolo da cidade moderna. Os álbuns são repletos de imagens de trabalhadores, consumidores e usuários urbanos geralmente homens em idade produtiva (Imagem 205). São pessoas nas fábricas, em bancos, nas ruas, em bondes, nas lojas, nos museus, nos restaurantes, nos clubes e nas igrejas. A multidão

\footnotetext{
é desejável e bem vinda, um sinal de modernidade inquestionável, mais do que isso, ela é uma evidência quantificável e classificável. (...) Como atributo moderno da cidade, a multidão é quase sempre apresentada em movimento nas ruas, não estando associada a nenhum evento em especial, mas a uma das funções essenciais da cidade - a circulação. ${ }^{51}$
}

Ao passo que nos álbuns antigos a via pública tinha sua importância como coisa física e espacial - eram destacados a pavimentação, o alinhamento e os trilhos do bonde -, nos álbuns da década de 1950 a rua foi substituída pela presença maciça de pessoas e automóveis (Imagem 206), identificada com o 49 MEYER, Regina. Apud: CAMARGO, Op. cit, p.52.

50 CAMARGO. Op. cit, p. 51.

51 LIMA, CARVALHO. Op. cit, p.184. 


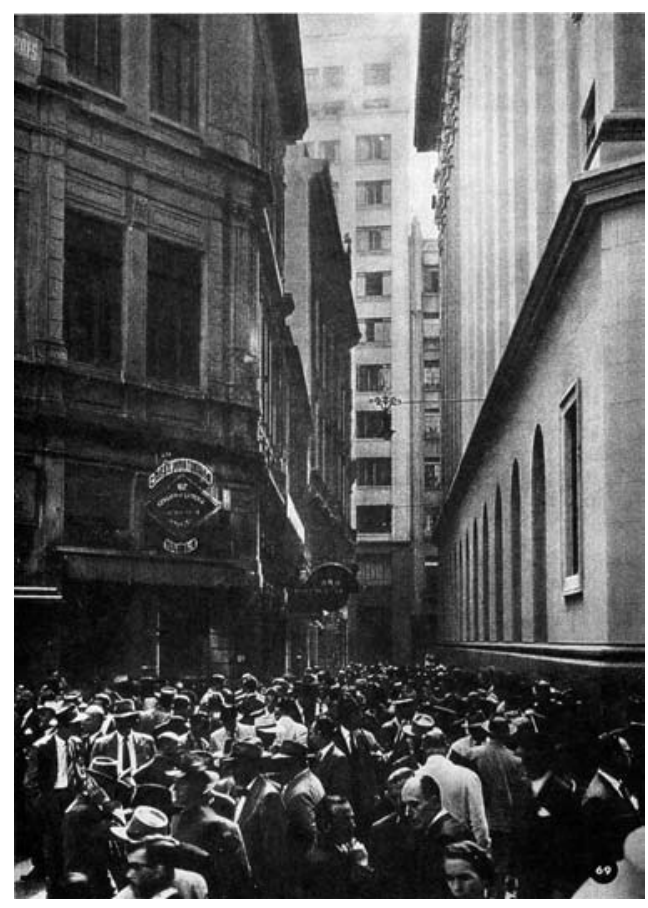

Imagem 205. Bolsa do Café. Autoria: Georg Paulus Waschinski. Eis São Paulo, p.69. Fonte: LIMA; CARVALHO (1997), p.34.

crescimento populacional e a intensificação das funções urbanas. Trata-se da passagem de uma visão de cidade como meio de circulação e infra-estrutura de mercado para uma visão de cidade como espaço passível de mercantilização, associada, naturalmente, ao desenvolvimento tecnológico, industrial, econômico e cultural. "Fora da perspectiva do consumo, parte das imagens dos álbuns perderia completamente o sentido." ${ }^{52}$ Segundo Lima e Carvalho, dentro do processo de formação da sociedade de consumo, a cidade tornou-se a imagem de sociedade de massas e afastou-se da conotação de espaço urbano como local de vivência ou como infra-estrutura para circulação de capital ${ }^{53}$.

O sentido de modernidade, pois, desdobra-se em valores associados à eficiência e ao desenvolvimento tecnológico, à rapidez, ao dinamismo econômico, 


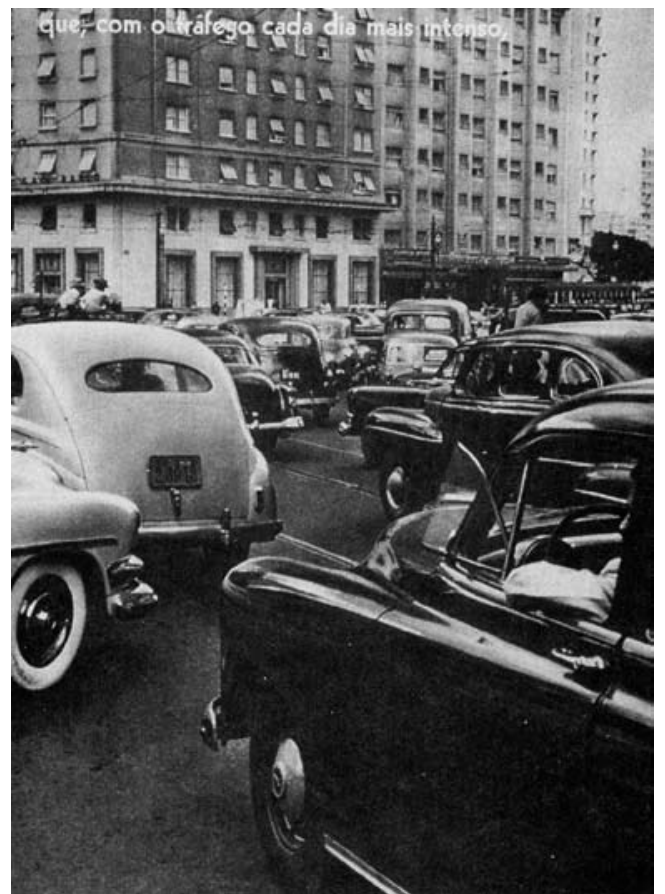

Imagem 206. Praça da Bandeira. “(...) as companhias de transportes que, com o tráfego cada vez mais intenso, cruzam as ruas congestionadas (...)" (legenda original). Autoria: Georg Paulus Waschinski. Eis São Paulo, p. 103. Fonte: LIMA; CARVALHO (1997), p.199.

à funcionalidade e ao conforto, relacionadas à diversidade, crescimento, transformação, modernidade e comunicação, qualidades próprias da condição metropolitana ${ }^{54}$. O centro, o "quadrilátero reduzido, onde todos os lugares poderiam ser alcançados a pé" e "onde a vida mundana se desenrolava" ${ }^{55}$, era o berço desta modernidade que, durante os festejos do IV Centenário, recebeu outro palco: o Parque do Ibirapuera. No Anteprojeto da Exposição do IV Centenário de São Paulo, Joaquim Cardoso exprimiu o significado do parque:

$54 \quad$ LIMA, CARVALHO. Op. cit, p.150.

55 ARRUDA, Maria Arminda do Nascimento. Metrópole e Cultura - São Paulo meio de século. São Paulo: FFLCH - USP, 2000. Tese de Livre Docência, p. 49. 
A Comissão organizadora do IV Centenário de São Paulo encontra, portanto, nesse conjunto arquitetônico a indicação perfeita e adequada, a linguagem ideal para transmitir, a quantos quiserem saber, a importância e o grau de desenvolvimento técnico e industrial do grande Estado, através de quatro séculos de existência. ${ }^{56}$

O projeto do Parque do Ibirapuera tem um forte significado simbólico para a história da cidade e da arquitetura paulista. $\mathrm{O}$ amplo complexo que acomodaria os principais eventos programados deveria ter uma "proposta arquitetônica digna da ousadia com que se planejava o futuro da capital paulista" ${ }^{57}$. Para a empreitada, somente um arquiteto brasileiro era "compatível com a grandeza do evento" 58: Oscar Niemeyer. Ele associou-se a Eduardo Kneese de Mello, Hélio Uchoa Cavalcanti, Zenon Lotufo e teve como colaboradores Carlos Lemos e Gaus Estelita.

A concepção concentrou-se nos fluxos do público. Assim, a marquise foi fundamental ao interligar todos os pavilhões - dos Estados, das Nações, das Indústrias e das Exposições. Este arranjo formou o núcleo central do parque. Neste caso, as palavras de Argan sobre a relação da arquitetura e cidade são igualmente válidas para a relação da arquitetura e a modernidade: não "só a arquitetura Ihe dá corpo e estrutura, mas também a torna significativa" 59 .

Os eventos organizados pela Comissão Comemorativa do IV Centenário da Cidade de São Paulo ${ }^{60}$ eram extremamente ritualizados e enalteciam o trabalho, a diversidade racial e cultural e a economia. A Il Bienal de Artes Plásticas inaugurou

\footnotetext{
$56 \quad$ Apud: ARRUDA. Op.cit, p.65.

57 CAMARGO. Op. cit, p.56.

58 CAMARGO. Op. cit, p.57.

$59 \quad$ ARGAN. Op. cit, p. 243.
}

60 Criada em 1951 durante o mandato do então prefeito Armando de Arruda Pereira, era presidida por Francisco Matarazzo Sobrinho - Cicillo. Em 1953, Jânio da Silva Quadros foi eleito para a prefeitura. Sua política de contenção de despesas prejudicou o orçamento da comissão, o que levou Cicillo a se demitir. Em 1954 foi substituído por Guilherme de Almeida. Ver: CAMARGO. Op. cit, p.54. 
as solenidades e o parque, em 1953. Paralelamente ocorreu a Exposição Internacional de Arquitetura, com a presença de Le Corbusier, Max Bill, Afonso Eduardo Reidy, Gregório Warchavchik, José Luís Sert e Walter Gropius. Houve centenas de atividades artístico-culturais ao longo de 1954, como concursos em várias áreas artísticas, congressos internacionais, palestras, festivais internacionais de cinema e teatro e a apresentação do Ballet do IV Centenário no Ginásio do Pacaembu. Todos estes eventos buscavam inserir São Paulo no compasso da cultura internacional, "tendo em vista expor a existência de uma sociabilidade ilustrada, à busca de uma dignidade social assentada em critérios outros que não os do dinheiro" ${ }^{61}$.

O ápice das comemorações, entretanto, foi a Exposição Industrial, inaugurada em 21 de agosto de 1954, no Palácio das Indústrias, o maior dentre os pavilhões. Contava com representações dos estados brasileiros, da indústria nacional e de firmas estrangeiras, sendo empresas particulares e concessionárias dos serviços públicos. Sob o patrocínio do poder público, um dos objetivos das comemorações era promover a indústria paulista no mercado interno e externo. Até então dedicada a bens de consumo, São Paulo agora se desenvolvia em outros setores, como o de energia, siderurgia, mecânica, elétrica e eletrônica, e tornava-se o centro manufatureiro hegemônico do Brasil. "As comemorações (...) significavam, para políticos e empresários, a consolidação da hegemonia do Estado de São Paulo no panorama nacional." 62

Os símbolos escolhidos pela comissão para representar os festejos foram o bandeirante e a espiral desenhada por Niemeyer. O bandeirante, desbravador, foi associado a um valor moderno e passou a representar a "gente forte" 63 e trabalhadora da cidade. Foi reverenciado no Monumento às Bandeiras, de

$61 \quad$ ARRUDA. Op. cit, p.73.

62 CAMARGO. Op. cit, p. 52.

63 MILLIET, Sérgio. Álbum cartográfico da cidade de São Paulo. São Paulo: Comissão do IV Centenário da Cidade de São Paulo, 1954, s/p. 
Victor Brecheret, que representa a bravura do povo paulista, que caminha junto para o progresso. A espiral "sugeria um quatro e simbolizava um contínuo crescimento rumo ao infinito" ${ }^{64}$, contudo foi construída e ruiu. Para Arruda, tanto o monumento quanto a espiral "constroem o sentido de uma cidade simbolicamente refundada" 65.

Nota-se, portanto, que as comemorações visavam à projeção de uma imagem progressista, cosmopolita e moderna de São Paulo. Isso está presente nos álbuns, desdobramentos naturais das intenções dos festejos e de um mercado extremamente favorável. Todas as inclusões e omissões resultantes da edição das fotografias concordavam com o espírito da época, a "celebração do poder dos paulistas" ${ }^{66}$.

$64 \quad$ CAMARGO. Op. cit, p.58.

$65 \quad$ ARRUDA. Op. cit, p.82.

66 ARRUDA. Op. cit, p.54. 
Capítulo 4 - São Paulo como síntese da produção de Peter Scheier até os anos 1950

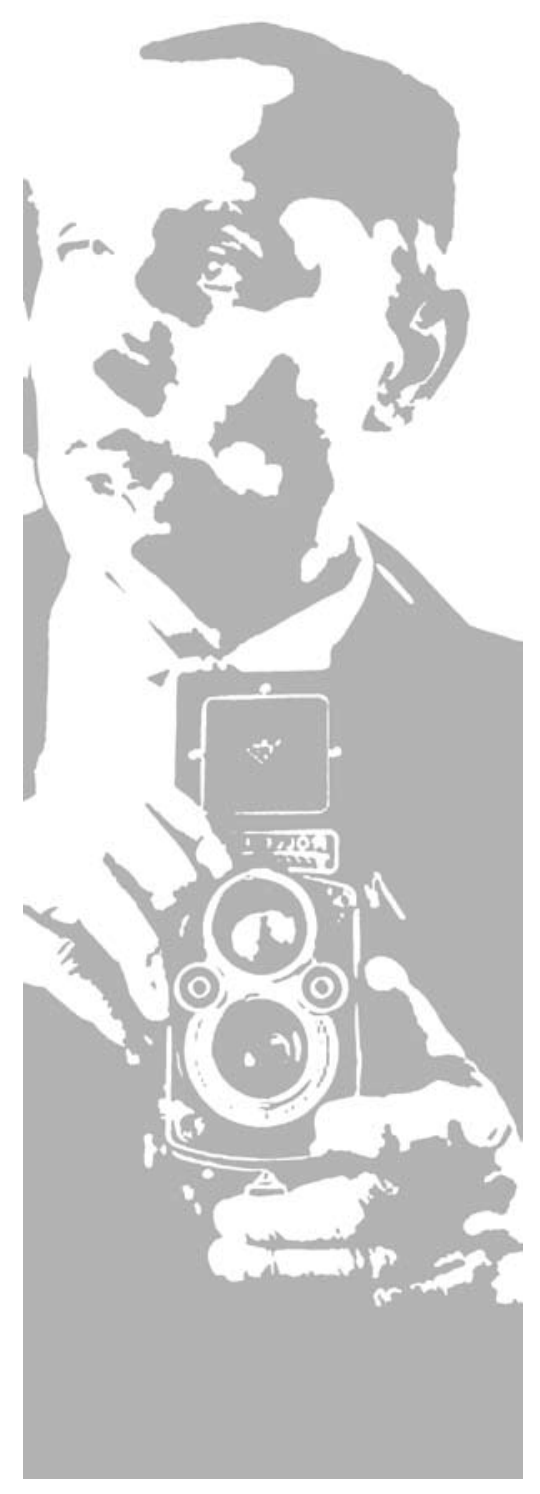


São Paulo fastest growing city in the world ${ }^{1}$ faz parte de um conjunto de cerca de sete álbuns lançados entre 1951 e 1954, no contexto das festividades do IV Centenário da cidade. Foi impresso na Holanda² e publicado em 1954 pela Livraria Kosmos Editora, numa edição limitada de luxo de 350 exemplares $^{3}$ e outras duas edições. Com 128 páginas 28,8 X 30,3 cm, o álbum apresenta 165 fotografias, das quais nove são coloridas. Além das fotografias de Peter Scheier, quatro são de Siqueira e Silva, duas são de Hans Günter Flieg e catorze são de George Rado, que também foi o responsável pela edição. A capa é de Salomão Schlier.

O álbum é bilíngüe em inglês e francês, indicador de que o público alvo

1 Para esta dissertação foram consultados os exemplares de São Paulo fastest growing city in the world que se encontram na biblioteca da Faculdade de Arquitetura e Urbanismo da USP. Há outros exemplares no Arquivo Histórico Municipal Washington Luís, na Biblioteca Municipal Mário de Andrade e no Arquivo Histórico Judaico Brasileiro.

2 Nederlandsche Rotogravure Maatschappij N.V., Leiden.

3 "Of this book there has been published a de luxe limited edition of 350 copies, printed on special Dutch vellum paper, of which this book carries number." Transcrição da nota da editora. 
era o estrangeiro. Esta característica o difere dos demais álbuns da época, que apresentavam em geral legendas em português e inglês. A introdução - nas duas línguas citadas - é de Frank Knox. Apenas o prefácio de Sérgio Milliet, "Quatrocentos Anos", é apresentado em português. Segundo Lima e Carvalho, a introdução, nestes álbuns, define-se como uma argumentação retrospectiva, que procura elencar "aquelas características que explicariam o fenômeno da transformação urbana que a cidade vinha conhecendo" ${ }^{4}$. Buscavam transmitir a idéia, em muitos pontos equivocada, de que tudo funcionava bem e em harmonia. Nas legendas, raros e superficiais comentários eram feitos sobre os problemas da cidade, como o déficit habitacional e as questões urbanas. Não há visualidade da totalidade da cidade: o centro é adotado como um padrão que repercute por todas as regiões, num processo de modernização homogêneo.

Sérgio Milliet inicia seu prefácio com considerações sobre a cidade no final do século XIX, quando a cafeicultura introduziu mudanças irreversíveis na sociedade e no traçado urbano. Explicita o crescimento vertiginoso e o ilustra com cifras de fato espantosas. Demonstra lucidez ao admitir que a construção civil e a infra-estrutura não acompanharam tal crescimento. "Daí o estado permanente de crise em que vive a cidade, ampliando-se por saltos, em meio a contrastes violentos que lhe dão esse aspecto a um tempo imponente de metrópole e tranqüilo de província (...)" ${ }^{5}$. A seguir, Milliet se entrega ao discurso ufanista e discorre sobre as belezas e encantos da cidade e de seus bravos moradores.

A edição de São Paulo fastest growing city in the world foi conduzida segundo dois aspectos: o ideário de modernidade e ufanismo do IV Centenário e o acervo de Peter Scheier. Assim, as fotografias foram desvinculadas de sua

4 LIMA, Solange Ferraz de, CARVALHO, Vânia Carneiro de. Fotografia e Cidade: da razão urbana à lógica do consumo - Álbuns de São Paulo (1887-1954). Campinas: Mercado das Letras, São Paulo: FAPESP, 1997, p.23.

$5 \quad$ MILLIET, Sergio. Quatrocentos Anos. In: SCHEIER, Peter. São Paulo fastest growing city in the world. São Paulo: Livraria Kosmos Editora, 1954, s/p. 
primeira realidade para adaptar-se aos propósitos editoriais. Os assuntos foram explorados de forma a reiterar o texto introdutório e toda a ideologia do momento. As vistas urbanas enfatizam as áreas adensadas e verticalizadas do centro, dele se desviando apenas em momentos pontuais e pela imperiosa necessidade de mostrar outros aspectos, como as casas de alto padrão nos Jardins. Os principais temas são a economia, com destaque para a cafeicultura e a indústria; a construção civil, arquitetura e mercado imobiliário; entretenimento e cultura; e outros como infra-estrutura urbana, saúde, ciência, religião e educação.

Em todos os álbuns produzidos nesta época, a iconografia era idêntica. Mesmos locais, ângulos e composições, diagramações similares e formato idem: quase todos os álbuns pesquisados ${ }^{6}$ seguiram as mesmas premissas editoriais, apesar de serem publicados por editoras diferentes e da autoria distinta das fotografias, sendo que algumas se repetem em vários álbuns. Navio e porto, avião e aeroporto de Congonhas eram recorrentes, assim como o Estádio do Pacaembu, o Jóquei Clube, a Biblioteca Municipal, o Museu do Ipiranga e, claro, a região da Praça da República e do Vale do Anhangabaú. Há similitudes curiosas, como o close no processo de extração do veneno da cobra no Instituto Butantã, presente em três álbuns.

Aquele com o qual o livro de Peter Scheier se assemelha mais é Eis São Paulo: uma obra realizada e editada no ano de 1954, editado pela Monumento, com fotos em grande parte de Georg Paulus Waschinski ${ }^{7}$. Embora o projeto gráfico deste seja mais ousado, com a sobreposição das legendas às imagens, as fotografias selecionadas são similares em temas, ângulos e ordem dentro da paginação. Vila Normanda, cinema, cafezinho, cantina, vista aérea de indústria, vitrine, carnaval e religião são comuns, assim como a comparação com lugares

$6 \quad$ Foi pesquisado o acervo do Arquivo Histórico Municipal Washington Luís. A relação dos álbuns pesquisados se encontra na bibliografia.

7 Eis São Paulo: uma obra realizada e editada no ano de 1954. São Paulo: Monumento, 1954. 
no exterior - Wall Street no Eis São Paulo e Broadway em São Paulo - e o fechamento com um monumento simbólico - Monumento às Bandeiras no Eis e O Semeador no de Scheier. A adoção de ângulos fechados - closes -, ângulos ascendentes e exploração gráfica de elementos construtivos também aproximam o trabalho dos dois fotógrafos, coerentes com a linguagem da época. Segundo Lima e Carvalho, "nos álbuns da década de 1950, o modo seqüencial e analítico de organização das imagens, o gosto pelo instantâneo, o uso de closes e de páginas inteiras têm a sua matriz mais próxima nas revistas ilustradas, especialmente 0 Cruzeiro" ${ }^{8}$.

Formalmente, pois, São Paulo fastest growing city in the world carrega as características da linguagem fotográfica da época, somadas às singularidades do trabalho de Scheier. Seu filtro cultural foi composto por sua origem estrangeira, formadora de seu quadro referencial e de seu interesse por peculiaridades cotidianas, distintas daquelas vivenciadas em seu país natal e, portanto, imbuídas do sentido de novidade e pitoresco; foi composto também por sua vivência cotidiana pelas ruas do centro, em torno da Praça da República e do Vale do Anhangabaú, cuja documentação reproduz, em parte, seu trajeto na cidade; sua profissão de fotojornalista na revista O Cruzeiro, com uma produção expressiva de imagens marcadas por closes, flash direto e ângulos inovadores; seu trabalho na arquitetura, com registros precisos; por fim, sua documentação de eventos sociais, que proporcionou sua proximidade com as pessoas, tão prezada em sua carreira.

Embora a ideologia da "cidade que mais crescia no mundo" circundasse todo o projeto editorial, a visão particular de Peter Scheier é notada em algumas sutilezas, como na procura de algo essencialmente humano em meio ao trânsito da cidade - uma mãe que atravessa a rua segurando a mão do filho, por

8 LIMA, CARVALHO. Op. cit, p.108. 
exemplo. Em registros como esse, a relação estabelecida entre os habitantes e a cidade prevalece sobre a grandiosidade dos arranha-céus. É possível afirmar que o álbum se divide em duas partes: a primeira é dominada pela macro-escala ou escala urbana, em que os temas da infra-estrutura, pujança econômica e progresso estão presentes, e uma segunda, definida numa micro-escala ou escala humana, em que o citadino, munido de uma câmera, e o sempre atento fotojornalista documentam pequenos gestos humanos dentro de uma esfera maior. A multidão cede lugar ao indivíduo.

Esta documentação da escala humana está presente na produção de vários fotógrafos, cujos trabalhos não se restringiram ao registro do crescimento da cidade. Dezenas poderiam ser citadas, mas a concentração no grupo de imigrantes cujas histórias pessoais se cruzaram no momento de partida da Alemanha nazista e a chegada a São Paulo reflete consistentemente as questões culturais envolvidas na produção visual da época. Por sua atuação nas áreas de arquitetura, indústria e publicidade, o trabalho de Hans Günter Flieg tem maior correspondência com os ideários progressistas da época, documentando sistematicamente o processo de verticalização e o desenvolvimento econômico da cidade. Por sua vez, Hildegard Rosenthal, fotojornalista, mostrava sensibilidade ao retratar a cidade em suas peculiaridades como um dia chuvoso, um florista no Largo do Arouche, o leiteiro ou o pequeno engraxate. Contudo, a delicadeza de Peter Scheier no retrato do cotidiano está mais relacionada com o trabalho de Alice Brill, sua colega na revista Habitat. A semelhança de suas posturas em determinadas situações, como na hora do cafezinho, na travessia de pedestres, no comércio local, no bonde e na fábrica é evidente e chega a extremos como no Aeroporto de Congonhas (Imagem 209/210). Porém, a cidade de Alice Brill é romântica, poética e intimista, marcada pela presença feminina e das crianças, das pombas que a sobrevoam e do gato preguiçoso que dorme num degrau banhado pelo sol. Talvez aí resida um ponto relevante de distinção entre as duas 
produções.

Lima e Carvalho apontam para a questão das imagens terem sido "produzidas desvinculadas da proposta da organização de um álbum sobre a cidade, não guardando, assim, a coerência de uma produção projetada" 9 . A base do livro foi o material oriundo, quase totalmente, do trabalho profissional de Scheier. O Cruzeiro, MASP e arquitetura respondem por uma significativa parcela das imagens, resultando freqüentemente em proporções mal resolvidas, como as oito imagens dedicadas ao MASP. Desprovidas de seus contextos originais, as fotografias do arquivo de Scheier ganharam novos significados para adequarse às intenções editoriais.

São Paulo, pois, apresenta uma visão subjetiva e repleta de lacunas dentro do quadro que se pretendia mostrar, como a Avenida Paulista, a Casa Modernista de Gregori Warchavchik, o Parque Trianon e - talvez a maior lacuna - o Parque do Ibirapuera. Entretanto, essas e outras ausências, como o Pátio do Colégio, o Largo São Francisco, a Estação da Luz, o Mercado Central, a Universidade de São Paulo, os teatros - como o Teatro Brasileiro de Comédia - e os rios que atravessam a cidade são compartilhadas pelos demais álbuns da época. Isto é São Paulo. 104 flagrantes da capital bandeirante, por exemplo, exibe solitariamente uma fotografia da Estação Júlio Prestes e uma vista aérea da Avenida Paulista; Karfeld é o único a se referenciar ao bairro de Santana, a partir do qual fez uma vista do centro; Eis São Paulo: uma obra realizada e editada no ano de 1954 é o único a exibir uma imagem interna de um dos pavilhões do Ibirapuera.

Portanto, a análise de São Paulo fastest growing city in the world, embasada no levantamento teórico realizado, especialmente em Boris Kossoy, pondera todos estes pontos, a fim de, coerentemente, compreender o processo de $9 \quad$ LIMA, CARVALHO. Op. cit, p.29. 


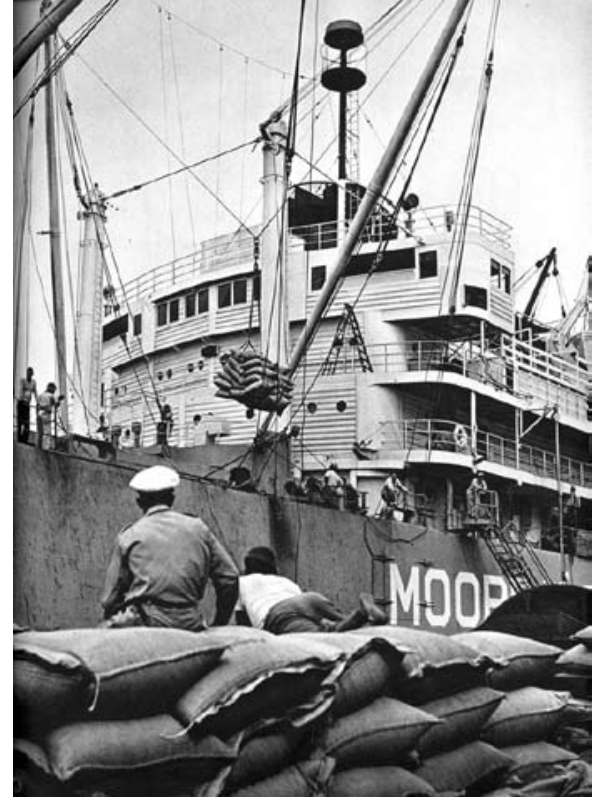

Imagem 207. Navio no porto. Autoria: P. Scheier. Fonte: SCHEIER (1954), p.11.

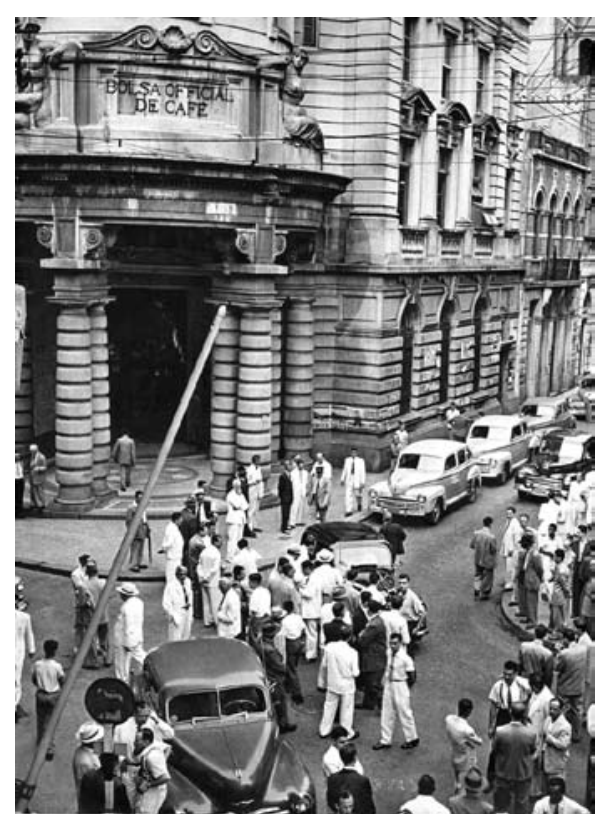

Imagem 208. Bolsa do Café em Santos. Autoria: P. Scheier. Fonte: SCHEIER (1954), p.12.

construção desta representação da cidade de São Paulo, materializado cultural, estética, ideológica e tecnicamente, de acordo com visão particular e a intenção do fotógrafo e dos demais agentes.

\subsection{A narrativa}

A narrativa que tece o álbum inicia-se com a imagem de um navio no porto (deduz-se que seja o de Santos) e é encerrada com a foto de um avião decolando. Metaforicamente, ambas remetem ao movimento de chegar a São Paulo - ancorar em seu porto - e partir após vivenciar suas riquezas. Uma "viagem" à qual o leitor é convidado pelo editor.

No entanto, à metáfora da chegada se junta o tema cafeicultura, introduzido pela imagem do navio atracado ao cais (Imagem 207). A fotografia é relacionada ao tema através da edição do álbum, uma vez que não há nenhum elemento que 
comprove que os sacos empilhados no primeiro plano e aqueles transportados por cabos contenham café. As quatro imagens seguintes - Bolsa do Café, ensacamento de grãos e exames qualitativos - revelam a linha narrativa pela qual seremos conduzidos. O café, "a principal fonte de riqueza de São Paulo e (...) largamente responsável pelo espetacular desenvolvimento da cidade" ${ }^{10}$, eliminou os vestígios coloniais de São Paulo e colocou-a na vanguarda. Nada mais conveniente que abrir o álbum com o agente que concretizou todas as conquistas mostradas nas páginas seguintes.

O imponente edifício eclético da Bolsa Oficial do Café (Imagem 208), localizado na Rua XV de Novembro, no centro da cidade de Santos ${ }^{11}$, é mostrado na seqüência da imagem do porto. A rua está movimentada com vários automóveis estacionados e uma multidão que ocupa as calçadas e a pista. A multidão, essencialmente masculina ${ }^{12}$, distribui-se em rodas de conversa e parece em espera. O nome do edifício em destaque no canto superior esquerdo enfatiza a associação imediata entre o capital advindo da exportação do café e o progresso e urbanidade.

O Aeroporto de Congonhas introduz a parte final do álbum. Projeto do arquiteto Hernani do Val Penteado, começou a operar em 12 de abril de 1936, como alternativa ao Campo de Marte, que inundava com freqüência devido a enchentes no Rio Tietê. Nos anos 1950, Congonhas chegou a ser o terceiro maior aeroporto do mundo em volume de carga aérea, perdendo apenas para

10 SCHEIER. Op. cit, p.13.

11 O edifício foi inaugurado em 1922, época na qual Santos era a maior praça de café do mundo, sendo que o produto aí negociado e chancelado era muito valorizado no mercado externo. O último pregão aconteceu na década de 1950, quando os negócios do café foram transferidos para a cidade de São Paulo. No local atualmente funciona o Museu do Café. Fonte:

http://www.saopaulo.sp.gov.br/saopaulo/cultura/museus_cafe.htm. Acesso em: 21 jul 2008, às 22:00.

12 Este aspecto será observado em outras imagens deste capítulo. 


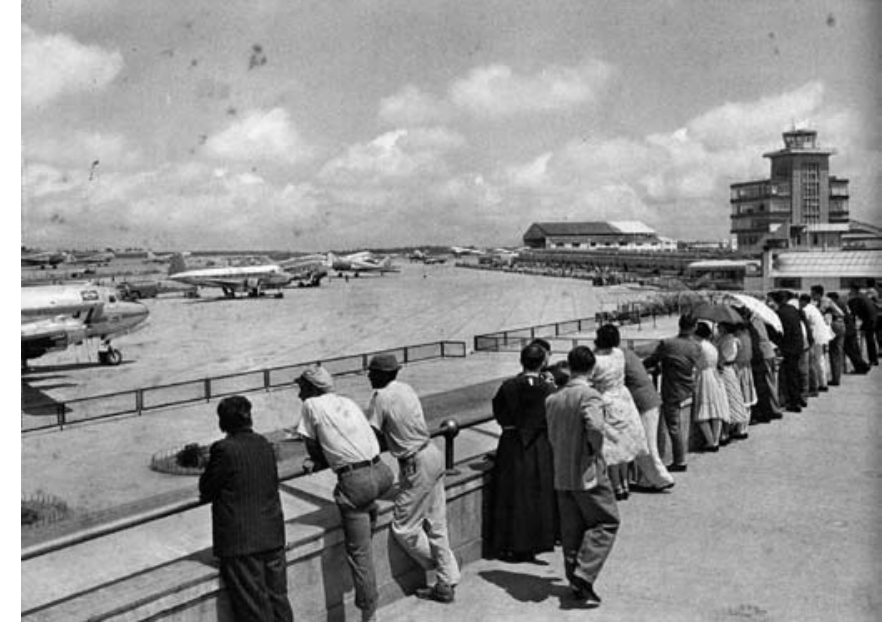

Imagem 209. Aeroporto de Congonhas. Autoria: P. Scheier. Fonte: SCHEIER (1954), p.126.

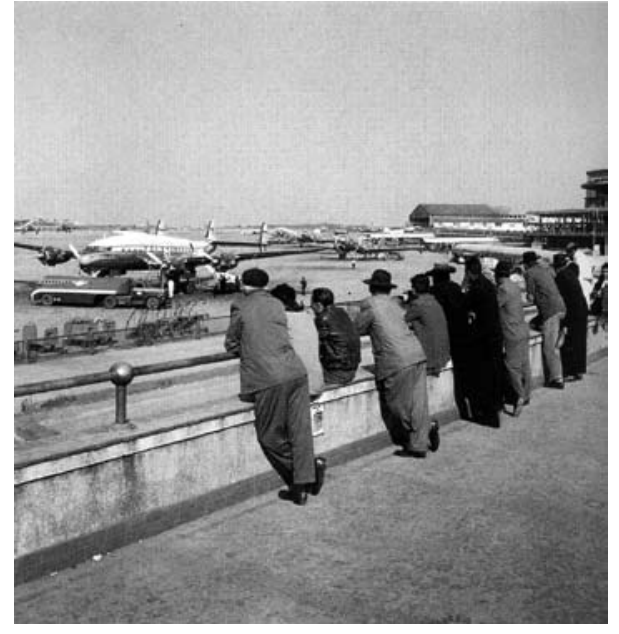

de Congonhas. Autoria: Alice Brill. Fonte: FRANCESCHI (2004), p.214.

Londres e Paris ${ }^{13}$. Adotando um ângulo usual, Peter Scheier registrou o grupo de pessoas que observavam os aviões na pista, talvez aguardando o desembarque (Imagem 209). A obliqüidade acentuada pelo gradil e pela linha de pessoas conduz o olhar para a torre de controle, ao fundo.

O fechamento do livro se dá com duas fotografias. A primeira é de um avião em vôo, cujo curso se projeta para além das bordas da imagem (Imagem 211). Essa composição eficientemente sintetiza a idéia de partida e encerra a narrativa do álbum. No processo de edição, essa idéia prevaleceu sobre o seu contexto original, a sua primeira realidade, que remete ao sertão de Goiás. Ela foi publicada originalmente em 1949 na revista O Cruzeiro, numa reportagem sobre o agricultor e pecuarista Hugo Borghi, ex-Secretário de Agricultura de Adhemar de Barros $^{14}$. A aeronave da foto era o bimotor "Douglas-DC-3", que realizava o transporte de maquinaria e trabalhadores nas propriedades de Borghi.

13 Fonte: http://www.infraero.gov.br/impr_noti_prev.php?ni=848\&menuid=impr. Acesso em 09 jul 2008, às 13:30. Na legenda do álbum, porém, Congonhas é citado como o segundo mais intenso no mundo.

14 SILVA, Arlindo. Borghi invade o Brasil central. O Cruzeiro, São Paulo, p.13-17, 12 nov 1949. 


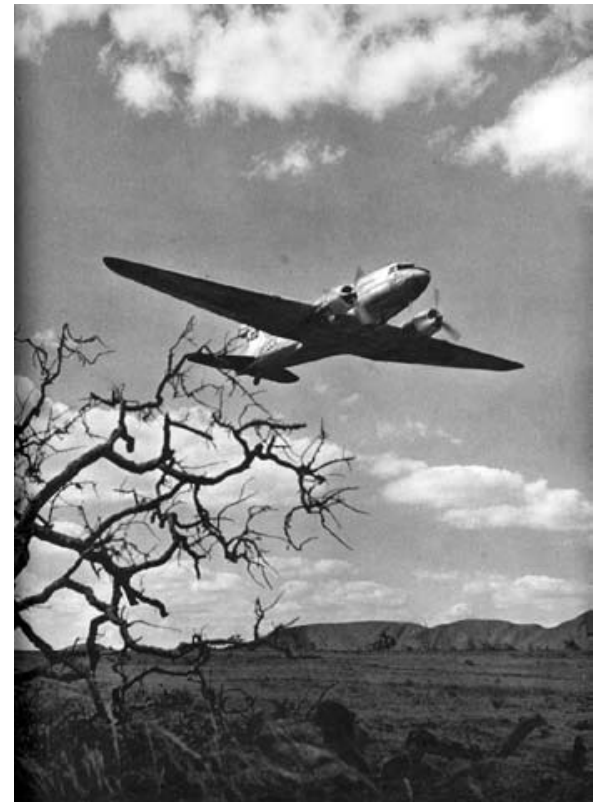

Imagem 211. Avião no sertão de Goiás. Autoria: P. Scheier. Fonte: SCHEIER (1954), p.127.

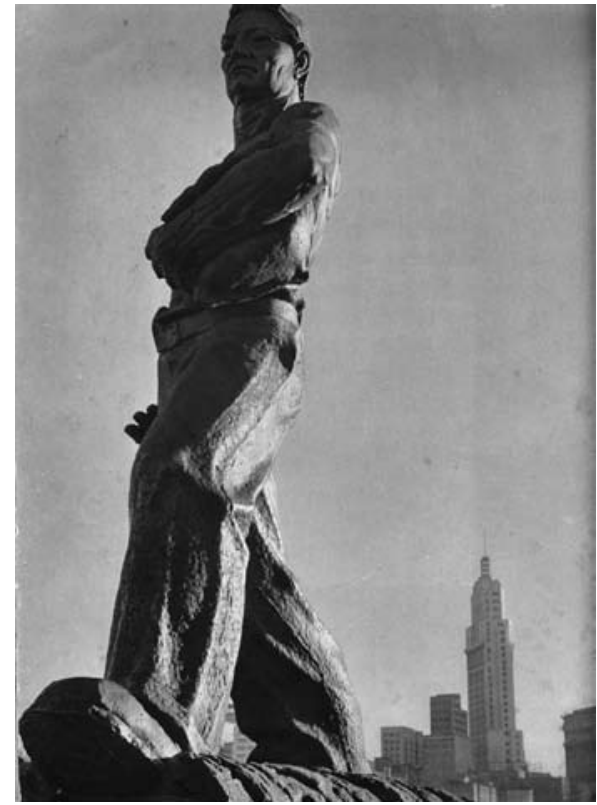

Imagem 212. "O Semeador", no Parque D. Pedro II. Autoria: P. Scheier. Fonte: SCHEIER (1954), p.128.

A foto do avião sintetiza nossas imagens mentais e a noção de partida. Assim, a última imagem do álbum, da escultura O Semeador ${ }^{15}$, do Escultor italiano Caetano Fraccaroli, pode parecer deslocada (Imagem 212). Contudo, se considerarmos toda a ideologia do IV Centenário, parece-nos adequado que o Monumento ao Trabalho, como também é conhecida a estátua, conclua o discurso. Ao fechar o álbum, a imagem que permanece é a do trabalho, da força do povo paulistano que conquistou tudo o que está contido nas páginas, fruto da riqueza iniciada com o café e do suor da labuta. O Semeador representa um agricultor semeando a terra e remete diretamente ao Monumento às Bandeiras, de Victor Brecheret, e à imagem do bandeirante desbravador, "cheio de iniciativa, coragem e força física" ${ }^{16}$.

Observada com acuidade, nota-se que esta foto não enquadra apenas

15 A escultura foi instalada na década de 1940 no jardim do Parque Dom Pedro Il. Atualmente encontra-se na Praça Apecatu, próxima ao Ceagesp. Fonte: http://www.monumentos.art.br/ monumento/semeador. Acesso em 16 jul 2008, às 19:00.

16 LIMA, CARVALHO. Op. cit, p.209. 
a escultura. Ao fundo destaca-se o Edifício do Banco do Estado, na época o mais alto da cidade. Dois elementos emblemáticos incluídos numa imagem de conclusão. Pelo arranjo da composição, há uma inversão de escala, na qual a estátua se agiganta frente ao edifício. A leitura que se propõe é de que o trabalho se sobrepõe aos bens materiais, que só existem em função do labor. Portanto, de todas as riquezas do povo paulistano, a maior delas é a força do trabalho.

\subsection{Vistas Urbanas}

Como já colocado, para fins de análise, São Paulo fastest growing city in the world foi dividido em duas partes. A primeira é composta por vistas urbanas, incluindo a fotografia de arquitetura moderna. A segunda parte traz as características do fotojornalismo de Peter Scheier e aborda os detalhes cotidianos da cidade, seus habitantes e seus costumes. Deve-se ressaltar que esta divisão é apenas um modo de leitura e que ela não tem correspondência física no álbum. As fotografias das duas partes estão mescladas ao longo de suas páginas, embora nas cinqüenta primeiras haja uma concentração das vistas urbanas.

Estas vistas contemplam a área central, especialmente a região da Praça da República e o Vale do Anhangabaú. Estes locais sintetizavam a idéia de progresso que se desejava transmitir por apresentarem grande adensamento e verticalização e concentrarem a vida econômica, social e cultural da cidade. Segundo Lima e Carvalho, o Vale era a própria representação da cidade, demonstrando grande diversidade e articulação. Em suas vistas estavam presentes os expoentes da indústria (como o Edifício Matarazzo) e do poder público e financeiro (Banco do Estado e Banco do Brasil), o serviço comercial e terciário, as vias de passagem (viadutos do Chá e Santa Ifigênia), transeuntes, 
automóveis, elementos de vegetação e detalhes topográficos (a Serra da Cantareira ao fundo) ${ }^{17}$.

As vistas panorâmicas dessas áreas eram produzidas em larga escala pelos fotógrafos atuantes naquele momento - Francisco Albuquerque, Alice Brill, Hans Günter Flieg, Hildegard Rosenthal, Thomaz Farkas, Henri Ballot e Marcel Gautherot, entre outros. Os ângulos eram sempre muito próximos e ilustravam o impressionante crescimento de São Paulo, que, naquele momento, parecia inabalável. E não é infundado afirmar que aquele cenário exercia maior efeito sobre os imigrantes, em especial os refugiados da Segunda Guerra, como Peter Scheier, Flieg, Brill e Rosenthal: a fartura e progresso presenciados eram completamente opostos ao ambiente de guerra vivido em seu país de origem. A esta altura, a pequena Glogau ainda perecia sob as ruínas da guerra. E Scheier vivenciava o dia-a-dia da "cidade que mais crescia no mundo".

Embora as vistas panorâmicas demonstrem pontos de vista usuais, é possível, ao longo do álbum, notar o olhar particular de Scheier sobre aquelas áreas. Vicente aponta uma característica dos rolos de filme produzidos pelo fotógrafo:

\footnotetext{
Então você tem trabalhos (...) para Elevadores Villares. [Peter Scheier] foi lá na cidade fazer as escadas rolantes das Grandes Galerias, na São João. O resto do filme tem cenas na rua, o ônibus, o trânsito, o operário. Tem o auto-retrato dele quando foi fotografar bares de café. Muitas vezes são pontas de filme. ${ }^{18}$
}

Estas pontas dos filmes revelam a postura descompromissada de Scheier, livre das pautas da redação de O Cruzeiro ou de exigências de clientes. São

17 LIMA, CARVALHO. Op. cit, p.151.

18 Carlos Fadon Vicente, fotógrafo, em entrevista à autora em 03 ago 2006. 


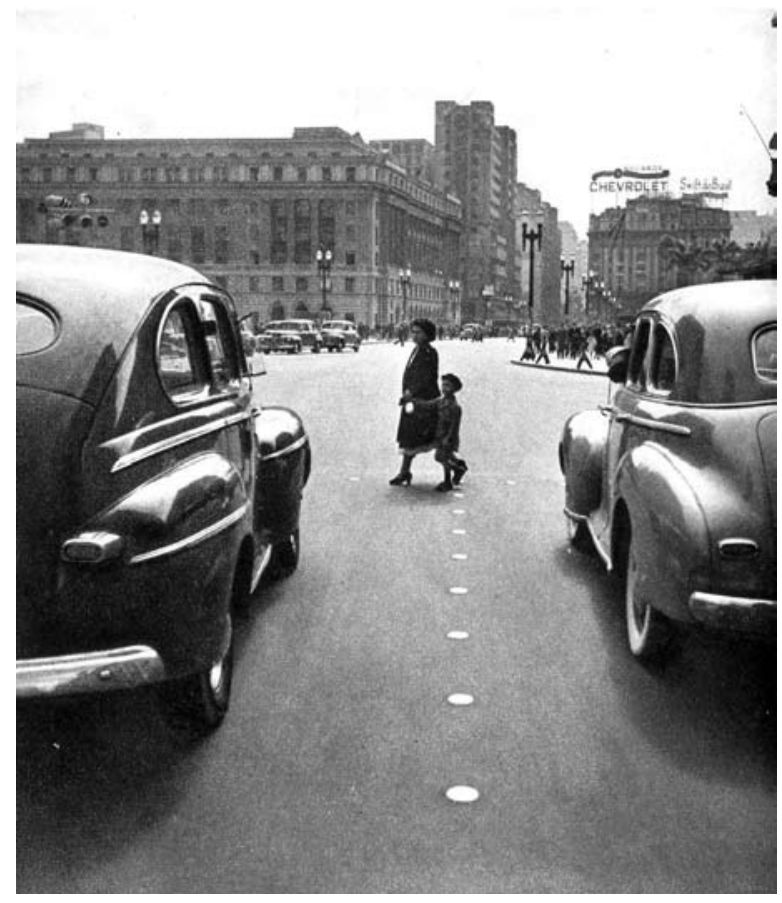

Imagem 213. Viaduto do Chá. Autoria: P. Scheier. Fonte: SCHEIER (1954), p.58.

imagens que não visam a grandiosidade da cidade, mas a esfera humana de seu cotidiano ou seus ângulos inusitados. Consideremos que, além de fotógrafo, diariamente Scheier era um pedestre na região da Praça da República. As imagens reconstituem seu trajeto através da Praça ou do Vale em direção ao Edifício dos Diários Associados. E lembremos que sua primeira residência em São Paulo foi na Rua Teodoro Baima.

Esta postura de Scheier pode ser notada ao colocar-se entre os carros parados no semáforo no Viaduto do Chá para centralizar no fotograma a travessia da rua de uma mulher acompanhada de um garoto (Imagem 213). O Edifício Mackenzie e as demais construções da Rua Conselheiro Crispiniano, Barão de Itapetininga e arredores, assim como os luminosos, são coadjuvantes desta cena. A composição, cuidadosa, se organiza em função destes dois personagens.

Percebe-se a mesma postura na vista da Avenida Ipiranga em que ele se 


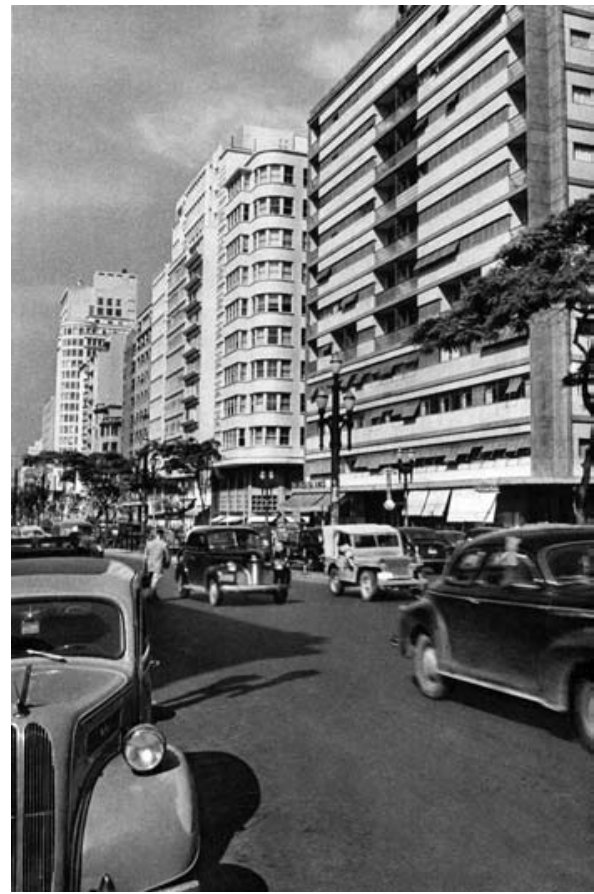

Imagem 214. Avenida Ipiranga, com

o Edifício Esther à direita. Autoria:

P. Scheier. Fonte: SCHEIER (1954), p.38.

posicionou em meio aos carros estacionados rentes à calçada adjacente à Escola Normal Caetano de Campos (Imagem 214). Direcionou a câmera na direção da Avenida São João, registrando os veículos que transitavam nos dois sentidos. Um homem atravessava a larga avenida em meio aos carros, muito próximo ao fotógrafo. Depois de alguns instantes, provavelmente Scheier faria o mesmo, virando em seguida na Rua Sete de Abril - esquina marcada pelo Edifício Esther - e dirigindo-se à sede dos Diários Associados.

Em outra imagem, a partir do centro da Praça, ele registrou os altos edifícios da Ipiranga permeados pelas árvores e refletidos na água (Imagem 215). Os estabelecimentos comerciais instalados nos pavimentos térreos dos edifícios se mesclam aos veículos e às plantas. Entre eles, identifica-se a Casa TV Philco, registrada em detalhe páginas adiante no álbum, com seus eletroeletrônicos expostos, examinados por um possível comprador (Imagem 216). 


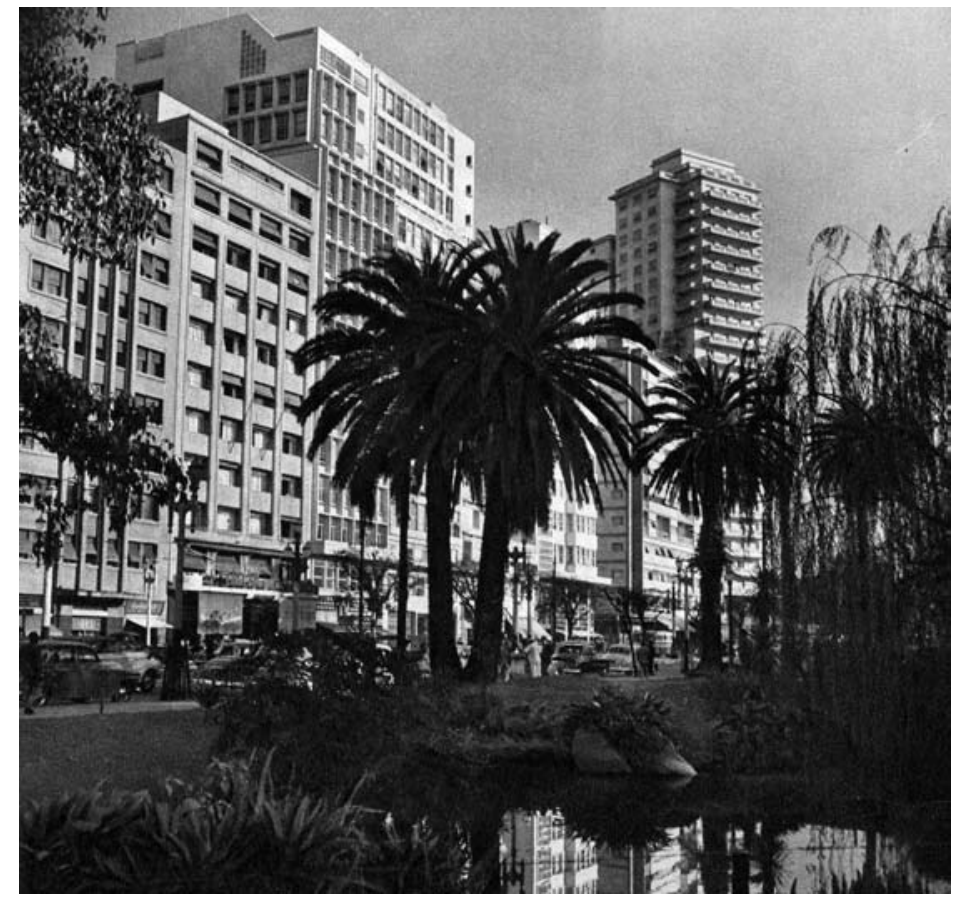

Imagem 215. Praça da República e Avenida Ipiranga ao fundo. Autoria: P. Scheier. Fonte: SCHEIER (1954), p.38.

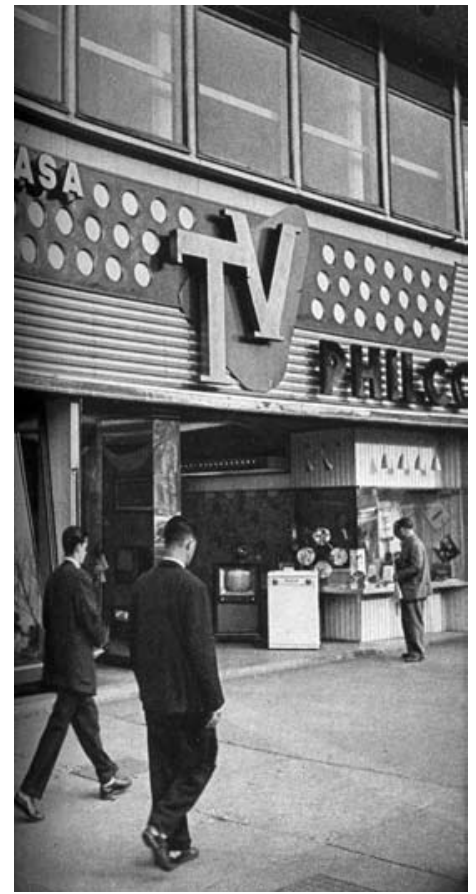

Imagem 216. Loja na Avenida Ipiranga. Autoria: P. Scheier. Fonte: SCHEIER (1954), p.67.

Lima e Carvalho apontam para o fato de a Praça da República ter sido visualmente explorada de modo exaustivo pelos fotógrafos da época. Nos álbuns, suas imagens transmitiam a falsa noção de amplas áreas verdes e a idéia de natureza domesticada e inofensiva, ornamental, não ameaçada pelo crescimento e assimilada como atributo urbano e qualificativo da cidade. A combinação de edifícios altos com a Praça significava um equilíbrio visual e espacial entre densidade e espaço aberto ${ }^{19}$.

Estas imagens são diferenciadas dentro do conjunto de vistas urbanas do álbum. Nas demais, características como a presença de multidão, verticalização, automóveis e publicidade - segundo as autoras, indicadores do progresso ${ }^{20}$ ficam mais explícitas. Em alguns casos é evidente a condição de adensamento

19 LIMA, CARVALHO. Op. cit, p. 159.

20 Ver Capítulo 3. 


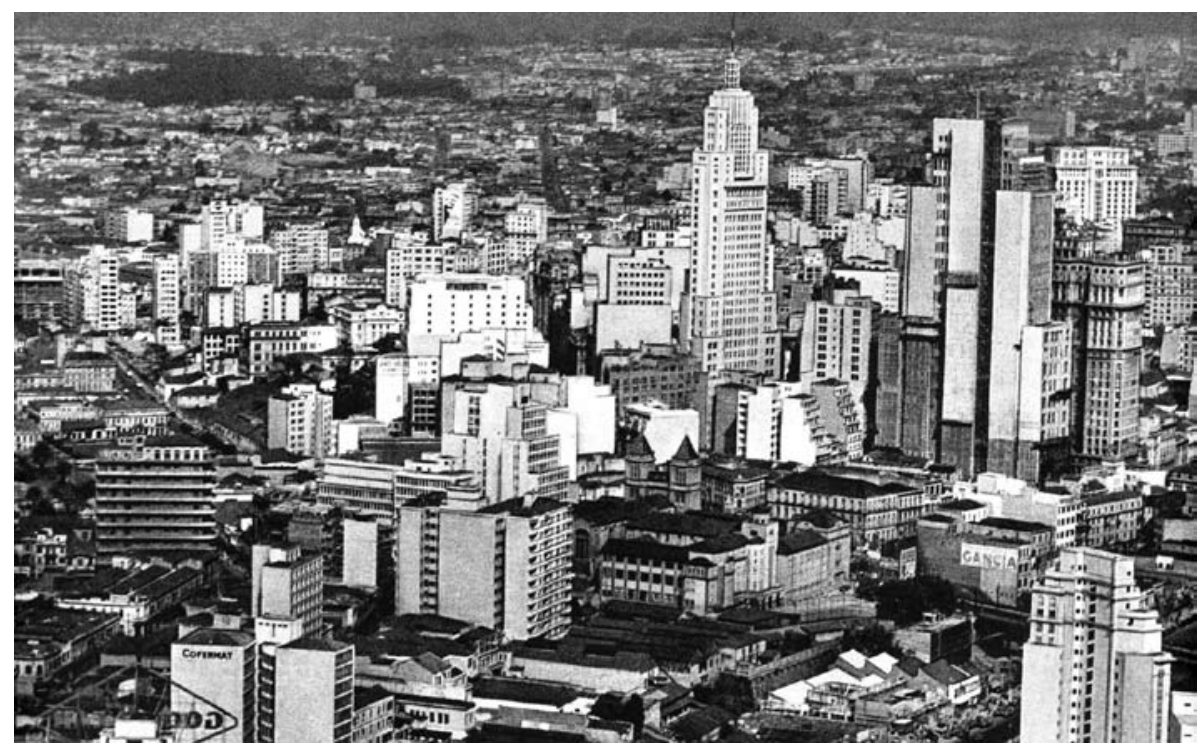

Imagem 217. Vista aérea do centro de São Paulo. Autoria: P. Scheier. Fonte: SCHEIER (1954), p.18.

e verticalização restrita à área central. Em uma imagem aérea (Imagem 217), nota-se, ao fundo, o caráter da região da Várzea do Carmo e dos bairros do Brás e Moóca distinto daquele do centro. Contudo, o primeiro plano dominado pelos prédios altos, notadamente o Edifício Altino Arantes (Banco do Estado), atrai a atenção. O Banco representava a ação do capital financeiro e promovia a associação entre modernização, desenvolvimento e internacionalização ${ }^{21}$.

Em geral, os álbuns refutavam tais imagens por negarem, de certa forma, a idéia difundida de crescimento e progresso generalizado. Fotografias com o foco mais fechado na área central funcionavam melhor dentro da ideologia das festividades. É o caso da imagem (Imagem 218) que se concentra nos arredores da Avenida Ipiranga. Na parte inferior vê-se a Praça da República e a Escola Normal; do outro lado da Ipiranga, o Edifício Esther, marco da arquitetura moderna em São Paulo. O limite superior da imagem atinge o Vale do Anhangabaú, vendo-se, da esquerda para direita, o Edifício CBI - "referencial

$21 \quad$ LIMA, CARVALHO. Op. cit, p.157. 


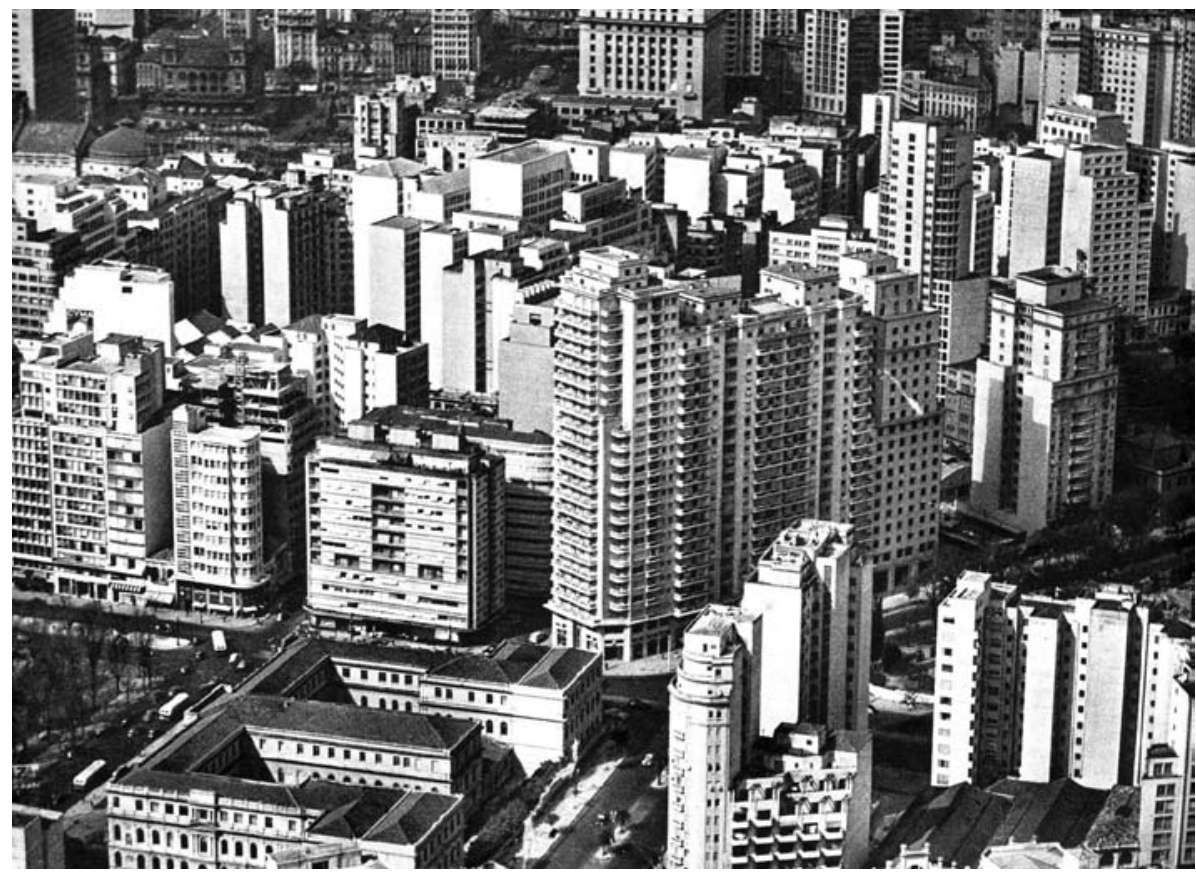

Imagem 218. Vista aérea da Avenida Ipiranga, Praça da República e Avenida São Luís. Autoria: P. Scheier. Fonte: SCHEIER (1954), p.18.

para a verticalização do centro de São Paulo no final dos anos 40" 22-, o Teatro Municipal, a Praça Ramos de Azevedo com suas inconfundíveis palmeiras, o Palacete Prates e o Edifício Matarazzo.

Nesta mesma imagem, nota-se na esquina da Ipiranga com a Avenida São Luís o imponente conjunto composto pelos edifícios de apartamentos São Thomaz, Santa Virgília e Santa Rita, projeto do arquiteto Wilson Maia Fina e erigido pela construtora Arnaldo Maia Lello de 1944 a 1949. O São Thomaz, na esquina, era o mais valorizado, com um apartamento por andar e quatro andares a mais, para destacá-lo em relação aos outros. Ao lado do conjunto, vê-se o Edifício Roosevelt, edifício comercial com lojas, sobrelojas e escritórios, projeto do engenheiro Sylvio Jaguaribe Ekman, concluído em 1948, e o Edifício Princesa Isabel, projetado pelo engenheiro Alfredo Mathias e concluído em

22 FALBEL, Anat. Um arquiteto no exílio. Revista aU - Arquitetura \& Urbanismo, São Paulo, p.82, mai 2008. 
1949. Entre o Roosevelt e o Princesa nota-se um vazio, que seria ocupado alguns anos depois pelos edifícios modernistas Ouro Preto e Moreira Salles. O primeiro seria projetado pelo arquiteto Franz Heep e concluído em 1958, quando a construção do Edifício Itália - outro projeto seu, localizado na esquina oposta já iniciara. O arquiteto Gregori Warchavchik projetaria o prédio de apartamentos Moreira Salles, construído pelo escritório técnico Severo \& Villares a partir de 1952. Esta foto - feita entre 1949 e 1952, segundo as datas de construção dos edifícios $^{23}$ - documenta o processo de transformação da Avenida São Luís, com a substituição dos antigos casarões - dos quais um remanescente pode ser visto à direita - por altos edifícios.

Composição semelhante é encontrada em uma fotografia da região da Rua Líbero Badaró (Imagem 219). Vistas aéreas ${ }^{24}$ é um destaque na produção de Scheier, contratado com freqüência por empresas como Klabin, Rhodia, Ultragaz e Volkswagen para produzir imagens aéreas de suas fábricas (vide capítulo 2). No centro desta foto estão o Edifício Altino Arantes, o Edifício Martinelli e o Banco do Brasil (em construção), simbólicos dentro do crescimento da época. O Martinelli representava o poder econômico privado, do imigrante italiano Giuseppe Martinelli, recentemente superado pelo poder público: até a construção do Banco do Estado, em 1947, o Martinelli era o mais alto da cidade. Os outros dois incorporavam a imagem do poder das instituições financeiras do governo.

Por seus atributos físicos, que Ihe garantiam sua ampla visibilidade, e por seu valor intrínseco, este núcleo de arranha-céus é onipresente nas vistas panorâmicas. Sua forte presença urbana atraía as lentes fotográficas, que

23 Os dados dos edifícios são encontrados em LEFÈVRE, José Eduardo de Assis. De Beco a Avenida. A História da Rua São Luiz. São Paulo: Editora da Universidade de São Paulo, 2006, p.212-257.

24 Henri Ballot também produziu nesta época imagens da área central de São Paulo a partir de helicóptero. 


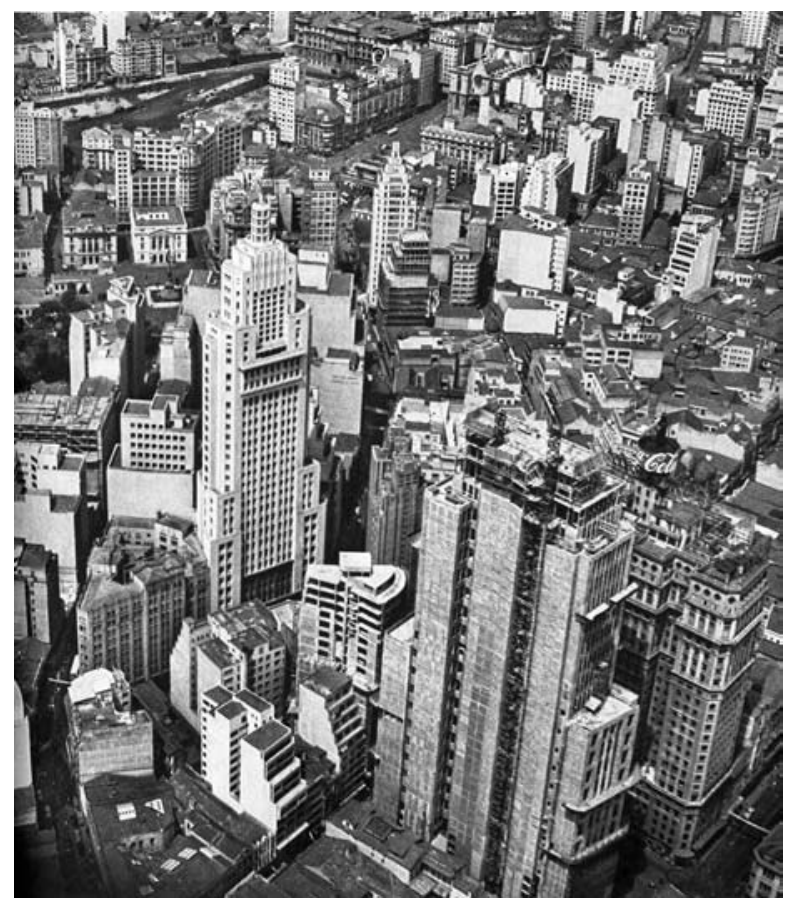

Imagem 219. Vista aérea do centro, com destaque para os edifícios Altino Arantes, Martinelli e Banco do Brasil. Na parte superior vê-se a Catedral da Sé em construção; à esquerda, o Pátio do Colégio, com seu monumento "Glória Imortal aos Fundadores de São Paulo", de Amadeo Zani. Autoria: P. Scheier. Fonte: SCHEIER (1954), p.51.

criavam composições e registros memoráveis. Mesmo na ausência eles eram notados: vistas panorâmicas da área central eram feitas, em geral, a partir de seus últimos pavimentos. Pelo ângulo da tomada e a altura do observador, é possível dizer com precisão em qual deles o fotógrafo se posicionou.

Documentar a Avenida São João em toda a sua extensão só era possível do topo do Edifício Altino Arantes, de onde Scheier registrou-a marcada pelos trilhos de bonde e pela multidão que caminhava (Imagem 220). A névoa produzida pela luz rasante do fim de tarde confere infinitude à avenida, que se perde no horizonte em meio à profusão de arranha-céus. Na legenda, é comparada à norteamericana Broadway, paradigma de cultura e vida social agitada. Equiparar-se aos Estados Unidos era constante no discurso do IV Centenário, uma vez que 


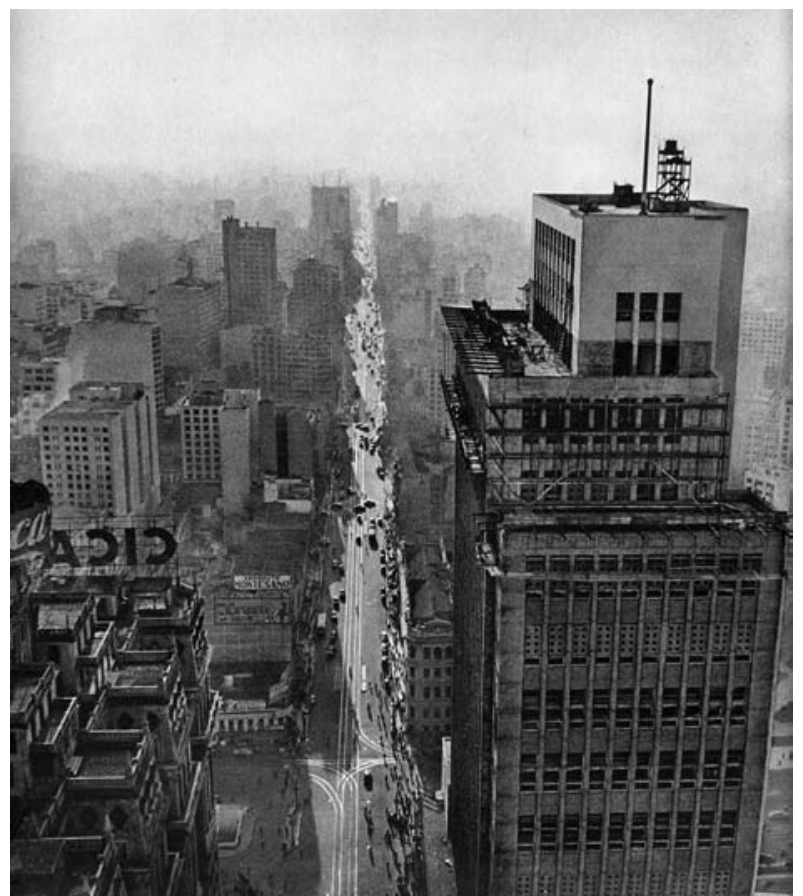

Imagem 220. Avenida São João a partir do edifício Altino Arantes. Em primeiro plano, o cruzamento com a Rua Líbero Badaró, no qual se vêem os edifícios Martinelli, à esquerda, e o Banco do Brasil em obras, à direita. Autoria: P. Scheier. Fonte: SCHEIER (1954), p.14.

eram tidos como referência de modernidade, uma vez que, no pós-guerra, aquele país apresentava uma condição privilegiada.

Observadas a partir da Rua Líbero Badaró, no nível do pedestre, estas três construções se avolumavam e se impunham aos passantes como entidades às quais era devido respeito (Imagem 221). Aos três gigantes Scheier acrescentou um guarda de trânsito em close, cuja presença é justificada pela necessidade de disciplina e ordem, explícita na faixa parcialmente visível na parte superior: "entreà esquerda". Semelhanças formais são notadas entre esta imagem e as produzidas pelo arquiteto alemão Eric Mendelsohn, na década de 1920, e publicadas no livro Amerika: Bilderbuch eines Architekten, em 1926 (Imagem 222). A rua estreita e o alto gabarito do Equitable Trust Building, em New York, levaram-no a inclinar sua máquina para cima, conferindo, assim, uma direção ascendente enfática. 


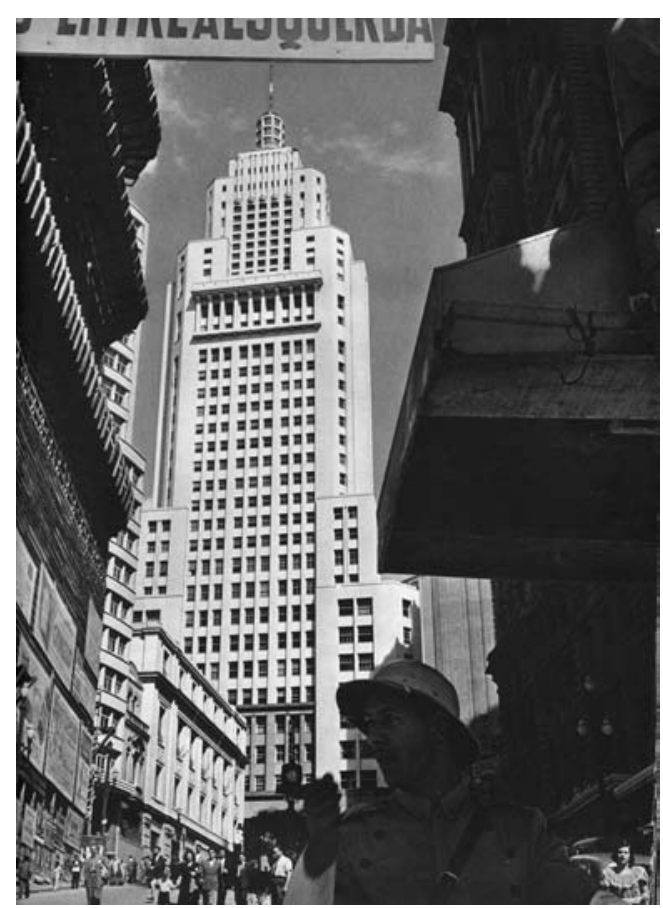

Imagem 221. Avenida São João, com o edifício Altino Arantes ao centro. À esquerda, Banco do Brasil em construção. Sobre o tapume da obra, vários anúncios de cigarros e dos móveis "Ambiente". Foto tirada às 11:30, conforme indica o relógio. Autoria: P. Scheier. Fonte: SCHEIER (1954), p.15

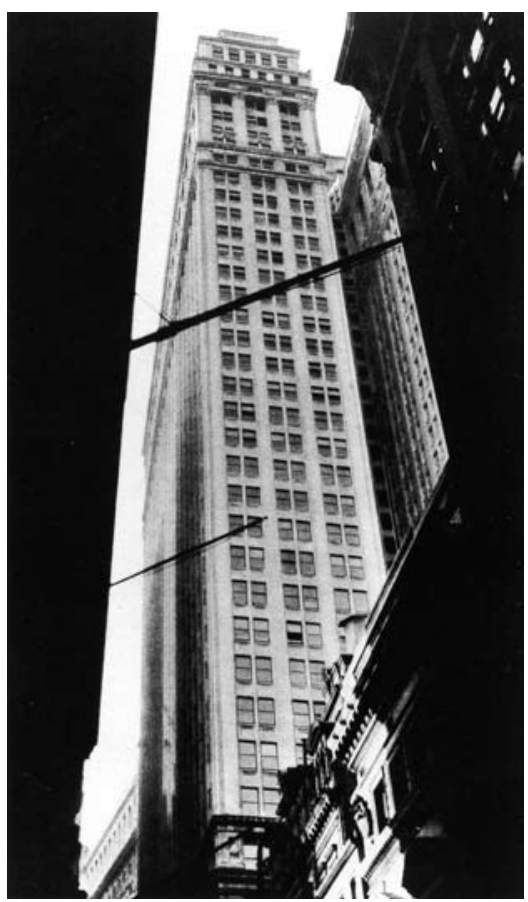

Imagem 222. Equitable Trust Building, em New York. Autoria: Eric Mendelsohn. Fonte: ELWALL (2004), p.132.

Segundo Elwall, estes pontos de vista radicalmente ascendentes transmitiam bem a excitação que o arquiteto sentiu pela primeira vez que andou pelas ruas de New York, Chicago e Detroit ${ }^{25}$, talvez o mesmo sentimento que os três arranha-céus paulistanos despertavam nos transeuntes. Ainda segundo o autor, o uso de perspectivas distorcidas foi parcialmente resultado do aparecimento do arranha-céu, que exigia um novo jeito de ver a cidade. Munido de câmeras mais versáteis e leves como a Leica - compatíveis com a rapidez do olhar humano ao fotógrafo não havia outra opção senão apontar a câmera para cima e aceitar o resultado com as verticais convergentes ${ }^{26}$.

25 ELWALL, Robert. Building with Light: the international history of architectural photography. Londres: Merrel Publishers, 2004, p.122.

26 ELWALL. Op. cit, p. 121. 


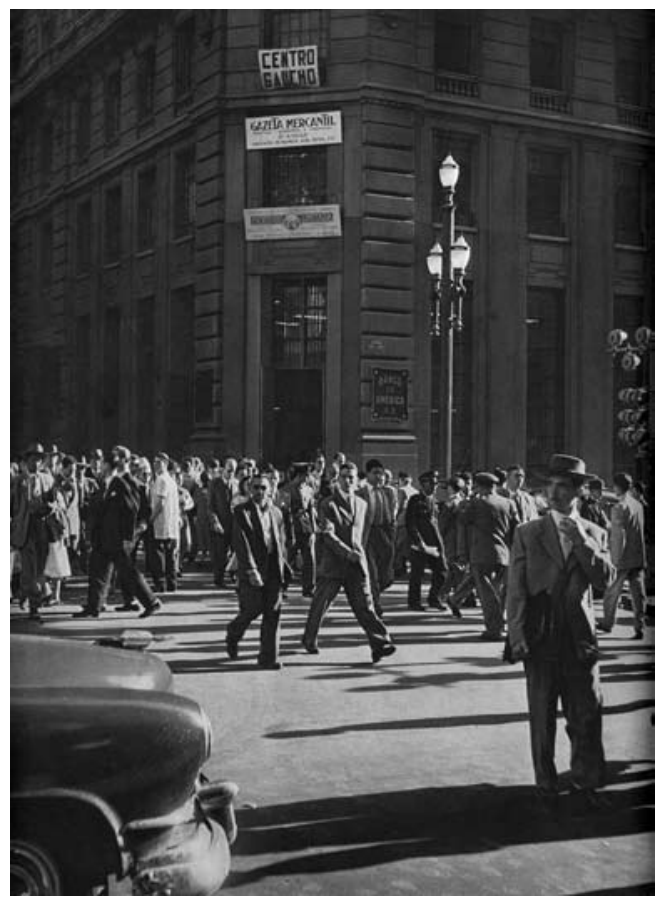

Imagem 223. Esquina da Rua São Bento com Avenida São João. No térreo do Martinelli ficava o Banco da América. Lêem-se ainda as placas do "Centro Gaúcho", "Gazeta Mercantil - industrial - econômica e financeira - 5음 andar publicação de balanços, atas, editais, etc", "Escritório Levy Limitada". Autoria: P. Scheier. Fonte: SCHEIER (1954), p.54.

A metropolização de São Paulo se manifesta nas imagens não só através de seus arranha-céus, mas também da presença de multidão. Para Lima e Carvalho, esta multidão é essencialmente composta por homens adultos trajando terno, com o corpo ereto em movimento de locomoção, que sintetizam, assim, a imagem do homem em trabalho ${ }^{27}$. Na esquina da Avenida São João com Rua São Bento, com a entrada do Edifício Martinelli ao fundo, Scheier registrou a multidão que saía do trabalho no fim de tarde (Imagem 223). É possível identificar apenas quatro mulheres - e essa operação exige muita atenção. A presença parcial do automóvel à esquerda introduz a questão dos problemas de trânsito e o conflito entre pedestre e veículos. A postura do homem em primeiro plano, parado no 
meio da rua e fitando em direção ao automóvel, parece sintetizar um sentimento de desafio.

A convivência pedestre-automóvel é registrada em diversas imagens, em especial naquelas do Vale do Anhangabaú, objeto de intervenção urbana do Plano de Avenidas implantado por Prestes Maia, prefeito da cidade de 1938 a 1945. Prestes Maia via a urgência de "um plano para disciplinar a cidade em seu crescimento e reordenar a área central" ${ }^{28}$, uma vez que

São Paulo marcha com passo mais rápido que o normal, e de tal modo se vai distanciando das suas congêneres deste e dos outros continentes, que não pode subsistir dúvida que ela está em uma fase decisiva da sua existência: a da sua passagem para o rol das grandes metrópoles. ${ }^{29}$

Prestes Maia definiu o Perímetro de Irradiação com largas avenidas "destinado a desafogar e ampliar o centro comercial", mudando "inteiramente a constituição e o aspecto do Centro e o seu esquema circulatório" ${ }^{30}$. Ao perímetro foi acrescido um grande eixo norte-sul, conhecido como Sistema Y, por sua configuração formal. Sua implantação se deu através da abertura da Avenida Anhangabaú (futura Avenida 23 de Maio) e a desobstrução do trecho central do Vale para encontrar a Avenida 9 de Julho, comunicando, assim, o Parque Anhangabaú e a Avenida Tiradentes. "As hastes do Y são as Avenidas Nove de Julho e Itororó (em começo), e o tronco é a Avenida Anhangabaú inferior (...) que, ligado à Avenida Tiradentes, constitui um dos principais eixos da cidade."31

28 TOLEDO, Benedito Lima de. Prestes Maia e as origens do urbanismo moderno em São Paulo. São Paulo: Empresa das Artes, 1996, p.14.

29 MAIA, F.P. \& CINTRA, J.F.U. - Um problema atual. Os grandes melhoramentos. Boletim do Instituto de Engenharia, n. 26-27, p.56-60. Apud: TOLEDO. Op. cit, p. 119.

30 MAIA, F.P. São Paulo no IV Centenário. Apud: TOLEDO. Op. cit, p.17

31 MAIA, F.P. Loc cit. 


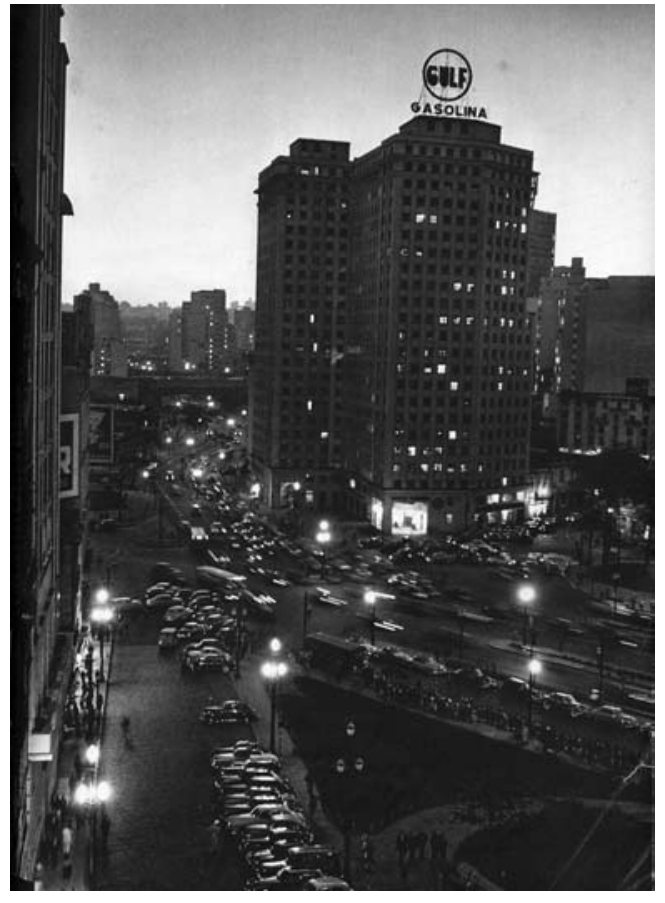

Imagem 224. Praça das Bandeiras. Autoria: P. Scheier. Fonte: SCHEIER (1954), p.29.

O entroncamento das hastes e do tronco do Y é a Praça da Bandeira. No Iusco-fusco, Peter Scheier a registrou a partir da Rua Líbero Badaró, na altura do Viaduto do Chá (Imagem 224). A curva no centro da imagem mostra o ponto de encontro da Avenida Anhangabaú com a 9 de Julho, oculta pelo grande edifício. Pela borda direita da imagem segue o Vale do Anhangabaú, sentido zona norte. Era um momento intenso de tráfego no fim de tarde, quando veículos e pessoas se dirigiam para casa. A fila de passageiros no ponto de ônibus era longa.

O topo do alto edifício da imagem era marcado pelo grande luminoso da gasolina norte-americana Gulf. A entrada de combustível importado no Brasil se iniciou no final da década de 1930, com companhias como Shell, Texaco e Atlantic, além da Gulf32. No térreo deste mesmo prédio havia um posto do Touring Club do Brasil, sociedade afiliada a organismos internacionais de turismo $32 \quad$ Fonte: http://www.gulfbrasil.com.br/publique/cgi/cgilua.exe/sys/start.htm?sid=4. Acesso em 23 jun 2008, às 21:00. 


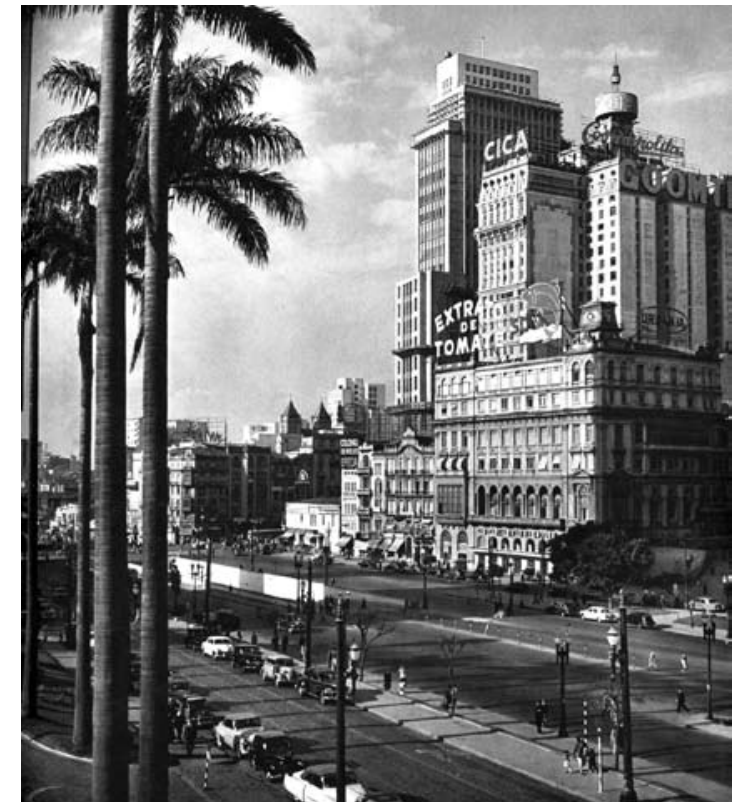

Imagem 225. Vale do Anhangabaú. Autoria: P. Scheier. Fonte: SCHEIER (1954), p.41.

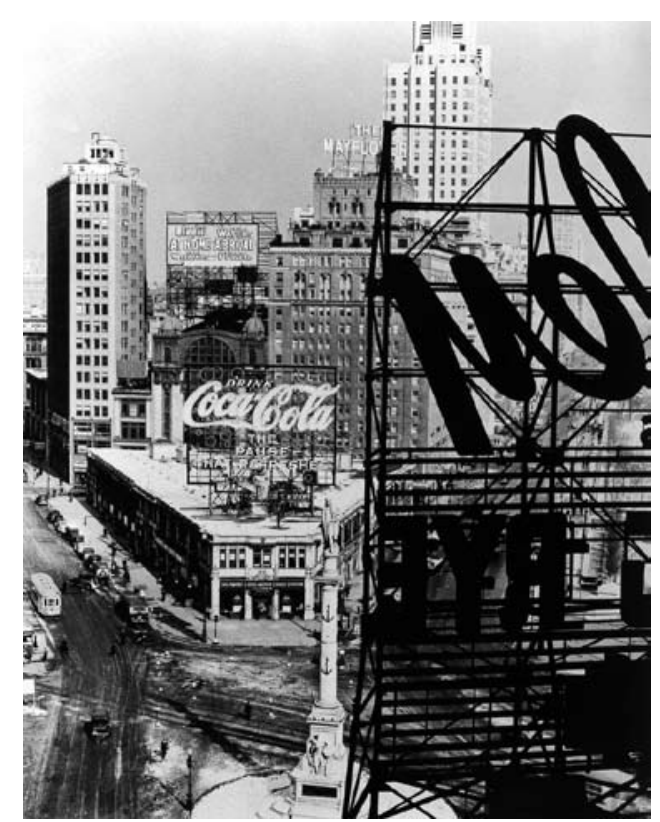

Imagem 226. New York, década de 1930. Autoria: Berenice Abbot. Fonte: ELWALL (2004), p.152.

que, a partir de 1930, iniciou a prestação de serviços automobilísticos, como assistência automotiva, licenças e matrículas de motoristas, emplacamento de carros e serviço de guinchos ${ }^{33}$. Por todos os seus elementos constituintes - amplo sistema viário, congestionamento, anúncio de combustível e posto de serviços automotivos - esta fotografia sintetiza a sociedade paulistana daquele momento, que privilegiava o automóvel, então símbolo do progresso material, coletivo e individual.

O Vale do Anhangabaú aparece em muitas outras imagens, com seus edifícios marcantes e seus numerosos luminosos publicitários. Na esquina da Rua Dr. Miguel Couto, o palacete era "coroado" com o anúncio do Extrato de Tomate Peixe e da Urbania Capitalização (Imagem 225). O Edifício Martinelli suportava quatro luminosos: Cica, Goomtex, Cosmopolita (marca de fogões) e um tridimensional da Coca-Cola, em formato de garrafa. O edifício Sampaio 


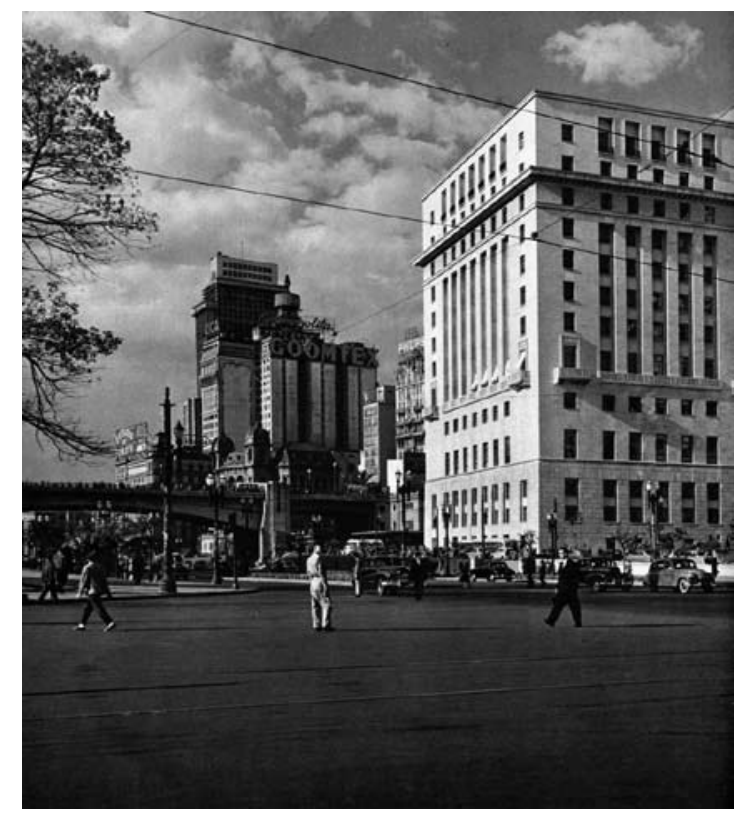

Imagem 227. Vale do Anhangabaú e Edifício Matarazzo. Autoria: P. Scheier. Fonte: SCHEIER (1954), p.40.

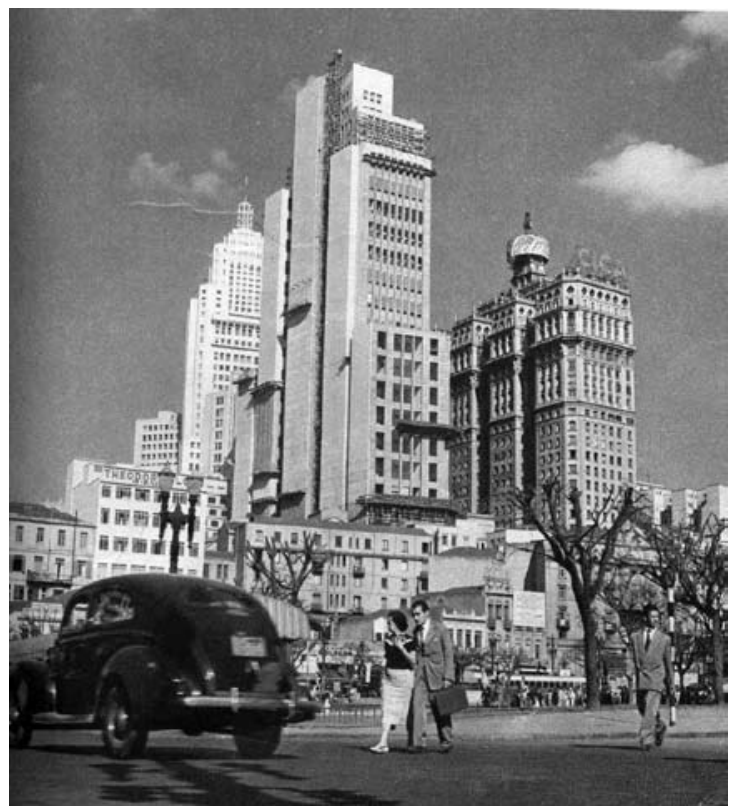

Imagem 228. Vale do Anhangabaú. Autoria: P. Scheier. Fonte: SCHEIER (1954), p.45.

Moreira, edifício mais alto antes da construção do Martinelli, era facilmente identificado pelo luminoso das Lâmpadas Philips, ao passo que seu vizinho ostentava o do Moinho Santista. Vermouth Montesano, Crush, Vermouth Gancia, Cinzano, Biotônico Fontoura, Goodyear, Arno e tantos outros produtos ganhavam visibilidade nas empenas, tapumes e coberturas das construções. As fotos de Berenice Abbot de New York na década de 1930 mostram a mesma presença maciça de anúncios que, para Elwall, eram apresentados como nova forma da iconografia urbana, suplantando a tradicional estatuária cívica ${ }^{34}$ (Imagem 226).

Do centro do Vale e olhando para o Viaduto do Chá, Scheier fez uma imagem cujo enquadramento transmite claramente a relação de escala entre o pedestre e o Vale, cuja travessia era feita sem sinalização e em meio aos veículos que trafegavam (Imagem 227/228). Público intenso atravessava o Viaduto, atrás do qual se vê o Palacete Prates, cujo gabarito e estilo eclético das primeiras 


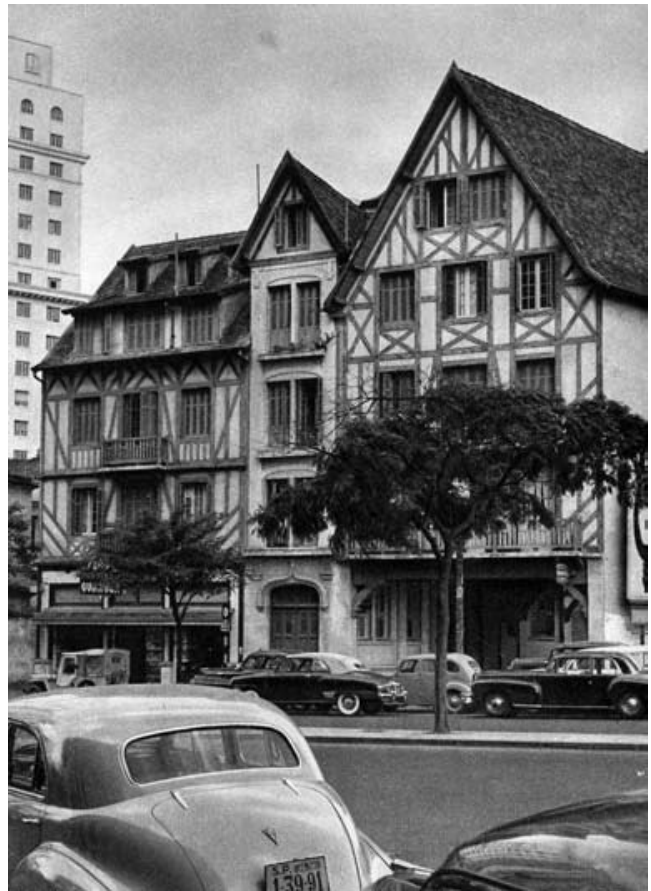

Imagem 229. Vila Normanda. Autoria: P. Scheier. Fonte: SCHEIER (1954), p.45.

décadas do século XX - com suas abóbadas ogivais - contrapunham-se aos modernos edifícios circundantes, como o Edifício Matarazzo, o "tumor fascista" ${ }^{35}$ em São Paulo, nas palavras de Mário de Andrade:

Que o edifício Matarazzo deslumbra, isso deslumbra, sou o primeiro a afirmar. E porque deslumbra, muitos dizem que é belo, não é. (...) O edifício Matarazzo deslumbra, também, pela estupidez grossolana da massa e pela maravilhosa beleza da pedra de revestimento. Que pedra sublime, cruz-credo! Dá vontade de comer! Mas nem comidas, nem revestimentos ainda são arquitetura. ${ }^{36}$

Estranhamento idêntico ao provocado pelo Palacete Prates acontece ao nos depararmos com a fotografia da Vila Normanda, com os carros na Avenida

35 ANDRADE, Mário de. "Brazil Builds". In: XAVIER, Alberto (org.). Depoimento de uma geração - arquitetura moderna brasileira. São Paulo: Cosac \& Naify, 2003, p. 177.

36 ANDRADE. Op. cit, p. 178. 


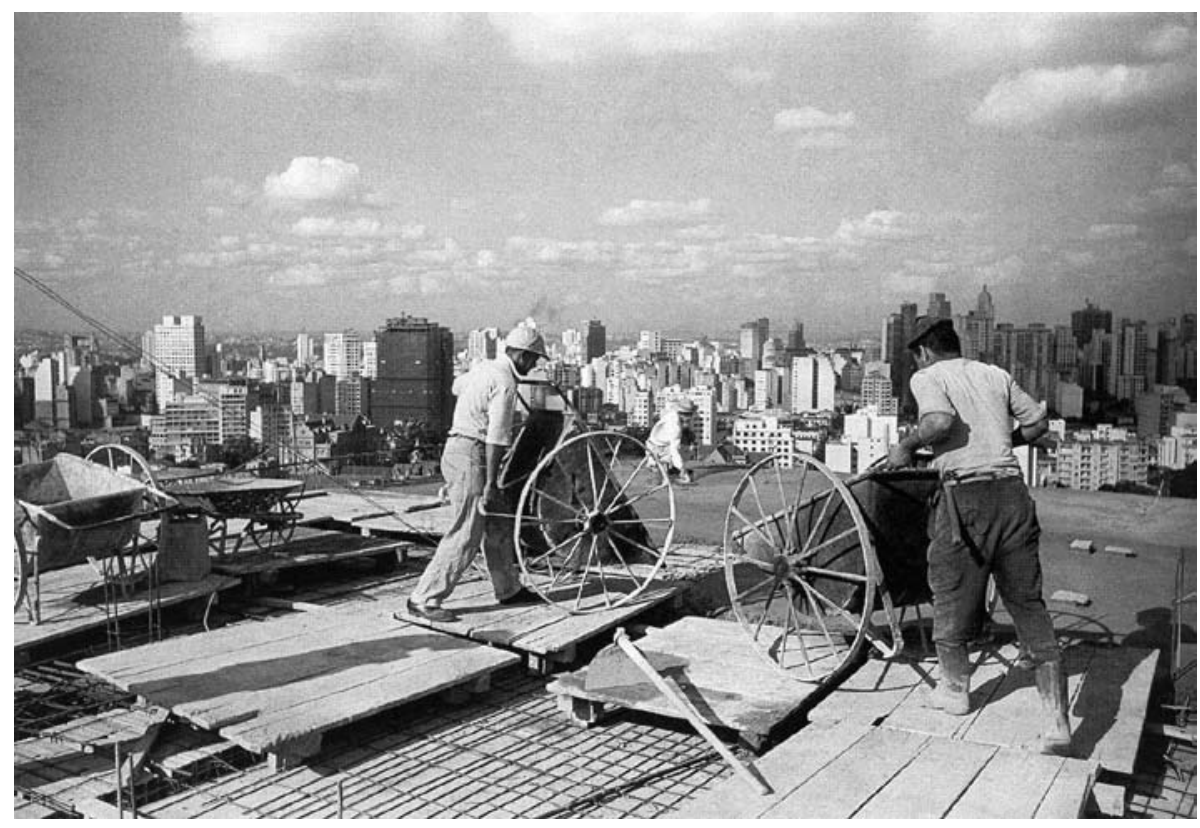

Imagem 230. Obra na cobertura do Edifício Vitória Régia. Autoria: Hans Günter Flieg. Fonte: FRANCESCHI (2004), p.198.

Ipiranga à frente (Imagem 229). A Vila era um "conjunto de cinco edificações de nível médio, com arquitetura inspirada nas construções de enxaimel da Normandia, talvez numa referência à nacionalidade da esposa do conde, $d$. Honorine" ${ }^{37}$. O conde em questão era Sílvio Álvares Penteado, o responsável pela implantação do conjunto. É possível que Scheier se sentisse sensibilizado com esta presença alemã tão explícita no centro de São Paulo, porém o caráter pitoresco do lugar por si constituía um motivo fotográfico.

A construção civil também atraía com freqüência a atenção dos fotógrafos. Na dinâmica do crescimento daquele momento, a cidade passava por obras de infra-estrutura simultaneamente ao surgimento de novos edifícios. Emblemático é o registro que Hans Günter Flieg fez da obra na cobertura do Edifício Vitória Régia, na Rua Marquês de Itu, na década de 1950 (Imagem 230). Com ênfase nos operários que manipulavam os equipamentos, Flieg registrou o skyline de São Paulo ao fundo, numa composição que lembra a imagem do MASP na $37 \quad$ LEFÈVRE. Op. cit, p.101. 


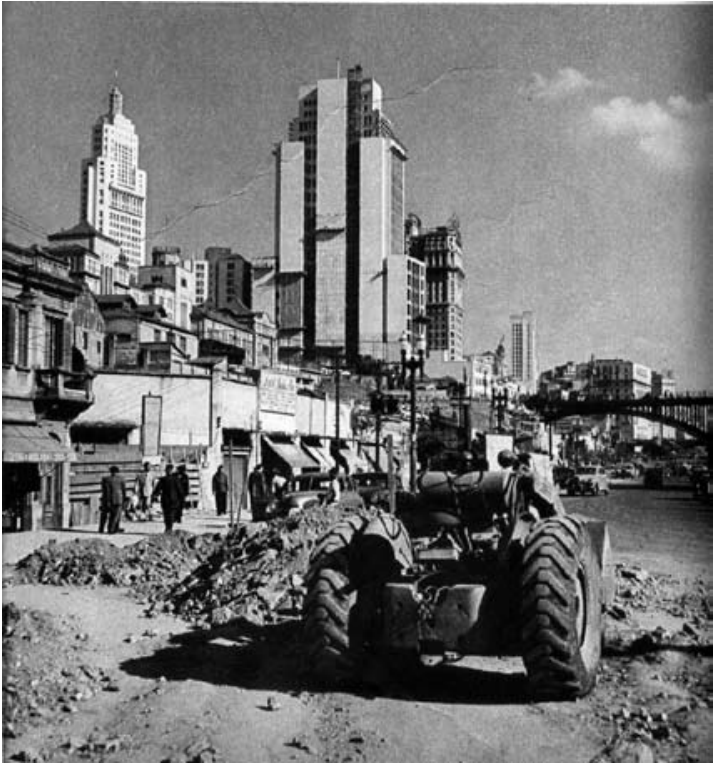

Imagem 231. Obra no Vale do Anhangabaú. Autoria: P. Scheier. Fonte: SCHEIER (1954), p.52.

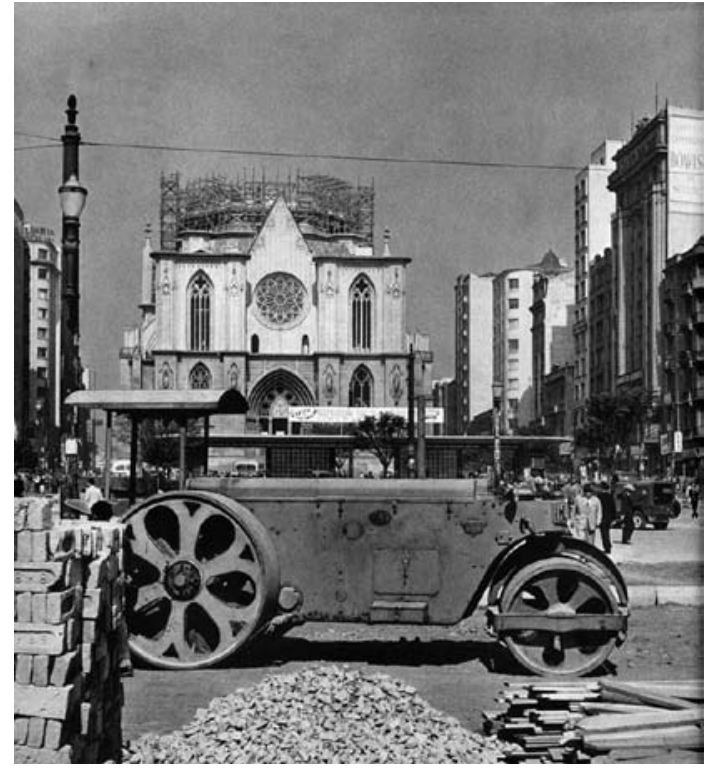

Imagem 232. Obra na Praça da Sé. Autoria: P. Scheier. Fonte: SCHEIER (1954), p.22.

Avenida Paulista em construção, mostrada no capítulo 2.

As imagens de construção publicadas em São Paulo estranhamente não focam no elemento humano, no homem-operário, como visto nas imagens sobre a cafeicultura ou indústria. Nelas o foco recai sobre máquinas, com materiais ao seu redor e a vista da cidade ao fundo. No caso do Vale, são vistos o Altino Arantes, o Banco do Brasil, o Martinelli, o Viaduto Santa Ifigênia e, no último plano, o Viaduto do Chá e o Edifício Matarazzo (Imagem 231). Em outra imagem, o plano frontal é dominado por um veículo pesado da marca Huber, circundado por uma pilha de tijolos, monte de brita e ripas de madeira (Imagem 232). Ao fundo, a inacabada Catedral da Sé, com seus andaimes, é mostrada secundariamente, oculta por outros elementos que a ela se sobrepõem, como veículos, postes, ponto de ônibus e uma faixa na qual se lê "Visite no Cine Odeon a Exposição Têxtil S.Paulo. O futuro de São Paulo está em nossa indústria". 


\subsection{A arquitetura moderna}

Segundo Mascaro, existem três formas distintas de abordar arquitetura. A primeira é o documento (ou registro), objetiva e metódica, compromissada em informar precisamente o edifício com relação às suas proporções, cores e materiais. Declara que esta forma é típica das fotografias das revistas e livros especializados, nas quais o edifício impõe seus ângulos e o fotógrafo registra o que vê, sem interferir no objeto ${ }^{38}$. A segunda é a ilustração, mais elaborada e na qual prevalece a visão própria do fotógrafo sobre o edifício. Ele comenta a obra, destacando seus defeitos e qualidades. A terceira é a imagem, uma postura livre e criativa, na qual o fotógrafo não registra especificamente a arquitetura, mas descobre nos espaços expressões da vida urbana. É a descoberta pessoal dos valores arquitetônicos. Se analisarmos esta categorização baseados nos conceitos explorados até aqui, obviamente contestaremos seus termos. Esta classificação foi elaborada por volta de 1985, em sua dissertação de Mestrado $^{39}$. Mascaro demonstra uma postura de crença no valor testemunhal da foto, como se fosse possível à fotografia não registrar a visão pessoal do fotógrafo. Essa postura foi contestada por ele mesmo quase dez anos depois, em seu Doutorado ${ }^{40}$, quando afirmou ser um equívoco esperar da foto o registro fiel do que a arquitetura é ou do que se imagina ou do que se gostaria que ela fosse.

Segawa afirma que a "fotografia tem a virtude de, mesmo sendo uma mentira, despertar o interesse." ${ }^{41}$ Esta afirmação é rica de significados. Primeiro,

38 Interpretamos esta interferência como sendo física. De acordo com os preceitos teóricos explícitos na Introdução deste trabalho, afirmamos que não se trata de um registro imparcial, como as palavras do autor tendem a concluir.

$39 \quad$. O uso da imagem fotográfica na interpretação do espaço urbano e arquitetônico. São Paulo: Faculdade de Arquitetura e Urbanismo da Universidade de São Paulo, 1985. Dissertação de Mestrado.

40 MASCARO, Cristiano. A Fotografia e a Arquitetura. São Paulo: Faculdade de Arquitetura e Urbanismo da Universidade de São Paulo, 1994. Tese de Doutorado.

41 SEGAWA, Hugo. Voyeurismo: olhando a arquitetura. Revista Projeto, São Paulo, n. 176, p. 65, jul 1994. 
lembra que a lente resulta em uma visão impossível a olho nu. Remete também à condição de testemunho do real que foi imposta à fotografia desde seus primórdios, quando se acreditava que não era arte por se tratar de um registro feito por uma máquina e não por um homem, servindo apenas à função de "bloco de notas", como afirmava Baudelaire ${ }^{42}$. A riqueza de informações presentes na fotografia, indiciais de um referente real, contribui para que a idéia de prova incontestável permaneça. Entretanto, restringir a fotografia a essa condição, seja ela de arquitetura ou de outro tema, é ignorar a existência de um ser criador por trás do equipamento, que elaborou mentalmente o registro, baseado em suas experiências, seu filtro cultural, social, sua intenção, sua interpretação e sua necessidade. Antes de registrar a arquitetura, o fotógrafo é seu usuário: além da percepção espacial não estar fundada unicamente na visualidade, mas englobar todos os demais sentidos, ela é individual, baseada nos valores e informações pessoais. O fotógrafo, no momento do registro, faz uma seleção. A foto de arquitetura, portanto, é o registro de um indivíduo, e não uma verdade universal. A fotografia, como a arquitetura, é uma realidade construída.

A classificação de Mascaro, contudo, tem o mérito de levantar as diversas posturas que os fotógrafos tomam frente a um edifício. Ele pode tender a uma visão mais geral, registrando todas as elevações externas, seu entorno e a extensão de seus espaços internos, procurando estabelecer relações de proporção e de contigüidade. Pode enfatizar sua relação com os usuários e com a cidade, num registro com características do fotojornalismo. O fotógrafo também pode fixar-se nos detalhes a fim de demonstrar soluções construtivas. Ou ainda explorar a arquitetura de forma abstrata, concentrando em texturas, jogos de luz e sombra e elementos geométricos. É o que acontece nas imagens de arquitetura moderna presentes no álbum São Paulo. Longe de serem formas rígidas de

42 BAUDELAIRE, Charles. Salão de 1859. In: A modernidade de Baudelaire. Rio de Janeiro: Paz e Terra, 1988, p.63. 
classificação, essas observações devem ser entendidas como processo de leitura e interpretação da edição do livro.

De um modo geral, a arquitetura moderna tem grande participação nos álbuns do IV Centenário por transmitirem a idéia de progresso e vanguarda tão em voga. Edifícios como o C.B.I. (Companhia Brasileira de Investimentos) e o Cine Ipiranga aparecem constantemente, em exaltação às novas técnicas de construção, especialmente o concreto armado. Em São Paulo fastest growing city in the world, ao lado das construções modernas do Vale do Anhangabaú e redondezas, muito recorrentes, são privilegiados dois arquitetos cujas obras Peter Scheier documentou, Rino Levi - com Cine Ipiranga, Edifício Prudência e Banco Paulista - e Lina Bo Bardi - com a Casa de Vidro, MASP e obras de interiores do Palma Studio de Arte e Arquitetura - Mapa Importadora e Olivetti Securit.

Obviamente, não era objetivo do álbum traçar um panorama da arquitetura moderna em São Paulo da última década. Em segundo lugar, oálbum foi elaborado a partir do arquivo de Scheier, o que resulta em um forte comprometimento da edição com os serviços fotográficos executados por ele. Assim, compreende-se a ausência de nomes como Gregori Warchavchik, Eduardo Kneese de Melo, Oswaldo Arthur Bratke, João Batista Vilanova Artigas, Ícaro de Castro Melo, Eduardo Corona e Franz Heep, entre tantos outros, cujas obras marcaram incisivamente a paisagem paulistana. Deste modo, justifica-se o que, a princípio, soa como uma falha editorial.

Em determinadas vistas urbanas, a arquitetura recebe um foco diferenciado em que, embora a cidade seja o mote, o edifício torna-se o objeto central da foto. $\mathrm{Na}$ imagem feita a partir da Praça da República, por exemplo, o Hotel Excelsior está em segundo plano, atrás da densa vegetação (Imagem 233). Entre os troncos das árvores, os transeuntes e os veículos estacionados na Avenida 


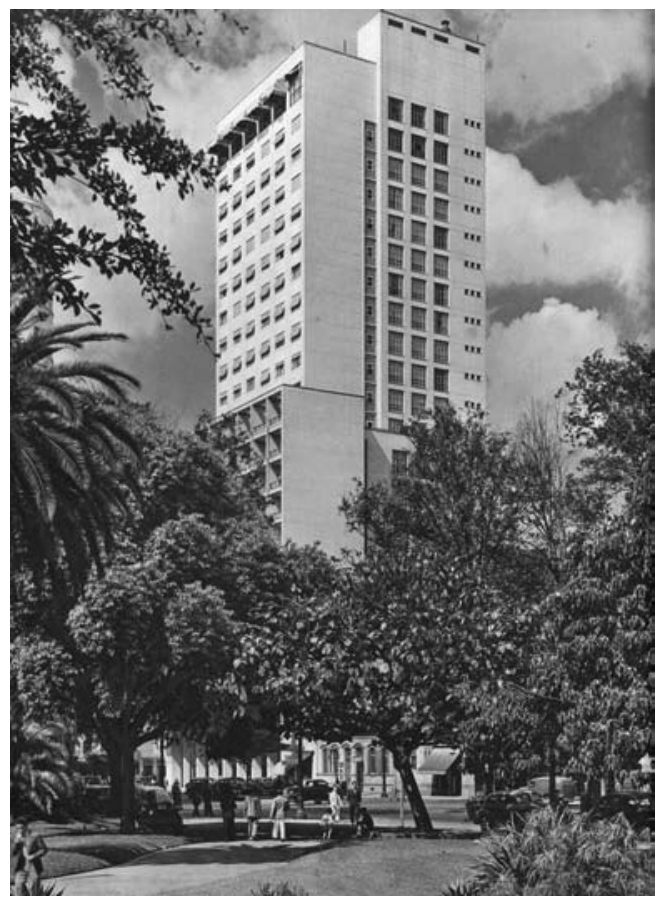

Imagem 233. Cine Ipiranga e Hotel Excelsior a partir da Praça da República. Autoria: P. Scheier. Fonte: SCHEIER (1954), p.32.

Ipiranga, nota-se a colunata do foyer de entrada do cinema. O Cine Ipiranga aparece ainda com duas imagens internas (Imagem 177/270), editadas dentro da seção que trata da cultura e diversão na cidade.

Para fotografar o Edifício Prudência, Scheier posicionou-se da mesma maneira, em meio a um jardim e obliqüamente ao prédio (Imagem 234). $O$ primeiro plano é dominado pela vegetação, em especial uma palmeira que marca o eixo vertical da composição e que encobre parcialmente a fachada. A presença no álbum de serviços contratados como este traz como conseqüência a inclusão de outros bairros além do centro.

A documentação do Banco Paulista do Comércio (Imagem 235)- outra encomenda do arquiteto Rino Levi - é apresentada através de uma imagem muito próxima às já apresentadas no capítulo 2 (Imagem 168/169). À semelhança do 


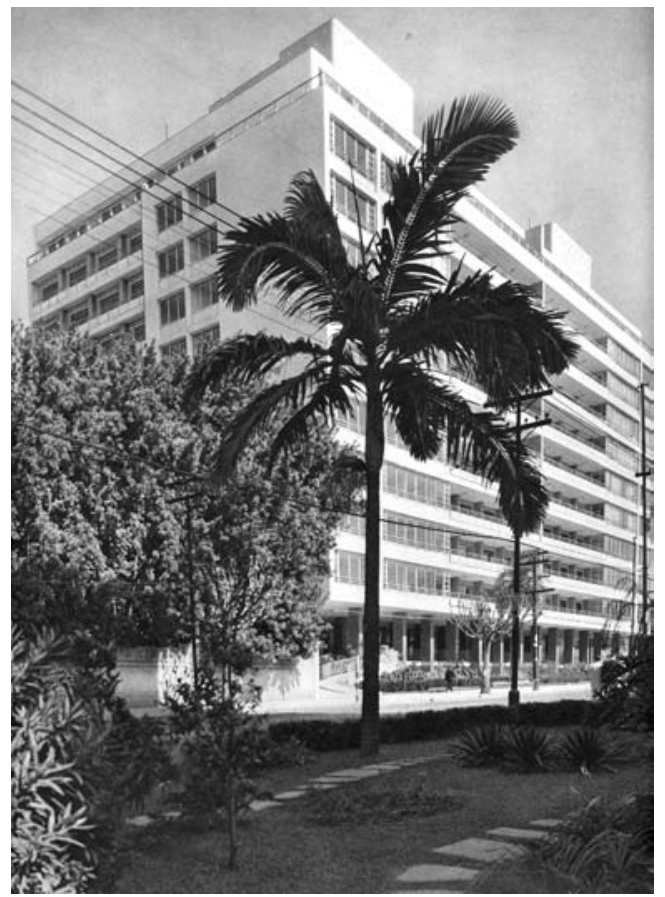

Imagem 234. EdifícioPrudência. Autoria: P. Scheier. Fonte: SCHEIER (1954), p.42.

Hotel Excelsior, o Banco aparece circundado pelo entorno da Rua Boa Vista, em obras. As características modernas do Banco, como a transparência e o gabarito mais alto, distinguem-se das construções antigas lindeiras, mais baixas, opacas e encobertas por letreiros - Casa Semin (tecidos nacionais e importados), alfaiataria, Casa Manon (instrumentos musicais) e Gaitas Hering. A relação urbana que se estabelece nesse contexto é "de transição e o velho é freqüentemente vizinho do novo, mesmo no centro da cidade" ${ }^{43}$. Para Lima e Carvalho, trata-se de uma forte ambigüidade, apesar de idéia de complementaridade e harmonia que a edição quer transmitir ${ }^{44}$.

O Edifício C.B.I. Esplanada, do arquiteto Lucjan Korngold, foi fotografado frontalmente a partir do Viaduto do Chá (Imagem 236). No primeiro plano, pessoas atravessavam o Viaduto, num raro registro urbano em que há marcante 


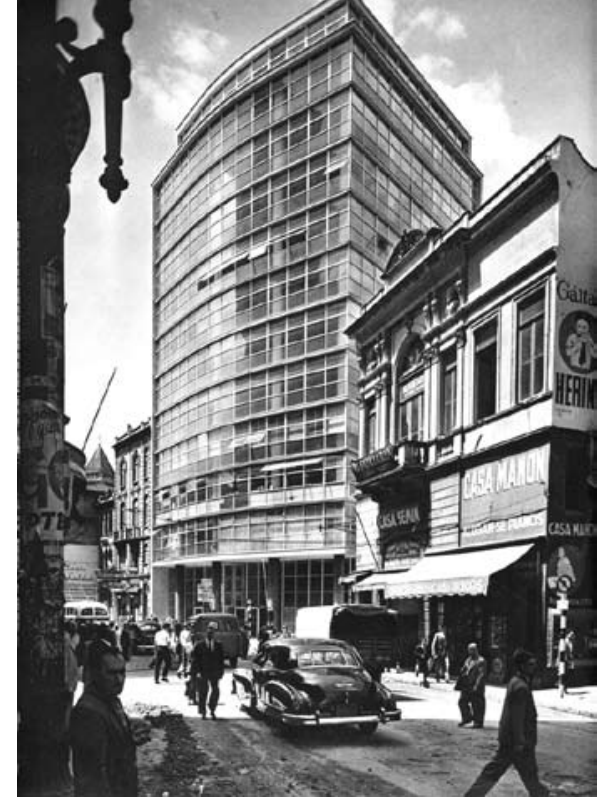

Imagem 235. Banco

Paulista. Autoria: P. Scheier. Fonte: SCHEIER (1954), p.24.

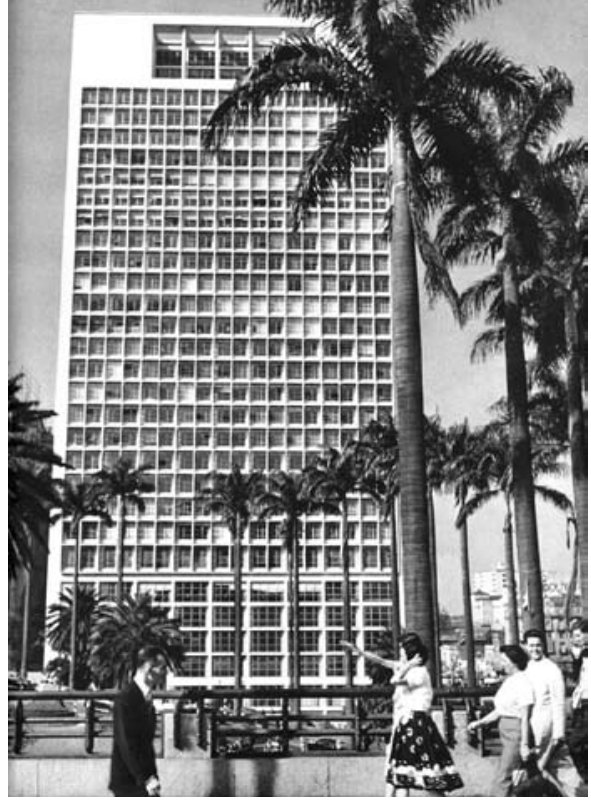

Imagem 236. Edifício C.B.I., a partir do Viaduto do Chá. Autoria: P. Scheier. Fonte: SCHEIER (1954), p.27.

presença feminina. Em segundo plano, as palmeiras da Praça Ramos exibem seus longos troncos, em simbiose com as linhas verticais da grelha da fachada do edifício. Embora esteja no último plano compositivo, o foco da imagem recai sobre o edifício, reforçando a idéia de ser ele o objeto principal da imagem. Esta é a segunda foto de uma seqüência de prédios modernos, iniciada com o Banco Paulista e continuada por duas fotografias de George Rado, do O Estado de S.Paulo e do Altino Arantes. George Rado valeu-se de ângulos ascendentes para conferir isolamento dos edifícios e sua total descontextualização. Nesta seqüência, Scheier apresenta um olhar mais amplo. A arquitetura moderna, neste caso, aparece inserida no contexto urbano e relacionando-se com os elementos circundantes, como os edifícios mais antigos e a praça.

Assim como Rado, Scheier utilizou recursos modernos de composição fotográfica em imagens de outros edifícios modernos, isolando-os do contexto urbano e concentrando-se em aspectos geométricos e em efeitos formais. É o 


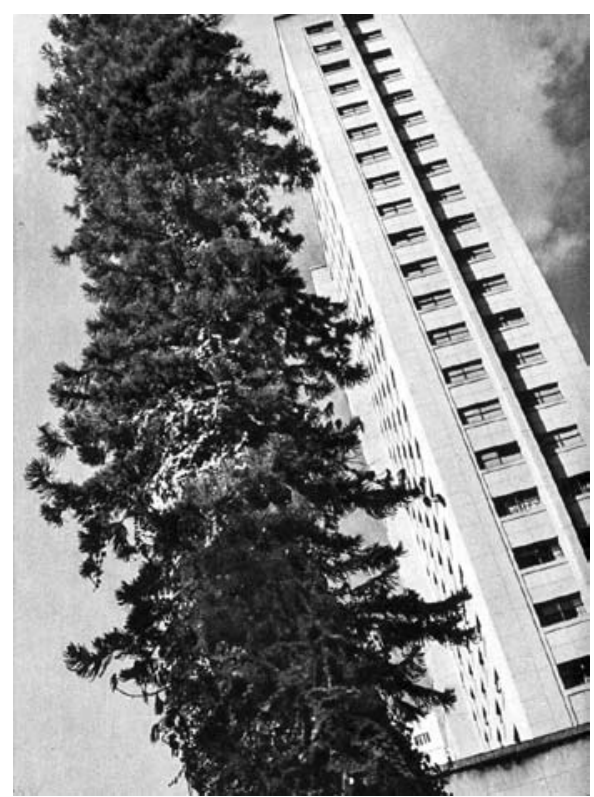

Imagem 237. Biblioteca Municipal. Autoria: P. Scheier. Fonte: SCHEIER (1954), p.70.

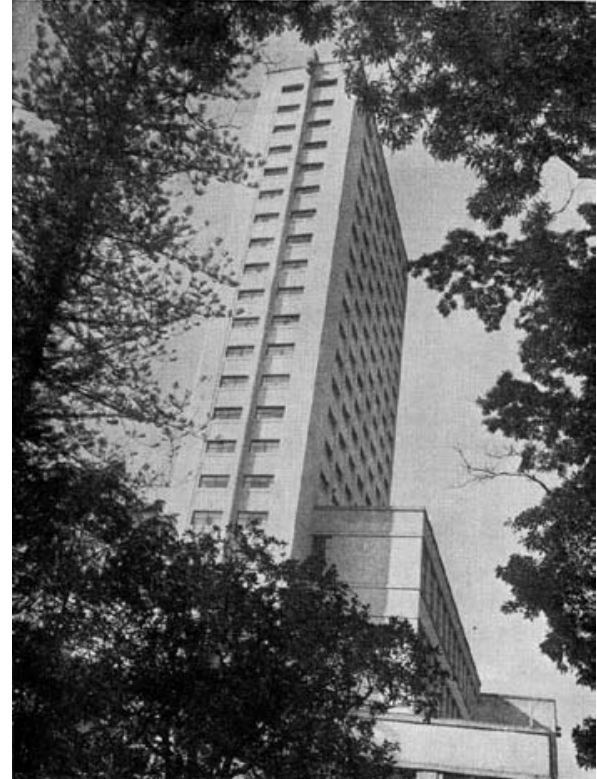

Imagem 238. Biblioteca Municipal. Autoria: Leon Liberman. Fonte: Acrópole, n.68, p.208.

caso da fotografia externa da Biblioteca Municipal, com uma acentuada diagonal ascendente e com um arranjo que estabelece relações formais análogas entre a torre e uma árvore (Imagem 237). Comparando-a com uma fotografia de Leon Liberman publicada na revista Acrópole ${ }^{45}$ em 1943, em uma ampla reportagem sobre o edifício, notamos a mesma postura (Imagem 238).

A fotografia feita a partir das escadas da Galeria Prestes Maia vale-se de uma composição moderna que combina ao ângulo ascendente um elemento em primeiro plano em contra-luz, conferindo-Ihe um caráter vanguardista (Imagem 239). Em certa medida lembra a imagem do Flatiron Building, em New York ${ }^{46}$, produzida no início do século XX por Alfred Stieglitz (Imagem 240). Contudo, esta comparação é meramente formal e joga luz sobre um possível conhecimento

45 Biblioteca Municipal de S.Paulo. Acrópole, São Paulo, n. 68, p.208, dez 1943.

46 Edifício comercial em estrutura metálica, projetado pelo arquiteto Daniel Burnham e construído em 1902. Sua planta triangular marca o cruzamento da Broadway com a Fifth Avenue. Fonte: http://www.greatbuildings.com/buildings/Flatiron_Building.html. Acesso em: 09 ago 2008, às 15:00. 


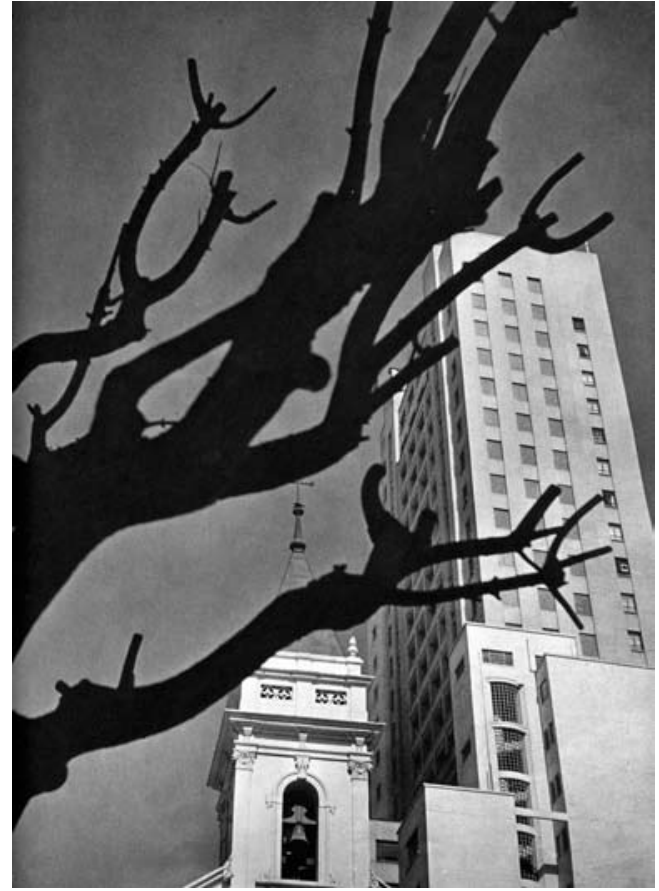

Imagem 239. Igreja de Santo Antônio, na Praça do Patriarca. Autoria: P. Scheier. Fonte: SCHEIER (1954), p.31.

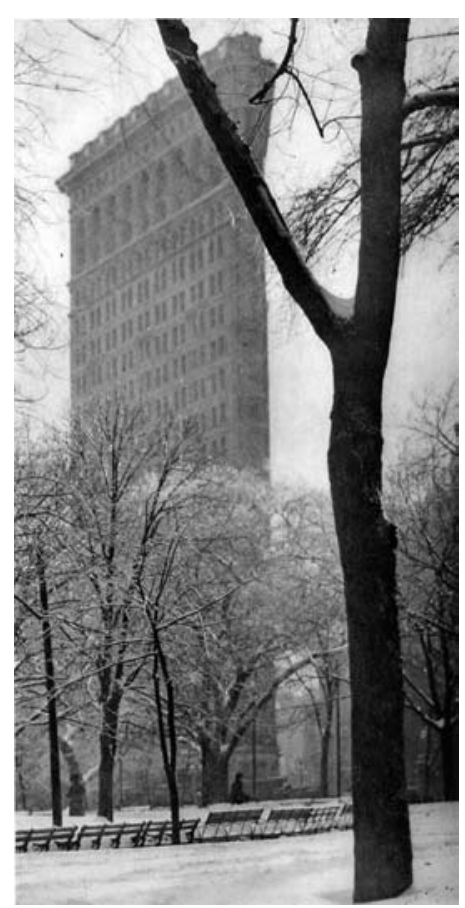

Imagem 240. Fl a t i r o n Building, em New York. Autoria: Alfred Stieglitz. Fonte: ELWALL (2004), p.113.

de Scheier do trabalho daquele fotógrafo. Fora desta leitura, a comparação é infundada, uma vez que a produção de Stieglitz se insere dentro da corrente picturialista, ao passo que Scheier apresenta traços claros da vanguarda européia, em especial a alemã e a russa.

Ao subir a escada rolante que dá acesso à Praça do Patriarca, Peter Scheier compôs esta imagem. Inclinando a máquina para cima e enquadrando um tronco de árvore em primeiro plano, ele registrou a torre sineira da Igreja de Santo Antônio e o edifício de vinte e seis andares da sede da Companhia Paulista de Seguros, na Rua Líbero Badaró. Esta foto é anterior à construção do Othon Palace Hotel, no terreno vizinho à Igreja, inaugurado em 1954.

A rotação da câmera marca a fotografia do Edifício Sobre as Ondas, dos arquitetos Oswaldo Corrêa Gonçalves e Jayme Campello Fonseca Rodrigues 


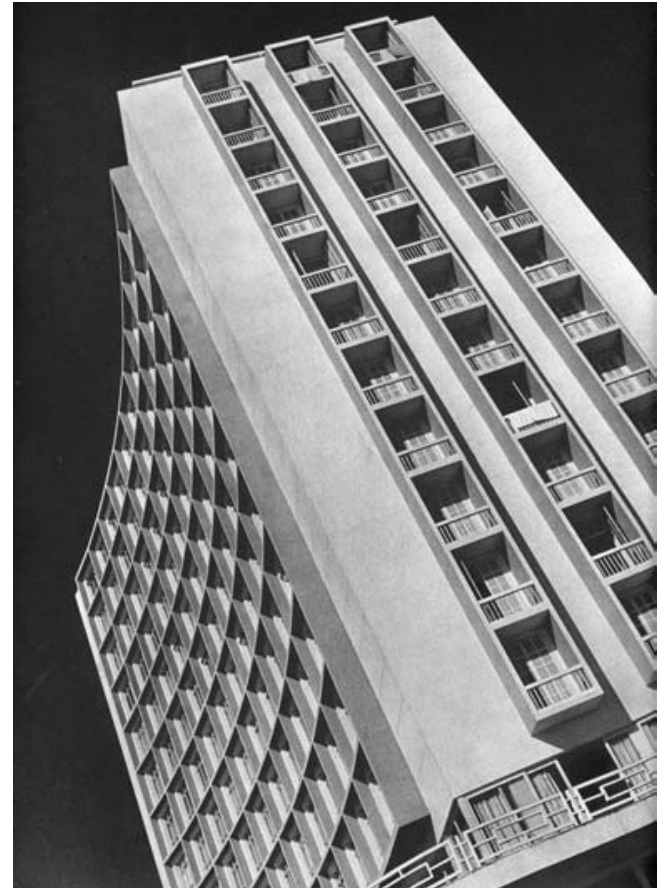

Imagem 241. Edifício Sobre as Ondas, Guarujá. Autoria: P. Scheier. Fonte: SCHEIER (1954), p.100.

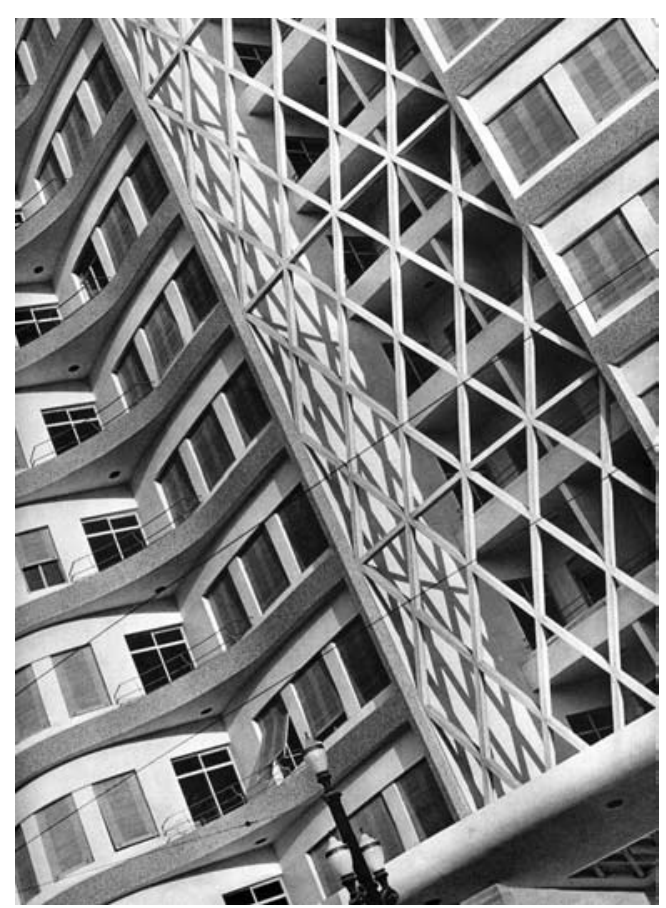

Imagem 242. Edifício

Residencial Washington. Autoria: P. Scheier. Fonte: SCHEIER (1954), p.35.

(Imagem 241). Embora a legenda descreva-o como um "ultramoderno hotel" 47 no Guarujá, trata-se de um edifício de apartamentos, com três tipologias de unidades $^{48}$. O geometrismo da fachada, a curva da planta, os efeitos da sombra e o céu extremamente escuro - resultado do provável uso de filtro - acentuam a arquitetura como volume isolado e descontextualizado. Esta relação culmina no ângulo fechado da imagem do edifício residencial Washington, na Avenida General Olímpio da Silveira, $427^{49}$ (Imagem 242). Ainserção urbana da construção se esvai totalmente, assim como sua volumetria. A arquitetura é documentada através de seu jogo de elementos, de linhas inclinadas e curvas.

A residência Lina Bo Bardi é contemplada com duas imagens, uma externa (Imagem 243) e outra interna, com o jardim em primeiro plano e ao fundo a sala $47 \quad$ SCHEIER. Op. cit, p.101.

48 Acrópole, São Paulo, n.95, p.298-299, mar 1946.

49 Projeto e Construção: Escritório Técnico Bernardo Rzezak. Fonte: Habitat, São Paulo, n.12, s.p., set 1953 . 


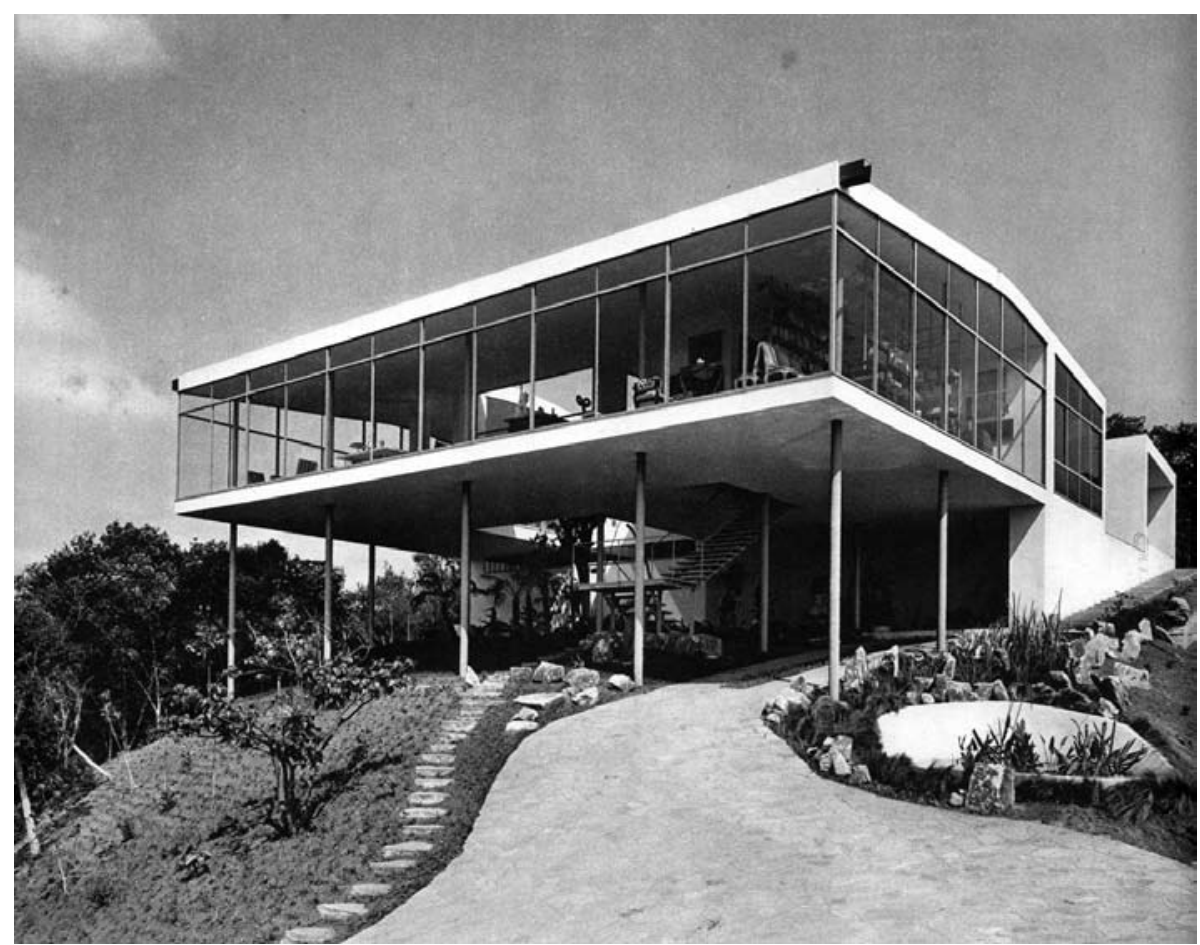

Imagem 243. Residência Lina Bo Bardi. Autoria: P. Scheier. Fonte: SCHEIER (1954), p.82.

e a cidade, ou melhor, o deserto bairro do Morumbi (Imagem 244). Para Lima e Carvalho, a Casa de Vidro representava o tipo perfeito, não como alvo literal do desejo de posse, mas indutor da aspiração pela unidade imobiliária ${ }^{50}$. A casa é referenciada na legenda, com indicação até mesmo da autoria.

Nem todo paulista mora em um apartamento; muitos são sortudos o suficiente para desfrutar de uma casa agradável, suspensa numa colina ensolarada, como esta habilmente desenhada e construída por Dona Lina do (sic) Bardi. ${ }^{51}$

A Casa de Vidro introduz a questão da habitação, que passa por uma seqüência inexplicavelmente longa de seis páginas contendo onze imagens

$50 \quad$ LIMA, CARVALHO. Op. cit, p. 190.

51 SCHEIER, Op. cit, p. 82. Tradução da autora. 


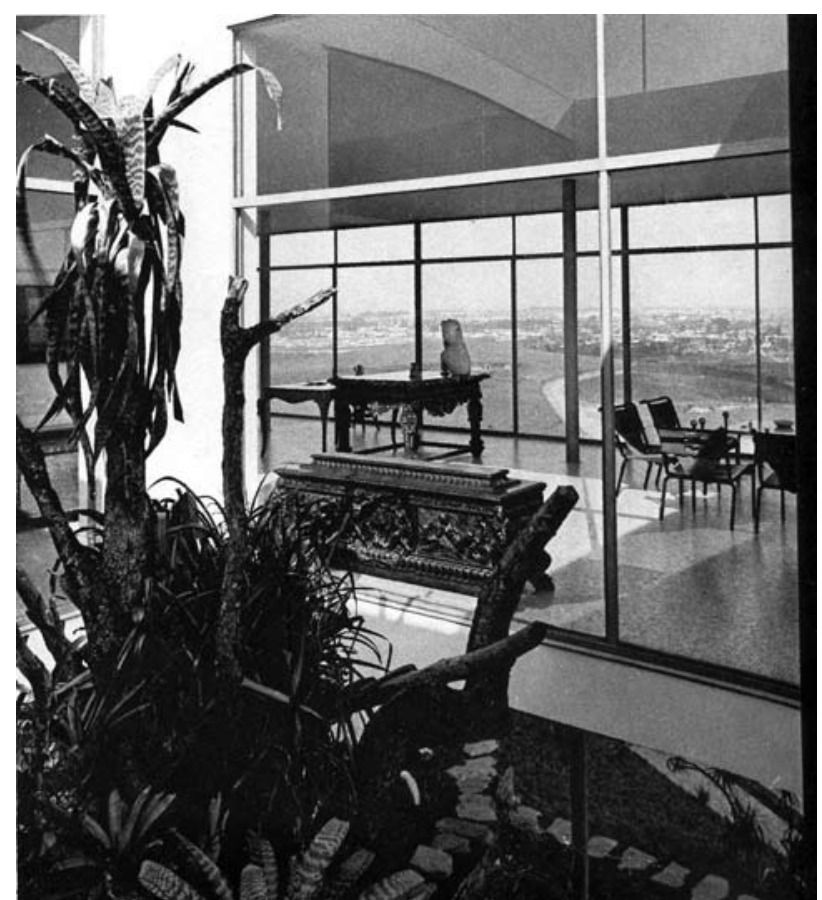

Imagem 244. Jardim interno da residência Lina Bo Bardi. Autoria: P. Scheier. Fonte: SCHEIER (1954), p.82.

de residências de alto padrão. Em geral são vistas externas de residências vazias, sem a presença humana, cuja ênfase cai sobre seus jardins e suas árvores frondosas. A casa própria, como desejo de cada habitante da cidade, culmina numa página dupla com quatro imagens do processo de compra e venda de imóveis, sendo que em duas delas é possível identificar o objeto das negociações: as unidades do Edifício Copan, projeto de Oscar Niemeyer para a Companhia Panamericana de Hotéis. Sobre o estouro imobiliário paulistano no segundo pós-guerra, Lemos lembra que "São Paulo, a cidade que mais cresce no mundo, simplesmente alastrava-se desordenadamente qual tecido doente, sem a assistência de ninguém" 52 .

A produção arquitetônica de Niemeyer em São Paulo teve como principal cliente o Banco Nacional Imobiliário - BNI. Para o desenvolvimento dos projetos 52 LEMOS, Carlos A.C. Arquitetura Contemporânea. In: ZANINI, Walter (org.) História Geral da Arte no Brasil. São Paulo: Instituto Walther Moreira Salles, 1983, vol. II, p. 855. 


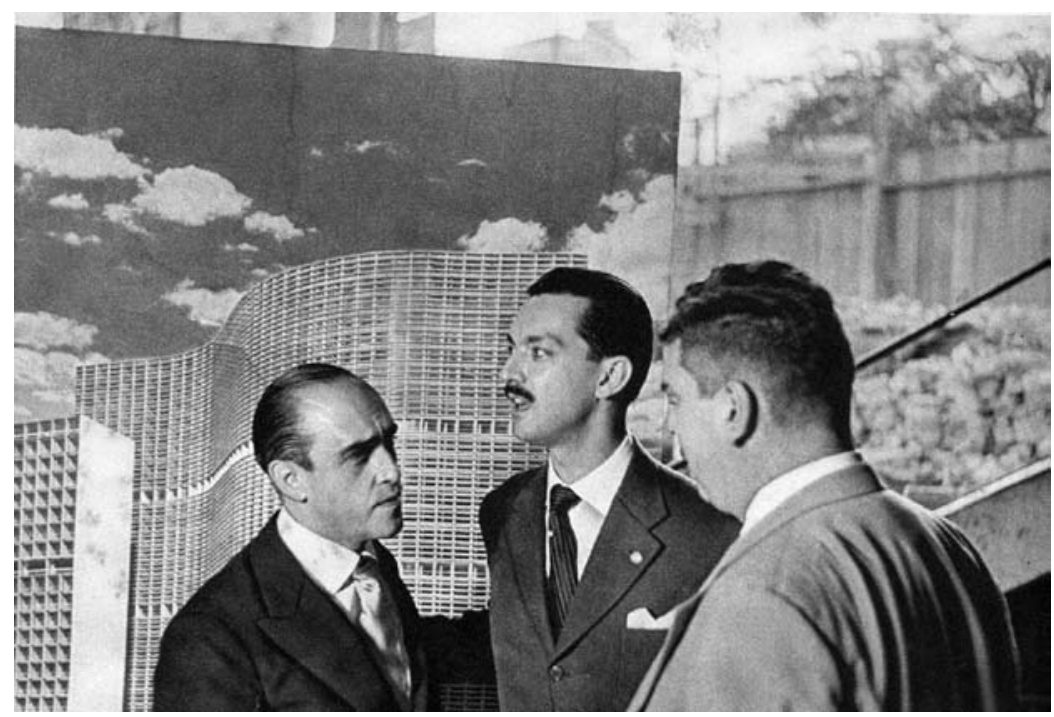

Imagem 245. Oscar Niemeyer em frente à imagem do Edifício Copan. Autoria: P. Scheier. Fonte: SCHEIER (1954), p.89.

e o cumprimento dos prazos, foi montado na cidade um escritório satélite, sob a direção de Carlos Lemos. Ao arquiteto foram encomendadas cinco obras: os edifícios Copan, Montreal e Eiffel, mais voltados para o uso residencial, e Califórnia e Triângulo, para comércio e serviços. O público alvo do Banco não eram grandes investidores, mas "pessoas simples, trabalhadores em sua primeira conta bancária, uma classe em ascensão com o impulso do desenvolvimento econômico do período" 53 .

\footnotetext{
Suas obras são voltadas diretamente para as necessidades do mercado de construções, carente na época de habitações a preços acessíveis. O BNI investiu num tipo de produção imobiliária conhecida como "condomínio a preço de custo", uma espécie de cooperativa de construções através de financiamento e parcelamento de gastos. ${ }^{54}$
}

53 LEAL, Daniela Viana. Oscar Niemeyer e o mercado imobiliário de São Paulo na década de 1950: o escritório satélite sob direção do arquivo Carlos Lemos e os edifícios encomendados pelo Banco Nacional Imobiliário. Campinas: Unicamp / Instituto de Filosofia e Ciências Humanas, 2003. Dissertação de Mestrado, p. 41.

54 LEAL. Op. cit, p. 9. 


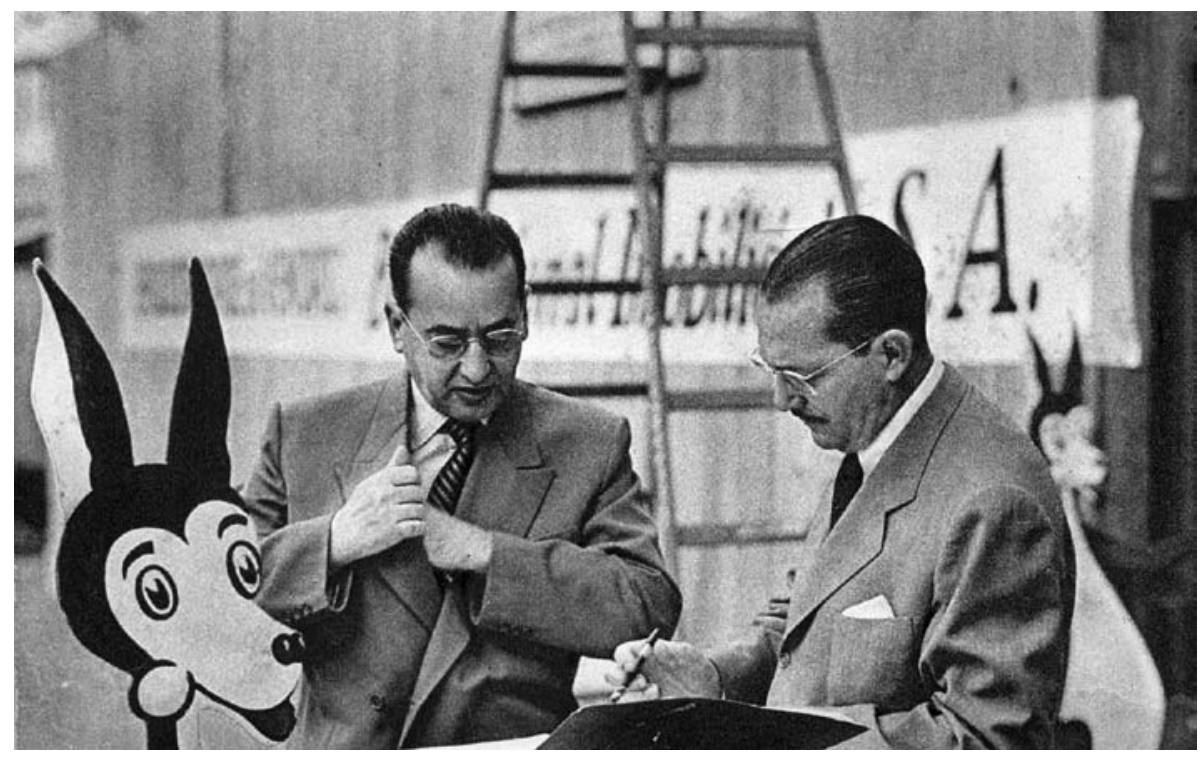

Imagem 246. Processo de compra e venda de imóvel construído pelo Banco Nacional Imobiliário. Autoria: P. Scheier. Fonte: SCHEIER (1954), p.88.

Não se pode afirmar com certeza que as quatro imagens tratam do processo de venda das unidades do Copan, embora sua edição o sugira. Há a referência direta na última imagem da série, em que o arquiteto Oscar Niemeyer conversa com dois homens, à frente de uma ilustração do edifício (Imagem 245). Em outra fotografia, dois homens negociam: o da esquerda faz um movimento para pegar algo no bolso interno do paletó, enquanto o da direita segura uma pasta aberta e uma caneta (Imagem 246). Ao fundo, uma faixa anuncia "Banco Nacional Imobiliário S.A." e aparece o canguru, personagem de uma campanha lançada pelo BNI em 1950, chamada "Clube do Kanguru Mirim", em que pequenos cofres em forma de canguru eram distribuídos para incentivar crianças a juntar moedas que posteriormente poderiam ser depositadas em uma conta em seu nome ${ }^{55}$. Scheier conferiu um toque descontraído e inusitado à composição ao enquadrar a cabeça do canguru em primeiro plano, insinuando sua "participação" na conversa dos dois homens. 


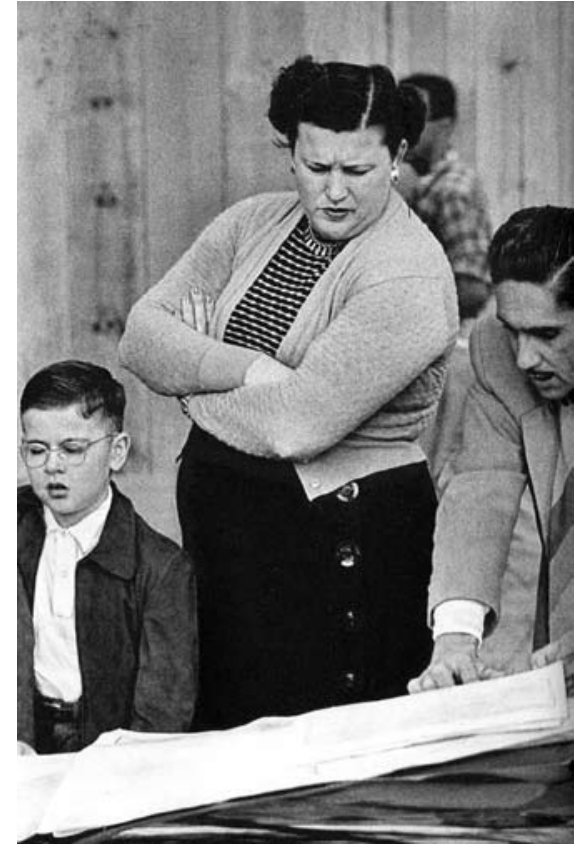

Imagem 247. Mulher analisa os documentos do imóvel. Autoria: P. Scheier. Fonte: SCHEIER (1954), p.88.

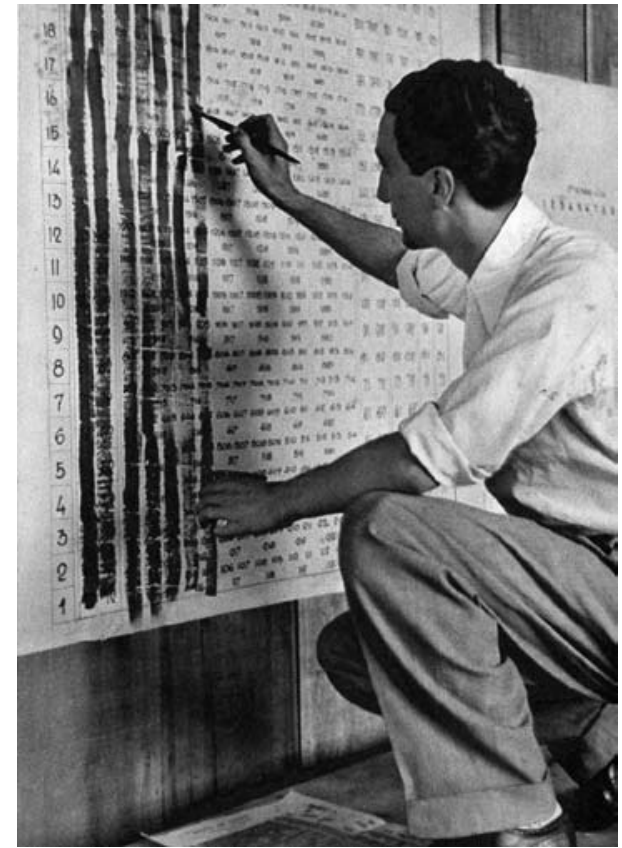

Imagem 248. Homem marca as unidades já vendidas. Autoria: $P$. Scheier. Fonte: SCHEIER (1954), p.89.

O contraponto aos dois homens que aparentemente fecham o negócio é a imagem da mulher, aparentemente de classe mais baixa, que observa desconfiada as plantas que o homem Ihe mostra (Imagem 247). Sua postura de lado, com os braços cruzados, demonstra certa resistência, desinteresse ou até dificuldade de compreensão das informações que lhe são transmitidas. Essas duas imagens - a da mulher e a dos dois homens - publicadas na mesma página montam o discurso de que a compra de imóvel era acessível a todos. A foto do rapaz que marca com um pincel as unidades já vendidas em um diagrama completa a série, ressaltando a velocidade de venda de apartamentos (Imagem 248).

No álbum, não há menção a mais nenhuma outra obra de Oscar Niemeyer na cidade. Nem mesmo os edifícios do Parque Ibirapuera, paradigma da arquitetura moderna paulistana e símbolo dos festejos, foram referenciados. Essa característica, aliás, é comum a outros álbuns da época. A exceção é Eis 


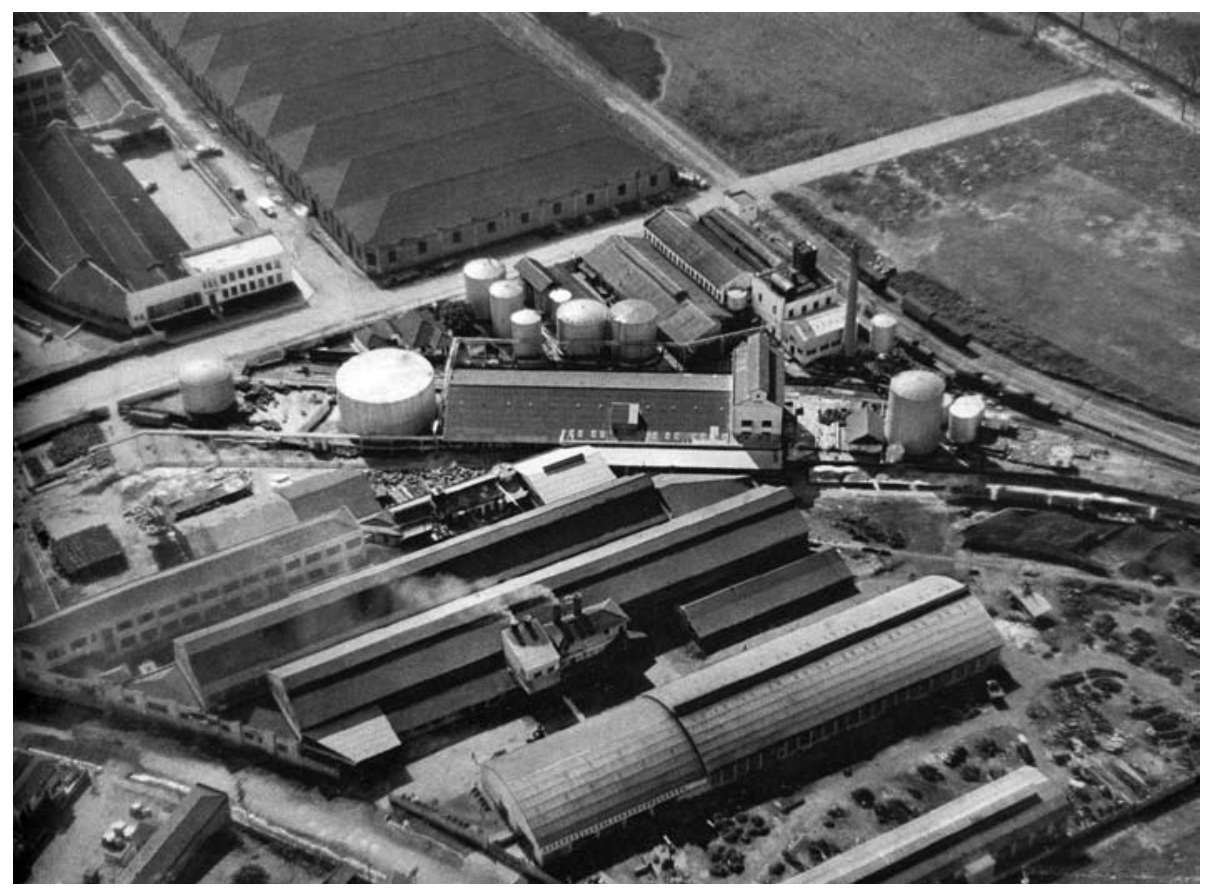

Imagem 249. Vista aérea de indústria. Autoria: P. Scheier. Fonte: SCHEIER (1954), p.123.

São Paulo: uma obra realizada e editada no ano de $1954^{56}$, em que o interior de um dos pavilhões é contemplado com uma fotografia.

\subsection{Indústria}

A análise da segunda parte do álbum de Scheier começa com suas fotografias industriais. O início do fotógrafo nesta área remonta ao ano de 1952, quando realizou seus primeiros trabalhos para a Ultragaz. Até o lançamento do álbum São Paulo, Scheier listava ao menos outros três clientes de porte nesta área, Klabin, Rhodia e Volkswagen, aos quais se juntariam tantos outros nos vinte anos seguintes. As vistas aéreas das instalações, produto fotográfico comumente entregue por Scheier, aparecem duas vezes no álbum (Imagem

56 Eis São Paulo: uma obra realizada e editada no ano de 1954. São Paulo: Monumento, 1954. 


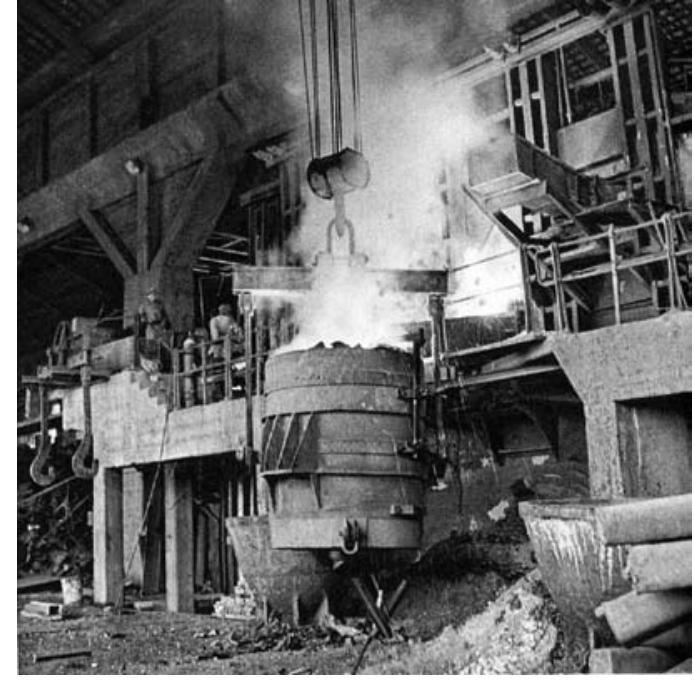

Imagem 250. Indústria siderúrgica em Mogi das Cruzes. Publicada originalmente em $O$ Cruzeiro de 01/01/1950, à página 73. Autoria: P. Scheier. Fonte: SCHEIER (1954), p.123.

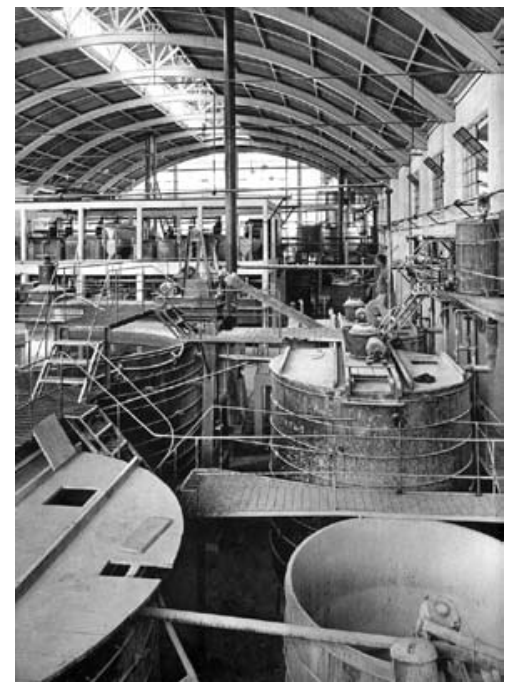

Imagem 251. Interior de uma fábrica. Autoria: P. Scheier. Fonte: SCHEIER (1954), p.124.

249). Da mesma forma que as vistas aéreas da área central, suas características de enquadramento - que inclui apenas uma pequena porção espacial e exclui a linha do horizonte - provocam uma sensação de continuidade e repetitividade generalizada do padrão, isto é, da verticalização e adensamento no caso do centro, e de extenso parque industrial, no caso das fábricas. Esta generalização ratifica a condição de "maior centro industrial na América do Sul, com 25.000 fábricas" ${ }^{57}$, explicitada na legenda do álbum.

Nas imagens internas, Scheier adotava dois focos, o maquinário e os operários. No primeiro caso, a ênfase recai sobre o vapor, as texturas, as estruturas metálicas das plataformas (Imagem 250/251). Embora presente, o homem quase desaparece na composição, num mimetismo com o ambiente circundante. Em meio ao espaço definido por elementos geométricos de aço, a forma humana se camufla entre os arcos da cobertura, os tirantes que suportam as tubulações, as vigas e grades metálicas das plataformas e escadas e os 


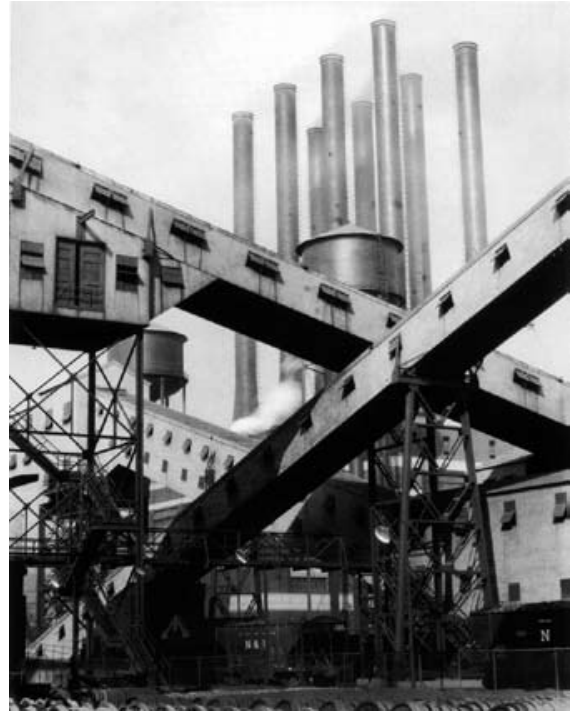

Imagem 252. Fábrica da Ford, em Detroit, década de 1920. Autoria: Charles Sheeler. Fonte: ELWALL (2004), p.146.

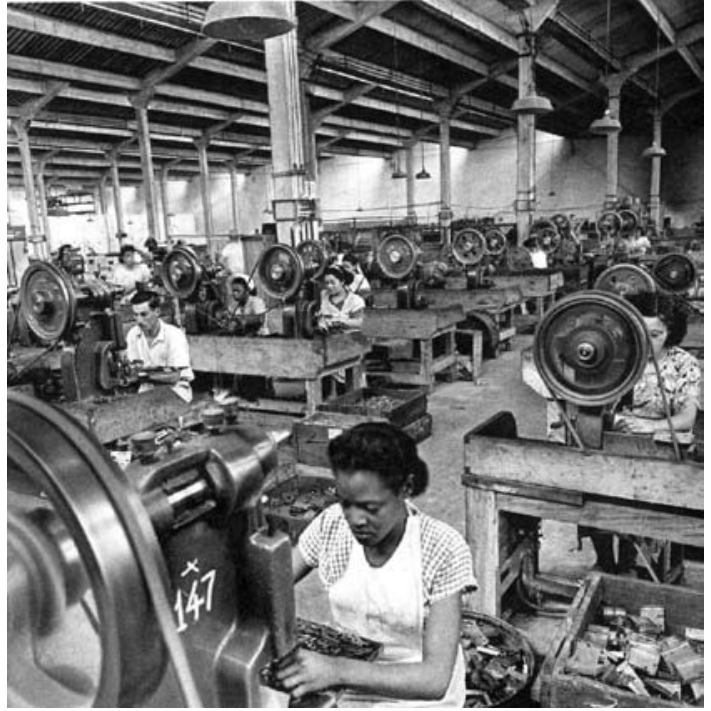

Imagem 253. Interior da fábrica Aliança. Autoria: P. Scheier. Fonte: SCHEIER (1954), p.125.

grandes tanques e máquinas. Este cruzamento de planos de diversas direções remete às fotografias industriais do norte-americano Charles Sheeler, cuja documentação da fábrica da Ford, em Detroit, na década de 1920, se tornou simbólica do avanço industrial dos Estados Unidos (Imagem 252).

Quando retratava os operários exercendo suas tarefas, Scheier às vezes fazia tomadas gerais dos galpões, como na imagem da fábrica de ferragens Aliança, publicada anteriormente na revista O Cruzeiro, em 195058 (Imagem 253). O ângulo oblíquo ressalta a extensão do galpão e as inúmeras máquinas e operários, remetendo à produção em massa, referenciada diretamente na legenda da revista. Ao contrário das vistas urbanas, é surpreendente a quantidade de mulheres na linha de produção, assim como na imagem da saída da fábrica no Brás (Imagem 254), já comentada no capítulo 2 , também proveniente de uma reportagem jornalística ${ }^{59}$ e republicada no álbum. Ambas mostram a mulher que 


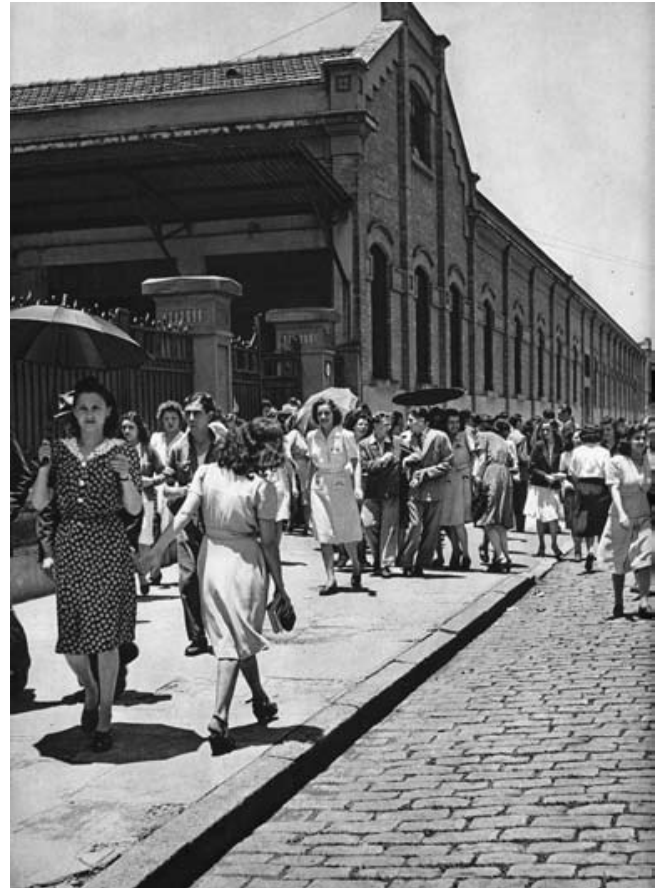

Imagem 254. Fábrica no Brás. Autoria: P. Scheier. Fonte: SCHEIER (1954), p.118.

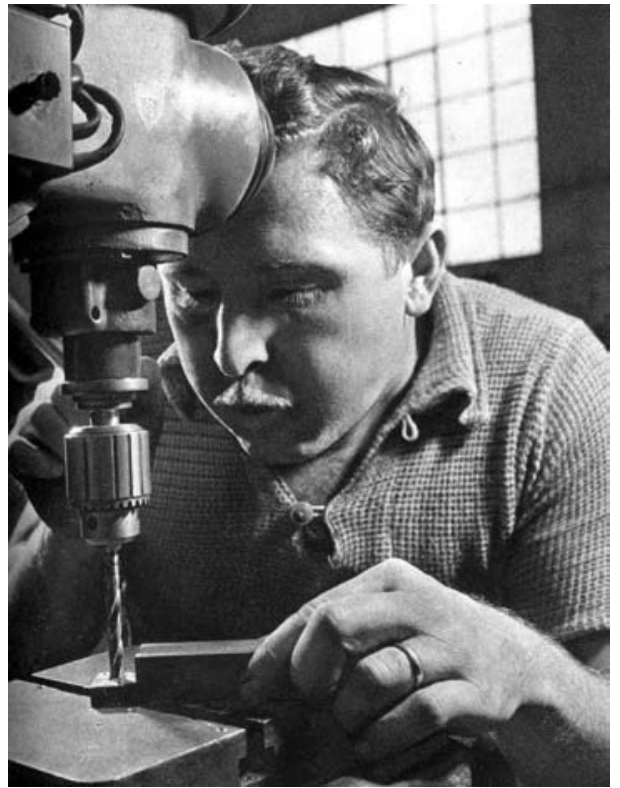

Imagem 255. Operário da fábrica Aliança. Autoria: P. Scheier. Fonte: SCHEIER (1954), p.125.

ocupava um novo espaço dentro da sociedade, sendo economicamente ativa, dentro do ambiente de trabalho ou de vivência, não acompanhada da figura masculina - pai, marido, noivo ou namorado -, nem mesmo de filhos.

Contudo, as fotografias em que Peter Scheier se aproximava dos operários para registrar com detalhe suas atividades demonstram composições mais expressivas e closes típicos do fotojornalismo, em geral posados. Uma das imagens mostra um operário manipulando uma furadeira, na fábrica Aliança (Imagem 255). O ângulo fechado é similar aos adotados nas reportagens industriais publicadas em O Cruzeiro, nas quais o operário era retratado junto a um equipamento. Outra fotografia do álbum é proveniente de uma reportagem sobre a siderurgia em Mogi das $\operatorname{Cruzes}^{60}$ (Imagem 256). Ela é a primeira de uma seqüência de movimentos do operário que manipulava o lingüete de aço, em jan 1950. 


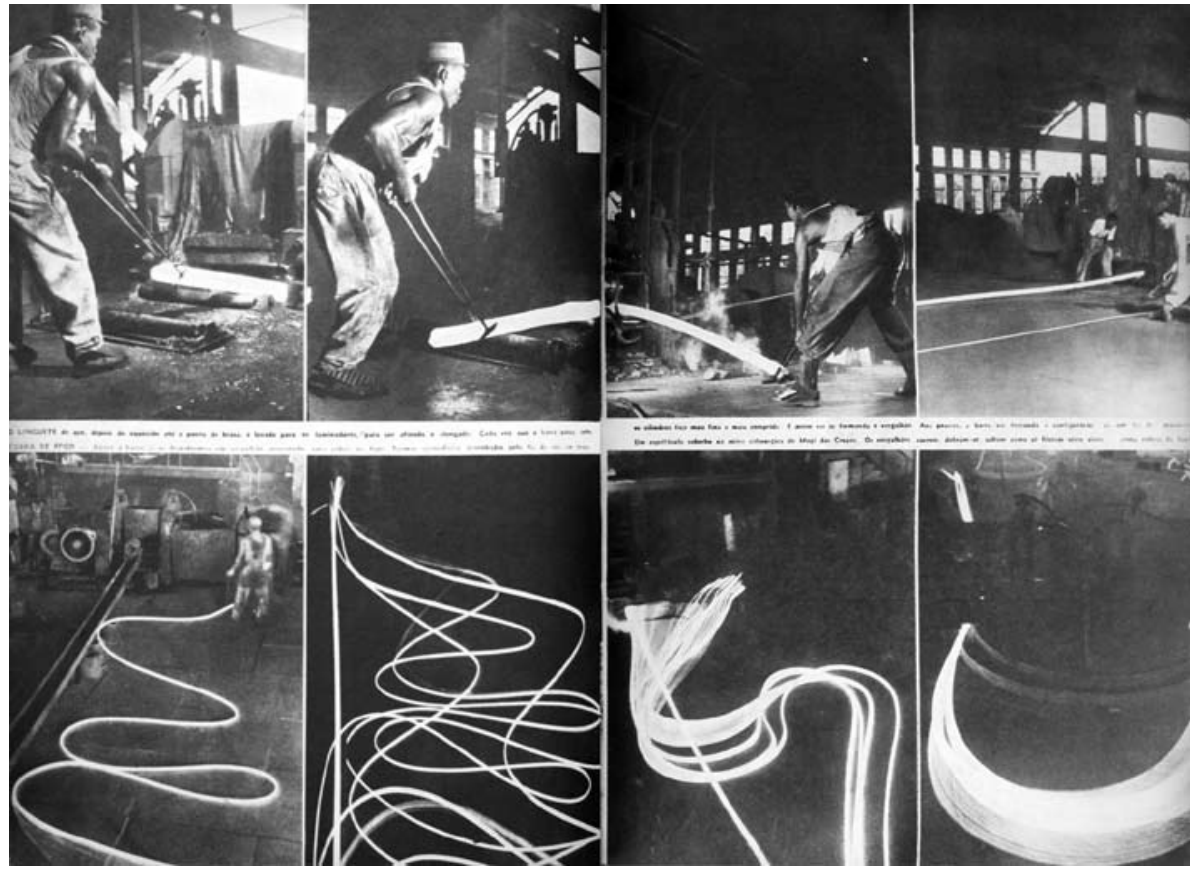

Imagem 256. Fac símile das páginas 70 e 71 da reportagem "Mogi das Cruzes, cidadela do aço", em O Cruzeiro de 07/01/1950. Autoria: P. Scheier. Fonte: Acervo do MASP.

ponto de brasa. Scheier estava muito próximo a ele, obliquamente, de forma a captar o ambiente, o maquinário e a movimentação do homem.

Com freqüência, Scheier enquadrava o trabalhador em meio às engrenagens e maquinários (Imagem 257), em composições similares às adotadas por outro fotógrafo industrial, Hans Günter Flieg. Em 1948, Flieg produziu o primeiro calendário fotográfico para a Pirelli, no formato $35 \mathrm{~mm}^{61}$ (Imagem 258), fortemente influenciado pelo livro Arbeit!, do fotógrafo alemão Paul Wolff, lançado em $1937^{62}$ (Imagem 259). São imagens que captam a individualidade do operário em meio à massa de maquinários. Não é possível afirmar com certeza se Peter Scheier conhecia tal publicação, mas suas fotografias remetem ao trabalho de Wolff e Flieg - talvez uma influência direta, talvez uma similitude de olhares formados dentro da mesma cultura visual.

$61 \quad$ Fonte: http://www.fotoplus.com/flieg/index.html. Acesso em: 10 ago 2008, às 14:00.

62 WOLFF, Paul. Arbeit! Frankfurt am Main: H. Bechhold, 1937. 

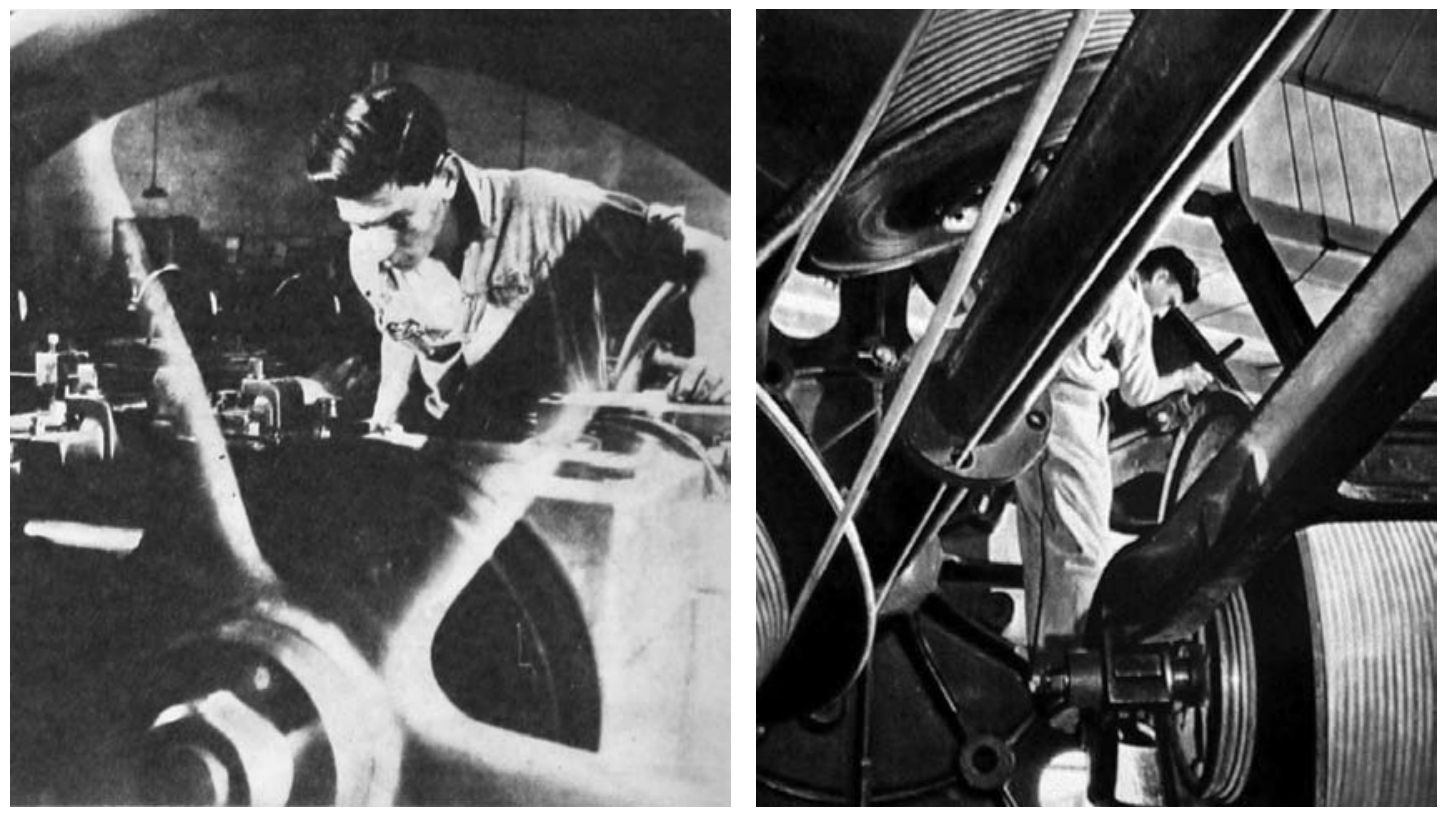

Imagem 257. Operário na fábrica Aliança. Imagem 258. Foto publicadano calendário Publicada na reportagem "A "Aliança" faz a Pirelli, em 1948. Autoria: Hans Günter Flieg. força" em O Cruzeiro de 14/01/1950, p.59. Fonte: http://www.fotoplus.com/flieg/index. Autoria: P. Scheier. Fonte: Acervo do MASP. html.

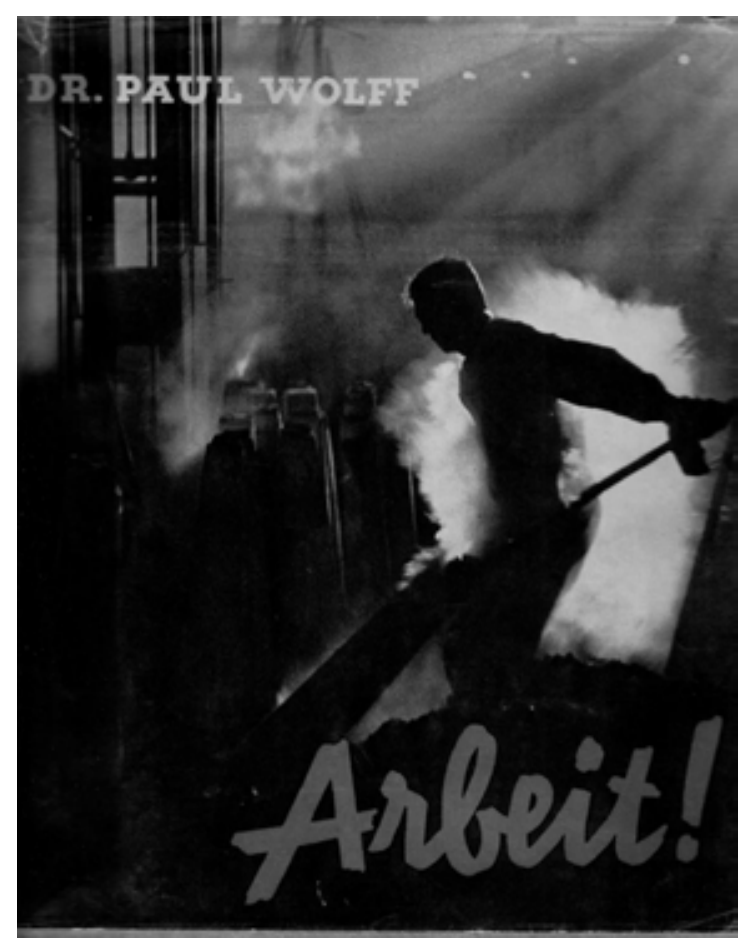

Imagem 259. Capa do livro Arbeit!, de Paul Wolff. Fonte: http://home.snafu.de/boehme/ Liste14/221\%20wolffarbeit.JPG. 


\subsection{Cultura, entretenimento e outros temas}

No campo cultural, a cidade exibia o mesmo desenvolvimento que a economia. Arruda aponta para as transformações pelas quais a sociedade passava e seus reflexos. Com a crise dos modos de vida provenientes da cafeicultura e a chegada de imigrantes, novas formas de sociabilidade de desenvolveram no centro. A modernização cultural - iniciada em 1934 com a criação da Universidade de São Paulo - colocava a cidade em uma posição de destaque. A ampliação do cenário das artes e da cultura criava novas oportunidades para o exercício das atividades artísticas, expressas através de grupos de teatro, revistas, livrarias, clubes, galerias e exposições. A década de 1940 testemunhou a criação de duas grandes instituições, o Museu de Arte de São Paulo (MASP, 1947, de Assis Chateaubriand) e o Museu de Arte Moderna (MAM, 1948, de Francisco Matarazzo Sobrinho). Estas instituições amplificaram as relações com a produção internacional, através principalmente da presença de artistas estrangeiros na cidade. As Bienais de Arte romperam com o isolamento dos artistas brasileiros e os colocaram em contato com as vanguardas. São Paulo tornava-se, assim, proeminente também no campo cultural. ${ }^{63}$

Para São Paulo fastest growing city in the world, as instituições mais modernas e atuantes da época foram selecionadas: MASP, MAM e Biblioteca Municipal. Juntas representavam um novo núcleo de expressão artística, localizado nos arredores da Praça da República. O Teatro Municipal, cenário da Semana de Arte Moderna de 1922, aparece no álbum apenas como ícone urbano, não sendo referenciado como espaço artístico. Este deslocamento dos pólos de cultura, que em 1951 iniciara uma nova fase com a $1^{\text {a }}$ Bienal e a posterior

63 ARRUDA, Maria Arminda do Nascimento. Metrópole e Cultura - São Paulo meio de século. Faculdade de Filosofia, Letras e Ciências Humanas da Universidade de São Paulo, 2000. Tese de Livre Docência. P.88 


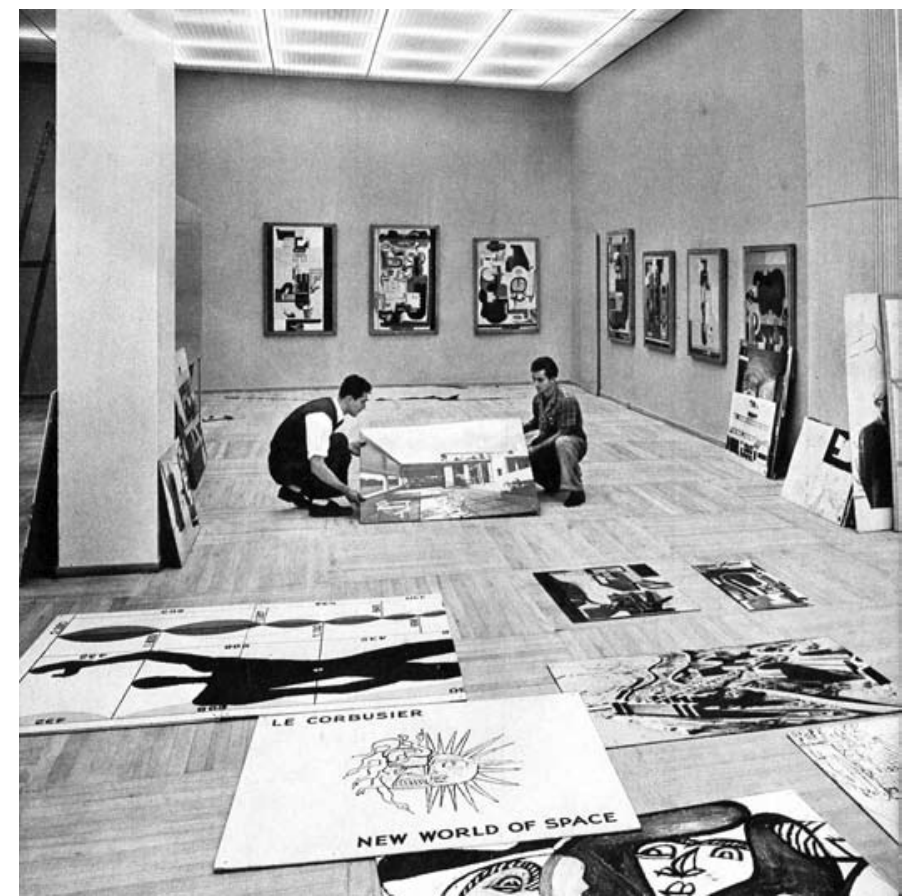

Imagem 260. Montagem da exposição "New World of Space". Autoria: P. Scheier. Fonte: SCHEIER (1954), p.77.

construção do MASP na Avenida Paulista, ilustra também o deslocamento da centralidade urbana. Naquele momento do IV Centenário, a região da Praça da República e Anhangabaú representava o progresso e a modernidade melhor que qualquer outra área da cidade.

Sem adotar o acervo do fotógrafo como base do álbum, torna-se incompreensível a ausência de determinadas instituições, como o Teatro Cultura Artística, inaugurado em 1942 e ícone da elite cultural da cidade. Da mesma forma, não se compreende o número excessivo de imagens do MASP - oito no total em comparação às demais instituições. A Biblioteca Municipal é referenciada em quatro imagens ${ }^{64}$. O MAM é representado pela $1^{\text {a }}$ Bienal Internacional de São Paulo, numa imagem da exibição da França e num close da escultura Unidade Tripartida, de Max Bill, ganhadora do prêmio de escultura estrangeira. As duas

$64 \quad$ Uma dessas imagens é de George Rado. 


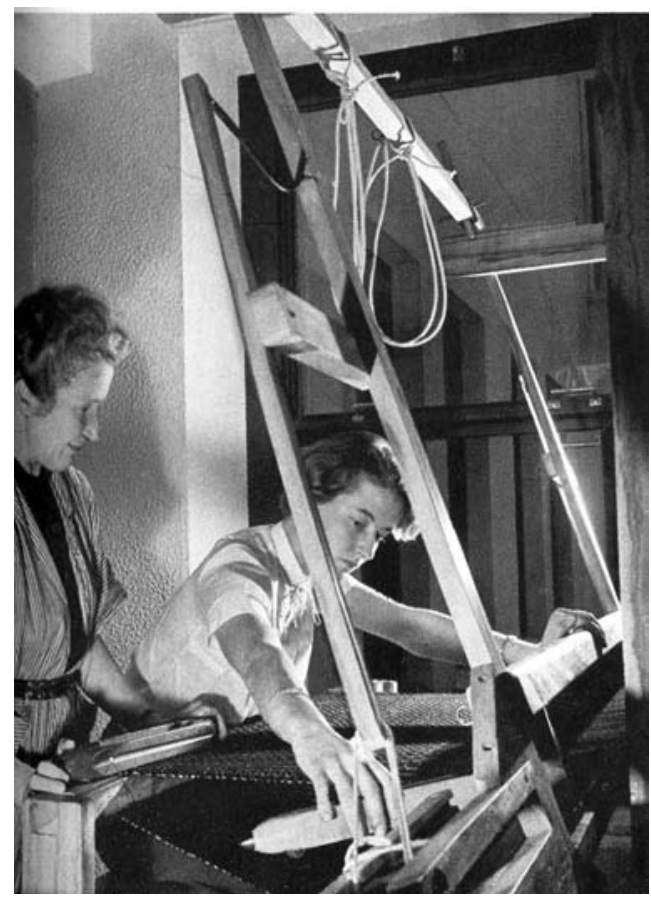

Imagem 261. Curso de tecelagem do IAC. Autoria: P. Scheier. Fonte: SCHEIER (1954), p.77.

fotografias da Bienal são de Hans Günter Flieg. Embora Peter Scheier tenha produzido imagens externas e internas do pavilhão da $1^{\text {a }}$ Bienal ${ }^{65}$, estranhamente elas não foram incluídas no álbum. Talvez porque documentassem a exposição ainda em montagem. Ou talvez a ligação de Scheier com o MASP lance luz à questão. A $2^{\text {a }}$ Bienal, ocorrida em 1953, já no pavilhão construído no Parque do Ibirapuera, e que marcou efetivamente o IV Centenário, não teve nenhuma menção no álbum.

Da documentação feita para o MASP foram selecionadas duas tomadas gerais da pinacoteca, com destaque para o volume transparente e suspenso da "vitrine das formas", que separava a exposição permanente da periódica (Imagem 147/148). Uma delas fora publicada anteriormente na revista Habitat ${ }^{66}$. Ambas seriam publicadas dois anos depois em Modern Architecture in

$65 \quad$ Sobre o assunto, ler o capítulo 2.

66 Habitat, São Paulo, n.1, p.34, out-dez 1950. 


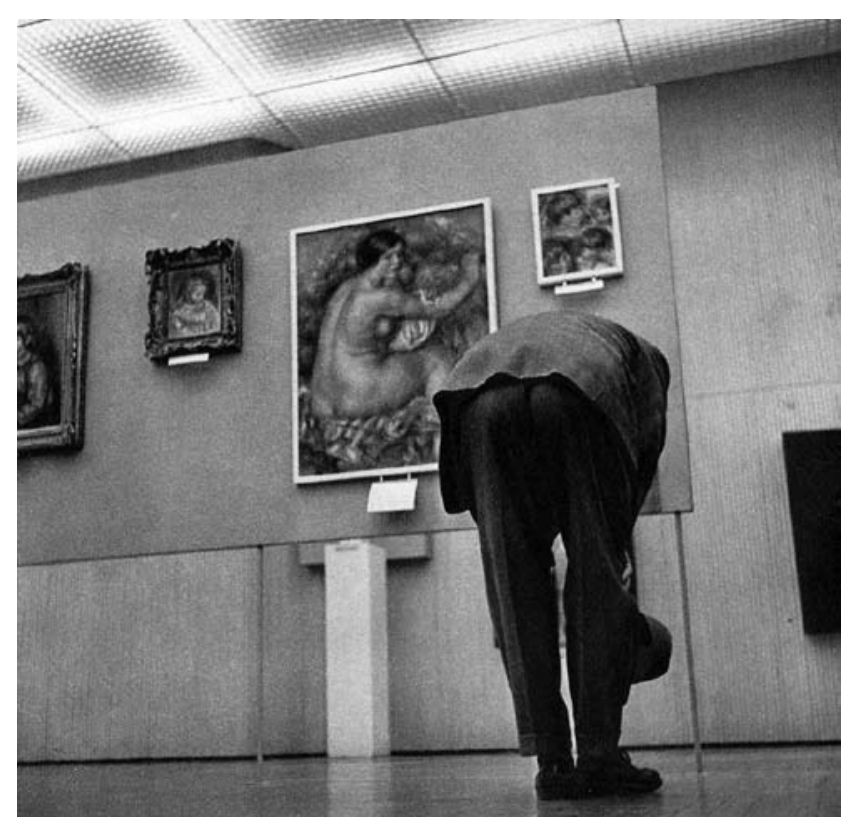

Imagem 262. Visitante no MASP. Autoria: P. Scheier. Fonte: SCHEIER (1954), p.75.

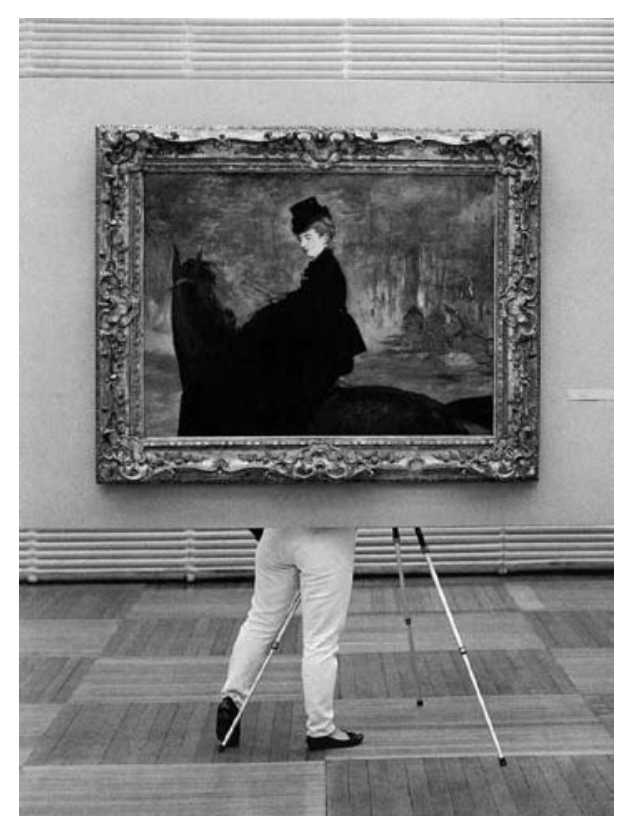

Imagem 263. Pinacoteca do MASP. Autoria: Hans Günter Flieg. Fonte: FRANCESCHI, p.199.

Brazil, de Henrique Mindlin ${ }^{67}$. Em uma, se vêem os painéis da exposição "New world of space", organizada pelo Instituto de Arte Contemporânea de Boston, contemplando a obra completa de Le Corbusier. Na página seguinte do álbum está uma foto do processo de montagem da exposição, em que dois homens organizam os painéis espalhados pelo chão - dentre os quais identificamos o grande painel com o "Modulor" (Imagem 260). Esta imagem lembra as fotos internas da $1^{\text {a }}$ Bienal, nas quais Scheier retratou a preparação da exposição.

No álbum há também três imagens dos cursos do Instituto de Arte Contemporânea-IAC, sendo uma da aula de música, outra de tecelagem (Imagem 261) e do ballet infantil. Nelas prevalecem os elementos formais típicos do seu fotojornalismo já abordados, como o uso de flash direto e a diagonal marcada. Uma imagem é única dentro das oito selecionadas, por ter uma abordagem diferente (Imagem 262). É possível que, durante o trabalho de documentação 


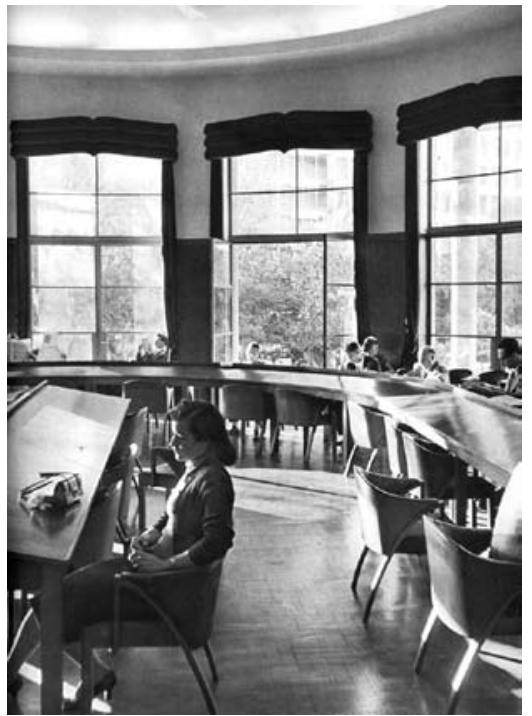

Imagem 264. Sala de leitura da Biblioteca Municipal. Autoria: P. Scheier. Fonte: SCHEIER (1954), p.73.

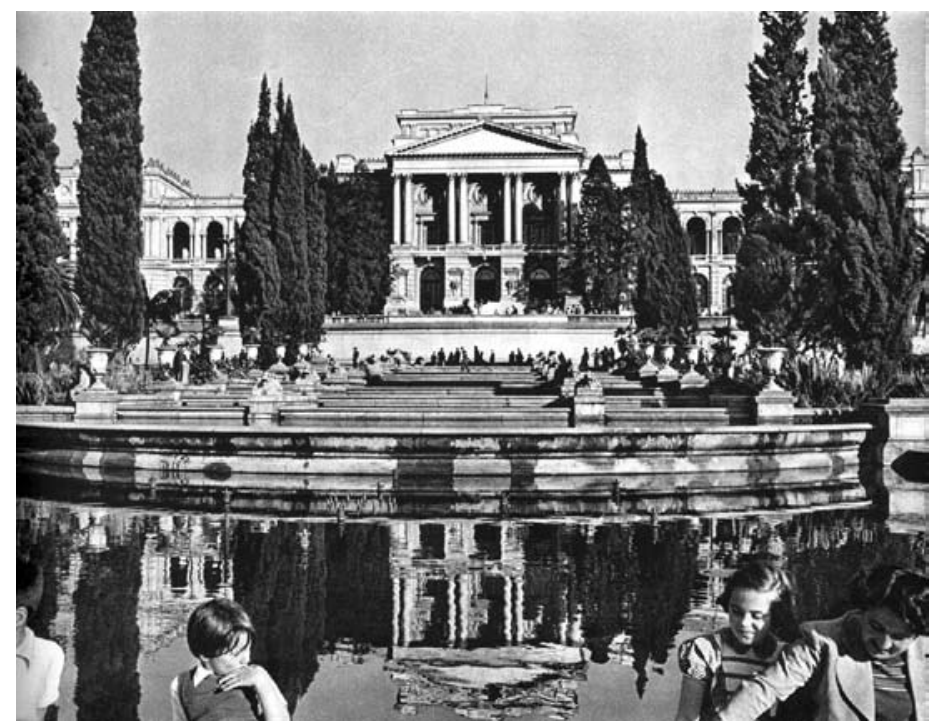

Imagem 265. Museu do Ipiranga. Autoria: P. Scheier. Fonte: SCHEIER (1954), p.79.

do museu, Scheier tenha captado alguns flagrantes dos freqüentadores, como o de um visitante do museu que se reclinava, com o chapéu na mão direita, provavelmente para ler algo no painel sobre o qual se expunham algumas telas, como "Le grand nu" de Renoir. Devido à postura do homem, seu tronco está quase oculto e praticamente só se vêem suas pernas. No início da década de 1960, Hans Günter Flieg trabalharia o mesmo tema, numa composição muito similar: apenas as pernas de uma mulher - e de um tripé - são visíveis sob os painéis de exposição (Imagem 263).

Numa imagem da sala de leitura de revistas e jornais da Biblioteca Municipal, Scheier também aplicou suas características do fotojornalismo e da documentação do MASP (Imagem 264). Dirigiu a pose da moça em primeiro plano, ao passo que as pessoas ao redor continuavam suas leituras. Ao fundo, a Praça Dom José Gaspar é vista através dos grandes caixilhos, pelos quais penetrava uma luz rasante e agradável. 


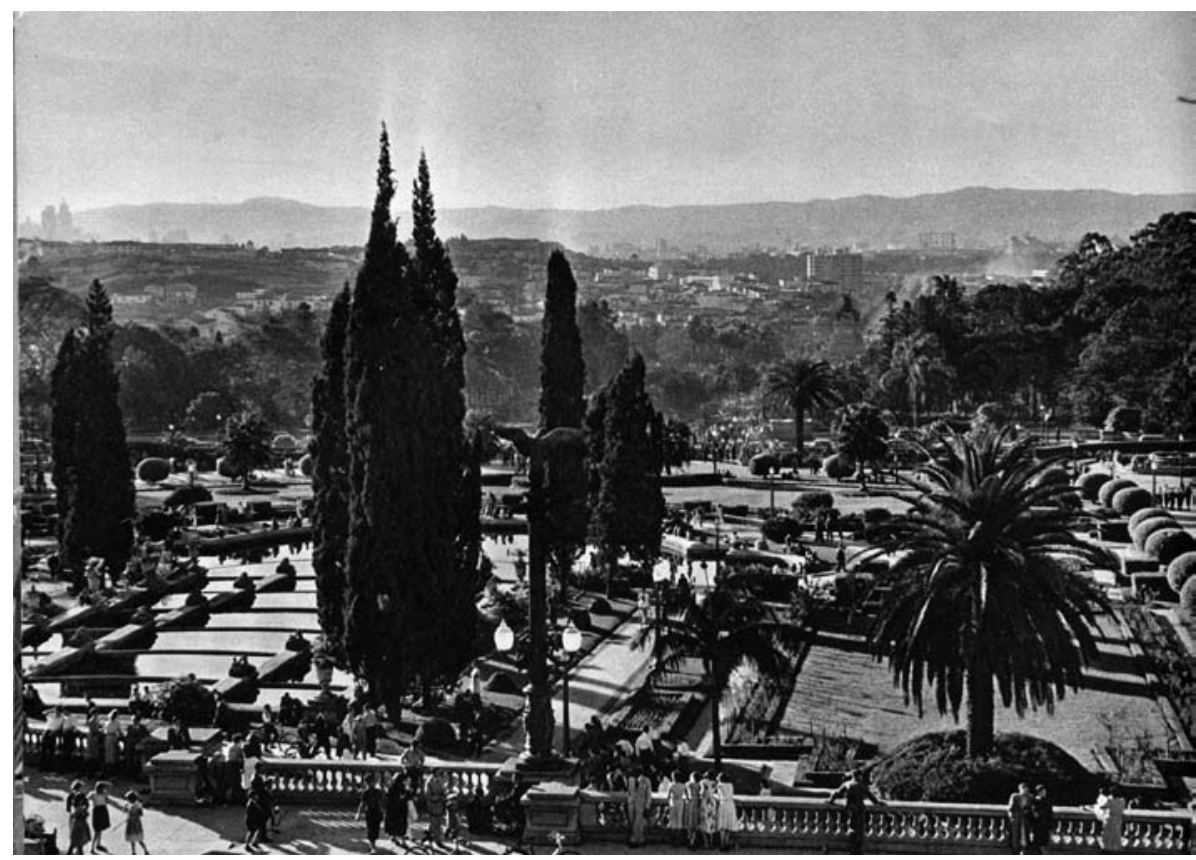

Imagem 266. Vista dos jardins do Museu do Ipiranga. Autoria: P. Scheier. Fonte: SCHEIER (1954), p.78.

O Museu Paulista (Imagem 265), embora carregue a conotação histórica consigo e se difira dos outros museus presentes no álbum, foi destacado em uma página dupla. Na seqüência das páginas sobre o MAM, Biblioteca Municipal e MASP, ele parece deslocado e quebra a narrativa. Provavelmente selecionado por sua monumentalidade e por representar a independência do Brasil, é o único edifício antigo enfatizado no álbum. O Teatro Municipal, por exemplo, aparece nas vistas urbanas, em meio ao centro adensado e verticalizado, sem uma fotografia específica. A Vila Normanda, por sua vez, entrou como o pitoresco ainda preservado, mas claramente condenado ao desaparecimento pelo processo de mudança dos arredores.

A imagem dos jardins do museu (Imagem 266), num fim de tarde, traz um importante documento de outra área da cidade, fora dos limites do centro, resultante de um passeio com a família, presente em uma das imagens. A região apresentava pouca densidade, com construções baixas e esparsas, 


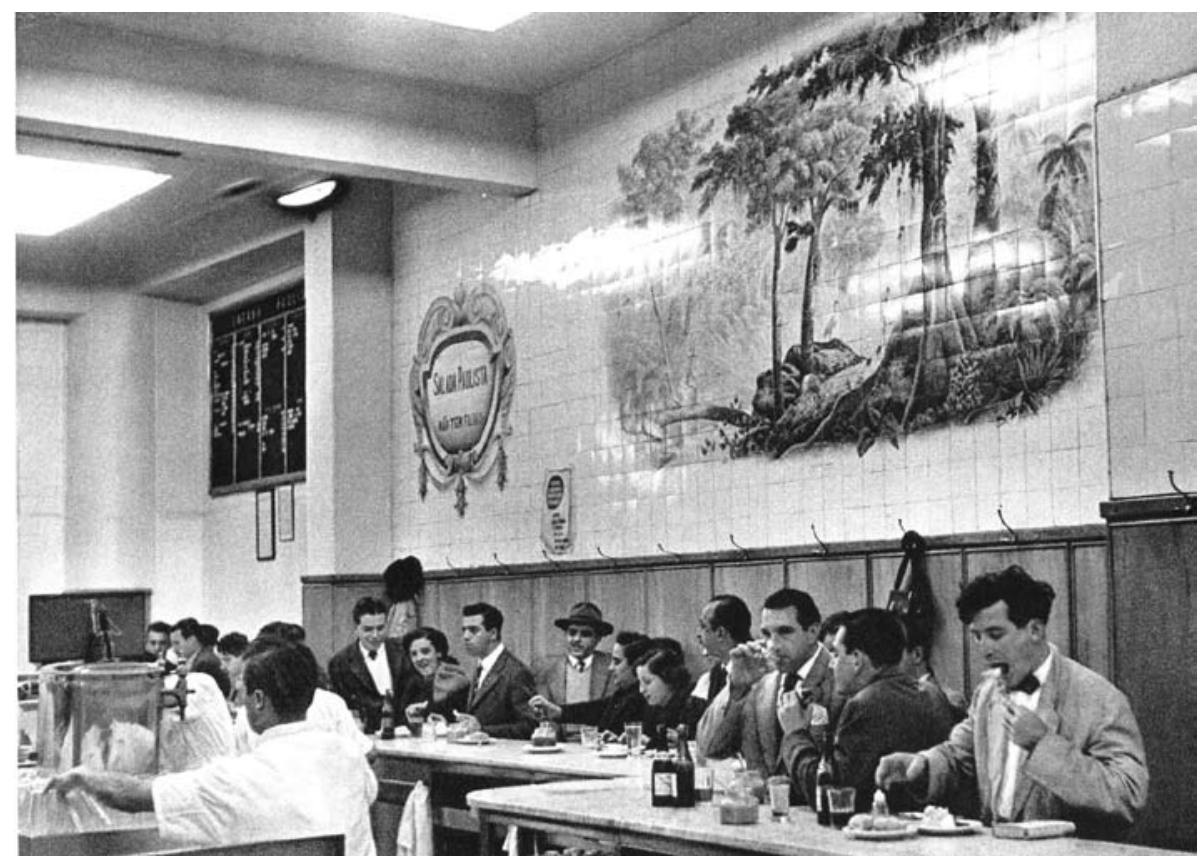

Imagem 267. Lanchonete "Salada Paulista". Autoria: P. Scheier. Fonte: SCHEIER (1954), p.119.

principalmente no Morro da Aclimação. Também possuía muita área verde para além dos limites do parque. Ao fundo, nota-se a Avenida Dom Pedro I, bem delineada e, na direção do eixo vertical da imagem, o Hospital Militar Federal se destaca em meio às baixas edificações. A Avenida Dom Pedro conduz o olhar para os bairros do Brás, Mooca e Belenzinho, também de baixo gabarito. $\mathrm{Na}$ borda esquerda, destacando-se do contorno da Serra da Cantareira, dois emblemáticos arranha-céus, percebidos à distância: o Edifício Altino Arantes e o Martinelli.

A nova sociabilidade explicitada por Arruda e documentada nas imagens do MASP, MAM e Biblioteca Municipal era vivenciada em outros ambientes da cidade. Ainda segundo Arruda, nos anos 1950 os bares também desempenhavam um papel sociabilizador, tornando-se "espaços de vivência ampla, de estímulo aos sentidos e do cultivo do intelecto" ${ }^{68}$. Paribar (na Praça Dom José Gaspar), 


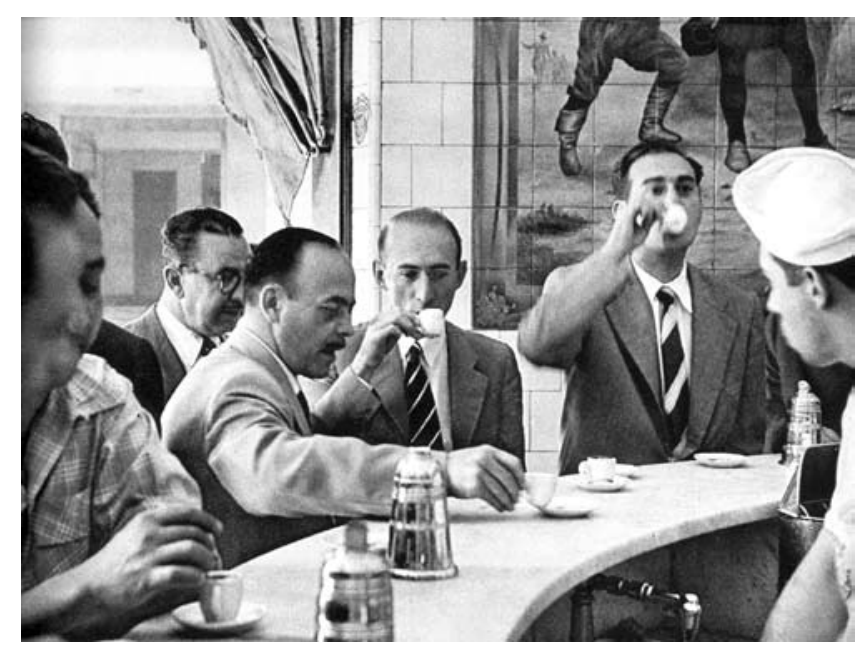

Imagem 268. Cafezinho na "Salada Paulista". Autoria: P. Scheier. Fonte: SCHEIER (1954), p.59.

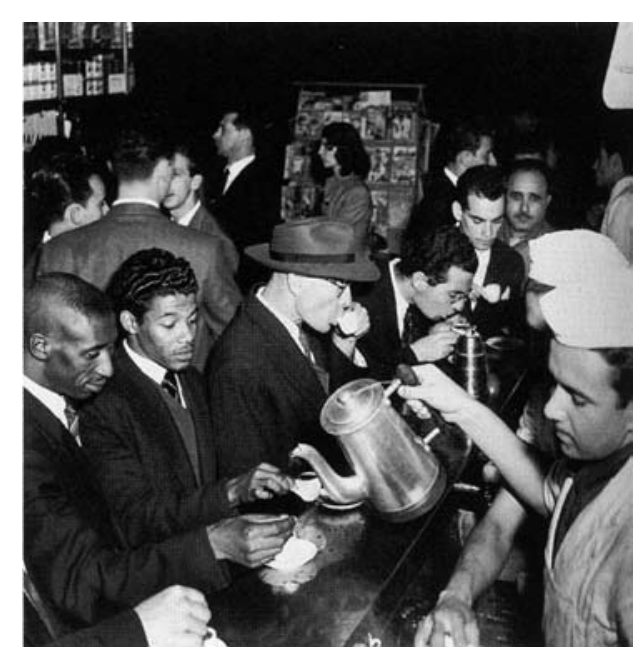

Imagem 269. Cafezinho. Autoria: Alice Brill. Fonte: FRANCESCHI (2004), p.208.

Barbazul e Arpège (ambos na Avenida São Luís) eram alguns, normalmente freqüentados por estudantes, professores, escritores, dramaturgos, jornalistas, publicitários, jovens ricos e intelectuais - como o crítico Sérgio Milliet, diretor da Biblioteca Municipal -, convivendo francamente, sem tensão.

A lanchonete "Salada Paulista", na Avenida Ipiranga - em frente à Praça da República e ao lado do Cine Marabá - era um tradicional reduto de boêmios e intelectuais (Imagem 267). Ficou famosa pela criação do hambúrguer americano, nos anos 1940, e pela ausência de cadeiras, "que ensinou aos paulistas o hábito americano de comer em pé" ${ }^{69}$. Fundada entre os anos 1920 e 1930, a lanchonete mantinha um mural de azulejos - executado pela Cerâmica Artística Barbosa - com as imagens dos donos, de pontos de São Paulo e da primeira missa celebrada no Brasil $^{70}$.

Peter Scheier provavelmente era uma das pessoas a almoçar em pé, junto

69 PERRONE, Carlos. São Paulo por dentro - um guia panorâmico de arquitetura. São Paulo: Editora SENAC, 2000, s/p.

70 Fontes: http://www.saopaulominhacidade.com.br/list.asp?ID=76. Acesso em 21 jul 2007, às 19:00. http://www.saopaulominhacidade.com.br/list.asp?ID=58. Acesso em 30 jun 2008, às 22:30. 


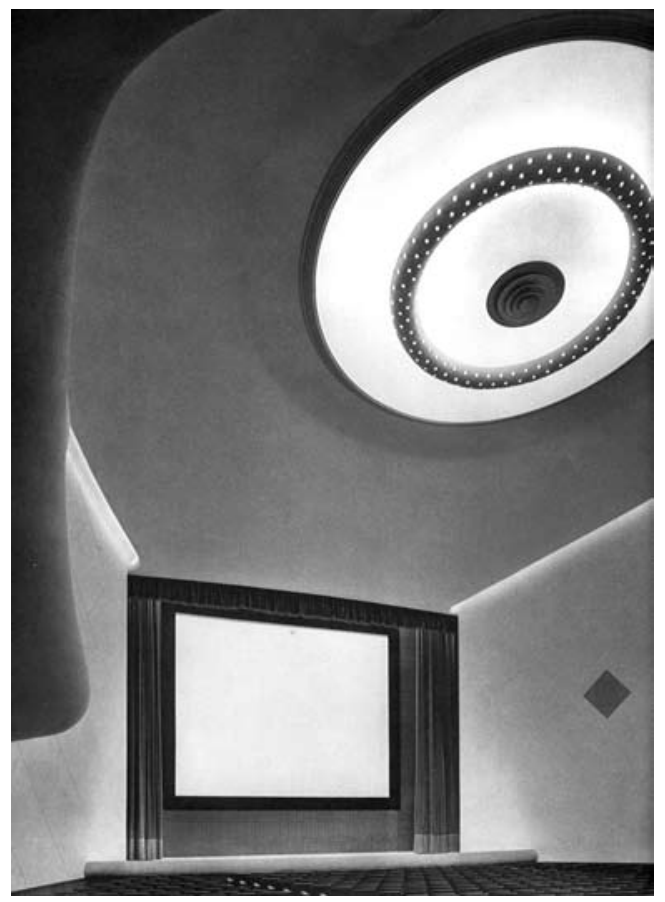

Imagem 270. Sala de projeção do Cine Ipiranga. Autoria: P. Scheier. Fonte: SCHEIER (1954), p.64.

ao balcão central da lanchonete. Possivelmente freqüentou inúmeras vezes o local, para comer ou tomar um cafezinho, uma vez que ficava próximo ao seu trabalho. Com a máquina fotográfica a postos e para aproveitar as últimas poses dos filmes, Scheier retratava momentos típicos do seu cotidiano, como seu trajeto urbano, o jantar na cantina e o almoço na Salada. Metaforicamente, estas fotos são auto-retratos de Scheier, pois ele se reconhecia no outro, interpretado como o reflexo dele mesmo.

O mesmo pode se dizer da foto da hora do "cafezinho", feita na mesma lanchonete, reconhecível pelo balcão de mármore, os azulejos brancos e seus painéis (Imagem 268). Se compararmos com uma foto com o mesmo tema, de Alice Brill, notamos a diferença de postura entre os dois fotógrafos (Imagem 269). Brill fotografou os homens tomando seu café a partir de um ponto de vista mais elevado. De fato, ela documentava um costume típico do paulistano. 


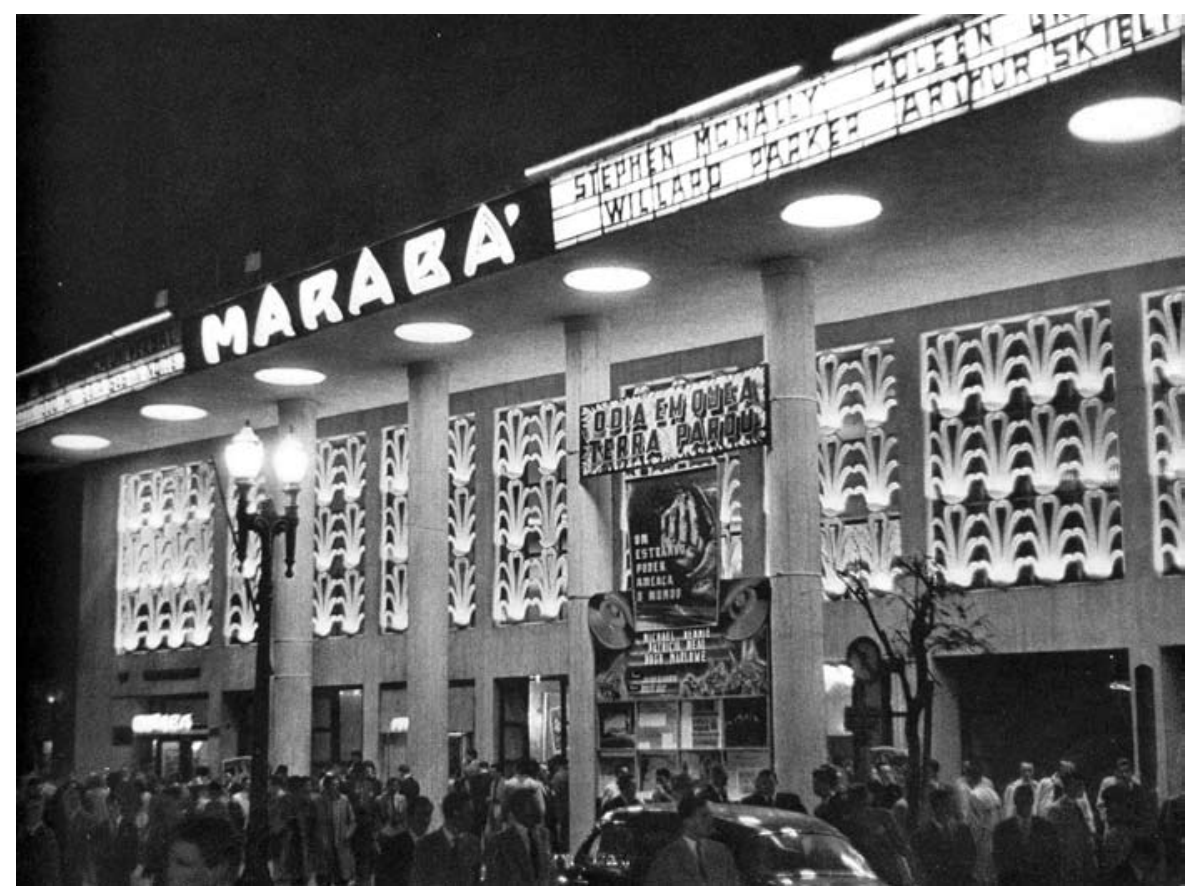

Imagem 271. Fachada do Cine Marabá. Autoria: P. Scheier. Fonte: SCHEIER (1954), p.65.

Scheier fez a fotografia do nível do balcão, incluindo-se naquele grupo de degustadores e ambientando o leitor no clima da lanchonete.

O cinema era outro ambiente de sociabilidade, representado no álbum pelo Cine Ipiranga e o Cine Marabá. As duas imagens do Cine Ipiranga, da sala de projeção (Imagem 270) e do hall de entrada, foram encomendadas pelo arquiteto Rino Levi e foram publicadas anteriormente na revista Acrópole em $1943^{71}$. Mostram um espaço sem nenhuma presença humana, típico da fotografia de arquitetura de Scheier ${ }^{72}$. O Cine Marabá (Imagem 271), por sua vez, foi documentado no momento da saída de uma sessão: a calçada da Avenida Ipiranga estava tomada de homens engravatados (novamente não se nota nenhuma mulher). O Cine Marabá foi projetado pela Sociedade Construtora Duarte Ltda. e inaugurado em 1945. Seu programa era similar ao do Cine Ipiranga,

71 Cine Ipiranga. Acrópole, São Paulo, n.61, p. 489-493, 1943.

72 Ver capítulo 2. 


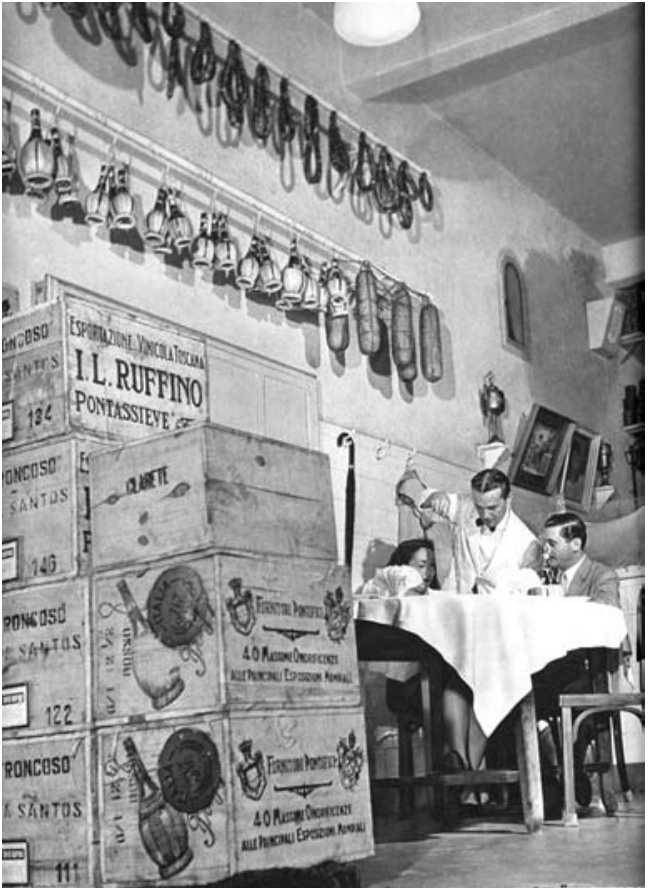

Imagem 272. Casal no restaurante. Os caixotes de garrafas de vinho italianos ocupam o primeiro plano: "Fornitori Pontifici" e "Il Rufino". Os queijos tipo parmesão e as lingüiças pendurados no teto e nas paredes completam a ambientação do local. Autoria: P. Scheier. Fonte: SCHEIER (1954), p.116.

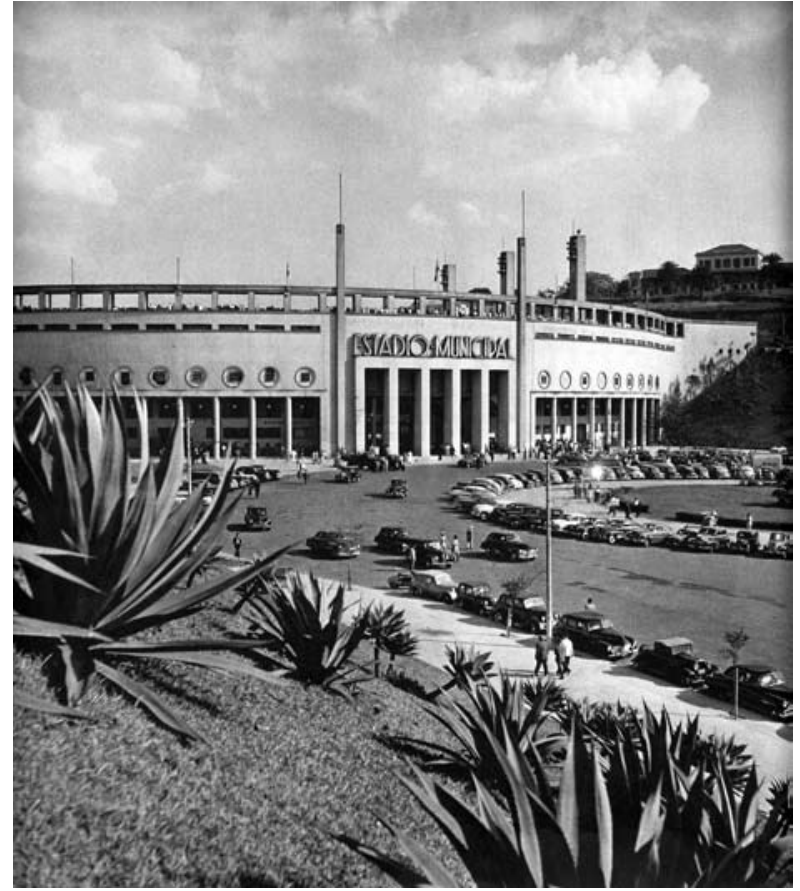

Imagem 273. Praça Charles Miller e Estádio do Pacaembu. Autoria: P. Scheier. Fonte: SCHEIER (1954), p.46.

incluindo cinema e hotel. Sua fachada é marcada pelos elementos vazados Art Decó$^{73}$. Na data em que foi feita a foto, exibia a ficção científica "O dia em que a Terra parou" ${ }^{74}$, cujo cartaz com os dizeres "Um estranho poder ameaça o mundo" aparece no centro da imagem. O elenco, também legível na foto, incluía Michael Rennie, Patricia Neal e Hugh Marlowe. No mesmo cinema também era exibido o faroeste "Flechas da Vingança".

O álbum então passa por uma série de imagens que retratam o entretenimento do paulistano. Cantinas, bailes, circo e esportes compõem esta

73 SANTORO, Paula Freire. Do provincialismo ao cosmopolita. A relação da sala de cinema com o espaço urbano em São Paulo. São Paulo: FAUUSP, dissertação de Mestrado, 2004, p. 149.

74 The Day the Earth Stood Still, 1951, EUA. 


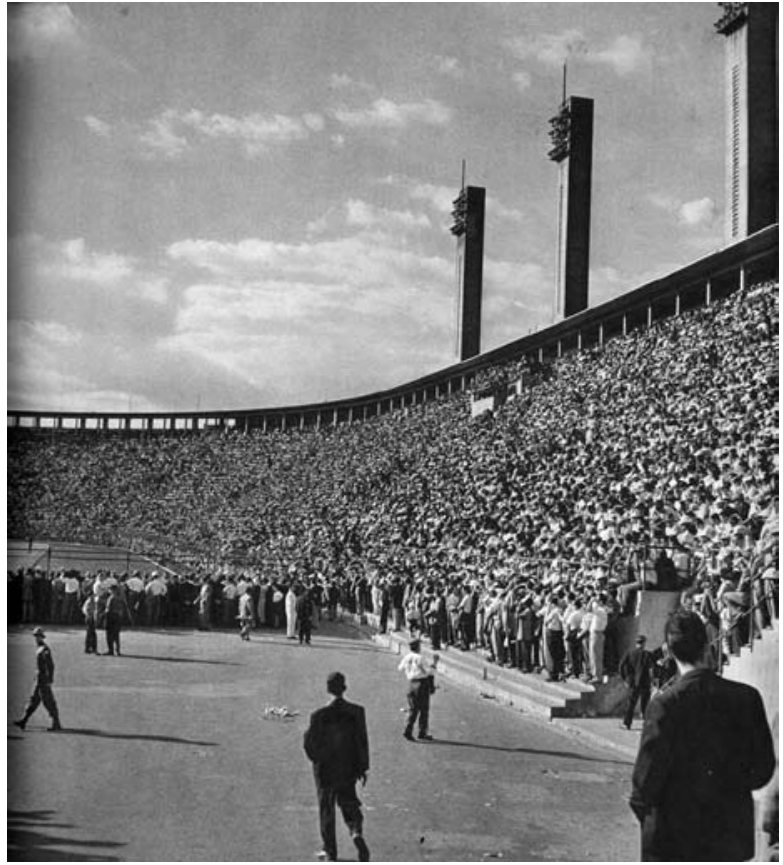

Imagem 274. Interior do Estádio do Pacaembu. Autoria: P. Scheier. Fonte: SCHEIER (1954), p.97.

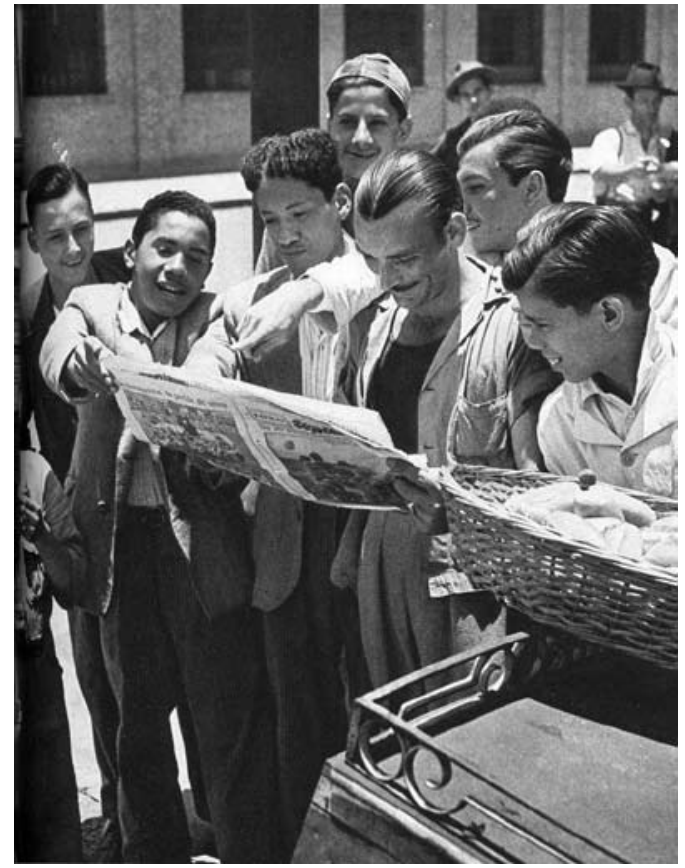

Imagem 275. Homens lendo jornal de esportes. Autoria: P. Scheier. Fonte: SCHEIER (1954), p.113.

série. Misturam-se aqui fotografias realizadas para reportagens da O Cruzeiro e aquelas feitas sem fins de publicação. Este segundo é o caso de uma fotografia do interior de uma cantina (Imagem 272). O enquadramento indica uma altura baixa da câmera, perfeitamente plausível se lembrarmos que Scheier usava uma câmera médio formato, cujo visor de vidro polido ficava na parte superior do equipamento. Se imaginarmos Scheier sentado em outra mesa, nota-se que seria fácil para ele fazer esta foto sem ser percebido, principalmente por não ter usado flash.

O Jóquei Clube e o Estádio Pacaembu são exaltados no álbum como locais de diversão nos fins de semana, quando o povo paulistano dedicava-se a outras atividades que não o trabalho. Uma panorâmica da Praça Charles Miller exibe o estádio lotado, com a última fileira da arquibancada completamente ocupada (Imagem 273). Na praça, centenas de carros estacionados e muitos 
transeuntes. Para fazer esta foto, Scheier estava sentado no talude gramado da praça, em meio aos arbustos que compõem o primeiro plano, numa composição que lembra algumas posturas adotadas, por exemplo, na documentação da casa Francisco Matarazzo Sobrinho. Toda a monumentalidade da praça e do estádio é enfatizada, contrapondo-se ao bairro pouco adensado, do qual é possível ver apenas uma construção na foto, no alto do morro. Segundo Lima e Carvalho, o Estádio Pacaembu era um símbolo da mudança de escala das funções públicas da cidade, constituindo num mecanismo "de absorção, e, portanto, disciplinamento, de uma massa populacional urbana potencialmente trabalhadora e consumidora, que se encontra (...) eletrizada pelo jogo" 75 .

$\mathrm{Na}$ imagem interna (Imagem 274), Scheier registrou a multidão presente no evento, no estádio completamente lotado, cujas arquibancadas e escadas de acesso estavam ocupadas por uma platéia essencialmente masculina - trajada de terno, gravata e chapéu. O ângulo aberto captou a multidão e a curva do estádio, que se projetam para além das bordas. Quando fotografou eventos no estádio para O Cruzeiro, Scheier mesclou ângulos abertos com closes nos espectadores. Em 1945, cobriu a jornada democrática da União Democrática Nacional - um comício para lançamento do brigadeiro Eduardo Gomes para a presidência da República ${ }^{76}$. Em 1950, por ocasião da copa, documentou dois jogos no mesmo estádio, entre as seleções da Espanha e Uruguai ${ }^{77}$ e Espanha e Suécia ${ }^{78}$. O interesse pelo esporte se completa no álbum com a imagem do grupo de homens lendo o jornal, cuja última página trazia na manchete “... da partida de ontem" e uma foto posada de um time (Imagem 275).

A viagem às praias também eram apontadas como as opções de lazer,

$75 \quad$ LIMA, CARVALHO. Op. cit, p. 89.

76 MOTTA, Nelson. A jornada do Pacaembu. O Cruzeiro, São Paulo, p. 54-61, 30 jun 1945.

77 FERREIRA, Jorge. Luta de gigantes. O Cruzeiro, São Paulo, p. 114-115, 29 jul 1950.

78 SILVA, Arlindo. Suécia - 3ํ lugar. O Cruzeiro, São Paulo, p. 116-117, 29 jul 1950. 


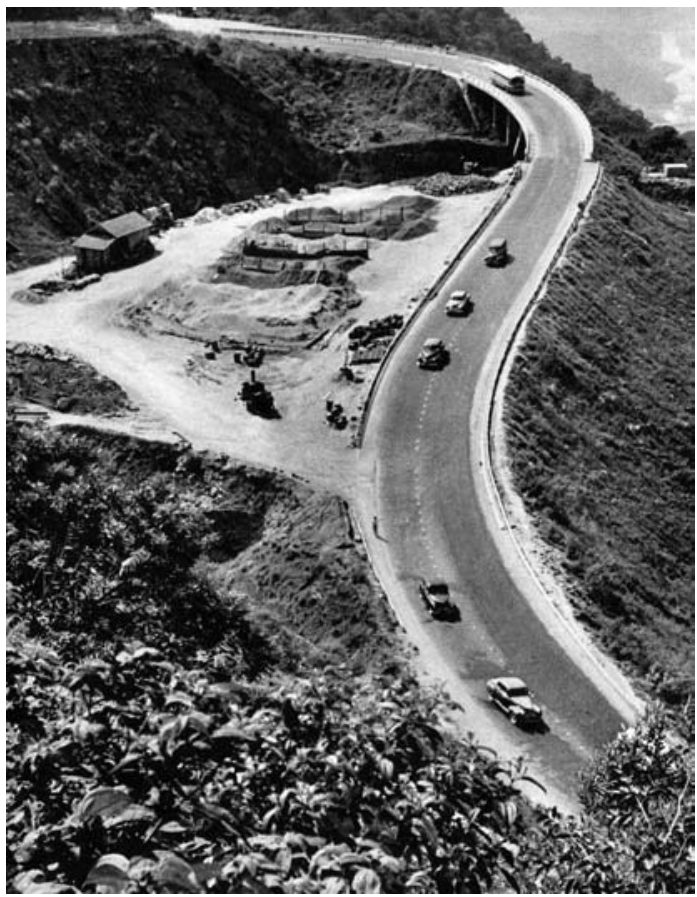

Imagem 276. Via Anchieta. Autoria: P. Scheier. Fonte: SCHEIER (1954), p.98.

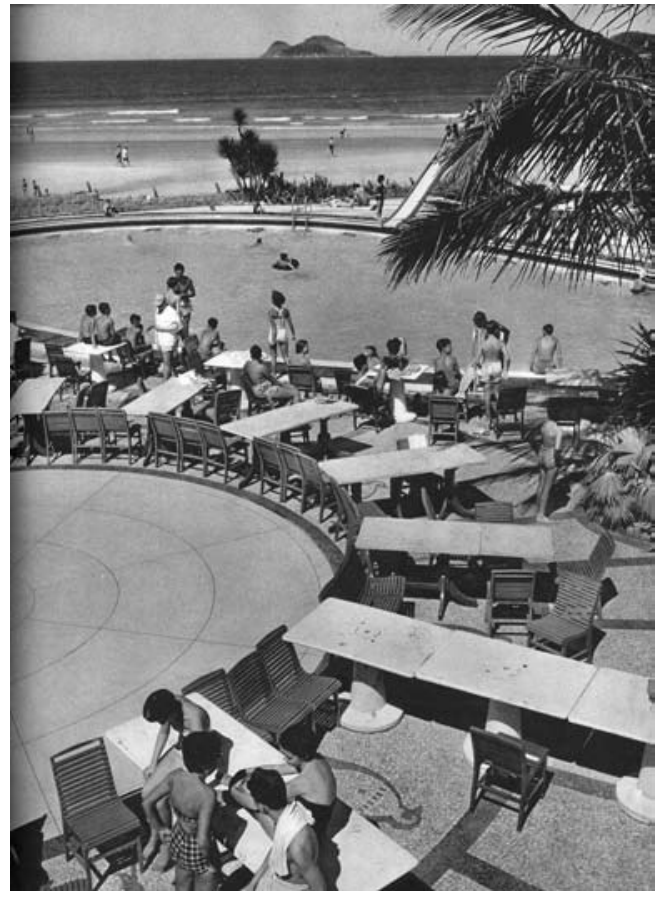

Imagem 277. Clube da Orla, no Guarujá. Autoria: P. Scheier. Fonte: SCHEIER (1954), p.99.

viáveis devido à inauguração da Via Anchieta, em 1947. Lima e Carvalho apontam esta estrada como um paradigma da arquitetura moderna no período, um sinal de domínio e de convivência pacífica entre natureza e cidade ${ }^{79}$. A partir da pista de subida da rodovia, Scheier documentou a de descida, na qual trafegavam cinco carros e um ônibus (Imagem 276). No canteiro lateral, a presença de máquinas indica que a estrada ainda estava em obras.

No arranjo do álbum, às fotos da Via Anchieta seguem as da praia, cuja primeira mostra o Clube da Orla no Guarujá (Imagem 277). Sol, mar, areia, piscina, palmeiras, mulheres de biquíni e instalações à beira mar eram elementos que compunham o imaginário estrangeiro sobre o Brasil. Possivelmente resultantes de uma viagem particular, estas imagens de praia e da Via Anchieta formam, no contexto editorial, um discurso em torno das modernidades de São Paulo e das 


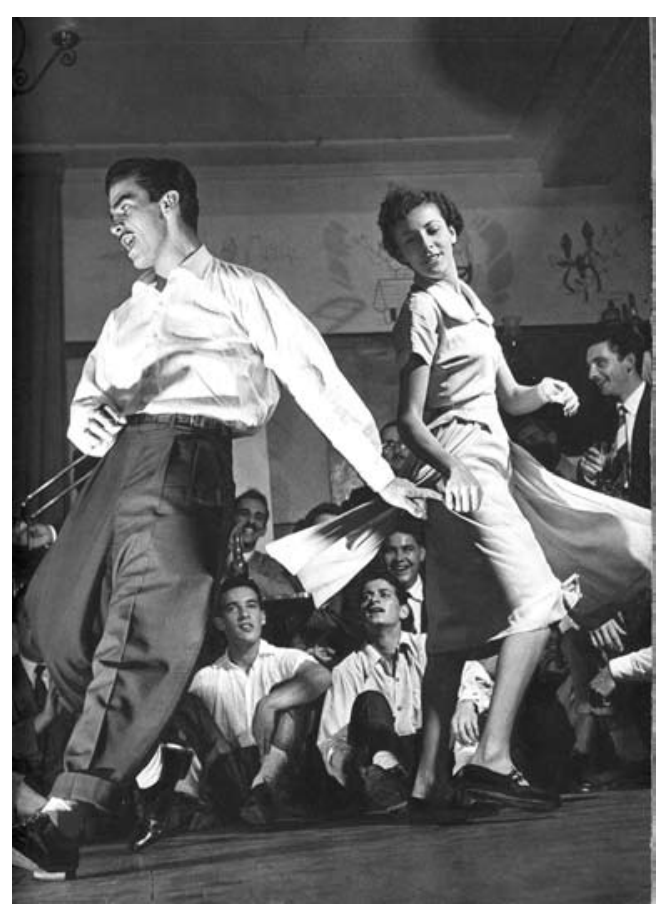

Imagem 278. Casal dançando boogiewoogie. Autoria: P. Scheier. Fonte: SCHEIER (1954), p.93.

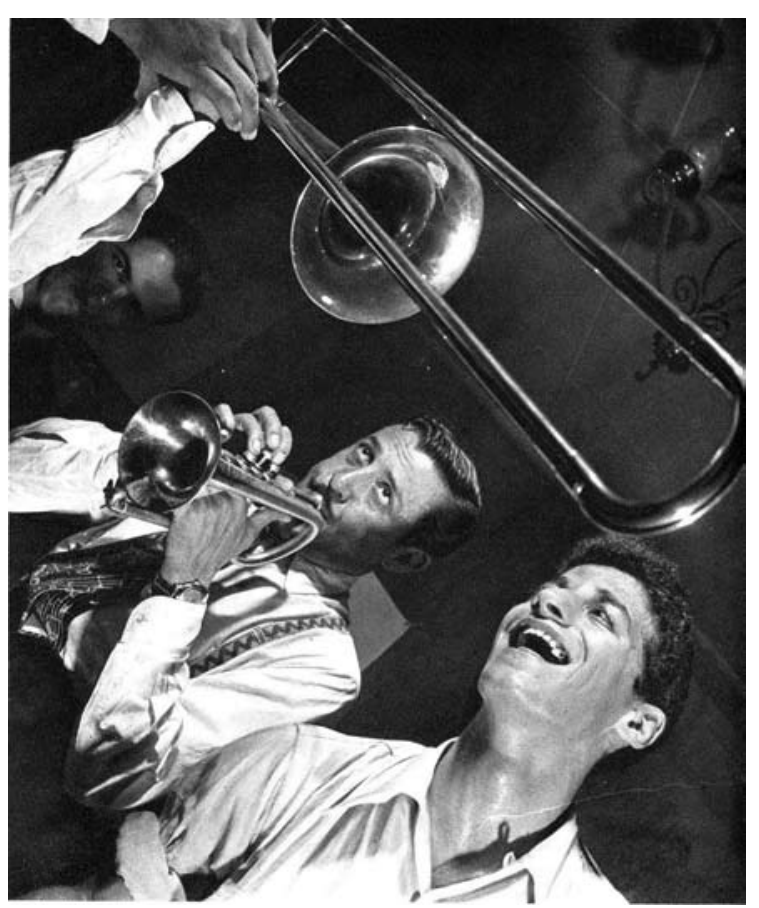

Imagem 279. Banda toca em baile. Autoria: P. Scheier. Fonte: SCHEIER (1954), p.92.

mordomias que proporcionam. A cidade não tem praia, mas com uma "rodovia de primeira classe" ${ }^{80}$ chega-se aquilo que o clima tropical pode oferecer de melhor. Num álbum bilíngüe - inglês e francês - não se pode descartar o apelo turístico de tal arranjo.

Da mesma forma que o clima tropical, o carnaval não poderia deixar de ser mencionado. O carnaval foi destacado em sete imagens, embora duas delas tenham sido produzidas em contexto diferente. Trata-se de duas fotografias publicadas na O Cruzeiro sobre o baile de boogie-woogie, na boate da Rádio América ${ }^{81}$. Uma mostra um casal dançando agitadamente, observado pelos rapazes sentados sobre o chão ou acomodados nas cadeiras e mesas (Imagem 278). A banda que animava o baile foi retratada numa imagem com uma diagonal

$80 \quad$ SCHEIER. Op. cit, p. 98. Tradução da autora.

81 SILVA, Arlindo. Boogie-Woogie Brasileiro. O Cruzeiro, São Paulo, p. 38-41, 16 set 1950. 


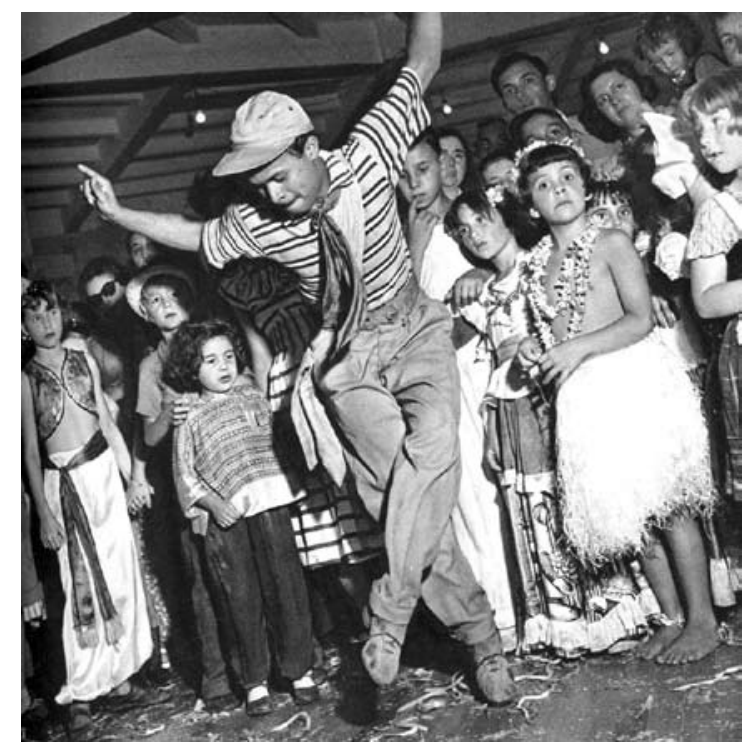

Imagem 280. Baile infantil de carnaval. Autoria: P. Scheier. Fonte: SCHEIER (1954), p.91.

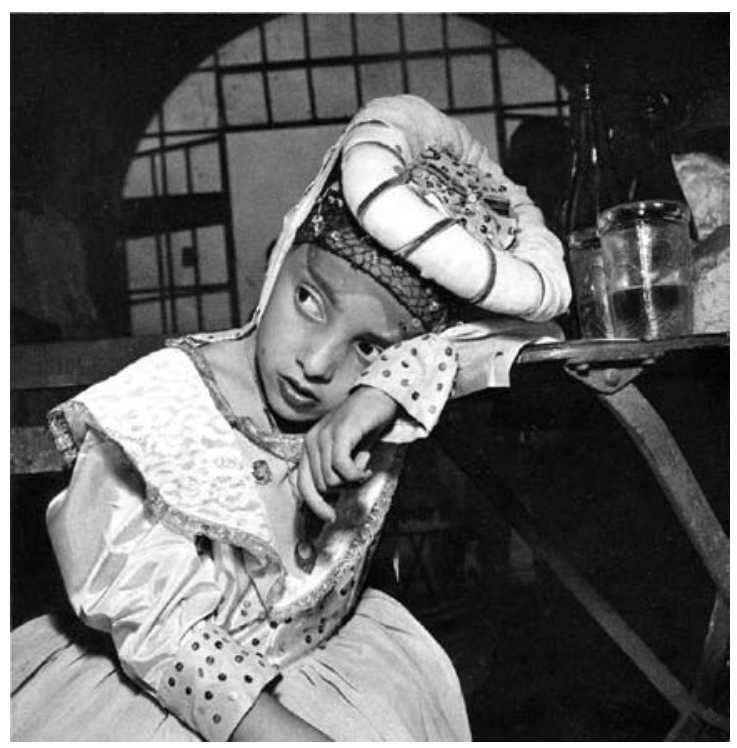

Imagem 281. Criança descansa em baile infantil de carnaval. Autoria: P. Scheier. Fonte: SCHEIER (1954), p.91.

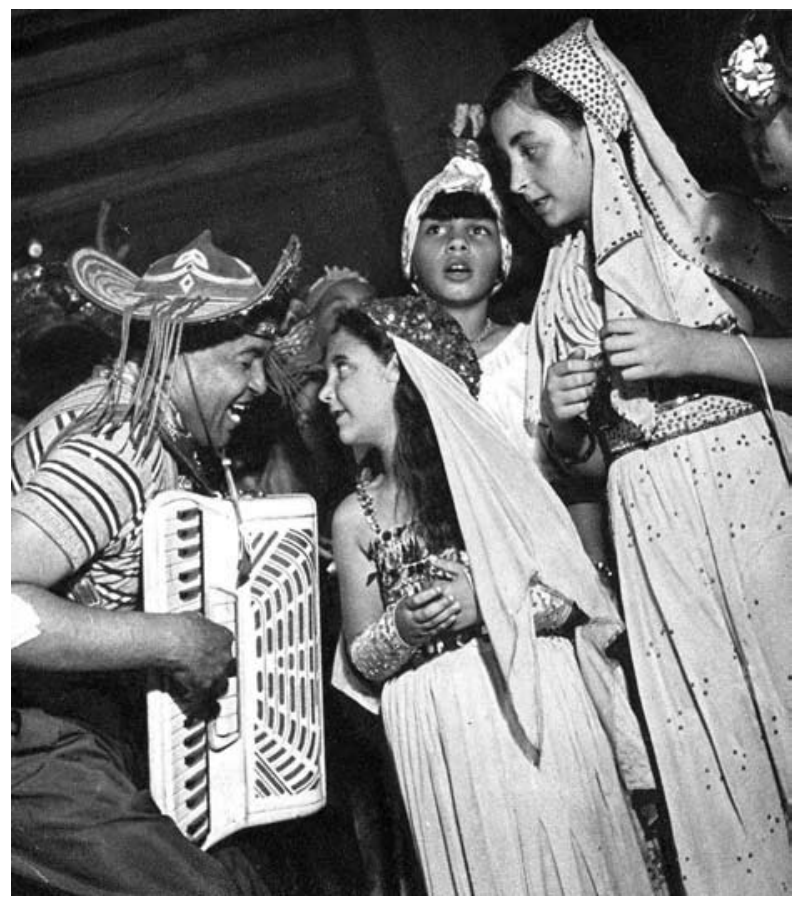

Imagem 282. Luiz Gonzaga toca para crianças em baile de carnaval. Autoria: P. Scheier. Fonte: SCHEIER (1954), p.92. 


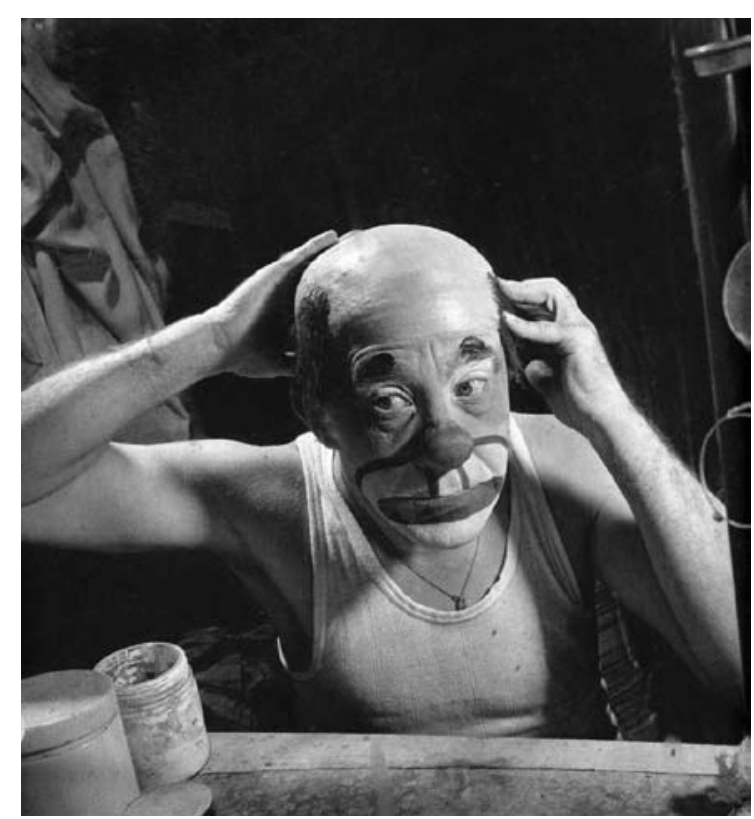

Imagem 283. Palhaço Piolim. Autoria: Scheier. Fonte: SCHEIER (1954), p.90.

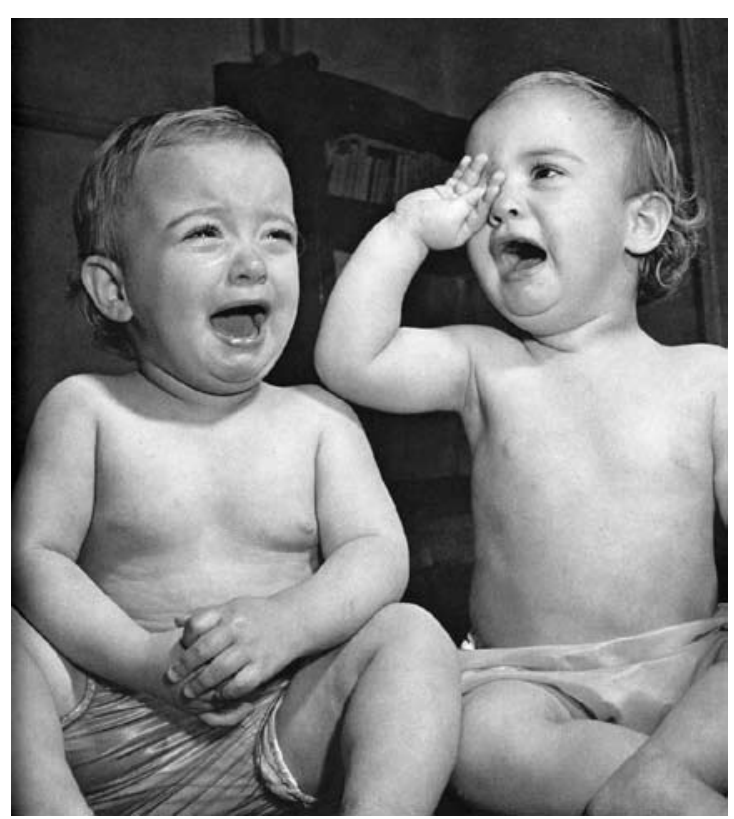

P. Imagem 284. Bebês choram. Autoria: P. Scheier. Fonte: SCHEIER (1954), p.111.

ascendente acentuada, enfatizada pela alça do trombone que se projeta sobre os músicos (Imagem 279).

As demais fotografias mostram o baile infantil promovido no salão do Trianon, com a presença de Luiz Gonzaga, em 1951 ${ }^{82}$. O edifício ficava em frente ao parque, no local onde ocorreu a $1^{\text {a }}$ Bienal e onde mais tarde foi erguido o MASP. No pavimento superior contava com área pavimentada, pérgula e bar, e no inferior ficava o grande salão de baile, com janelas voltadas para a Avenida Nove de Julho ${ }^{83}$. Peter Scheier gostava de fotografar crianças, sendo este um dos ramos de atividade mais produtivos de seu estúdio. A proximidade ao retratado, típica deste tipo de trabalho, aparece nas imagens do garoto que exibe suas habilidades de dança (Imagem 280), da menina cansada que recosta sua cabeça no tampo da mesa (Imagem 281) ou do próprio Luiz Gonzaga descontraído, a

82 Estes dados foram encontrados no acervo do fotógrafo no Arquivo Histórico Judaico Brasileiro.

83 Fonte: GAMA, Lúcia Helena. Nos bares da vida: produção cultural e sociabilidade em São Paulo, 1940-1950. São Paulo: SENAC, 1998, p.106. 

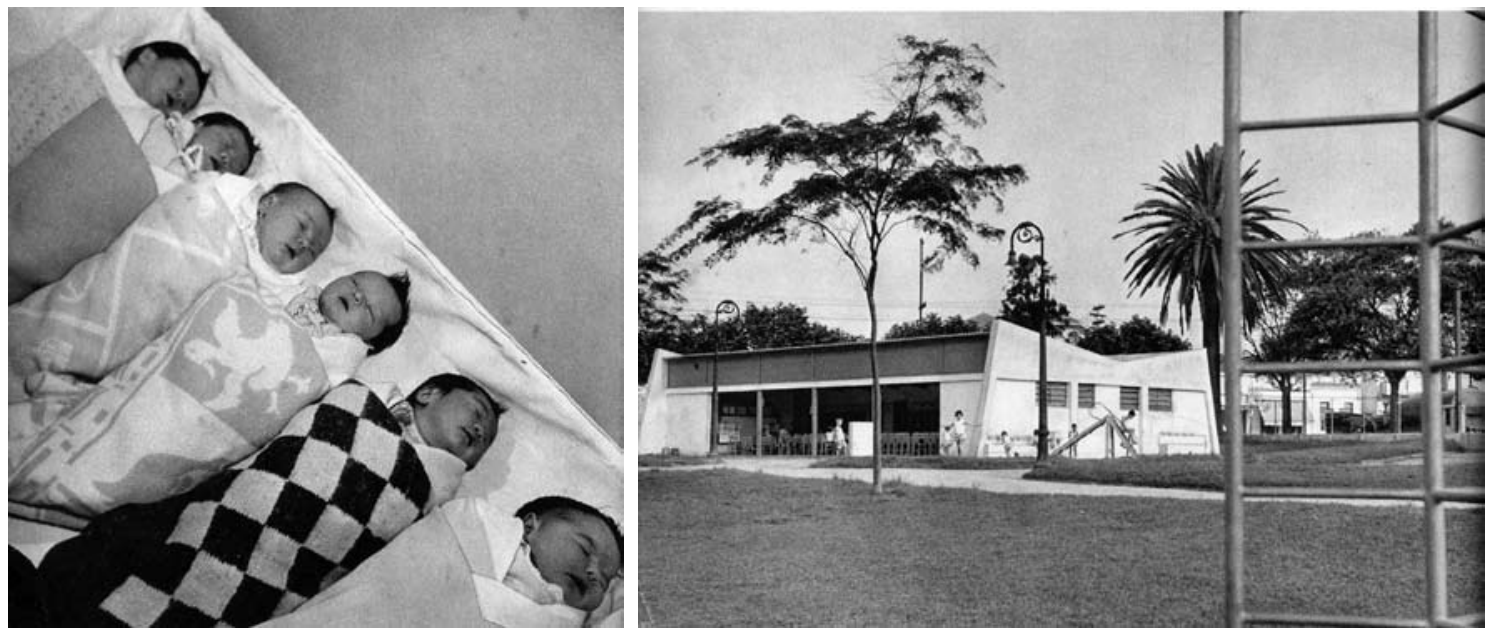

Imagem 285. Bebês dormem. Autoria: Imagem 286. Escola infantil. Autoria: P. Scheier. P. Scheier. Fonte: SCHEIER (1954), Fonte: SCHEIER (1954), p.108. p.108.

tocar acordeão para uma garota (Imagem 282).

O registro da infância passa pelo retrato de Abelardo Pinto, numa das etapas de sua caracterização como Palhaço Piolim, publicadas na O Cruzeiro (Imagem 283). Na reportagem, o circo de Piolin era apontado como "uma coisa tão familiar aos paulistanos como, por exemplo, o prédio do Martinelli. Pode o morador da Paulicéia deixar de ir ao teatro de revista, ao cinema ou à cantina, mas ao circo de Piolin aos domingos - nunca." ${ }^{84}$ Passa também por retratos de bebês chorando ${ }^{85}$ (Imagem 284) ou dormindo ${ }^{86}$ (Imagem 285), publicadas igualmente na revista. O retrato de seis bebês, curiosamente todos com traços orientais, ilustrava uma reportagem sobre o tratamento da tuberculose, cuja legenda era poética e generalista, o que sugere que a foto talvez não tenha sido publicada conforme seu contexto original: "O sono da inocência. Mas os inimigos do organismo humano estão à espreita em todos os lugares. Defender as crianças é o nosso dever." No álbum, esta imagem recebeu uma legenda

$84 \quad$ SILVA, Arlindo. O aprendiz de palhaço. O Cruzeiro, São Paulo, p.95, 15 abr 1950.

85 SILVA, Arlindo. Inflação de Gêmeos. O Cruzeiro, São Paulo, p.106-113, 22 out 1949.

86 SILVA, Arlindo. O general B.C.G. ataca. O Cruzeiro. São Paulo, p.59-63, 09 jul 1949. 

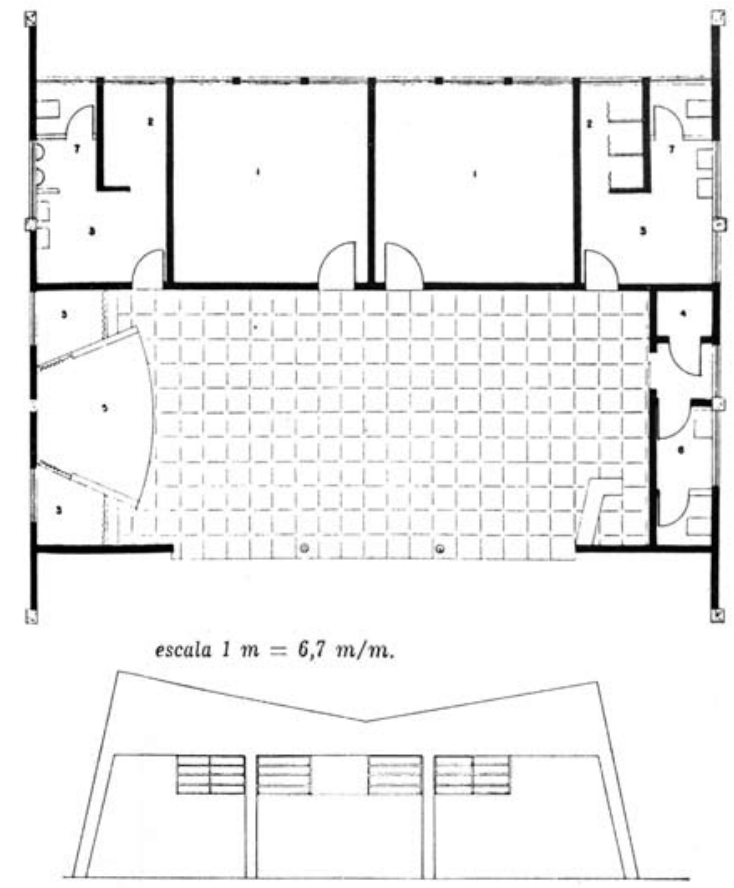

Imagem 287. Planta e elevação de escola típica da arquitetura do Convênio Escolar. Fonte: Habitat, n.04, p.17.

relacionada ao crescimento populacional ${ }^{87}$.

A infância ainda é retratada através da educação. Uma escola com arquitetura típica do Convênio Escolar da década de 1950 é apresentada numa imagem com ângulo aberto, que mostra o edifício e toda a área de gramado ao seu redor, na qual crianças brincam (Imagem 286). A origem desta foto talvez seja a matéria especial sobre o Convênio Escolar ${ }^{88}$ elaborada pela revista Habitat,

87 Esta imagem não foi encontrada no acervo do fotógrafo, de forma a recuperar sua primeira realidade. Assim, após passar provavelmente por dois processos de edição, seu contexto original se perdeu.

88 O Convênio Escolar (1949-1954) foi um acordo firmado entre a Prefeitura Municipal e o Estado, para cumprir às determinações da Constituição de 1946, que obrigava União, Estados e Municípios a investirem uma porcentagem mínima dos recursos arrecadados na educação primária. A Prefeitura era responsável pela construção dos prédios para cobrir o déficit, ao passo que o Estado era responsável por ministrar o ensino. A Comissão Executiva do Convênio Escolar foi criada em 1948, com o arquiteto Hélio Duarte como diretor técnico e membros como Eduardo Corona, Roberto Tibau, Oswaldo Corrêa Gonçalves e Ernest Mange. O objetivo era que até 1954, ano do IV Centenário, nenhuma criança paulistana ficaria fora da escola. Fonte: FERREIRA, Avany de Francisco; CORRÊA, Maria Elizabeth Peirão; MELLO, Mirela Geiger. Arquitetura Escolar Paulista - Restauro. São Paulo: FDE (Fundação para o Desenvolvimento da 


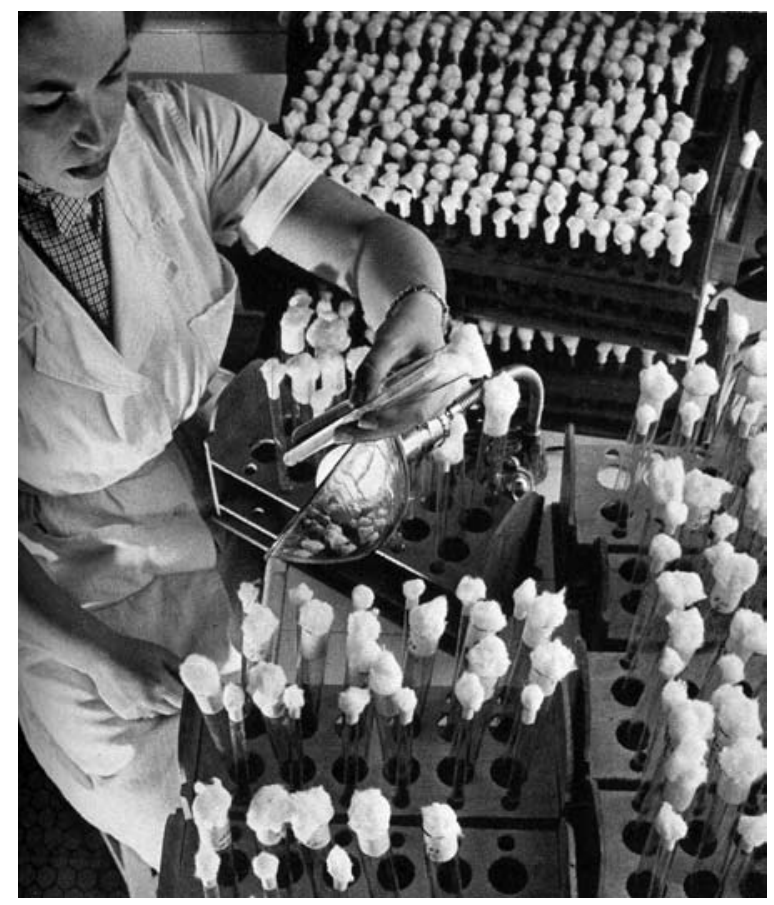

Imagem 288. Mulher manipula tubos de ensaio. Autoria: P. Scheier. Fonte: SCHEIER (1954), p.81.

em seu quarto número ${ }^{89}$ (Imagem 287). Apesar de não ser publicada na revista, pode integrar o material produzido para ela. O nome de Scheier consta da lista inicial de fotógrafos do número supracitado, embora não esteja diretamente relacionado a esta reportagem.

O desenvolvimento da ciência é representado por quatro imagens do Instituto Butantã, provavelmente oriundas da série produzida para uma reportagem em $1946^{90}$. A seqüência inicia-se com uma foto impactante, um close nas mãos de laboratoristas que extraiam o veneno de uma cobra, numa composição típica do fotojornalismo da O Cruzeiro. As demais retratam os ambientes de trabalho, com ângulos ascendentes ou descendentes que mostram o laboratorista em meio a tubos de ensaio e amostras armazenadas (Imagem 288).

Educação) / Imprensa Oficial, 1998.

89 As arquiteturas do Convênio Escolar. Habitat, São Paulo, n.4, p. 7-40, jul-set 1951.

90 MOTTA, Nelson. Tocaia no Butantan. O Cruzeiro, São Paulo, p. 56-61, 09 mar 1946. 


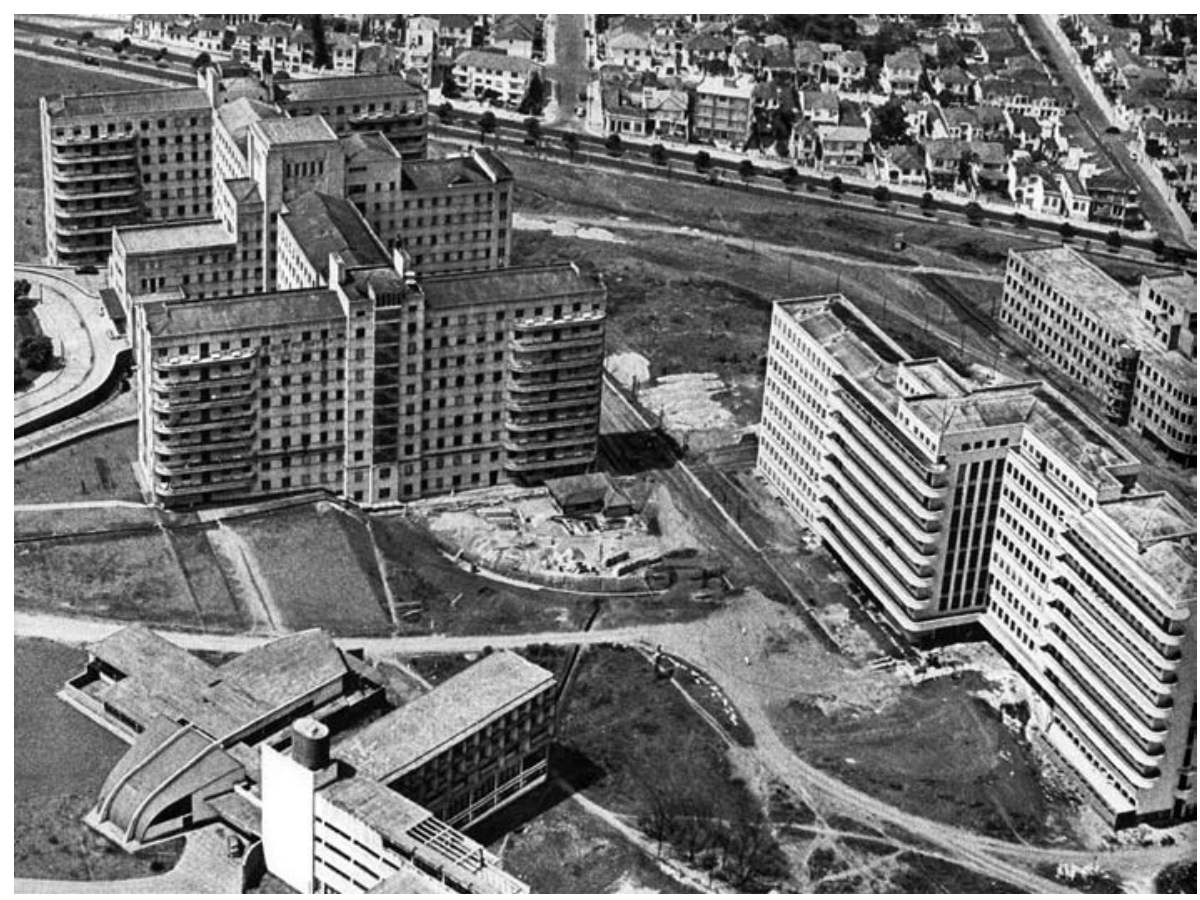

Imagem 289. Vista aérea do Hospital das Clínicas. À frente vemos a Escola de Enfermagem. À direita, o Instituto de Psiquiatria e, à sua frente, a Clínica Ortopédica e Traumatológica. À esquerda, no segundo plano, vemos o Instituto Central. Ao fundo vemos a Avenida Rebouças, com árvores espaçadas no canteiro central, a Alameda Lorena e a Alameda Tietê. Autoria: P. Scheier. Fonte: SCHEIER (1954), p.120.

A saúde pública também é mencionada com fotografias do Hospital das Clínicas. Uma apresenta ângulo levemente distinto daquela apresentada na reportagem "Trinta mil doentes!", na revista O Cruzeiro, na qual fora retratada uma cirurgia ${ }^{91}$ (Imagem 54). Uma foto aérea mostra o complexo hospitalar, com a Escola de Enfermagem, o Instituto Central, o Instituto de Psiquiatria e a Clínica Ortopédica e Traumatológica (Imagem 289). Ao fundo, a Avenida Rebouças separa o hospital do Jardim Paulista, densamente ocupado por sobrados.

A religião é apresentada através de imagens do clero, de fiéis em oração, de elementos arquitetônicos de igrejas e conventos e de rituais. A seqüência de oito imagens se inicia com um monge dominicano lendo a Bíblia (Imagem 290), cuja legenda na revista $O$ Cruzeiro, na qual foi inicialmente publicada, mencionava

$91 \quad$ Vide capítulo 2. 


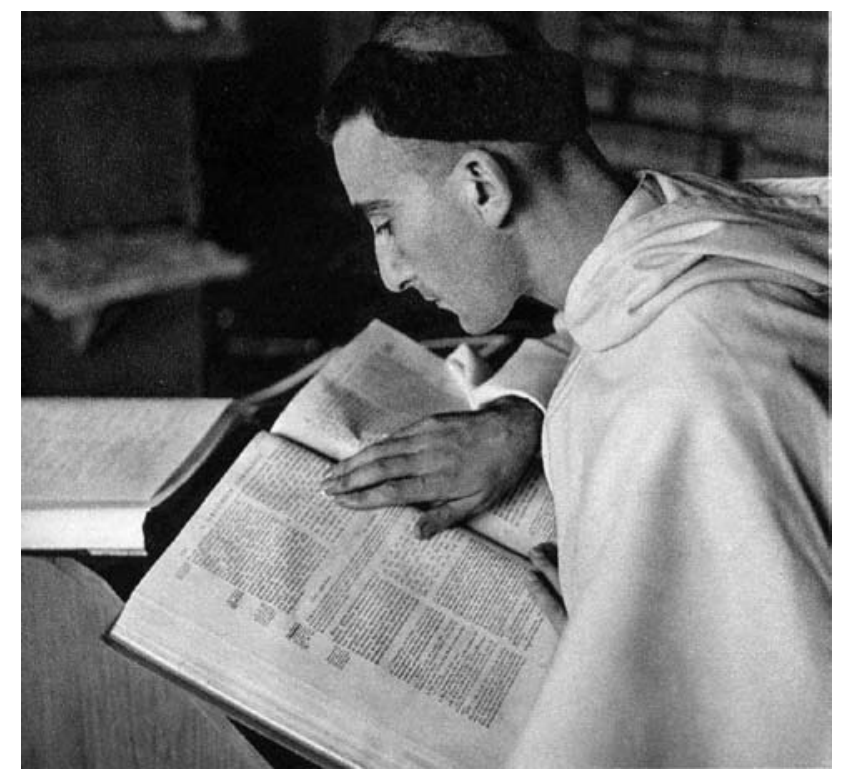

Imagem 290. Monge dominicano. Autoria: $P$. Scheier. Fonte: SCHEIER (1954), p.102.

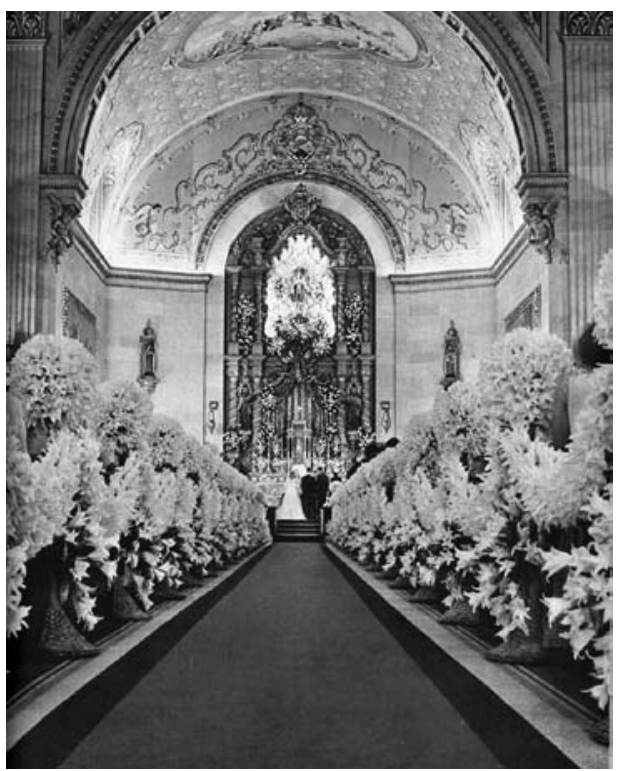

Imagem 291. Interior da Igreja Nossa Senhora do Carmo. Autoria: P. Scheier. Fonte: SCHEIER (1954), p.107.

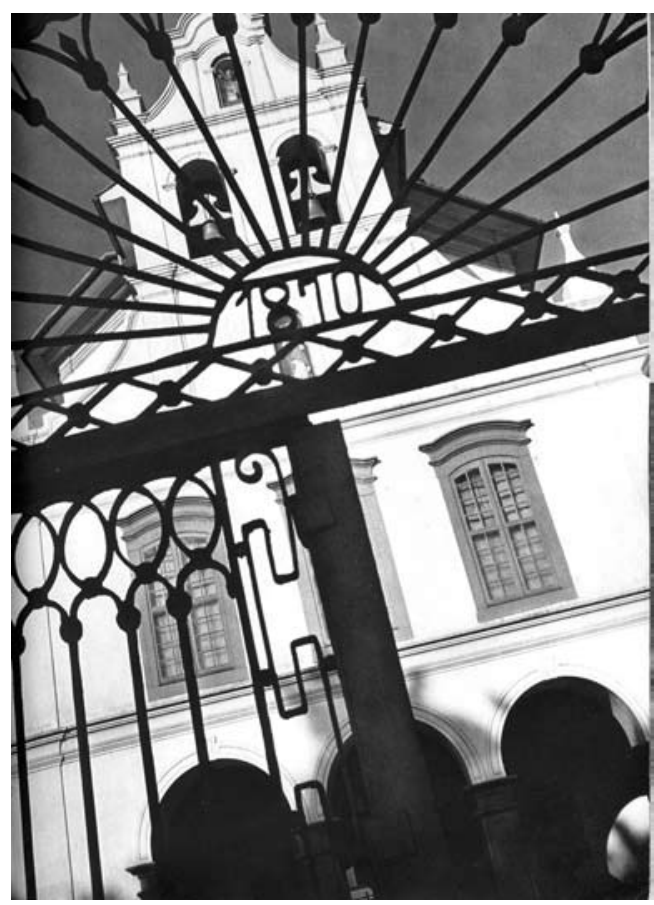

Imagem 292. Portão do Mosteiro da Luz. Autoria: P. Scheier. Fonte: SCHEIER (1954), p.103. 


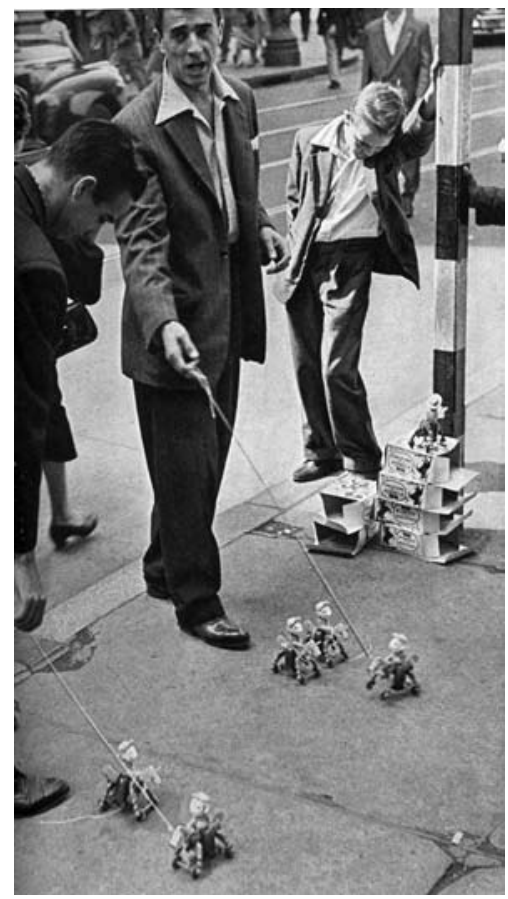

Imagem 293. Vendedor ambulante. Autoria: P. Scheier. Fonte: SCHEIER (1954), p.57.

"Homens de estudo - os dominicanos são intelectuais" 92. A produção do Foto Studio Peter Scheier na documentação de eventos sociais se faz presente no álbum através da foto de uma cerimônia de casamento na Igreja Nossa Senhora do Carmo, na Bela Vista (Imagem 291). Agachado no corredor central da igreja, Scheier fez uma imagem com acentuada perspectiva frontal, enfatizada pelo tapete e os arranjos de flores, que conduzem o olhar para o casal no altar. Coincidentemente, esta mesma igreja aparece em outros dois álbuns da época, Isto é São Paulo - 104 flagrantes da capital bandeirante ${ }^{93}$ e São Paulo: álbum de fotografias em cores $^{94}$.

92 SILVA, Arlindo. Os dominicanos. O Cruzeiro, São Paulo, p. 10, 09 ago 1947.

93 Isto é São Paulo - 104 flagrantes da capital bandeirante. São Paulo: Melhoramentos, 1954.

94 KARFELD, Peter Kurt. São Paulo: álbum de fotografias em cores. São Paulo: Melhoramentos, 1954. 


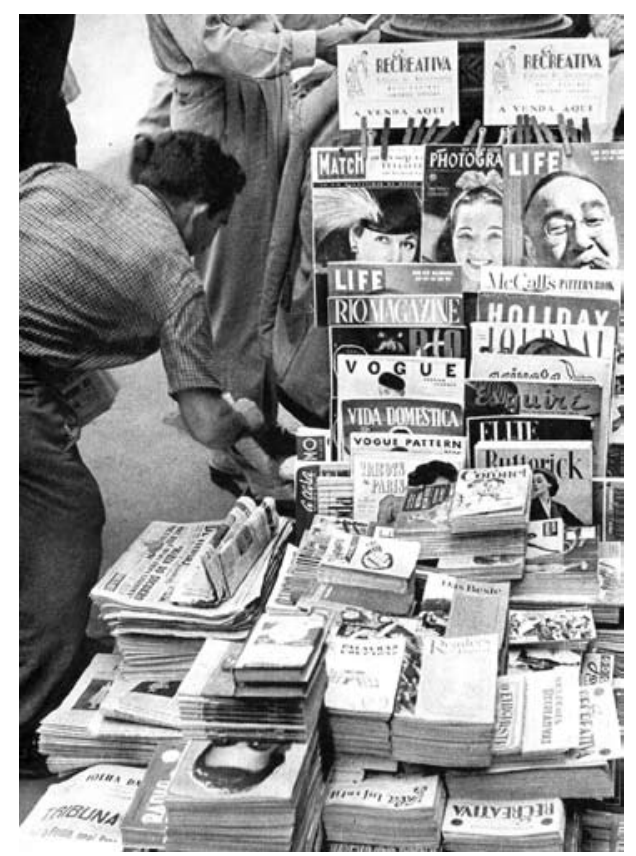

Imagem 294. Banca de revistas. Autoria: P. Scheier. Fonte: SCHEIER (1954), p.58.

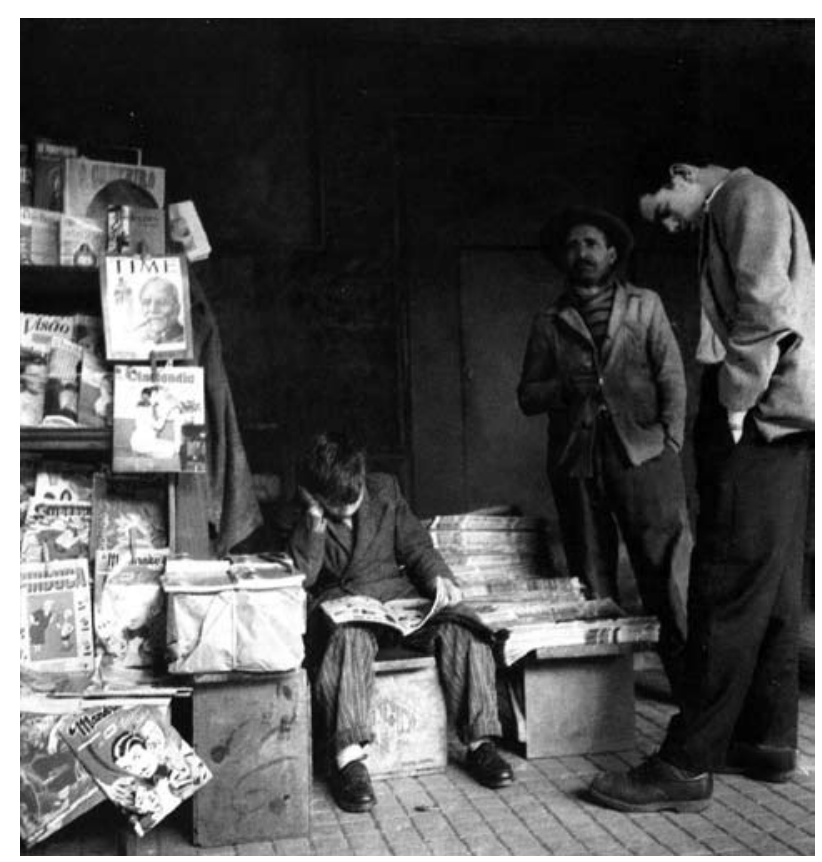

Imagem 295. Banca de revistas. Autoria: Alice Brill. Fonte: O mundo de Alice Brill (2005), p.25

O Mosteiro da Luz ${ }^{95}$, fundado e construído por Frei Antonio de Sant'Anna Galvão, em 1774, foi retratado através de um fragmento de seu portão e sua fachada (Imagem 292). Único exemplar da arquitetura colonial presente no álbum, não recebe nenhuma referência textual específica e sua identificação fica condicionada ao reconhecimento de seus elementos, como o portão, a torre sineira, as janelas e os arcos. Ao rotacionar a câmera, Scheier definiu uma forte linha diagonal traçada pelo montante do portão. A linguagem fotográfica vanguardista aplicada a um edifício de forte significação arquitetônica, histórica e religiosa dá-lhe um novo valor, o estético. Sua leitura como imagem religiosa é retomada apenas em função da ordenação das páginas do álbum.

O comércio paulistano é apresentado através de vários aspectos. No álbum, aqueles populares foram privilegiados, talvez por constituir um acervo produzido inicialmente sem a finalidade de publicação, apresentando, assim, uma 


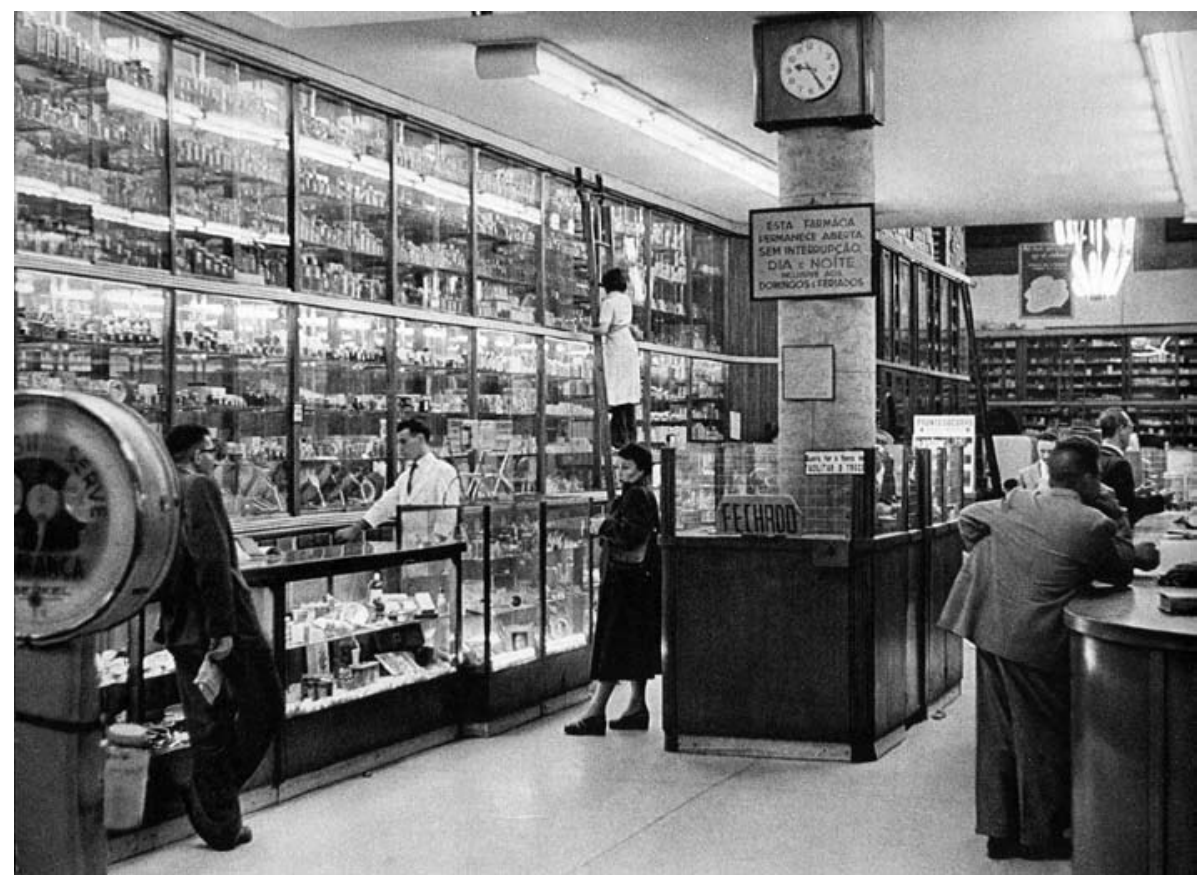

Imagem 296. Farmácia. Autoria: P. Scheier. Fonte: SCHEIER (1954), p.61.

postura descompromissada de Scheier e um registro peculiar do cosmopolismo paulistano. O vendedor ambulante exibindo seus bonecos "O cowboy" (Imagem 293), a banca de revistas e a loja de autopeças constituem registros genuínos de quem passava pela rua e captava estas singularidades.

O costume das pessoas de, a caminho do trabalho, pararem para, em pé, ler as últimas notícias nas bancas de revistas, mal estruturadas, improvisadas com tábuas e apoiadas nos postes de luz atraía a atenção de muitos fotógrafos (Imagem 294). Peter Scheier enfatizou a variedade de revistas e jornais nacionais e importados, como Life, Match, Vogue, A Recreativa, Vida Doméstica, A Tribuna, Folha da Manhã, que dominam mais da metade da foto e cujo arranjo parece se expandir para além dos limites das bordas. Os homens aparecem parcialmente, escolhendo um jornal ou lendo-o em pé. Alice Brill também fez registros deste costume (Imagem 295): um garoto entretido com uma revista, um rapaz em pé lendo as manchetes do jornal e um homem que olha desconfiado para a 


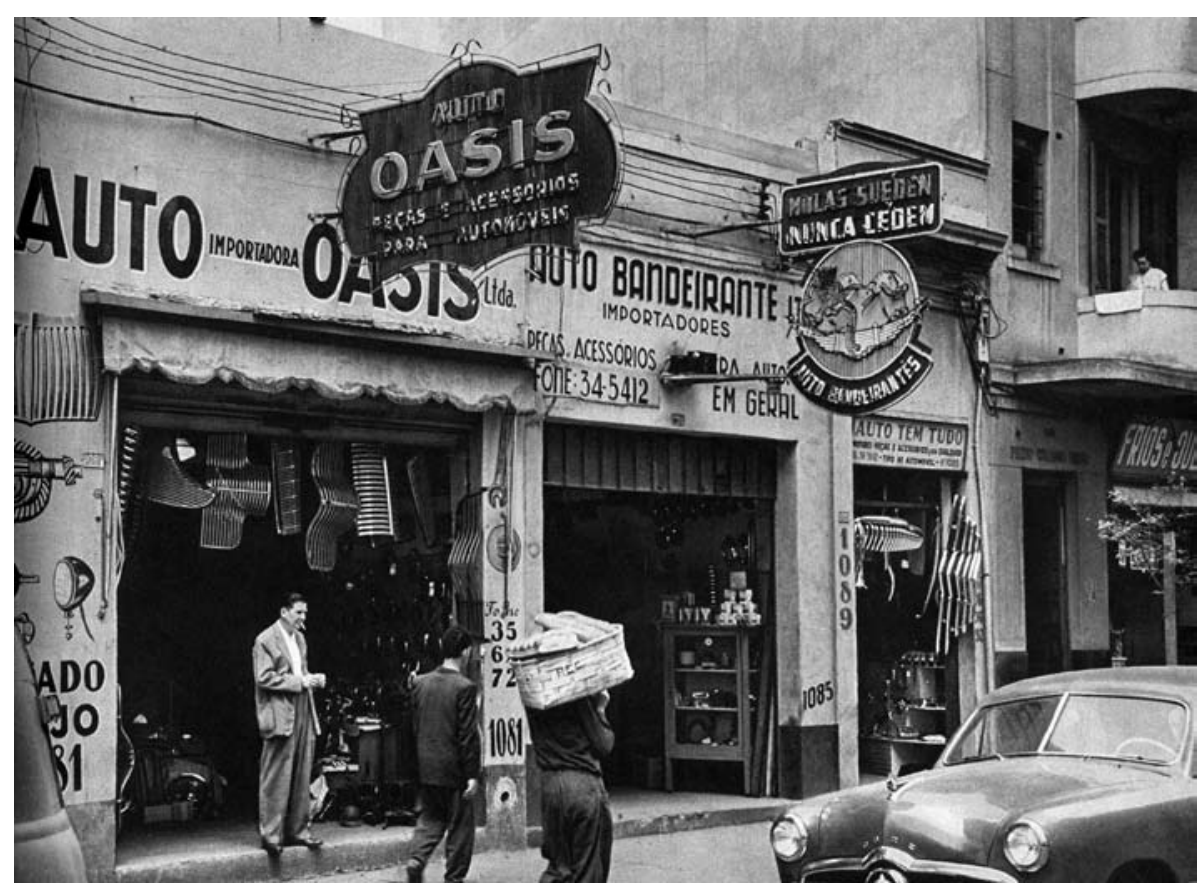

Imagem 297. Comércio de auto peças na Avenida São João. Autoria: P. Scheier. Fonte: SCHEIER (1954), p.62.

câmera formam, junto com as revistas expostas, um retrato interessante deste costume.

Embora tenha também fotografado lojas mais sofisticadas - como aquelas cujos projetos foram desenvolvidos pelo Studio d'Arte Palma (Mapa Importadora e Olivetti Securit, na Rua 7 de Abril, 267 e na Rua 24 de Maio, respectivamente), o comércio mais popular foi privilegiado no álbum. A farmácia (Imagem 296) que "permanece aberta sem interrupção, DIA e NOITE, inclusive aos domingos e feriados", conforme o cartaz, foi registrada com todas as suas peculiaridades: o relógio marcando 9:25, provavelmente da noite; o cartaz no caixa fechado com os dizeres "Queira ter a fineza de facilitar o troco"; a balança em primeiro plano; a placa "Pronto-Socorro"; os clientes aguardando os farmacêuticos encontrarem, com o auxílio das escadas deslizantes, os medicamentos nos altos armários envidraçados, que refletiam as várias lâmpadas acesas, criando, assim, uma sensação de amplidão que talvez tenha atraído a atração de Scheier. 


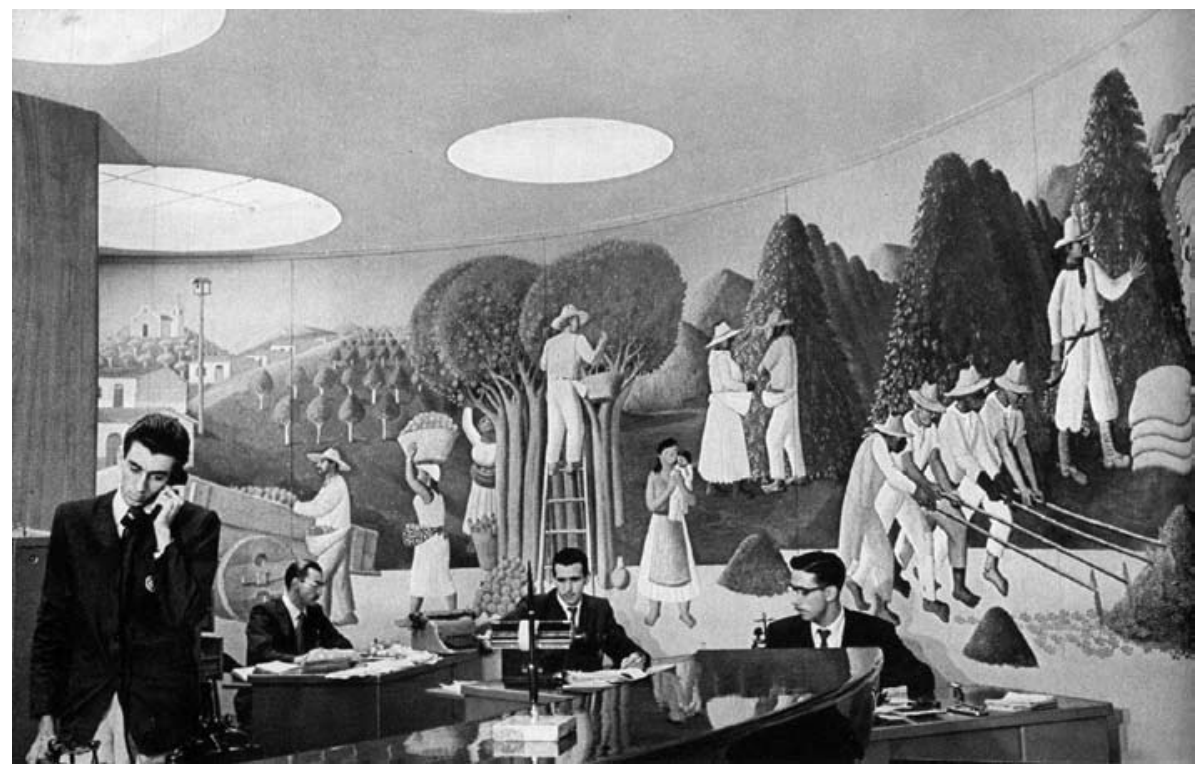

Imagem 298. Interior do Banco da América. Autoria: P. Scheier. Fonte: SCHEIER (1954), p.66.

O comércio de autopeças na Avenida São João, próximo ao Largo do Arouche, também foi documentado pelas lentes de Scheier (Imagem 297). Um conjunto de três estabelecimentos nos números 1081, 1085 e 1089 da avenida, respectivamente Auto Importadora Oasis Ltda - Peças e Acessórios para automóveis - atacado e varejo, Auto Bandeirante Ltda - Importadores - (tel: 34-5412) e Auto Tem tudo - tel: 36-3692, exibia seus produtos pendurados nas portas. Vizinhos às lojas estavam um edifício residencial, em cuja varanda uma mulher pendurava uma toalha e em cujo térreo estava instalado um comércio de frios e queijos. Scheier captou toda a atmosfera do cotidiano, com o vendedor que fumava um cigarro na porta da loja, enquanto um homem caminhava e o vendedor carregava o cesto de pães sobre o ombro. O ângulo escolhido captou a diversidade deste trecho da São João, de aspecto bem distinto daquela primeira panorâmica cuja legenda associava-a à Broadway norte-americana.

A referência direta aos serviços é feita através de duas imagens do interior 


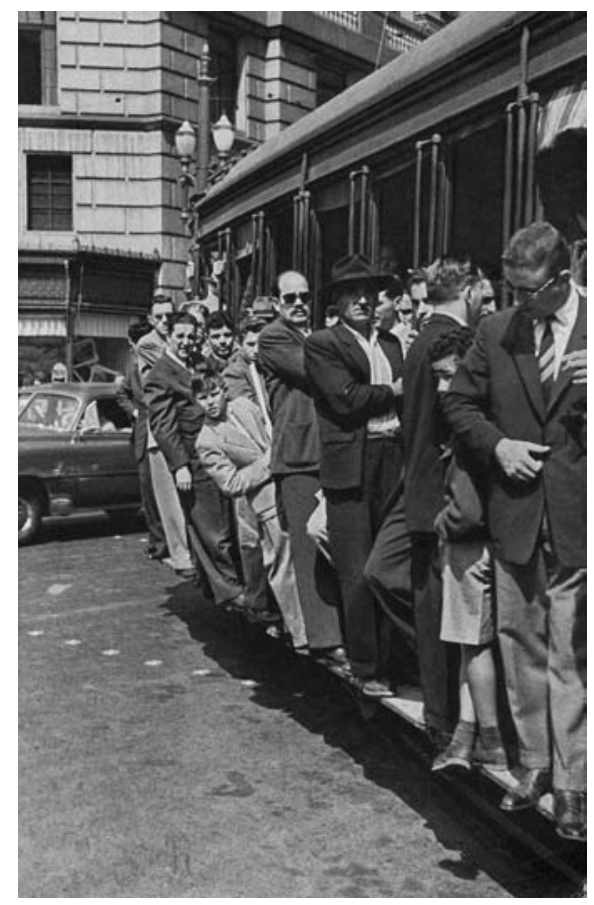

Imagem 299. Passageiros no bonde. Autoria: P. Scheier. Fonte: SCHEIER (1954), p.57.

do Banco da América, na Rua Marconi, "a rua mais elegante da cidade" 96 (Imagem 298). É provável que estas imagens tenham sido feitas durante uma reportagem de arquitetura de interiores da Habitat, em 1952, o que pode ser confirmado pelo calendário em uma delas, que indica 14 de agosto, dois meses antes do lançamento do número 9 da revista, em outubro. A legenda do álbum refere-se aos murais, muito freqüentes em bancos. Aqui se trata de um painel de Fulvio Pennacchi, representando a evolução da economia agrícola e industrial de São Paulo. O painel mostra aspectos da cafeicultura, agricultura, indústria, construção civil, navios e aviões (representando a exportação). À frente de todos estes elementos, os banqueiros controlam tudo pelo telefone. Assim, os homens se mesclam com os personagens do painel, que enfatiza que o trabalho leva à prosperidade econômica. Nota-se também a disciplina e concentração dos homens em seus afazeres, acomodados em um ambiente apertado, ocupado 


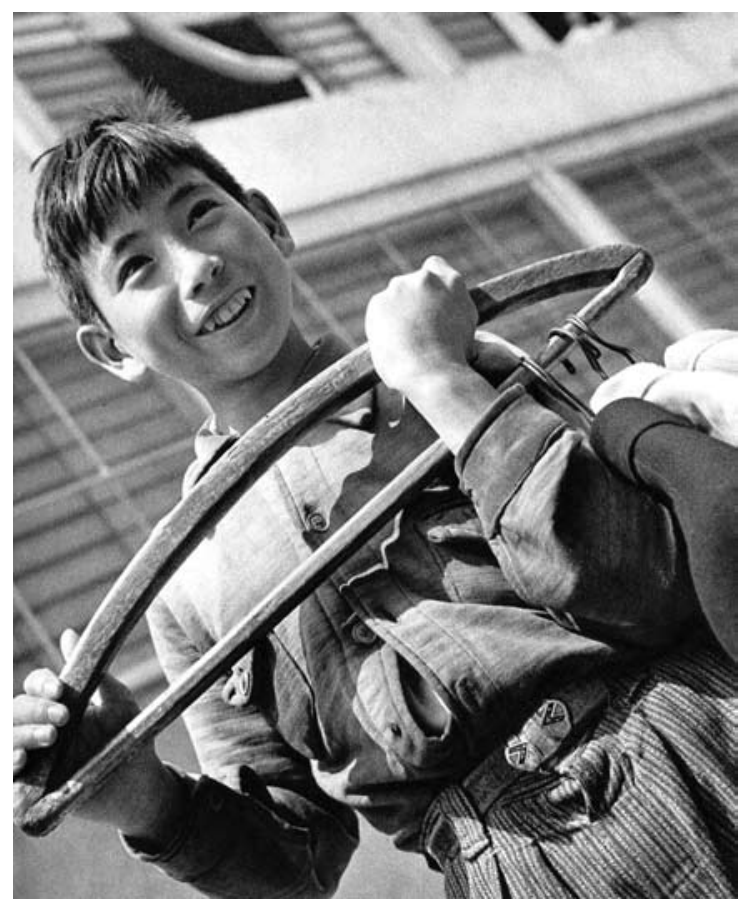

Imagem 300. Entregador de lavanderia. Autoria: P. Scheier. Fonte: SCHEIER (1954), p.114

por mobiliário, sem aparente iluminação natural.

Além das vistas urbanas, registros da arquitetura moderna e dos grandes temas, foram contemplados no álbum os flagrantes do cotidiano da cidade, que explicitam as posturas de Peter Scheier e sua apreciação dos tipos humanos e de suas atividades. Como na imagem do bonde lotado (Imagem 299), em que dezenas de homens se equilibravam enquanto o bonde trafegava. Um garoto chama a atenção ao projetar seu corpo para fora, como se quisesse se destacar na fotografia. Outro garoto, mais à frente e quase oculto entre os homens, imprime certa descontração à situação, ao trajar bermuda e cruzar suas pernas, de forma que seu pé direito fique para fora da plataforma.

Ou ainda numa fotografia de um garoto mestiço que trabalhava como entregador de uma lavanderia (Imagem 300). Sua espontaneidade frente à câmera demonstra a simpatia que Scheier apresentava ao se aproximar das 
pessoas para fotografá-las. Com freqüência, o retrato não the bastava, e com um tripé e um disparador ele se juntava ao fotografado, para documentar aquele pequeno vínculo que se estabeleceu por um instante. Em imagens deste tipo percebe-se o prazer que Scheier sentia em registrar tudo a sua volta, como se cada fotograma fosse uma peça de um grande mosaico, sem o qual a idéia de cidade se perderia. 


\section{Conclusão}

Esta dissertação partiu do pressuposto de que a linguagem de Peter Scheier foi construída a partir de seus referenciais advindos de sua vida na Europa das primeiras décadas do século XX, marcada por um conjunto de manifestações vanguardistas e acontecimentos históricos que compuseram o seu quadro cultural. A Segunda Guerra Mundial culminou no processo de imigração para o Brasil, país desconhecido para Scheier, para quem a fotografia, hábito amador adquirido na Alemanha, se apresentava como uma possibilidade de interação, integração e sobrevivência.

Ao quadro referencial primeiro foram acrescidos outros elementos, em especial a experiência no fotojornalismo da revista O Cruzeiro e no Museu de Arte de São Paulo, nos quais Scheier conviveu com artistas e outros fotógrafos, muitos também imigrantes. A redação de O Cruzeiro era um local de experimentação 
fotográfica, onde uma nova linguagem fotojornalística se desenvolvia a partir de referências modernas no mercado europeu ( $V u$, Paris Match e jornais ilustrados) e americano (Life). O MASP era um local de efervescência cultural e inovação. O trabalho conduzido dentro destes dois cenários potencializou, assim, as referências vanguardistas já vivenciadas por Scheier em anos anteriores.

Este quadro cultural - ou filtro cultural, nas palavras de Boris Kossoy - é percebido no conjunto de fotografias reunido neste trabalho. Através da seleção da produção fotojornalística, da documentação do museu e da fotografia de arquitetura, aliada à confrontação com a produção fotográfica da época, foi possível definir claramente os traços marcantes da fotografia de Peter Scheier: formalmente, assinalamos as diagonais marcantes e os ângulos ascendentes e tematicamente, destacamos o seu prazer em retratar as pessoas.

Embora o álbum São Paulo fastest growing city in the world demonstre um compromisso editorial claro, sua leitura meticulosa permite reconhecer a maneira pela qual Peter Scheier retratava a cidade, isto é, através de seus cidadãos, através de suas atividades e de seu intenso fluir. Em seu olhar, a cidade não existiria sem a ação humana e a dinâmica troca de informações e de experiências entre as pessoas. Para ele, talvez São Paulo fosse a metáfora de sua vida pós-Alemanha, construída com constante esforço e convívio com classes distintas, para vencer as dificuldades e diferenças. São Paulo não era apenas a cidade do progresso - que o discurso do IV Centenário pretendia tornar generalizado. Nela se encontravam muitos opostos, que por fim descobriam uma forma de convivência pacífica - como os milhares de imigrantes que aqui desembarcaram. Uma realidade distinta daquela da Alemanha nazista, da qual os julgados diferentes foram expulsos ou exterminados. Este acolhimento talvez tenha evoluído para o apreço de Scheier pelos brasileiros, que a ele se mostraram tolerantes e hospitaleiros. 
Imigrante, a postura de Peter Scheier não era defensiva nem excludente. Ao documentar, não mantinha a distância do retratado. Ao contrário, era impulsionado por uma curiosidade de quem deseja entender e fazer parte, como na hora do cafezinho, do passeio no parque ou no baile no Clube América. Não era um estrangeiro em busca de imagens exóticas rentáveis embora mantivesse uma postura comercial e profissional constante -, mas sim de retratos cotidianos dos lugares pelos quais transitava. $O$ gosto pelas viagens mostrava a vontade de anotar todo o possível, para que nada se perdesse. Para tanto, despia-se de preconceitos e restrições, levando sua câmera desde as áreas mais pobres até os eventos da alta sociedade. Por este viés, encontramos um ponto crucial de diferenciação dentro da fotografia moderna no Brasil: pelas condições que enfrentava, o grupo de fotógrafos imigrantes propôs a inserção da fotografia na sociedade através de seus trabalhos profissionais - em especial o fotojornalismo e publicidade -, ao passo que os fotoclubistas apresentavam uma postura voltada para a experiência fotográfica com status artístico, restrita aos seus salões expositivos.

A primeira parte desta dissertação pretendeu desenvolver as características formais dos primeiros quinze anos de trabalho de Peter Scheier, que culminaram na publicação do álbum. Implicou na análise de acervo e publicações para o levantamento dos temas abordados, da sua inserção dentro da cidade e de sua visão como documentador. A segunda parte analisou seu trabalho dentro de uma edição específica, com o desmantelamento do contexto original e a introjeção de novos significados nas fotografias. A pesquisa buscou resgatar a primeira realidade das imagens para confrontá-la com o discurso o qual agora integravam. A seleção das imagens para o álbum foi feita por assunto e com o objetivo claro de difusão da idéia de modernidade, aplicando-lhes, assim, um sentido generalizado e ilustrativo. É um álbum elaborado sobre conceitos - progresso, futuro, grandiosidade - e não sobre pontos concretos e 
identificados.

Além do comprometimento editorial, comum a todos os álbuns produzidos na época, a seleção esteve sujeita ao conteúdo do acervo produzido pelo fotógrafo, o que causa por vezes estranhamentos e deslocamentos na narrativa, contornados com legendas generalistas e superficiais. Provoca também uma leitura nostálgica, se notarmos que muitas vistas urbanas foram feitas no fim da tarde, o que nos leva a concluir que, no caminho de volta para casa, Scheier utilizava as pontas dos filmes para fazer as fotos que queria, livre de qualquer pauta.

Mais que conclusiva de um processo de pesquisa, esta dissertação deve ser interpretada como a memória de um percurso, iniciado com a intenção do traçado de um panorama da fotografia urbana e de arquitetura no século $\mathrm{XX}$. Deste primeiro projeto se derivaram campos com amplo potencial explorativo. A concentração em um único profissional, com produção significativa, e a escolha de um trabalho para a análise profunda permitiu contemplar satisfatoriamente os conceitos, referenciais culturais e as especificidades de um ofício e de uma época tão fértil quanto o IV Centenário da cidade de São Paulo.

A obra de Peter Scheier não se esgota nestas páginas, pois seu amplo acervo se estende por mais quinze anos além dos aqui revelados. Sua produção oferece inúmeras possibilidades de leituras e abordagens. Esta dissertação trilhou apenas um dos caminhos possíveis. 


\section{Referências Bibliográficas}

\section{Livros}

ANDRADE, Mário de. "Brazil Builds". In: XAVIER, Alberto (org.). Depoimento de uma geração - arquitetura moderna brasileira. São Paulo: Cosac \& Naify, 2003, p. 177-180.

ANELLI, Renato; GUERRA, Abílio; KON, Nelson. Rino Levi - arquitetura e cidade. São Paulo: Romano Guerra Editora, 2001.

ARGAN, Giulio Carlo. História da Arte como História da Cidade. Tradução de Píer Luigi Cabra. São Paulo: Martins Fontes, 1998.

Tradução de Denise Bottmann e Federico Carotti. Arte Moderna. São Paulo: Companhia das Letras, 1992, p. 228 - 269.

ARRUDA, Maria Arminda do Nascimento. Metrópole e Cultura - São Paulo meio de século. São Paulo: FFLCH - USP, 2000. Tese de Livre Docência.

BARDI, Lina Bo; FERRAZ, Marcelo Carvalho. Casa de Vidro - The Glass House. Lisboa, Editorial Blau, 1999.

BAUDELAIRE, Charles. Salão de 1859. In: A modernidade de Baudelaire. Rio de Janeiro: Paz e Terra, 1988, p.59-74.

BENÉVOLO, Leonardo. História da Cidade. São Paulo: Editora Perspectiva, 
1997, p.595.

CALVINO, Ítalo. Tradução de Diogo Mainardi. As cidades invisíveis. São Paulo: Companhia das Letras, 1990.

CARNEIRO, Maria Luiza Tucci. Brasil, um refúgio nos trópicos. São Paulo: Estação Liberdade, 1996.

CORBUSIER, Le. Por uma arquitetura. São Paulo: Editora Perspectiva, 1998.

COSTA, Helouise \& SILVA, Renato Rodrigues da. A fotografia moderna no Brasil. São Paulo: Cosac Naify, 2004.

COSTA, Helouise. Aprenda a ver as coisas: fotojornalismo e modernidade na revista O Cruzeiro. São Paulo: Escola de Comunicações e Artes de São Paulo, 1992. Dissertação de mestrado.

. Um olho que pensa. São Paulo: FAUUSP, 1998. Tese de Doutorado.

ELWALL, Robert. Building with Light: the international history of architectural photography. Londres: Merrel Publishers, 2004.

FERRAZ, Marcelo Carvalho (org.). Lina Bo Bardi. São Paulo: Empresa das Artes / Instituto Lina Bo e P.M.Bardi, 1993.

FERREIRA, Avany de Francisco; CORRÊA, Maria Elizabeth Peirão; MELLO, Mirela Geiger. Arquitetura Escolar Paulista - Restauro. São Paulo: FDE (Fundação para o Desenvolvimento da Educação) / Imprensa Oficial, 1998.

GAMA, Lúcia Helena. Nos bares da vida: produção cultural e sociabilidade em São Paulo, 1940-1950. São Paulo: SENAC, 1998.

GOODWIN, Philip L. e SMITH, G.E.Kidder. Brazil Builds: architecture new and old 1652-1942. New York: The Museum of Modern Art, 1943.

HITCHCOCK, Henry-Russell. Latin America Architecture since 1945. New York: The Museum of Modern Art, 1955.

KOSSOY, Boris. "Construção de uma visualidade moderna". In: O mundo de Alice Brill. Catálogo de exposição. São Paulo: Instituto Moreira Salles, set 2005, p. 6-14.

"Luzes e sombras da metrópole: um século de fotografias em São Paulo (1850-1950)". In: PORTA, Paula (org.). História da Cidade de São Paulo: a cidade no Império. São Paulo: Paz e Terra, 2004, v. 2, p. 387-455.

. Dicionário Histórico-Fotográfico Brasileiro - Fotógrafos e ofício da fotografia no Brasil (1833-1910). São Paulo: Instituto Moreira Salles, 2002.

Fotografia \& História. São Paulo, Ateliê Editorial, 2001.

. Os Tempos da Fotografia: o Efêmero e o Perpétuo. Cotia, SP: Ateliê 
Editorial, 2007. 2002. Realidades e Ficções na Trama Fotográfica. São Paulo, Ateliê Editorial, LAGO, Pedro Corrêa do. Militão Augusto de Azevedo. Rio de Janeiro: Capivara, 2001.

LEAL, Daniela Viana. Oscar Niemeyer e o mercado imobiliário de São Paulo na década de 1950: o escritório satélite sob direção do arquivo Carlos Lemos e os edifícios encomendados pelo Banco Nacional Imobiliário. Campinas: Unicamp / Instituto de Filosofia e Ciências Humanas, 2003. Dissertação de Mestrado.

LEFÈVRE, José Eduardo de Assis. De Beco a Avenida. A História da Rua São Luiz. São Paulo: Editora da Universidade de São Paulo, 2006, p.212-257.

LIMA, Solange Ferraz de, CARVALHO, Vânia Carneiro de. Fotografia e Cidade: da razão urbana à lógica do consumo - Álbuns de São Paulo (1887-1954). Campinas: Mercado das Letras, São Paulo: FAPESP, 1997.

LOURENÇO, Maria Cecília França. Operários da Modernidade. São Paulo: Hucitec / EDUSP, 1995.

MACHADO, Antônio de Alcântara. Brás, Bexiga e Barra Funda. Disponível em: http://www.biblio.com.br/conteudo/alcantaramachado/mbrasbexiga.htm. Acesso em: 09 nov, 2006.

MARIEN, Mary Warner. Photography: a cultural history. London: Laurende King Publishing, 2002.

MASCARO, Cristiano. A Fotografia e a Arquitetura. São Paulo: Faculdade de Arquitetura e Urbanismo da Universidade de São Paulo, 1994. Tese de Doutorado.

. O uso da imagem fotográfica na interpretação do espaço urbano e arquitetônico. São Paulo: Faculdade de Arquitetura e Urbanismo da Universidade de São Paulo, 1985. Dissertação de Mestrado.

MILLIET, Sérgio. Álbum cartográfico da cidade de São Paulo. São Paulo: Comissão do IV Centenário da Cidade de São Paulo, 1954.

MINDLIN, Henrique E. Modern Architecture in Brazil. Rio de Janeiro / Amsterdam: Colibris Editora Ltda., 1956.

PEDROSA, Mário. A Arquitetura Moderna no Brasil. In: XAVIER, Alberto (org.). Depoimento de uma geração - arquitetura moderna brasileira. São Paulo: Cosac \& Naify, 2003, p. 98-105.

PERRONE, Carlos. São Paulo por dentro - um guia panorâmico de arquitetura. São Paulo: Editora SENAC, 2000.

PONTES, José Alfredo Vidigal. São Paulo de Piratininga: de pouso de tropas a 
metrópole. São Paulo: O Estado de S.Paulo / Editora Terceiro Nome, 2003.

SANTORO, Paula Freire. Do provincialismo ao cosmopolita. A relação da sala de cinema com o espaço urbano em São Paulo. São Paulo: FAUUSP, 2004. Dissertação de Mestrado.

SANTOS, Maria Cecilia Loschiavo dos. Móvel moderno no Brasil. São Paulo: Studio Nobel / FAPESP, 1995.

SCHEIER, Peter. Brasília vive!. São Paulo, Livraria Kosmos Editora, s.d. . Imagens do passado de Minas Gerais. Rio de Janeiro, Livraria Kosmos Editora, 1968.

Paraná, Brasil. Edição Comemorativa do $1^{\circ}$ Centenário do Estado do Paraná. Imprensa Paranaense, 1953. Editora, 1954.

São Paulo fastest growing city in the world. São Paulo: Livraria Kosmos

TOLEDO, Benedito Lima de. Prestes Maia e as origens do urbanismo moderno em São Paulo. São Paulo: Empresa das Artes, 1996.

TOLEDO, Benedito Lima de; KOSSOY, Boris; LEMOS, Carlos. Álbum comparativo da cidade de São Paulo/1862-1887: Militão Augusto de Azevedo. São Paulo: Prefeitura do Município de São Paulo - Secretaria Municipal de Cultura, 1981.

TOUCEDA, Adriana Marta Irigoyen de. Da Califórnia a São Paulo: referências norte-americanas na casa moderna paulista 1945-1960. São Paulo: FAUUSP, 2005. Tese de Doutorado.

WOLFF, Paul. Arbeit! Frankfurt am Main: H. Bechhold, 1937.

\section{Periódicos}

Acrópole, São Paulo, n.95, p.298-299, mar 1946.

Biblioteca Municipal de S.Paulo. Acrópole, São Paulo, n. 68, p.208, dez 1943.

Cine Ipiranga. Acrópole, São Paulo, n.61, p. 489-493, 1943.

CAMARGO, Mônica Junqueira de. IV Centenário da cidade de São Paulo: um espetáculo do progresso. Desígnio: revista de história da arquitetura e do urbanismo, São Paulo, v. 4, p. 51-61, 2005.

FALBEL, Anat. Immigrant Architects in Brazil: a Historiographical Issue. Docomomo. São Paulo, março 2006, n. 34, p. 58-65.

. Um arquiteto no exílio. Revista aU - Arquitetura \& Urbanismo, São Paulo, 
p.77-83, mai 2008.

RUDOFSKY, Bernardo. Three Patio Houses. New Pencil Points, East Stroudsburg, n 6, p. 48-65, jun 1943.

SEGAWA, Hugo. Voyeurismo: olhando a arquitetura. Revista Projeto, São Paulo, n. 176, p. 64-69, jul 1994.

SERAPIÃO, Fernando.Umasagafotográfico-arquitetônica. RevistaProjetoDesign, São Paulo, n. 323, p. 102-105, jan. 2007.

\section{O Cruzeiro}

AMÁDIO, José. Viva Villa! O Cruzeiro, São Paulo, p.86-89, 17 set 1949.

ANTÔNIA, Maria. A sociedade paulista vai ao futebol... O Cruzeiro, São Paulo, p.60-63, 16 jun 1945.

FERREIRA, Jorge. Luta de gigantes. O Cruzeiro, São Paulo, p. 114-115, 29 jul 1950 .

Museu de Arte de São Paulo "cidadela da civilização". O Cruzeiro, São Paulo, p. 94-103, 05 ago 1950.

Geraldo. $O$ café é rei em Boca Raton. O Cruzeiro, São Paulo, p. 86-87, 27 jan 1951.

IZAR, Margarida. Quatro Séculos de moda. O Cruzeiro, São Paulo, p. 114-119, 21 abr 1951.

Kikoler. Natal na Broadway. O Cruzeiro, São Paulo, p. 76-79, 25 dez 1948.

LÔBO, Fernando. Fiacres de Central Park. O Cruzeiro, São Paulo, p.38-42, 22 mar 1947.

MOTTA, Nelson. A jornada do Pacaembu. O Cruzeiro, São Paulo, p. 54-61, 30 jun 1945. 1945

A montanha contra a morte. O Cruzeiro, São Paulo, p. 8-15, 06 out A última fila. O Cruzeiro, São Paulo, p. 60-63, 12 out 1946.

. Barricada na cozinha. O Cruzeiro, São Paulo, p. 54-63, 23 jun 1945.

1945 .

. O enterro de um grande morto. O Cruzeiro, São Paulo, p. 8-17, 02 jun

Tocaia no Butantan. O Cruzeiro, São Paulo, p. 56-61, 09 mar 1946. 
NOBRE, Freitas. Bussocaba e Vila Mascote. O Cruzeiro, São Paulo, p. 52-57, 31 mar 1945.

. Casa das recordações. O Cruzeiro, São Paulo, p. 36-40, 05 abr 1947. . Circo-teatro do povo. O Cruzeiro, São Paulo, p. 8-13, 23 jun 1945.

. O Braz. O Cruzeiro, São Paulo, p. 8-16, 26 abr 1947. 1945. . Os cegos do "Padre Chico". O Cruzeiro, São Paulo, p. 56-61, 21 abr

OLIVEIRA, Franklin de. A bandeira de Roosevelt. O Cruzeiro, São Paulo, p. 1824, 27 nov 1948.

PENA, Alceu. Desfile em Boca Raton. O Cruzeiro, São Paulo, p. 76-79, 13 jan 1951.

PITTA, Rocha. Judeus sem dinheiro. O Cruzeiro, São Paulo, p. 62-64, 12 jan 1946. 1945.

. Um dia no bosque dos anões. O Cruzeiro, São Paulo, p. 62-67, 08 dez

RODRIGUES, Meira. A batalha da terra. O Cruzeiro, São Paulo, p.60-64, 09 nov 1946.

SCHEIER, Peter. A música e a dança. O Cruzeiro, São Paulo, p. 40-43, 23 abr 1949.

. Meia-volta volver. O Cruzeiro, São Paulo, p.84-90, 12 fev 1949.

SILVA, Arlindo. A "Aliança" fez a força. O Cruzeiro, São Paulo, p. 58-65, 14 jan 1950.

. Arte para milhões. O Cruzeiro, São Paulo, p. 54-60, 01 nov 1947.

. A ilha dos lobos. O Cruzeiro, São Paulo, p.46-49, 04 fev 1950.

. A nova abolição. O Cruzeiro, São Paulo, p. 58-61, 06 set 1947.

. A televisão funcionando! O Cruzeiro, São Paulo, p. 24-25, 12 ago 1950

. A televisão para milhões. O Cruzeiro, São Paulo, p. 37-39, 28 out 1950.

. Boogie-Woogie Brasileiro. O Cruzeiro, São Paulo, p. 38-41, 16 set 1950.

1949 .

. Borghi invade o Brasil central. O Cruzeiro, São Paulo, p.13-17, 12 nov

Inflação de Gêmeos. O Cruzeiro, São Paulo, p.106-113, 22 out 1949. 

jan 1950.

José Mojica, soldado da igreja. O Cruzeiro, São Paulo, p. 50-53, 29 jul 1950 Mogi das Cruzes, cidadela do aço. O Cruzeiro, São Paulo, p. 68-73, 07 O aprendiz de palhaço. O Cruzeiro, São Paulo, p.94-99, 15 abr 1950. . O general B.C.G. ataca. O Cruzeiro. São Paulo, p.59-63, 09 jul 1949. . O outro lado do mundo. O Cruzeiro, São Paulo, p. 08-13, 28 jun 1947. . Os dominicanos. O Cruzeiro, São Paulo, p. 8-14, 09 ago 1947. . PRG-2 conquista o espaço. O Cruzeiro, São Paulo, p.94-97, 07 jan 1950. $\overline{\text { jan } 1948 .}$

Santo Amaro, refúgio do paulistano. O Cruzeiro, São Paulo, p. 53-56, 24 . Suécia - 3o lugar. O Cruzeiro, São Paulo, p. 116-117, 29 jul 1950. . Tiro aos pombos. O Cruzeiro, São Paulo, p. 38-41, 31 mai 1947. Trinta mil doentes. O Cruzeiro, São Paulo, p. 57-62, 02 ago 1947.

SILVA, Gastão Pereira da. O destino dos jardins. O Cruzeiro, São Paulo, p. 6267, 27 abr 1946.

\section{Habitat}

A.C. Problemas de vitrina. Habitat, São Paulo, n. 10, p.77-78, jan-mar 1953.

As arquiteturas do Convênio Escolar. Habitat, São Paulo, n.4, p. 7-40, jul-set 1951.

BARDI, Lina Bo. Função social dos museus. Habitat, São Paulo, n.1, p.17, outdez 1950.

FONZARO, Guido. O museu num álbum. Habitat, São Paulo, n. 13, p.78-79, outdez 1953.

Habitat, São Paulo, n. 3, p.77, abr-jun 1951.

Habitat, São Paulo, n.1, p.34, out-dez 1950.

Habitat, São Paulo, n.12, s.p., set 1953.

Habitat, São Paulo, n.9, p.12, out-dez 1952. 
MARTINS, Frans. A jangada segundo Albuquerque. Habitat, São Paulo, n. 8, p.50-57, jul-set 1952.

MOTTA, Flávio. São Paulo e o "art nouveau”. Habitat, São Paulo, n. 10, p.3-18, jan-mar 1953.

Prefácio. Habitat, São Paulo, n.1, p.1, out-dez 1950.

Residência no Morumbi. Habitat, São Paulo, n. 10, p. 30-40, jan-mar 1953.

\section{Revista Íris}

Revista Íris - Revista Brasileira de Foto, Cinema e Artes Gráficas. São Paulo, n. 35, p.14, fev. 1950.

Revista Íris - Revista Brasileira de Foto, Cinema e Artes Gráficas. São Paulo, n. 43, p.1;9, out. 1950.

Revista Íris - Revista Brasileira de Foto, Cinema e Artes Gráficas. São Paulo, n. 46, p.4, jan. 1951.

Revista Íris - Revista Brasileira de Foto, Cinema e Artes Gráficas. São Paulo, n. 78, p.1, set. 1953.

\section{Supplemento em Rotogravura de O Estado de S.Paulo}

Supplemento em Rotogravura de O Estado de S.Paulo. São Paulo, n. 143, s/n, set. 1939.

Supplemento em Rotogravura de O Estado de S.Paulo. São Paulo, n. 144, s/n, out. 1939.

Supplemento em Rotogravura de O Estado de S.Paulo. São Paulo, n. 145, s/n, out. 1939.

\section{Sites na Internet}

http://en.wikipedia.org/wiki/G\%C5\%82og\%C3\%B3w. Acesso em: 30 jan. 2008, às 16:00.

http://pt.wikipedia.org/wiki/Adolfo_Bloch. Acesso em: 10 mar 2008, às 17:00

http://www.anpedesign.org.br/artigos/pdf/O\%20Moderno\%20e\%200\%20

Vern\%E1culo\%20no\%20M\%F3vel\%20de\%20Lina\%20Bo\%20Bardi.pdf. Acesso 
em: 11 out 2008 , às 08:00.

http://www.fotoplus.com/flieg/index.html. Acesso em: 10 ago 2008, às 14:00.

http://www.greatbuildings.com/buildings/Flatiron_Building.html. Acesso em: 09 ago 2008, às 15:00.

http://www.gulfbrasil.com.br/publique/cgi/cgilua.exe/sys/start.htm?sid=4. Acesso em 23 jun 2008, às 21:00.

http://www.infraero.gov.br/impr_noti_prev.php?ni=848\&menuid=impr. Acesso em 09 jul 2008, às 13:30.

http://www.institutobardi.com.br/bardi/masp/masp2.html. Acesso em: 07 nov. 2007 às 11:30.

http://www.itaucultural.org.br/aplicexternas/enciclopedia_ic/index. cfm?fuseaction $=$ artistas_biografia\&cd_verbete $=1481 \& c d$ item $=1 \& c d$ _ idioma $=28555$. Acesso em: 07 nov. 2007 às 11:40.

http://www.monumentos.art.br/monumento/semeador. Acesso em 16 jul 2008, às 19:00.

http://www.saopaulo.sp.gov.br/saopaulo/cultura/museus_cafe.htm. Acesso em: 21 jul 2008, às 22:00.

http://www.saopaulominhacidade.com.br/list.asp?ID=76. Acesso em 21 jul 2007, às 19:00.

http://www.saopaulominhacidade.com.br/list.asp?ID=58. Acesso em 30 jun 2008, às 22:30.

http://www.touring.com.br/historia.php. Acesso em 23 jun 2008, às 21:00.

\section{Entrevistas e Depoimentos}

Anna Carboncini, coordenadora da coleção Masp-Pirelli de fotografia, em entrevista à autora, em 24 ago 2006.

Bettina Lenci, filha de Peter Scheier, em entrevista à autora, em 04 abr 2006.

Carlos Fadon Vicente, fotógrafo, em entrevista à autora em 03 ago 2006.

Hans Günter Flieg, fotógrafo, em entrevista à autora, em 05 set. 2005.

Luiz Hossaka, curador-chefe do MASP, em entrevista à autora em 10 ago 2006.

Depoimento de Benedito Junqueira Duarte - Fotografia paulista. Entrevistadores: Boris Kossoy, Moracy de Oliveira, Hans Günter Flieg e Máximo Barro. Data: 
14.05.1981. Acervo: Museu da Imagem e do Som. Transcrição feita por: Carolina da Costa e Silva.

\section{Álbuns Comemorativos do IV Centenário}

Eis São Paulo: uma obra realizada e editada no ano de 1954. São Paulo: Monumento, 1954.

Isto é São Paulo. 96 flagrantes da capital bandeirante. São Paulo: Melhoramentos, 1951.

Isto é São Paulo. 104 flagrantes da capital bandeirante. São Paulo: Melhoramentos, 1954.

KARFELD, Peter Kurt. São Paulo: álbum de fotografias em cores. São Paulo: Melhoramentos, 1954.

MEDINA, José. São Paulo, o que foi e o que é. s.I.: s.n.,1954.

São Paulo antigo, São Paulo moderno: álbum comparativo. Melhoramentos, 1953

SCHEIER, Peter. São Paulo fastest growing city in the world. Rio de Janeiro, Livraria Kosmos Editora, 1954.

\section{Obras Consultadas}

\section{Livros}

ALMEIDA, Maisa Fonseca de. As residências modernas paulistas e a construção de uma simbologia-O significado simbólico das tipologias residenciais modernas publicadas na revista Acrópole entre os anos de 1956 e 1971. São Carlos: EESC - Escola de Engenharia de São Carlos, 2007. Memorial de Qualificação para obtenção do Título de Mestre, p. 90-99.

ARNHEIM, Rudolf. La forma visual de la arquitectura. Editorial Gustavo Gili, S.A., Barcelona, 1978.

AZEVEDO, Mirandulina Maria Moreira. A experiência de Lina Bo Bardi no Brasil (1947-1992). São Paulo: FAUUSP, 1995. Dissertação de Mestrado.

BARDI, P. M. Em torno da fotografia no Brasil. São Paulo, Banco Sudameris Brasil, 1987.

BARTHES, Roland. A Câmara Clara: nota sobre a fotografia; tradução de Júlio 
Castañon Guimarães. Rio de Janeiro, Nova Fronteira, 1984.

BENJAMIN, Walter. Trad: MOITA, Maria Luz, CRUZ, Maria Amélia e ALBERTO, Manuel. "A Obra de Arte na Era da sua Reprodutibilidade Técnica". In: Sobre arte, técnica, linguagem e política. Lisboa: Relógio D’Água Editores, 1992, p. $71-113$.

Pequena História da Fotografia. In: Sobre arte, técnica, linguagem e política. Lisboa: Relógio D’Água Editores, 1992, p. 115-135.

BURLE-MARX, Roberto e FILHO, Nestor Goulart Reis (introdução). Rino Levi. Milão: Edizioni di Comunità, 1974.

CAPPELLO, Maria Beatriz Camargo. Arquitetura em Revista: Arquitetura Moderna no Brasil e sua Recepção nas Revistas Francesas, Inglesas e Italianas (19451960). São Paulo: FAUUSP, 2005. Tese de doutorado.

CAVALCANTI, Lauro. Moderno e brasileiro. Rio de Janeiro: Jorge Zahar Editor, 2006.

DUBOIS, Philippe. Trad: Marina Appenzeller. $O$ ato fotográfico e outros ensaios. Campinas: Papirus, 1994.

FALBEL, Anat. Peter Scheier, a modern photographer and the idea of city. Docomomo, São Paulo, n.37, p.12-19, set 2007

Peter Scheier: visões urbanas de um fotógrafo moderno na América. Anais do $7^{\circ}$ Seminário Docomomo, Porto Alegre, 2007.

FRANCESCHI, Antonio Fernando de (org). Cadernos de Fotografia Brasileira: São Paulo 450 anos. São Paulo: Instituo Moreira Sales / BEI, 2004.

GALLO, Antonella (org). Lina Bo Bardi architetto. Venezia: Marsilio Editori, 2004.

JUNIOR, Rubens Fernandes; LIMA, Michael Robert Alves de; VALADARES, Paulo. B.J.Duarte: caçador de imagens. São Paulo: Cosac Naify, 2007.

LEMOS, Carlos A.C. Arquitetura Contemporânea. In: ZANINI, Walter (org.) História Geral da Arte no Brasil. São Paulo: Instituto Walther Moreira Salles, 1983, vol. II, p. 825-865.

MACHADO, Arlindo. A perspectiva ou o olho do sujeito. In: A ilusão especular - introdução à fotografia. São Paulo: Brasiliense, 1984, p. 63-75.

MONTANER, Josep Maria. As formas do século XX. Barcelona: Editorial Gustavo Gili, 2002.

MORSE, Richard M. Formação Histórica de São Paulo (de comunidade à metrópole). São Paulo: Difusão Européia do Livro, 1970. 
NEWHALL, Beaumont. Historia de la fotografía. Barcelona: Editorial Gustavo Gili, 2002.

NOBRE, Ana Luiza. A eficácia do corte. In: FRANCESCHI, Antonio Fernando de. et al. O Brasil de Marcel Gautherot. São Paulo: Instituto Moreira Salles, 2001, p. 13-25.

NOBRE, Ana Luiza, KAMITA, João Masao, LEONÍDIO, Otavio, CONDURU, Roberto (org.). Um modo de ser moderno. São Paulo: Cosac Naify, 2004.

PALMA, Daniela. Fotografia: Arte e Sobrevivência. A trajetória de Hans Günter Flieg. São Paulo, Escola de Comunicações e Artes da Universidade de São Paulo, 2003. Dissertação de Mestrado.

PANOFSKY, Erwin. Significado nas artes visuais. São Paulo: Perspectiva, 2004.

PAOLI, Maria Cecília e DUARTE, Adriano. "São Paulo no plural: espaço público e redes de sociabilidade", In: PORTA, Paula (org.). História da Cidade de São Paulo: a cidade na primeira metade do século XX 1890-1954. São Paulo: Paz e Terra, 2004, v.3, p.63-78.

ROBINSON, Cervin e HERSCHMAN, Joel. Architecture Transformed. The MIT Press. New York. 1987.

SERAPIÃO, Fernando Castelo. Arquitetura Revista: a Acrópole e os edifícios de apartamentos em São Paulo (1938-1971). São Paulo: Universidade Presbiteriana Mackenzie, 2005. Dissertação de Mestrado.

SONTAG, Susan. Sobre Fotografia. Trad: Rubens Figueiredo. São Paulo: Companhia das Letras, 2004.

\section{Periódicos}

American Photography. New York, s/n, s/n, jan. 1950.

CAMARGO, Mônica Junqueira de. Brazilian presence in the historiography of twentieth century architecture. Docomomo, São Paulo, n. 34, p. 66-71, mar. 2006.

CORONA, Eduardo. Vida e morte de uma revista. Acrópole. São Paulo, n. 390/391, p.7, nov-dez 1971.

DEUTSCHES Architektur Museum. A Lifetime for Architecture: The Photographer Julius Shulman. 4 out - 11 dez 2005, Frankfurt, Alemanha. Catálogo de Exposição.

FALBEL, Anat. Peter Scheier, a modern photographer and the idea of city. Docomomo, São Paulo, n.37, p.12-19, set 2007. 
FELIZARDO, Luiz Carlos. Papel da fotografia - A inevitável atração entre fotografia e arquitetura. Revista Projeto, São Paulo, n. 176, p. 82-83, jul 1994.

FUÃO, Fernando Freitas. Papel do papel: As folhas da arquitetura e arquitetura mesma. Revista Projeto, São Paulo, n. 176, p. 84-85, jul 1994.

GALIANO, Luiz Fernández. Papel fotográfico - Imagens que constroem a arquitetura. Tradução de Anita Regina Di Marco. Revista Projeto, São Paulo, n. 176, p. 81, jul 1994.

MASCARO, Cristiano. Papel do fotógrafo - um profissional necessário. Revista Projeto, São Paulo, n. 176, p. 79-80, jul 1994.

SEGAWA, Hugo e DOURADO, Guilherme Mazza. Oswaldo Arthur Bratke. São Paulo: ProEditores, 1997.

SERAPIÃO, Fernando e KON, Nelson. Hans Günter Flieg (entrevista). ProjetoDesign, São Paulo, n.307, p. 6-8, set 2005.

SERAPIÃO, Fernando. Manfredo Gruenwald (entrevista). ProjetoDesign, São Paulo, n.312, p. 10-12, fev. 2006.

WAISMAN, Marina. O centro se desloca para as margens. Tradução de Anita Regina Di Marco. Revista Projeto, São Paulo, n. 129, p. 73-101, jan-fev 1990.

\section{Habitat}

Habitat, São Paulo, n.2, p. 4, jan-mar 1951.

Habitat 4 dedicada às Escolas. Habitat, São Paulo, n.3, p. 29, abr-jun 1951.

Habitat, São Paulo, n.8, p.1, jul-set 1952.

Ibirapuera. Habitat, São Paulo, n.11, p.3, jun 1953.

Editorial. Habitat, São Paulo, n.26, p.1, jan 1956.

Editorial. Habitat, São Paulo, n.40-41, p.1, mar-abr 1957.

O Museu de Arte e a Fundação A.A. Penteado. Habitat, São Paulo, n.44, p.86-90, set 1957.

BARDI, Lina Bo. Móveis novos. Habitat, São Paulo, n.1, p.53, out-dez 1950.

. Bela criança. Habitat, São Paulo, n.2, p. 3, jan-mar 1951.

. Primeiro: escolas. Habitat, São Paulo, n.4, p.1, jul-set 1951. jun 1952.

. Necessidade da crítica de arquitetura. Habitat, São Paulo, n.7, p.53, abr- 
BARDI, Lina Bo e BARDI, P.M. Declaração. Habitat, São Paulo, n.15, p.1, mar-abr 1954.

BARDI, P. M. Habitat, São Paulo, n.3, p. 77, abr-jun 1951.

CHATEAUBRIAND, Assis. Agora ou nunca mais. Habitat, São Paulo, n.2, p.53, jan-mar 1951.

KLEIN, Rodolfo. Declaração. Habitat, São Paulo, n.15, p.1, mar-abr 1954. . Editorial. Habitat, São Paulo, n.16, p.1, mai-jun 1954.

MAZZOCCHI, Maurício. A casa, sua construção e industrialização. Habitat, São Paulo, n.29, p.33, abr 1956.

SOUZA, Abelardo. Crítica de Arquitetura. Habitat, São Paulo, n.16, p.2, mai-jun 1954.

\section{Sites na Internet}

http://pt.wikipedia.org/wiki/Roland_Barthes. Acesso em: 26/09/2007, às 19:30.

http://pt.wikipedia.org/wiki/Vit\%C3\%B3ria_p\%C3\%ADrrica. Acesso em: 29 nov 2007, às 12:00.

http://www.estacaoliberdade.com.br/autores/barthes.htm. Acesso em: 26/09/2007, às 19:26.

http://home.snafu.de/boehme/Liste14/221\%20wolffarbeit.JPG. Acesso em: 16 ago 2008, às 12:20.

http://www.masters-of-photography.com/R/rodchenko/rodchenko.html. Acesso em: 29 nov. 2006, às 10:00.

http://www.moma.org/collection/browse_results.php?criteria=0\%3AAD\%3AE\% 3A5145\&page_number $=1 \&$ template_id $=6 \&$ sort_order $=1$. Acesso em: 31 jan. 2008, às 15:30.

http://www.richardavedon.com/. Acesso em: 07 mai 2008, às 10:10.

http://www.susansontag.com/biography.htm. Acesso em: 26/09/2007, às 19:24.

\section{Acervos e Bibliotecas}

Acervo fotográfico da Faculdade de Arquitetura e Urbanismo da USP FAUUSP 
Arquivo Histórico Judaico Brasileiro - AHJB

Arquivo Histórico Municipal Washington Luís - AHMWL

Biblioteca da Faculdade de Direito da USP - FDUSP

Biblioteca Municipal Mário de Andrade - BMMA

Instituto Lina Bo e P.M. Bardi - ILPB

Museu de Arte de São Paulo - MASP 


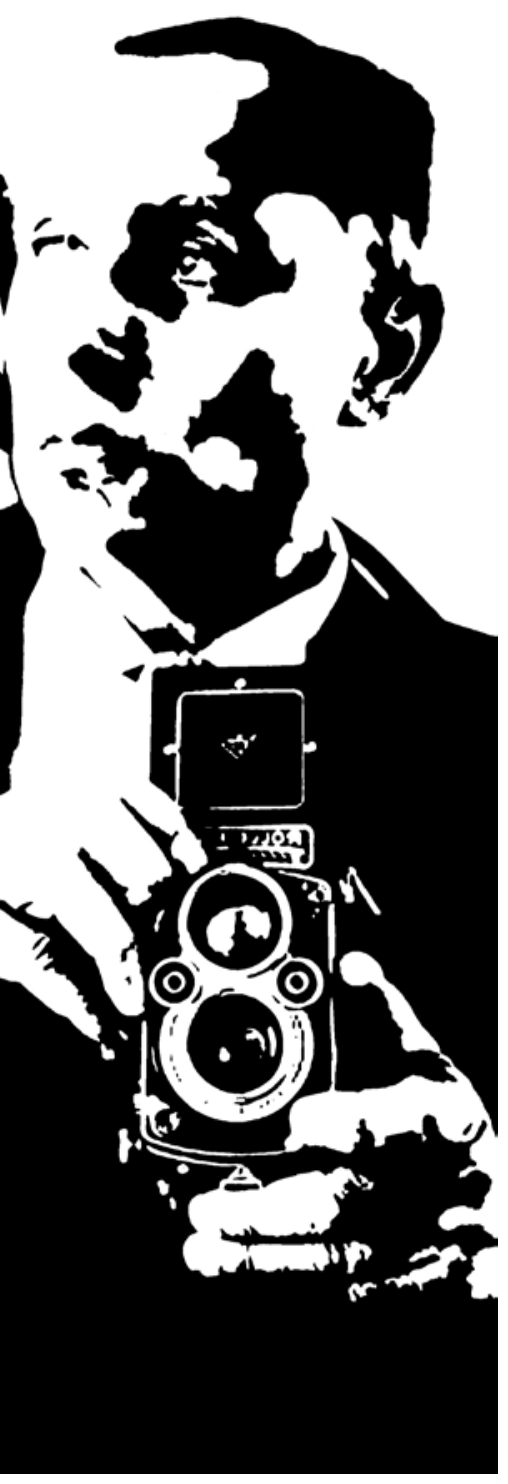




\section{Apêndice A - Cronologia de Peter Scheier}

\section{Cronologia de Peter Scheier Referências citadas no texto}

1908

Nasce Peter Scheier no dia 06 de junho, na cidade de Glogau, Alemanha.

1911

Movimento expressionista Der blaue Reiter.

1914-1917

Primeira Guerra Mundial.

1916

Prefeito Washington Luiz publica três álbuns comparativos de São Paulo, com fotografias de Militão Augusto e Aurélio Beccherini.

1918

Formação do Novembergruppe. 
1919

Assinatura do Tratado de Versalhes.

Fundação da Bauhaus.

Cinema: O Gabinete do Dr. Caligari, de Robert Wiene.

1922

Semana de Arte Moderna de São Paulo.

1923

Lászlo Moholy-Nagy convidado para a Bauhaus

Criação da Nova Objetividade.

1924

Lançamento da Leica para o grande público.

1925

Publicação de Malerei, Photographie, Film, de Lászlo Moholy-Nagy.

1926

Cinema: Metropolis, de Fritz Lang.

1927

Charles Sheeler faz as fotos da fábrica da Ford em Detroit (Ford Motor Company). 
1928

Fechamento da loja de departamento dos Scheier, em Glogau.

1931

Peter Scheier deixa Alemanha e parte para Áustria, permanecendo em Hohenau por quatro anos.
1928

Lançamento das revistas Vu (França) e o Cruzeiro.

Livro Die Welt ist shön, de Albert Renger-Patzch

1929

Exposição Film und Foto (FIFO), em Stuttgart

1931

Cinema: $M$ - O vampiro de Dusseldorf, de Fritz Lang.

1933

Hitler sobe ao poder.

Suspensão dos direitos humanos na Alemanha.

Fechamento da Bauhaus pelos nazistas.

Primeira grande onda emigratória de judeus alemães.

1934

As minhas experiências com a Leica, de Paul Wolff

Getúlio Vargas é eleito presidente pela Assembléia Nacional Constituinte

Alice Brill chega ao Brasil. 
1935

Proclamação das Leis de Nuremberg.

1936

Lançamento da Life Magazine (Estados Unidos).

Circulação dos dez números da Revista S.Paulo.

1937

1937

Peter Scheier deixa a Europa rumo ao Brasil, desembarcando no porto do Rio de Janeiro, em 25 de outubro. Consegue emprego no frigorífico.

Início do Estado Novo no Brasil.

Hildegard Rosenthal chega ao Brasil. 1938

Noite Dos Cristais.

Criação da revista Acrópole.

1938

Julius Scheier e Hedwig Strakosch deixam Glogau e partem para o Brasil.

1939

Hans Günter Flieg chega ao Brasil.

1938-39

1938 a 1941

Peter Scheier inicia sua carreira de fotógrafo, preparando um catálogo das cúpulas de abajour que vendia, para complementar seu salário como empregado do frigoríico.

Adhemar de Barros governa São Paulo como interventor.

1938-1945

Prestes Maia é prefeito de São Paulo e 1939 implanta o Plano de Avenidas.

Gertrude Willheim deixa a Europa rumo ao Brasil. 1939

Peter Scheier casa-se com Gertrude. Início da Segunda Guerra Mundial. 
Peter Scheier recebe o $1^{\circ}$. Prêmio do Concurso Centenário de Photographia, promovido pelo Suplemento de Rotogravura do jornal O Estado de S.Paulo.

1940

Com a colaboração da esposa, abre o estúdio fotográfico FOTO STUDIO PETER SCHEIER, na Rua Dr. Teodoro Baima, 87.

1940-43

Peter Scheier fotografa várias obras de Rino Levi: Instituto Sedes Sapientiae, Edifício Porchat, Cine Ipiranga e Hotel Excelsior e Companhia Jardim de Cafés Finos.

1941

Peter Scheier fotografa as residências João Arnstein e Virgílio Frontini, de Bernardo Rudofsky.

1942

Nasce seu primeiro filho, Thomas Roberto Scheier.

1944

A família Scheier muda-se para Alameda Casa Branca, 363.
Fundação do Foto Clube Bandeirante.

1940

Chegada ao Brasil de Jean Manzon, Henri Ballot e Marcel Gautherot. 
1945

Nasce sua segunda filha, Irene Elizabeth Scheier.

1945

Peter Scheier inicia colaboração para a revista $O$ Cruzeiro, para a qual realizou reportagens até 1951. A primeira reportagem é publicada em 13 de março, "Uma cruz entre dunas", com texto de Franklin de Oliveira.

1947

Peter Scheier torna-se fotógrafo oficial do MASP, registrando suas atividades, eventos e acervo. Publica reportagens sobre o MASP na revista $O$ Cruzeiro.

1947 [?]

Peter Scheier muda-se para os Estados Unidos.

1948-1950

Peter Scheier fotografa para o Palma Studio de Arte e Arquitetura.

1950-1953

Peter Scheier colabora com a revista Habitat, dirigida por Lina Bo Bardi
1945

Fim da Segunda Guerra Mundial. Fim do Estado Novo. Eurico Gaspar Dutra é eleito presidente da República.

1946

Lina Bo e Pietro Bardi chegam ao Brasil.

Pierre Verger também desembarca no país.

Fundação da Revista Íris - Revista Brasileira de Foto, Cinema e Artes Gráficas.

Fundação do Museu de Arte Moderna (MAM).

1947

Inauguração do MASP - Museu de Arte de São Paulo, na Rua Sete de Abril, em 04 de outubro.

1947-1951

Adhemar de Barros é eleito governador do estado de São Paulo.

1948

Pietro Bardi, Lina e Giancarlo Palanti fundam o Palma Studio de Arte e Arquitetura.

1950 
Peter Scheier fotografa a residência Lina Bo Bardi.

Fotografa as instalações da 1a Bienal Internacional de São Paulo.

Última reportagem de Peter Scheier publicada na revista $O$ Cruzeiro, "Um flagelo brasileiro: "barriga d'água", com texto de Arlindo Silva, em 27 de outubro.

1951-58

Peter Scheier fotografa várias obras de Rino Levi: Edifício OAB, Residência Milton Guper e Garagem América. Fotografa também a residência Oscar Americano, de Oswaldo Bratke, e a casa Valéria P. Cirrell, de Lina Bo Bardi.

\section{2}

Inicia seu trabalho em fotografia industrial, executando trabalhos para Ultragaz (1952-1954), Klabin (1953, 1963), Rhodia (1954-1968), Volkswagen (1954-1957), Labortherapica (1958), Bimetal (1958), Metalleve (1959), Usafarma (1961-1968), Coldex (19641966), Metalúrgica Barbará (1965), Aço Villares (1968).

1953

Publicação do livro Paraná, Brasil. Edição Comemorativa do $1^{\circ}$ Centenário do Estado do Paraná, pela Imprensa
Thomaz Farkas projeta e instala o laboratório fotográfico do MASP.

É inaugurada a TV Tupi de São Paulo por Assis Chateaubriand.

Criação da revista Habitat

1951

Getúlio Vargas é eleito presidente pela segunda vez.

\author{
e

o


Paranaense.

Última colaboração de Peter Scheier como fotógrafo do MASP.

1954

Por ocasião do IV Centenário da cidade de São Paulo, publica o álbum São Paulo: fastest growing city in the world, pela Livraria Kosmos Editora.

1958-1962

Peter Scheier trabalha como fotógrafo oficial dos eventos da TV Record a partir de setembro de 1958.

1959

Por ocasião do 10 o aniversário da criação do Estado de Israel (ocorrida em 1948), Scheier o visita. As fotos foram publicadas em uma série de reportagens no jornal Diário de São Paulo.
1954

Suicídio de Getúlio Vargas.

Inauguração da Catedral da Sé

Afastamento de Lina Bo e Pietro Bardi da direção da revista Habitat.

1955

Publicação de Latin American

Architecture since 1945.

Criação da revista Módulo

1956

Publicação de Modern Architecture in Brazil.

1956-1961

Governo de Juscelino Kubitschek.

$1959 / 1960$

É inaugurada a TV Excelsior de São Paulo. 
1960

Peter Scheier fotografa a casa de Francisco Matarazzo Sobrinho, em Ubatuba, projeto de Oswaldo Bratke.

Peter Scheier publica, pela Livraria Kosmos Editora, o livro Brasília Vive!.

1965

Peter Scheier cobre a visita de Robert Kennedy ao Brasil.

Inicia suas pesquisas em multivisão.

1966

Peter Scheier fotografa as obras do edifício do MASP, de Lina Bo Bardi, na Avenida Paulista. Dois anos antes já havia fotografado o terreno, as plantas e a maquete.

1968

Peter Scheier publica o livro Imagens do passado de Minas Gerais, pela Livraria Kosmos Editora.

Apresenta produção em multivisão na Feira Internacional de Alimentação em Paris.

1970

Em março é inaugurada a Exposição Mundial de Osaka, para a qual Peter Scheier produziu uma apresentação em multivisão.
1960

Inauguração de Brasília.

1963-1966

Adhemar de Barros é reeleito governador do estado de São Paulo.

1964

Início da ditadura militar no Brasil.
1968

Assis Chateaubriand morre em 04 de abril, em São Paulo.

A sede do MASP na Avenida Paulista é inaugurada em 7 de novembro. 
Acontece sua única exposição em vida, no MASP: 30 anos de Visão e Multivisão, de 07 a 27 de agosto.

1972

Peter Scheier muda-se para a Alameda Santos.

1975

Decidido a retornar à Alemanha, Scheier fecha seu estúdio.

1979

Peter Scheier morre em Ainring, Alemanha, em 08 de novembro. Scheier foi enterrado em Salzburg, no cemitério judaico, perto da estação de trem, em 1980.

1992

Exposição coletivano MASP: Saudades do Brasil: a era JK.

1996

Exposição coletiva: Brasil, um refúgio nos trópicos, no Centro Cultural São Paulo.

2002

Exposição coletiva: Três gerações de fotógrafos no CAP, na Sala de Artes Plásticas do Clube Athletico 
Paulistano.

Exposição coletiva: Da antropofagia a Brasília, no Museu de Arte Brasileira.

2003

Exposição coletiva: Coleção Pirelli/

MASP de fotografias - 12a edição, no MASP.

2004

Exposição coletiva: $S P$ 450: entre lembranças e utopias, no Museu de Arte Brasileira.

[?] data provável.

O acervo de Peter Scheier pertence atualmente ao Arquivo Histórico Judaico Brasileiro, que abriga toda a documentação do fotógrafo. A documentação fotográfica das obras do arquiteto Rino Levi pertence à biblioteca da FAUUSP. A documentação fotográfica de Lina Bo Bardi pertence ao Instituto Lina Bo e P.M. Bardi, sendo que a documentação do MASP também está disponível na sede do museu, que possui a coleção completa da revista $O$ Cruzeiro. 


\section{Apêndice B - Reportagens de Peter Scheier em 0 Cruzeiro - 1945 a 1951}

\section{Total: 116 reportagens}

\begin{tabular}{|l|l|l|l|l|l|l|l|}
\hline Ano & Edição & Pág. & Reportagem & Texto & Local & Assunto & $\begin{array}{l}\text { Palavras- } \\
\text { chave }\end{array}$ \\
\hline 1945 & $31 / 03$ & $52-57$ & $\begin{array}{l}\text { Bussocaba e Vila } \\
\text { Mascote }\end{array}$ & $\begin{array}{l}\text { Freitas } \\
\text { Nobre }\end{array}$ & São Paulo & $\begin{array}{l}\text { Abrigo de } \\
\text { mendigos, } \\
\text { idosos }\end{array}$ & Instituições \\
\hline 1945 & $21 / 04$ & $56-61$ & $\begin{array}{l}\text { Os cegos do } \\
\text { "Padre Chico" }\end{array}$ & $\begin{array}{l}\text { Freitas } \\
\text { Nobre }\end{array}$ & São Paulo & $\begin{array}{l}\text { Instituto } \\
\text { Padre Chico }\end{array}$ & Instituições \\
\hline 1945 & $05 / 05$ & $56-61$ & $\begin{array}{l}\text { Amor e morte na } \\
\text { cidade de cêra }\end{array}$ & Nelson Motta & São Paulo & $\begin{array}{l}\text { Apiário no } \\
\text { Parque da }\end{array}$ & Aariedades \\
\hline 1945 & $02 / 06$ & $56-61$ & $\begin{array}{l}\text { Aranca } \\
\text { Sofre! cabelo também }\end{array}$ & Alceu Pereira & São Paulo & Cabeleireiros & Variedades \\
\hline
\end{tabular}




\begin{tabular}{|c|c|c|c|c|c|c|c|}
\hline 1945 & 02/06 & 8-17 & $\begin{array}{l}\text { O enterro de um } \\
\text { grande morto }\end{array}$ & Nelson Motta & São Paulo & $\begin{array}{l}\text { Enterro de } \\
\text { Armando } \\
\text { Salles de } \\
\text { Oliveira }\end{array}$ & $\begin{array}{l}\text { Personalidades } \\
\text { Eventos }\end{array}$ \\
\hline 1945 & $16 / 06$ & $60-63$ & $\begin{array}{l}\text { A sociedade } \\
\text { paulista vai ao } \\
\text { futebol... }\end{array}$ & $\begin{array}{l}\text { Maria } \\
\text { Antônia }\end{array}$ & São Paulo & $\begin{array}{l}\text { Alta } \\
\text { sociedade no } \\
\text { estádio }\end{array}$ & $\begin{array}{l}\text { Personalidades } \\
\text { Eventos }\end{array}$ \\
\hline 1945 & $23 / 06$ & $54-63$ & $\begin{array}{l}\text { Barricada na } \\
\text { cozinha }\end{array}$ & Nelson Motta & São Paulo & $\begin{array}{l}\text { Escola } \\
\text { Santa Rita } \\
\text { - prepara } \\
\text { donas-de- } \\
\text { casa }\end{array}$ & Instituições \\
\hline 1945 & $23 / 06$ & $8-13$ & $\begin{array}{l}\text { Circo-teatro do } \\
\text { povo }\end{array}$ & $\begin{array}{l}\text { Freitas } \\
\text { Nobre }\end{array}$ & São Paulo & Circo Piolin & Lazer \\
\hline 1945 & $30 / 06$ & 54-61 & $\begin{array}{l}\text { A jornada do } \\
\text { Pacaembu }\end{array}$ & Nelson Motta & São Paulo & $\begin{array}{l}\text { Jornada } \\
\text { democrática } \\
\text { da União } \\
\text { Democrática } \\
\text { Nacional }\end{array}$ & Eventos \\
\hline 1945 & $04 / 08$ & $56-61$ & $\begin{array}{l}\text { A cruz vermelha } \\
\text { em São Paulo }\end{array}$ & $\begin{array}{l}\text { Maria } \\
\text { Antônia }\end{array}$ & São Paulo & $\begin{array}{l}\text { Cruz } \\
\text { Vermelha }\end{array}$ & Instituições \\
\hline 1945 & $11 / 08$ & $8-15$ & $\begin{array}{l}\text { Quando a crença } \\
\text { se faz carne }\end{array}$ & Nelson Motta & Aparecida & Religião & Religião \\
\hline 1945 & $01 / 09$ & $56-61$ & $\begin{array}{l}\text { Mensagem contra } \\
\text { o demônio }\end{array}$ & Nelson Motta & São Paulo & $\begin{array}{l}\text { Pregadores } \\
\text { cristãos - } \\
\text { Exército da } \\
\text { Salvação }\end{array}$ & Religião \\
\hline 1945 & $06 / 10$ & $8-15$ & $\begin{array}{l}\text { A montanha contra } \\
\text { a morte }\end{array}$ & Nelson Motta & $\begin{array}{l}\text { Campos do } \\
\text { Jordão }\end{array}$ & Tuberculose & Saúde \\
\hline
\end{tabular}




\begin{tabular}{|c|c|c|c|c|c|c|c|}
\hline 1945 & $08 / 12$ & $62-67$ & $\begin{array}{l}\text { Um dia no bosque } \\
\text { dos anões }\end{array}$ & Rocha Pitta & Santo André & $\begin{array}{l}\text { Colônia de } \\
\text { anões }\end{array}$ & Variedades \\
\hline 1945 & $15 / 12$ & $62-65$ & $\begin{array}{l}\text { Tem a palavra o } \\
\text { orador }\end{array}$ & Rocha Pitta & São Paulo & $\begin{array}{l}\text { Primeiro } \\
\text { Congresso } \\
\text { Infantil de } \\
\text { Escritores }\end{array}$ & Eventos \\
\hline 1945 & $22 / 12$ & $8-15$ & $\begin{array}{l}\text { O crime não } \\
\text { compensa }\end{array}$ & Rocha Pitta & São Paulo & $\begin{array}{l}\text { Laboratório } \\
\text { de Polícia } \\
\text { Técnica }\end{array}$ & Variedades \\
\hline 1946 & $12 / 01$ & $62-64$ & $\begin{array}{l}\text { Judeus sem } \\
\text { dinheiro }\end{array}$ & Rocha Pitta & São Paulo & $\begin{array}{l}\text { Gueto no } \\
\text { Bom Retiro }\end{array}$ & Sociedade \\
\hline 1946 & 09/03 & $56-61$ & Tocaia no Butantan & Nelson Motta & São Paulo & $\begin{array}{l}\text { Cobra come } \\
\text { sapo no } \\
\text { Instituto } \\
\text { Butantã }\end{array}$ & Variedades \\
\hline 1946 & $27 / 04$ & $62-67$ & $\begin{array}{l}\text { O destino dos } \\
\text { jardins }\end{array}$ & $\begin{array}{l}\text { Gastão } \\
\text { Pereira da } \\
\text { Silva }\end{array}$ & São Paulo & $\begin{array}{l}\text { Degradação } \\
\text { dos jardins } \\
\text { públicos }\end{array}$ & Cidades \\
\hline 1946 & $18 / 05$ & $56-61$ & $\begin{array}{l}\text { Um corvo na } \\
\text { cidade dos } \\
\text { pássaros }\end{array}$ & Nelson Motta & Santos & $\begin{array}{l}\text { Coleção de } \\
\text { pássaros }\end{array}$ & Variedades \\
\hline 1946 & $01 / 06$ & $64-65$ & $\begin{array}{l}\text { O barão em São } \\
\text { Paulo }\end{array}$ & $\begin{array}{l}\text { Maria } \\
\text { Antônia }\end{array}$ & São Paulo & $\begin{array}{l}\text { Barão do Rio } \\
\text { Branco }\end{array}$ & Personalidades \\
\hline 1946 & $15 / 06$ & $56-61$ & $\begin{array}{l}\text { Viagem num sêlo } \\
\text { de tostão }\end{array}$ & Nelson Motta & São Paulo & Selos & Variedades \\
\hline
\end{tabular}




\begin{tabular}{|c|c|c|c|c|c|c|c|}
\hline 1946 & 06/07 & $8-14$ & $\begin{array}{l}\text { O baile do boi } \\
\text { morto }\end{array}$ & Nelson Motta & São Paulo & Frigorífico & Variedades \\
\hline 1946 & $27 / 07$ & $54-57$ & $\begin{array}{l}\text { Saldanha não foi } \\
\text { degolado }\end{array}$ & Nelson Motta & São Paulo & $\begin{array}{l}\text { General João } \\
\text { Francisco }\end{array}$ & Personalidades \\
\hline 1946 & $17 / 08$ & $54-57$ & $\begin{array}{l}\text { A moda em dois } \\
\text { séculos }\end{array}$ & $\begin{array}{l}\text { Maria } \\
\text { Antônia }\end{array}$ & São Paulo & Moda & Variedades \\
\hline 1946 & $21 / 09$ & $56-61$ & $\begin{array}{l}\text { No acampamento } \\
\text { do rio das mortes }\end{array}$ & $\begin{array}{l}\text { Vergniaud } \\
\text { Gonçalves }\end{array}$ & $\begin{array}{l}\text { Chavantina, } \\
\text { Goiânia }\end{array}$ & Expedição & Variedades \\
\hline 1946 & $12 / 10$ & $60-63$ & A última fila & Nelson Motta & São Paulo & $\begin{array}{l}\text { Casa de } \\
\text { banho na } \\
\text { Rua Capitão } \\
\text { Salomão } \\
\text { (centro) }\end{array}$ & Sociedade \\
\hline 1946 & $19 / 10$ & $8-13$ & A ilha do perigo & Nelson Motta & São Paulo & Gasogênio & Variedades \\
\hline 1946 & 09/11 & $60-64$ & A batalha da terra & $\begin{array}{l}\text { Meira } \\
\text { Rodrigues }\end{array}$ & São Paulo & $\begin{array}{l}\text { Crise da } \\
\text { economia } \\
\text { agrária }\end{array}$ & Economia \\
\hline 1947 & $22 / 03$ & $38-42$ & $\begin{array}{l}\text { Fiacres de Central } \\
\text { Park }\end{array}$ & $\begin{array}{l}\text { Fernando } \\
\text { Lôbo }\end{array}$ & New York & Fiacres & Variedades \\
\hline 1947 & $05 / 04$ & $36-40$ & $\begin{array}{l}\text { Casa das } \\
\text { recordações }\end{array}$ & $\begin{array}{l}\text { Freitas } \\
\text { Nobre }\end{array}$ & São Paulo & $\begin{array}{l}\text { Casa dos } \\
\text { Atos (artistas } \\
\text { aposentados) }\end{array}$ & Instituições \\
\hline
\end{tabular}




\begin{tabular}{|c|c|c|c|c|c|c|c|}
\hline 1947 & $12 / 04$ & $60-64$ & $\begin{array}{l}\text { As duas vidas } \\
\text { do "Homem } \\
\text { Montanha" }\end{array}$ & $\begin{array}{l}\text { Peter } \\
\text { Scheier }\end{array}$ & São Paulo & Luta livre & Esporte \\
\hline 1947 & $26 / 04$ & $8-16$ & O Braz & $\begin{array}{l}\text { Freitas } \\
\text { Nobre }\end{array}$ & São Paulo & $\begin{array}{l}\text { O bairro do } \\
\text { Brás }\end{array}$ & Cidades \\
\hline 1947 & $24 / 05$ & $52-58$ & Lar São Francisco & $\begin{array}{l}\text { Freitas } \\
\text { Nobre }\end{array}$ & São Paulo & $\begin{array}{l}\text { Casa para } \\
\text { crianças } \\
\text { paralíticas }\end{array}$ & Instituições \\
\hline 1947 & $31 / 05$ & $38-41$ & Tiro aos pombos & Arlindo Silva & São Paulo & Atiradores & Lazer \\
\hline 1947 & $28 / 06$ & $08-13$ & $\begin{array}{l}\text { O outro lado do } \\
\text { mundo }\end{array}$ & Arlindo Silva & São Paulo & $\begin{array}{l}\text { Manicômio } \\
\text { do Juqueri }\end{array}$ & Instituições \\
\hline 1947 & $28 / 06$ & $58-61$ & $\begin{array}{l}\text { Nós acusamos os } \\
\text { russos! }\end{array}$ & Arlindo Silva & São Paulo & $\begin{array}{l}\text { Chegada de } \\
\text { imigrantes }\end{array}$ & Sociedade \\
\hline 1947 & $02 / 08$ & $57-62$ & Trinta mil doentes & Arlindo Silva & São Paulo & $\begin{array}{l}\text { Construção } \\
\text { do Hospital } \\
\text { das Clínicas }\end{array}$ & Instituições \\
\hline 1947 & $09 / 08$ & $8-14$ & Os dominicanos & Arlindo Silva & São Paulo & $\begin{array}{l}\text { Convento } \\
\text { dos } \\
\text { Dominicanos }\end{array}$ & Instituições \\
\hline 1947 & 06/09 & $58-61$ & A nova abolição & Arlindo Silva & São Paulo & $\begin{array}{l}\text { Campanha } \\
\text { de } \\
\text { Alfabetização } \\
\text { de Adultos }\end{array}$ & Sociedade \\
\hline
\end{tabular}




\begin{tabular}{|c|c|c|c|c|c|c|c|}
\hline 1947 & $13 / 09$ & $08-12$ & $\begin{array}{l}\text { O fumo, êsse } \\
\text { inimigo }\end{array}$ & Arlindo Silva & São Paulo & $\begin{array}{l}\text { Santa } \\
\text { Casa de } \\
\text { Misericórdia }\end{array}$ & Saúde \\
\hline 1947 & $13 / 09$ & $54-56$ & $\begin{array}{l}\text { Imigrantes Grã- } \\
\text { Finos }\end{array}$ & David Nasser & São Paulo & $\begin{array}{l}\text { Imigrantes } \\
\text { alemães }\end{array}$ & Sociedade \\
\hline 1947 & $20 / 09$ & $54-57$ & $\begin{array}{l}\text { Monitores para o } \\
\text { "Museu da Arte" }\end{array}$ & Arlindo Silva & São Paulo & $\begin{array}{l}\text { MASP - } \\
\text { escola } \\
\text { preparatória } \\
\text { para } \\
\text { monitores }\end{array}$ & Instituições \\
\hline 1947 & $18 / 10$ & $62-65$ & $\begin{array}{l}\text { Gaita para meio } \\
\text { mundo }\end{array}$ & Arlindo Silva & $\begin{array}{l}\text { Santa } \\
\text { Catarina }\end{array}$ & $\begin{array}{l}\text { Fábrica de } \\
\text { gaitas em } \\
\text { Blumenau }\end{array}$ & Variedades \\
\hline 1947 & $01 / 11$ & $54-60$ & Arte para milhões & Arlindo Silva & São Paulo & $\begin{array}{l}\text { MASP - } \\
\text { inauguração } \\
\text { do MASP }\end{array}$ & Instituições \\
\hline 1947 & $08 / 11$ & $56-61$ & $\begin{array}{l}\text { Os alemães } \\
\text { querem paz }\end{array}$ & Arlindo Silva & $\begin{array}{l}\text { Santa } \\
\text { Catarina }\end{array}$ & $\begin{array}{l}\text { Colonização } \\
\text { alemã no sul } \\
\text { (Blumenau e } \\
\text { Joinvile) }\end{array}$ & Sociedade \\
\hline 1947 & $22 / 11$ & $57-60$ & $\begin{array}{l}\text { Os pescadores de } \\
\text { diamantes }\end{array}$ & Arlindo Silva & Curitiba & $\begin{array}{l}\text { Garimpo de } \\
\text { diamantes }\end{array}$ & Variedades \\
\hline 1947 & $06 / 12$ & $68-74$ & $\begin{array}{l}\text { Bom Jesus de } \\
\text { Pirapora }\end{array}$ & Arlindo Silva & Pirapora (SP) & Religião & Religião \\
\hline 1948 & $17 / 01$ & $86-88$ & $\begin{array}{l}\text { O modelo nasce } \\
\text { em Brooklin }\end{array}$ & $\begin{array}{l}\text { Fernando } \\
\text { Lôbo }\end{array}$ & New York & Modelos & Variedades \\
\hline
\end{tabular}




\begin{tabular}{|c|c|c|c|c|c|c|c|}
\hline 1948 & $24 / 01$ & $53-56$ & $\begin{array}{l}\text { Santo Amaro, } \\
\text { refúgio do } \\
\text { paulistano }\end{array}$ & Arlindo Silva & São Paulo & $\begin{array}{l}\text { Lazer em } \\
\text { Santo Amaro }\end{array}$ & Cidades \\
\hline 1948 & $07 / 02$ & $39-41$ & $\begin{array}{l}\text { Shoshaburo } \\
\text { conquista São } \\
\text { Paulo }\end{array}$ & $\begin{array}{l}\text { Samuel } \\
\text { Wainer }\end{array}$ & São Paulo & $\begin{array}{l}\text { Agricultor } \\
\text { - imigrante } \\
\text { japonês }\end{array}$ & Sociedade \\
\hline 1948 & $10 / 04$ & $60-65$ & A Festa do Divino & Arlindo Silva & Tietê (SP) & $\begin{array}{l}\text { Festa do } \\
\text { Divino }\end{array}$ & Religião \\
\hline 1948 & $01 / 05$ & $62-65$ & $\begin{array}{l}\text { Os adventistas } \\
\text { consideram já } \\
\text { chegados os sinais } \\
\text { do fim do mundo }\end{array}$ & Arlindo Silva & São Paulo & $\begin{array}{l}\text { Igreja } \\
\text { Adventista }\end{array}$ & Religião \\
\hline 1948 & $27 / 11$ & $18-24$ & $\begin{array}{l}\text { A bandeira de } \\
\text { Roosevelt }\end{array}$ & $\begin{array}{l}\text { Franklin de } \\
\text { Oliveira. } \\
\text { Fotos de } \\
\text { Kikoler e } \\
\text { Scheier }\end{array}$ & New York & $\begin{array}{l}\text { Reeleição } \\
\text { de Harry } \\
\text { Truman para } \\
\text { presidência } \\
\text { dos EUA. }\end{array}$ & Política \\
\hline 1948 & $25 / 12$ & $76-79$ & Natal na Broadway & Kikoler & New York & $\begin{array}{l}\text { Dia de Ação } \\
\text { de Graças }\end{array}$ & Sociedade \\
\hline 1949 & $12 / 02$ & $84-90$ & Meia-volta volver & $\begin{array}{l}\text { Reportagem } \\
\text { fotográfica } \\
\text { de Peter } \\
\text { Scheier }\end{array}$ & Washington & $\begin{array}{l}\text { Posse } \\
\text { Truman }\end{array}$ & Política \\
\hline 1949 & $26 / 03$ & $43-47$ & $\begin{array}{l}\text { Carnaval em São } \\
\text { Paulo }\end{array}$ & $\begin{array}{l}\text { Reportagem } \\
\text { fotográfica } \\
\text { de Peter } \\
\text { Scheier }\end{array}$ & São Paulo & Carnaval & Lazer \\
\hline 1949 & $23 / 04$ & $40-43$ & A música e a dança & $\begin{array}{l}\text { Reportagem } \\
\text { de Peter } \\
\text { Scheier }\end{array}$ & New York & $\begin{array}{l}\text { Pianista } \\
\text { Bernardo } \\
\text { Segall }\end{array}$ & Personalidades \\
\hline
\end{tabular}




\begin{tabular}{|c|c|c|c|c|c|c|c|}
\hline 1949 & $14 / 05$ & $52-57$ & $\begin{array}{l}\text { Jornada contra a } \\
\text { morte }\end{array}$ & Arlindo Silva & São Paulo & $\begin{array}{l}\text { Sanatorinhos, } \\
\text { Tuberculose, } \\
\text { Descoberta } \\
\text { cura (T-35) }\end{array}$ & Saúde \\
\hline 1949 & $09 / 07$ & $59-63$ & $\begin{array}{l}\text { O general B.C.G. } \\
\text { ataca }\end{array}$ & Arlindo Silva & São Paulo & $\begin{array}{l}\text { Tuberculose, } \\
\text { BCG }\end{array}$ & Saúde \\
\hline 1949 & $03 / 09$ & $\begin{array}{l}94- \\
101\end{array}$ & $\begin{array}{l}\text { Sensação sobre } \\
\text { Patins }\end{array}$ & Arlindo Silva & São Paulo & $\begin{array}{l}10 \\
\text { Campeonato } \\
\text { Paulista de } \\
\text { dança sobre } \\
\text { patins }\end{array}$ & Esporte \\
\hline 1949 & $10 / 09$ & $92-93$ & $\begin{array}{l}\text { Campeões do } \\
\text { Remo }\end{array}$ & Arlindo Silva & São Paulo & $\begin{array}{l}\text { Campeonato } \\
\text { de regatas }\end{array}$ & Esporte \\
\hline 1949 & $17 / 09$ & $86-89$ & Viva Villa! & José Amádio & São Paulo & $\begin{array}{l}\text { Heitor Villa- } \\
\text { Lobos }\end{array}$ & Personalidades \\
\hline 1949 & $22 / 10$ & $\begin{array}{l}106- \\
113\end{array}$ & $\begin{array}{l}\text { Inflação de } \\
\text { Gêmeos }\end{array}$ & Arlindo Silva & São Paulo & $\begin{array}{l}\text { Concurso de } \\
\text { gêmeos na } \\
\text { Cruzada Pró- } \\
\text { Infância }\end{array}$ & Variedades \\
\hline 1949 & $05 / 11$ & $30-33$ & $\begin{array}{l}\text { "Week end" em } \\
\text { Paracatu }\end{array}$ & Arlindo Silva & $\begin{array}{l}\text { Paracatu } \\
\text { (MG) }\end{array}$ & $\begin{array}{l}\text { Corrida de } \\
\text { cavalos }\end{array}$ & Personalidades \\
\hline 1949 & $12 / 11$ & $48-51$ & A cidade do ouro & Arlindo Silva & $\begin{array}{l}\text { Paracatu } \\
\text { (MG) }\end{array}$ & $\begin{array}{l}\text { Extração de } \\
\text { ouro }\end{array}$ & Variedades \\
\hline 1949 & $12 / 11$ & $13-17$ & $\begin{array}{l}\text { Borghi invade o } \\
\text { Brasil central }\end{array}$ & Arlindo Silva & Goiás & Agricultor & Personalidades \\
\hline
\end{tabular}




\begin{tabular}{|c|c|c|c|c|c|c|c|}
\hline 1949 & $17 / 12$ & $12-17$ & $\begin{array}{l}\text { Um louco abala o } \\
\text { Brasil }\end{array}$ & Arlindo Silva & Florianópolis & $\begin{array}{l}\text { Godofredo } \\
\text { Entres, } \\
\text { diretor da } \\
\text { revista Die } \\
\text { Brucke }\end{array}$ & Personalidades \\
\hline 1949 & $31 / 12$ & $40-43$ & Asas sem fronteiras & Arlindo Silva & Uruguai & $\begin{array}{l}\text { Encontro } \\
\text { aéreo }\end{array}$ & Eventos \\
\hline 1950 & $07 / 01$ & $68-73$ & $\begin{array}{l}\text { Mogi das Cruzes, } \\
\text { cidadela do aço }\end{array}$ & Arlindo Silva & São Paulo & $\begin{array}{l}\text { Indústria } \\
\text { siderúrgica }\end{array}$ & Economia \\
\hline 1950 & 07/01 & $94-97$ & $\begin{array}{l}\text { PRG-2 conquista o } \\
\text { espaço }\end{array}$ & Arlindo Silva & São Paulo & $\begin{array}{l}\text { Novo } \\
\text { transmissor } \\
\text { da Rádio Tupi }\end{array}$ & Eventos \\
\hline 1950 & $14 / 01$ & $13-18$ & $\begin{array}{l}\text { Profecias para } \\
1950\end{array}$ & $\begin{array}{l}\text { Texto de } \\
\text { José Leal, } \\
\text { Fotos de } \\
\text { Peter Scheier } \\
\text { e Douglas } \\
\text { Alexander }\end{array}$ & São Paulo & Profecias & Variedades \\
\hline 1950 & $14 / 01$ & $58-65$ & $\begin{array}{l}\text { A "Aliança" faz a } \\
\text { força }\end{array}$ & Arlindo Silva & São Paulo & $\begin{array}{l}\text { Fábrica } \\
\text { Aliança }\end{array}$ & Economia \\
\hline 1950 & $04 / 02$ & $46-49$ & A ilha dos lobos & Arlindo Silva & $\begin{array}{l}\text { Uruguai - } \\
\text { Punta Del } \\
\text { Leste (Mar } \\
\text { Del Plata) }\end{array}$ & $\begin{array}{l}\text { Leões } \\
\text { marinhos }\end{array}$ & Variedades \\
\hline 1950 & $25 / 02$ & $\begin{array}{l}100- \\
103\end{array}$ & $\begin{array}{l}\text { O casamento da } \\
\text { Dona Dorotéia }\end{array}$ & Arlindo Silva & Santos & $\begin{array}{l}\text { Pré-carnaval } \\
\text { em Santos }\end{array}$ & Lazer \\
\hline 1950 & $18 / 03$ & 54-61 & O frevo sensacional & Arlindo Silva & Recife & Carnaval & Lazer \\
\hline
\end{tabular}




\begin{tabular}{|c|c|c|c|c|c|c|c|}
\hline 1950 & $01 / 04$ & $92-97$ & $\begin{array}{l}\text { Os peixes voadores } \\
\text { abafam }\end{array}$ & Arlindo Silva & São Paulo & $\begin{array}{l}\text { Nadadores } \\
\text { japoneses }\end{array}$ & Esporte \\
\hline 1950 & $15 / 04$ & $94-99$ & $\begin{array}{l}\text { O aprendiz de } \\
\text { palhaço }\end{array}$ & Arlindo Silva & São Paulo & $\begin{array}{l}\text { Palhaço } \\
\text { Piolim }\end{array}$ & Lazer \\
\hline 1950 & 06/05 & $30-33$ & $\begin{array}{l}\text { O filho de } \\
\text { Vandenberg }\end{array}$ & Arlindo Silva & Paraná & $\begin{array}{l}\text { Agricultura } \\
\text { (milho) }\end{array}$ & Economia \\
\hline 1950 & $13 / 05$ & $60-63$ & Dólares Falsos & Arlindo Silva & São Paulo & $\begin{array}{l}\text { Falsificação } \\
\text { de dólares }\end{array}$ & Polícia \\
\hline 1950 & $13 / 05$ & $26-29$ & $\begin{array}{l}\text { Dia das Mães } \\
\text { - século das } \\
\text { crianças }\end{array}$ & Arlindo Silva & São Paulo & $\begin{array}{l}\text { Homenagem } \\
\text { às mães }\end{array}$ & Sociedade \\
\hline 1950 & $20 / 05$ & $94-97$ & $\begin{array}{l}\text { Punhos que } \\
\text { emocionaram o } \\
\text { mundo }\end{array}$ & Arlindo Silva & São Paulo & $\begin{array}{l}\text { Lutador } \\
\text { de boxe } \\
\text { americano } \\
\text { Joe Louis }\end{array}$ & Esporte \\
\hline 1950 & $27 / 05$ & $28-30$ & $\begin{array}{l}\text { A redenção do } \\
\text { caiçara }\end{array}$ & Arlindo Silva & São Paulo & $\begin{array}{l}\text { Campanha } \\
\text { de redenção } \\
\text { da criança }\end{array}$ & Saúde \\
\hline 1950 & $17 / 06$ & $58-63$ & $\begin{array}{l}\text { Olhos dos mortos } \\
\text { para os vivos }\end{array}$ & Arlindo Silva & São Paulo & $\begin{array}{l}\text { Cirurgias } \\
\text { de olhos no } \\
\text { Hospital das } \\
\text { Clínicas }\end{array}$ & Saúde \\
\hline 1950 & $24 / 06$ & $34-39$ & Salve o rei do café & Arlindo Silva & São Paulo & $\begin{array}{l}\text { Cafeicultor } \\
\text { Geremia } \\
\text { Lunardelli }\end{array}$ & Personalidades \\
\hline
\end{tabular}




\begin{tabular}{|c|c|c|c|c|c|c|c|}
\hline 1950 & $24 / 06$ & $\begin{array}{l}126- \\
127\end{array}$ & $\begin{array}{l}\text { Casamento do } \\
\text { "Hamlet" }\end{array}$ & Arlindo Silva & São Paulo & $\begin{array}{l}\text { Casamento } \\
\text { de Sérgio } \\
\text { Cardoso e } \\
\text { Nídia Lícia }\end{array}$ & Personalidades \\
\hline 1950 & $01 / 07$ & $\begin{array}{l}118- \\
121\end{array}$ & $\begin{array}{l}\text { Um paraíso na } \\
\text { Mantiqueira }\end{array}$ & Arlindo Silva & $\begin{array}{l}\text { Campos do } \\
\text { Jordão }\end{array}$ & $\begin{array}{l}\text { Agricultura, } \\
\text { plantação de } \\
\text { maçãs }\end{array}$ & Economia \\
\hline 1950 & $15 / 07$ & $\begin{array}{l}104- \\
105\end{array}$ & Suécia X Paraguai & Arlindo Silva & Curitiba & $\begin{array}{l}\text { Copa do } \\
\text { mundo }\end{array}$ & Esporte \\
\hline 1950 & $29 / 07$ & $\begin{array}{l}114- \\
115\end{array}$ & Luta de gigantes & $\begin{array}{l}\text { Jorge } \\
\text { Ferreira } \\
\text { (Fotos de } \\
\text { Peter Scheier } \\
\text { e Roberto } \\
\text { Maia) }\end{array}$ & São Paulo & $\begin{array}{l}\text { Copa do } \\
\text { mundo } \\
\text { (Pacaembu) }\end{array}$ & Esporte \\
\hline 1950 & 29/07 & $\begin{array}{l}116- \\
117\end{array}$ & Suécia - 3o lugar & $\begin{array}{l}\text { Texto: } \\
\text { Arlindo Silva } \\
\text { (fotos de } \\
\text { Peter Scheier } \\
\text { e Nicolau } \\
\text { Leite) }\end{array}$ & São Paulo & $\begin{array}{l}\text { Copa do } \\
\text { mundo } \\
\text { (Pacaembu) }\end{array}$ & Esporte \\
\hline 1950 & $29 / 07$ & $50-53$ & $\begin{array}{l}\text { José Mojica, } \\
\text { soldado da igreja }\end{array}$ & Arlindo Silva & São Paulo & $\begin{array}{l}\text { Inauguração } \\
\text { TV Tupi }\end{array}$ & Instituições \\
\hline 1950 & 05/08 & $\begin{array}{l}104- \\
105\end{array}$ & $\begin{array}{l}\text { A festa dos } \\
\text { grandes }\end{array}$ & Arlindo Silva & São Paulo & $\begin{array}{l}\text { Banquetes } \\
\text { no MASP }\end{array}$ & Instituições \\
\hline 1950 & $05 / 08$ & $\begin{array}{l}94- \\
103\end{array}$ & $\begin{array}{l}\text { Museu de Arte } \\
\text { de São Paulo } \\
\text { "cidadela da } \\
\text { civilização" }\end{array}$ & $\begin{array}{l}\text { Texto de } \\
\text { Jorge } \\
\text { Ferreira } \\
\text { (fotos de } \\
\text { Peter Scheier } \\
\text { e Roberto } \\
\text { Maia) }\end{array}$ & São Paulo & $\begin{array}{l}\text { Inauguração } \\
\text { do MASP }\end{array}$ & Instituições \\
\hline 1950 & $12 / 08$ & $24-25$ & $\begin{array}{l}\text { A televisão } \\
\text { funcionando! }\end{array}$ & Arlindo Silva & São Paulo & $\begin{array}{l}\text { Inauguração } \\
\text { TV Tupi }\end{array}$ & Instituições \\
\hline
\end{tabular}




\begin{tabular}{|c|c|c|c|c|c|c|c|}
\hline 1950 & $02 / 09$ & $12-16$ & $\begin{array}{l}\text { Três bandeiras } \\
\text { para o Real Forte } \\
\text { Príncipe da Beira }\end{array}$ & $\begin{array}{l}\text { Texto de } \\
\text { Flávio } \\
\text { Tambellini, } \\
\text { fotos de } \\
\text { Peter Scheier } \\
\text { e Roberto } \\
\text { Maia }\end{array}$ & Amazônia & $\begin{array}{l}\text { Forte do } \\
\text { período } \\
\text { colonial (Rio } \\
\text { Guaporé) }\end{array}$ & Variedades \\
\hline 1950 & 09/09 & $20-22$ & $\begin{array}{l}\text { História de uma } \\
\text { princesa russa }\end{array}$ & Arlindo Silva & São Paulo & $\begin{array}{l}\text { Maria } \\
\text { Paulovna }\end{array}$ & $\begin{array}{l}\text { Personalidades } \\
\text { Eventos }\end{array}$ \\
\hline 1950 & $16 / 09$ & $54-59$ & $\begin{array}{l}\text { Revolução branca } \\
\text { no Brasil }\end{array}$ & Arlindo Silva & São Paulo & $\begin{array}{l}\text { Agricultura; } \\
\text { adubo de } \\
\text { hiperfosfato }\end{array}$ & Economia \\
\hline 1950 & $16 / 09$ & $38-41$ & $\begin{array}{l}\text { Boogie-Woogie } \\
\text { Brasileiro }\end{array}$ & Arlindo Silva & São Paulo & Dança & Lazer \\
\hline 1950 & $16 / 09$ & $76-79$ & $\begin{array}{l}\text { Prestes Maia } \\
\text { madrugou na } \\
\text { estrada }\end{array}$ & Arlindo Silva & São Paulo & $\begin{array}{l}\text { Candidatura } \\
\text { de Prestes } \\
\text { Maia ao } \\
\text { governo do } \\
\text { Estado }\end{array}$ & Política \\
\hline 1950 & $30 / 09$ & $90-93$ & $\begin{array}{l}\text { As belas viram } \\
\text { feras }\end{array}$ & Arlindo Silva & São Paulo & $\begin{array}{l}\text { Luta livre } \\
\text { feminino }\end{array}$ & Esporte \\
\hline 1950 & $07 / 10$ & $46-48$ & $\begin{array}{l}\text { A rainha dos } \\
\text { fotógrafos }\end{array}$ & Arlindo Silva & São Paulo & $\begin{array}{l}\text { Sonia Vaz, } \\
\text { ganhadora } \\
\text { do Miss } \\
\text { Objetiva }\end{array}$ & $\begin{array}{l}\text { Personalidades } \\
\text { Eventos }\end{array}$ \\
\hline 1950 & $28 / 10$ & 37-39 & $\begin{array}{l}\text { A televisão para } \\
\text { milhões }\end{array}$ & Arlindo Silva & São Paulo & $\begin{array}{l}\text { Primeira } \\
\text { estação } \\
\text { televisora } \\
\text { da América } \\
\text { Latina }\end{array}$ & Variedades \\
\hline 1950 & $28 / 10$ & $54-56$ & $\begin{array}{l}\text { Um sertanejo de } \\
\text { batina }\end{array}$ & Arlindo Silva & Paraná & $\begin{array}{l}\text { Vilarejo } \\
\text { de Padre } \\
\text { Antônio }\end{array}$ & Variedades \\
\hline
\end{tabular}




\begin{tabular}{|c|c|c|c|c|c|c|c|}
\hline 1950 & $28 / 10$ & $94-95$ & $\begin{array}{l}106 \text { Promessas } \\
\text { para Garcez não } \\
\text { morrer }\end{array}$ & Arlindo Silva & São Paulo & $\begin{array}{l}\text { Lucas } \\
\text { Nogueira } \\
\text { Garcez, } \\
\text { governador } \\
\text { eleito de } \\
\text { SP, após } \\
\text { acidente de } \\
\text { avião }\end{array}$ & Personalidades \\
\hline 1950 & $04 / 11$ & $58-61$ & $\begin{array}{l}\text { "Popeyes" contra } \\
\text { "caveiras" Mac- } \\
\text { Med }\end{array}$ & Arlindo Silva & São Paulo & $\begin{array}{l}\text { Mac-Med: } \\
\text { competição } \\
\text { estudantil } \\
\text { (Mackenzie x } \\
\text { Medicina) }\end{array}$ & Esporte \\
\hline 1950 & $25 / 11$ & $\begin{array}{l}116- \\
119\end{array}$ & $\begin{array}{l}\text { O teimoso } \\
\text { Cavalcanti }\end{array}$ & David Nasser & São Paulo & $\begin{array}{l}\text { Cineasta } \\
\text { Alberto } \\
\text { Cavalcanti } \\
\text { - filme } \\
\text { "Caiçaras", } \\
\text { da Vera Cruz } \\
\end{array}$ & Personalidades \\
\hline 1950 & $16 / 12$ & $\begin{array}{l}107- \\
110\end{array}$ & $\begin{array}{l}\text { "Glamour" Girl } \\
1950\end{array}$ & Arlindo Silva & São Paulo & $\begin{array}{l}\text { Concurso de } \\
\text { beleza }\end{array}$ & $\begin{array}{l}\text { Personalidades } \\
\text { Eventos }\end{array}$ \\
\hline 1951 & $13 / 01$ & 76-79 & $\begin{array}{l}\text { Desfile em Boca } \\
\text { Raton }\end{array}$ & Alceu Pena & $\begin{array}{l}\text { Boca Raton } \\
\text { (Flórida) }\end{array}$ & $\begin{array}{l}\text { Desfile de } \\
\text { moda }\end{array}$ & Eventos \\
\hline 1951 & $27 / 01$ & $86-87$ & $\begin{array}{l}\text { O café é rei em } \\
\text { Boca Raton }\end{array}$ & Geraldo & $\begin{array}{l}\text { Boca Raton } \\
\text { (Flórida) }\end{array}$ & $\begin{array}{l}\text { Convenção } \\
\text { Anual da } \\
\text { Associação } \\
\text { Nacional de } \\
\text { Café dos } \\
\text { EUA }\end{array}$ & Eventos \\
\hline 1951 & $03 / 02$ & $68-71$ & Olha o Maracatu & Arlindo Silva & Recife & $\begin{array}{l}\text { Maracatu - } \\
\text { carnaval }\end{array}$ & Lazer \\
\hline 1951 & $17 / 02$ & $\begin{array}{l}100- \\
101\end{array}$ & Gillette sem fio & $\begin{array}{l}\text { Mario } \\
\text { Camarinha }\end{array}$ & Flórida & $\begin{array}{l}\text { Senador } \\
\text { Gillette - } \\
\text { campanha } \\
\text { para baixar } \\
\text { preço do café } \\
\text { brasileiro }\end{array}$ & Economia \\
\hline 1951 & $03 / 03$ & $50-53$ & $\begin{array}{l}\text { Entre o touro e o } \\
\text { urso }\end{array}$ & $\begin{array}{l}\text { Geraldo } \\
\text { Banas }\end{array}$ & New York & $\begin{array}{l}\text { Wall Street. } \\
\text { Sobre Bolsas } \\
\text { de NY, São } \\
\text { Paulo }\end{array}$ & Economia \\
\hline
\end{tabular}




\begin{tabular}{|l|l|l|l|l|l|l|l|}
\hline 1951 & $21 / 04$ & $\begin{array}{l}114- \\
119\end{array}$ & $\begin{array}{l}\text { Quatro Séculos de } \\
\text { moda }\end{array}$ & $\begin{array}{l}\text { Margarida } \\
\text { Izar (fotos } \\
\text { de Peter } \\
\text { Scheier } \\
\text { Henri Ballot) }\end{array}$ & São Paulo & $\begin{array}{l}\text { Desfile no } \\
\text { MASP }\end{array}$ & Instituições \\
\hline 1951 & $12 / 05$ & $\begin{array}{l}107- \\
110\end{array}$ & O baile branco & Alceu Pereira & São Paulo & $\begin{array}{l}\text { Baile de } \\
\text { debutantes }\end{array}$ & Eventos \\
\hline 1951 & $02 / 06$ & $14-20$ & $\begin{array}{l}\text { Conceição } \\
\text { apanhou como o } \\
\text { diabo }\end{array}$ & $\begin{array}{l}\text { Jorge } \\
\text { Ferreira }\end{array}$ & São Paulo & $\begin{array}{l}\text { Briga na } \\
\text { Assembléia }\end{array}$ & Política \\
\hline 1951 & $27 / 10$ & $\begin{array}{l}108- \\
112\end{array}$ & "Barriga d'água" & Arlindo Silva & São Paulo & Esquistossomose & Saúde \\
\hline
\end{tabular}




\section{Apêndice C - As fotos de São Paulo fastest growing city in the world}

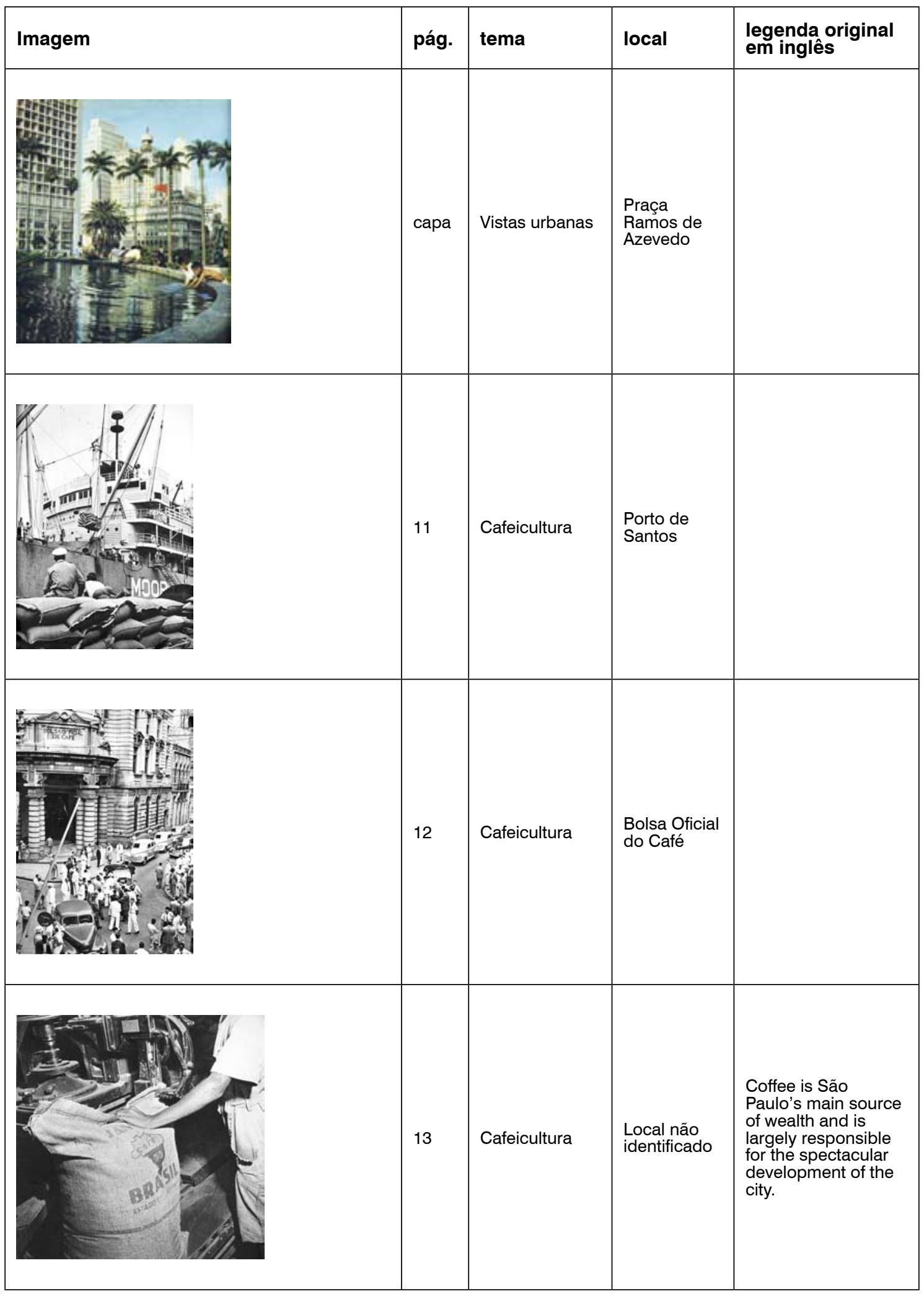




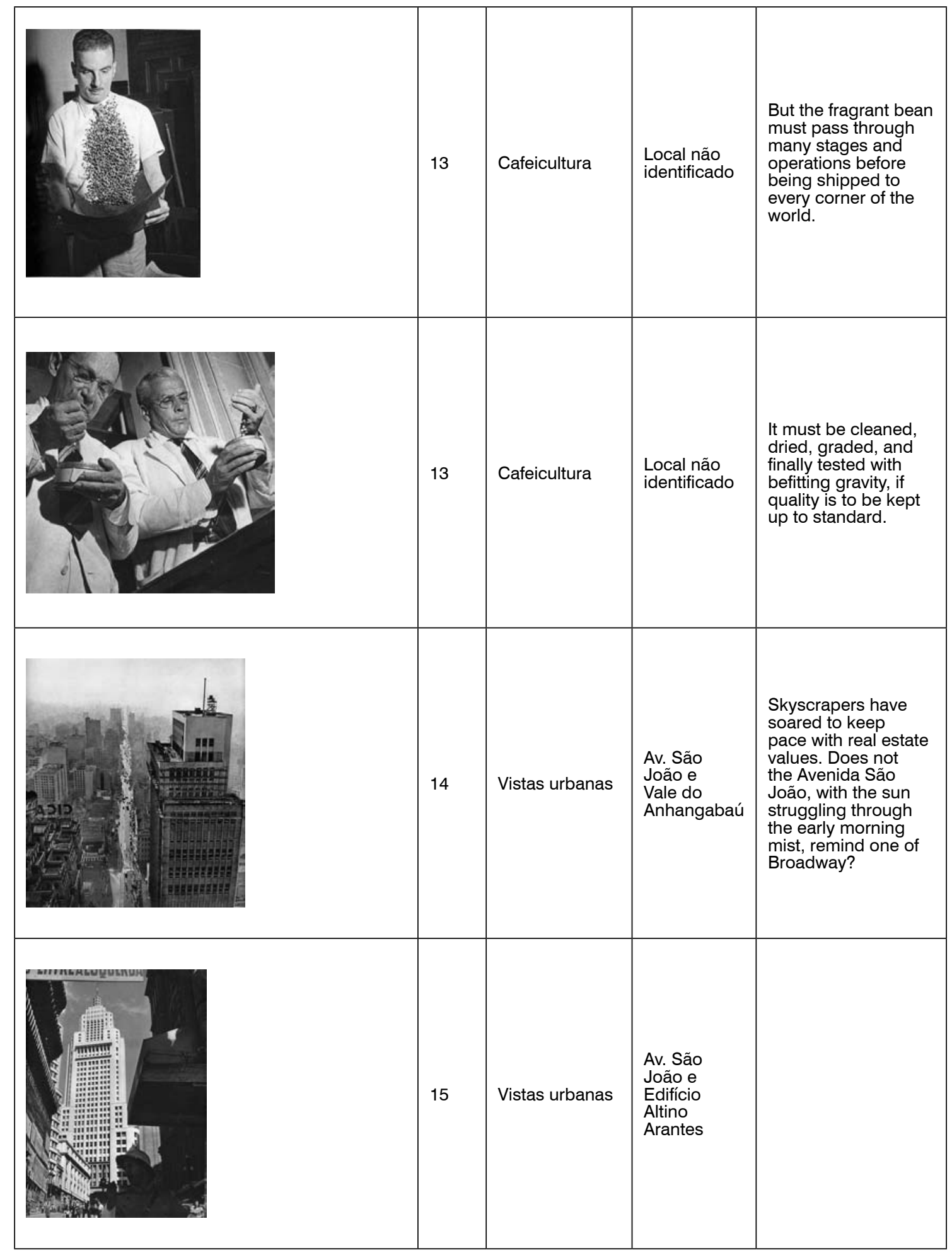




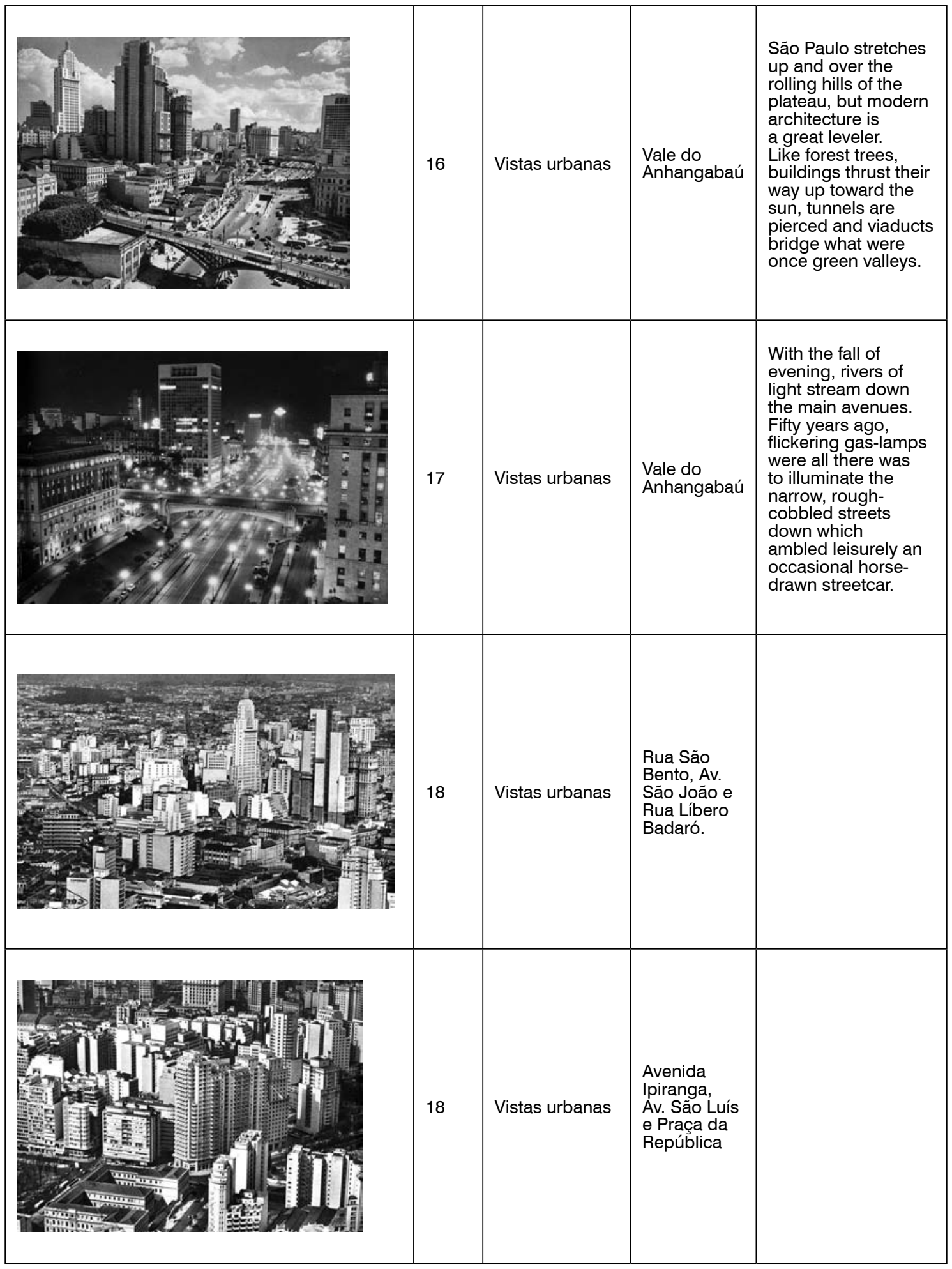




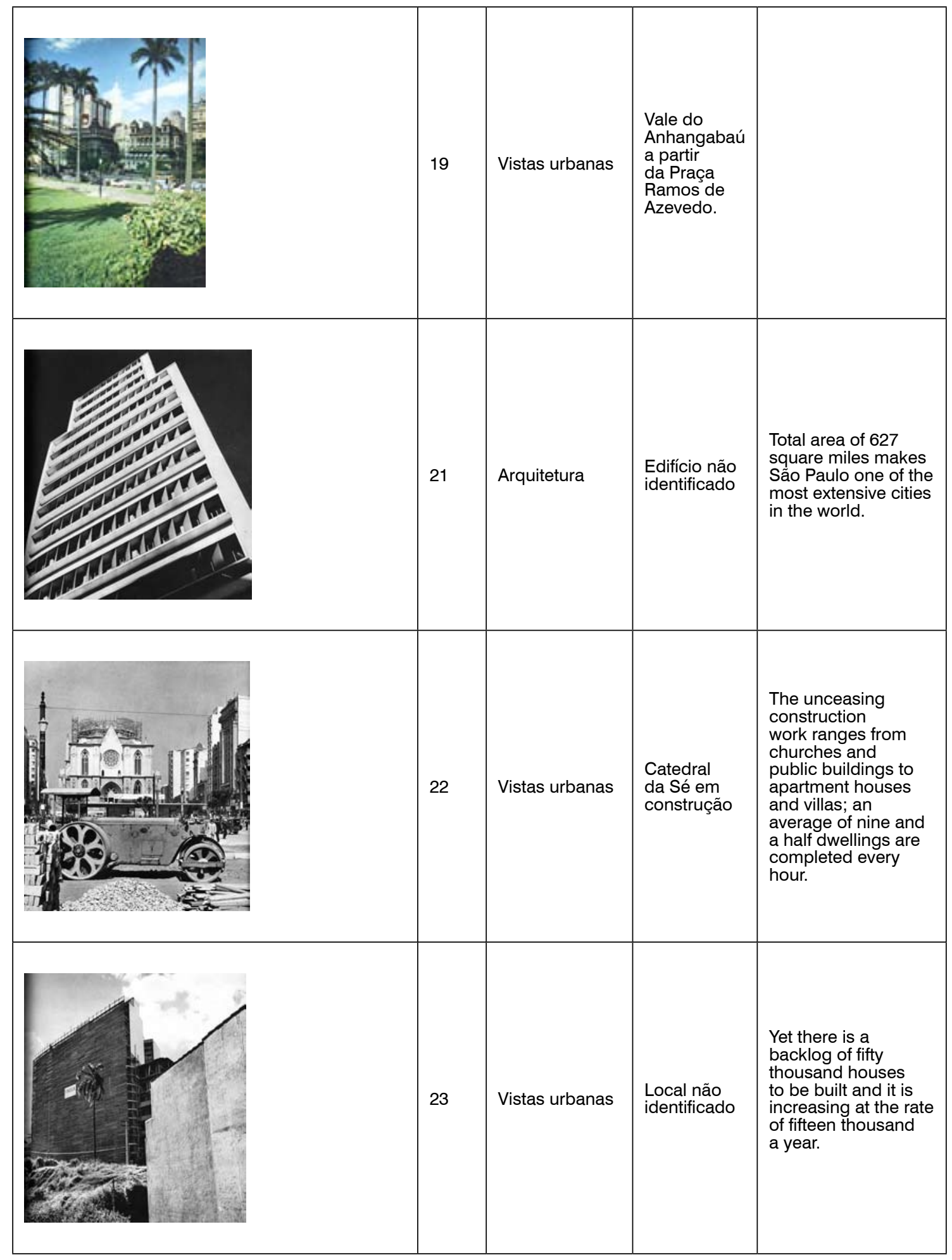




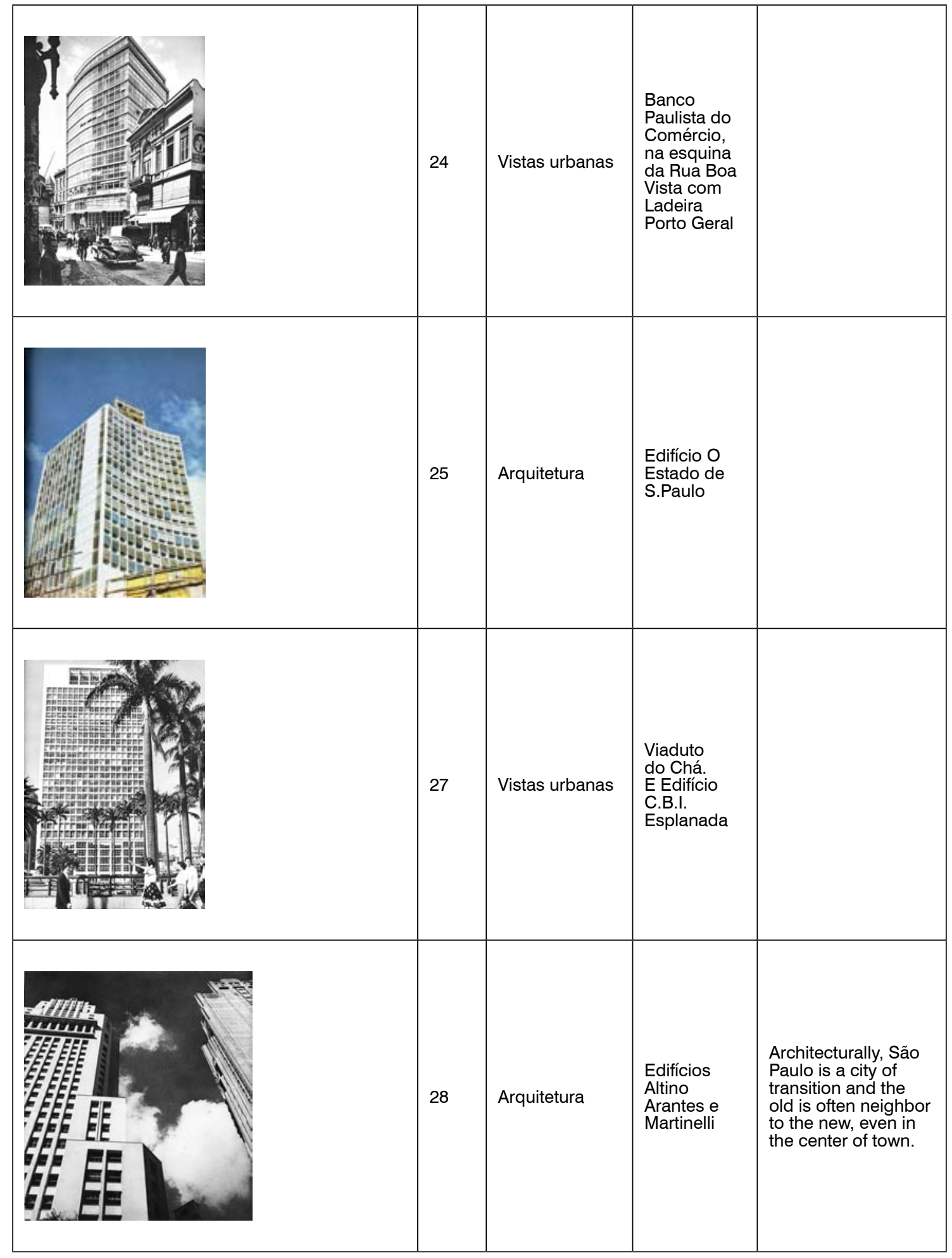




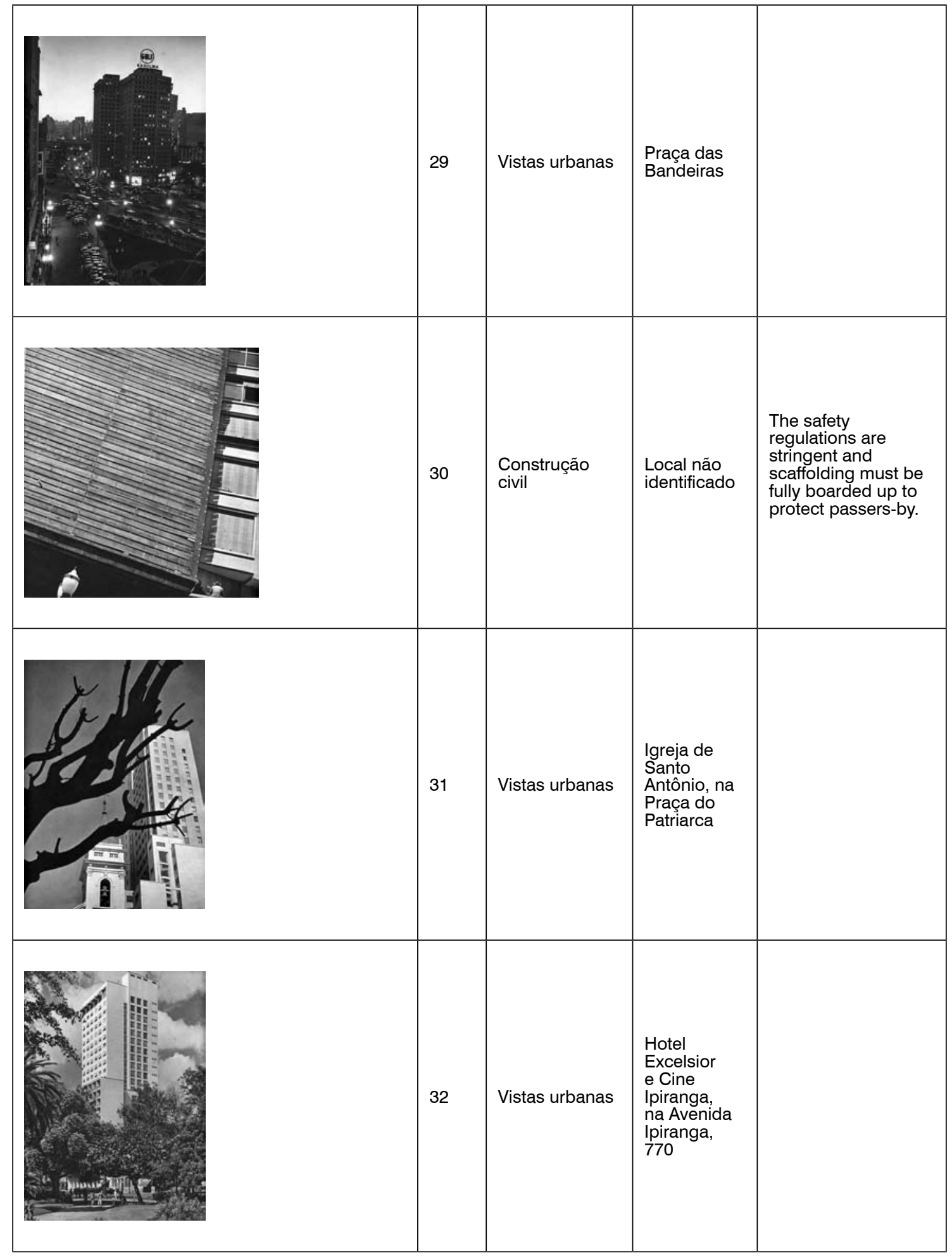




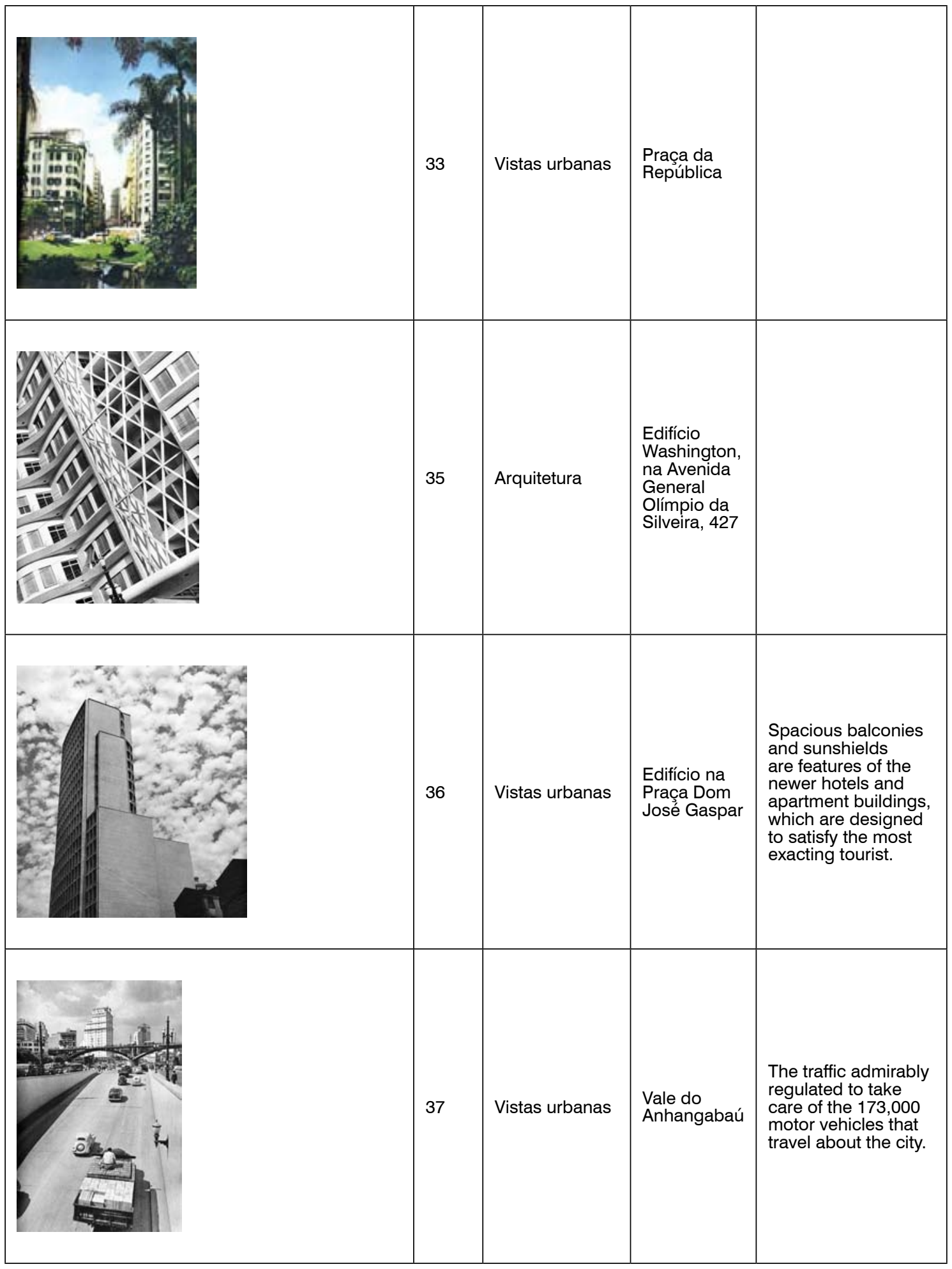




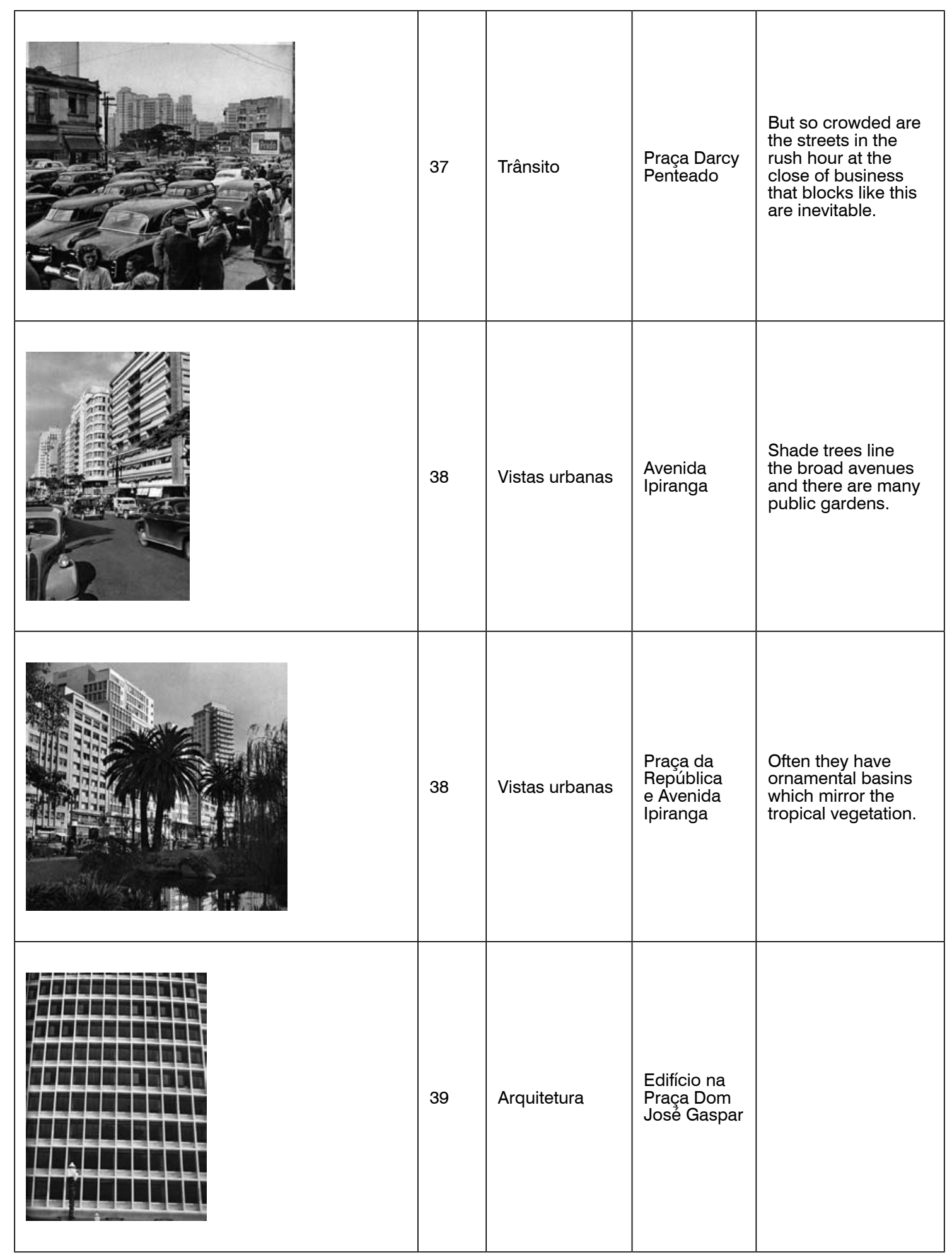




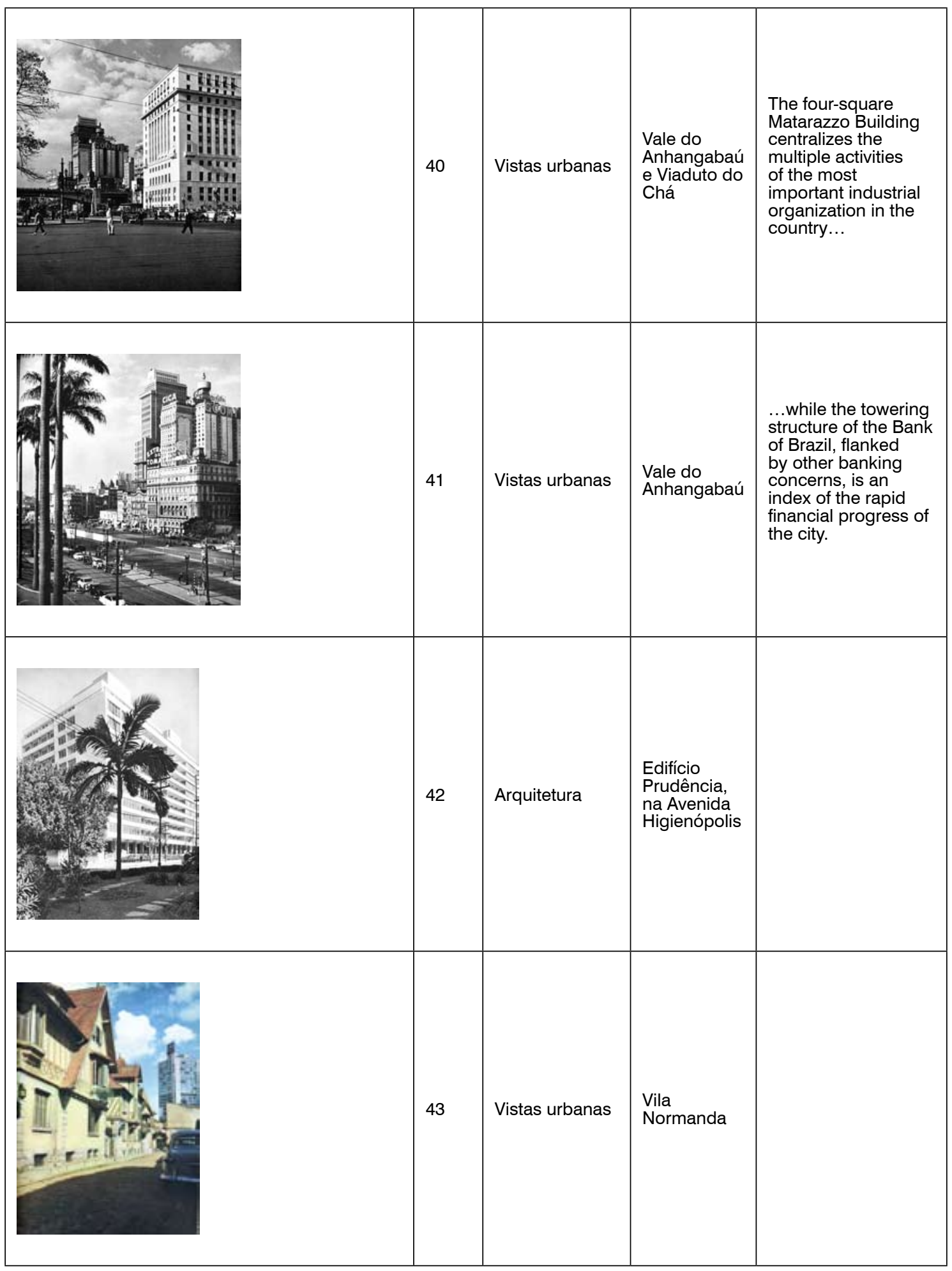




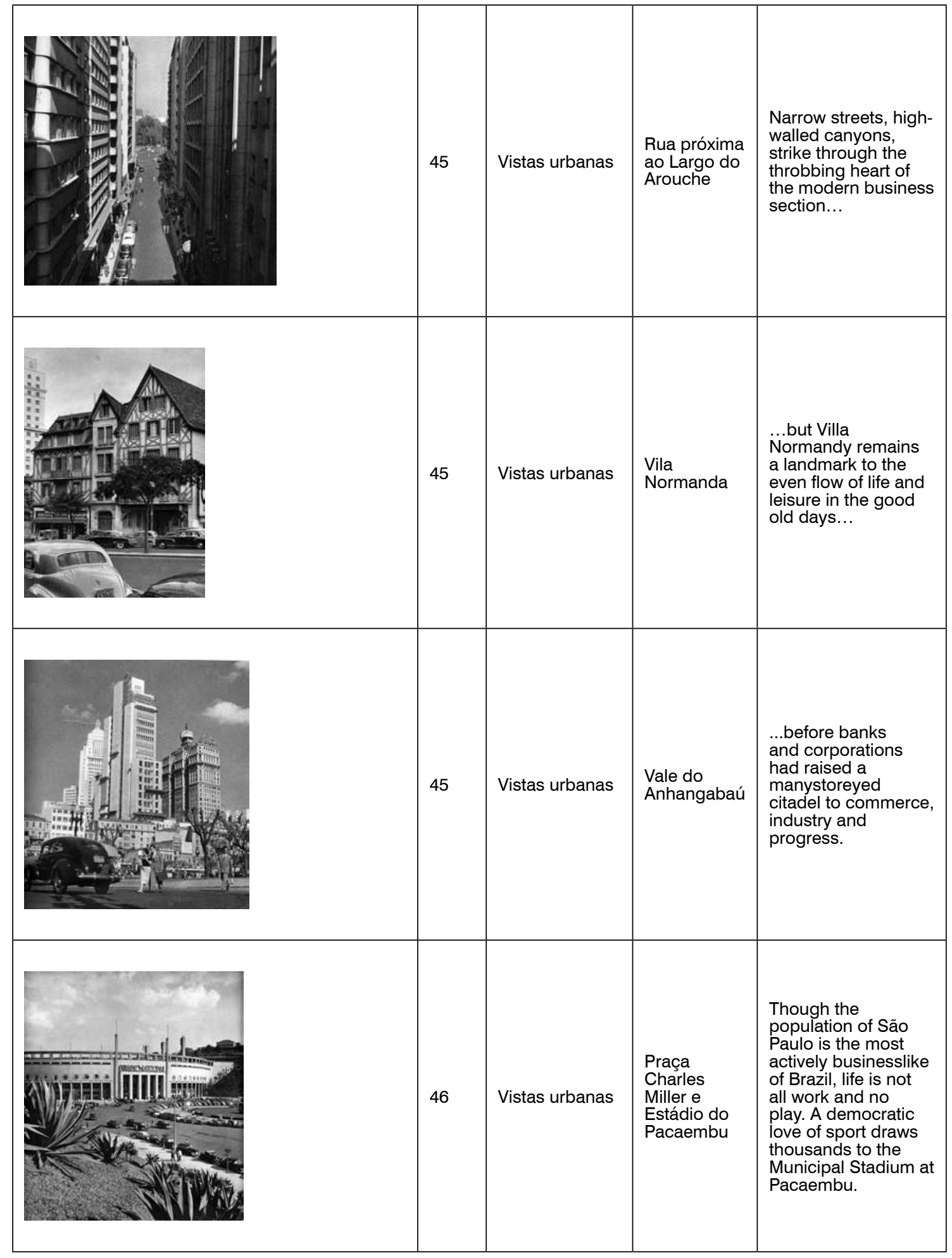




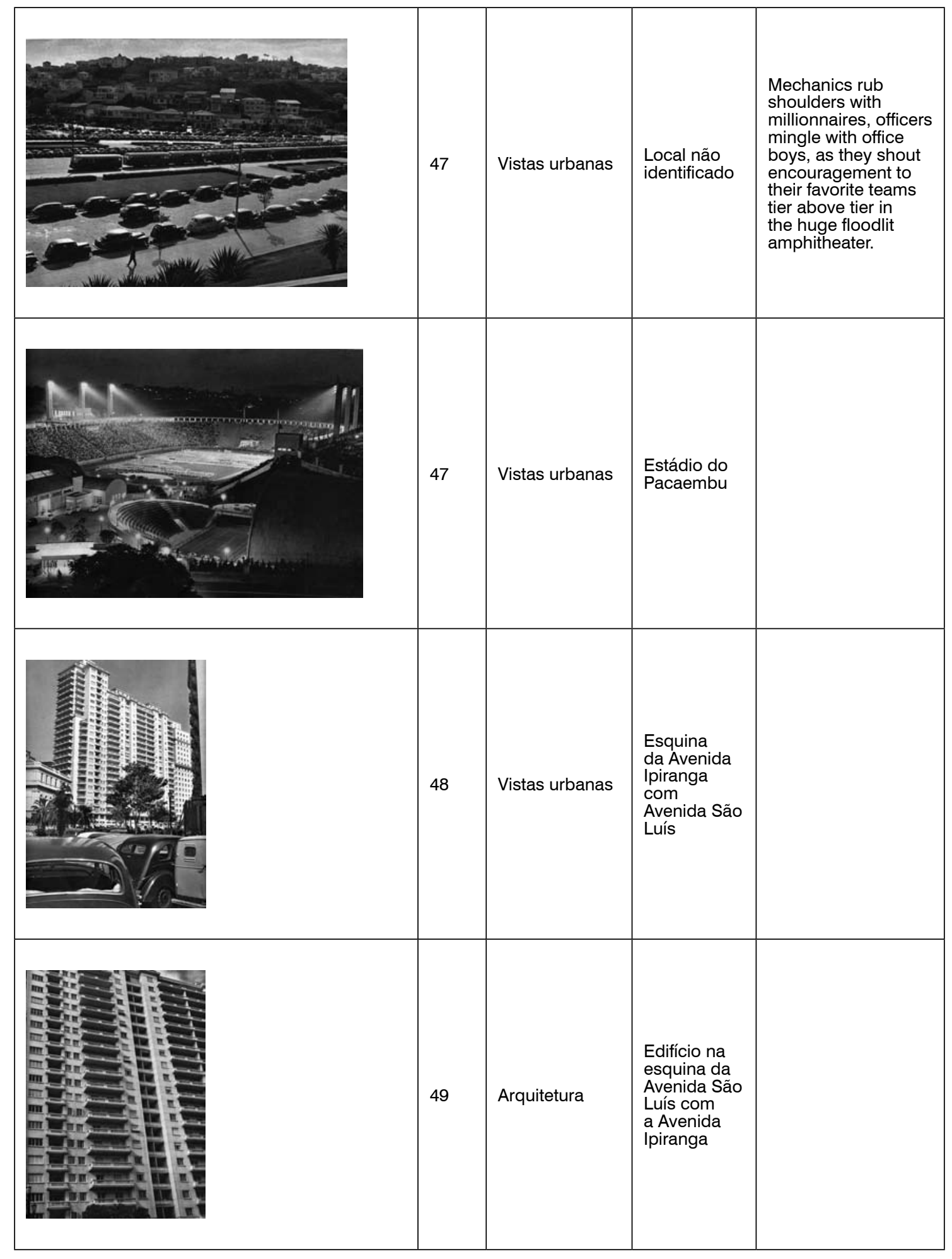




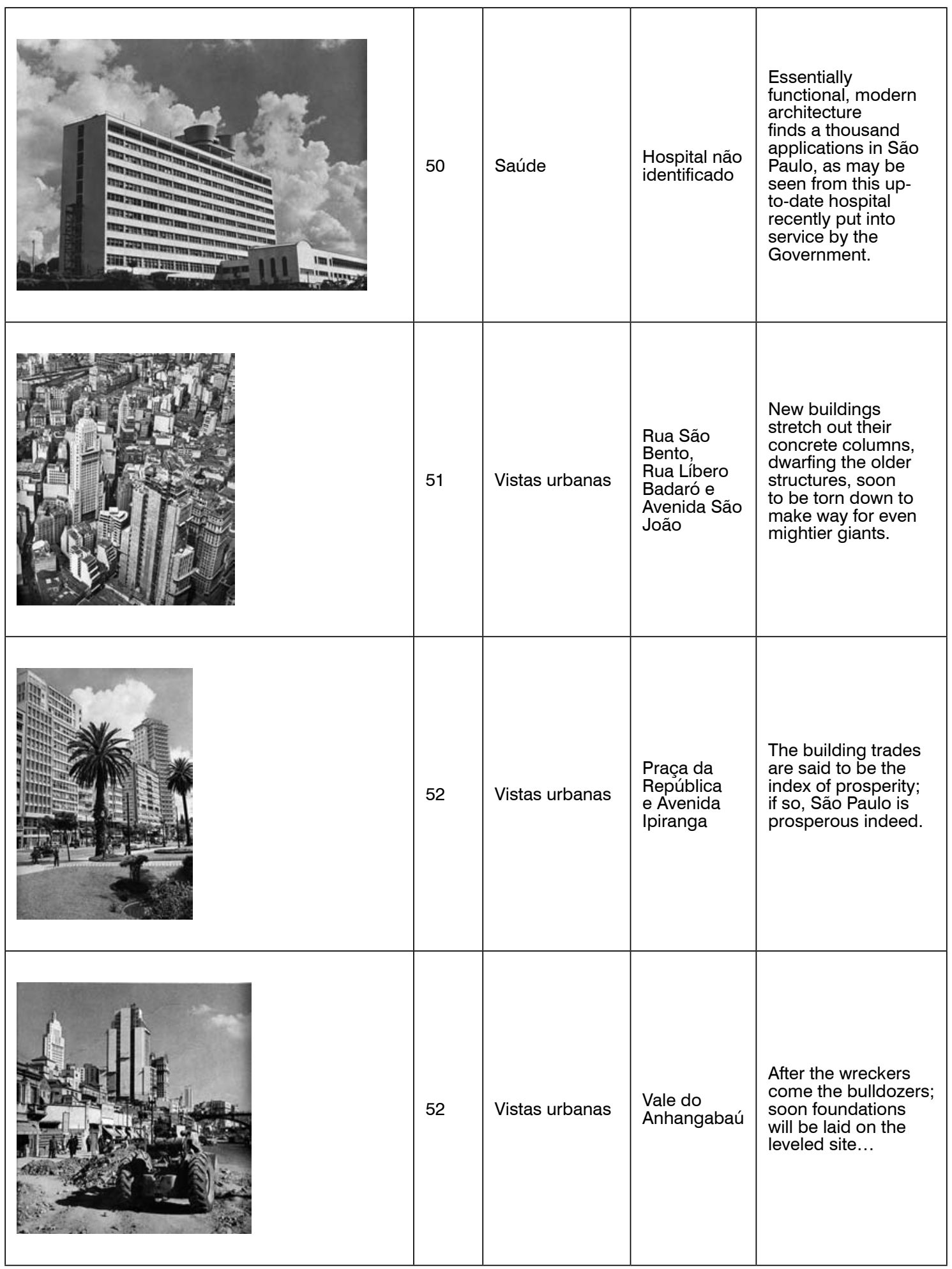




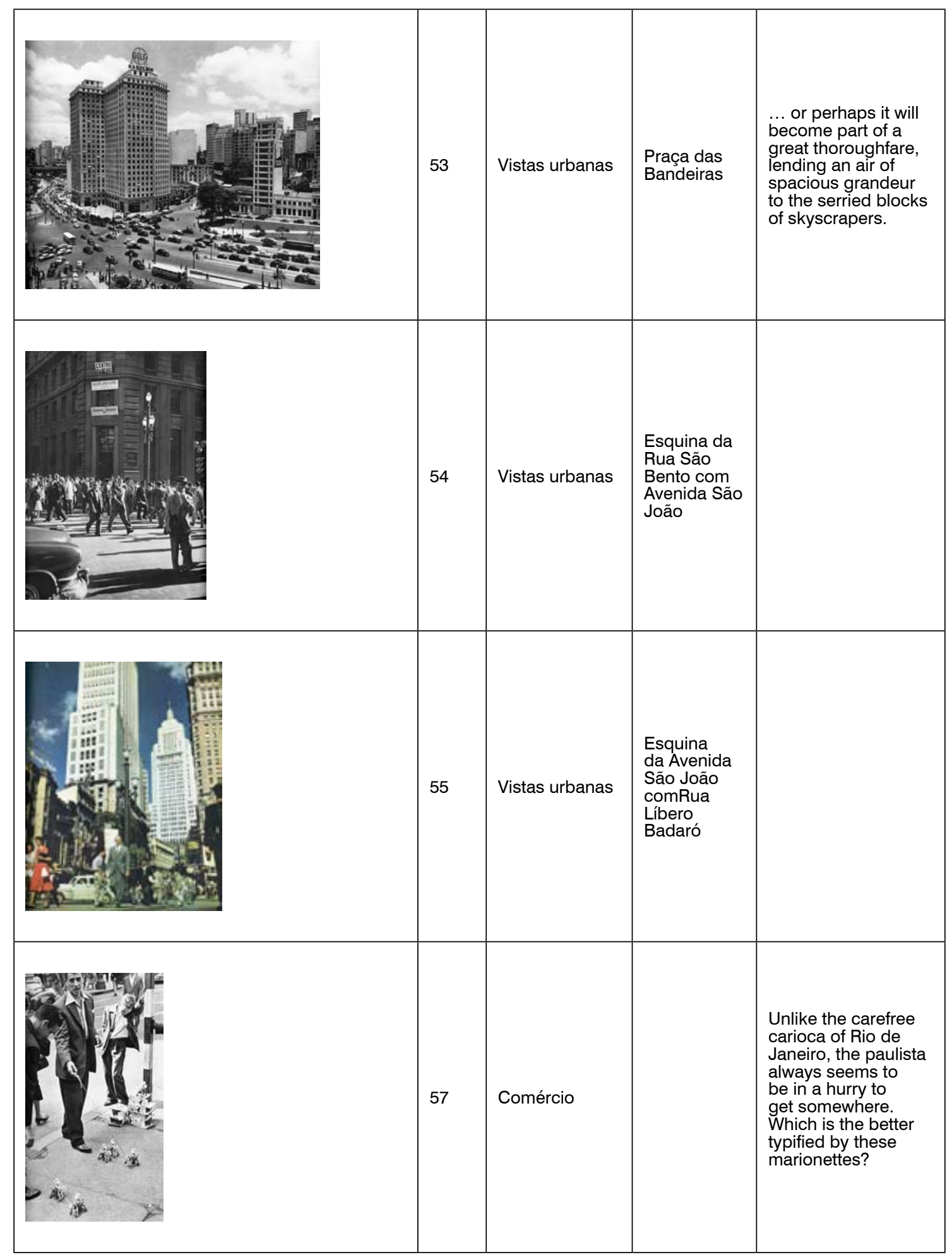




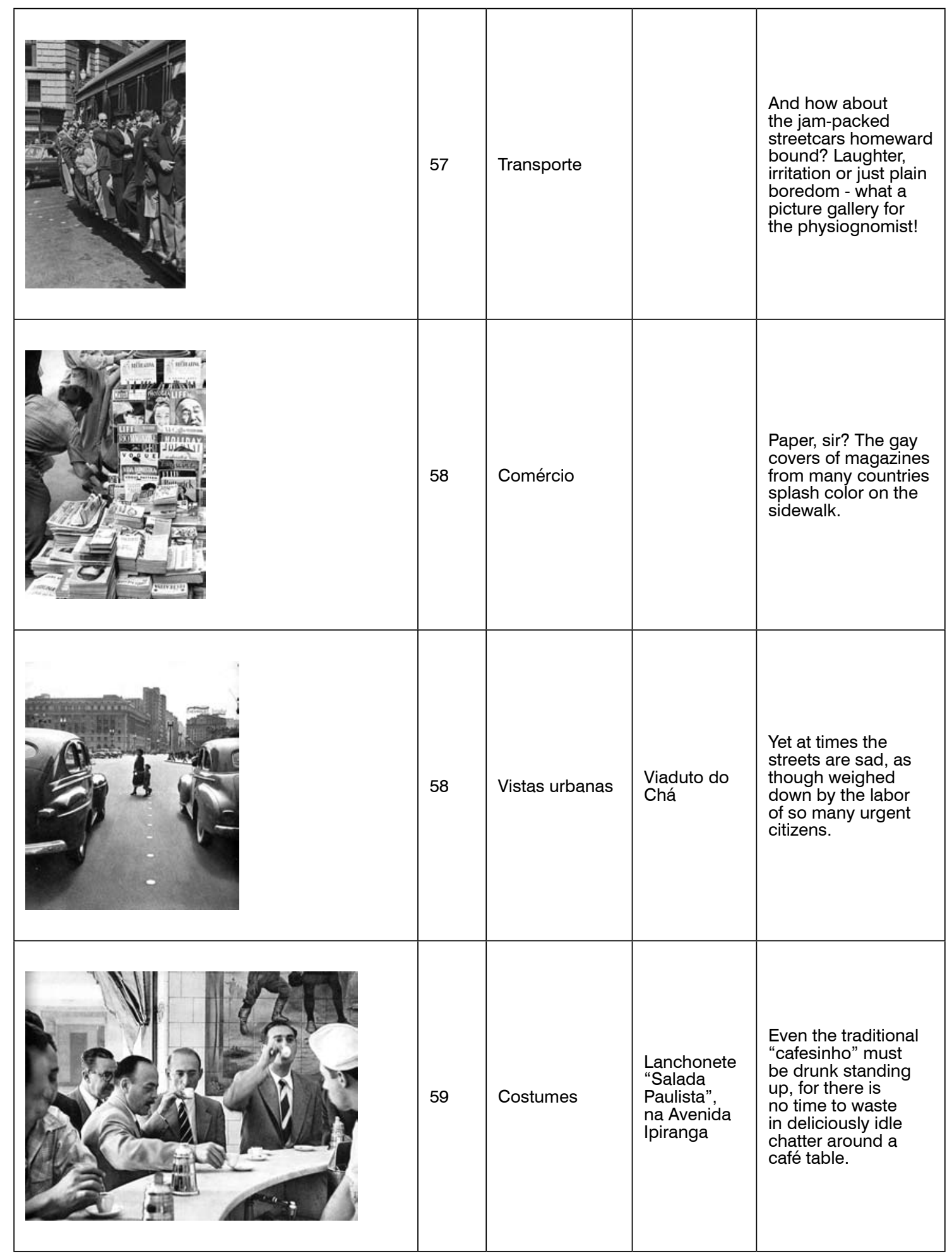




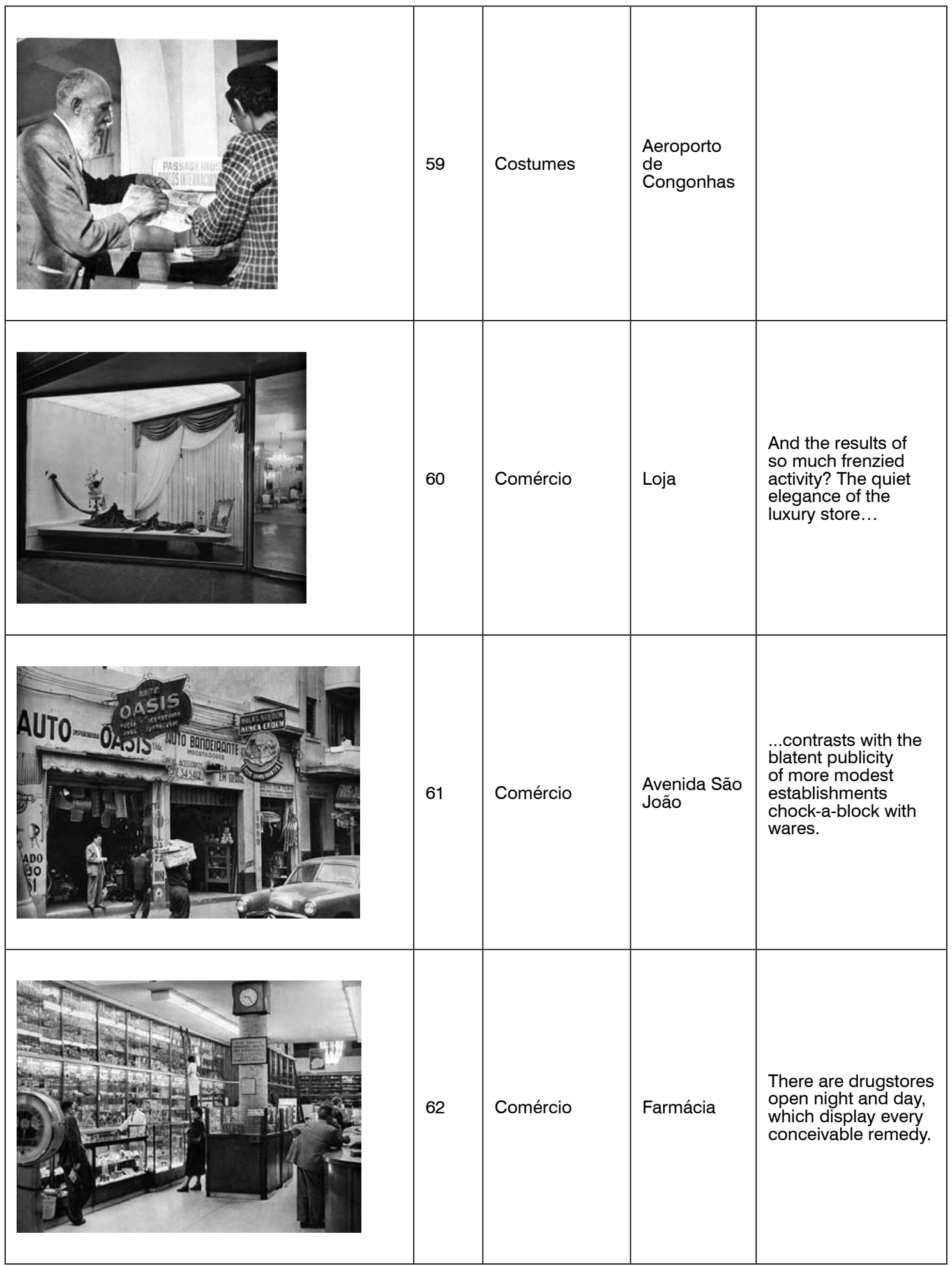




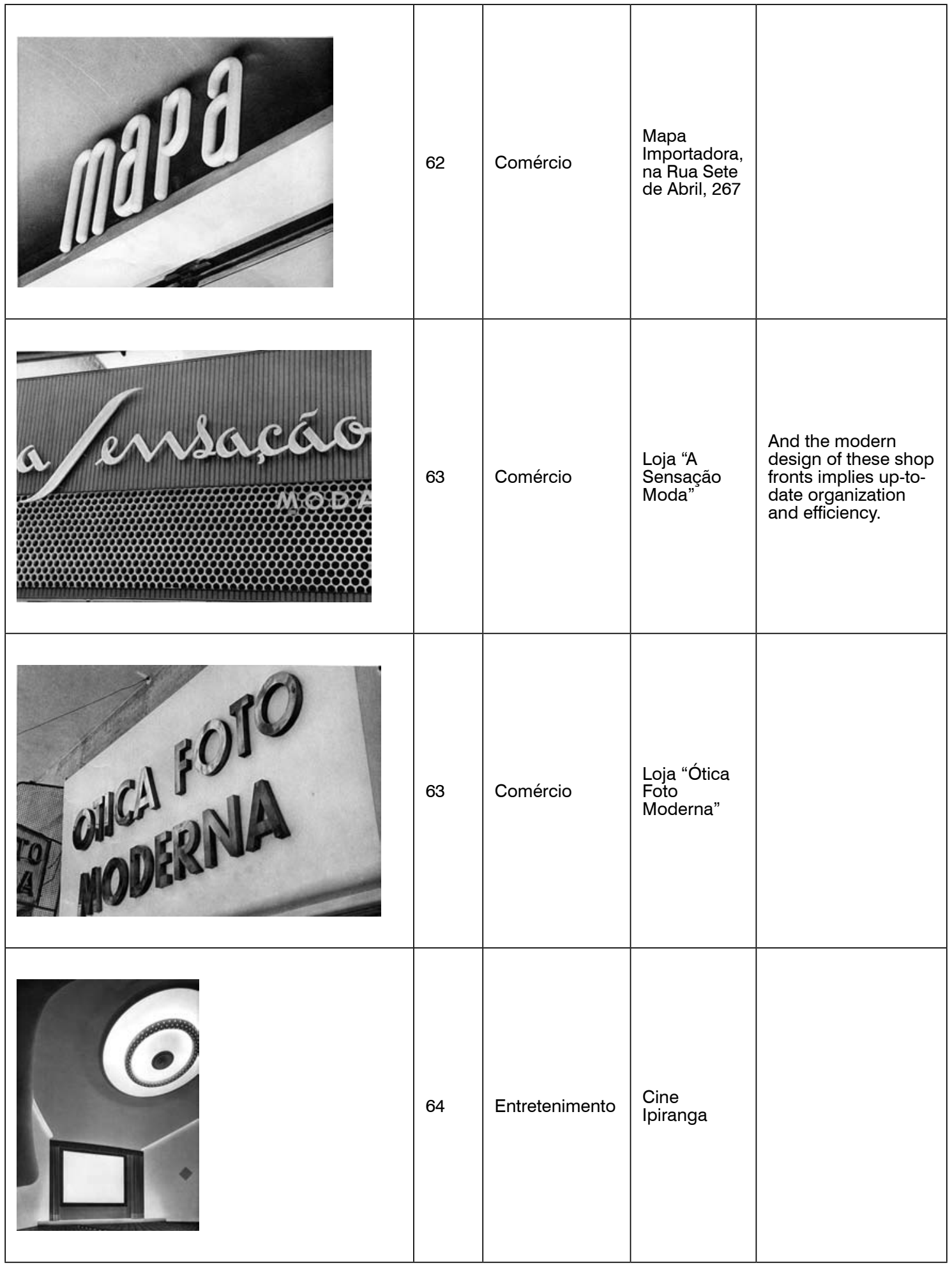




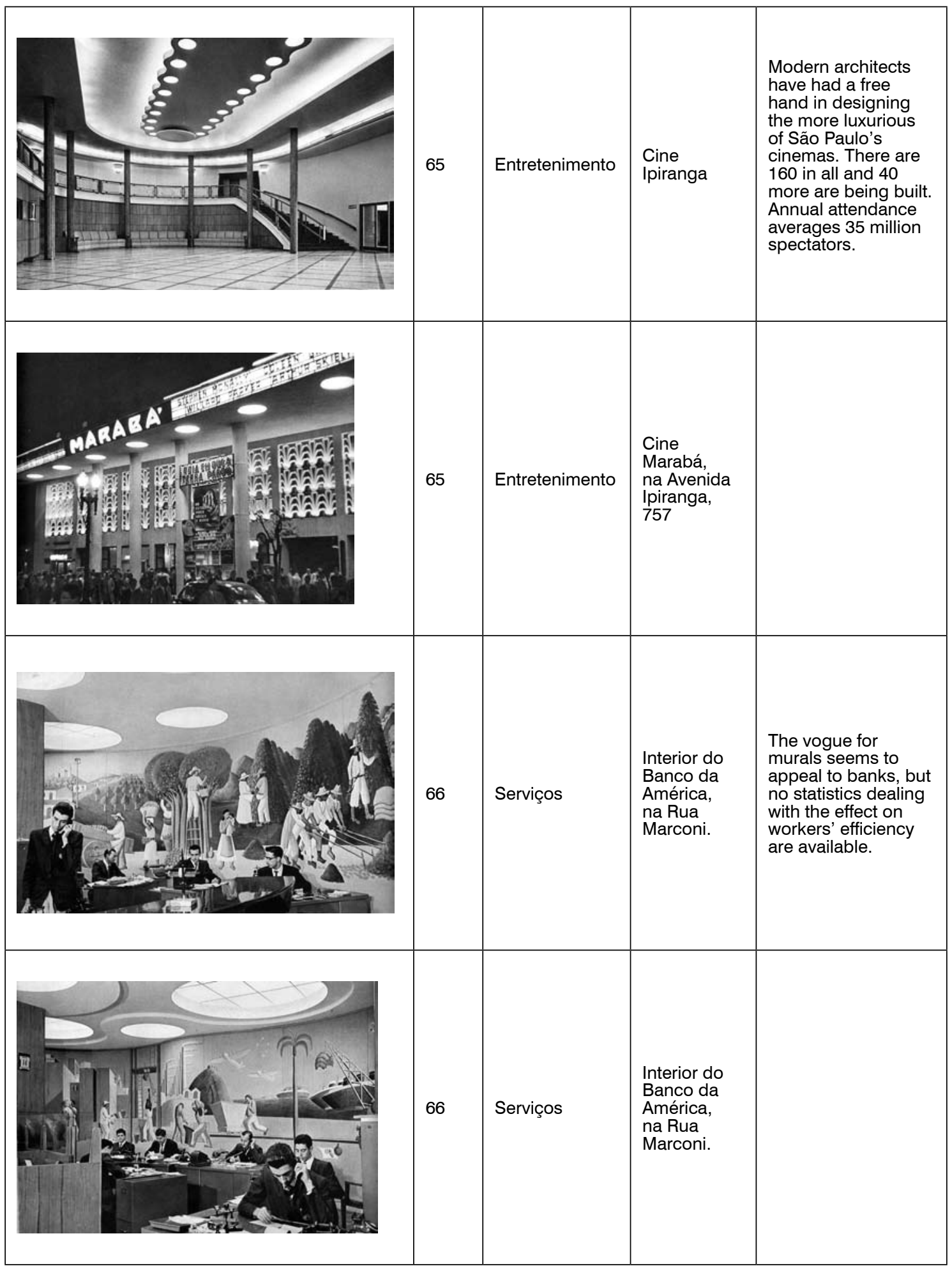




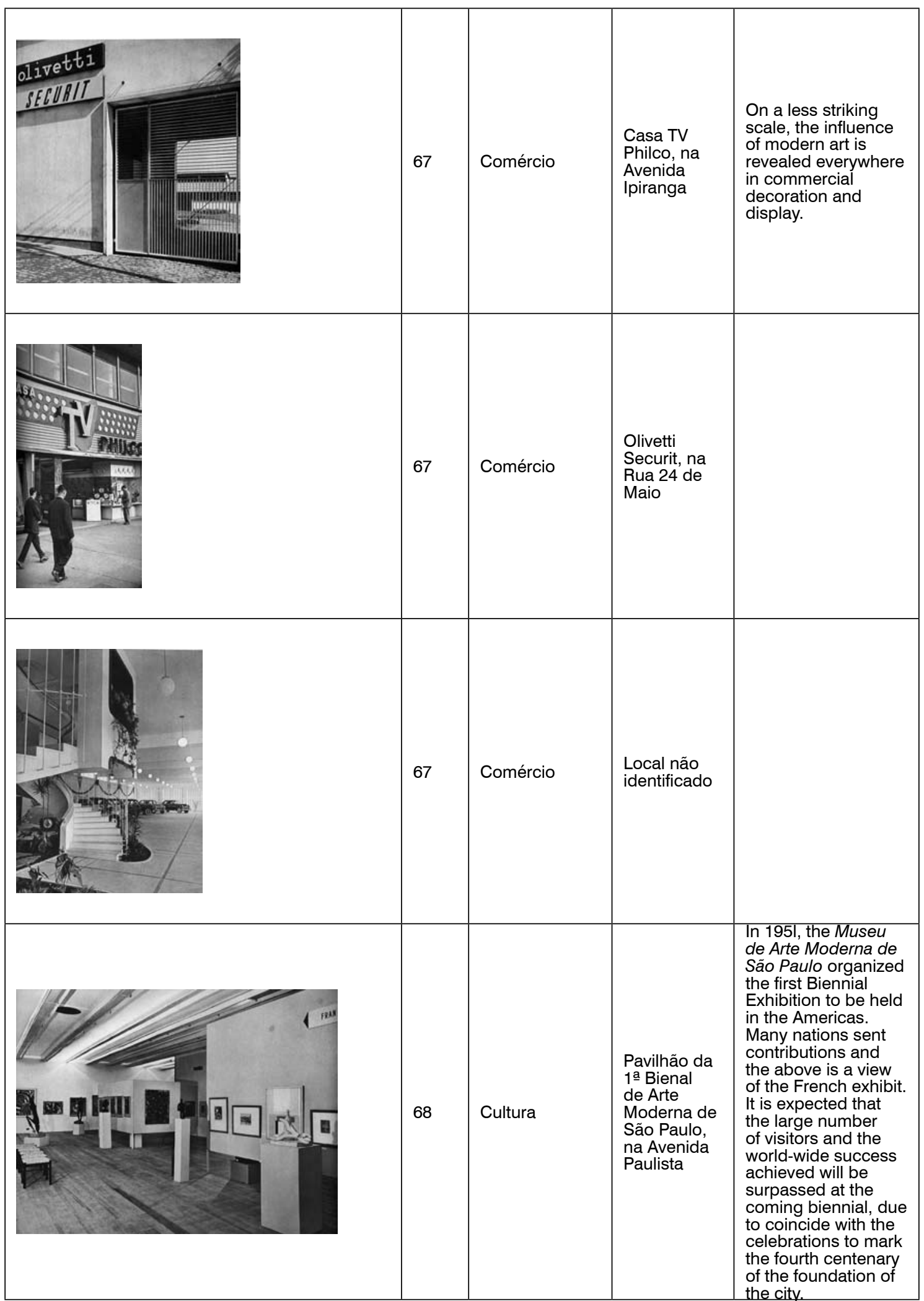




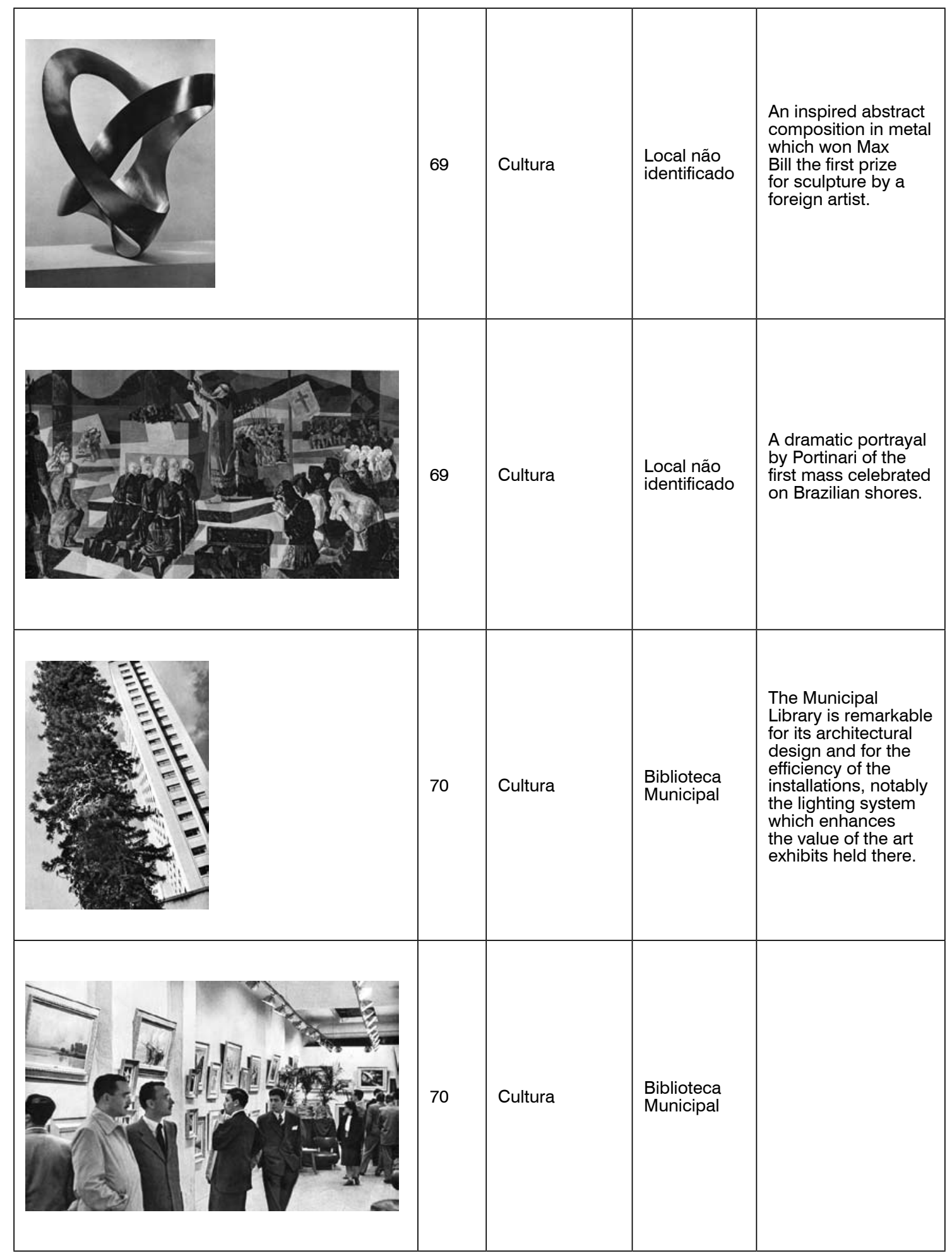




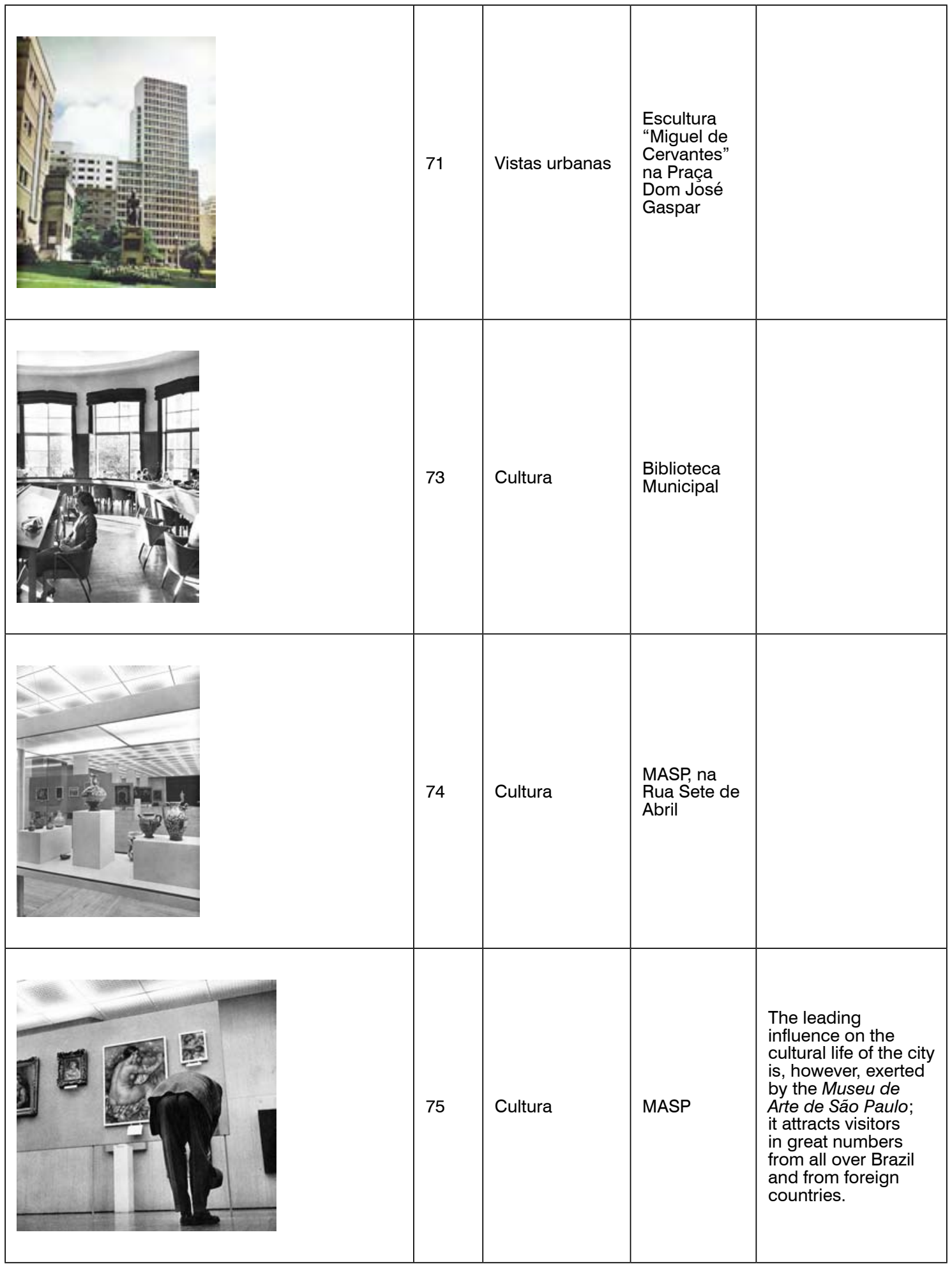




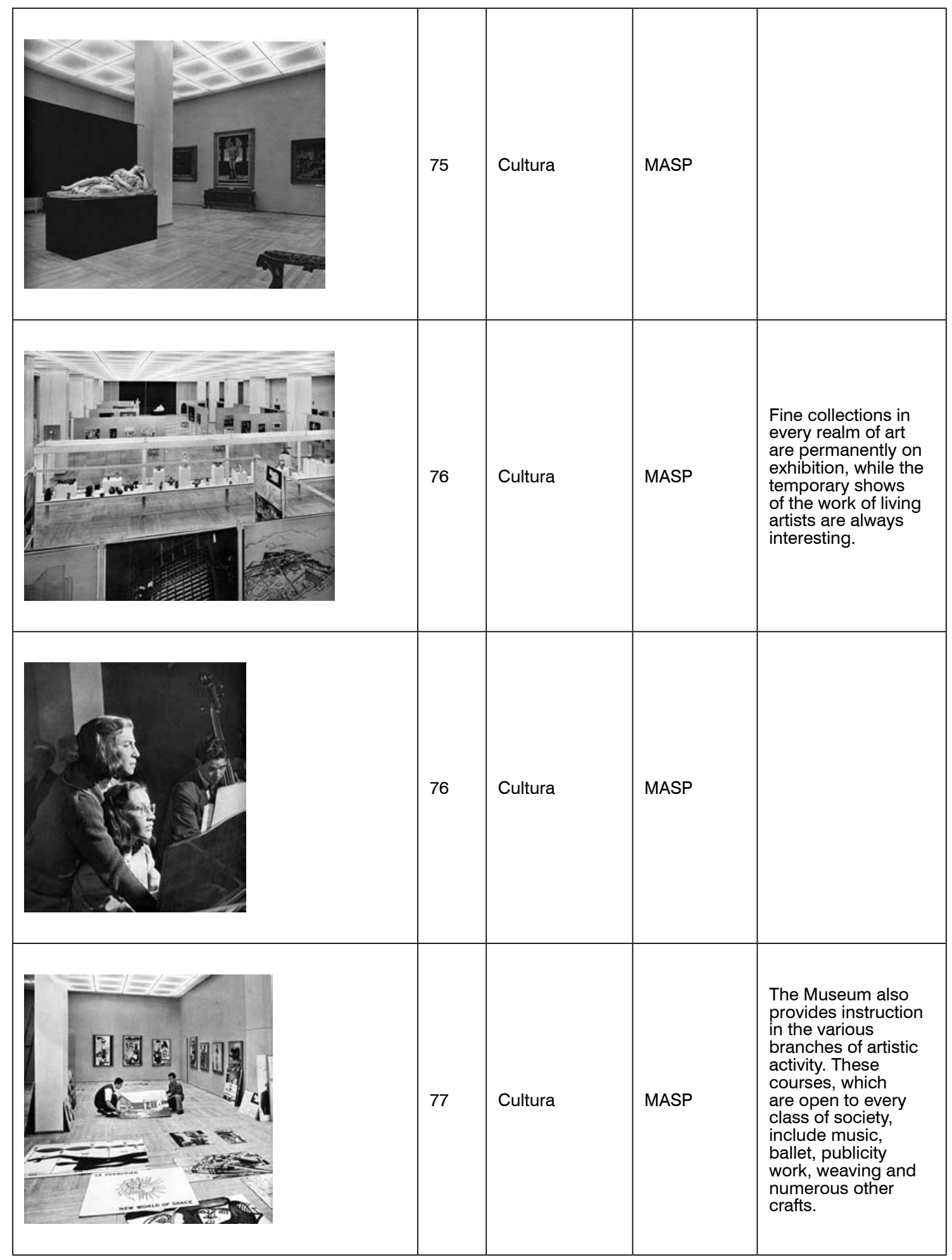




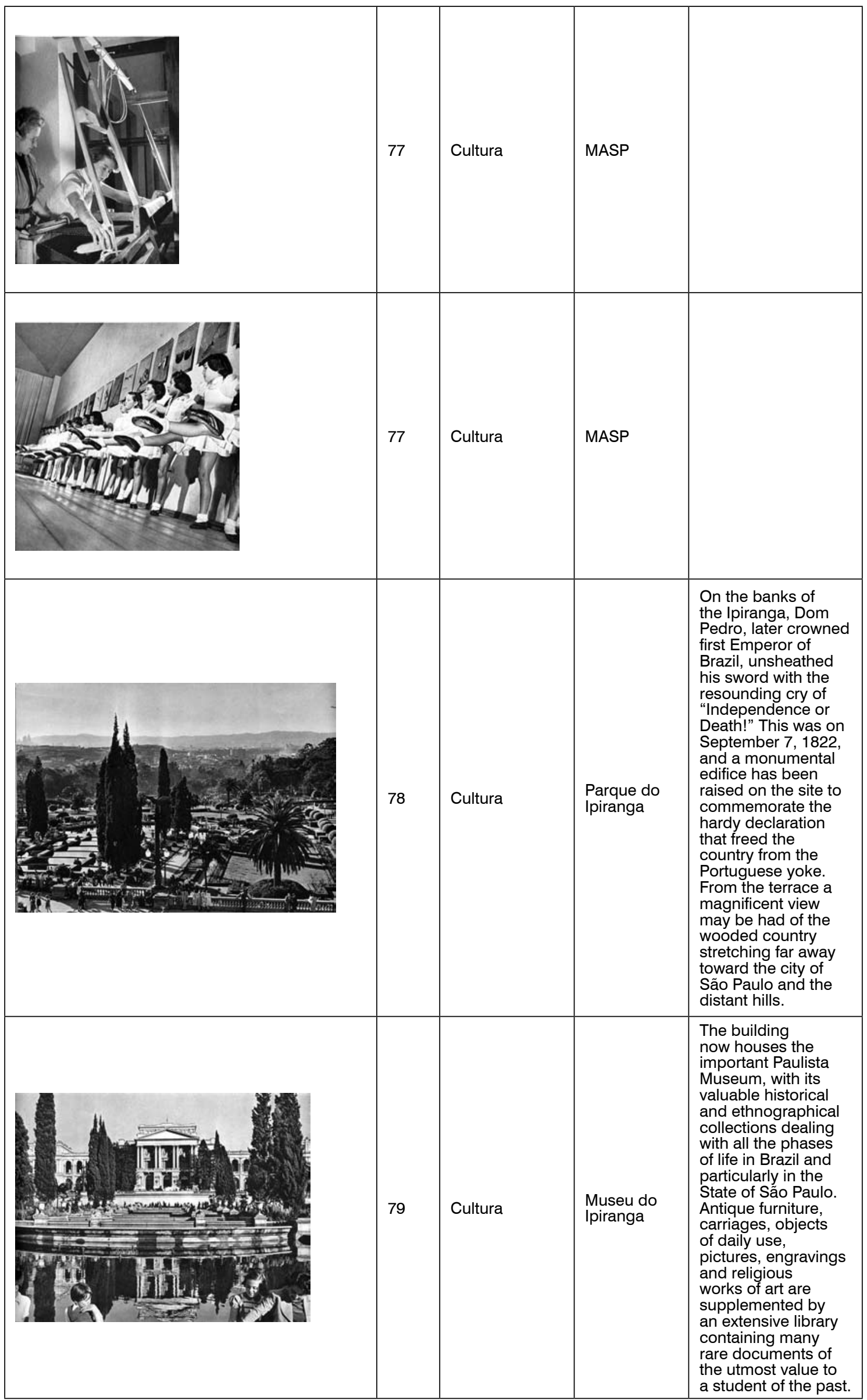




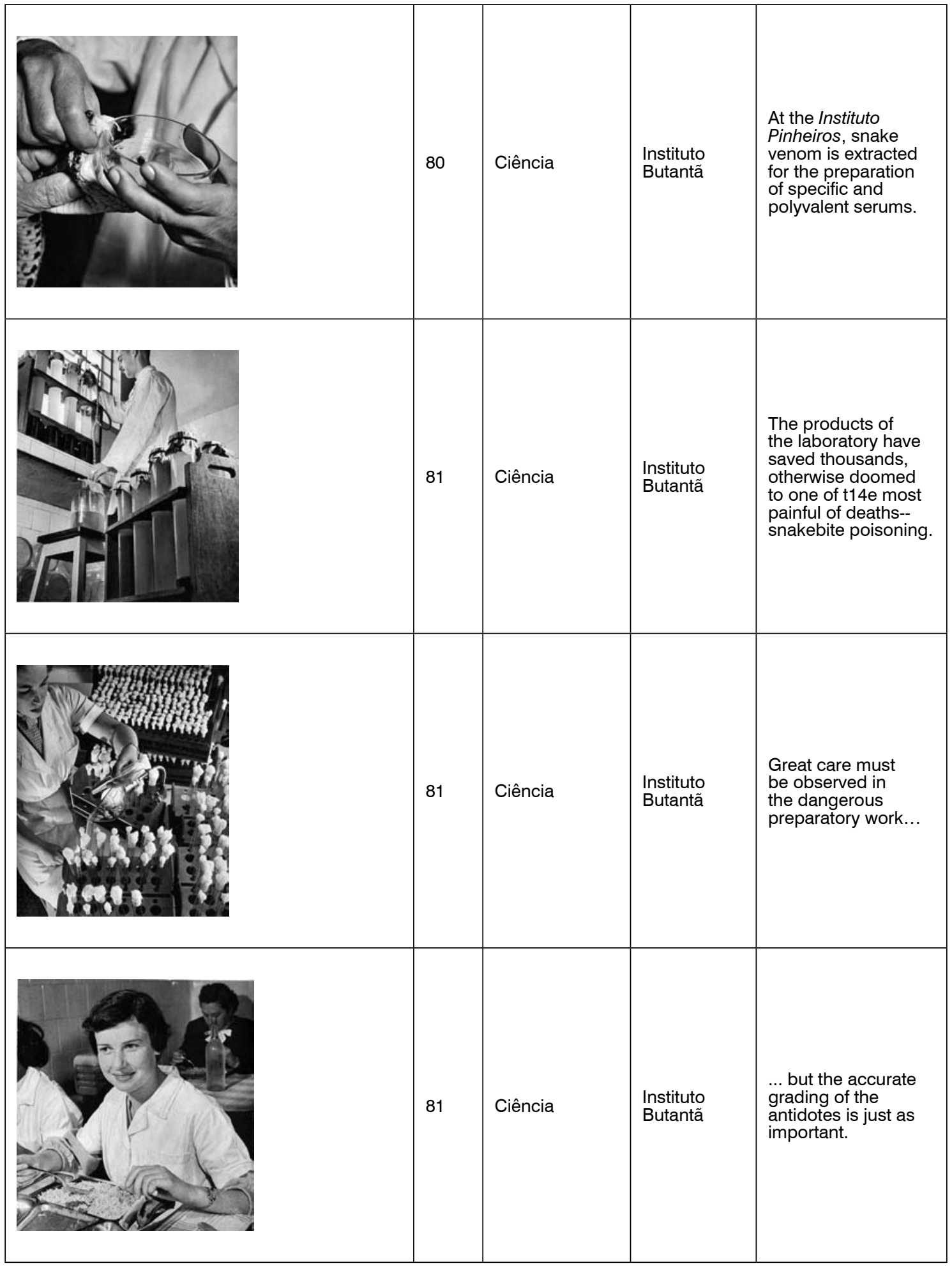




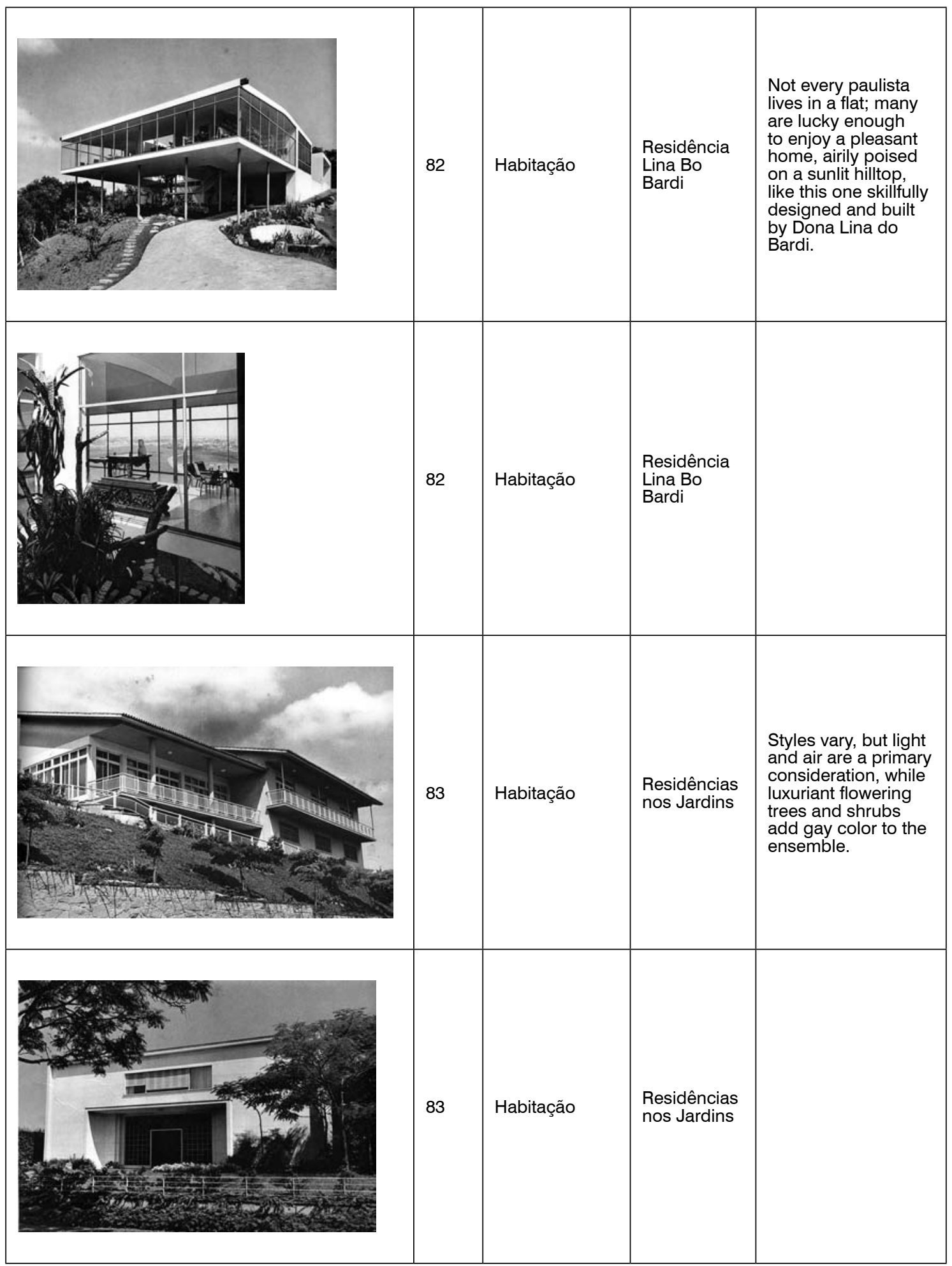




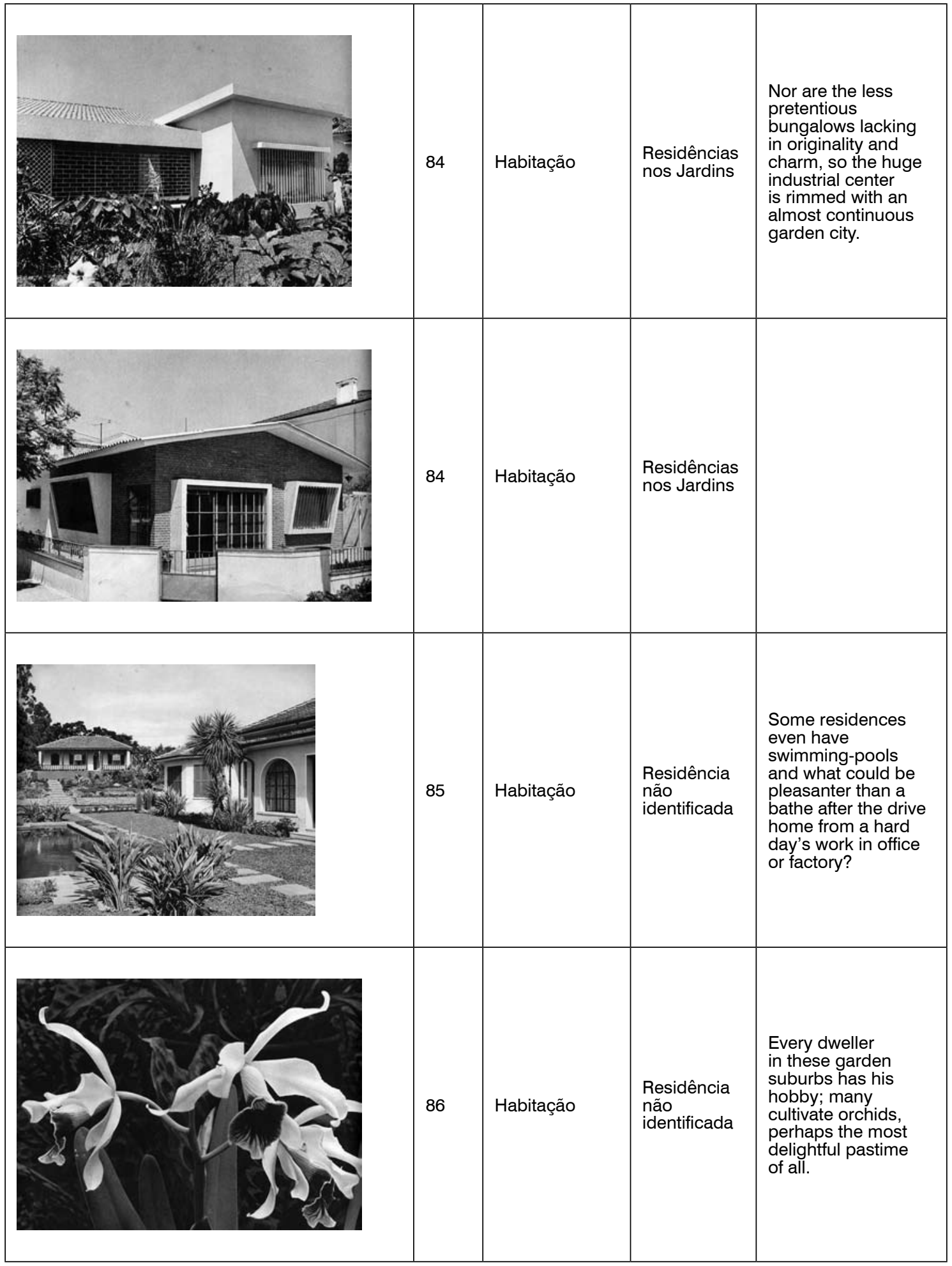




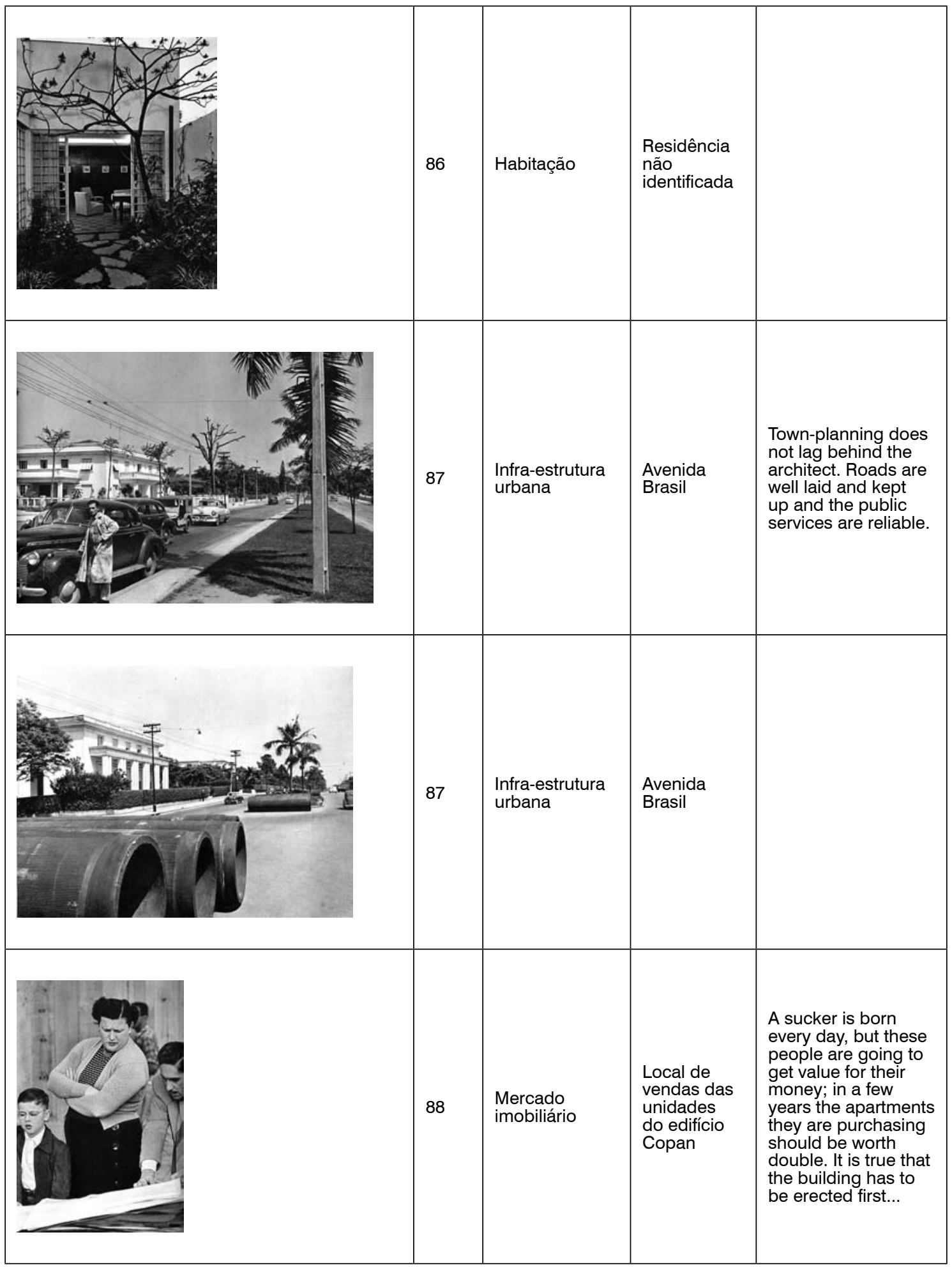




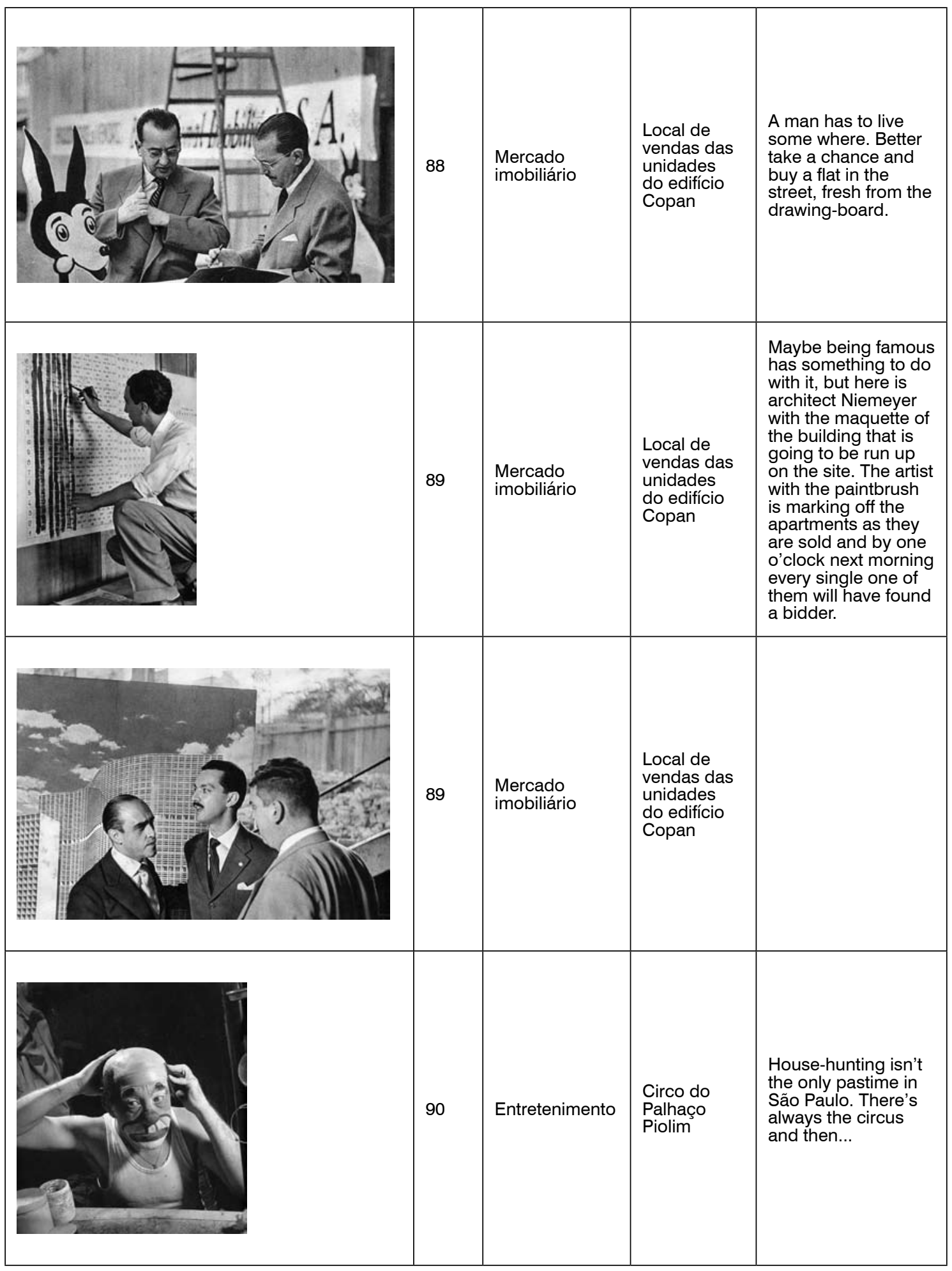




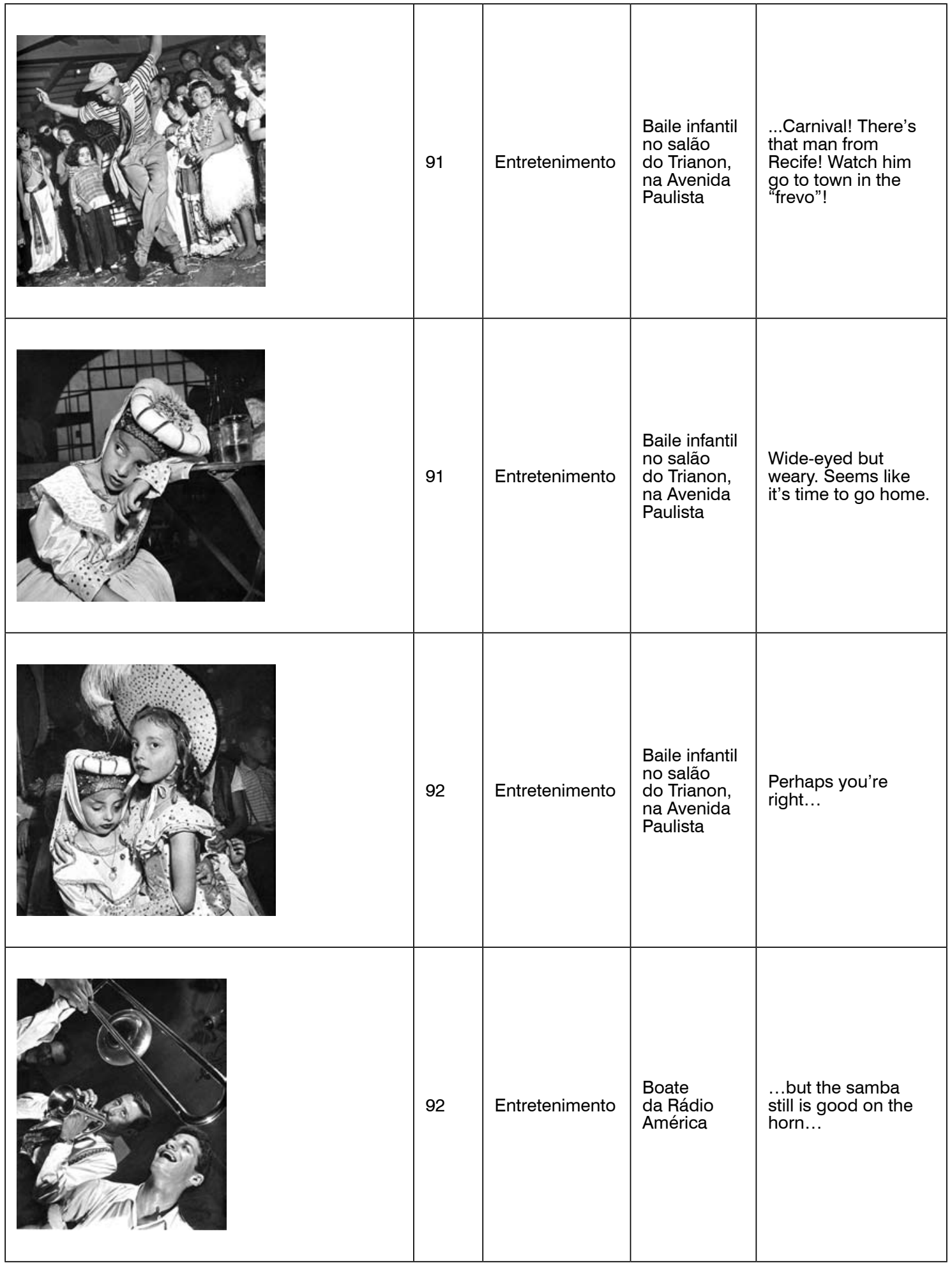




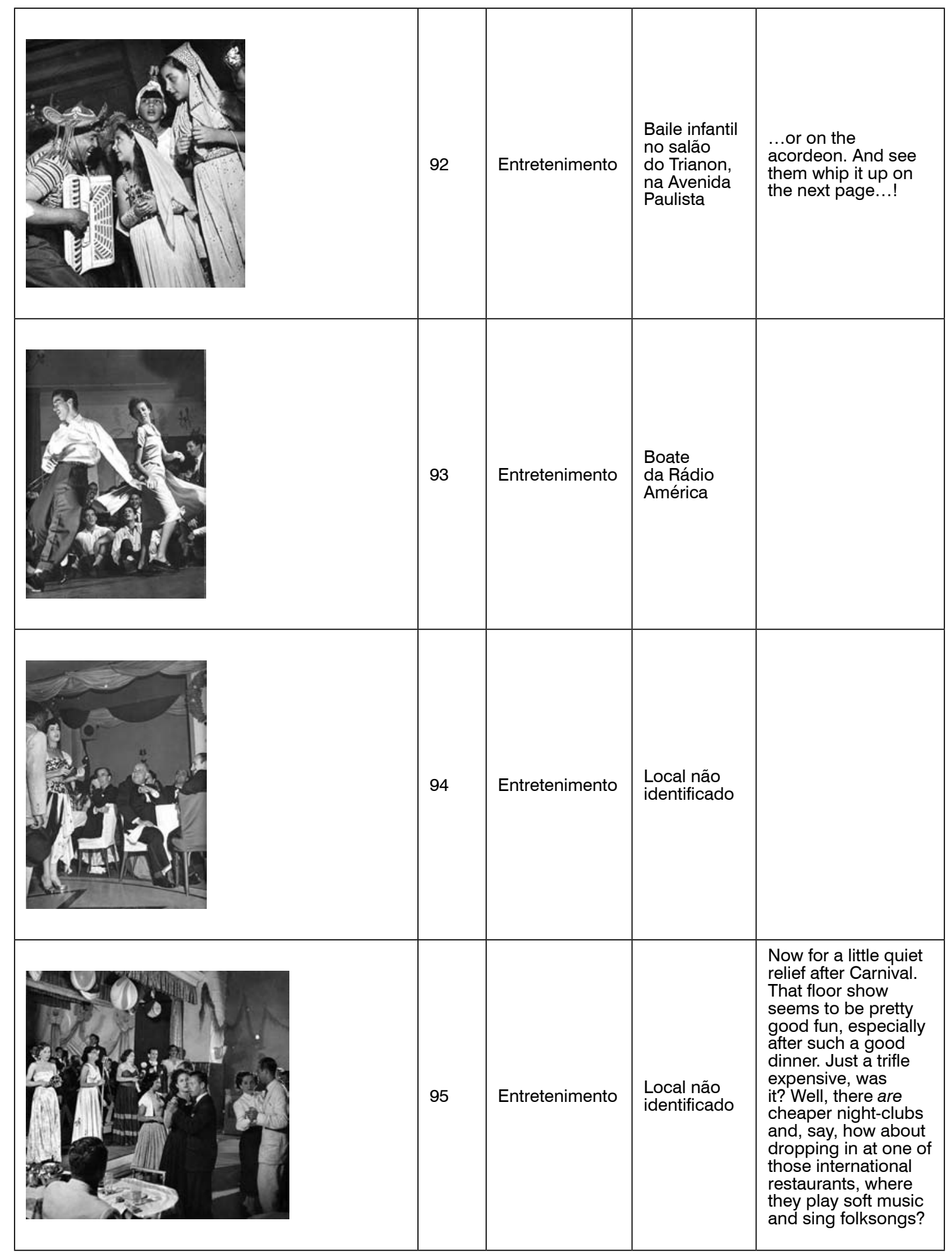




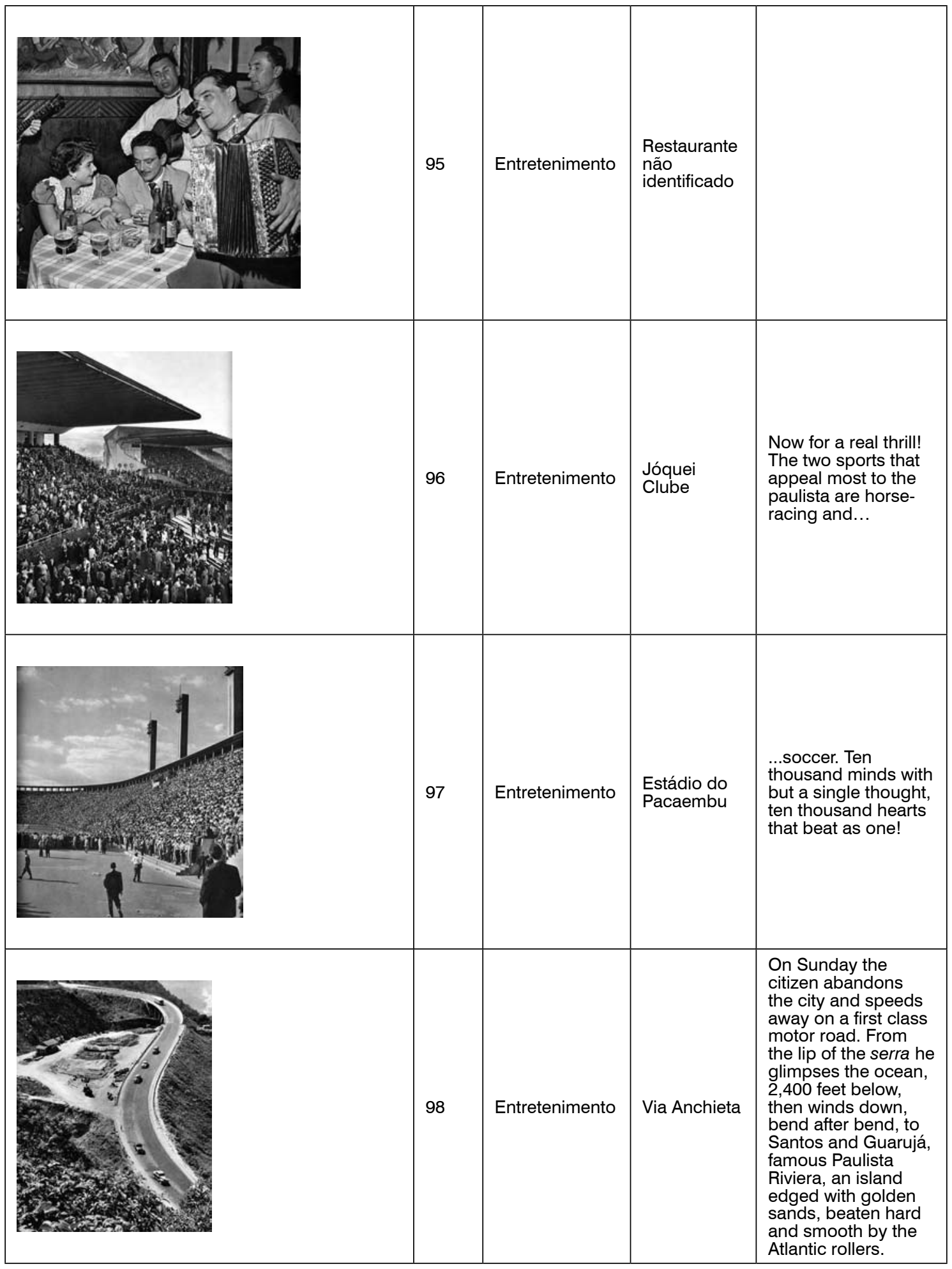




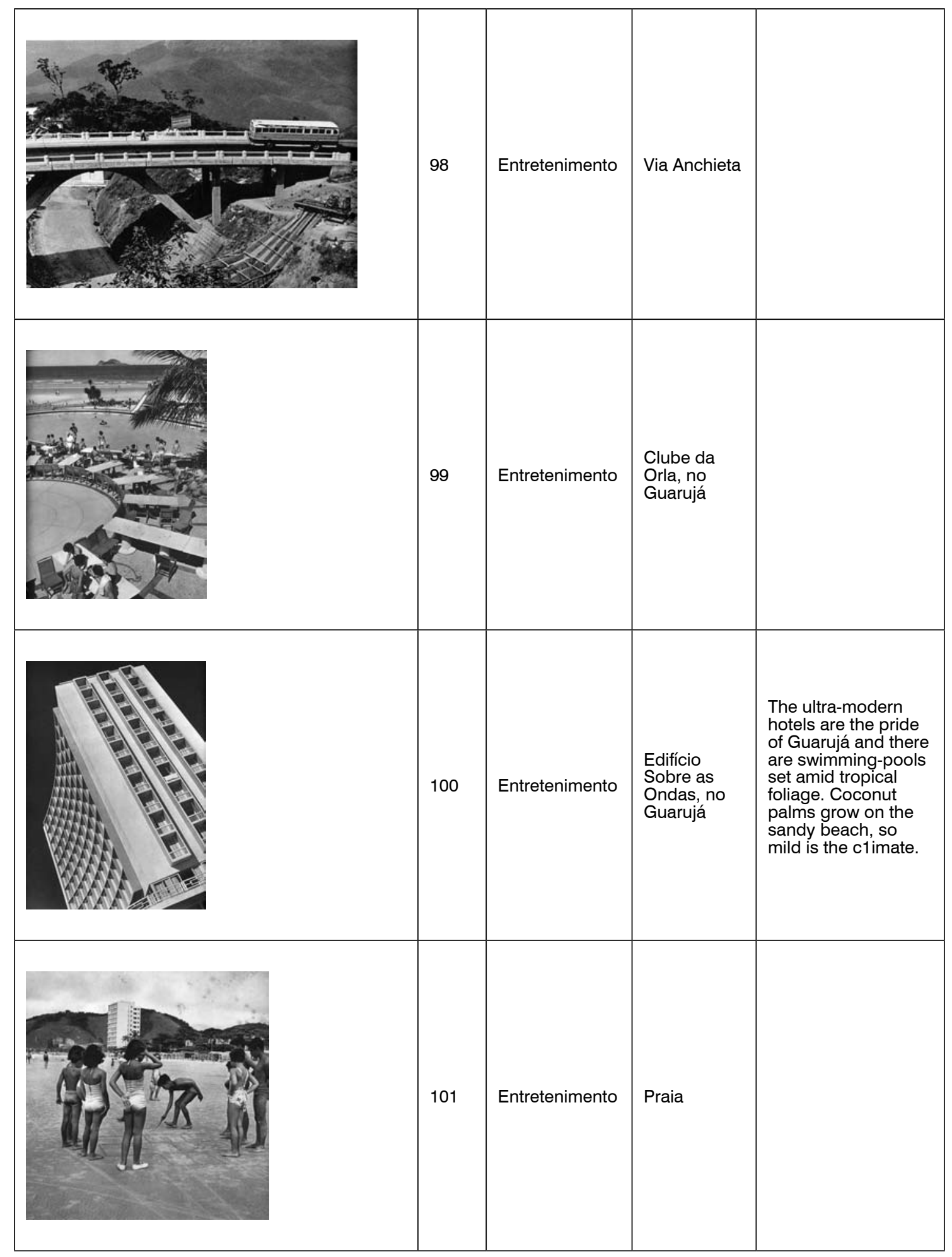




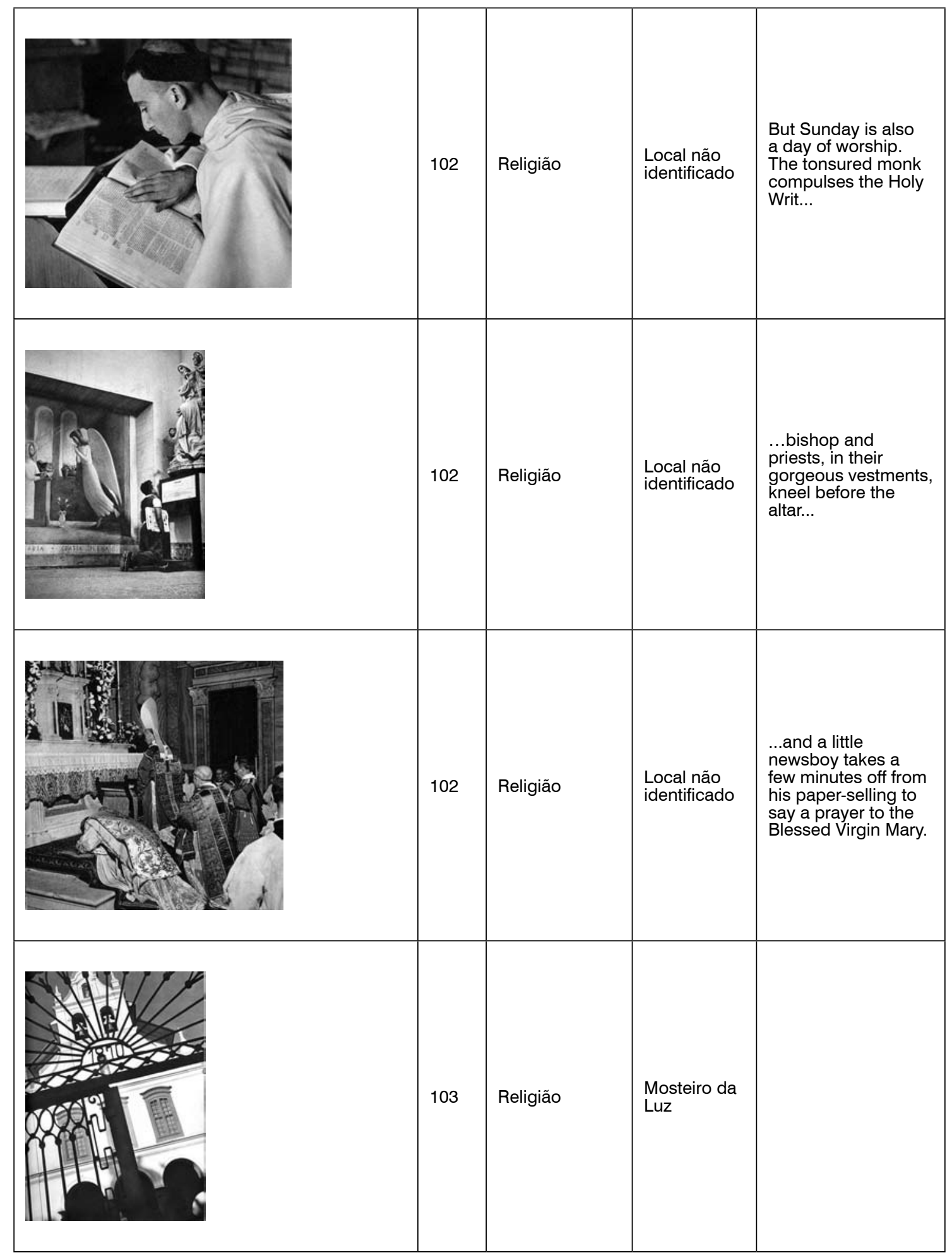




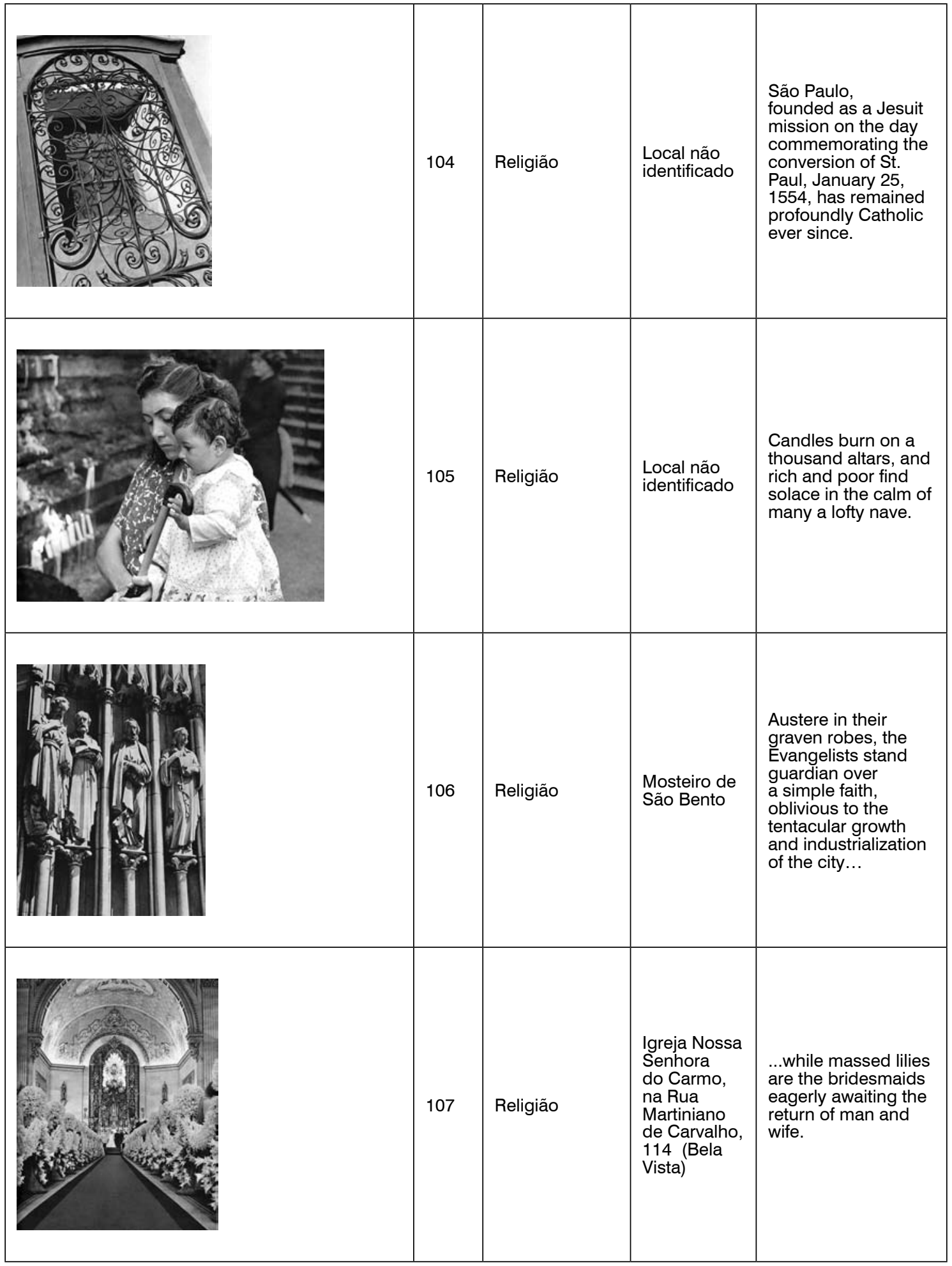




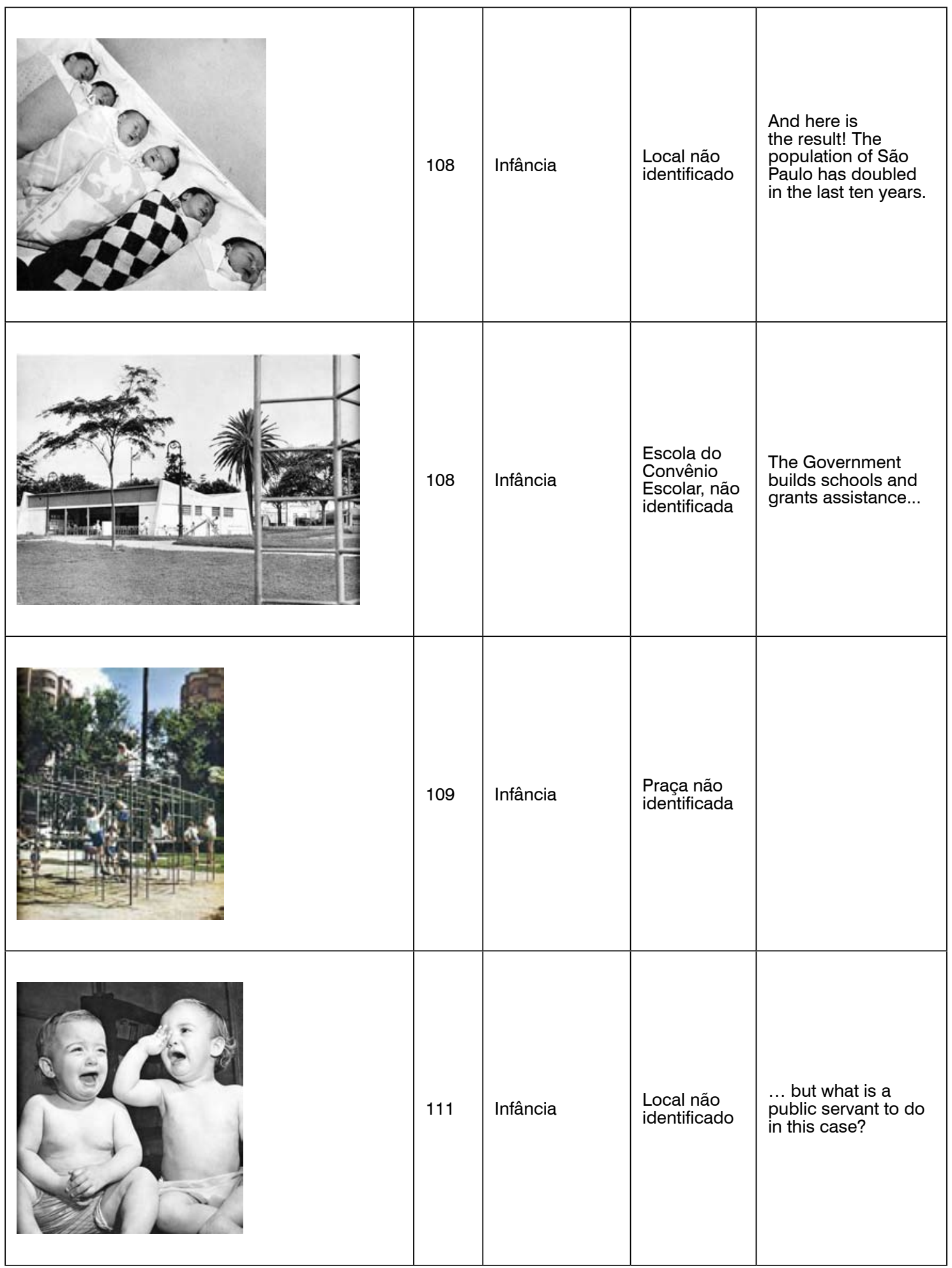




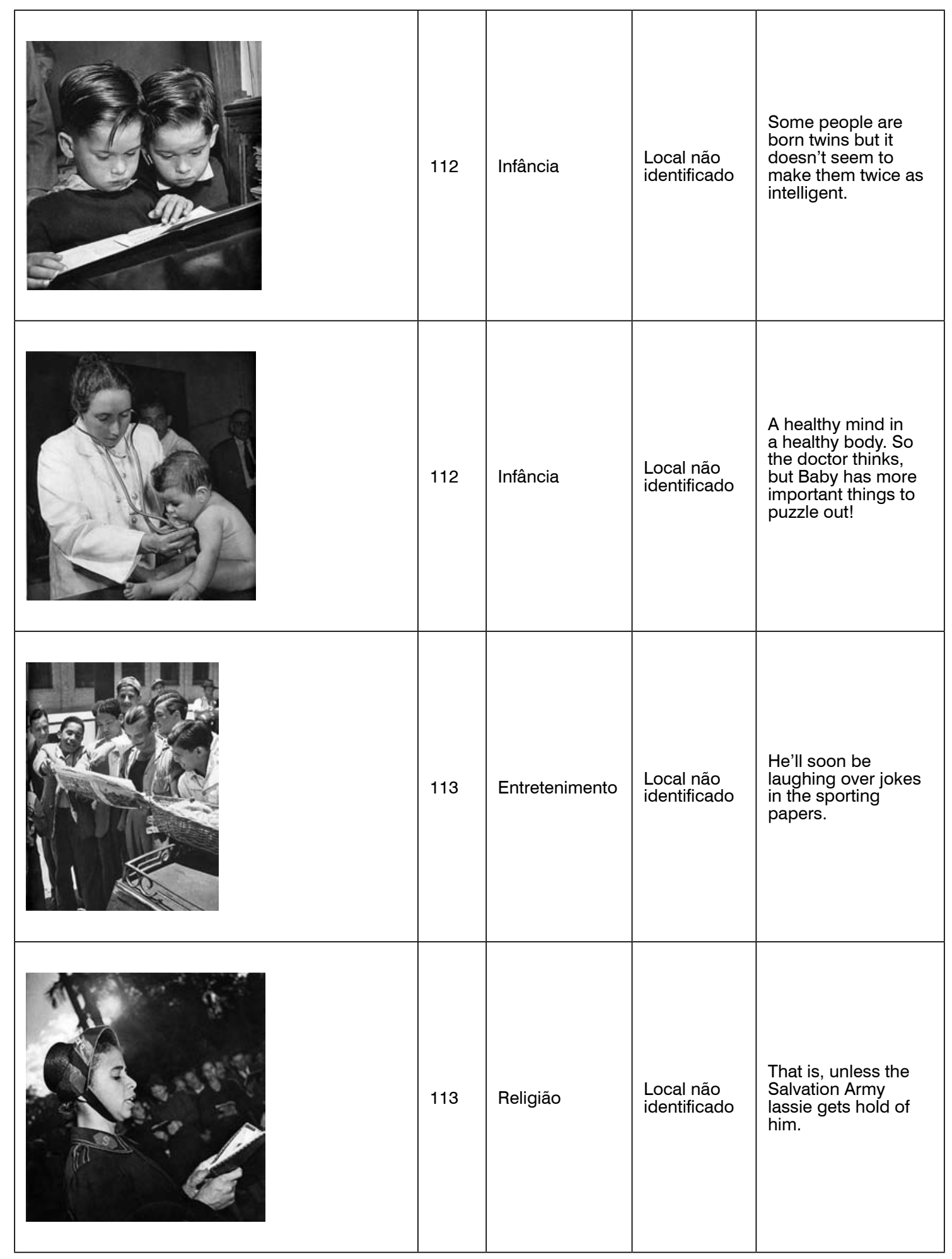




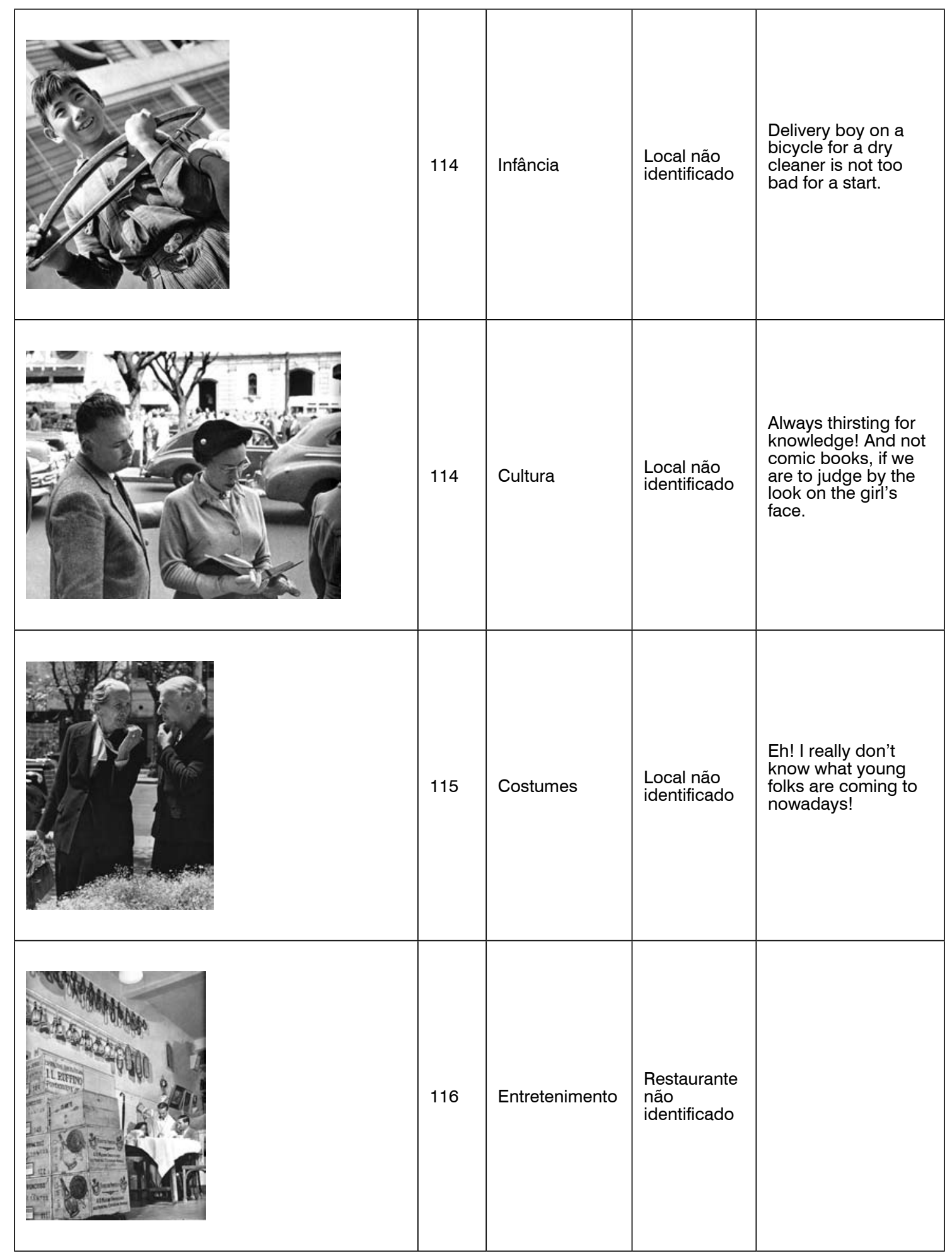




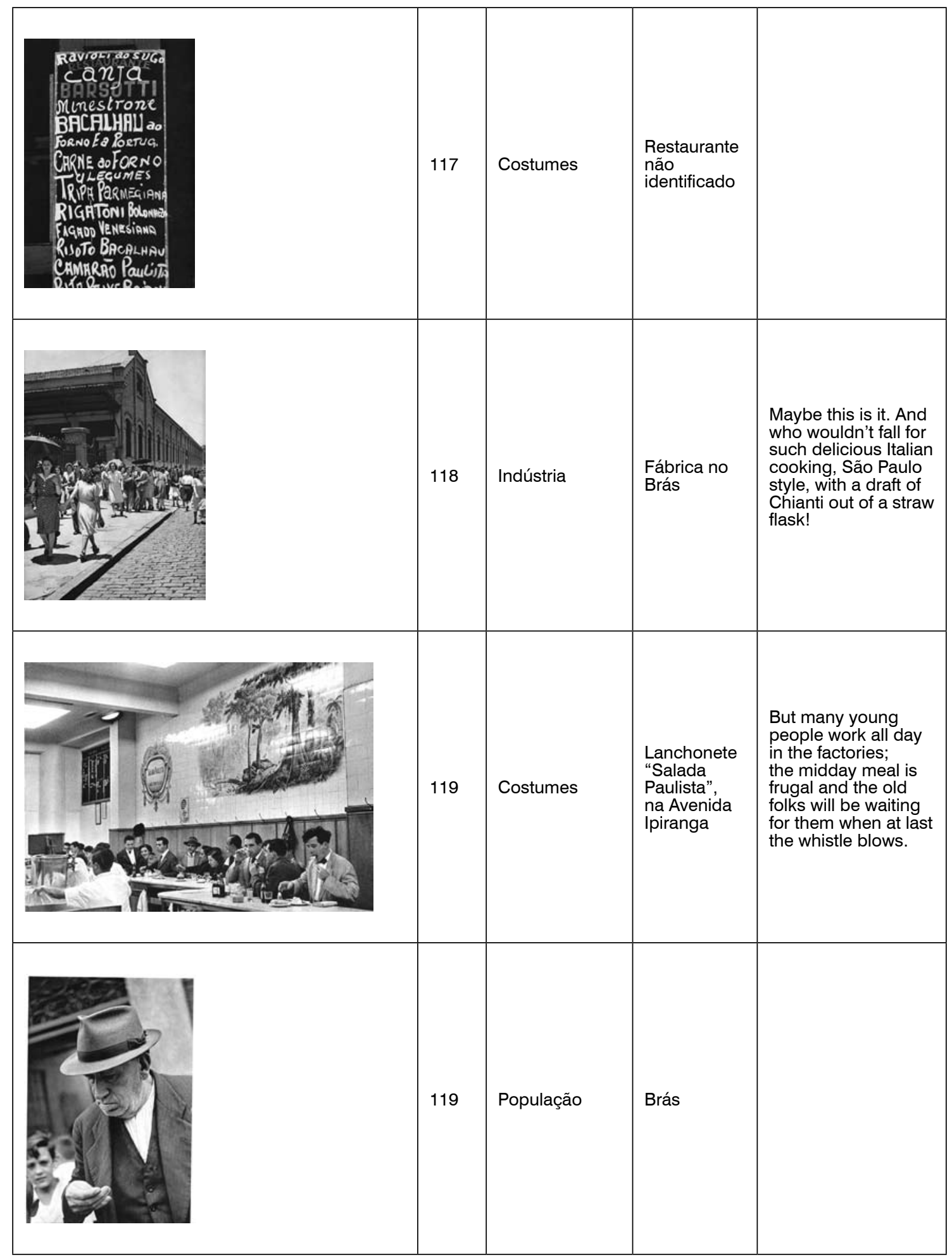




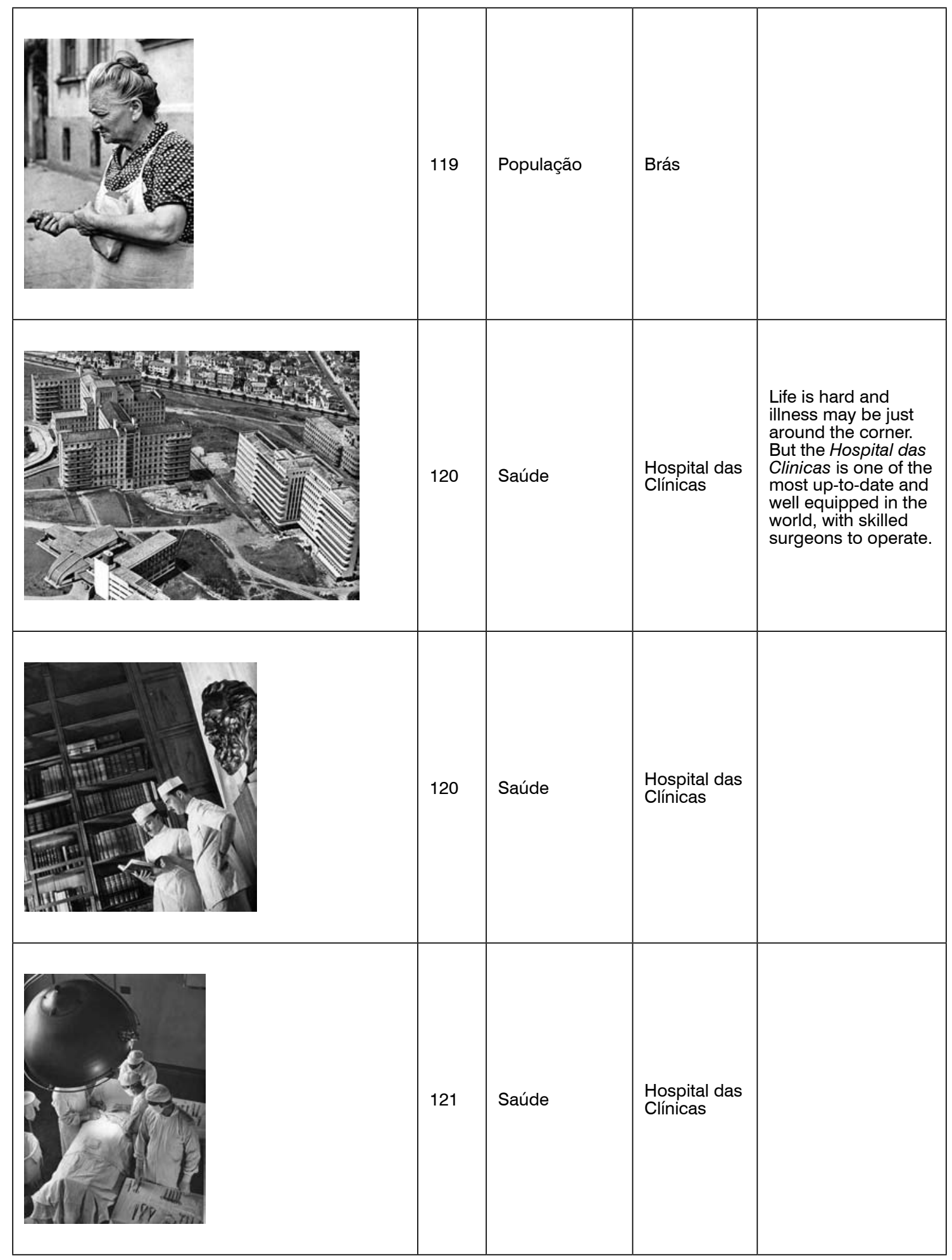




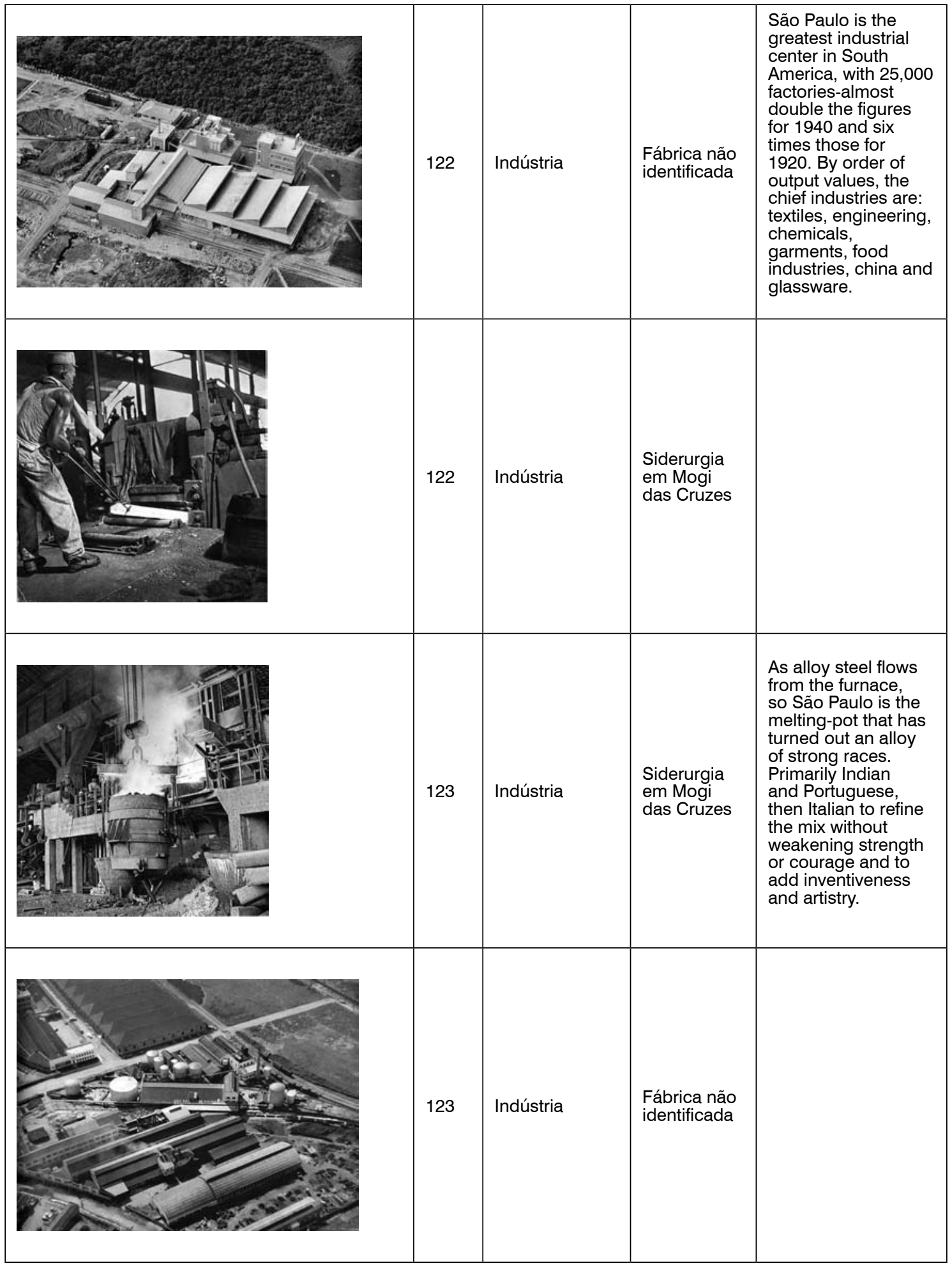




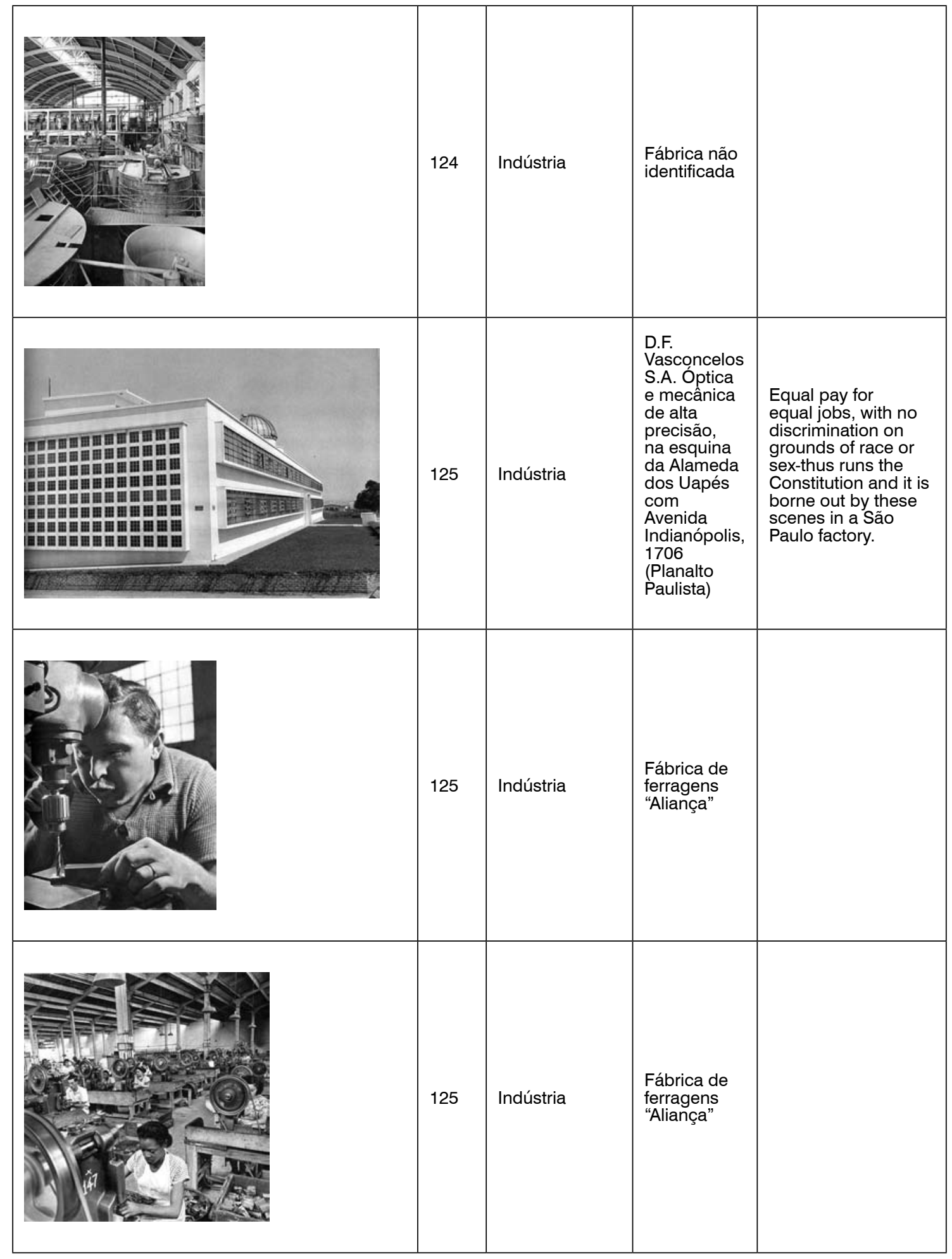




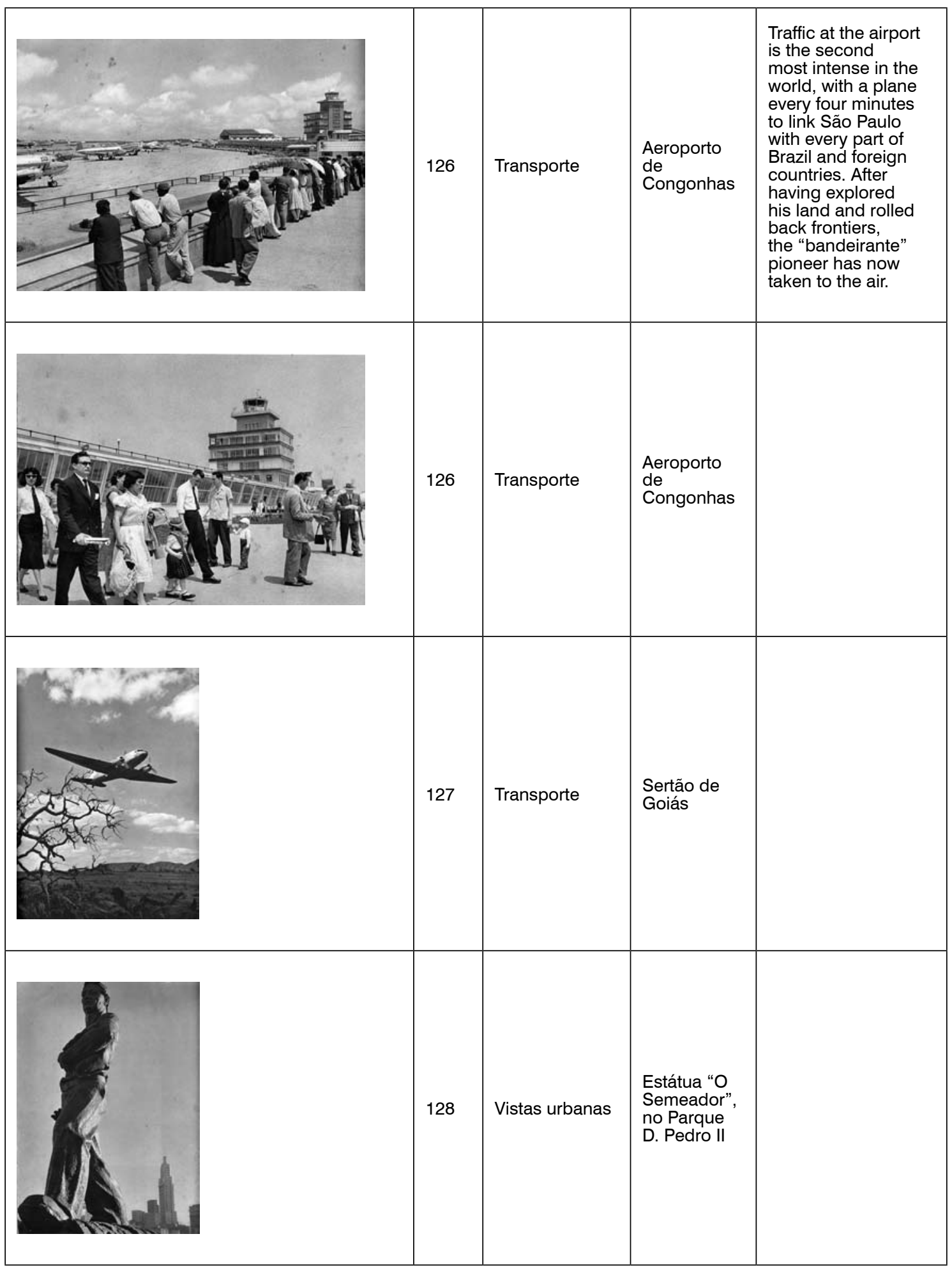

Todas as fotografias são de Peter Scheier, exceto:

Siqueira e Silva: 16, 17, 47, 53

George Rado: 21, 23, 25, 28, 33, 36, 39, 49, 55, 71, 101, 106, 115, 117

Hans Günter Flieg: 68, 69

Salomão Schlier: capa 


\section{Apêndice D - O caminho de Peter Scheier no álbum São Paulo fastest growing city in the world}

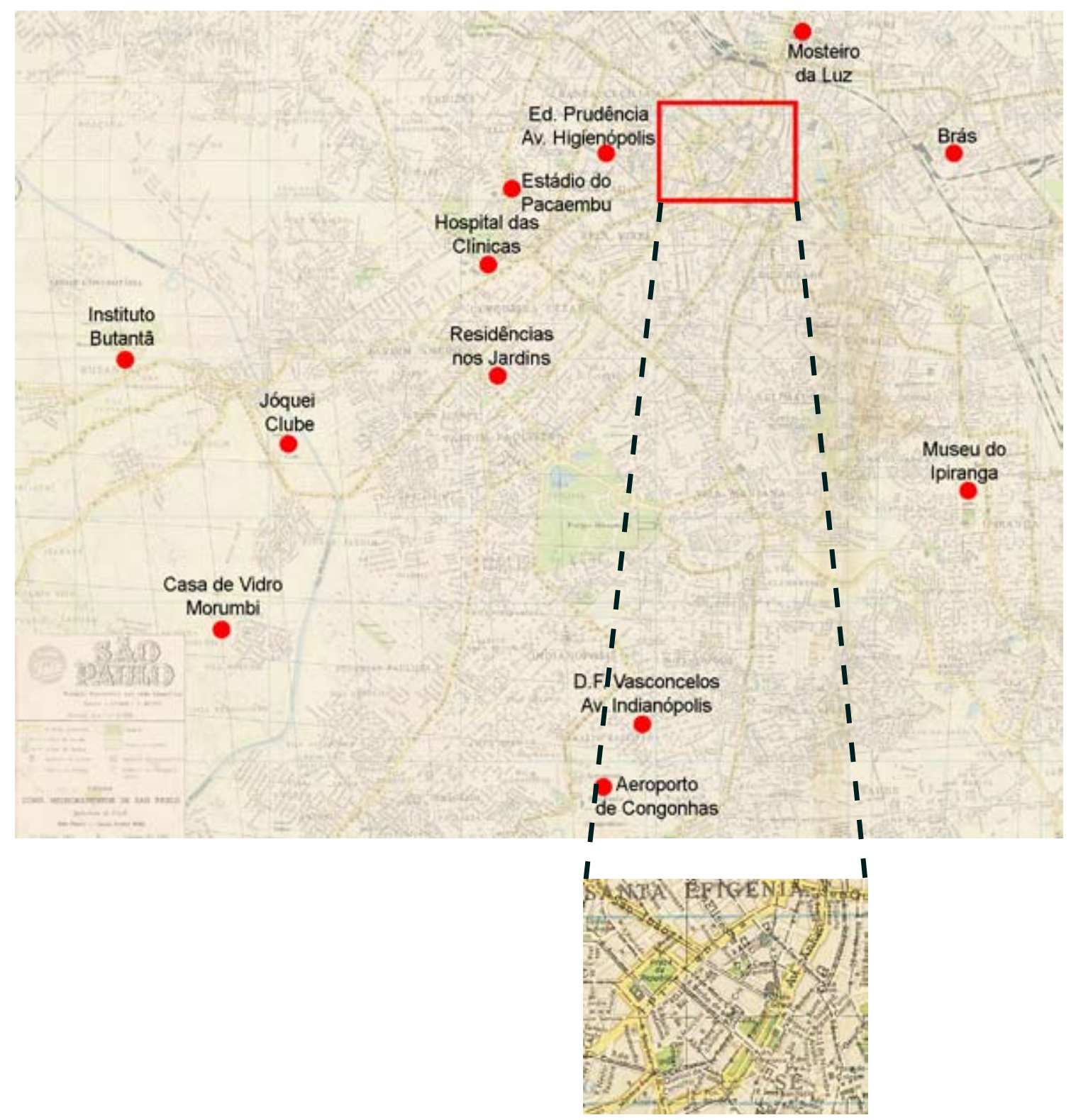

Localização de pontos fotografados por Peter Scheier na cidade de São Paulo e publicados no álbum São Paulo fastest growing city in the world. Em destaque, a área com maior incidência de fotografias: Vale do Anhangabaú e arredores da Praça da República.

Mapa: São Paulo, Projeção hiperboloid com rêde kilométrica em 1951. Fonte: Secretaria de Estado de Economia e Planejamento. "Instituto Geográfico e Cartográfico - IGC. Coordenadoria de Planejamento e Avaliação. Disponível em: http://sempla.prefeitura.sp.gov.br/historico/1950. php. Acesso em: 21 out 2008, às 23:30. 


\section{Anexo A - Textos introdutórios do álbum São Paulo fastest growing city in the world}

\section{Foreword}

São Paulo is the industrial leader of South America. This city of close on two and a half million inhabitants is the capital of a state larger than New York and Pennsylvania put together and about the same size as Great Britain and Northern Ireland. If we consider that one third of this expanse of land is still almost uninhabited, we find that the density of the population in the remaining two-thirds is greater than that of Illinois, twelfth highest in the United States. The resulting figure -145 inhabitants per square mile, as com pared with 97 for the whole state- is equal to that for the state of Rio de Janeiro, six times smaller, and only exceeded by the Federal District, a sixth part of which is built over.

But the paulistas, or natives of the state of São Paulo, are far more goahead than their neighbors of Rio de Janeiro state or the cariocas of Rio de Janeiro city. Although São Paulo straddles the tropic of Capricorn, which indeed 
passes right through the capital, it enjoys a pleasant, temperate climate owing to the altitude (1,500 to 3,000 feet) of the uplands which leave only a narrow strip of seaboard and in places end in a steep slope plunging down into the Atlantic Ocean. But climate is not the only stimulating factor. The racial heritage of Portuguese and Indian blood seems to have preserved the finest qualities of both peoples. In the early days of the colony, it produced the "bandeirantes" or half-caste pioneers who were largely responsible for extending the dominion of the crown of Portugal over nearly half of South America, roughly the area which the United States of Brazil occupies today. Later the influx of Italian immigration (one and a half million between 1820 and 1940, though it really only began about 1850) has tended to gravitate to São Paulo, adding the spirit of ingenuity and invention that gradually laid the basis for the amazing industrial development of this century.

Capital, however, as well as brains is needed for the expansion of industry and São Paulo found wealth in the fertile soil on which the coffee plant thrived so exuberantly that it took the place of sugar as the major element in the economic set-up of the country and still accounts for $28 \%$ of the total value of agricultural production (1952 statistics) and contributed $60 \%$ to the value of Brazil's export trade in 1951. Of the total output of over a million tons São Paulo produces half, and it was in coffee that the first great paulista fortunes were made.

If we are to seek the origins of industry in Brazil, we must go back to the sixteenth century when we find that iron was first produced according to the primitive

African system in a charcoal forge set up at Sorocaba in São Paulo, a bare fifty miles from the state capital. The center of the incipient smelting industry subsequently shifted to the neighboring state of Minas Gerais and it was there that pig iron flowed from the first blast furnaces in 1818. Minas, however, failed 
to retain the leadership in industrial progress, which passed to Rio de Janeiro where great headway was made during the last half of the nineteenth century principally for two reasons: on the one hand the fact that the city of Rio was the seat of the imperial court until the Republic was declared in 1889 and on the other hand the far-sighted initiative and drive of a born industrialist, the baron of Mauá. He it was who built the first gas-works and engineered the first railroad which was inaugurated in 1854. But towards the end of the century São Paulo was creeping up and by 1910 it had wrested the position of largest industrial producer from the Federal District. From then on, it has never looked back. By 1945 the industrial output of the state and chiefly the city of São Paulo was more than two and a half times that of the Federal District and more than half the total for the whole country.

The increase in size of the city of São Paulo has kept pace with its industrial development. Three hundred and twenty years after its foundation as a Jesuit convent and settlement in 1554, there were still only 32,000 inhabitants living in the low, Portuguese-colonial houses or strolling leisurely about the narrow, winding streets. At the turn of the century, when an electric bulb had replaced the uncertain gas-jet at the top of an occasional lamp-post, the population was approaching 240,000 . Forty years later the census returns recorded $1,258,482$ inhabitants and in the course of the next ten years this figure was raised by almost 750,000, passing the two million mark and lessening the gap between São Paulo and Rio to a mere 300,000 .

Meanwhile the whole aspect of the city has changed. Skyscrapers soar from the center of town, wide avenues radiate, industrial plants vie with luxury villas and stately homes to spread the urban fringe farther and farther over the rolling hills of the upland countryside. This, of course, creates problems, some of them acute. Housing and traffic, for instance. But the paulista is undismayed. 
He works, plays and lives intensely, tackling each problem as it comes up. Art in all its forms comes in for a fair share of his enthusiasm; the Biennale founded in 1951 and the first in South America, is there to prove that São Paulo is in the forefront of the modernist movement, while the admirable museums display acknowledged treasures of the past.

On the threshold, then, of the fifth century of her existence, to be ushered in with a lavish display, not only of pomp and pageantry, but also and above all of the real values she has achieved, São Paulo regards the future with confidence rare in a troubled world, a confidence that is justified by the progress already made and by the increasing rhythm at which development in every domain is going ahead.

\section{Quatrocentos Anos}

SERGIO MILLIET

A planta oficial de S. Paulo em 1877 mostra-nos uma cidade modesta, construída sobre colinas isoladas umas das outras e se encerrando num retângulo formado pelo Largo dos Guaianazes, Jardim da Luz, Largo da Liberdade, Piques, e Largo 7 de Abril (Praça da Republica). Essa a área urbana propriamente dita. Em verdade S. Paulo já projetava seus tentáculos pelos campos do Braz e as elevações de Santana, Nossa Senhora do Ó, Pinheiros e Santo Amaro.

Estava-se ás vésperas da Abolição, em plena atividade cafeeira (10 milhões de arrobas), e a vida da capital provinciana já perdera a tranqüilidade do início do 
século, pois, de 1872 a 1877, em cinco anos apenas, a população dobrara quase, passando de 26.000 habitantes a 47.000. O código de posturas municipais de 1886 revela as preocupações da administração em face do crescimento rápido e desordenado e, sabiamente, estabelece normas para a construção de novos prédios, a limpeza das ruas, a abertura de estradas, a circulação dos veículos, etc..

Por mais previdentes que fossem, não o seriam entretanto bastante para que essas normas não se tornassem dentro em pouco obsoletas, diante do fenômeno da arrancada progressista. E essa insuficiência de uma previsão sempre superada pela realidade iria repetir-se periodicamente até os nossos dias. É que São Paulo, na sua qualidade de entreposto e centro de distribuição das riquezas produzidas e das mercadorias que em conseqüência se adquiriam, crescia vertiginosamente, apresentando aos seus edís problemas dia a dia mais complexos.

Alguns dados esclarecem o monstruoso crescimento. Em 1900 a capital já está com 30.000 habitantes, em 1910 com 400.000, em 1920 com 600.000, em 19401.400 .000 e com 2.300.000 em 1950. Calcula-se que alcançará 3.000.000 no ano do seu quarto centenário. Paralelamente, não puderam desenvolver-se com igual rapidez as construções, embora seu ritmo seja desde ha anos o mais elevado do mundo. Nem se pôde produzir a energia necessária ás exigências de sua vida normal e de suas indústrias que empregam hoje cerca de um milhão de operários. Dai o estado permanente de crise em que vive a cidade, ampliandose por saltos, em meio a contrastes violentos que the dão esse aspecto a um tempo imponente de metrópole e tranqüilo de província, masculino como o de Chicago ou feminino como o de certos recantos bucólicos da zona suburbana parisiense. Crise de crescimento, crise de puberdade, crise promissora de um futuro grandioso a induzir-se de um presente de afirmação. 
São Paulo é uma cidade feia, dizem os paulistanos, de olhos voltados para o espetáculo do Rio de Janeiro, ou para os horizontes barrocos da Bahia e de Minas. Mas não é. É apenas de um a beleza e de um pitoresco que não se entregam facilmente aos viajantes desprevenidos. No próprio contraste de sua grandeza e de sua modéstia já se deparam valores estéticos e sentimentais nada desprezíveis. Assim, quem venha da Avenida Paulista para o Centro, pela Avenida 9 de julho, terá, como primeiro plano ao conjunto massiço de arranhacéus, a elegância das rampas arborizadas dos túneis. Quem se dirija para o Ipiranga pela avenida que beira o Tamanduateí, descansará nos chorões das margens a vista a todo instante solicitada pelas linhas modernas das fábricas e armazéns recém construídos. Beleza não é só harmonia. É também expressão, e se São Paulo se desconjunta por vezes na sua ascensão tumultuaria, não carece jamais de caráter próprio. Seus bairros populares exprimem no conjunto de seus traços heterogêneos as realizações de um a população que, vinda de todas as partes da Europa e de todos os recantos do país, aqui se misturou numa das mais curiosas experiências biológicas e sociais. $E$ ha igualmente os bairros típicos em que se localizaram certos grupos de imigrantes. Os sírios, os japoneses os judeus concentraram-se em determinadas ruas, conservando alguns de seus costumes típicos, perdendo outros ou os adaptando a nova pátria. Assim é que os moleques de origem nipônica não desdenham a "pelada", para maior irritação das donas de casas cujas vidraças correm sempre grandes riscos. Mas não é só nas ruas e praças que se poderão observar essa pitoresca formação de um novo tipo de paulista, tão orgulhoso de sua cidade e de seus avós... bandeirantes, quanto o descendente das famílias tradicionais. 
É igualmente nos parques infantis, nas escolas, na Universidade, na Câmara Municipal, e na Assembléia Legislativa.

Em geral, as cidades cosmopolitas caracterizam-se pela falta de personalidade. Mas são cidades de turismo, pelas quais passeia o estrangeiro sem nada dar de si, á exceção do dinheiro. São Paulo cosmopolita é porem uma cidade de trabalho, onde cada qual deixa um pouco de seu amor, onde todos plantam uma muda de esperança, para a qual o homem de fora constrói pensando no filho já paulistano, á qual o imigrante oferece algum as de suas tradições em troca de costumes que faz seus. Enriquecem-se desse modo os paulistanos, adquirindo uma divisão do mundo cada vez mais ampla e humana, o que se reflete necessariamente nas suas atividades e os leva a encarar 0 futuro com a confiança e a tenacidade dos primeiros colonizadores que tiveram a ousadia de atravessar os pantanais do Cubatão, galgar a serra de florestas virgens e animais selvagens, a fim de erguer, no planalto, entre os índios ariscos, as primeiras casas de taipa de que partiriam os desbravadores ambiciosos, á caça de índios para o trabalho nas roças, e á procura de ouro e pedras preciosas.

Nem índios nem ouro duraram muito. Ao findar o setecentismo, a situação da cidade era calamitosa. Os capitães generais referem-se com desanimo ao estado da capitania toda. Só que a coragem dos habitantes não esmorecera. Novo surto de energia ia verificar-se, cujos resultados ai estão. "Non ducor duco", diz a divisa paulistana, e essas orgulhosas palavras mais do que nunca merecem figurar no brazão da cidade, ao iniciar-se o seu quinto século de existência. 
Clima, conjuntura econômica, mistura de raças, quais as razões dessa espantosa evolução de São Paulo, ainda longe de se encerrar? Pouco importa a primazia de um ou outro fator, pouco importa se deva essa expansão á loucura das guerras, que favoreceram o progresso do país, ou a incapacidade alheia de resolver os problemas da super população, o que nos auxiliou a povoar o nosso próprio território. Tudo isso em nada diminui a gloria paulista de haver edificado, sob o tropico de Capricórnio, a cidade, do mundo, que mais rapidamente se desenvolve.

Parodiando Walt Whitman, que viveu momento semelhante na historia dos Estados Unidos, eu diria agora, conclamando os povos todos a participarem da festa do IV centenário de São Paulo.

Quem quer que sejas,

Vós todos da Ásia, África, Europa, Austrália, pouco importa o lugar!

Vós todos das ilhas inúmeras dos arquipélagos do mar!

E vós dos séculos vindouros, quando me ouvireis!

E vós, cada um de vós, em todos os lugares, que não cito sequer, mas todos incluo!

Saúdo a todos! Amizade para todos vós, de minha parte e da parte de São Paulo! 